
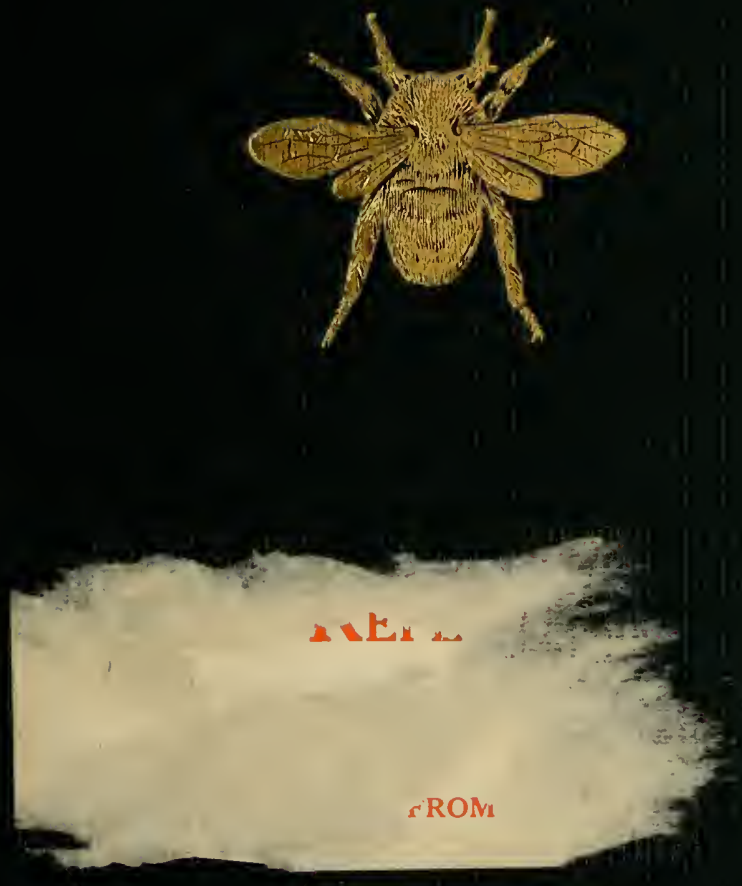


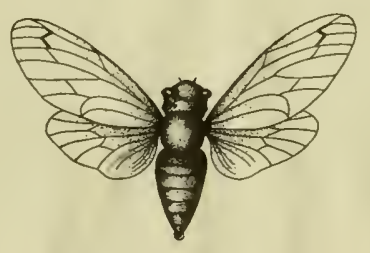

LIBRARY OF

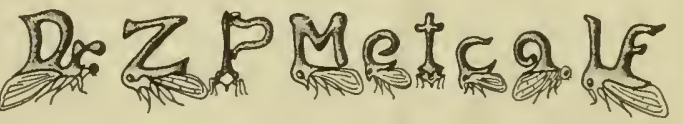
1885_1956 






\section{ENTOMOLOGY FOR BEGINNERS}

FOR THE USE OF

YOUNG FOLKS, FRUIT-GROWERS, FARMERS, AND GARDENERS

BY

A. S. PACKARD, M.D., Pн.D.,

Author of "Zoology for High Schools and Colleges," "First Lessons in Zoology," "Guide to the Study of Insects," etc.

FLOREAT ENTOMOLOGIA !

-DARWIN, Life and Letters, i. 497

THIRD EDITION, REVISED

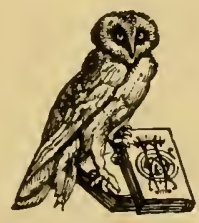

NEW YORK

HENRY HOLT AND COMPANY

1899 
Copyright, 1888 ,

BY

Henry Holt \& Co. 
TO THE

Inemory

OF

\section{JOHN L. LE CONTE, M.D.,}

The Leading Entomologist of America,

THIS LITTLE BOOK IS GRATEFULLY DEDICATED IN RECOGNITION OF

HIS ADMIRABLE QUALITIES AS A MAN AND NATURALIST,

OF THE IMPULSE HE GAVE TO THE STUDY OF

ENTOMOLOGY IN THE NEW WORLD, AND

OF THE AID HE RENDERED TO

BEGINNERS IN THAT

SCIENCE. 



\section{PREF A CE.}

Ix preparing this little book the aim has been to make it generally useful to different classes of readers. Beginners in the study will find in it copious directions for collecting and preserving insects, how to form cabinets, how to mount insects for the microscope, and how to prepare them for study, as well as guides to the literature containing the description of species. While amateurs and dilettanti entomologists may find useful hints, the needs of those who wish to make a serious study of these animals hare not been orerlooked, and it is hoped that the book will be of some service in leading such students to pay more attention to the modes of life, transformations, and structure of insects than has yet been done in this country.

The book is also designed as a hand-book for the farmer, the fruit-grower, and the gardener. Besides treating of the ilements of the science and the means of ascertaining to what order and family their insect pests belong, the reader is referred to descriptive works and reports for fuller information, while Chapter $\mathrm{V}$. gires the fundamental principles of Economic Entomology, with brief accounts of the nore injurions insects and the natural and artificial means of ehecking their attacks. On account of the prominence giren to this topic it is hoped that the book will, with its copions glossary, be serviceable to agricultural editors and nseful as a text-book in agricultural schools and colleges.

As a first book in entomology it is also designed to be an introduction to the author's "Guide to the Study of In. sects," 
The classification presented is in accordance with recent studies and the conviction that certain of the lower so-called "orders" of insects, such as the "Orthoptera," "Pseudoneuroptera," are heterogeneons, unnatural groups, which for the sake of clearness and truth to nature should be broken up into distinct orders. The class of insects, therefore, is divided into sixteen orders instead of eight, as may be seen in tabular form on p. 56, and the usual succession of orders has been reversed, the book beginning with the lowest, the wingless insects, and ending with the highest, the Hymenoptera. This order agrees with the probable mode of evolution of the class, and with the geological succession of insects, so far as we know it; insects like cockroaches, grasshoppers, etc., being the first to appear, those with a metamorphosis, as neuroptera, beetles, flies, moths, ants, and bees, succeeding them.

In 1863 the an thor proposed a new classification of insects, placing the Hymenoptera at the head of the insect-series, the Coleoptera having, because, perhaps, from being the favorites of collectors, been assigned this position. Since that time it has been gratifying to see that, at the present time, not only in the United States, but in England and on the Continent, the Hymenoptera by general consent crown the summit of the tree of insect life.

The present scheme of classification was in part worked ont by the anthor (contrary to his early convictions or prejudices) and published in 1883, when ten orders instead of eight were adopted; while it was remarked that the three groups (i.e., white ants, etc., the may-flies, and the dragonflies) composing the "Psendoneuroptera" might hereafter be regarded as entitled to the rank of orders. It shonld also be borne in mind that some of the leading entomologists, as Westwood and others, had for many years regarded the ear-wigs, the caddis-flies, the Thripidx, and the fleas as representing distinct orders. While we were considering it a debatable question whether these importunt types had not been unwarrantably "lumped" with the older Limman 
orders, Kraepelin's careful analysis of the affinities of the fleas appeared in 1854, and the year after Dr. F. Braner's "Systematisch-Zoologische Studien," in which he carefully and yet boldly discusses the classification of inseets, and takes more analytical views than any of his predecessors. Referring the Thysanura to a separate sub-class, Braner then, as we had previously done, divides the winged insects into a number of super-order's, whose limits, however, differ much from those assigned to the super-orders proposed by us; yet we both agree as to the necessity of such groups.

Braner then proceeds to divide the winged insects into sixteen orders, beginning, as we had done, with the earwigs, Dermaptera, and ending with the Hymenoptera. He regards the may-flies, the dragon-flies, the stone-flies (Perlidæ), the white ants and their allies, the 'Ihripidæ, the forceps-tails, the caddis-flies, and the fleas as types of distinct orders. When so able and somnd a systematist arrives at such conchusions, we feel emboldened to adopt them, particularly as they coincide with our own maturer views.

We have ventured to give the ordinal name Plectopter a to the may-flies, and Mecopter to the Panorpatæ of Braner, but the credit of referring these types to distinct orders belongs mainly to that eminent systematist.

Although these changes in classification are based on our increased knowledge of insects, it is also very convenient to adopt a larger number of orders. 'There are probably about a million species of insects now existing, and it is unmatural to crowd them into the old Linnaan orders. While the Mollusks (about 40,000 living speeies) are divided into twelve orders, and the 5000 species of Crustacea into six; and while the 10,000 species of living fishes are variously divided into from six to fourteen orders, the class of reptiles into eleven orders, the 7000 to 8000 species of existing birds into from seren to eighteen orders, and the 3500 described living speeies of mammals into fourteen orders, it seems not unreasonable to suppose that the number of insect orders is at least proportionately as great. 
So progressive a science as Zoology, and especially its subdivision entomology, is in a transitory state, especially systematic entomology. We cannot, like the Chinese, actually worship Linnæus, our zoological Confucius; we cannot pay too great deference to any system. Our ideas of classification must change with our increasing knowledge. With the evolution theory as a useful instrument of research, our systems of classification representing what we suppose to be the phylogeny of the class, we have a philosophical basis, a working theory, which will throw light on dark places, and solve many a knotty point. It is for this reason that we need to study the embryology and life-history of insects, supplementing these with anatomical investigations, besides carrying on the work of collecting, describing, and thus enlarging our knowledge of the distribution of insects in space and time.

The author gratefully acknowledges kind aid received from several eminent naturalists in revising the portions dealing with subjects of which they have a special knowledge. Dr. P. R. Uhler has read the original ms. and proof of the pages treating of the Hemiptera; Mr. Samuel Henshaw the same of the Colcoptera; and Dr. S. W. Williston the pages devoted to the Diptera; while Professor Farlow of Harvard University has kindly read the proof of the section on Diseases of Insects due to Animal and Vegetable Germs; Mr. N. N. Mason of Providence, R. I., has also read the proof of Chapter VIII., and made some valuable suggestions.

Besides a number of cuts purchased of Prof. C. V. Riley, which are acknowledged in the text, Figs. 87, 88, and 89 are taken from Darwin's Descent of Man (D. Appleton \& Co., New York); for electrotypes of several figures, from his work on butterflies, I am indebted to S. H. Scudder, Esq. ; Fig. 238 was loaned by Prof. J. A. Lintner; Fig. 186 by the U. S. Agricultural Department; and of Fig. 83 the author was allowed the use by the Secretary of the Smithsonian Institution. A number of electrotypes from Judeich 
and Nitsche's work on forest insects was also purchased of the Vienna publisher.

'The figures are, unless stated to be of natural size, enlarged; in some of them a line by the side indicates the length of the specimen from which the figure was drawn.

Providence, R. I., June 25, 1888. 



\section{TABLE OF CONTENTS.}

\section{CHAPTER I.}

THE STRUCTURE OF INSECTS.

External anatomy

Abdomen, . . . . . . . . . . . . . . 2

Thorax, . . . . . . . . . . . . . . 4

Head, . . . . . . . . . . . . . 6

Internal anatomy, . . . . . . . . . . . . . . . . 7

Esophagus, . . . . . . . . • • . 7

Crop, . . . . . . . . . . . . . . . 9

Proventriculus, . . . . . . . . . . . . . . . 9

Stomach and gastric cœca, . . . . . . . . . . 9

Urinary tubes, . . . . . . . . . . . . 11

Intestine, . . . . . . . . . . . . . . . . 11

Digestion, . . . . . . . . . . . . . . . . 11

Nervous system, . . . . . . . . . . . . 13

How insects walk and fly, . . . . . . . . . . . . . 17

How insects breathe, . . . . . . . . . . . . . . . . 19

The senses of insects, . . . . . . . . . . . . . . . . 21

The eyes and sense of sight, . . . . . . . . . 22

The olfactory organs and sense of smell, . . . . . 26

The gustatory organs and sense of taste, . . . . . . 27

The ears and sense of hearing, . . . . . . . . 28

Sounds produced by insects, . . . . . . . . . 30

Tactile organs, . . . . . . . . . . . 31

CHAPTER II.

GROWTH AND METAMORPHOSIS OF INSECTS. 32-53

Egg-producing organs, . . . . . . . . . . . . . . . 32

The ovaries, . . . . . . . . . . . . . . 34

The ovipositor, . . . . . . . . . . . . 34 
The testes, . . . . . . . . . . . . 34 The egg, . . . . . . . . . . . . . . . . . . . 34 Growth of the insect within the egg, . . . . . . . . . . . 35

The egg-cutter, . . . . . . . . . . . . . . . 38

Metamorphosis of insects-the larta, . . . . . . . . . . 38

Number of larval moults, . . . . . . . . . . . 39

The pupa, . . . . . . . . . . . . . . . . . 40

The imago, . . . . . . . . . . . . . . . . . . . 41

Parthenogenesis, . . . . . . . . . . . . . . . . . 41

Broods or generations of insects, . . . . . . . . . . . . 42

Contagious diseases of insects due to animal and regetable germs, . 42

The destruction of insect pests by means of insect fungi, . . . . 45

Unusual increase in the number of insects, . . . . . . . . . 48

Influence of changes of temperature on insect-life, . . . . . . 49

Periodicity in insect-life, . . . . . . . . . . . . . . 52

Number of species of insects, . . . . . . . . . . . . 52

\section{CHAPTER III.}

CLASSIFICATION OF INSECTS.

Synopsis of the orders of insects, . . . . . . . . . . . . 54

Tabular view of the orders of insects, . . . . . . . . 56

Order I. Thysanura, . . . . . . . . . . . 56

Order II. Dermaptera,. . . . . . . . . . . . . . 58

Order III. Orthoptera, . . . . . . . . . . . . . . 59

Order IV. Platypter', . . . . . . . . . . . . . 63

Order V. Odonata, . . . . . . . . . . . 68

Order VI. Plectoptera, . . . . . . . . . . . . 71

Order VII. Thysanoptera, . . . . . . . . . . 73

Order VIII. Hemiptera, . . . . . . . . . . . . . 74

Order IX. Neuroptera, . . . . . . . . . . . 84

Order X. Mecaptera, . . . . . . . . . . . 88

Order XI. Trichoptera, . . . . . . . . . . . . 90

Order XII. Coleoptera, . . . . . . . . . . . . 91

Orter XIII. Siphonaptera, . . . . . . . . . . 115

Order XIV. Diptera, . . . . . . . . . . . . . 117

Order XV. Lepidoptera, . . . . . . . . . . . . 137

Order XVI. Hymenoptera, . . . . . . . . . . 161 
CHAPTER IV.

INSECT-ARCHITECTURE.

PAGE

178-188

Leaf-rollers,

Gall-makers,

Leaf-miners,

Case-worms,

Nests of ants, 183

Nests of wasps 183

Nests of bees,

\section{CHAPTER V.}

INSECTS INJURIOUS AND BENEFICIAL TO AGRICULTURE. 189-223 Economic Entomology, 189

Insects injurious to field and garden crops, . . . . . . . . 191

Injuring wheat, . . . . . . . . . . . . . . 191

Injuring corn, . . . . . . . . . . . . . . 198

Injuring the cotton plant, . . . . . . . . . 200

Injuring the potato, . . . . . . . . . . . . . 202

Injuring the cabbage, radish, etc., . . . . . . . 205

Injuring the hop-vine, . . . . . . . . . . 208

Injuring the grape-vine, . . . . . . . . . . . . 209

Injuring fruit-trees, . . . . . . . . . . . . . 211

Insects beneficial to agriculture, . . . . . . . . . . . 217

Insectivorous insects, . . . . . . . . . . . . 220

Preventive and direct remedies against the attacks of insects, . . . 221

Insecticides, . . . . . . . . . . . . . . 222

Miscellaneous remedies, . . . . . . . . . . 223

\section{CHAPTER VI.}

DIRECTIONS FOR COLLECTING, PRESERTING, AND REARING INSECTS.

224-288

Where to look for insects, . . . . . . . . . . . . 224

Collecting apparatus, . . . . . . . . . . . . . 226

Killing insects for the cabinet, . . . . . . . . . . . . . 228

Pinning insects, . . . . . . . . . . . . . . . . . 230

Preservative fluids, . . . . . . . . . . . . . . 231

Preparing insects for the cabinet, . . . . . . . . . . . . 234

Insect cabinet, . . . . . . . . . . . . . . . . . . 238

Transportation of insects, . . . . . . . . . . . . . 240 
PAGE

Preservation of lavice, . . . . . . . . . . . . . . 240

Rearing aquatic larve, . . . . . . . . . . . . . . 242

Rearing insects in general, . . . . . . . . . . . . . 243

Sugaring for moths, . . . . . . . . . . . . . . . 246

Traps for moths, . . . . . . . . . . . . . . . . 246

Rearing caterpillars, . . . . . . . . . . . . . . 247

Hibernatiny larve, . . . . . . . . . . . . . . . . 252

Management of pupa, . . . . . . . . . . . . . . 252

Pairing or mating Lepidoptera in captivity, . . . . . . . . 253

Treatment of the eggs, . . . . . . . . . . . . . . . 254

Collecting and rearing Micro-lepidoptera, . . . . . . . . . 254

Preserving micro-larve in alcohol, . . . . . . . . . . . 266

Preserving larve dry, . . . . . . . . . . . . . . . 267

Bleaching the wings for the study of the venation, . . . . . . 268

Mounting the wings of Micro-lepidoptera, . . . . . . . . . 269

Mounting the wings of Macro-lepidoptera, . . . . . . . . . 269

To remove grease, . . . . . . . . . . . . . . . 270

Collecting and Preserving Coleoptera, . . . . . . 271

Rearing tiger-and ground-beetles, . . . . . . . . . 276

Rearing of burying-beelles, . . . . . . . . . . . 278

Rearing wood-boring larva, Longicorns, etc., . . . . . 278

Rearing of bark- and bast-boring beetles, . . . . . . . 279

Rearing larve of dung-beetles, . . . . . . . . . . 279

Cleansing greasy beetles, . . . . . . . . . . . . 280

To wash old, soiled specimens, . . . . . . . . . 280

Collecting and Preserving Hemiptera, . . . . . . . 280

Examining live Aphides, . . . . . . . . . . . . 281

Preservation of Orthoptera, . . . . . . . . . . . 282

Preservation of Dragon-flies, Maf-Flies, Caddis-Flies,

ETC., • • . • . . . . • . . • . • • • . 282

Collecting and Rearing Diptera, . . . . . . . . . 284

C'ollection and Preservation of Hymenoptera, • • • . 287

\section{CHAPTER VII.}

MODE OF DISSECTING INSECTS.

The external anatomy, . . . . . . . . . . . . 289

The internal anatomy, . . . . . . . . . . . . . . 289

Dissection of Aphides, . . . . . . . . . . . . 292 


\section{CHAPTER VIII.}

PAGE

CUTTING AND MOUNTING MICROSCOPIC SECTIONS OF INSECTS AND MOUNTING THEM WHOLE, ETC. 294-325

Fixation of the histological elements, . . . . . . . . . . . 295

Dehydration, . . . . . . . . . . . . . . . . . . 295

Embedding, staining, and cutting, . . . . . . . . . . . 296

Mounting sections, . . . . . . . . . . . . . . 300

To render small insects or larve transparent, . . . . . . . . 301

Mounting transparent aquatic insects, . . . . . . . . . . . 301

Transmission, preservation, and mounting Aphides and similar

insects,

Thomas W. Starr's method of preparing and mounting with pressure

insects entire as transparent objects, . . . . . . . . . . 305

Method of preparing minute entomostraca, mites, spiders, and insects, 307

Carbolic ucid in balsam mounting, . . . . . . . . . . . 307

Killing and preserving insects, . . . . . . . . . . . . 307

Bleaching fluid for insects, . . . . . . . . . . . . . . 308

To clear objects for balsam mounting, . . . . . . . . . . . 308

Mounting insects in balsam without pressure, . . . . . . . . . . 308

Preparing and mounting dissections of the appendages, etc., . . . 309

Mounting minute insects and acari in balsam, . . . . . . . . 309

Sections of the brain, . . . . . . . . . . . . . . . . 310

Preparing the sympathetic nervous system of the cockroach, . . . 311

Making sections through and bleaching the eyes of insects, . . . . 311

Expanding and mounting the tongue of the louse and blow-fly, . . 314

Microscopic sections of the proboscis of flies, bugs, and bees, . . . 315

Sections of the ovipositor or sting, . . . . . . . . . . . 315

Mounting the gizzards of insects, . . . . . . . . . . . 316

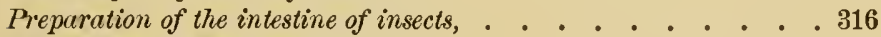

Preparation of insect spiracles, . . . . . . . . . . . . 317

Mounting of trachea, . . . . . . . . . . . . . . . . . . . . . . . . . . . . . .

Mounting legs, etc., of insects, . . . . . . . . . . . 318

Mounting the skin of caterpillars, . . . . . . . . . . 318

Dissection and preparation of the spermatic filaments, . . . . . 318

Making sections of eggs, . . . . . . . . . . . . . . . 319

Preparing embryos of insects, . . . . . . . . . . . . . 321

Surface study of eggs, and hardening for cutting, etc., . . . . . 322

Mounting dry the eggs of insects, . . . . . . . . . . . 323

Preparing fire-flies, etc., . . . . . . . . . . . . . . 323

Mounting dry the appendages of insects for pinning in the cabinet, . 323

Mounting the "saw" of the Tenthredinida, . . . . . . . . 324 


\section{'THE EN'TOMOLOGIST'S LIBRARY.}

PAGE

$326-335$

Bibliographical works on Entomology, . . . . . . . . . . 326 Entomological Periodicals, . . . . . . . . . . . . . 327

General Entomology, . . . . . . . . . . . . . 328

External Anatomy and Morphology, . . . . . . . . . 329

Internal Anatomy and Histology, . . . . . . . . . . . 329

(a) The nervous system, . . . . . . . . . . . . 330

(b) Organs of special sense and their physiology, . . . 330

(c) Organs of circulation and respiration, . . . . . . 331

(d) Organs of digestion, . . . . . . . . . . . . 331

(e) Organs of locomotion and their physiology, . . . . 332

(f) Organs of reproduction, ovipositor, etc., . . . . . 332

Embryology of Insects . . . . . . . . . . . . . . . 332

Phylogeny or Origin of Insects, . . . . . . . . . . . . 333

Insects and the Fertilization of Plants, . . . . . . . . . . 333

Geographical Distribution, . . . . . . . . . . . 333

Fossil Insects, . . . . . . . . . . . . . . • . . . 334

Economic Entomology, . . . . . . . . . . . . . 334

Glossary, . . . . . . . . . . . . . 337

INDEX, . . . . . . . . . . . . . . 355 


\section{ENTOMOLOGY.}

\section{CHAPTER I.}

\section{THE STRUCTURE OF INSECTS.}

WHEN we consider that the class of insects alone comprises about four fifths of the animal kingdom, and that there are upwards of 200,000 species in collections, it would seem a hopeless task to define what an insect is. One may study a definition of the class of insects, and read pages and even volumes about the structure of insects in general, but such knowledge would be second-hand, and it is far better for the beginner to simply catch a grasshopper, and carefully examine it for himself. By so doing he will learn more in a few hours than the mere student of books will accomplish in weeks. Still, one who knows nothing about insects needs some guide to give the names to the parts readily seen, and to point out those organs and their details which might be overlooked.

We will suppose that the beginner has a common redlegged locist or grasshopper in his hand; and in order to readily examine it he should be provided with a Coddington or any other lens, and a stand to hold it when both hands are needed to dissect the specimen, a pair of slender iron forceps, and a needle mounted in a pine handle with which to separate the legs and month-parts. Directions for collecting and dissecting insects will be found in the sixth chapter. Meanwhile we may say that any boy or girl ean catch a grasshopper, and after it is caught it may be killed 
without its suffering any pain, by throwing it into a bottle containing cotton saturated with ether. It may when dead be taken out of the collecting-bottle and dried. It is most convenient to pin it. 'This may be done by thrusting a slender insect-pin through the collar. For class use it is better to preserve a lot of grasshoppers in alcohol; before nsing them they can be soaked in water to take out the alcoholic odor, and can then be easily handled without being pinned, and the wings infolded or the mouth-parts and legs moved without their breaking off.

External Anatomy.-On making a superficial examination of the locust (Caloptenus femur-rubrum), or the Rocky Mountain locust ( $C$. spretus), its body will be seen to consist of an external crust, or thick, hard integument, protecting the soft parts or viscera within. This integument is at intervals segmented or jointed, the segments more or less like rings, which, in turn, are subdivided into pieces. 'I'hese segments are most simple and easily comprehended in the abdomen or hind-body, which is composed of ten of them. The body consists of seventeen of these segments, variously. modified and more or less imperfect and difficult to make out, especially at each extrenity of the bodyi.e., in the head and at the end of the abdomen. These seventeen segments, moreover, are grouped into three regions, four composing the head, three the thorax, and ten the hind-body, or abdomen. On examining the abdomen, it will be found that the rings are quite perfect, and that each segment may be divided into an upper (tergal), a lateral (plemal), and an under (sternal) portion, or arc (Fig. 1, A). T'hese parts are respectively called tergite, pleurite, and sternite; while the upper region of the body is called the tergum, the lateral the pleurum, and the ventral or under portion the sternum.

As these parts are less complicated in the abdomen, we will first study this region of the body, and then examine the more complex thorax and head. T'he abdomen is a little over half as long as the body, the tergum extending fa: 
down on the side and merging into the plenrum withont any suture or seam. The pleurum is indicated by the row of spiracles, which will be noticed firther on. The sternum
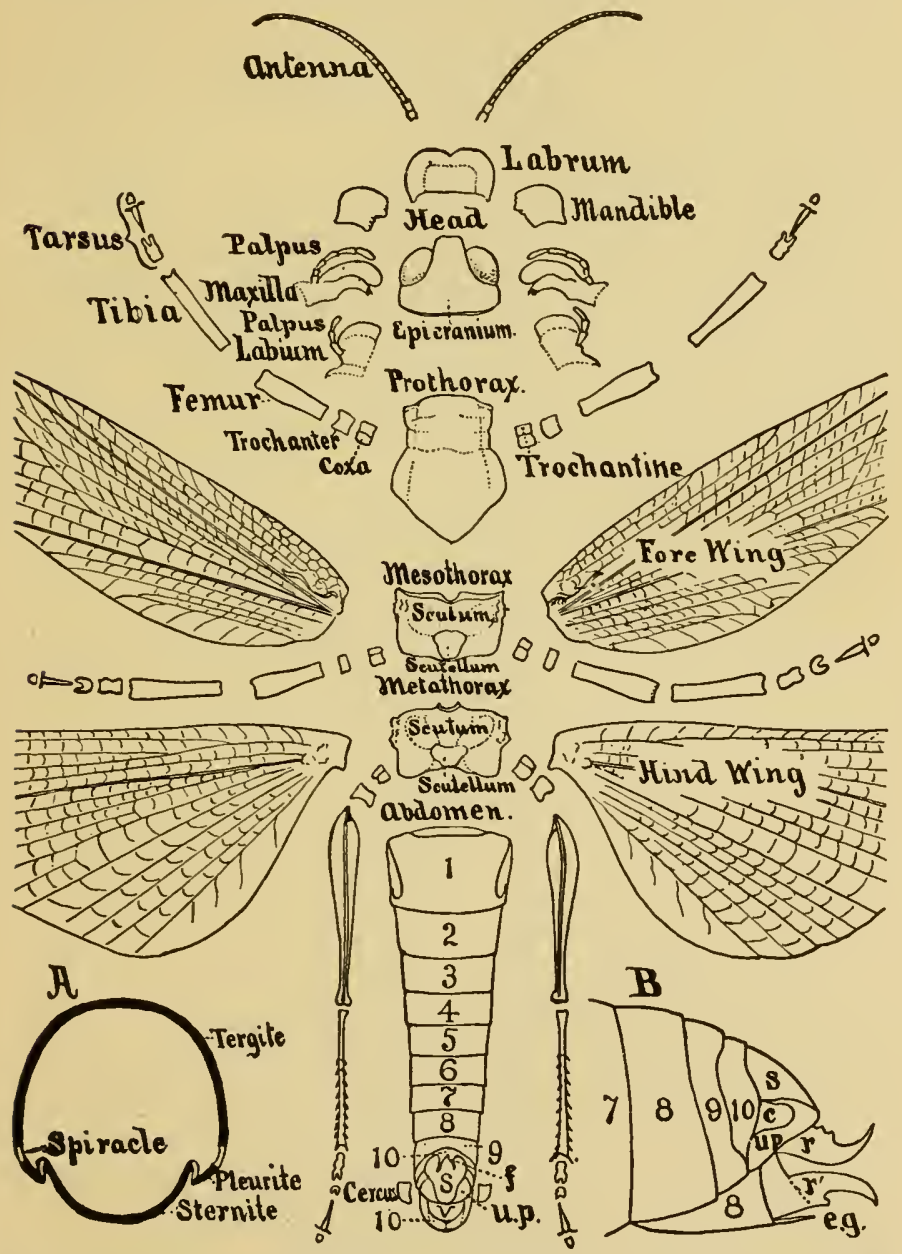

F1G. 1.-External anatomy of Caloptenus spretus, the head and thorax disjointed.-Kingsley del. 
forms the ventral side of the abdomen, and meets the pleurum on the side of the body.

In the female (Fig. 1, B) the abdomen tapers somewhat toward the end of the body, to which are appended the two pairs of stout, hooked spines, forming the ovipositor (Fig. 1, $B, r, r^{\prime}$ ). The anus is situated above the upper and larger pair, and the external opening of the oviduct is situated between the smaller and lower pair of spines; it is bounded on the ventral side by a movable, triangular acute flap, the egg-guide (Fig. 1, B,e g, and Fig. 4).

The thorax, as seen in Fig. 1, consists of three segments, called the prothorax, mesothorax, and metathorax, or fore, middle, and hind thoracic rings. 'They each bear a pair of legs, and the two hinder each a pair of wings. The upper portion (tergum) of the middle and hind segments, owing to the presence of wings and the necessity of freedom of movement to the muscles of flight, is divided or differentiated into two pieces, the scutum and scutellum* (Fig. 1), the former the larger, extending across the back; the scutellum being a smaller, central, shield-like piece. The protergum, or what is usually in the books called the prothorax, represents either the scutum or both scutum and scuteilum, the two not being differentiated.

'The fore wings are long and narrow, and thicker than the hinder, which are broad, thin, and membramous, and most active in flight, being folded up like a fan when at rest and tucked away out of sight under the fore wings, which act as wing-covers.

Turning now to the side of the body under the insertion of the wings (Fig. 2), we see that the side of each of the middle and hind thoracic rings is composed of two pieces, the anterior, episternum, resting on the sternum, with the epimerum behind it; these pieces are vertically high and

* There are in many insects, as in many Lepidoptera, Hymenoptera, and Neuroptera, four tergal pieces-i.e., præscutum, scutum, scutellum, and postscutellum, the first and fourth pieces being usually very small and often obsolete. 


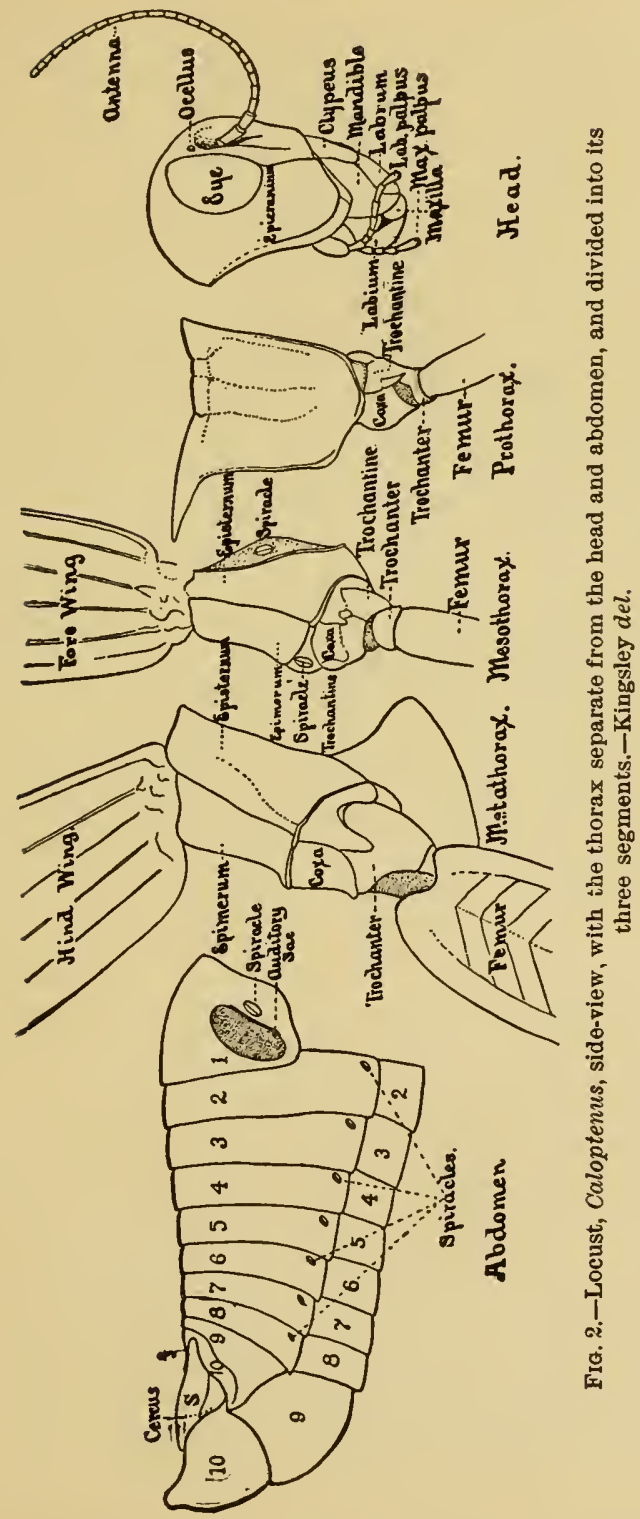


narrow, and to them the leg is inserted by three pieces, called respectively coxa, trochantine, and trochanter (see Fig. 2), the latter forming a true joint of the leg.

The legs consist of five well-marked joints, the femur (thigh), tibia (shank), and tarsus (foot), the latter consisting in the locust of three joints, the third bearing two large claws with a pad between them. The hind legs, especially the femur and tibia, are very large, adapted for hopping.

The sternum is broad and large in the middle and hind thorax, but small and obscurely limited in the prothorax, with a large conical projection between the legs.

The head in the adult locust is mainly composed of a single piece called the epicranium (Figs. 2 and $3, E$ ), which carries the compound eyes, ocelli, or simple eyes (Fig. 3,

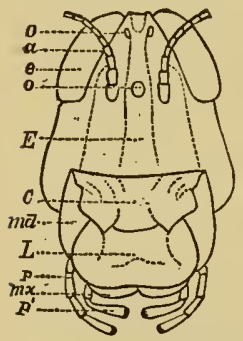

Fig.3.-Front view of the head of C. spretus. $E$, epicranium; $C$, clypeus; $L$, labrum; o o, ocelli; $e$, eye; $a$, antenna; $m d$, mandible; $m x$, portion of maxilla uncovered by the labrum; $p$, maxillary palpus; $p^{\prime}$, labial palpus.Kingsley del. $o$ ), and antennæ. While there are in reality four primary segments in the head of all winged insects, corresponding to the four pairs of appendages in the head, the posterior three segments, after early enbryonic life in the locust, become obsolete, and are mainly represented by their appendages and by small portions to which the appendages are attached. The epicranium represents the antennal segment, and mostly corresponds to the tergum of the segment. The antennæ, or feelers, are inserted in front of the eyes, and between them is the anterior ocellus, or simple eye, while the two posterior ocelli are situated above the insertion of the antennæ. In front of the epicranium is the clypeus (Fig. 3), a piece nearly twice as broad as long. 'To the clypens is attached a loose flap, which eovers the jaws when they are at rest. This is the upper lip or labrum (Fig. 3). There are three pairs of month-appendages: first, the true jaws or mandibles (Fig. 1), which are single-jointed, and are broad, short, solid, with a toothed cutting and grinding 
edge, adapted for biting. The mandibles are situated on each side of the mouth-opening. Behind the mandibles are the maxillæ (Fig. 1), which are divided into three lobes, the inner armed with teeth or spines, the middle lobe unarmed and spatula-shaped, while the onter forms a fivejointed feeler ealled the maxillary palpus. The maxillie are accessory jaws, and probably serve to hold and arrange the food to be ground by the true jaws. 'The floor of the month is formed by the labium (Figs. 1 and 2), which in reality is composed of the two second maxillæ, soldered together in the middle, the two halves being drawn separately in Fig. 1.

Within the mouth, and situated upon the labium, is the tongue (lingua), which is a large, membranous, partly hollow expansion of the base of the labrum; it is somewhat pyriform, slightly keeled above, and covered with fine, stiff hairs, which, when magnified, are seen to be long, rough, chitinons spines, with one or two slight points or tubercles on the side. 'These stiff hairs probably serve to retain the food in the mouth, and are, apparently, of the same strueture as the teeth in the crop. The base of the tongue is narrow, and extends back to near the pharynx (or entrance to the gullet), there being on the floor of the month, behind the tongue, two oblique slight ridges, eovered with stiff, golden hairs, like those on the tongne.

The student may separate the body, after being hardened in alcohol, into the parts represented by Fig. 1, as indieated by the table on the following page, and neatly gum them in their proper order upon a card with liquid glue or mueilage.

Internal Anatomy.-The in ternal anatomy may be studied by removing the dorsal wall of the body, and also by hardening the inseet several days in alcohol and cutting it in two longitudinally by a sharp scalpel.

The oesophagus (Fig. 4,, ) is short and eurved, continnous with the roof of the mouth. There are several longitudinal irregular folds on the inner surface. It terminates in the centre of the head, direetly muder the brain or supraœsophageal ganglion, the end being indicated by several 


\section{TABULAR VIEW OF THE EXTERNAL PARTS OF AN}

\section{INSECT'S BODY.}

Head (composed of 4 segments).

Parts of the skin, or integument, $\left\{\begin{array}{l}\text { Occiput. } \\ \text { Epicranium, bearing the antennæ }\end{array}\right.$ above................. $\left\{\begin{array}{l}\text { Clypeus. } \\ \text { Labrum, upper lip. }\end{array}\right.$

Epipharynx.

Parts of the skin, or integument, \{ sides and below........... Gena, cheeks. Gula $\{$ Mentum, chin.

Antennæ, feelers.

Appendages.............. $\left\{\begin{array}{l}\text { Mandibles, jaws. } \\ \text { 1st Maxillæ, with their palpi. }\end{array}\right.$

2d Maxillæ, or labium, with its

Thorax (composed of 3 segments).

1st segment: Prothorax........ $\left\{\begin{array}{l}\text { Pronotum. } \\ \text { Propleurum, with a spiracle. }\end{array}\right.$

Prosteruum.

Fore legs.
I Præscutum.
Scutum.
Scutellum.

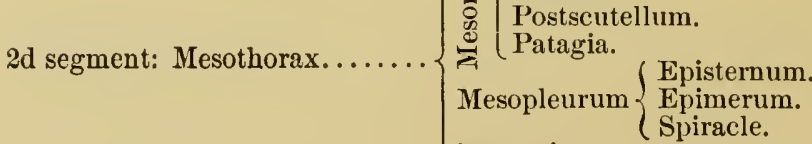

Fore wings.

Middle legs.

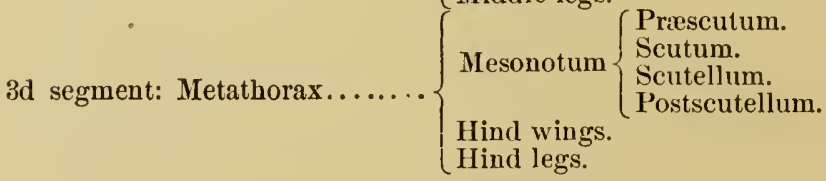

Ardomen (composed of 10 and in some insects 11 segments).
Sergite.
Segments or uromeres......... $\{$ Pleurite.
Sternite or Urosteruite.
Ovipositor.

Anal stylets, cerci or cercopoda (1 pair)-8 pairs of spiracles. 
small eonical valves closing the passage, thus preventing the regurgitation of the food. The two salivary glands consist each of a bunch of follicles, emptying by a common dnet into the floor of the month.

The oesophagus is succeeded by the crop (ingluvies). It dilates rapidly in the head, and again enlarges before passing out of the head, and at the point of first expansion or enlargement there begins a circular or oblique series of folds, armed with a single or two alternating rows of sinple spinelike teeth. Just after the crop leaves the head, the folds become longitudinal, the teeth arranged in rows, each row formed of groups of from three to six tecth, which point backward so as to push the food into the stomach. It is in the crop that the "molasses" thrown ont by the locust originates.

The proventriculus is very small in the locust, easily overlooked in dissection, while in the green grasshoppers it is large and armed with sharp teeth. A transverse section of the crop of the cricket shows that there are six large irregular teeth armed with spines and hairs. (Fig. 5). It forms a neek or constriction between the crop and true stomach. It may be studied by laying the alimentary canal open with a pair of fine scissors, and is then seen to be armed with six flat folds, suddenly terminating posteriorly, where the true stomach (chyle-stomach, ventriculus) begins. The chyle-stomaeh is about one half as thick as the crop, when the latter is distended with food, and is of nearly the same diameter thronghout, being much paler than the reddish erop, and of a flesh-color.

From the anterior end arise six large pouches called gastric cœen, which are dilatations of the true chyle-stomach, and probably serve to present a larger surface from which the chyle may escape into the body-cavity and mix with the blood, there being in insects no lacteal vessels or lymphatic system.

The stomach ends at the posterior edge of the fourth abdominal segment in a slight constriction, at which point 


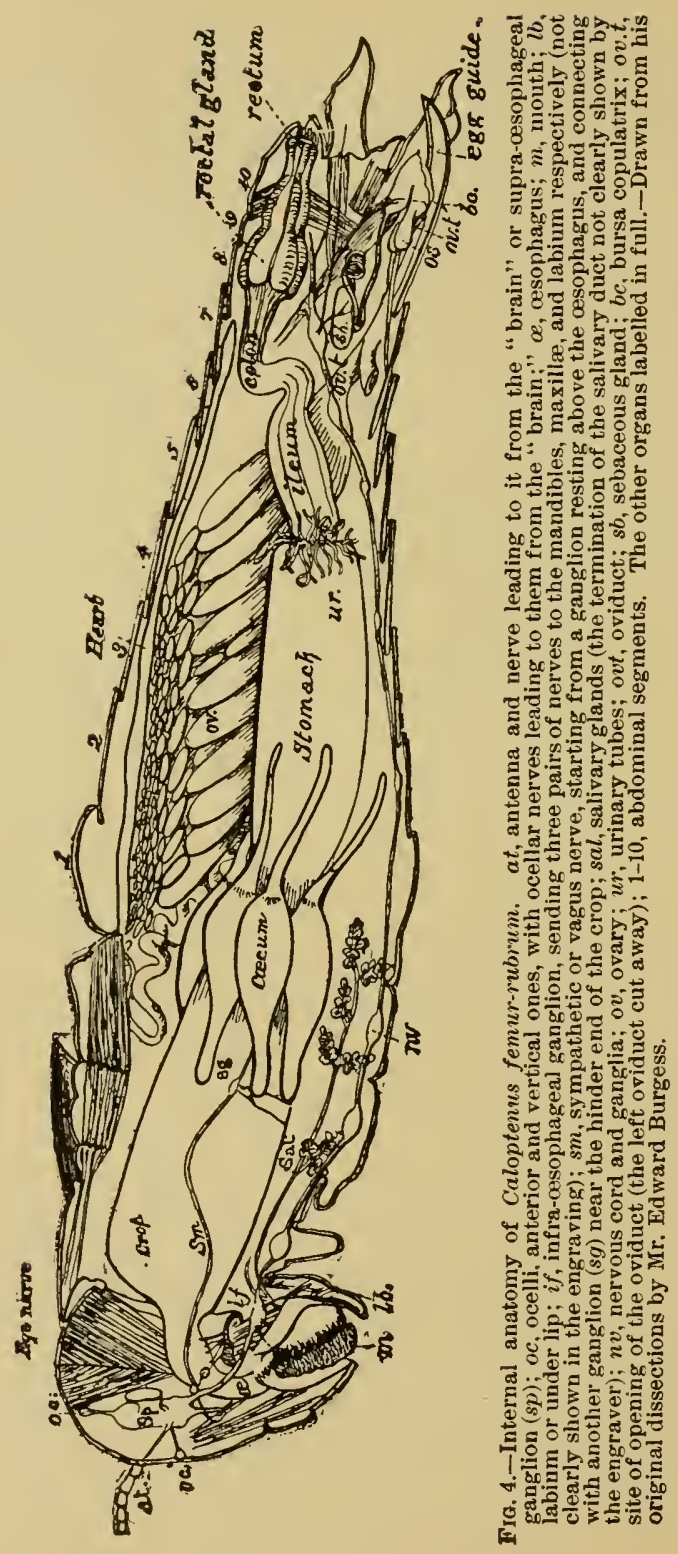


(pyloric end) the urinary tubes (vasa urinaria, Fig. 4, ur) arise. These are arranged in ten groups of about fifteen tubes, so that there are about one hundred and fifty long, fine tubes in all.

The intestine (ileum) lies in the fifth and sixth abdominal segments.

Behind the intestine is the colon, which is smaller than the intestine proper, and makes a partial twist. The colon suddenly expands into the rectum, with six large rectal glands on the outside, held in place by six muscular bands attached anteriorly to the hinder end of the colon. The rectum turns up toward its end, and the vent is situated just below the supra-anal plate.

Having described the digestive canal of the locust, with which that of the beetle (Fig. 6) and the fly (Fig. i) may be compared, we may state in a summary way the functions of the different divisions of the tract. The food after being cut up by the jaws is acted upon while in the crop by the salivary fluid; which is alkaline, and possesses the property, as in vertebrates, of rapidly transforming the

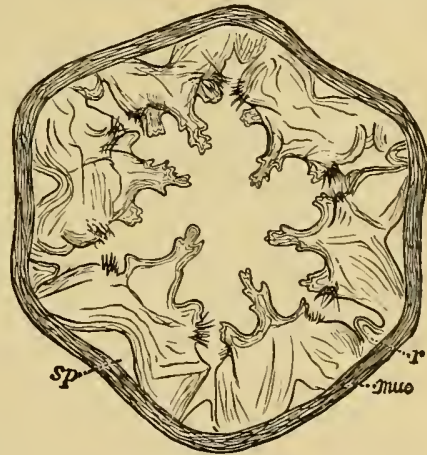

Fig. 5.-Transverse section of the proventriculus of Gryllus cinereus of Europe ; muc, muscular walls ; $r$, horny ridge between the large teeth. -After Minot. starchy elements of the food into soluble and assimilable glucose. The digestive action carried on in the crop (ingluvies) then, in a regetable-feeding insect like the locust, results in the conversion of the starchy matters into glucose or sugar. This process goes on rery slowly. When digestion in the crop has ended, the food submitted to an energetic pressure by the walls of the crop, which make peristaltic contractions, filters gradually through the short, small proventriculus, directed by the furrows and chitinous 
projections lining it. The apparatus of teeth does not triturate the food, which has been sufficiently comminuted by the jaws. This is proved by the fact, says Platean, that the parcels of food are of the same form and size as those in the crop, before passing through the proventriculus. The six large lateral pouches (cæca) emptying into the commencement of the stomach (ventriculus) are true glands,

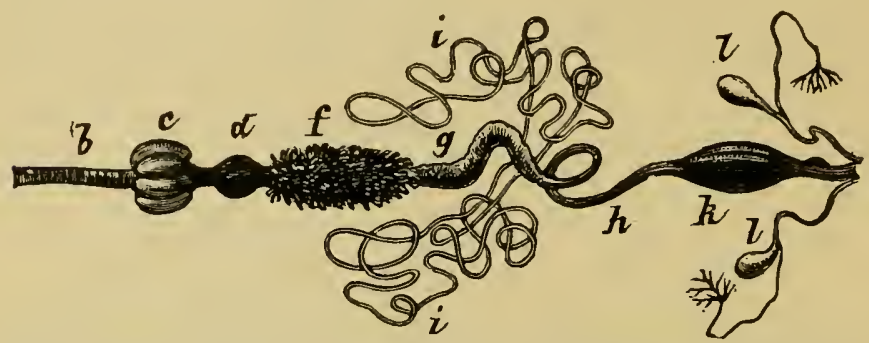

FiG. 6.-Digestive canal of a Carahid beetle. $b$, cesophagus; $c$, crop; $d$, proventriculus; $f$, chyle-stomach: $g$, posterior division of the stomach; $i$, the two pairs of urinary tuhes; $h$, intestine; $k$, rectum; $l$, anal glands.-After Dufour, from Judeich and Nitsche.

which secrete an alkaline fluid, probably aiding in digestion. In the stomach (ventriculus) the portion of the food which has resisted the action of the crop is submitted to the action of a neutral or alkaline liquid, never acid, secreted by special local glands or by the lining epithelium. In the ileum and colon active absorption of the liquid portion of the food takes place, and the intestine proper (ileum and colon) is thus the seat of the secondary digestive phenomena. The reaction of the secretion is neutral or alkaline. The rectum is the stercoral reservoir. It may be empty or full of liquids, but never contains any gas. The liquid products secreted by the urinary tubes are here accumulated, and in certain circumstances here deposit the caleuli or crystals of oxalic, uric, or phosphatic acid. Inseets, says Platean, have no special vessel to carry off the chyle, such as the lacteals or lymphaties of vertebrates; the products of digestion-viz., salts in solution, peptones, sugar in solution, and emulsionized greasy matters-pass through the fine coatings of the 
digestive canal by osmosis, and mingle outside of this canal with the currents of blood which pass along the ventral and lateral parts of the body.

Into the pyloric end of the stomach empty the urinary tubes, their secretions passing into the intestine. These organs are exclusively depuratory and urinary, relieving the body of the waste products. The liquid which they secrete contains urea (?), uric acid, and urates in abundance, hippuric acid (?), chloride of sodium, phosphates, carbonate of lime, oxalate of lime in quantity, leucine, and coloring matters.

The nervous system of the locust, as of other insects, consists of a series of nerve-centres, or ganglia, which are con-

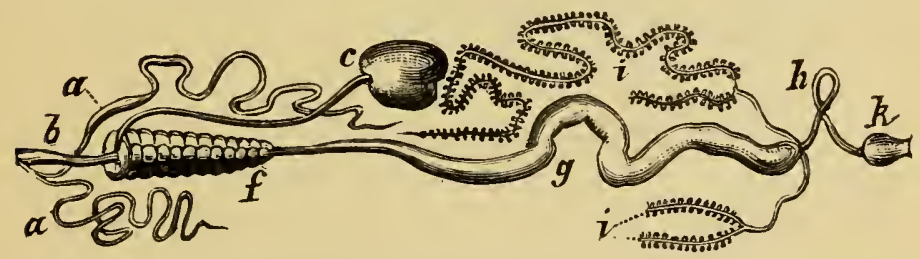

FIG. 7.-Digestive canal of Sarcophaga carnari . $a$, salivary gland; $b$, oesoph. agus; $f, g$, stomach; $h$, intestine; $i$, urinary tuves; $k$, rectum.-From Judeich and Nitsche.

nected by two cords (commissures), the two cords in certain parts of the body in some insects united into one. There are in the locust ten ganglia, two in the head, three in the thorax, and five in the abdomen. The first ganglion is rather larger than the others, and is called the "brain." The brain rests upon the osophagus, whence its name, supra-œsophageal ganglion. From the brain arise the large, short, optic nerves (Fig. 8, op), which go to the compound eyes, and from the front arise the three slender filanents which are sent to the three ocelli (Fig. 8, oc). From immediately in front, low down, arise the antennal nerves (Fig. 4, at).

The infra-œsophageal ganglion (Fig. 8, if), as its name implies, lies under the cesophagus at the base of the head, 
under a bridge of ehitine (the tentorium) and directly behind the tongue. It is connected with the supra-œsophageal

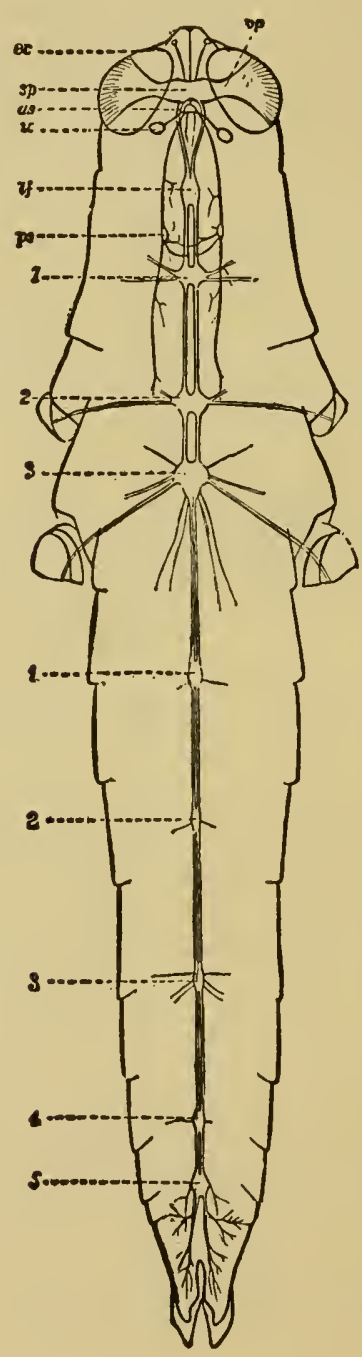

ปิ่

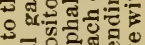
2. क्व.

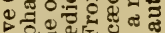

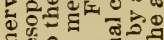
요원

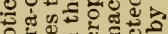
응년 용

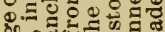
क人 त्रफ

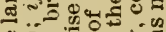
욜 世

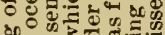
bo क $\frac{1}{2}$ क

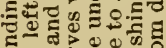

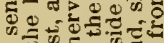

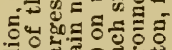

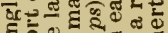

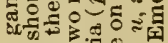
का

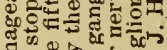

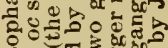
४.

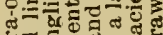
대 옳 ถో

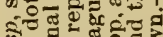
के ․․ के 횐 द्व

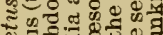

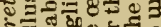
ลेष

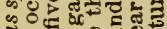
¿ิศ ड़ ญ्य है,

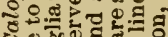

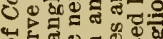

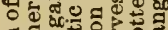
령 0 马े

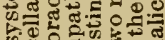

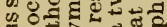
ह क 50

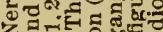
7 雨

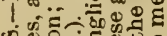

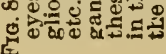


ganglion by two commissures passing up each side of the asophagus. From the under side of the infra-csophageal

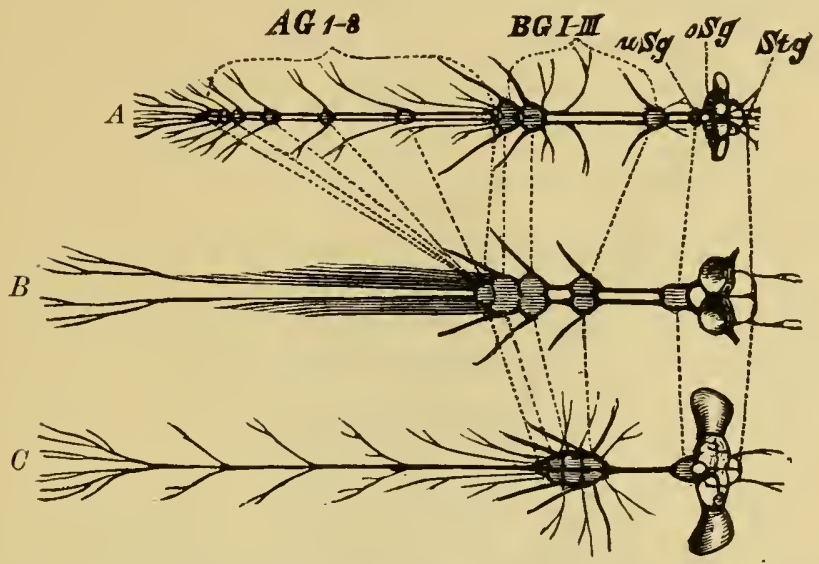

Fıg. 9.-A, nervous system of ant, Formicr rufa; $B$, Melolontha; $C$, flesh-fly, Sarcophaga camaria; Stg, frontal ganglion of the sympathetic nerve; $0 S g$. brain; $u S g$, infra-cesophageal gauglion; $B G$, thoracic ganglia; $A G$, abdominal ganglia: the dotted lines passing through homologous ganglia.-From Judeich and Nitsche.

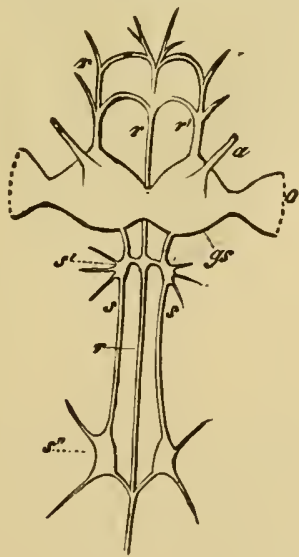

Fia. 10.-Supra-cesophageal ganglion and visceral (or sympathetic) nervous system of the silk-worm moth (Bombyx mori). gs, supra-cesophageal ganglion ("brain"); $a$, antennary nerve; o. optic nerve; $r$, azrgos trunk of the visceral nervous system: $r^{\prime}$, its roots arising from the supra-cesophageal ganglion: $s$. paired nerve with its ganglionic enlargements, $s^{\prime} s^{\prime \prime}$.-After Brandt, from Gegenbaur. 
ganglion arise three pairs of nerves, which are distributed to the mandibles, maxillæ, and iabium. The mandibular nerves project forward and arise from the anterior part of the ganglion, near the origin of the supra-cesophageal commis-

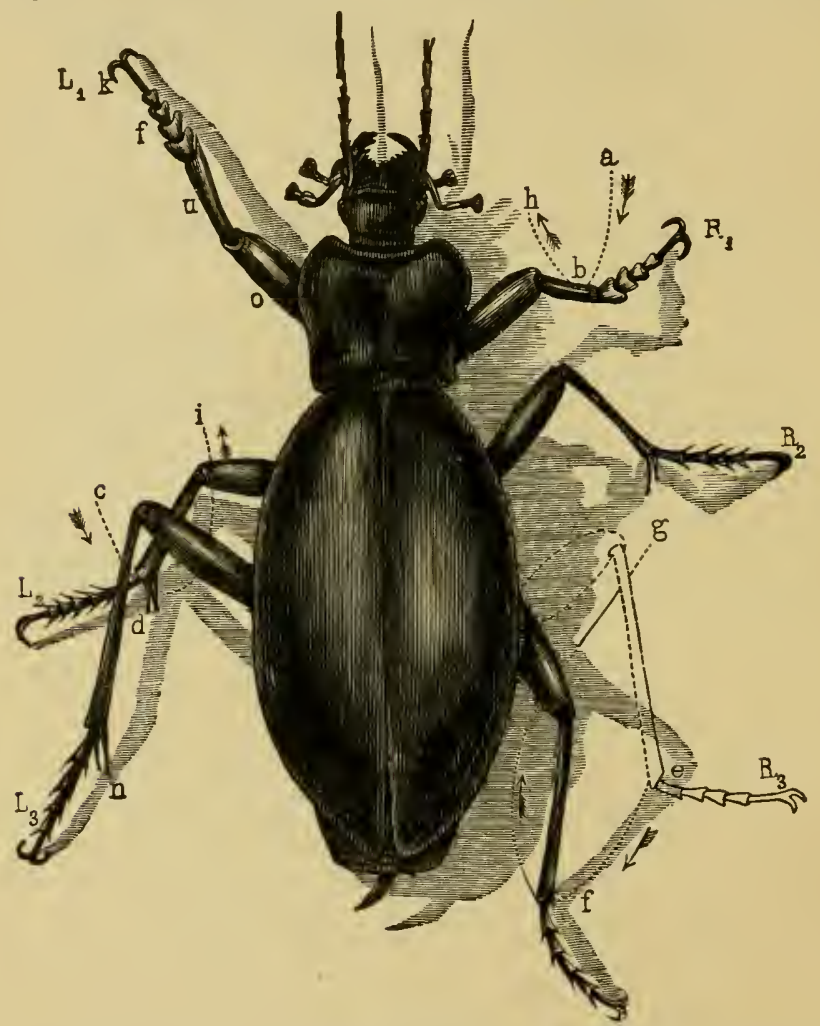

Frg. 11. A Carabus beetle in the act of walking or running. Three legs $\left(L_{1}\right.$, $\left.R_{2}, L_{3}\right)$ are directed forward, while the others $\left(R_{1}, L_{2}, R_{3}\right)$, which are directed backward toward the tail, have ended their activity. $a b, c d$, and $e f$ are curves described by the end of the tibiæe and passing back to the end of the body: $b h, d i$, and $f g$ are curves described by the same legs during their passive change of position.-After Graber.

sures, while the maxillary and labial nerves are directed downward into those organs.

'T'he sympathetic ganglia are three in number; one situuated just behind the supra-œsophageal ganglion (Fig. 8, 
$a s)$, resting on the oesophagus, and two others situated each side of the crop, low down. Each of the two posterior ganglia is supplied by a nerve from the anterior ganglion. Two nerves pass under the crop commecting the posterior ganglia, and from each posterior ganglion a nerve is sent backward to the end of the proventrienlus. A pair of nerves pass under the cesophagus from cuch side of the anterior sympathetic ganglion, and another pair pass downward to a round white body, whose nature is unknown (Fig. 8, $u$ ).

How Insects Walk and Fly.-In walking, the locust, beetle, or, in fact, any insect, raises and puts down its six legs alternately, as may be seen by observing the movements of a beetle (Fig. 11). As Carlet states, an insect's legs move according to the following formula:

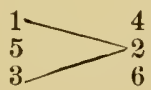

With the claws on their fore legs they pull themselves forward; the middle legs seem to support and steady the body, also pushing it somewhat; while the hind legs in many beetles push the body forward.* While the structure of the limb of a vertebrate and inseet is not lomologous, yet the meehanism or functions of the parts are in the main the same as indicated in Figs. 12 to 15.

The footprints of insects are

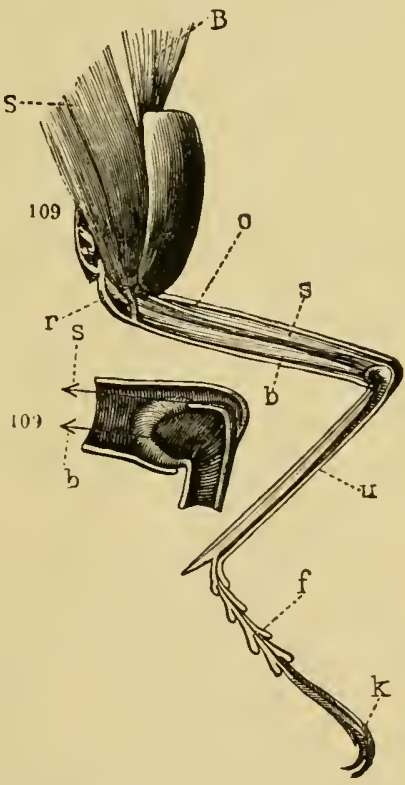

FIG. 12.-Section of the fore leg of a Stag beetle, showing the muscles. $S$, extensor, $B$. flexor, of the leg; $s$, extensor, $b$, flexor, of the femur; $o$. femur; $u$, tibia; $f$, tarsus; $k$, claw; $109_{x}, s$, extensor, $b$, flexor, of the femoro-tibial joint, both enlarged.-After Graber. 
sometimes left in fine wet sand on the banks of streams or by the seaside.

In Fig. 16 the black dots are made by the fore, the clear
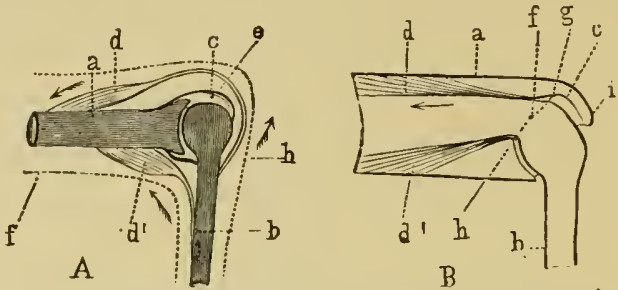

FIG. 13.-Diagram of the knee-joint of a vertebrate $(A)$ and an insect's limb $(B)$. $a$, upper, $b$, lower, shank, united at $A$ by a capsular joint, at $B$ by a folding joint; $d$, extensor or lifting muscle; $d^{1}$, flexor or lowering muscle of the lower joint. The dotted line indicates in $A$ the contour of the leg.-After Graber.

circle by the middle, and the black dashes by the hind legs (Graber).

The wings are dereloped as folds of the integument, and

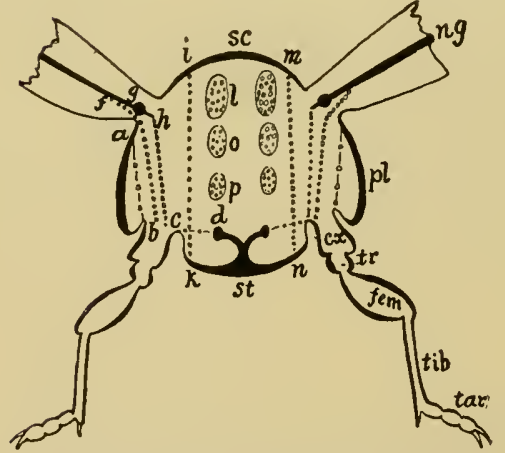

FIG. 14.--Cross-section through the thorax of a butterly. $a b$, muscles for raising, $c d$, for drawing downward and inwarl, the legs; $d$, entothorax arising fiom the sternum, $k$, st; $n g$, wing-vein; $g$, fulcrum, ol tırningpoint; $c h$, muscles for lowering, $b f$, for raising, the wing; $i k$ and $m n$, nuuscles for lowering, lo $p$, for raising, the dorsal plates.

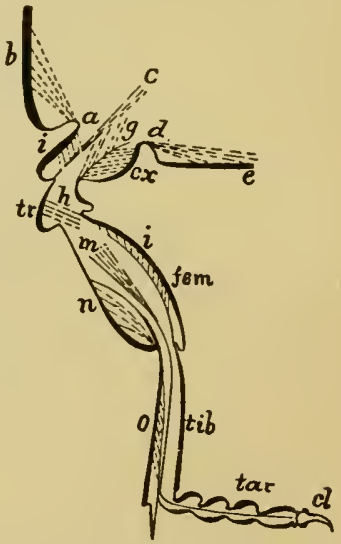

FIG. 15. - Diagram of muscles of an insect's leg. Besides the muscles at the insertion of the limb for raising and lowering it, in the trochanter $(t r)$ is a muscle for rotating the leg: $i$, for stretching the tibia $(t i b)$; $n$, Hexor of tibia: $o$, flexor of the tar. sus: $m$, retractor of the tarsus and claws $(c l)$.-After Graber. 
strengthened by hollow rods called "veins;" their branches being the "venules." There are in the wings of most insects six main veins-i.e., the costal, the subcostal, median, submedian, internal, and anal. They are hollow and usually contain an air-tube, and a nerve often accompanies the trachea in the principal veins. 'The arterial blood from the heart (as seen in the cockroach by Moseley) flows directly into the costal, subcostal, median, and submedian reins; here it is in part aerated, and returus to the heart from the hinder elge of the wings through the hinder smaller branches and the main trunks of the internal and anal veins. So that the wings of insects act as lungs as well as organs of flight. For the latter purpose, the principal veins are situated near the front edge of the wing, called the costa, and thus the wing is strengthened where the most strain comes during the beating of the air in flight.

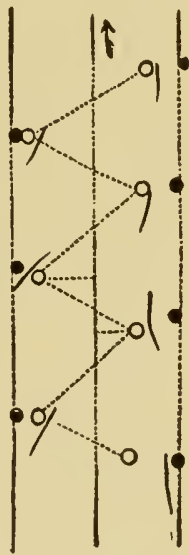

Fig. 16. - Foottracks of Necrophorus vespillo. Natural size.After Graber.

The wing of an insect in making the strokes during flight describes a figure 8 in the air. A fly's wing makes 330 revolutions in a second, executing therefore 660 simple oscillations.

How Insects Breathe.-Insects breathe by means of a complicated system of air-tubes ramifying throughout the body, the air entering through a row of spiracles, or breathing-holes (stigmata), in the sides of the body. 'There are in locusts two nairs of thoracic aud eight pairs of abdominal spiracles. The first thoracic pair (Fig. :) is situated on the membrane comnecting the prothorax and mesothorax, and is covered by the hinder edge of the pronotum (usually called prothorax). The second spiracle is situated on the posterior edge of the mesothorax. 'There are eight abdominal spiracles, the first one sitnated just in front of the auditory sac or tympanum, and the remaining seven are small openings along the side of the abdomen (Fig. 2). From these 
spiracles air-tubes pass into the interior, sending branches into every part and appendage of the body, including the antennæ, month-parts, and wings. There is thus an intricate system of air-tubes, the finer branches of which end in cells, through whose walls the air passes out and mixes with the blood. Moreover, certain tracheæ expand into large airsacs, of which there are in the locust nearly fifty in the head; while there are a few, but large, sacs in the thorax and hind body which, when filled with air, serve to lighten the body by increasing its bulk.
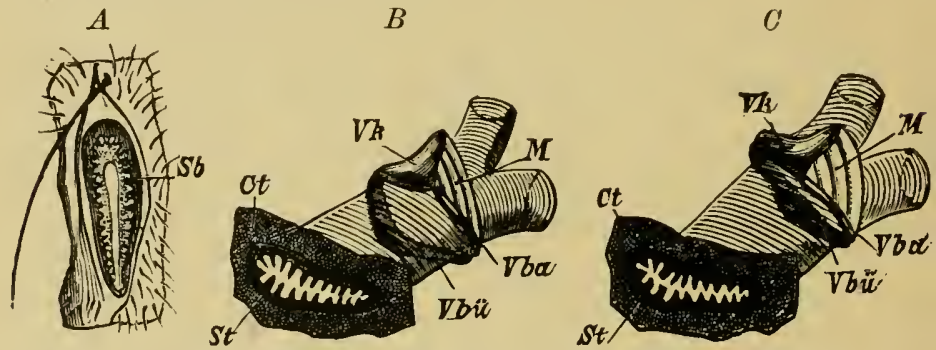

FIa. 17.- $A$, thoracic stigma of the house-fly: $S b$, valve which closes the opening. $B, C$, diagrammatic figures of the internal apparatus which closes the trachea, in the stag-beetle: $B$, the trachea open; in $C$, closed: $s t$, the stigma, with its grated lips: $C t$, cuticula of the body-walls; $V k$, closing-poucls; $V b u ̈$, closing-bow; $V b a$. closing-band; $\boldsymbol{M}$, occlusor muscle.-From Judeich and Nitsche, after Landois.

Fig. 17 represents at $B$ and $C$ the elastic "bow," "band," and muscle, said by Landois to act in closing the trachea, so that pressure may be exerted mpon the air within by the muscles of the abdomen. It should be horne in mind that insects breathe by the abdomen and not the thorax.

By holding the red-legged locust in the hand one may observe the mode of breathing. During this act the portion of the side of the body between the stigmata and the pleurum contracts and expands; the contraction of this region canses the spiracles to open. T'he general movement is causerl by the sternal, moring much more decidedly than the tergal, portion of the abdomen. When the pleural portion of the abdomen is forced out, the soft pleural membranous region under the fore and hind wings contracts, as 
do the tympanum and the membranons portions at the base of the hind legs. When the tergum or dorsal portion of the abdomen falls and the pleurmm contracts, the spiracles open; their opening is nearly but not always exactly co-ordinated with the contrictions of the plemrum, but as a rule it is. There were sixty-five contractious in a minute in a locust which had been held between the fingers about ten minutes. It was noticed that when the abdomen expanded, the air-sacs in the first aludominal ring contracted. The air passes into the spiracles during the expansion of the abdomen. In most insects, says Plateau, only the expiratory movement is active; inspiration is passive, and effected by the elasticity of the body-walls.*

It is evident that the enormous powers of flight possessed by the locust, especially its faculty of sailing for many hours in the air, are due to the presence of these air-sacs, which float it up in the atmospheric sea, increasing the bulk of the body, withont rendering it heavier. Other insects with a powerful flight, as the bees and flies, have well-developed air-sacs, but they are less numerons. It will be seen that, once having taken flight, the locust can bnoy itself up in the air, constantly filling and refilling its internal buoys or balloons with little muscular exertion, and thus be borne along by favorable winds to its destination. It is evident that the process of respiration can be best carried on in clear, sumy weather, and that when the sun sets, or the weather is clondy and damp, its powers of flight are lessened, owing to the diminished power of respiration.

The Senses of Insects.-It is difficult to explain many of the actions of insects, from the fact that it is hard for us to appreciate their instincts and general intelligence. 'That they have sufficient intellectual powers to enable them to maintain their existence may be regarded as an axiom. But insects differ much in intelligence, and also in the degree of perfection of the organs of sense. The intelligence of in-

* See Miall and Denny's “'The Cockroach,” p. 163. 
sects depends, of course, largely on the development of the organs of special sense, especially those of sight and smell.

'There are in nearly all insects two kinds of eyes, the simple and the compound. Of the simple eyes there are usually three, arranged, as in locusts, bees, etc., in a triangle on the tol, of the head. 'There is a single pair of compound eyes. 'The simple eye, or ocellus, consists of a single smooth, shining, convex area, called the cornea or facet, while in the compound eyes there are many facets, which can be seen

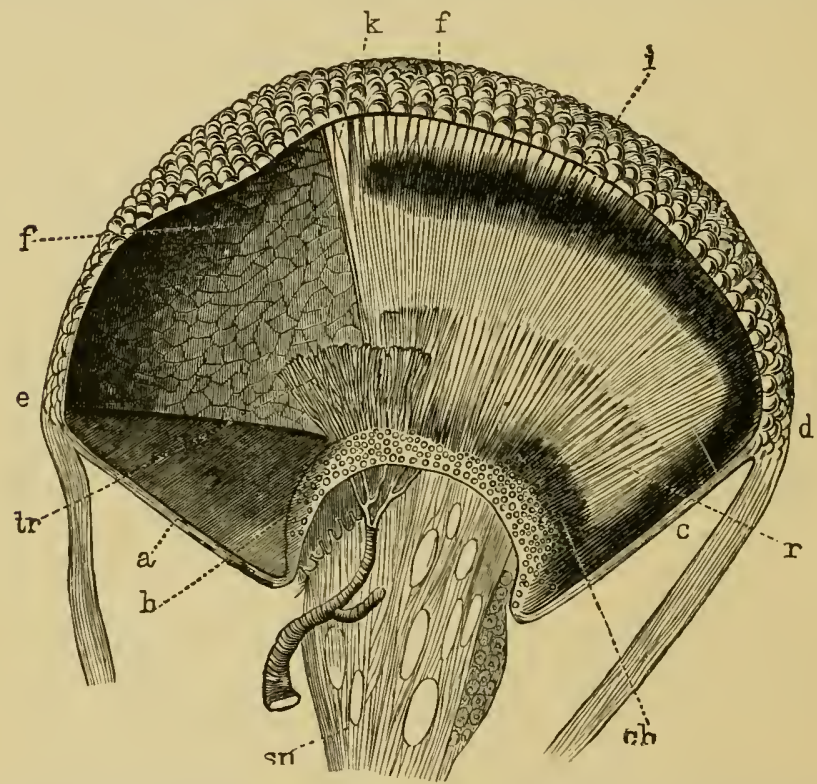

Fig. 18.-Longitudinal section of the faceted eye of a moth. $f$, the rod-like ending of the optic nerve-fibres; $k$. crystalline lens; $s n$, optic nerve; $t r$, tracliea lost in fine fibrillæ; $i, c h$, retina.-After Leydig, from Graber.

with a hand-lens. The compound eyes, which are usually round and very prominent, differ much in size and the number of facets, the latter varying from fifty, as in the ant, to several, even twenty, thousand, as in certain beetles.

The structure even of the simple eye is too complicated for description here, but the esscntial parts are: the cornea, 
the crystalline cone, the retina, and the optic nerve. How an inseet sees is not well understood; but the eorneal lens aets like an ordinary glass lens to eondense the light, or form an image of a moving body, either of $A$ which, as the ease may be, falls upon the eone behind the lens. Behind each cone is a nerve-roil (rhabdom) which, though extermally simple for most of its length, is found on eross-section to eonsist of from four to eight sections, called rhabdomeres. These separate in front to receive the apex of the cone whieh is wedged in between them; these nerve-rods are enreloped by retinal eells. The retina, a mass of black pigment-cells enveloping the ends of the eones and their stalks or rods, and further comprising, as Ifickson thinks, all that part of the eye lying between the erystalline cones and true optic nerve, is of use, especially in the compound eye, in elabolating and combining the image formed by the eorneal lens. Now the eompound eye is simply, so to speak, a compound simple eye: not, as used to be thonght, a eollection of simple eyes joined together. The compound eye grows ont of, or is "differentiated" from, a simple eye; it is, as Patten says, "a modified
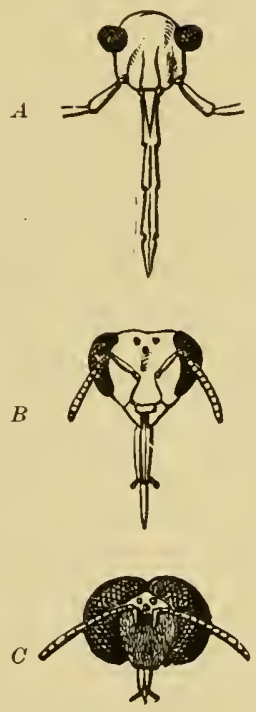
ocellus;" and this observer concludes that the majority of eompound eyes are adapted " for the pereeption of inverted images formed by the corneal facets upon the crystalline cones." Of course, as with us, the effeet upon the inseet's mind is that of seeing a single objeet.

Experiments by Plateau on the simple eyes of eentipedes show quite deeidedly that these ereatures can do little more than distinguish light from darkness; they do not make ont the form of objects, though some can perceive the more 
olvious movements of bodies. On spiders, which do not possess compound eyes, Plateau has experimented, and he quite fully proves that in general they are near-sighted, only perceiving at a distance the displacement of large bodies; while the hunting spiders (Attidæ and Lycosidæ) are probably the only kinds which see the movements of small bolies, and that only at a distance of between 2 and 20 centimeters (.80 to 8 inches); while the distance at which their prey is seen well enough to be captured is from 1 to 2 centimeters (.40 to .80 inch); and he adds, even at this distance spiders cannot see distinctly, because they often miss grasping their booty.

It is so with all larva, grubs, and caterpillars, as well as such perfect insects as do not have compound eyes; they can only tell daylight from darkness, and indistinctly see moving objects near at hand.

Even insects with compound eyes have a less perfect vision than formerly supposed. Both Exner* and Plateau have discarded the mosaic theory of vision, and the latter claims that inseets, such as flies and bees, see the outline of objects indistinctly, and only when in motion. Platean experimented in the following way: In a darkened room, with two differently shaped but ncarly equal light-openings, one square and open, the other subdivided into a number of small holes, and therefore of more difficult egress, he observed the choices of opening made by insects flying from the other end of the room. Careful practical provisions were made to eliminate error; the light-intensity of the two openings was as far as possible equalized or else noted, and no trees or other external objects were in view. 'The room was not darkened beyond the limit at which ordinary type ceases to be readable, otherwise the insects refused to fly (it is well known that during the passage of a thick cloud insects usually cease to fly). These observations were made on

* Exner finds that the focus of a corneal lens in the compound eye of Hydrophilus is about $3 \mathrm{~mm}$. away, and some distance behind the eye. (Miall and Denny's “The Cockroach," p. 105, note.) 
insects both with and without ocelli, in addition to the connpound eyes, and with the same results.

From repeated experiments on flies, bees, etc., butterflies and moths, dragon-flies and beetles, Platean concludes that insects with compound eyes do not notice differences in form of openings in a half-darkened room, but fly with equal readiness to the apparently easy and apparently difficult way of escape; that they are attracted to the more intensely lightened opening, or to one with apparently greater surface; hence he concludes that they cannot distinguish the form of objects, at least only to a very slight extent, though they readily perceive objects in motion.

It is well known that honey-bees on leaving their hives fly about as if making out the form of objects near their home, and, after thus taking in the landmarks, can after a few flights make a bee-line from a distance to their hives. While this would seem opposed to the result of Plateau's experiments, it may be said that a rery near-sighted man can find his way home; objects even perceived very indistinctly serving to gnide him. Insects also without doubt distinguish the difference in color of objects; it is well known that butterflies will descend from a position high in the air, mistaking white bits of paper for white flowers; while, as we have observed, white butterflies (Pieris) prefer white flowers, and yellow butterflies (Colias) appear to alight on yellow flowers in preference to white ones.

Until further experiments are made, it seems probable, then, that all insects do not have acute sight, that they see objects best when moving, and on the whole-except dragonflies and other predaceous, swiftly flying insects, such as certain flies, wasps and bees, which have very large rounded eyes-insects are guided mainly rather by the sense of smell than that of sight.

Some insects can only detect light from darkness; while, to go to the other extreme, a few may see "with clearness and precision, by means of inverted images, either a landscape or small neighboring objects." We may add with 
Patten: "The difference in vision is due more to the powers of association than to variation in the strueture of the eye" ("Eyes of Mollusks and Arthropoda," Naples, p. 699).

It is now generally agreed that the olfactory organs are situated in the antemn. 'This has been experimentally proved. When the antennx of insects whieh show a deeided dislike to strong or disagreeable smells, such as the odor of earbolic aeid, oil of turpentine, or vinegar, are removed, the actions of the inseets operated upon show that they are not affected by such smells; insects fond of decaying flesh do not run or fly toward it when deprived of their antennæ, nor are they, after losing their feelers, able to go to their mates. As Forel says, in many inseets which are gnided by sight, such as dragon-flies and eieadæ, tle antennæ are minute, rudimentary, and do not have the sense of smell, thongh the cieada may be guided by the sense of hearing.

'The organs of smell, according to Hauser, eonsist, in inseets,-i.e., all Orthoptera, Psendonenroptera (i.e., white ants, Perlæ, Psoci, dragon- and may-flies), Diptera, and Hymenoptera, also in most Lepidoptera, Neuroptera, and Coleoptera,- -

1. Of a thiek nerve arising from the brain whieh is sent into the antemnæ.

2. Of a sensitive apparatus at the end, eonsisting of staff-like cells, which are modified hypodermis cells, with whieh the fibres of the nerves eomnect.

3. Of a supporting and accessory apparatus, consisting of pits, or peg- or tooth-like projections filled with a serons fluid, and whieh may be regarded as invaginations and outgrowths of the epidermis. These appear as mieroseopic pits and teeth, usually situated at or near the end of the antemm. The number of these olfaetory pits and projections is sometimes enormous. In the European eockchafer (Melolontha vulgaris) 39,000 oecur in the leaves of the male antennæ, and about 35,000 in those of the female (Fig. 20). In Vespa crabro each joint of the antenna (flagellum) possesses between 1300 and 1400 pits, nearly 60 teeth, and 
about $\% 0$ tactile hairs; on the terminal joint there are more than 200 teeth, so that each antenna has between 13,000 and 14,000 olfactory pits and about \%00 teeth.

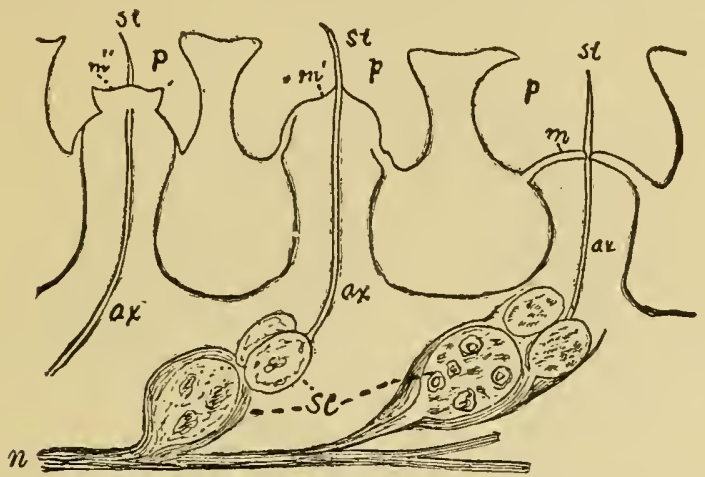

FIG. 20.-Organs of smell in Melolontha. $n$, olfactory or antennal nerve; $s c$, ganglion-cells from which a thread-like fibre is sent to each pit $(p)$, ending in a hair or style $(s t) ; m$, olfactory membrane.-After Kraepelin.

Similar pits occur in the long, jointed anal stylets of the cockroach, and in those of certain flies (Chrysopila).

Plateau, as well as Will and Forel, deny that the palpi have the sense of taste, but maintain that they are simply organs of touch; Forel appears to have experimentally proved this by cutting off the palpi of wasps and ants, and feeding them with meal with which quinine and morphine had been mixed, which they still rejected, though they would

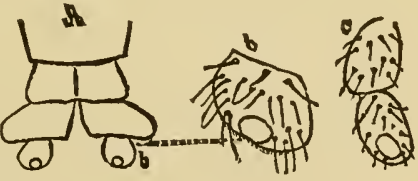
eat pure, unadulterated meal. Yet in the end of the palpi of Perla we have found a sense-pit (Fig. 21,c).

Little is positively known of the organs of taste, but the researches of $\mathrm{F}$. Will show that wasps and bees are provided either with microscopic pits or goblet-like projections on the base of the ligula (which forms the end of the under lip), as well as on the under side of the maxillx. The gustatory 
nerve ends on the surface, and is thus accessible to direct chemical stimulation, while the parts can be washed with the saliva. The supply of hooks and bristles on the skin partly retains the saliva for cleansing purposes, and partly defends the delicate ending of the nerves. All these pits and goblets are situated where they come in direct contact with the food. Forel, basing his opinions on the observations of different anatomists as well as his own, thinks that the organs of taste occur in the proboscis of flies; in the maxillæ, and in the end of the tongue, of ants; and in the palate or epipharynx of bees and beetles.

While most insects appear to be deaf, certain organs which are generally considered to be ears are well developed in the locust, and we think that the sense of hearing must be present, not only from the fact that a lond alarum with kettles and pans affects them, but because the movements of persons walking through the grass invariably disturb them. Besides this, they produce a fiddling or stridulating sound by rubbing their hind legs against their folded wingcovers, and this noise is a sexual somnd, evidently heard and appreciated by individuals of the other sex. Any insect which produces a sound must be supposed to liave ears to hear the sound produced by others of its species.

'The ears (or anditory sacs) of the locust* are situated, one on each side, on the basal joint of the abdomen, just behind the first abdominal spiracle (Fig. 2\%). The apparatus consists of a tense membrane, the tympanum, surrounded by a horny ring (Fig. 2\%). "On the internal surface of this membrane are two horny processes $(0, u)$, to which is attached

* Forel, however (“ Recueil Zoologique Suisse,” 1887), denies that these tympanic organs are necessarily ears, and thinks that all inseets are deaf, with no special organs of liearing, but that sounds are heard by their tactile organs, just as deaf-mutes perceive at a distance the rumbling of a carriage. But he appears to overlook the fact that many Crustacea, and all shrimps and crabs, as well as many mollusks, have organs of hearing. The German anatomist Will believes that insects hear only the strilulation of their own species. Lubbock thinks that bees and ants are not deaf, but hear sounds so shrill as to be beyond our hearing. 
an extremely delicate resicle (bi) filled with a transparent fluid, and representing a membranous labyrinth. 'This vesiclo is in connection with an auditory nerve $(n)$ which

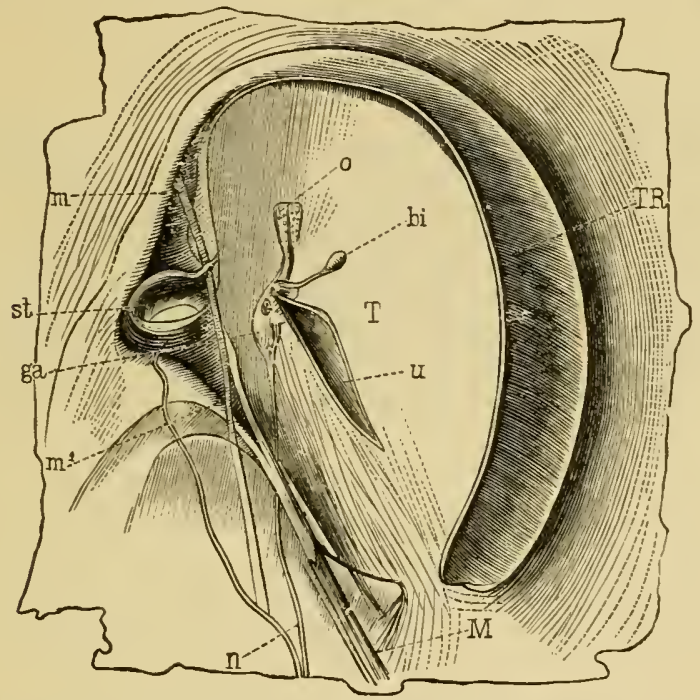

FIG. 20.-Ear of a locust (Caloptenus italicus), seen from the inner side. $T$, tympanum; $T R$, its border; $o, u$, two horn-like processes; $b i$, pear-shaped vesicle; $n$, auditory nerve; $g a$, terminal ganglion; st, stigma; $m$, openiug, and $m^{\prime}$ closing. muscle of the same: $\boldsymbol{M}$, tensor muscle of the tympanum-mernbrane.-After Graber.
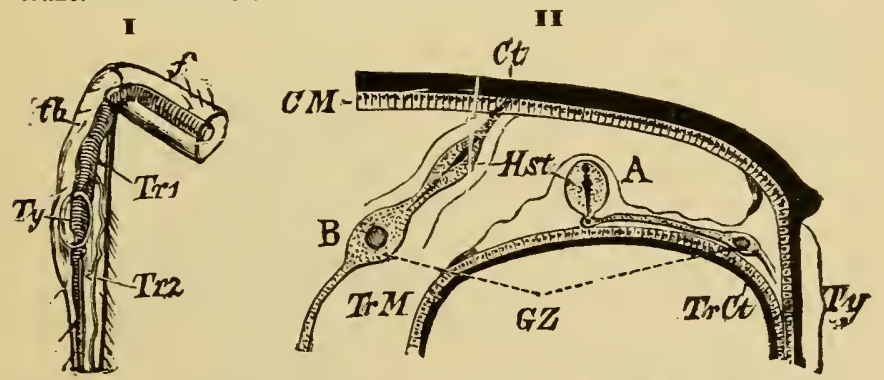

Fig. 23.-I, fore tibia of a European grasshopper (Meconema), containing tlie. ear: $T y$, tympanum or outer membrane: Tr1, Tr2, trachea. II, diagrammatic cross-section through the tibia and ear of the same: $T y$, ty mpanum; $C t$, cuticula; $C M$, hypodermis: $A$, the auditory organ connecting with the tyinpanum; $B$. supra-tympanal auditory organ ; $G Z$, the ganglion-cell belonging to them; Hst, the auditory rod connecting with the ganglion-cells.-After Fraber, from Judeich and Nitsche. 
arises from the third thoracic ganglion, forms a ganglion (ga) upon the tympanum, and terminates in the immediate neighborhood of the libyrinth by a collection of cuneiform, staff-like bodies, with very finely-pointed extremities (primitive nerve-fibres?), which are surrounded by loosely aggre-

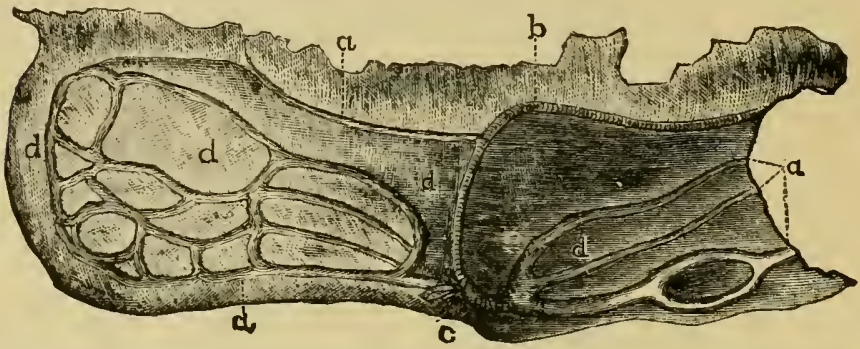

FIG. 24.-Musical apparatus of cricket. $n, a$, tracheal tube; $b$, rasp or ridge bearing vibratory flanges; $d$, resonant surface, with ridges.

gated ganglionic globules" (Siebold's "Anatomy of the Invertebrates"). In the green grasshoppers, katydids, and their allies, the ear's are situated on the fore legs (tibiæ), where these organs ean be found after a careful search (Fig. 23).

Having ears to hear, locusts, grasshoppers, katydids, and crickets are also very musical. One may sometimes see the red-legged locust standing on the ground and rubbing one leg against the folded wing, and a shrill chirruping noise may be heard. The noise is made by a row of dull spines on the inside of the femur, forming a rude file which rasps the wing. Certain grasshoppers, as the katydid and the crickets (Figs. 24 , 25), have on the under side of the uppermost of the fore wings a sort of file which rubs over a resonant surface,

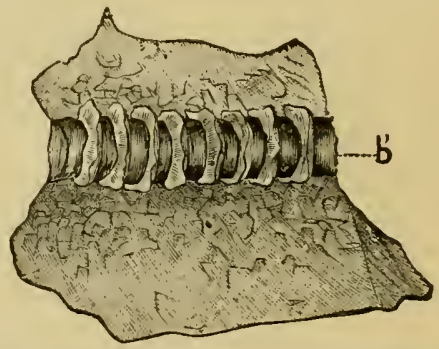

FIG. 25.-Enlarged view of the vibratory flanges seen at $b^{\prime}$, Fig. 21.-This and Fig. 19 after N. B. Pierce.

like a drum's head. 'The file may be likened to the bow, and 
the drum-like space to the body of the violin. Thus, most grasshoppers are fiddlers, and during the summer, both by day and night, the air resounds with the music of these primitive violinists. This noise may add to our pleasure, or become tedious and disagreeable. 'This makes little difference, for insect-music is all-important. It is the cricket's love-call; and were erickets, etc., deaf and dumb, we are safe in saying the breed would soon run out, because they would not otherwise readily mate.

Insects also have the sense of tonch highly developed; its seat is in the numerous hairs and bristles which clothe the antennæ and palpi, as well as the legs and the body itself.*

The hairs of inseets form an interesting subject for miero scopic study, since they vary so much in shape. 'The simplest are seen in the smaller catterpillars, and the larger naked kinds, in which the hairs are minnte and very slender: while in the lairy species, as the aretians, they are densely barbed; in certain caterpillars, as those of the maia, io, and the native silk-worm moths, the hairs are spine-like, with sharp spinules, and are poisonous, having at their base a minute poison-gland. Hairy or spiny caterpillars are not eaten by birds, or so easily molested by ichnenmon-flies. The hairs sometimes become flat and broad as in the scales of moths and butterflies, as well as certain flies and beetles.

* To examine the heads of insects in order to wateh the movements of the appendages and mouth-parts, we may sometimes follow with advantage $\mathrm{Mr}$. E. T. Draper's recommendation of using a cone of pasted paper to be made rather larger than the specimen, with the apex cut off. A vigorous insect will soon project its head through the aperture. When in this position it should be blocked behind with cotton wool slightly wetted. The cone can then be gummed to a slip, apex upward. Insects held in this way will allow one to observe the movements of the antennie, palpi, jaws, ete, and the effects produced by excitation with saceharine or nitrogenous fluids, administered with a sable pencil. (Science-Gossip, 1884, 26.) 


\section{CHAPTER II.}

\section{GROWTH AND ME'TANIORPHOSIS OF INSECTS.}

INSECTs are of distinct sexes, and besides males and females the social species, such as ants, wasps, and bees, are largely represented by workers, which are undeveloped females, not being normally capable of laying eggs.

Insects differ sexmally in that the female often appears to have one abdominal segment less (one disappearing during the semi-pupa state, when the ovipositor is formed). They are also larger (except in the stag-beetles, some dragon-flies, and certain bees), fuller, and duller-colored than the males; while the latter often differ in sculpture and ornamentation and are more active than the females. Certain female moths are wingless, * the organs of locomotion as well as of smell (antemm) and sight being better developed in the male than in the female. The females of some water-beetles (Dytiscus) have deeply-grooved elytra, or, as in Acitius sulcatus, they are thickly set with hairs.

Egg-producing Organs.-With some notable exceptions (i.e., cases of partluenogenesis), all insects develop from eggs, which are formed in delicate tubes sitnated in the abdomen, as in Fig. 4, ov. In the locust the ovaries consist of two sets of about twenty long tubes, within which the eggs may

* The only partial exception to the rule that the females are wingless while the males are winged is the male of two chalcids (West wood's Class. Insects, ii. 160). This fact was quoted by Darwin (Descent of Man, i. 264). Darwin seems not to have been aware that Newport figured these inseets (Trans. Linn. Soe, xxi., Tab. VIII. p. 4) as Anthophorabia fasciutu Newport and $A$. retusa Newport. The males also are without compound eyes. only a simple eye being present in place of each compound one (Fig. 26). 
be found in various stages of development. The eggs pass in two main tubes which unite to form the single oviduct (ov.t) which lies on the floor of the abdomen. Abore

A

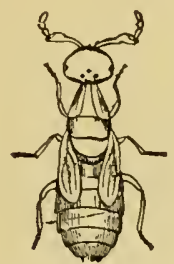

$B$

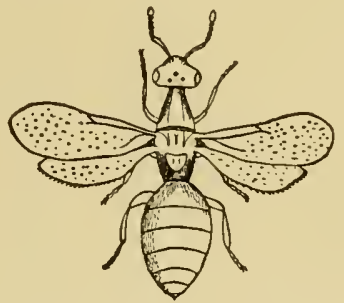

Fig. 26.-Anthophorabia retusa. $A$, male; $B$, female.-After Newport. the opening of the oviduct is the sebific gland and its duct. This gland secretes a copious supply of a sticky fluid, which is, as in many other insects, poured out as the eggs pass out

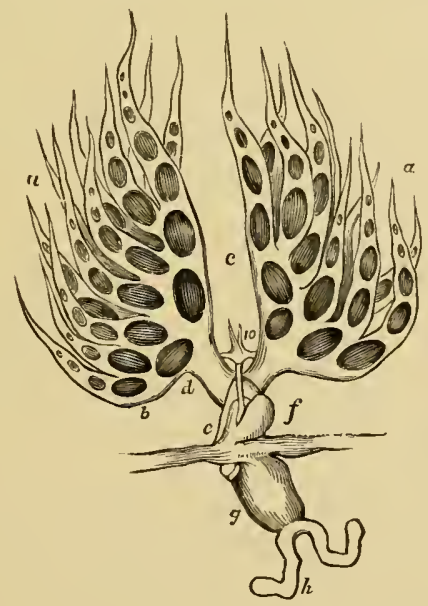

FiG. 27.-Egg-tube of a saw-fly (Athalia). $a, b, c$, egg-tubes; $e$, oviduct; $f$, spermatheca or reservoir for the seminal fluid: $y$. poison-sac, and its secretory vessels $(h) ; 10$, the last nerve-centre of the abiomen.-From Newport.

of the oviduct, thus surrounding them with a tough coat (compare Fig. 27). 
The external parts consist of the ovipositor (Fig. 1, B), which is formed of two pairs of spines (rhabdites) adapted for boring into the earth; and of the egg-guide (Fig. 4, eg), a triangular flap guarding the under side of the opening of the oviduct.

The eggs are fertilized while in the oviduct during pairing. The sperm-cells are secreted in little glands in the

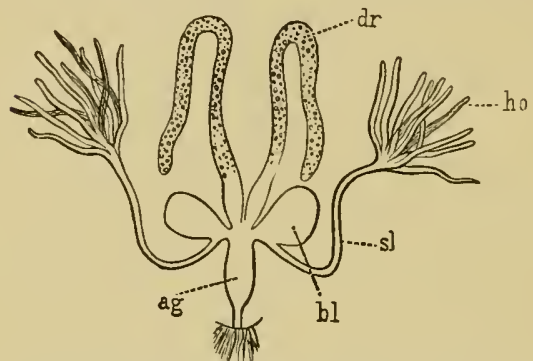

Fig. 28.-Male glands of a Bark-beetle. sl, vas deferens; ho, testis; $b l$, sperm-sac; $a g$, ductus ejaculatorius.-From Graber.

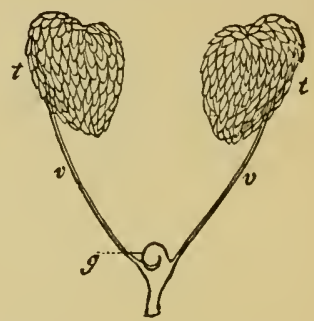

Fig. 29.- $t$, testis; $v$, vas deferens; $g$, seminal vesicle of Acheta campestris.From Gegenbaur.

male called testes, which form a single mass of tubular glands, resting in the upper side of the third, fourth, and fifth segments of the hind body. Figs. 28 and 29 represent these structures in other insects.

The Egg.-In shape the eggs of insects are usually either more or less spherical or oval. 'The shell which envelops them is called the chorion. It is dense and brittle, and often covered by a delicate mosaic-work of more or less regular facets. In those of many moths the surface is finely granulated, while in those of most butterflies the surface is beautifully ornamented with ribs and furrows.

In some eggs there are radiating appendages at one end, as in those of Nepa (Fig. 30, o), which surround the micropyle; this being a microscopic opening through which a spermatic particle enters to fertilize the egg.

The mosquito lays its slender cylindrical eggs glued together in a boat-shaped mass, which floats on the surface of pools or cisterns; the Copris beetle, or "tumble-bug," 
places its egg in the centre of a ball of dung, which it rolls away to a secure place; the flesh-fly oviposits on fresh or

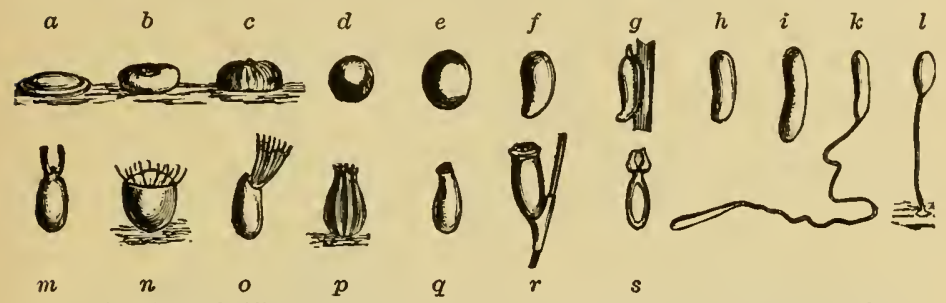

FIG. 30.-Eggs of different insects. $a$, Tortrix; $b$, Liparis; $c$, a noctuid, Trachea; $d$, usual shape of those of bark-boler, etc.; $e$, Melolontha; $f$, Chironomus; $g$. Lyda; $h$. Musca; $i$, honey-bee; $k$, Rhodites rosa; $l$, Chrysopa; $m$, Drosophila; $n$, Pentatoma; o, Nepa; $p$, Pieris cratagi; $q$, bed-bug; $r$ lonse, fastened to a hair; $s$, Hypoderma actæon, bot-fly.-From Judeich and Nitsche.

putrid meat, and moths and butterflies lay their eggs on the leaves or stems of the food-plant, where the caterpillar, upon its exit from the egg, shall readily find an ample supply of food.

No collection of insects is complete without specimens of the eggs neatly gummed on a card and pinned next to the insect.

Growth of the Insect within the Egg.-The germ or

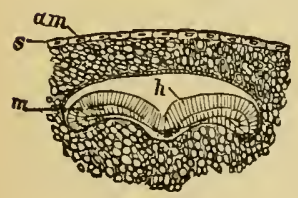

Fig. 31.-Section of Sphinx embryo, the germ immersed in the yolk. $s$, serous membrane; am, amnion; $h$, outer, $m$, inner, germ-layer.

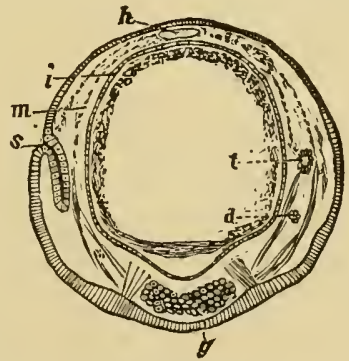

FIG. 32.-Embryo of Sphinx much more advanced. $h$, heart; $g$, ganglion; $i$, intestine; $m$, rudimentary muscular bands running to the heart; $s$, stigma and beginning of a trachea $(t): d$, a gland.-This and Figs. 33 and 34 after Kowalevsky

young insect before hatching is called the embryo, and the study of the growth or development of the embryo is called Embryology. 
There is a remarkable uniformity in the mode of development of the winged insects. In general, after fertilization of the egg, a few cells appear at one end of the egg; these multiply, forming a single layer around the egg, this layer constituting the blastoderm. 'This layer thickens on one side of the egg, forming a whitish patch called the primitive streak or band. The blastoderm moults, sloughing off an onter layer of cells, a new layer forming beneath; the

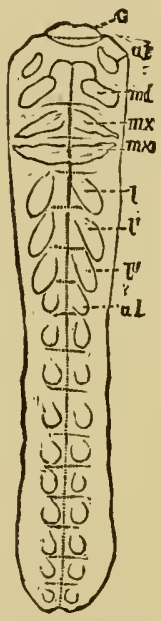

FıG. 33.-Primitive band or germ of a Sphinx moth, with the segments indicated, and their rudimentary appendages. $c$, upper lip; at, antennæ; $m d$, mandibles: $m x, m x$, first and second maxillæ; $l, l^{\prime}, l^{\prime \prime}$, legs; al, abdominal legs.

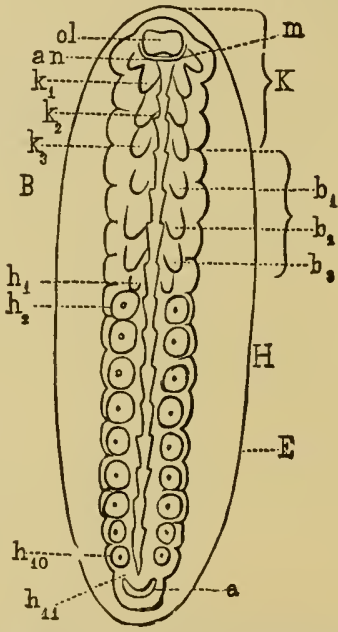

FIG. 34.-Embryo of a Water-beetle (Hydrophilus). $E$, egg; $K$, head; ol, upper lip; $m$, mouth; an, antennæ; $k_{1}$, mandibles; $k_{2}, k_{3}$, maxillæ; $B$. thorax; $b_{1}, b_{2}, b_{3}$, legs; $h_{1}-h_{10}$, ten pairs of rudimentary abdoninal legs, of which all except $k_{1}$ disappear before the insect hatches; $a$, anus.-After Kowalevsky.

skin thus thrown off is called the serous membrane; the second germ-layer (ectoderm) then arises, and a second membrane (called amnion, but not homologous with that of vertebrates) peels off from the primitive band just as the appendages are budding out. so that the body and appenlages of the embryo insect are encased in the amnion as the hand and fingers are encased by a glove. As seen in the 
accompanying Figs. 31-36, the appendages bud out from the under side of the primitive band, and antennæ, jaws, legs, ovipositor (or sting), and the abdominal feet of caterpillars are at first all alike. Soon the appendages begin to assume the form seen in the larva, and just before the

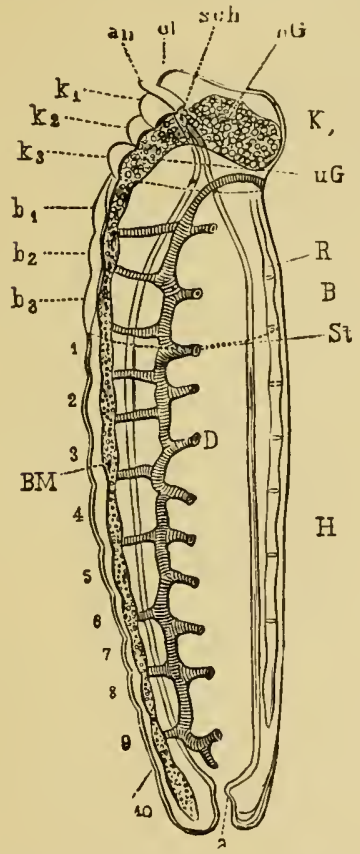

FIG. 35. - Profile view of embryo Honey-bee, lettering as in Fig 34 . $B M$, nervous cord; $u G$, brain; $D$, digestive eanal; sch, the cesophagus; $S t$, stigmatal openings of the tracheal system; $R$, heart. - After Blïtschli.

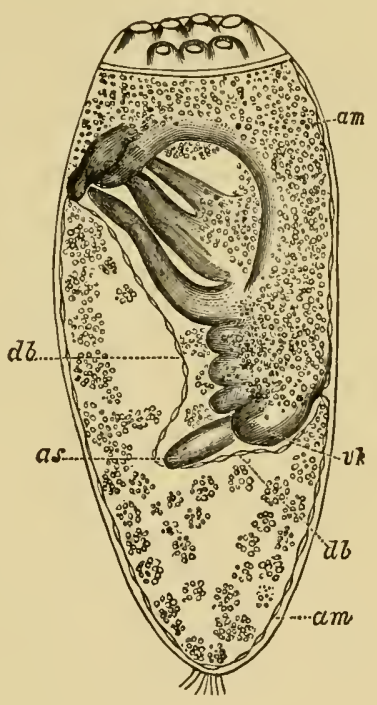

Fig. 36.-Embryo of the Louse. am, serous membrane; $d b$, amnion; $a s$, antennæ; $v k$, foreliead.-After Melnikow.

insect hatches the last steps in the elaboration of the larval form are taken.

As to the development of the internal organs, the nervous system first originates; the alimentary canal is next formed; and at about this time the stigmata and air-tubes arise as 
invaginations of the outer germ-layer. The development of the salivary glands precedes that of the urinary tubes; which, with the genital glands, are originally offshoots of the primitive digestive tract. Finally the heart is formed.

When the insect hatches, it either cuts its way through the egg-shell by a temporary egg-cutter, as in the flea; or the expansion of the head and thorax and the convulsive movements of the body, as in the grasshopper, burst the shell asunder. The serons membrane is left in the shell, but in the case of grasshoppers the larva on hatching is still enreloped in the amnion. This is soon cast as a thin pellicle.

Metamorphosis of Insects-The Larva. -The life of the insect may be divided into four stages, represented by the egg, the larva, the pupa, and the imago or adnlt. The change from the egg to the adult is called a metamorphosis. .The larva (Latin larva, a mask) was so called beeause it was thought to mask the form of the perfect insect. The larva of a moth or butterfly is ealled a caterpillar; that of a beetle, a grub; and that of a fly, a maggot. The larvæ of other groups have no distinctive common names.

The principal change from the larval to the adult locust or grasshopper is the acquisition of wings. In such insects, then, as the Orthoptera and Hemiptera, in which the adults differ from the newly hatched larva mainly in the possession of wings, metamorphosis is said to be incomplete. Its development is direct. In the beetle, fly, butterfly, or bee, the metamorphosis is complete ; the caterpillar, for example, is a biting insect, is voracions, and leads a different life from the quiescent, sleeping pupa, or chrysalis, which takes no food; on the other hand, the imago, or butterfly, has mandibles, which are rudimentary and incapable of biting, while the maxilla, or "tongne," which was rndimentary in the caterpillar, becomes now greatly developed; and the butterfly takes liquid food and but little of it, while its surroundings and mode of life are entirely changed with its acquisition of wings. 'Thus the butterfly leads three different 
lives, differing greatly in structure, externally and interually, at these three periods, and with a different enviromment.

Most caterpillars moult four or five times; the onter layer of the skin being cast off at each moult. The skin opens on the back behind the head, the caterpillar drawing itself out of the rent. In the change from the caterpillar to the chrysalis, there are remarkable transformations in the muscles, the nerrous, digestive, and circulatory system, inducing a change of form, external and internal, characterizing the different stages in the metamorphosis.

While the changes in form are comparatively sudden in flies and butterflies, the steps that lead to them are gradual. How gradual they are may be seen by a study of the metamorphosis of a bee. In the nest of the humble- or honeybee, the young may be found in all stages, from the egg to the pupa, gayly colored and ready to emerge from its cell. It is difficult to indicate when the chrysalis stage begins and the larva stage ends, yet the metamorphosis is more complete-that is, the adult bee is more unlike the larrathan in any other insect.

The better way to understand how an insect transforms is to rear a moth or butterfly, a fly, and a bee or saw-fly from the larra, closely observing each change. By thus observing the transformations of moths, flies, and beetles, the popular opinion that the smaller flies and moths are the young of the larger ones will be seen to be an error; all winged insects being adults, and fully mature.

* 'The caterpillars of most North American buttertlies moult four times, but in case of hibernation five times, three times being a very rare exception (Psyche, iii. 161). MIr. W. Buckler says that the number of moults varies in different species. "I have myself made sure that six is the number for some and nine for others, as in the case of Nola centonalis" (Ent. Month. Mag., July, 1880). Mr. Edwards adds that in two instances Callosamia promether moulted but three times, and he thinks that this species varies in the number of moults with the latitude or locality. Telea polyphemus moults four times, as does Attacus atlas bred in England (Pysche, iii. 171-174). Hellins records a variable number of moults (three to five) in larva of Orgyiu antiqua from the same batch of eggs (Ent. Month. Mag., Sept., 1881, p. 88) 
The Pupa.-A few days (usually from one to three) before assuming the pupa or chrysalis state, the caterpillar becomes restless, stops eating, deserts its food, wanders about, and if it is a spinner, such as the silk-worm or certain other moths, spins a silken cocoon; or if a borer, makes one of earth or chips, and then prepares for the change to the pupa state.

Cocoons are usually oval, and either compact and thick, or loose and open like network. In the course of one summer the beginner can collect a large number, and realize how varied in form and structure they are. They are usually spun out of a silken thread. The silky material is formed in the silk glands, two long tubes which lie on the under side of the body of the caterpillar and open into the under lip by a common duct; the little projection or papilla ont of which the silk passes is called the spinneret. 'The silk is fluid before it is forced out, but becomes threadlike on exposure to the air.

Before changing, the body of the caterpillar becomes shorter and thicker, and remains so for one or several days; that of the saw-fly remains in this state through the winter. During this period, called the semipupal stage, the pupa develops, its skin separating from that of the larva.

It should be borne in mind that the skin is composed of

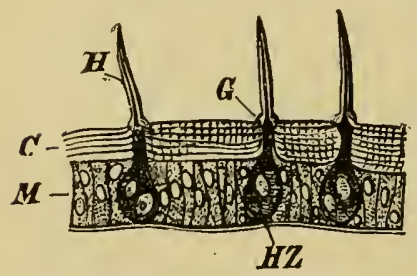

FIG. 37. - Cross section through the cuticula, $C$. and hypodermis, $\boldsymbol{M}$. The setæ or hairs, $H$, are articulated at $C$ with the cuiticula; $H Z$, cell. The poison-glands at the base of the bristles of some insects resemble these.-From Judeich and Nitsche. two layers; the under one formed of cells and called the hypodermis (Fig. 3\%), which secretes the hard, chitinous, structureless outer layer or crust. The hypodermis of the growing pupa tends more and more to assume the slape of the pupa, and the muscles and other organs within change their shape, until finally the old larval skin ruppupa slips out of the rent. 
'The pupa of different insects vary greatly in form. In the insects with an incomplete metamorphosis the pupa only differs from the larva in having pad-like rudimentary wings. In such insects development is direct, and properly speaking they pass through no true larval or pupal stages. Indeed, some authors with good reasoin apply the term nymph to the early stages of Orthoptera, white ants, mayflies, dragon-flies, etc.; this term embracing what is usually called the larval and pupal states of those insects, as during these periods they are active and take food.

The Imago.-This is the final or adult state, when the wings are dereloped and the insect is able to fly about and lay its eggs. As soon as insects, such as moths or butterflies, wasps or bees, have completed their transformations they pair, and the females seek a suitable place to deposit their eggs. After this act is accomplished, the adults usually soon die. This period of reproduction may occur at any time during the summer, but, taking into account the great mass of species, it in general occurs toward the end of summer, and early in the antumn; hence during the winter the spccies in most cases is represented by the egg alone. Rarely does the adult insect hibernate; though one will find a few ichneumons, beetles, and bugs nnder leaves and the bark of trees; but in many species, especially motlis, the pupa hibernates to disclose the imago in the spring or early summer. Larvæ seldom live throngh the winter, although there are some well-known exceptions to this law.

When insects are prevented from mating, they will live much longer than wonid be otherwise the case. Réanmur kept a virgin butterfly for two years in his hot-house. The pupal state of moths and butterflies may be greatly prolonged by keeping the chrysalids on ice.

Parthenogenesis.-Besides the normal mode of development, certain insects, as the plant-louse (Aphis), the barklouse (Coccus), the honey-bee, the Polistes wasp, the currant saw-fly (Nematus), the gall-flies, and a few other's, pro- 
duce young from unfertilized eggss. Certain moths, as the silk-worm moth (Bomby.x mori) and others, have been known to lay unfertilized eggs from which caterpillars have hatched.

The most surprising case is that of the larva of a dipterons gall-fly (Miastor); which brings forth numbers of young maggots like itself, the eggs developing in the ovaries of this precocions maggot. 'The pupa of another fly (Chironomus) lays eggs from which the maggots hatch.

This anomalons mode of reproduction is called parthenogenesis, and fundamentally is only a modification of the mode of producing young by budding which is universal in plants, and is not munsual among the lower branches of the animal kingdom. The object or design in nature, at least in the case of the plant-lice and bark-lice, as well as the gall-flies, is the production of large numbers of individuals by which the perpetuity of the species is maintained.

Broods or Generations of Insects. - Most insects live one year; hatching from the egg early in the summer, they pass through the larval state, and early in the autumn become pupæ, to appear as imagines for a few days or weeks in the succeeding summer. Many moths and butterflies, however, are double-brooded, and some have even three broods. Papilio ajax has in West Virginia four and sometimes five generations a year. There are other insects, such as certain kinds of flies, bugs, beetles, etc., which keep up a constant and irregular succession of broods. On the other hand, the serenteen-year Cicada has a generation only once in seventeen years.

Cold retards the development of insects, while warmth stimulates it; and insects which are as a rule single-brooded may be artificially forced into having a second brood during the same season.

Contagious Diseases of Insects due to Animal and Vegetable Germs.*-While many insects, especially the white

* For the latest résumé of this subject see S. A. Forbes's article "On the Present State of our Knowledge concerning Contagious 
ants and wood-eating kinds, are infested by hosts of apparently harmless microscopic parasites, both animal and vegetable, there are certain species which give rise to grave contagions discases. Thongh most of these minute parasites are vegetable, the common silk-worm is in Europe infested by what Balbiani regards as an animal. It is a very minute parasitic Amœba-like form (called Wicrosporidium bombycis), belonging, according to Balbiani, to a group called Sporozoa, and allied to the psorosperms occurring in fishes, etc., and to the Gregarinas. The disease produced by this organism is called pebrine, its symptoms being the appearance of black specks on the skin and internal organs, while the blood is filled with the spores of the parasite. This disease, however, is in this country practically unknown, and Forbes believes that it probably cannot be artificially cultivated or propagated in insects related to the silk-worm.

Of the vegetable disease-germs, the most simple and minute are the Bacteria, Bacilli, and Micrococci, the diseases they produce being called "bacterial." The most destructive of these to the siln-worm is varionsly called flacherie, maladie des morts-blancs, maladie des morts-flats. The germ of this disease, which is called Micrococcus bombycis by Cohn

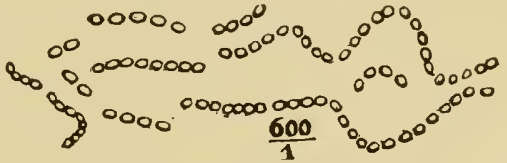

FIg. 38.-Flacherie germs.-After Cohn.

(Fig. 38), is, like its allies, among the smallest organisms known; it is a microscopic, oval mass of protoplasm, and multiplies very rapidly by self-division, the new individuals often forming chains. In this way a few germs introdnced into an insect will multiply with immense rapidity, finally disorganizing the blood and tissues, and causing rapid decay

Insect Diseases" (Psyche, v., Jan., Feb., 1888, 1). See also Judeich and Nitsche's "Lehrbuch des Mitteleuropäischen Forstinsektenkunde;" the works of Quatrefages and Pasteur on the silk-worm disease; and Balbiani's "Leçons sur les Sporozoaires," Paris, 1884. 
and death. It is very contagious, being transmitted to healthy larvæ by the infection of their food either with fresh excrement or with the dust of infected silk-worm nurseries of the previous year. Forbes has studied the flacherie of the caterpillars of Pieris rape and of Datuna ministra, and has shown that the spontaneous disease due to a species of micrococcus " may be unquestionably conveyed to other lepidopterous species, and even to the white grubs;" he has also seen wide-spread epidemics of flacherie in the caterpillars of Pieris ropce, of Pyrameis cardui, and of Nephelodes violans, and has met with it here and there in numbers of other caterpillars and hymenopterous larvæ, as well as the chinch-bug; while from the researches of Cheshire and Cheyne "foul-brood" in bees is now known to be produced by Bacillus alvei.

The disease known as "muscardine," often causing widespread destruction to both larval and adult insects, is caused by fungi, or moulds, which are often visible to the naked eye. They are species of Botrytis, Isaria, Cordyceps, Empusa, Entomophthora, etc. The spores of these moulds enter the bodies of their hosts through the spiracles, being inhaled, not penetrating through the mouth; their spores also germinate on the surface of the body, sending slender threads through the skin into the body; these threads separate into small single cells (cylindrical "conidia"), which, growing and dividing again and again, derive their nourishment from the blood and tissues, the victim dying a slow death, after which the body becomes filled with the mycelial threads, which finally, as in certain species of Isaria and Cordyceps, send up long filaments, more or less clubshaped, when they are called "caterpillar fungi." A large proportion of the flies and other insects in different stages found in autumn dead and stiff on fences, weeds, trees, and within houses, are victims of Entomophthoræ.

De Bary says: Should we carefully look in the leaves and moss on the ground in forests in the wet portions of the year, we should be astonished at the number of insects 
concealed in them which are infested by regetable parasites. The commonest example is the mould (Empusa muscee,

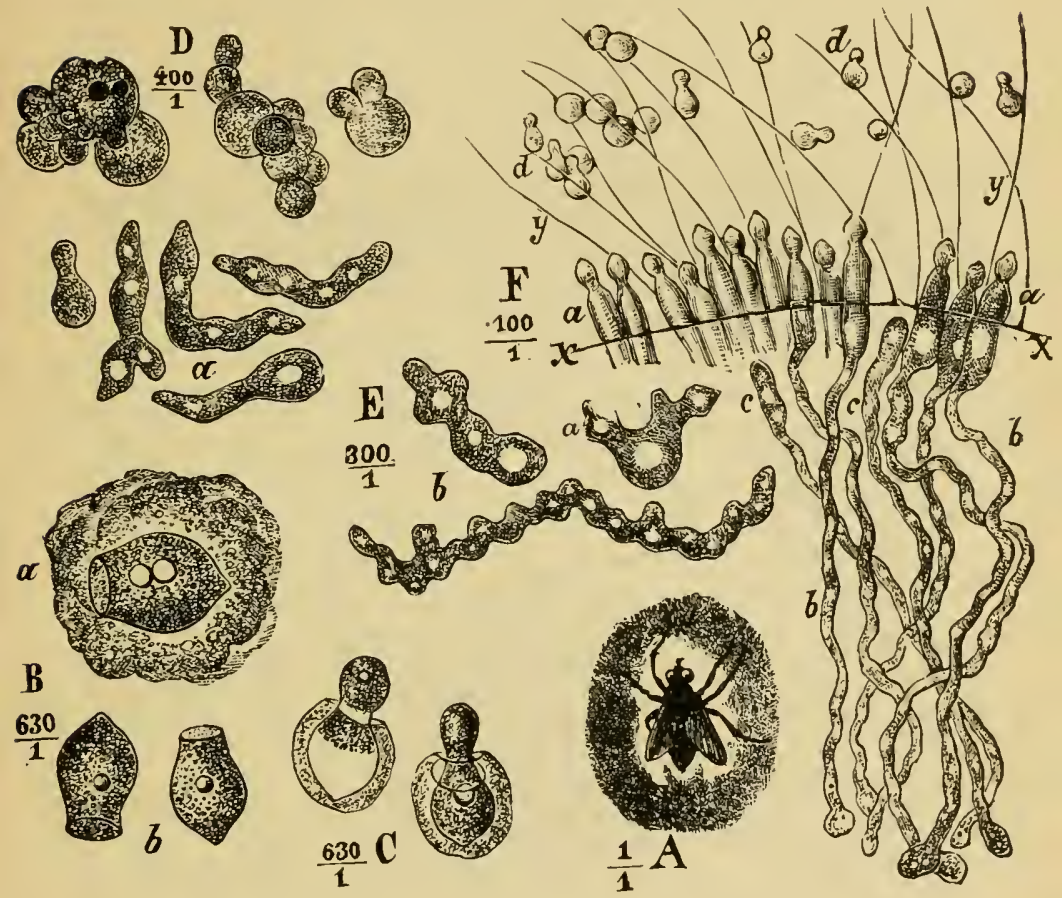

Fig. 39.-Empusa musca Cohn. $A$, a dead fly, surrounded by spores; $B$, spores; $C$. germinating spores forming secondary spores; $D$, empusa cells growing in the fat-body of a fly: at $E$ forming tubes: $F$, partly diagrammatic representation of the fructification; $x$, the skin of the fly; $y$, its hairs; at $a$ the spores beiring hypha-ends boring through the skin; $b$, the hypha-tubes remaining in the body: $c$. nne not yet penetrating the skin; $d$, spores thrown off from the body, and adhering to the hairs.-After Brefeld, from Judeich and Nitsche.

Cohn, Fig. 39), which destroys the common house-fly at the beginning of autumn.

The Destruction of Insect Pests by means of Insect Fungi. -When insects so multiply and abound in great numbers as to become overcrowded, epidenics are liable to arise and carry them off in great numbers. These insect plagues are 
apparently due in some cases to bacteria, in others to the larger fungi. Forbes states that epidemics due to the latter have been noticed among grasshoppers (CEdipo: and Pezotettix); among various noctuid larvæ-especially Agrotis segetum in Europe, and some American cut-

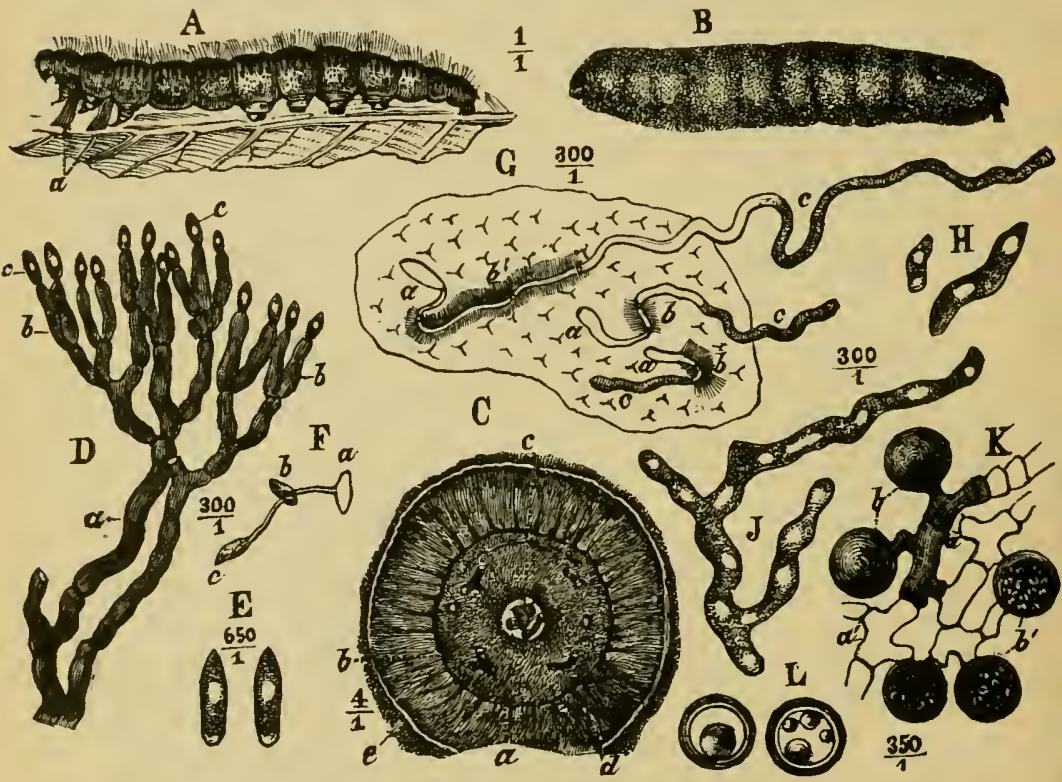

FIG. 40.-Entomophthora radicans Brefeld, A, caterpillar of Pieris brassicae killed by it; $a$, the hyphæ growing out from it: $B$, the same at a later stage; $c$, cross-section throigh $B$-all the soft parts of the caterpillar are replaced by mycelium threads: $D$, fruit-hyphæ; $c$, the spores; $E$, single spores; $G$, a piece of the skin, with spores, $a$, germinating and growing out at $c ; H$, isolated mycelium branches free-swimming in the caterpillar's blood; $J$, branched my. celial thread; $K$, resting-spores. bearing mycelial threads, $a$, filled with protoplasm; at $a^{\prime}$ empty; at $b$ beginning to develop; $b^{\prime}$, ripe resting-spores; $L$, ripe resting-spores with a thick skin and fat-drops within.-After Brefeld, from Judeich and Nitsche.

worms; among the two European cabbage-worms (Pieris rapce and $P$. Brassica); among various flies, the common honse-fly, blow-flies, Syrphida, Culex, and even larval Chironomus; and, finally, among Coccidæ and Aphides (A. corni and A. rumicis). According to Dr. Bail, in the 
forests of Pomerania and Posen the caterpillars have been killed by Empusa aulice in such quantities as to have saved the trees from total destruction. These Entomophthora forms are difficult to cultivate artificially, but in 1881 Brefeld cultivated them in sterilized real soup, and previonsly he experimented with the conidia of Entomophthor' radicans (Fig. 40), applying them to 120 cabbage caterpillars, with the result that 81 speedily died of the fungus disease resulting. But the most hopeful results, Forbes thinks, from the artificial cuitivation of vegetable insecticides will attend the use of the muscardine inngi (Botrytis, Isaria, and Cordyceps), since their spores and conidia "have germinated freely again and again in sweetened water, in sterilized beer-mash, in solutions of gelatine and of gum, and may even grow to some extent in pure water. In these the Botrytis stage arises, and may form its spherical conidia in vast abundance; and these have been nsed with perfect success for the infection of lealthy insects in great variety."

The question has been asked: Cannot we propagate thebacterial insect-diseases and utilize them as destructive agents against insect-pests? Metschnikoff has suggested the feasibility of the cultivation of insect-bacteria, and the application of the cultivated fungus in quantity to places infested by these insects; and several years previonsly the famous experimenter, Pasteur, recommended to the French Phylloxera Commission to find a means of destroying the Phylloxera by inoculation with a microscopic fungus. Balbiani finds that certain Bacilli when inocnlated in the blood of other insects kill them. Death follows in from twelve to forty-eight hours, according to external temperature, the number and origin of spores, and the size, age, and susceptibility of the subject. They die with all of tha symptoms which characterize flarlerie in silk-worms.

The practical difficulty in experiments in this direction appears to be that, thongh the air is more or less fillerl with floating disease-germs, insects like other animals, and man 
himself when healthy and living under favorable conditions, resist their attacks. Even if one or a few individuals were inoculated, the disease might not spread. When, however, insects are superabundant and crowded, and the conditions favorable to any disease arise, the timely inoculation of ever a few individuals might result in the destruction of immense numbers of insect-pests. Future experiments in this direction may give a new phase to economic entomology.

Unusual Increase in the Number of Insects.-It is frequently noticed that certain insects abound in profusion which are ordinarily rare or not common. This is due, as we shall see farther on, either to favorable weather or to the absence of their parasites. 'Thus canker-worms, the Hessian fly, the chinch-bug, the cotton-worm, as well as the Rocky Mountain and other locusts, may in certain years become vastly more numerous, and consequently more destructive, than in others. If all the eggs laid by insects came to maturity, the eirth would be overwhelmed with them, and every green thing would be devoured. In what a ratio insects might increase, were it not for these natural checks, may be seen by the following statements.

Tomicus typographus in 18\%, in the Bohemian forests, had three broods. Judeich assumes that in the middle of April the female laid in its maternal gallery 90 eggs; and he therefore reckons that early in June at least 30 individuals became capable of reproduction. Each of these 30 females again lays in the maternal gallery 90 eggs, producing also in all 2700 individuals; and by the beginning of August of the third brood again, only a third part of them being females, these would gnaw 900 maternal galleries and lay in them 8100 eggs. Having reached this number again, the next spring a third would be ready for oviposition, so that there would be of the first brood in April already 2\%,000 descendants of the single female which flew about the preceding April, and which would be now capable of laying $2,430,000$ eggs. 
"In Kruman, in the Bohemian forests, have been counted, during a period of great increase of fir barkbeetles in these forests from 1871 to 1875 , in a portion of bark a square meter in extent, from 1400 to 4800 larræ" (Judeich and Nitsche).

\section{Influence of Changes of Temperature on Insect-life.-} Perhaps changes of temperature and unfavorable seasons have, next to the increasing competition or struggle for existence among insects, and the attacks of parasites, the greatest effect in maintaining the balance of nature, and preventing the undue increase of destructive insects. Dr. Shimer gives an accomnt of an epidemic among the chinchbugs in Illinois, which "was at its maximum during the moist warm weather that followed the cold rains of June and the first part of July, 1865." Mr. C. Thomas claims that the high temperature of $1854,18 \% 1$, and 1874 , together with the diminished rainfall, furnishes the key to the cause of the vast increase of chinch-bugs during those years. * Wet weather is favorable and dry weather is unfavorable to the increase of the cotton-worm. In times of drought the eggs dry and fail to hatch, the worms are enfeebled, "web up" prematurely, and die in attempting to transform into the chrysalis state, and when they succeed the chrysalides decay. "Nourishment and fecundity being correlated, it is more than probable that the moths, poorly nourished, will lay fewer eggs under such circumstances. All the effects descr bed are intensified and become nost marked during extreme drought, so that frequently at the end of a dry spell, such as is not infrequent in July and early August, not a worm can be found. A rainy season, following such a spell, will produce a most noticeable change." $\dagger$

The Hessian fly flourishes best in seasons when the chinch-bug flourishes least. The hot, dry summer of 1881

* Amer. Entomologist, iii. 241.

† Riley, in Fourth Report U. S. Entomological Commission, 84. 
caused the pupa-cases or flaxseed to dry up, and eren destroyed the parasites. *

The canker-worm, tent caterpillar, and most larræ abound less after wet and cool springs. The spring of 1885 was unusually cold, rainy, and backward, and we noticed that as the result the lack of caterpillars and other forest-insects, as compared with the season of 1884, was rery marked; late in the summer and early in autumn there was a remarkable scarcity of caterpillars on oaks, maples, poplars, etc., while they were rery abundant during the previous autumn.

An English entomologist, C. G. Barrett, in an excellent article on the influence of adrerse or farorable climatic changes on insect-life, states that in the south of England, after an unusually cold winter, with no thaws, moths became unusually abundint for sereral following seasons. As he remarks: "I think there can be no doubt that in the case of those insects whose mode of life includes the. capacity for hibernation, their constitution is greatly strengthened, and their chance of arriving at maturity increased, if the cold of winter is sufficiently serere to induce complete torpidity, undisturbed by warm and spring-like weather at unseasonable times, and this may account for the rast increase in numbers in species which hibernate in the egg state; it also probably has a strengthening effect on those which pass the winter as small social larræ under a silken tent on the ground, or which, like Noctuæ, hibernate in the larral state on the ground or among dead leares, and are tempted out to feed by erery warm and genial erening.

"On the other hand, there cau be no doubt that mild winters act directly to cause the destruction of both hibernating larræ and pupæ, in two ways. One is by encouraging the growth of mould, which we know attacks them as soon as, from excess of rain or humidity, they become

* C. V. Riley, Amer. Nat., Nov. 1881, 916. 
sickly; the other by permitting the continued actirity of predaceous creatures.

"These are very numerous. Moles continue at work in mild winters, instead of burying themselres deep in the ground; and mice are constantly actire. These small mammalia destroy great numbers of Lepidopterous pupæ, and they abound in this district, as also do birds during the winter in an extraordinary degree. As soon as serere cold sets in to the north and east, the birds come down in swarms to the open fields and sheltered hillsides of this district, and it is hardly necessary to point them out as most industrious and perserering destrojers of larræ. Predaceous beetles and earwigs are generally on the alert all through rery mild winters; and although ther probably do not eat much at that time, and, indeed, are not rery plentiful in Pembrokeshire, they must destror many larræ and pupæ, haring little else to subsist upon. But I beliere that the mischief done by all these added together does not equal that done by the Onisci." *

In his work on bark-beetles Eichloff tells us that the chief factors in the growth of these insects are good weather and sufficient food. An uninterrupted dry, and hence hot, summer checks the growth of the larræ, and retards their speedy derelopment, and more often prerents a repetition of the broods than an uninterrupted wet and cold spring and summer. Hence on account of the great heat and drought many trees surrire which otherwise would be injured by the later broods of bark-beetles. The most farorable conditions for the increase of bark-beetles are doubtless a warm early spring, a warm summer with frequent rains, and a long mild autumn.

It is well understood in central Europe that great numbers of may-beetles die during a cold wet May. After an exceptionally warm and dry summer and autumn we may

* Psyche, iv. 83; abstract from Ent. Month. Wrag., June, 1882, 1. 
expect invasions of the northern army-worm (Leucania unipunctu).

Periodicity in Insect-life-As there may be a succession of seasons favorable to the development of insect-life, so there may be a corresponding increase in the numbers of insects, until they abound to excess. In this way periodical invasions of locusts happen the world over. A number of successive favorable seasons may result in a greater number of eggs of Leucania hatching, and the caterpillars nearly all arriving at maturity, none dying from bad weather, they abound in extraordinary numbers, and in great armies march through grass-lauds and wheat-ficlds in what seen to us countless numbers. We thus realize how many vicissitudes await the caterpillars in ordinary seasons, and how few pairs survive. Another striking case is that of the spruce-bud Tortrix ( $T$. fumiferancer), which for a number of years destroyed the spruce and firs on the coast of Maine, this species being rare and seldom captured either in the larva or imago stage in other years.

Number of Species of Insects.-The insects number about four-fifths of the animal kingdom, since it is estimated that there are not less than from 200,000 to 250,000 species in public and private collections. The Coleoptera are the most numerous, there being 100,000 species known, 90,000 species at least existing in museums; of Hymenoptera and Lepidoptera as well as Diptera there are not less than 25,000 species of each order; of Hemiptera about 2\%,000 species exist in mnseums, and Uhler supposes that the entire number is nearly 50,000 ; the species of the smaller orders would easily carry the total number of known species up to 200,000 . As recently remarked by Dr. Sharp, probably only from a fourth to a tenth of the existing species of insects are known; and as McLachlan has stated, it is not improbable that the number of species of insects now living on the earth's surface will be found to be about 1,000,000.

The number of described species of American insects 
north of Mexico has been stated by Mr. J. A. Lintuer (1886) to be as follows:

Hymenoptera......

Lepidoptera: Butterflies (Edwards's List, 1884, 614; Scndder's estimate, 1887).......... 500

Larger Moths (Grote's Check List, 1882), 3184-additions since making about... 3271

Tineidæ (Chambers's List, 18\%8, not included in Grote's List)............. $779-4550$

Diptera (Osten.Sacken's estimate in 1878).............. 2500 Coleoptera (Henshaw's List of 1885,9238 ; up to '88, 275)...... 9513 Hemiptera: Homoptera (Uhler's estimate).......... 1200

Heteroptera (Uhler's Check List, 1886).... 1448--2648 Orthoptera (Scudder's estimate).................... 450 All other orders, not estimated; perhaps............... 1000

Total........................ $\overline{25,111}$

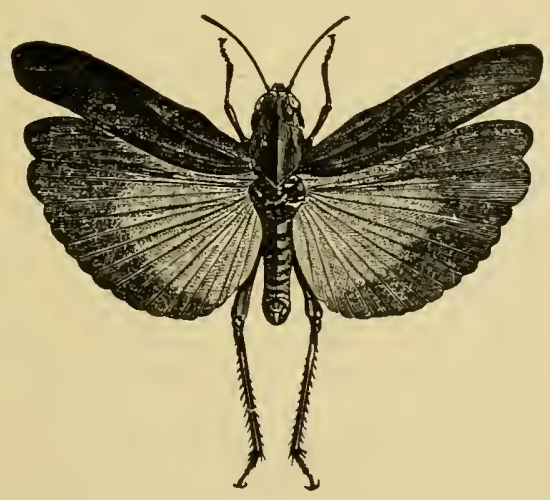

Edipoda xanthoptera. 


\section{CHAPTER III.}

\section{CLASSIFICATION OF INSECTS.}

Having examined the locust with the aid of the foregoing description, the student should make his studies comparative by carefully examining a cricket and a green grasshopper. Then he might turn to the following descriptions of examples or types of the order of white ants, dragon-flies, hugs, beetles, flies, moths, bees, etc., and as the result of his work he will be able to grasp the fact that the species of insects, as a rule, have bodies composed of seventeen segments, which are arranged in three regions, viz., a head, thorax, and hind body or abdomen; that the thorax bears two pairs of wings, and three pairs of jointed or segmented, legs; that they breathe by internal air-tubes opening externally by spircicles, and llact in growing they either develop directly, or undergo a complete metamorphosis.

The class of insects is divided or classified into orders, families, genera, and species, and the study of the classification of insects is called Systematic Entomology. The class, as regards existing forms, is divided into sixteen orders, as follows, beginning with the lowest or wingless order, Thysanura, and ending with the highest or most complicated group, the Hymenoptera.

\section{CLASS INSECTA.}

Jointed animals with a distinct head, thorex, and abdomen; three pairs of legs, and usually two pairs of vings; breathing by trachere; usually with a metamorphosis, viz., "l larval, pupal, and adult stage.

SEries I. Ametabola, or with an incomplete metamorphosis.

Order 1. Thysanura.-Wingless, minute, with a spring, or abdomen ending in a pair of caudal stylets; usually no compound eyes; no metamorphosis. (Examples: Podura, Campodea, Scolopendrella, Lepisma.)

Order 2. Dermaptera.-Body flat; the abdomen ending in a forreps; fore wings small, elytri-like; hind wings ample, folded under the first pair. (Forficula.) 
Order 3. Orthoptera - Wings net-veined; fore wiugs narrow, straight, not often used in tlight; hind wings large, and folded when at rest under the first pair; metamorphosis incomplete; pupa active. (Caloptenus, Loeusta, Phaneloptera, Acheta)

Order 4. Platyptera.-Body nswally Hattened; pronotum usually large and square; often wingless. (Mallophaga or bird-lice, Perla, Psocus, white ants.)

Order 5. Odonata.-Prothorax small; remainder of the thorax spherical; both pairs of wings of nearly the same size, net-veined. Larva and pupa ayuatic; labium of the larva forming a large mask. (Agrion, Libellula.)

Order 6. Plectoptera.-Mouth-parts nearly obsolete; wings netveined, hinder pair small, sometimes wanting; abdomen ending in three filaments. Larvie aquatic, with large jaws, and with gills on the sicles of the hind body. (Ephemera.)

Order 7. Thysanoptera.-Mouth-parts forming a short conical sucker; palpi present; wings narrow, not veined, fringed; feet bulbous at the end, withont elaws. (Thrips.)

Order 8. Hemiptera.-Mouth-parts forming a sucking beak; prothorax usually large; fore wings often thickened at base; pupa active. (Coreus, Cimex, Arma, Pentatoma, Cicada, Coccus, Aphis.)

SERIEs II. Metabola, or with a complete metamorphosis.

Order 9. Neuroptera. - Wings net-veined; mouth-parts free, adapted for biting; ligula large, rounded; pronotum large and square. Larva ofteu aquatic. (Corydalus, Chrysopa, Myrmeleon )

Order 10. Mecaptera.-IVings somewhat net-veined, or absent; head leugthened into a beak-like projection. Larva like caterpillars. (Panorpa, Boreus.)

Order 11. Trichoptera. - IVings and body like those of Tineid moths; mandibles obsolete in the imago. Larva usually aquatic, living in cases. (Pliryganea.)

Order 12. Coleoptera.-Fore wings thick, ensheathing the hinder pair, which are alone used in flight; month-parts free, adapted for biting; metamorphosis complete. (Doryphora, Prionus, Lucanus, Harpalus, Cicindela.)

Order 13. Siphonaptera.-Wingless; mouth-parts adapted for sucking. Jarve maggot-like, but with a well-developed head and mouth-parts. (Pulex.)

Order 14. Diptera.-Only two wings; month-parts adapted for lapping and sucking; a complete metamorphosis. (Musea, CEstrus, Syrphus, Cecidomyia, Tipula, Culex.)

Order 15. Lepidoptera.-Body and wings covered with seales; maxillæ lengthened into a very long tongue; larvæ (catelpillars) with abdominal legs. (Tinea, Geometra, Noctua, Bombyx, Sphinx, Papilio.)

Order 16. Hymenoptera.-Wings clear, with few veins; mouthparts with a variety of functions, i.e., biting, lapping liquids, etc. In the higher families the thorax consists of four segments, the first abdominal segment of the larva being transferred to the thorax in the pripa and imago. Metamorphosis complete. (Tenthredo, Cynips, Ichneumon, Sphex, Vespa, Apis.) 
Tabular View of the Orders of Insecta.

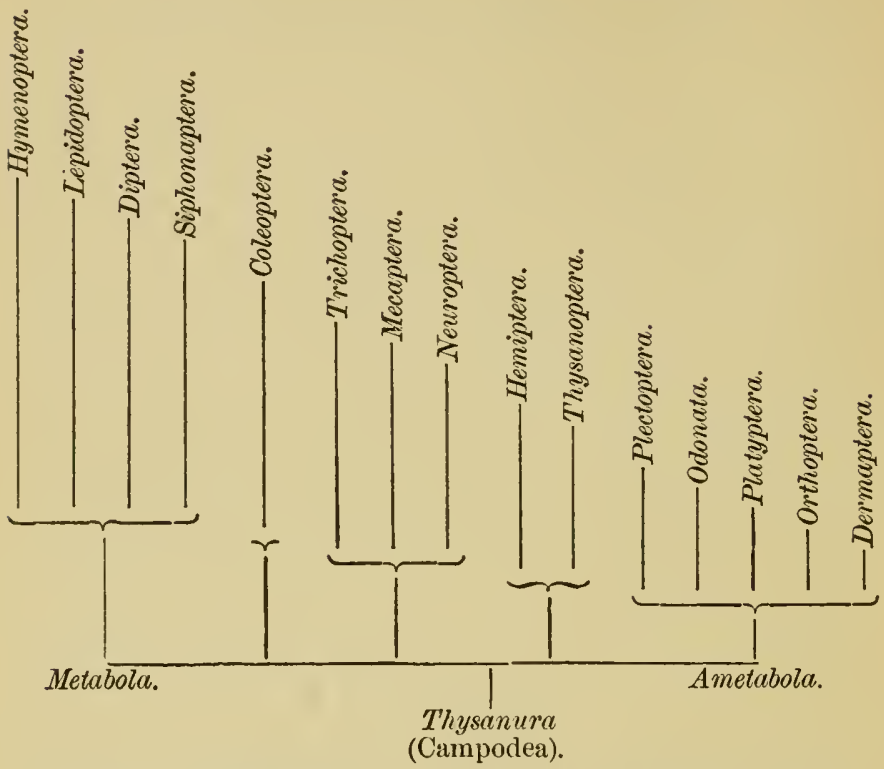

\section{Order I. Thysanura* (Spring-tails and Bristle-tails).}

The 'Thysanura are very primitive forms, are all wingless, with usually simple eyes, and undergo no metamorphosis. They usually live in damp places under stones,

\section{* Selected Works.}

Gervais, P., in Walckeuaer, "Hist. Nat. des Insectes Aptères," iii. 377 (1844).

Haliday, A. H. Iapyx, a new genus of insects, etc. (Trans. Linn. Soe., London, xxiv., 1864).

Lubbock, J. Monograph of the Collembola and Thysanura (Roy. Soc., London, 1873).

Meinert, F. Campoder, a family of Thysanura (Naturhist. Tidsskrift, Copenhagen, 1865) (Swedish and Latin).

Nicolet, $\mathrm{H}$. Reeherches sur les Podurelles (Neuchatel, 1842).

Packard, A. S. Bristle-tails and Spring-tails (Amer. Nat., v., 1871), and "Our Common Insects" (1873).

- Synopsis of the Thysanura of Essex County, Mass. (5th Rep. Peab. Acad. Se. Salem, 1872).

Tullberg, J. F. Swedish Poduridæ (Stockholm, 1872).

— Coilembola boreali (Roy. Swedish Acad., Stockholm, 1876). 
et.e, though the bristle-tails prefer warm and dry situations, and either, as in the Cimuru, run swiftly, or, as in the Poduridæ, vigorously leap by means of a long appendage at the end of the body, which on being released throws the insect high in the air. The higher members of the order, as Campodea and Scolopendrella, are connecting links between the true insects and the centipedes (Myriopoda). In many Podurids the trachea are wanting.

Sub-order 1. Collembola.-The spring-tails are degraded forms, with the mouth-parts quite rudimentary, and retracterl within the head, only the ends projecting. What correspond to the anal stylets of Campodea and Lepisma are in the Podurids united at the base anc $\vec{i}$ bent under the hind body to form the spring, which is held in place by a hook or tenaculum; on the under side of the hind body is a sort of sucker (collophore), and as no other insects possess this singular apparatus, the group is named from it Collembola, which means to throw out a sucker, so as to adhere to surfaces. Their bodies are covered with scales.

These spring-tails occur everywhere under leaves, the bark of trees, etc., and rarely live except in moist or shaded places, where their eggs are deposited. The snow-flea (Achorutes nivicola) is sometimes seen in great numbers leaping on snow. They should be preserved in vials of alcohol, and can be collected by placing an ether vial over them and allowing the creatures to spring into it, or the finger wet witl the saliva can be lightly laid on them, when they can be transferred to a vial of alcohol. They can also be monnted in balsam on glass slides. Fig. $\begin{gathered}41 .-S m y n t h u z \\ \text { rus, a spring-tail. }\end{gathered}$

Family Poduridæ.-Body long and slender, head small, Tomocerus plumbeus (Linn.); or body short, Smynthurus elegans Fitch.

Sub-order 2. Symphyla.*-A remarkably composite type, having the head of a Camporlea, while the abdomen hats a pair of legs to each joint, like the centipedes.

Family scolopendrellidx, with the chinacters of the sub-order. Scolopendrella immaculata Newport.

* The Symphyta should be regarded as forming a distinct order. 
Sub-order 3. Cinura.--Here belong the bristle-tails, the

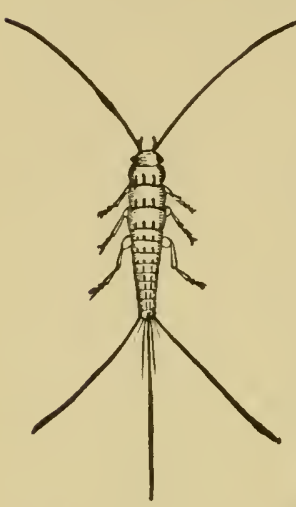
hind body being long. and with small, rudimentary processes corresponding to the abdominal feet of Scolopendrella.

Family Campodidæ.-With long, slender bodies and long, delicate caudal stylets. Campodea staplylinus Westw.

Family Iapygidæ.-Like Campodea, but the boly ending in a pair of forceps. Iapy.x subterraneus Pack.

Family Lepismatidæ. - Body flattened, covercl with seales, with five caudal stylets, three of which are very long. Sometimes injurious to papers and books. Lepismu saccharina Linn., L. domestica Pack. has injured books in the library of Wellesley College. L. 4-seriata Pack. (Fig. 42). In Machilis the eves are large and compound. Fig. 42.-Lepisma 4-seriata. Machilis veriubilis Say.

\section{Order II. Dermaptera* (Etrwigs).}

This small group comprises the earwigs, which are nocturnal insects very rare in this country, except in the Southern States, but common in Europe. Usually placed among the Orthoptera, the earwigs have certain important characters which forbid our placing them in that order. The fore wings are very small and short, like the elytra of the rove-beetles, while the large, broad, transparent, hinder wings are folded under the anterior pair, the process of folding being aided by the large forceps at the end of the body; the latter is long and narrow and much flattened.

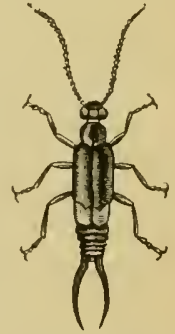

FIG. 43.-Forficula croce $i$ pennis.

Family Forficulidx.-Body long, Forficula; body short, Labia.

$$
\text { * Selected Works. }
$$

Dufour, L. Recherches anatomiques sur les Labidoures or Perceoreilles (Ann. des Sc. Nat., xiii.). 1828.

Meinert, F. Anatomia Forficularum. Copenhagen, 1863.

Packard, A. S. (External Anatomy, in third report U. S. Eut. Commission, 1883 , p. 304 , Pls. XXIII, XXIV).

scudder, S. H. Notes on Forficularie, with list of described species (Proc. Bost. Soc. Nat. Hist., xviii., 1876). 
ORder III. ORTHOPTERA * (Locusts, Grasshoppers, Crickets, etc.).

By no means do all the members of this group, as the name of the order would imply, have straight fore wings, but in the locusts and grasshoppers they are generally narrow, straight, and thicker than the hinder pair, serving as wing-covers to protect the hinder, thinner ones. The antennre may be very long, while the pronotum is almost invariably broad and large, flattened or compressed and moving freely on the rest of the thorax, which is covered by the wings when folded. The hind wings are much larger than the front ones, and have numerous longitudinal and cross veins, while the ovipositor, when present, varies much in shape and size; and the number of tarsal joints varies from two to five.

Fig. 44 illustrates the incomplete metamorphosis of the common red-legged locust; it represents the freshly-hatched larva, which moults once before its wings begin to bud out, as at $3 b$; this stage (3b) may be called the first pupal

\section{* Selected Works.}

Glover, T. Illustrations of North American Entomology. Orthoptera. (4to, 13 pls. Washington, 1872.)

Riley, Packard, and Thomas. First, Second, and Third Reports U. S Entomological Commission, 1877-83.

Saussure, H. de. Studies of the Orthoptera of Mexico and Central America (Paris, 1870-74). (In French.)

Scudder, S. H. Materials for a Monograph of the N. A. Orthoptera (Jour. Bost. Soc., vii., 1862).

- Catalogue of North American Orthoptera (Smithsonian Misc. Coll., viii. Washington, 1868).

- Revision of the Mole Crickets (Mem. Peabody Acad., No. 1. Salem, 1869).

Serville, A:- Natural History of the Orthoptera (suites ì Buffon). (1 vol., 8vo. Paris, 1839.) (In French.)

Stoll, C. Representations of the Phasmidæ, Mantidæ, Acrididæ, Gryllidæ (etc.), of the four parts of the world (2 vols., 4to, 70 pls. Amsterdam, 1815). (In French.)

Thomas, C. Synopsis of Acrididæ of North America (Final Report U. S. Geol. Surv., vc!. v. 4to. Washington, 1875).

Walker, F. Complete catalogue of Dermaptera Saltatoria $(4$ vols and suppl. 8vo. London, 1869-71). 

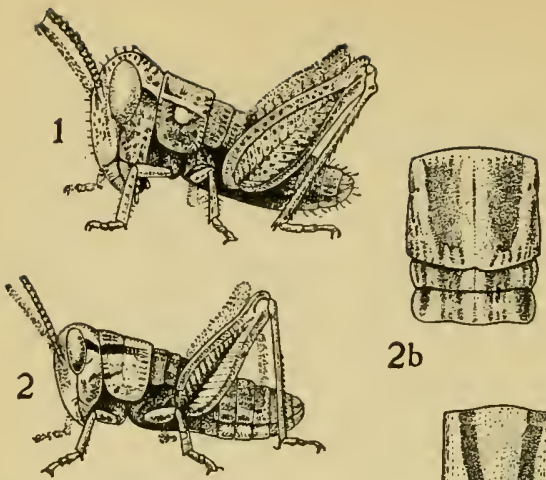

$2 b$
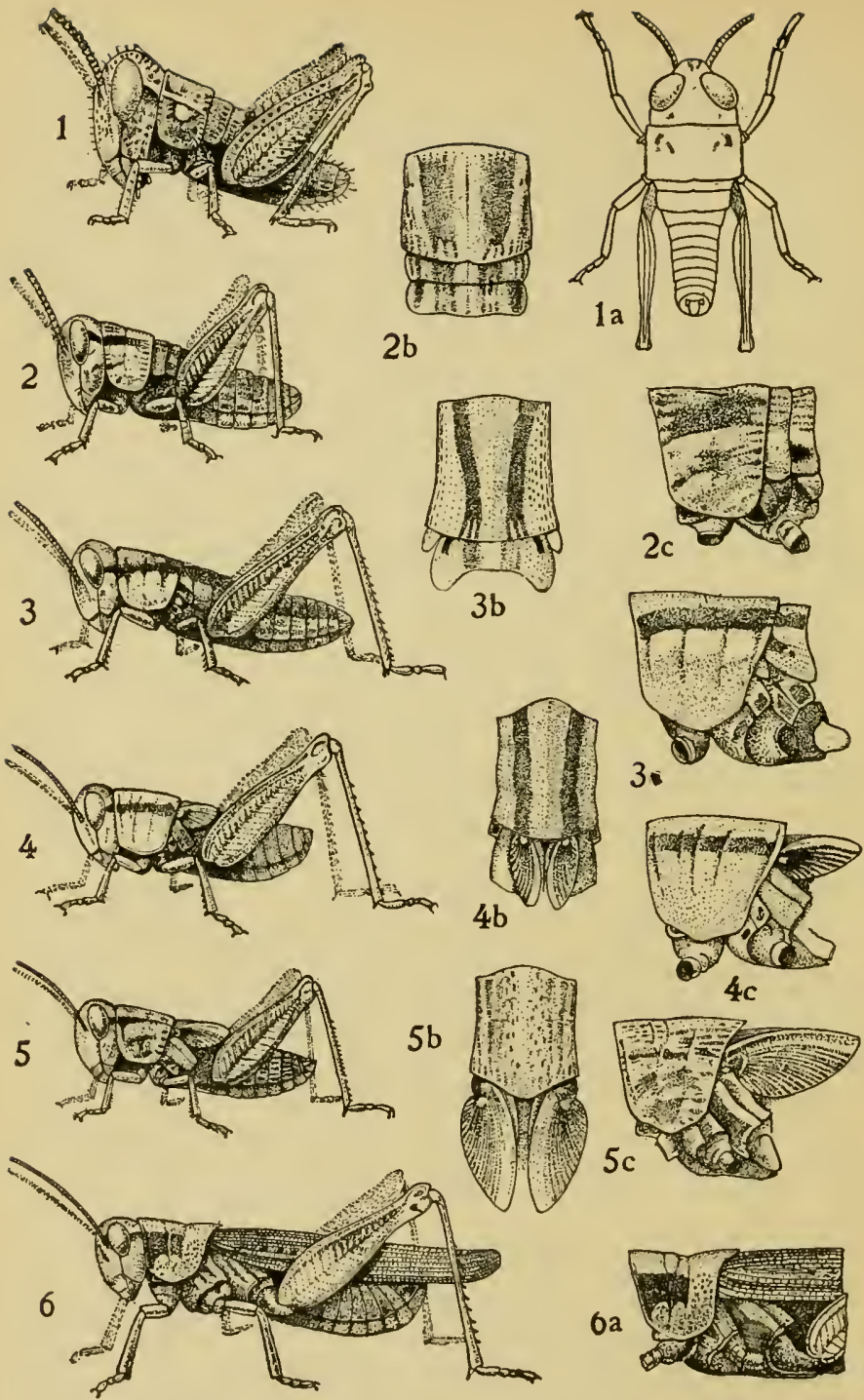

$5 c$ 16.

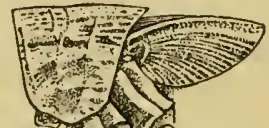

FIG. 44.-Fcomplete metamorphosis of the common red-legged locust, Caloptenus femur-rubrum. $1,1 a, 2,2 b, 2 c$, the two larval stages: $3-5$, the three pupal stages; $6,6 a$, the adult.-Emerton del. (To face page 61.) 
stage, and as the locust monlts twice afterwards before the final imago stage is reached, it may be said to have three pupal stages. When we compare the freshly-hatched larva with the adult, we see that the only important difference is the presence of wings.

There is no great change, such as marks the life-history of a butterfly. Perhaps it is by reason of their incomplete metamorphosis, the general uniformity of their habits, and their living on vegetable food, that Orthoptera are not numerous in species compared with the beetles and higher orders.

The locusts lay their eggs in packets in the ground (Fig. 45). With its ovipositor, which is made up of

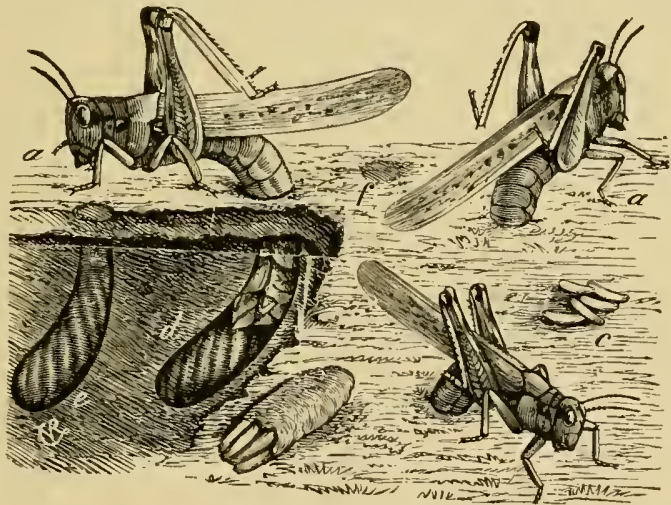

FIG. 45.-Rocky IIountain locust laying its eggs (c) one by one, forming an oval mass. All natural size.-After Riley.

three pairs of short spines, the two onter pairs very large and stont, the locust thrusts its hind body deep into the earth and deposits a packet of eggs.

Many dangers attend the life of these insects. To overcome or to avoid them, many of them, as certain katydids, the leaf-insects, and the stick-insects, mimic leaves and sticks, so that insectivorous birds are deceived by them.

Locusts are also attacked by parasites: little red mites stick to their bodies; hair-worms, and especially the mag- 
got of the flesh-fly, infest them, and thus thousands of them are swept away. All this is of use, however, for were it not for the kindly aid thins rendered, the earth would be each year overrun with locusts.

The males of many Orthoptera, as the crickets, green grasshoppers, katydids, etc., and locusts, produce loud, shrill sounds, by which they attract the females; but in the European Ephippigera, one of the Locnstidæ, the female is provided with well-developed vocal organs. They stridulate in three ways-i.e., first, by rubbing the base of one wing-cover on the other (crickets and green grasshoppers); second, by rubbing the inner surface of the hind legs against the outer surface of the front wings (some locusts); third, by rubbing together the upper surface of the front edge of the hind wings and the under surface of the wingcovers during flight (some locusts).

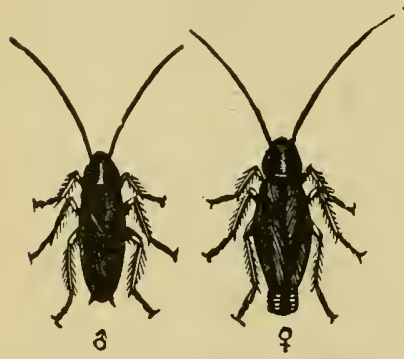

Fra. 46.-Croton bug, Ectobia germanica. Natural size.

Family Blattariæ.-Body flattened, oval, with a broad pronotum; fore wings broad oval; antennæ long and filiform. Blatta orientalis Linn., and Periplaneta americana (Linn.). While troublesome from eating clothing, etc., and mischievous in bakeries and storehouses, they are serviceable in clearing houses and ships of bedbugs. The eggs are laid in a beanshaped capsule (oötheca), which is divided into two compartments, each containing about thirty eggs. Our native species, Platamodes pensylvanica (De Geer), lives under stones.

All are nocturnal in their habits. The metamorphosis of $B$. orientalis is said to require four years.

Family Mantidæ. - Fore legs adapted for seizing their prey, which

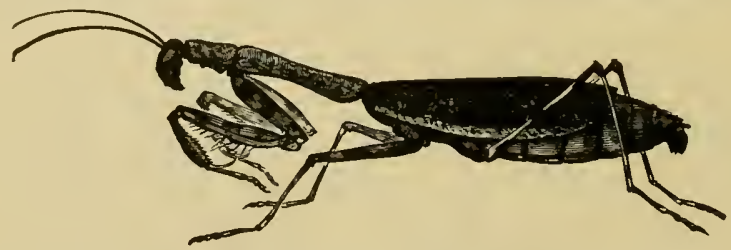

Fig. 4i.-Mantis carolina, soothsayer. Natural size.

consists of other insects. Eggs laid in large bunches on various plants 
Family Phasmidæ-The walking-sticks or spectres, represented by our Diapheromera femoratum Say, which resemble twigs, are very slender, with more or less cylindrical bodies and long legs; their wings are either wanting or ruclimentary, or if developed, strikingly leaf-like, as in the leaf-insect (Fig. 48, Phyllium siccifolium Linn.).

Family Acrydiidæ. - Locasts have short antennæ, and the body is laterally compressed; the ears are at the base of the hind body, while the ovipositor is short. OEdipoda carolina (Linn.), Caloptenus spretus, and $C$. femur-rubrum.

Fanily Locustidæ.-Body compressed; but the antennæ very long and slender, while the ovipositor is very large and sabreshaped. Some forms, as Ceuthophilus, are Fig. 48.-Leaf-insect, Phylwingless. The large green grasshoppers livm. Half natural size. represent this group, of which the katydid and its allies (Phaneroptera curvicauda De Geer) are familiar examples. Certain forms closely resemble leaves.

Family Gryllidæ.-In the crickets the body is somewhat flattencel vertically, or it may be more or less cylindrical, and the abdomen ends in a pair of long stylets. The mole-cricket, Gryllotalna borealis Burm., burrows in moist earth. The tree-cricket (Écrenthns nivens Serville) makes a loud shrilling noise by mbbing the npper on the under wings, and injures raspberry-bushes and other shrubs by laying its eggs in the twigs.

\section{Order IV. Platyptera* (White Ants, ete.).}

This group comprises the bird-lice, Psocidæ, stone-flies (Perlidæ), and the white ants. In all except the Psocidæ

\section{* Setected Works. \\ Platyptera in general.}

Hagen, H. A. Synopsis of the Neuroptera of North America (Smitl. Inst. 1861).

Packard, A. S. (External anatomy, in third report U. S. Ent. Commission, 1883 , pp. 292, 322, with plates.)

\section{a. Mallophaga.}

Denny, H. Monographia Anoplurorum Britanniæ (London, 1862). Grosse, F. Beiträge zur Kenntniss der Mallophagen (Zeits. f. Wissen. Zool., xlii., 1885, 530. A Astract by G. AIcCloskey in Amer. Nat., $1886,340)$.

Melnikow, N. Beiträge zur Embryonalentwicklung der Insekteu (Archiv f. Naturg., xxxv., 1869). 
the body is flattened, and the head extended horizontally. The pronotum is large, broad, and more or less square; the

Nitsch, C. L. Die Familien und Gattungen der Thierinsekten (Germar's Mag. d. Ent., iii., 1812). Insecta epizoa (Leipzig, 18i4. Edited by Giebel).

Packard, A. S. On the systematic position of the Mallophaga (Proc. Amer. Phil. Soc., xxiv., 188\%, p. 264).

Piaget. Les Pédiculines (Leyden, 1880).

\section{b. Perlidæ (Plecopter $)$.}

Gerstaecker, A. Ueber das Vorkommen von Tracheenkiemen bei ausgebildeten Insekten (Zeits. f. Wissen. Zool., xxiv., 1874).

Hagen, H. A. Synopsis of N. A. Neuroptera.

Newport, G. On the anatomy and aftinities of Pteronarcys regalis (Trans. Linn. Soc., London, xx., 1851).

Packard, A. S. (External anatomy of Pteronarcys, in third report U. S. Ent. (ommission, 1883, p. 322, Pls. XI, XLIV, LVII).

Pictet, $\mathbf{F}$. Histoire naturelle, etc., des insectes Neuroptères: Part 1., Perlides; Part II., Ephémérines. (Genève, 1841-45. With colored plates.)

c. Psocidæ (Corrodentic in part).

Burgess, E. The anatomy of the head, and the structure of the maxilla, in the Psocide (Proc. Bost. Soc. Nat. Hist., xix., 1878, 291).

Hagen, H. A. Synopsis of N. A. Neuroptera.

Beiträge zur Monographie der Psociden (Stettin Ent. Zeit., 1882).

Nitzsch. C. L Leber die Eingeweide der Bücherlaus, Psocus pulsatorins (Germar's Mag. d. Eut., iv., 2i6).

Packard, A. S. (External anatomy of Psocus, in third report U. S. Ent. Commission, 1883, p. 325, Pls. XXXIX, XLIII).

\section{d. Embidæ.}

Hagen, H. A. Monograph of the Embidina (Canadian Ent, xvii., 1885 ).

Westwood, J. 0. Characters of Embia, a genus of insects allied to the white ants (Trans. Linn. Soc., xvii., 369).

See also the writings of MIcLachlan, Wood-Mrason, etc.

\section{e. Termitidæ (Corrodentia in part).}

Hagen. H. A. Monographie der Termiten (Linnæa Entomolog., x., xii., and xiv.).

Müller, F. Beiträge zur Kenntniss der Termiten (Jena. Nat. Zeitsch., vii., 1873).

Packard, A. S. (External anatomy, in third report U. S. Ent. Commission, 1883, p. 326, Pls. XXXIX-XLIII).

Smeathman, $\mathbf{H}$. Some account of the Termites, which are found in Africa and other hot climates (Phil. Trans, , lxxi., 1781. London). 
meso-and metanotum are remarkable on account of the imperfectly formed scuta and scutella, the latter being indefinite in outline, though large. 'T'he chest-pieces (or' sterna) are large and broad; and there are often eleven segments in the abdomen. The order receives its name from the fact that the wings are usually laid flat upon the back when the insect is at rest.

'I'he bird-lice (Mallophaga), thongh usually associated with the true lice (which are wingless parasitic Hemiptera), in reality seem to be degraded, wingless Platyptera, and in
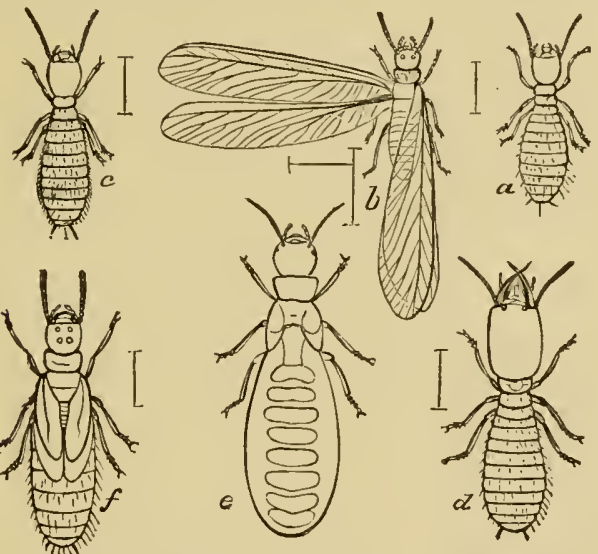

Fig. 49.-Termes flucipes, white ant. a, lama; b. winged male; $c$, worker; $d$, soldier; $e$, large female; $f$, wympl or pupa.-From Riley.

the shape of the body and mouth-parts are more nearly allied to the family Psocidce, which includes the deathtick, than any other group of insects; hence we regard these parasites as forming a sub-order of the present group. All the insects of this order have some remarkable peculiarities. The stone-flies or Perlidæ, which as larvæ live in the water and breathe by extermal tufts of gills growing on the under side of the thorax, in some cases, as in the species of Pteronarcys, retain them in the winged state. 
'The white ants top the Platypterous series; they live, like ants, in stumps and fallen trees, and do much liarm, especially in the tropics, by undermining the sills of houses, and destroying furniture, books, etc. 'Their colonies are very large and populous.

In our Termes flavipes there are, besides males and females, workers and soldiers; the workers being white, small, ant-like, and wingless, with small round heads, while the soldiers have large square heads, with long jaws; the pupa are active. In Brazil a species of white ant is differentiated into six different sets of individuals: viz., winged and wingless females; winged and wingless males; workers and soldiers. A wingless male and female may, on the death of a normal winged male and female, replace them in the colony. A male or king was found by Mïller living with thirty-one complemental females.

Sub-order 1. Mallophaga.-The bird-lice live usually as

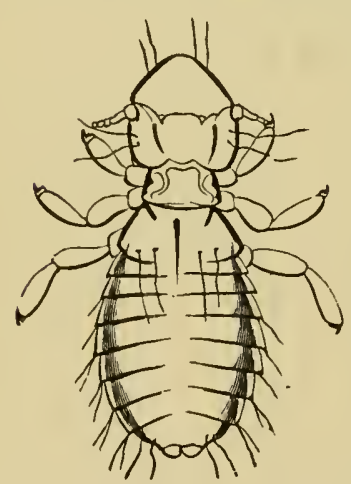

parasites under the feathers of birds, eating the feathers; but the species of two genera (Trichodectes and Gyropus) live on mammals, eating the young hairs, and sometimes clots of blood. They differ from lice in having jaws adapter for biting. They can be mounted in balsam as transparent objects for the microscope.

Family Philopteridæ.-With filamentous 3- or 5-jointed antenne, but no palps. Trichodectes canis De Geer, paraFig. 50,-Goniocotes of domestic sitic on dogs; Goniocotes burnettii Pack. fowl. on the domestic fowl.

Fanily Liotheidæ.-With club-shaped 4 -jointed antennæ and palps. Gyropus porcelli Shrank, on the porpoise; $G$. oralis, on the Guinea pig; in the U. S., Menopon pallidum Nitsch, on fowls.

Sub-order 2. Corrodentia.-This group includes the normal, winged forms. 
Family Perlidæ. - Body long and tlat; prothorax square; antennx long and thread-like; abdomen ending in two long stylets; wings
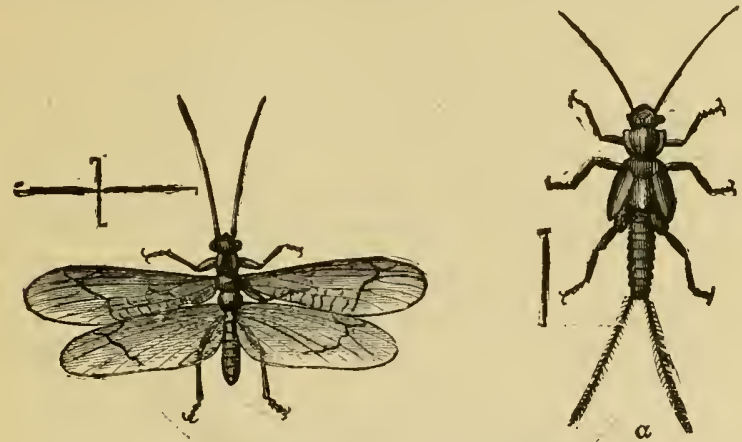

Fig, 51.-A Perlid (Nemoura). a, pupa (nymph) and imago.

with transverse veins, and folded tlat on the back. The larvæ and pupe active, living under stones in streams, the imagines frequenting damp, shady places by water-courses. Perla abnormis Newman; Pteronarcys regalis Newman.

Family Psocidæ. - Small insects, with short cylindrical bodies, a small prothorax, and a swollen elypeus, resembling Aphides; wings small, deflexed, with few veins; living on lichens, etc., and on the under side of leaves. Psocus nove-scotice Walker, Ciecilius (Fig. 52). The book-louse, Atropos pulsatorius (Linn.), is wingless; it is sometimes called the "death-

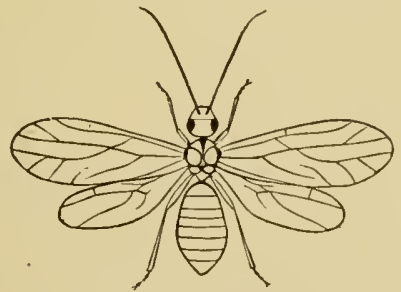

Fig. 52.-Cocilius.

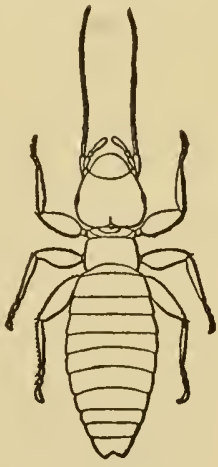

Fig. 53.-Atropos pulsutorius.

watch" or " death-tick," from being erroneously supposed to make a ticking noise like the Anobium beetle. It is common in books, and is injurious to cabinet specimens of small moths and other delicate inseets.

Family Embidæ.-Body long, tht, and narrow; wings with few veins. Embia sarigni Westw., Egypt, none in the U. S.

Family Termitidæ.-The white ants in some features closely resemble the cockroaches, but they are smaller, with narrower bodics 
and wings, the latter being thin and finely net-reined alike in both pairs; antennæ short, 18-20-jointed. Termes flavipes Kollar (Fig. 49), Massachusetts southward.

\section{Order V. 0donata* (Dragon-fies).}

In the dragon-flies the head is large, the eyes in the typical forms enormous, while the antennæ are minute, like short bristles, the sense of sight predominating over that of smell, and the jaws are large and strong, these insects being carnirorons, greedily snapping up flying insects, such as mosquitoes, small flies, etc., which they probably perceive

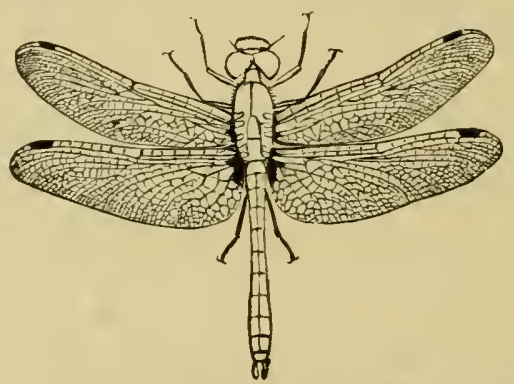

FIG. 54.-A dragon-fly, Diplax berenice. Male; natural size.

at a much greater distance than can most other insects. The thorax is large, round, and differs from that of other insects in the great development of the side pieces (espe-

* Selected Works.

Cabot, L. The immature state of the Odonata (Mem. Mus. Comp. Zool., i., 18i2).

Gerstaecker, A. Zur Morphologie der Orthoptera amphibiotica (Berlin, 1873).

Hagen, H. A. Synopsis of the Neuroptera of North America.

- Synopsis of the Odonata of America (Proc. Bost. Soc. Nat. Hist., xviii., 1875).

Monograph of the earlier stages of the Odonata (Trans. Amer. Ent. Soc., xii., 249. 1885).

Packard, A. S. Embryological studies on Diplax [Eschna?], Perithemis, etc. (Mem. Peab. Acad. Sc.. 18r1).

Viallanes, H. Le ganglion optique de la Libellule (Eschna). (Ann. Sc. Nat. Zool., 1884.)

Also the writings of Charpentier, De Selys-Longchamps, Hagen, IIcLachlan, Pictet, Rambur, Scudder, and Walker. 
cially the episterna) and the rery small prothorax. 'The abdomen is very long and slender, cylindrieal, ending in a pair of claspers in the male. 'The wings are large, densely net-veined, the hinder pair being often a little larger than the front pair.

Dragon-flies either, as in Libellula and allies, lay their eggs in jelly-like masses on the surface of ponds, or, as in Agrion, they crawl deep in the water along the stems of submerged plants, and with their sword-like oripositor cut gashes into the stalk in which they insert their eggs.

The larva of the dragon-fly conceals its powerful jaws, for it is very destructive to the smaller creatures about it, by its enormous labium or under lip. 'This forms a broad smooth mask covering the lower part of the face; it is armed at the broad spoonshaped extremity with two sharp movable hooks, adapted for seizing and retaining its prey. It breathes by arl- FIg. 55.-Eschna larva mitting water through the rent into (nymph). Natural size. the intestine, which near the end is lined with folds of membrane rich in trachex, by which the air is extracted

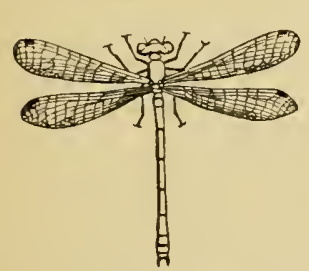
from the water and mixes with the blood; the folds are also so arranged that the water thus introduced can be forced ont as if from a syringe, by which the insect is suddenly propelled over the bottom. The entrance to the intestine is protected by from three Fra. 56.-Agrion. Nat. size. to five conical horny valves, which open and shut at will. The larva of Agrion and its allies have three external broad, leaf-like, traeheary gills sitnated at the end (in the larva of Euphæa the gills are attached to the sides) of the body. Male dragon-flies are sometimes 
sensibly larger, and never smaller, than the females, and do not generally pair with the fenales, until a week or fortnight after emerging from the pupa, and until they have assumed their proper masculine colors (Darwin's Descent of Man, i. 33\%).

The larvæ are interesting creatures to keep alive in aquaria, where their transformations can be watched, especially if collected in the spring. Little is known regarding their habits, and any one who can spend the necessary time and patience in rearing them, so as to trace $\mathrm{np}$ the different stages from the larva to the dragon-fly, and describe and accurately figure them, will do good service to science. When about to cast its skin, a rent opens along the back of the thorax, and the insect having fastened its claws into some object at the bottom of the pool, it gradually works its ways out of the larva skin. When about to change to the adult fly, the pupa climbs up some plant to near the surface of the water, its back then yawns apart, and from the rent the dragon-fly showly emerges. For an hour or more it remains torpid and listless, with its flabby, soft wings remaining motionless. The fluids leave the surface, the wings expand, the skin hardens and dries, the colors appear, and the dragon-fly rises into the air. The colors of dragon-flies are very striking, consisting of rich green, blue, yellow, vermilion and metallic tints, and the sexes differ in color. Certain dragon-flies appear to be attracted by particular colors, as the blue males of an Agrion were seen to settle in numbers on the blue float of a fishing-line. The males, in several genera, when they first emerge from the pupa are colored exactly like the females; but' in a short time they assume a conspicuous milky-blue tint, owing to the exudation of a kind of oil, soluble in ether and alcohol. Certain species of Neurothemis are dimorphic, some females having their wings netted as nsual, while others have them richly netted as in the males of the same species. In several species of Agrion a certain number of individuals are of an orange color. (Darwin's Descent of Man, i. 352.) 
Family Libellulidæ.-Calopteryx apicalis Burm., Agrion civile Hagen, _Eschna heros Fabr., Libellula trimaculata De Geer.

\section{Order VI. Plectoptera* (May-flies).}

Like the dragon-flies, the Ephemeræ or May-flies are in their own way very peculiar insects, and camnot be placed in any of the older established orders. We have therefore proposed the name Plectoptera for the group, in allusion to the fine, gauzy network of their wings.

The adult May-flies are characterized by the very rudimentary eondition of the month-parts. In examining the under side of the head there is a hollow, with only slight rudiments of the mandibles, maxillæ, and labium. As these insects live but a few hours, only long enough to provide for the continuance of the species, they need to take no food, hence the moutli-parts are
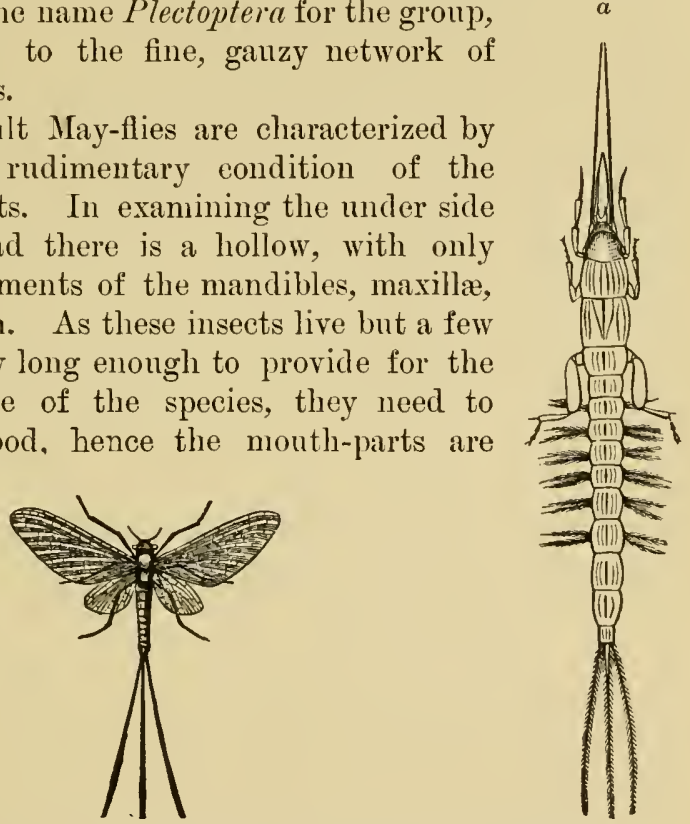

FIG. 57.-May-tiy, natural siz9. $\quad \alpha$, larva, twice enlarged.

nearly aborted, and the antennæ are small and bristle-like.

\section{* Selected Works.}

Eaton, A. E. A revisional monograph of recent Ephemeridæ or Mayflies. Parts I.-IV. (Trans. Linn. Soc., London, 1883-85).

Hagen, H. A. Synopsis of the Neuroptera of North America (1861). Lubbock, J. Development of Chloëon dimidiatum (Trans. Linn. Soc., London, xxiv.-v., 1865-66).

Packard, A. S. (External anatomy, in third report U. S. Entomolog. Conmission, 1883; pp. 333-335, Pls. XLV-XLVI).

Swammerdam, J. Ephemerie Vita (Amsterdam, 1675).

Vayssière, A. Recherehes sur l'organization des larves des Ephémérines (Ann. Sc. Nat., xiii., 1882). 
'The thorax is also peculiar in being globular, the prothorax is small and collar-like, while the mesothorax is very large, and the metathorax very small. The wings are finely net-veined, and the hinder pair are very small, sometimes wanting. The abdomen is very long and slender, ending in three long, jointed stylets, while in addition there are in the males beneath the stylets two pairs of jointed claspers, a feature peculiar to these insects. Horeover, as in the Dermaptera, the genital openings of both sexes are double; in all other insects there is but a single opening.

But if the May-fly takes no food, it is quite otherwise with the larva and pupa. Fig. 5\%, $a$, represents the larva or nymph of Palingenia; its body is long and slender, with long slender antennæ, while the jaws are very large, the creature being voracious and feeding on other insects. Along the sides of the hind body are either leaf-like or bushy tracheary gills, and the body ends in long hairy bristles.

The larvæ are said to live two or three years, residing in burrows in the mud, under stones, or among grass and weeds, where they may be taken with the water-net in great abundance, and are beantiful objects for the aquarium. Some of the group, if not all, differ from other insects in moulting so many times; thus Chloëon casts its skin twenty-one times before it assumes the imago state. In another respect the May-flies are peculiar: after transforming from the nymph, the winged insect, called the subimago, takes a short flight, and then casts another skin before assuming the final, imago, state.

May-flies often appear in immense numbers, and falling into the water become stranded in windrows along the borders of lakes. The perfeet.insects should be preserved in alcohol for study, and described when alive if possible, as the body shrivels up and the colors fade when pinned.

Family Ephemeridæ. Characters of the order. Potamanthus mar. ginatus Zett. (Fig. 57), Pulingeniu bilineata Say (Fig. 57, a, nymph). 


\section{ORDER VII. THYSANOPTERA.*}

Represented by the little group of which Thrips is the type, and placed by some among the Hemiptera, to which they seem closely allied, it may be said that though the head ends in a short beak, yet these insects differ from the bugs in having maxillæ bearing 2-3-jointed palpi, while the labial palpi are present, and, though very short, are composed of from two to three joints. 'The order derives its name from the long delicate fringe on its long, narrow, and often veinless wings. In some species the wings are wanting, at least in the males. 'The abdomen, in certain species, ends in the males by a slender joint, and in the females by a 4 -valved borer.

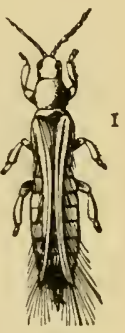

FIG. 58.

Thrips

striatus.

The eggs are somewhat like those of Hemiptera, being cylindric, round at one end and crowned with a knob at the other. The larva and pupa are both active, and in the rather sluggish pupa the antennæ are tmrned back on the head, while the limbs and wings are enclosed in a thin filmy membrane; the feet end in bulbous enlargements, hence the name "bladder-footed" (Physapoda) applicd to the group by Burmeister.

The wheat 'Thrips, Limothrips cerealium Haliday, is injurious to wheat; Thrips striatus Osborn (Fig. 58) destroys onion-plants. These insects injure plants by puncturing and killing the leaves; all the species are minute, and little is known of them in the United States.

Family Thripidæ.-Characters of the order as given above.

\section{* Seluected Works.}

Haliday, A. H. An epitome of the British genera in the order Thy. sanoptera (Entomological Mag., iii. 439. 1836).

Packard, A. S. (Standard Natural History, second edit., 1888; also contains a list of described N. A. species by Th. Pergande.)

Reuter, 0. M. Thysanoptera Fennica. (1880.)

Uljanin, W. H. Embryology of Plyysapoda (Mloscow. In Russian). 


\section{Order VIII. Hemiptera* (Bugs, Plant-lice, etc.).}

While the preceding groups are of limited eratent as regards number of species, the one now before us is very rich in this respect. We are now to take into account insects which

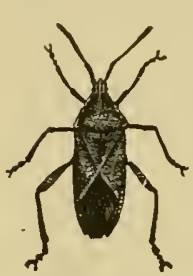
gain their livelihood by piercing and sucking the sap of plants or the blood of other insects; and the change in the jaws by which a sucking beak is formed is very curious.

Owe can obtain an excellent idea of what a bug is by dissecting a common squash-bng (Fig. 59). With a lens fixed on a stand, and a Fra. 59.-Squash- needle mounted in a handle, the student can, bug. Nat. size.

after a few trials, dissect the head from the body, examine the beak, the wings; separate the thorax

\section{* Selected Works.}

Amyot, C., and Serville, A. Hemiptères (Paris, 1843).

Buckton, G. B. Ilonograph of the British Aphides (Ray Society. i., ii. London, 18;6- $; 9$ ).

Comstock, J. H. Report of U. S. Entomologist (Dept. Agr.) for 1879-1881 (Washington, 1880-82).

Douglas and Scott. British Hemiptera. I. Heteroptera. (Ray Society. London, 1865.)

Fieber, F. X. European Hemiptera (Vienna, 1861.) (In German.)

Geise, 0. Mundtheile der Rhynchoten (Archiv f. Naturg., xlix., 315. 1883).

Glover, T. Manuscript Notes: Hemiptera (Washington, 18\%6).

Oestlund, 0. W. Synopsis of the Aphididie of IIinnesota (St. Paul, 1887).

Riley and Monell. Notes on Aphidæe of the U. S. (Bull. U. S. Geol. Surv., v. Washington, 1879.)

Thomas, c. II Onograph of the Plant-lice (8th Report State Entomologist of Ill., 1879).

Uhler, P. R. Monographs of Cydnidie and Saldæe [etc.]. (Bull. U. S. Geol. Surv., iii., 18\%7).

Check-list of the Hemiptera-Heteroptera of North America (Brooklyn, 1886).

Walker, F. Catalogue of Hemiptera-Heteroptera in Britich Museum (8 vols. and suppl. 186i-74).

Witlaczil. E. Die Anatomie der Psylliden (Zeits. f. Wissensch. Zool., Bd. xhii. Wien, 1885).

Z Zur Morphologie und Anatomie der Cocciden (Zeits. f. Wissenseh. Zool. Wien, 1885).

Also the writings of Ashmead, Comstock, Forbes, Landois, Lo Baron, Monell, Osborn, Riley, Say, Thomas, etc. 

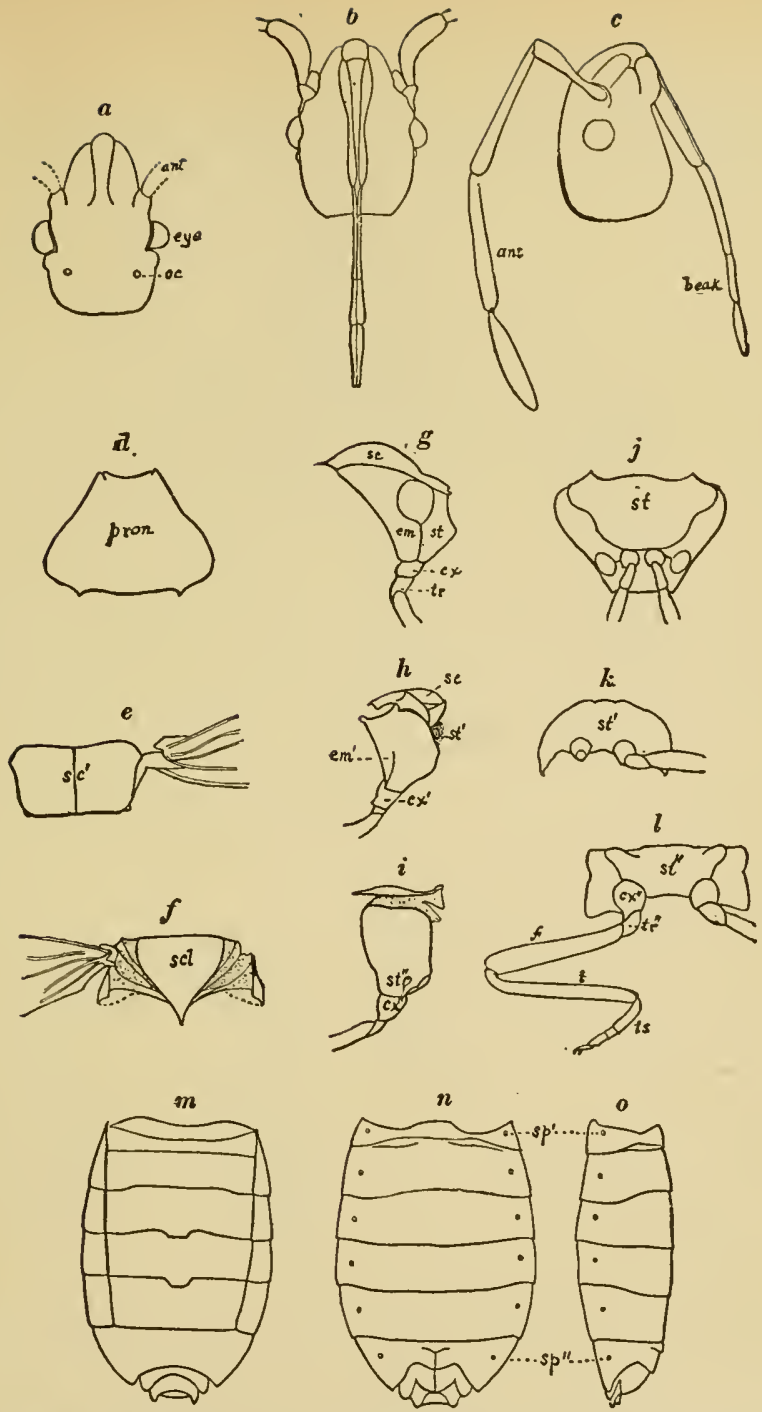

Fia. 60.-External anatomy of squash-bug, Anasa tristis. $a$, upper, $b$, under and $c$, side, view of head; ant, antenna; oc. ocellus; $d$, pro-, $e$, meso-, $f$, meta. notum; $s c^{\prime}$. meso scutum; scl. meso-seutellum; $g$, pro-, $h$, meso-, $i$, metapleurum; st, pro-, st', meso-, st', meta-scutum; epis, epis', epis', episternum of pro- meso-, and meta-thorax; em. em', em", epimerum of pro-, meso-, and meta-thorax; $j, k, l$, under side of the pro-, meso-, and meta-thorax; $c x^{\prime \prime}$. coxa ; $t r^{\prime \prime}$, trochanter; $f$, fecmur; $t$, tibia; $t$, tarsus; $m$, dorsal, $n$, ventral, $o$, side, view of abdomen; $s p^{\prime}, s p^{\prime \prime}$, six pairs of spiracles. (To face $p$. 74.) 
into its separate segments, dissect the hind body or abdomen from the thorax, and study these parts with the aid of Fig. 60 , always remembering to compare each part with its corre-

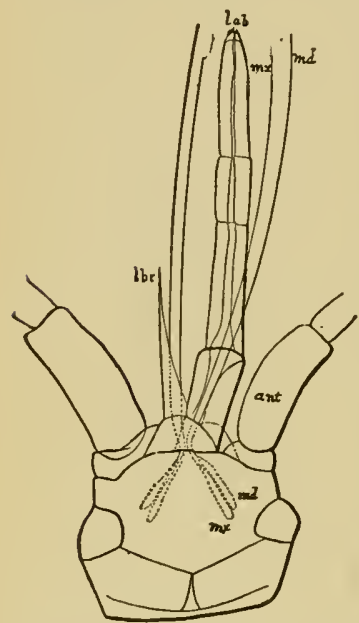

FIG. 61.- Head of bed-bug, showing the structure of the beak, lab. the four-jointed labium, which contains the bristle-like mandibles $(m d)$ and maxillæ $(m x)$, whose bases are shown by the dotted lines in the head; lbr, labrum; ant, antenna. sponding part in the grasshopper. It will be seen that the bug has, besides a pair of componnd eyes, two simple eyes behind; and that it takes its food by suction, plunging its long slender beak into the stems of plants or into the flesh of its victim. 'This beak is the distinctive mark of the bugs, which thus differ from other insects in their manner of taking their food. It is formed of the long, slender, needle-like mandibles and maxillæ, which are united so as to form a hollow sucking-tube. The tube thus formed is ensheathed by the under lip (labium), which is long, hollow, and composed of four joints. Above, the sucking-tube is protected by the labrum (Figs. 61 and $62, l b r)$. Another distinguishing mark is that bugs have no palpi, either maxiliary or labial.

There are c-timated to be nearly 10,000 species of bugs in North America, all having a beak; and through their different kinds of food and habits there is a chance for the individnals of each species to get a living.

The bugs also differ from other insects, and somewhat anticipate the beetles, in the large broad prothorax, and in the fore wings, which are thickened at the base so as to protect the thin under pair. Since the basal half of the fore wings is thus thickened, the bugs are called Hemipteru, from hemi, half, and pteron, wing.

Like the grasshopper, the bugs have an incomplete meta- 
morphosis. Fig. 63 represents the transformations of the chinch-bug, the young having no wings. After reaching

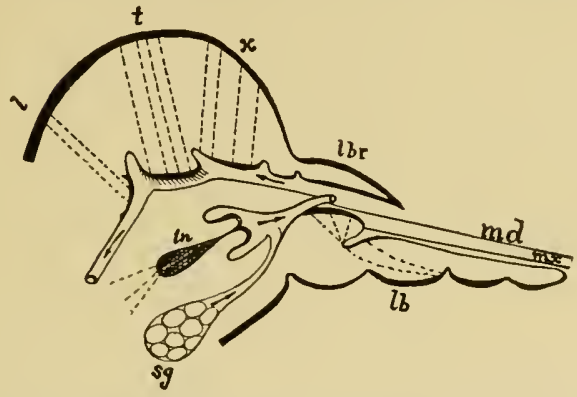

Fig. 62.-Longitudinal section of bug's head. $l b r$, labrum; $l b$, labium; $m d$, mandible; $m x$, maxilla; $s g$, salivary gland (the arrows pointing outward show the course of the salivary duct into the mouth; the inward-pointing arrows indicate the throat and the direction taken by the food in passing to the stomach); $l, t, x$, muscles which elevate the roof of the mouth.-After Graber.

the stage $e$, the wings appear as in the stages $f$ and $g$. 'This bug does immense harm to farmers by sucking the sap of wheat and corn.

Certain species of Hemiptera are apterous; the sexes
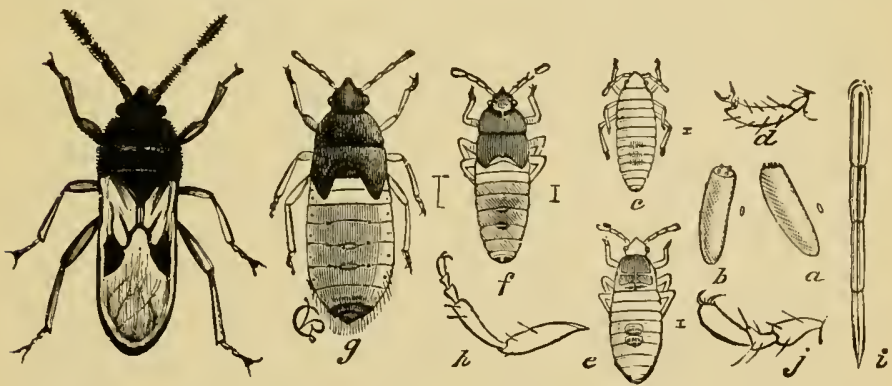

FIg. 63.-The Chinch-bug and its early stages. $a, b$, eggs: $c, e$, larval stages; $f, g$, pupæ; $i$, beak; $d$, tarsus of larva; $j$, tarsus of perfect bug; $h$, leg of ditto.

differ in the form of the body and fore wings, in the second joints of their antennæ, and in their tarsi; while the females are generally larger and more robust than the males, but they do not commonly differ much in color. (Darwin's Descent of Man, i. 339.) 
Although the Hemiptera are not so numerous in species as the Coleoptera, Diptera, or Hymenoptera, they possibly outnumber the Lepidoptera. Uhler states that abont 2\%,000 species occur in museums, and that the are probably not less than 50,000 species now existing. 'The known forms are distributed in very nearly the following proportions: Sonth America, 10,000; North America, 5000; Central America and the West Indies, 2000; Europe, 3000: Asia and its islands, 3000; Africa and its islands, 3000; and Australia, New Zealand, and the Philippines, about 1000 species.

Sub-order 1. Pediculina. - The parasitic Hemiptera or lice are wingless and have a beak-like sucker, which is soft and retractile, with two protrusible chitinous bristles. The feet are adapted for clinging to hairs, as they are hooked. while the body is soft, and the thoracic segments are not divided into separate pieces, as in other Hemiptera and nearly all other insects. The eggs, called "nits" (Fig. 30, $r)$, are oval and attached to hairs. All the species live ou mammals, none on birds.

Though evidently allied to the wingless Cimex, and forming a group standing near it, we have, as a matter of convenience, to place them at the bottom of the entire order in a sub-order by themselves, interpolating the Homoptera between them and the Heteropterous Hemiptera, to which they more nearly belong. Parasitism has so degraded them that the marks of relationship to their true ancestors have been effaced. The lice may be said to be a downward-bent twig of the Heteropterous branch, while the Homoptera form the highest branch of the ordinal tree.

Family Pediculidæ.-Pediculns capitis De Geer, the head-louse of man; P. vestimenti Burm. (larger and paler); Phthirius pubis (Linu.), the crab-louse.

Sub-order 2. Homoptera.-In Hemiptera of this group the wings are somewhat opaque throughout, or transparent, and lie roof-like over the body. The head is large, and the beak appears to arise between the fore legs. Many of the 
species are hoppers, the hind legs being enlarged, while many (except the plant and bark lice) have an ovipositor, for inserting eggs in the twigs of plants. Many species secrete, in numerous glands in the skin, a white waxy powder which cover's the body.

We have always regarded, and still regard, the typical Homoptera, such as Cicada, as a more highly specialized insect than any of the Heteropterons Hemiptera; but in treating of them in the pages of a book, and in deference to the views of Hemipterists, we interpolate the sub-order between the Pediculina and Heteroptera.

Family Coccidæ.-The bark-lice or seale insects are so called from the habits and shape of the females, which are wingless, with bodies resembling scales. They insert their long slender beak into the bark of trees or stems and leaves of plants, drawing in the sap, and when

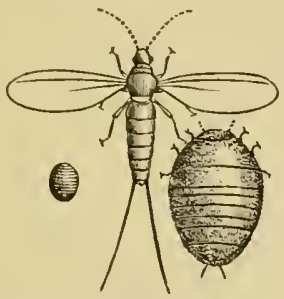

FIG. 64.-Cochineal insect, male; female, natural size and enlargerl.

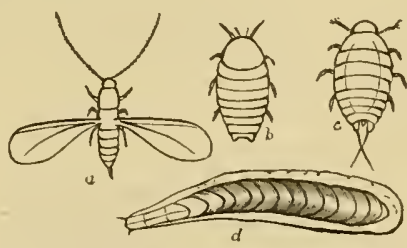

Fig. 65.-Orange-scale insect. $a$, male; $b$, female; $d$, its scale; $c$, another species.

very numerons ilo much harm to the plant or tree. On the other hand. the males have two wings and a pair of balancers, but no beak, and take no foot. The females lay their eggs beneath the end of their bodies. While the eggs are generally fertilized, in species of Lecanium and Aspirliotus, they develop without fertilization by the males. Unlike the females, the males undergo a metamorphosis, the larve spinning a cocoon; the pupse remaining therein without moving or taking foorl. While most of the speeies are injurious to vegetation, the cochineal Coceus (Fig. 64) produces a carmine dye, and the manna and lac inseets by their punctures cause a flow of vegetable juices, which, when dry, are a valuable article of merchandise.

With us the most injurious species is the Apple bark-louse, Mytilaspis pomorum Bouché, whose scales sometimes so abound on the bark as to kill young trees; oranges are injured by M. gloverii (Pack., Fig. 65), and the purple orange-scale, M. citricole (Pack.). Plants in hot-houses are often injured by the "mealy bug." Coceus (Ductylopius adonidum Linn.), whicls also oceurs in gardens, as does Leconium hesperidum, which especially affects the orange. Pulvinaria in numerabilis (Rathvon) injures the linden and soft maple. 
Family Aleyrodidæ.-Wings rounded, rather broad and white; larvæ scale-like and fixed to leaves; beak 2-jointed. Aleyrodes corni Hald.

Family Aphidæ. - The Aphides or plant-lice abound to an enormous extent; nearly every plant has one or more species peculiar to it, and the individuals are of ten to be numbered by millions; while a thousand species are already known. T'be males and females are usually w'inged; in rare cases are the males wingless, but the females are not seldom without wings, while the asexual individuals are wingless. They are all small insects, both sexes with a 3-jointed beak; the wings have few veins; the body is tlask-shaped, and in the species of Aphis and Lachnus near the end of the abdomen are two tubes for the exit of a sweet fluid called "honey-dew," which is lapped up by the ants seen frequenting a colony of these insects. Aphides are usually green, with a soft powdery bloom on the skin.

The Aphides or plant-lice abound by reason of their wonderful fertility, the young being brought forth alive. There are as many as

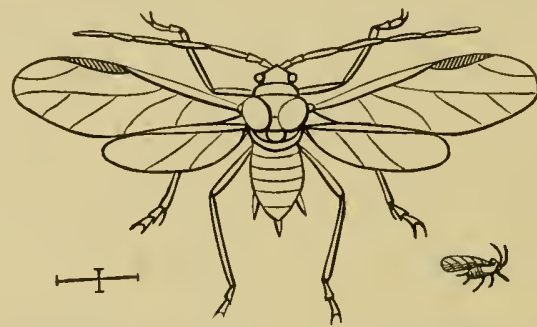

Fig. 66.-Apple Aphis. Natural size and enlarged.

nine or ten generations; a single Aphis becoming the parent in one summer of millions of children and grandchildren. Though they are devoured in enormous numbers by other insects and by birds, still hosts are left to prey on our fruit-trees. succulent vegetables, and household plants. Thus, these weak, defenceless creatures owe their success in life to their unusual powers of reproduction, the young budding forth within the parent, as the polyp sends forth bud after bud which eventually become jelly-fisb. The last brood of Aphides lay eggs in the autumn and then die.

Sexual forms (at time of birth already mature, wingless, and without a proboscis) sometimes occur in the spring, as in the European Pemphigus terebinthi (Derbès). Chermes and Phylloxera give birth in place of viviparous generations to a special egg-laying female, which also produces eggs, from which arise individuals which reproduce parthenogenetically. In Phyllorera quercus, besides the two generations, there is another generation which appears in autumn, and consists of very small maies and females (without a suctorial proboscis or alimentary caual. These animals arise from two kinds of eggs which are laid in the roots. The female after pairing lays only a single egg. It is the same with the Phylloxera of the vine (Claus). Of the latter there are two forms, one living in galls on the leaves, and the other forming small swellings on the roots. The root-form is either wingless or winged, the latter very rare. The leaf-form is said to be always wingless. 
Family Psyllidæ._These leaf-hoppers commonly live in all stages on the under surface of leaves, some of them forming galls. They

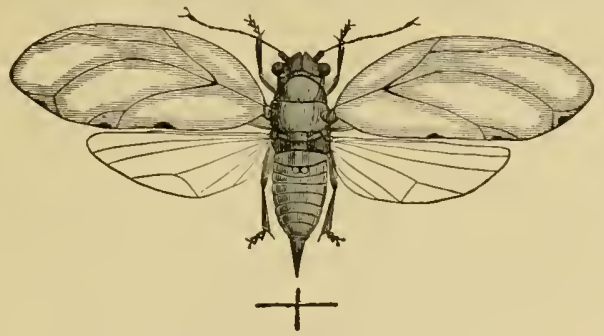

FIG. 67.-H'sylla tripunctata.-After Riley.

are generally conical, with a broad head, with long, 10 -jointed antennæ and short legs, the hinder ones adapted for springing; the
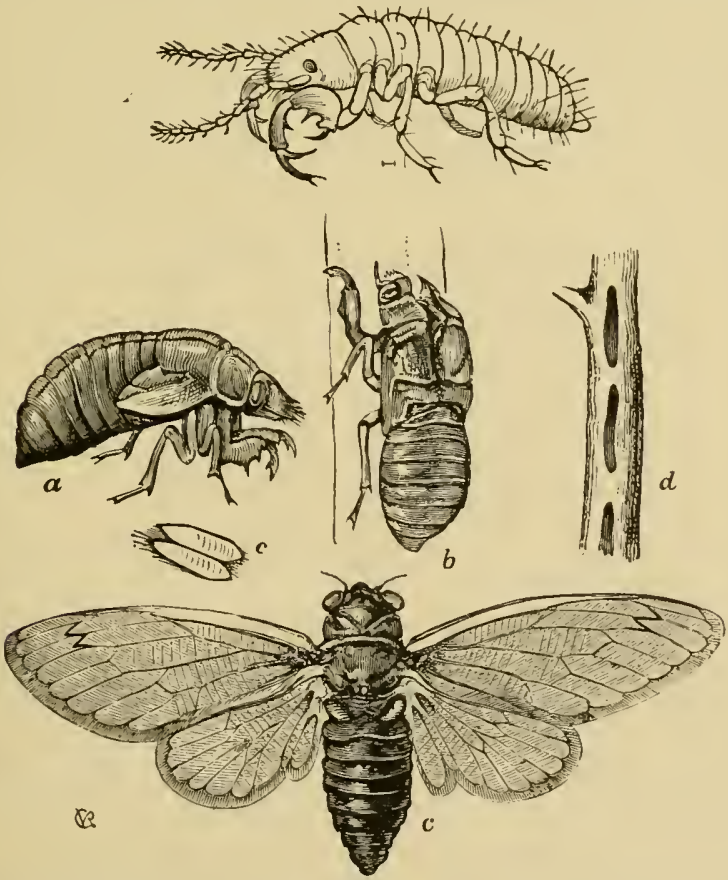

FIG. 68.-Seventeen-year Cicada. A, larva ; $a$, pupa; $b$, its cast skin split along the back; $e$ e eggs; $d$, gashes made for them in a twig. All except $A$ natura? size.-After Riley. 
wings are thickened, folded roof-like over the body, while the young are often covered with a white cottony mass. Psylla pyri Schmidt injures the pear-tree; and $P$. tripunctata Fitch is common on pinetrees.

Camily Membracidæ.-Head broad, prothorax very large and of varied form, being arched, compressed, hump-backed, conical, etc., in different species, and of ten with spines and projections. OMem. bracis foliata (Linn.); G'elamona monticola (Fabr.).

O Family Cicadidæ. - The Cicadæ are among the largest of insects. and besides their broad heads, prominent eyes, and well-developed ovipositor, have, in the males, a musical apparatus at the base of the abdomen, by which they produce a lond, shrill, piercing noise. The family also comprises the longest-lived of all insects, the 17year Cicadi9C. 17-decim Linn.) requiring seventeen years to attain its growth. A single brood appears only once in seventeen years in the same given region, while there are three broods which appear ouce in thirteen years.

OFamily Fulgoridæ.-Antennæe yith only three joints; the forehead or vertex enormously enlarged. O Laternaria phosphorea (Linn.), Surinam and Brazhl, Fulgora candelariu (Linn.), the lantern-fly of China, are both among the largest of insects. Nitive forms of much smaller size are Otiocerus coquebertii Kirby and Delphax arvensis Fitch. a Family Cercopidæ.-A large group of insects of medium or small size, living in grass and on leaves; with a large broad thorax. "Frog's spittle" insect, OPtyelus lineatus (Linn.).
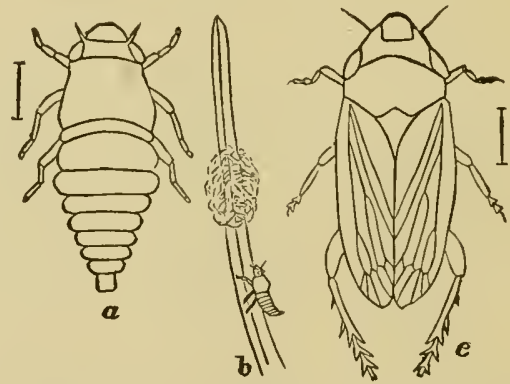

FIG. 69.-Ptyelus lineatus. Spittle insect. $a$, larra, enlarged; $b$, its natural size; above it the mass of froth or "spittle."

Family Jassidæ. - Slenderer insects than the Cercopide, and with longer hind legs, but like them living in grass and trees. Erythroneur't vitis (Harris), Dicdrocephala mollipes (Say).

Sub-order 3. Heteroptera.-The wings are in the true bugs laid flat on the back, those of the fore pair thickened on the basal half or two-thirds (hemelytra); the prothorax is large and broad. Many species give out an offensive smell, due to a secretion emitted from a gland situated 
in the meso- or metathorax, and, if in the latter place, opening between the hind legs. Many are wingless, and in some species the females are wingless. The definition of the families, and their arrangement, are taken from P. R. Uhler's account of the Hemiptera in "The Standard Natural History."

Family Corisidæ.-Aquatic insects, with broad heads, flattened bodies, and swimming feet, the beak passing through a little. hole above the actual end of the elypens. Corisa interrupta Say.

Family Notonectidæ.-Boat-shaped, aquatic forms, differing from all other Hemiptera by swimming on their backs. Notonecta undulata Sily.

Family Nepidæ. -Flat-bodied aquatic insects, the body often ending in two respiratory tubes. Voraeious and, as in Belostoma grisea (Say), destructive to fishes and tadpoles from its large size and powerful beak.

Family Naucoridæ.-Flat-bodied, oval, without caudal tubes. Pelocoris femoruta (Pal. Beauv.).

Family Galgulidæ. - Inseets living by the edge of ponds and streams, with the hind legs adapted for running. Galgulus oculatus Fabr.

Family Saldidæ.-Small, leaping, dull-colored insects, with the head free. Sulda signoretii Guerin.

Family Hydrobatidx.-The water-boatmen have long limbs, wherry. like bodies, and row themselves on the surface of the water. Gerris (Hygrotrechus) remigis Say; Halobates

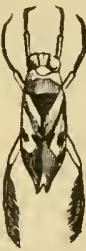

FIG. $\% 0$.

- Noto-

$n e c t a$ $u$ md $u$ l at $a$. Natural size. Wuellerstorfii White lives on the ocean far from land.

Family Veliidæ-Body short and deep, with short legs. Rhagovelia obesa Uhler.

Family Hydrometridæ.-Dull brown insects of linear shape, with long legs fitted for walking on the surface of pools and brooks. IIydrometra lineata Say

Family Emesidæ.-Body extrenely slender, with thread-like middle and hind legs, but with spinous, raptorial fore legs. Emesa longipes De Geer.

Family Reduviidæ. - Body thick, with short eoxæe, the fore legs set far baek. Conorhinus sanguisugus Lec., a large red-spotted bug, which inflicts a severe puncture. Milyas cinctus Fabr.

Family Nabidæ. -Body oblong, with a thiek head ending in a long slender beak. Nabis fusca Stein; Coriscus

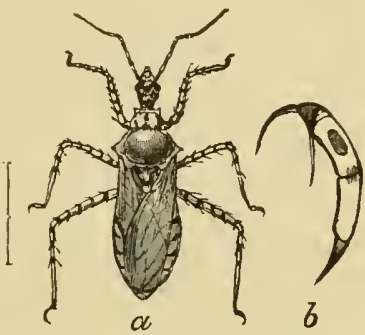

FIG. 7t.-Milyas cinctus, $b$, beak. -Áfter Riley. ferus Linn.

Family Aradidæ.-Body very flat, dead-ieaf-brown color. Aradus crenatus Say.

Family Phymatidæ.-Body thicker; fore legs raptorial. Phymutu erosa Herr-Sch.

Family Tingitidæ. - Small, very that bugs living on leaves. Cory- 


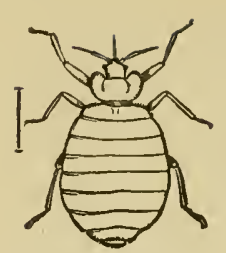

FIG. 72.-Bed-bug.

thuca ciliata (Say), common on oak-leaves. Tingis clavata Stal.

Family Cimicidæ.-Body broad and flat, species sometimes wingless. Cimex lectularia Linn., bedbug.

Family Capsidæ.-Body oval; antennæ threadlike, long, and 4-jointed; the end of the thick part of the hemelytra triangular, and incised outside. Precilncapsus lineratus (Fabr.).

Family Pyrrhocoridæ._Body stouter and larger than in the Capsidx. Iysdercus suturellus Herr-Sch., cotton-stainer.

Family Lygæidæ. - Body ovate or oblong ; head with a pair of distinct ocelli between the eyes; mostly red and black or black and yellow insects. Lygrus fusciutus Dallas, Blissus leucopterus (Say), chineh-bug.

Family Berytidæ.-Body very slender, with pointed head; and thread-like antenna, clubbed at tip. Neides spinosus Say.

Family Coreidæ-Body oblong-ovate; antennie 4-jointed; basal

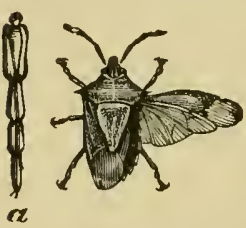

Fig. "3.-Podisus spinosus. $a$, beak. Natural size. - After Riley. joint of the beak usually the longest. Anasa tristis (De Geer), squash-bug.

Family Pentatomidæ. - Scutellum large, triangular; head mostly quadrangular; antenne 5-jointed.

Family Cydnidæ-Oval, highly-polished, jetblack insects, having flat heads with the edge furned $u$, and the legs very spinous. Pangreus bilineatus Say.

Family Corimelænidæ.-Body hemispherical, black; legs spinous, fitted for digging. Corimelena atra (Am. and Serv.).

Family Scutelleridæ. - Body tortoise-shaped, the seutellum covering nearly the whole upper surface of the abdomen. Pachycoris torridus Scop. Fla., Mex.

Family Arthropteridæ.-Body wide and flat, black, highly polished. Coptosoma globus (Fabr.). Eur.

Pratens:

Order IX. Neuroptera* (Ant-lions, Aphis-lions, Lacewinged Flies, etc.).

These are net-veined insects, with a metamorphosis, but

* Selected Works.

Brauer, F. Beiträge zur Kenntniss der Verwandlung der Neuropteren (Verb. Zool. bot. Ges., Wien, iv., v.).

- Ueber die Verwandlung des Bittacus italicus und hagenï (Verh. Zool. bot. Ges., Wien, 18:1).

Hagen, H. Synopsis of the Neuroptera of North America (1861. Smithsonian Institution).

Haldeman, S. S, and J. Leidy. History and transformations of Corydalis cornutus (Mem. Amer. Acad. Arts and Se., iv.. 1848).

Packard, A. S. (Exterual anatomy, in third report U. S. Ent. Comm. 1883, 335, Pls. LI-LVIII, LXIV)

Also the writings of Erichson, Fitch, McLachlan, Pietet, Rambur, Riley, Schneider, and Westwood. 
they also differ in important respects from net-veined insects without a complete metamorphosis. 'The head is horizontal and somewhat flattened; the body is flattened or cylindrical. The mouth-parts are free, adapted for biting, and the mandibles well developed. The ligula differs from that of the other net-veined insects in being entire, form-
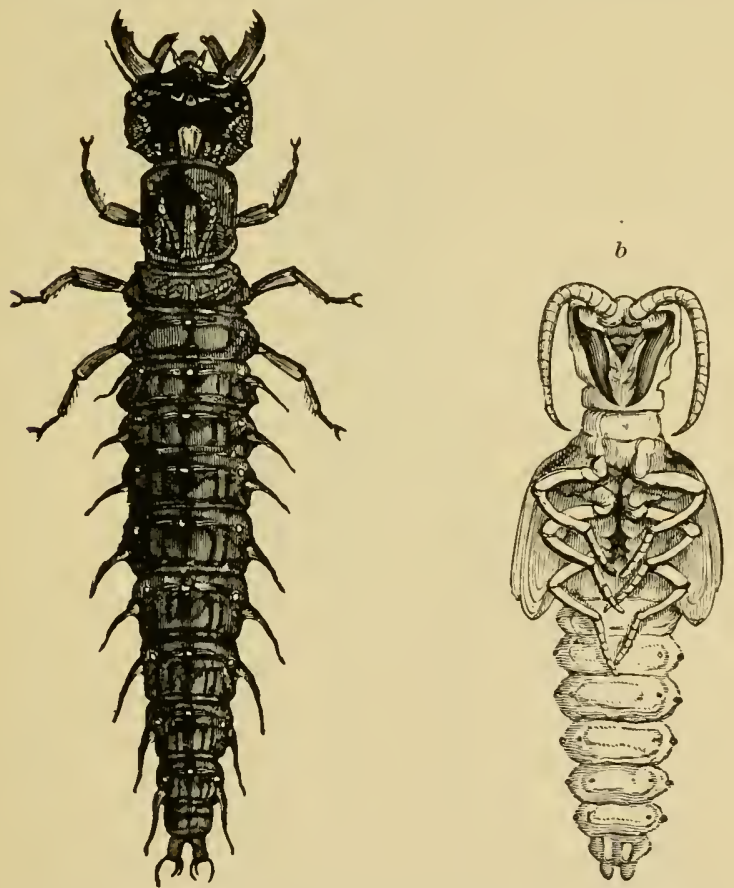

Figs, $74,75,-$ Larva and pupa (b) of Corydalis cornutus. Natural size.

ing a large, broad, flat, ronnded lobe. The prothorax is large, broad, and square, and the mesothorax and metathorax are nearly of the same size, while the wings correspond in being all of the same size; they are not so decidedly net-veined as in the Orthoptera, Platyptera, Odonata, and Plectoptera, the costal space being wide, while the trans- 
verse veinlets are few and far apart compared with those of the dragon- and may-flies, or the Orthoptera. Only Raphidia has an ovipositor, and there are no caudal stylets.

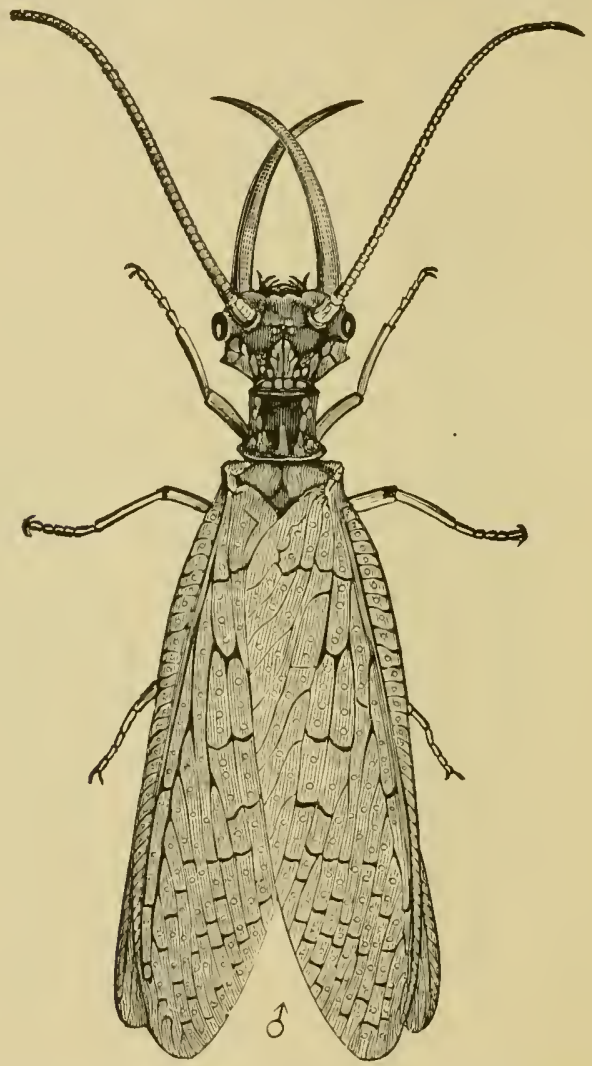

FIG. 76.-Imago of Corydulis conutus; male. Natural size.

The Neuroptera have a complete metamorphosis, the pupa being quite unlike the larva, and quiescent, being often protected by a cocoon. The shape of the larva is pecnliar, the body being broad, somewhat flattened, with large jaws, and of rather a primitive form, compared with those of the fillowing orders. 
Family Sialidæ.-Body somewhat flattened, of moderate length; the antenuie long and slender, sometimes serrated or pectinated; the wings are large, net-veined, the hinder pair with the anal space folded, while the tarsi are 5-jointed.

To this family belongs the great Corydalis cornutus Linn., whose wings expand six inches. The jaws of the male are enormously enlarged, heing nearly an inch long, and can scarcely be used for taking food. Its larva lives under stones in brooks, and is used for bait under the name of "hellgrammite." In Chauliodes pectinicornis Linn., a much smaller insect, the antennæ are pectinated. Species of Raphidia, which have a very long narrow prothorax, inhabit the Pacific coast.

Family Hemerobidæ. - The body is slender, cylindrical, with large net-veined wings, the hinder ones with no anal space. The larve are peculiar in having large sickle-shaped mandibles which have a groove beneath, in which the maxilla slide back and forth; with these they can pierce the bodies of small insects and suck their

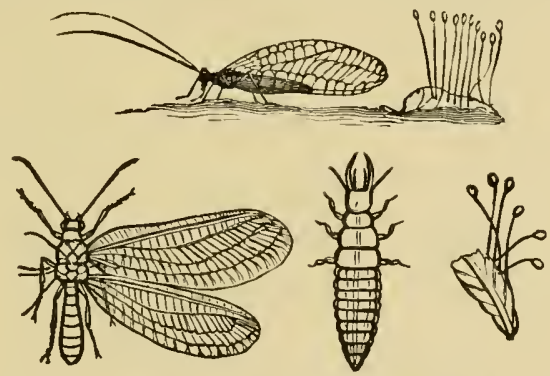

FIG. T. - Lace-wing fly, side and top view; eggs and larva. Eularged twice.

blood, without moving the mandibles on which the victin is im. paled. The larvæ of Chrysopa (Fig. 77) and Hemerobia are called Aphis-lions, and destroy great numbers of those pests. The ant-lion is the larva of Myrmeleon. It makes a pit in fine sand, lying at the
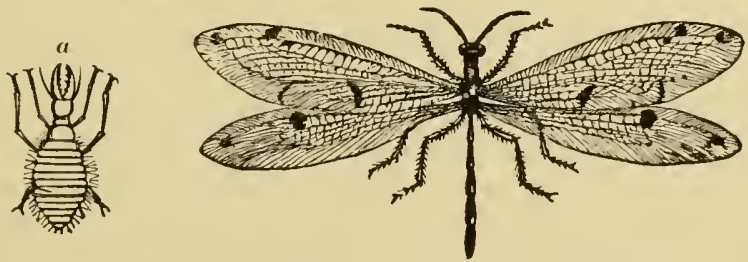

FIG. 78. -Myrmeleon, and $a$, its larva, the ant-lion.

bottom with its jaws wide open, ready to seize any luckless insect which may fall in. Mantispa (Figs. 79, 80) is noteworthy from the strange habits of its larva, which passes through two stages, the 
first of the normal form of the order, when it lives in the coconns of spiders; before the first moult it loses the use of its feet, and begins

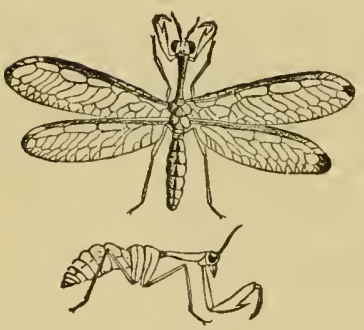

Fig. 79.

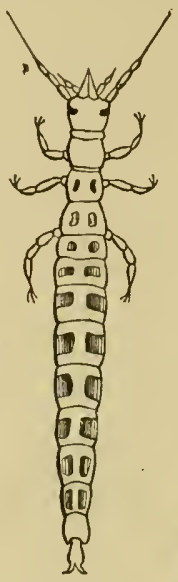

Fig. 80.

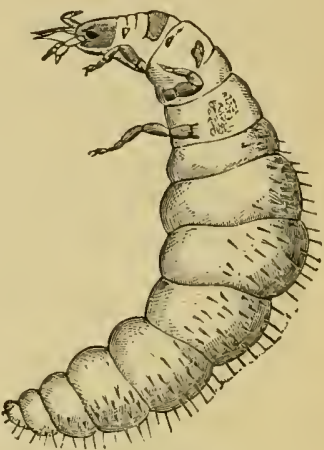

Fig. 80a.

Fig. 79.-Mantispa interrupta Say; and side view of the same without wings. Natural size.-Emerton del.

FIG. 80.-Freshly-hatched larva of Mantispa styriaca, enlarged.

Fig. $80 a$.-Larva of the same, but older, before the first mouit. Enlarged.After Brauer.

to change its form, until when fully grown it is cylindrical, with small feet and a small round head, mnch as in caterpillars.

\section{Order X. Mecoptera* (Scorpion-flies).}

We have given this name to the Panorpidæ, which have features separating them from the true Neuroptera. The front of the head is greatly elongated into a sort of beak, the clypeus being very long, and the minute mandibles are situated at the end of the snout. The prothorax is very small; and in the shape of the thorax as a whole, and in

\section{* Selected WORlis.}

Brauer, F. See Neuroptera.

Hagen, H. A. Syuopsis of N. A. Neuroptera.

Packard, A. S. (External anatomy, in third report U. S. Entom. Commission, 1883, 342, Pl. LIX, LX).

Westwood, J. 0. Monograph of the genus Panorpa (Trans. Ent. Soc. London, iv., 1846). 
the form of the side and breast pieces (pleurites and sternites), we have a striking approximation to the moths. The abdomen is long and slender, composed of ten segments, and in the male ending in a large forceps. The larva is caterpillar-like, the head small, the feet short and small, and there are eight pairs of abdominal feet, while the body is adorned with button-like, bristle-bearing warts or spines. 'The metamorphoses are complete, the pupæ being somewhat like those of the lowest moths, the limbs being free.

Family Panorpidæ. - With the characters of the order. In Panorpa the body of the male ends in a forceps. It has been known to attack fishes, piercing their eyes with its beak. Its larva bores an mch deep into moss-covered soil. The short, 4-jointed thoracic feet resemble those of caterpillars; but the most striking point of resemblince to the latter is seen in the eight pairs of abdominal feet. Not only the form of the body and legs, but also the arrangement and shape of the button-like, bristle-bearing warts on the body recall the general appearance of aretian caterpiliars. Bittacus has a very long slender body, with long legs, and the male abdomen bears no forceps. The larva is somewhat like that of Panorpa, but is adorned with
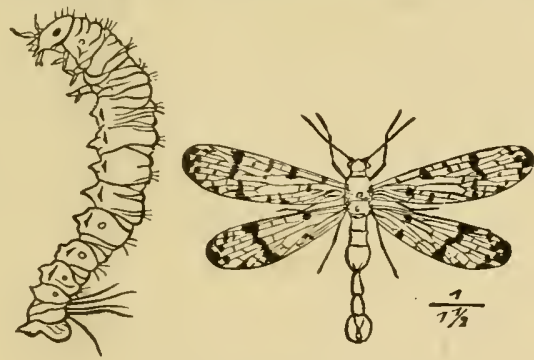

Fra. 81.-Panorpa or Scorpion-fly, and larva.

long seattered dorsal spines, and a lateral row of slender filaments; each of the nine abdominal segments bears a pair of soft, 2 -jointed feet. While the Lepidoptera are supposed to have originated from the same ancestors as the Trichoptera, it is a significant fact that the eruciform larvie of the Nreoptera actually have 2-jointed legs to each abdominal segment. This suggests that the Lepidoptert may have originated from the same stem-form as the Meeoptera; though it should be remarked that the moths themselves more ciosely resemble the caddis-tlies. A very rare and singular form is Mlerope tuber Newman, the male abdomen bearing a large forceps. The female Boreus is wingless; in the male the wings are rudimentary. $B$. nivoriundus Fitch has only been collected in the winter-time on snow. The species are brassy brown, brassy black, or deep bronze green. 


\section{Order Xi. Trichoptera* (Caddis-flies).}

The caddis-flies bear a still closer resemblance to the small. er moths than Panorpa, though the larvæ are less like caterpillars than those of the Mecaptera. The caddis-flies have a small, rounded head which in its general structure, though presenting some notable differences, closely resembles that of the smaller moths, even to the obsolete mandibles, these insects taking no solid food in the imago state. Hagen states that in Plectrotarsus graventorstii the proboscis is greatly developed, and in certain other genera is longer than the head and fitted to probe flowers. (In the CEstropsidce the maxilla and labium become aborted dur-
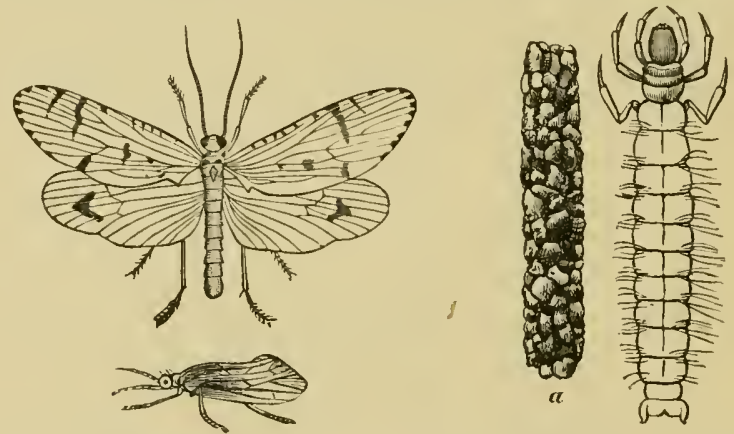

FIG. 82.-Caddis-fly (enlarged and natural size) and case-worm. a, case.

ing the pupa state.) The thorax is thronghout much like that of the smaller moths, the prothorax being small and collar-like; the metanotum formed on the lepidopterous

\section{* Selected Works.}

Hagen, H. A. Synopsis of N. A. Neuroptera.

McLachlan, R. A monographic revision and synopsis of the Trichoptera of the European fauna (London, 1874-1880).

Muller, F. Ueber die von den Triehopterenlarven der Provinz Santa Catharina verfertigten Gehïuse (Zeits. f. Wissen. Zool., xxxv., 1880).

Packard, A. S. (External anatomy, in third report U. S. Ent. Comm., 1883, 344, Pls. LIX, LXI). 
type, as is the rest of the thorax, especially the coxæ and site-pieces (plenrites); while the long, slender abdomen recalls the shape of that of moths. Moreorer, the body and wings, usually hairy, are sometimes covered with scales; and the venation is somewhat as in moths.

The transformations are much as in those of the lower moths, though in the pupa the limbs are free, not soldered to the body as in moths. 'The larva, which breathe by means of thread-like tracheal gills, construct cases of bits of sticks, or grains of sand, which they drag over the bottom of quiet pools; they live both on decaying leaves and small insects, water-fleas, etc. When about to pupate they close the mouth of the case with a grating, or, as in Helicopsyche, with a dense silken lid having a single slit, and in some instances spin a slight, thin, silken cocoon, within which the pupa state is passed. The female lays her eggs in clumps covered with jelly on stones and leaves at the water's edge.

Super-family Phryganidæ.-This great group is divided by McLachlan into seven families, chiefly according to the structure of the maxillary palpi, as follows: Hydroptilidie, Rhyacophitide, Hydropsychidae, Leptocerida, Sericostomatida, Limnophilida, and Phryganida. "In the Rhyacophilide and Hydropsychidee the larva inhabit fixed cases; in the others the cases are free, and carried about by the inmates. In the Rhyacophilidie the pupa is enveloped in a special cocoon." (McLachlan.)

\section{Order XiI. Coleoptera* (Beetles).}

Although so numerous in species, upwards of 100,000

\section{* Selected Works.}

Dejean et Aubé. Spécies générales de Coléoptères (6 vols., 8vo. Paris, 1825-38).

Gemminger and Harold. Catalogue of all described Coleoptera with synonyma (12 vols. Munich, 1868-r6). (Lat.)

Henshaw, S. List of the Coleoptera of North America. 1885. Supplement, pp. 8. 1887.

- The entomological writings of John L. LeConte (Cambridge, 1878).

1879) . entomological writings of George H. Horn (Cambridge,

Horn, G. H. Revision of North American Tenebrionidæ (Trans. Am. Phil. Soc., 1870).

— Synopsis of Parnidæ (Trans. Am. Ent. Soc., ii., 1870).

(Continued on next page.) 
existing in museums, the heetles are so different from all other insects that, with the exception, perhaps, of the two families Stylopidce and Platypsyllide, no one would confound them with the members of any other order. Beetles differ from other insects in the nature of the fore wings, which are usnally thick and solid, generally withont distinct reins, and serve as sheaths $(e l y t r a)$ to protect that part of the body situated behind the prothorax, which is large, broad, and moves freely on the rest of the thorax: while the mouth-parts are free and arlapted for biting.

In order to learu the names of the different parts, the beginner should have specimens of a ground-beetle and of a may-beetle, and compare them with Figs. 83 and 84 . This will save pages of dry description. How the antennæ vary in form in different beetles may be seen by reference to Fig. 85, while Fig. 86 represents the different forms of eyes. 'The jaws vary much in shape, while perhaps the extreme of variation in the maxilla is seen in many species of Nemognatha, in which the outer lobe is generally prolonged into

Horn, G. H. Descriptive catalogue of species of Nebria and Pelophila (Trans. Am. Ent. Soc., ii., 18\%0).

- Synopsis of Malachidie of U. S. (Trans. Am. Ent. Soc., iv., 18 (2).

- Brenthidæ of U. S. (Trans Am. Ent. Soc., jv., 18i2).

- Revision of species of Lebia (Trans. Am. Ent. Soc., iv., 18\%2).

A monograph of the species of Chrysobothris inhabiting the

United States (Trans. Am. Ent. Soc., xiii., 1886).

A monograph of the Aphodiini inhabiting the United States (Trans. Am. Ent. Soc., xiv., 1887).

Lacordaire, J. T., et Chapuis. Genera des Coléoptères (i.-vii. Paris, 1854). LeConte, J. L., and G. H. Horn. The Rhychophora of America north of Mexico (Proc. Am. Phil. Soc., 18\%6).

- Classification of the Coleoptera of North America (Smithsonian Inst., 1883).

Schaupp, F. G. Synopsis of the Cicindelidæe of the U. S. (Bnll. Ent. Soc., Brooklyn, vi., 1884. Five plates; every species with a colored figure. on four plates.)

Stal, C. Monograph of American Chrysomelidæe (Upsala, 1862-5).

Also articles by Austin, Blanchard,Casey, Fitch, Fuchs, Harris, Hubbard, Matthews, Melsheiner, Randall, Say, Schwarz, J. B. Smith, Ulke, Ziegler, Zimmermann, and others in Trans. Am. Ent. Soc. Pliil.; Bull. Brooklyn Ent. Soc.; Entomologica Americana; Can. Entomologist, etc. 


\section{3}

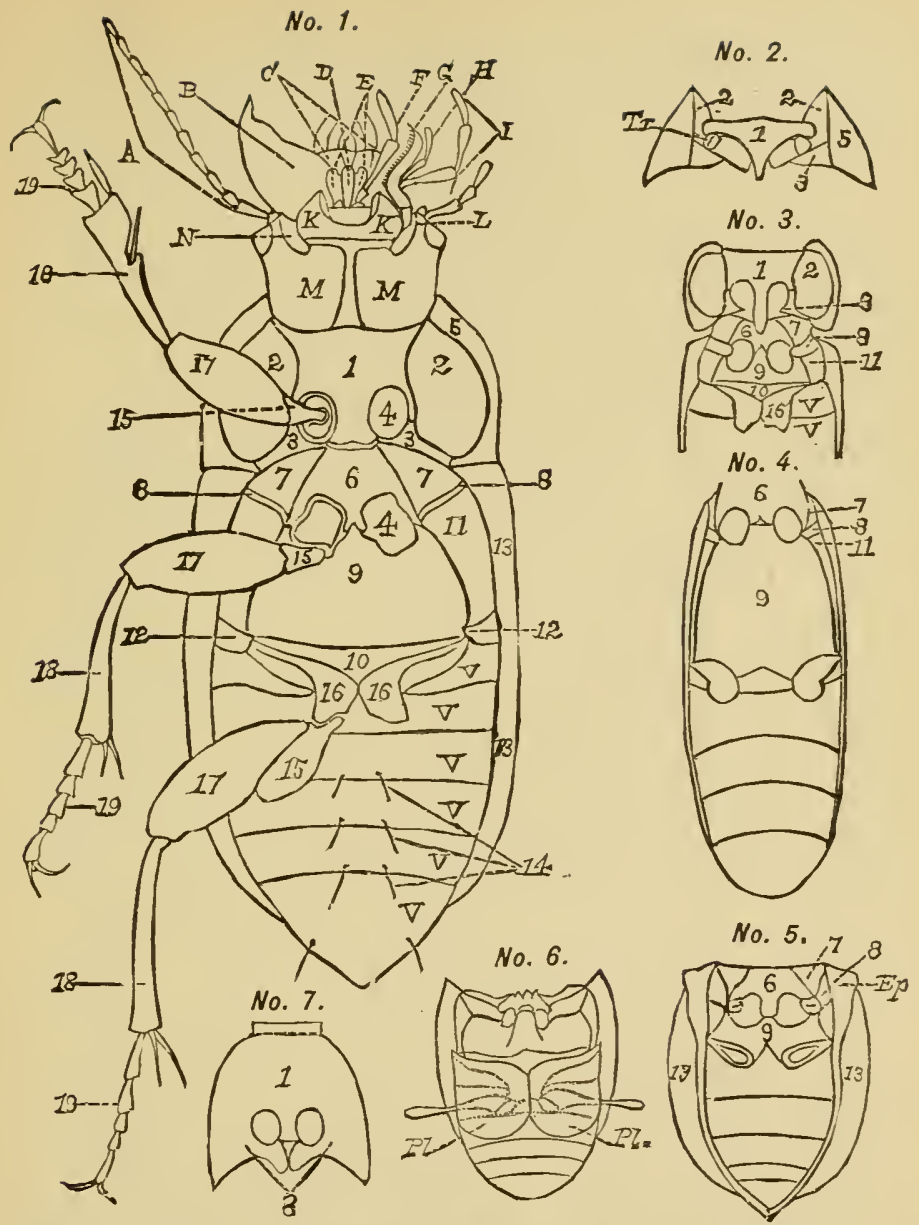

F16. 83.-Under surface of Harpalus caliginosus. No. 1: A, antenna: $B$. manlible: $C$, labrum; $D$, ligula; $E$, paraglossa: $F$. labial palpus: $G$, maxilla juner lobe; $H$, onter lobe; $I$. maxillary palpus; $\dot{K}$, mentum; $L$, genæ; $M$, gula with the gulal sutures; $N$, buccal fissure; $I$. ventral segments: 1 , prosterumm; 2, prosternal episternim: 3, prosternal epimerum: 4, coxal cavity closed behind; 5 , inflexed side of pronotum: 6 , mesosteruun: $\tau$. mesosternal episternum; 8 , mesosterual epimerum: 9 , metasternum; 10, antecoxal piece: 11 . metasternal episterum ; 1:, metasternal epimerunı: 13, inflexed side of elytrum; 14, ambulatorial setæ; 15, trochanters; 16, posterior coxæ; 1\%, femora: 18, tibize: 19, tarsi. No. 2: under side of protliorax of Hydroseapha, with open coxal cavities, and $T r$, trochantin. No. 3: under side of Calosoma. No. 4: under side of Rhyssodes. No. 5: under side of Eusattus erosus, showing the true epipleura, Ep. No. 6: inder side of Cnemidotus, showing the large coxal plates, $\mathrm{Pl}$. No. $\tilde{\tau}$ : under side of prothorax of Rhynchophorus, showing the closure of the coxal cavities by the epimera. - After LeConte and Horm. 

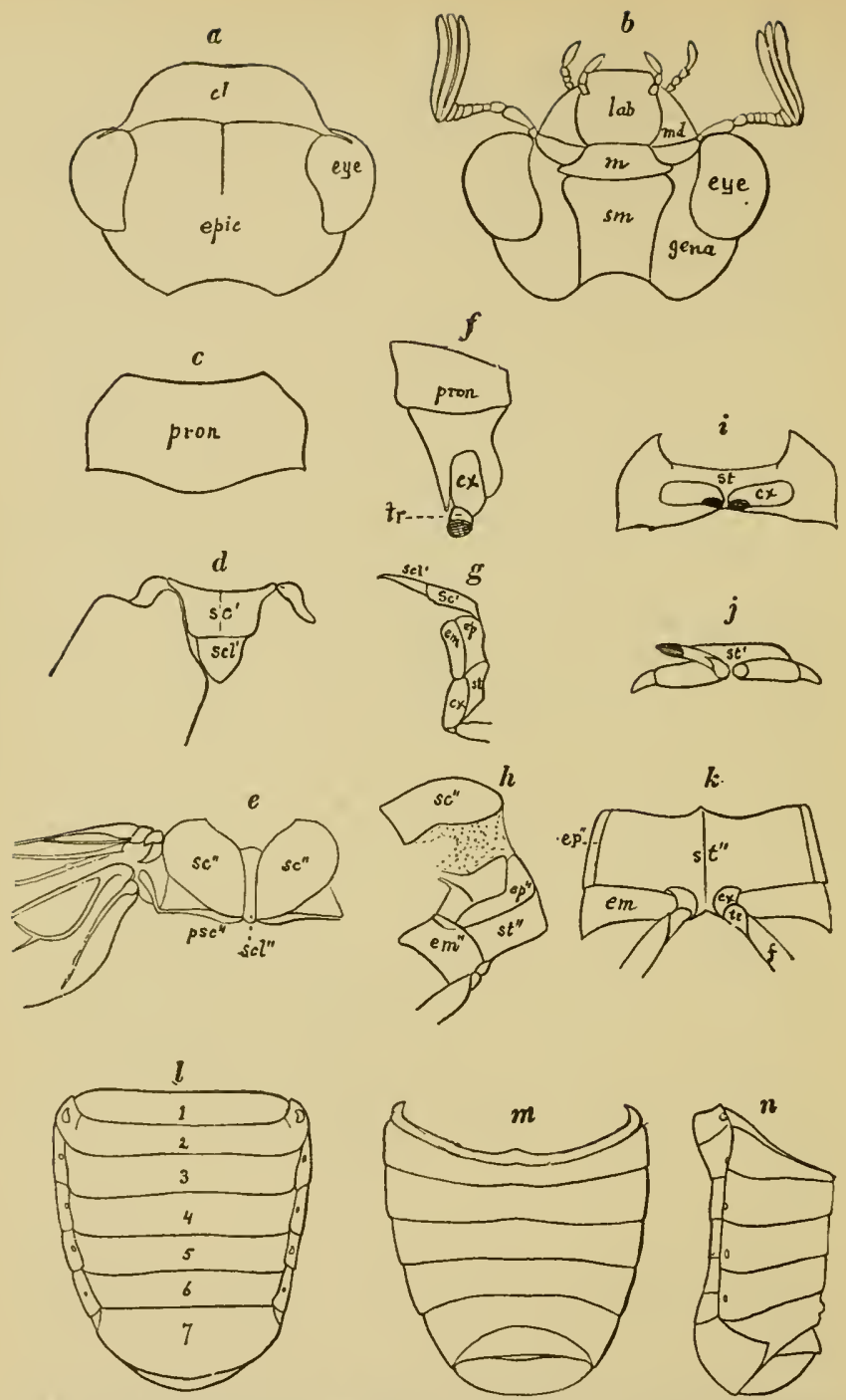

FIG. 81.-External anatomy of Mar-beetle, Lachnosterna fusca. a, upper side of head; epic, epicranium; $c l$. elypeus; $b$, under side: $m$, mentum; $s m$, submentum; lab. labium; md, mancible: $c$, pronotum; $d$, mesonotum; e, metanotum ; $f$, pro-, $g$, meso-, $h$, meta-plenrun; $i$, pro-, $j$, meso-, $k$, meta-pleurun; $l$, dorsal, $m$, veritial, $n$, side, view of abdomen: $1-\tau$, seven basal abdominal segments; $p s c^{\prime \prime}$, post-scutellum; other letters as in Fig. 60. (To face page 95.) 
a slender, flexible, hairy process, sometimes nearly as long as the body, and resembling the tongue of a bee, as when opposed they form a rude kind of tube. 'The legs vary greatly in shape, and the tarsi vary from five, the normal num.
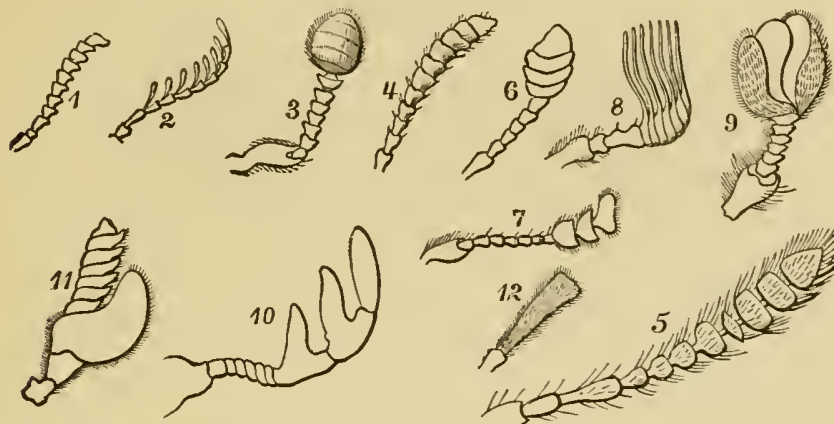

Fig. 85.-Different forms of antemma of beetles. 1, serrate ; 2 pectinate ; 3 , capitate (and also geniculate); $4-\bar{\tau}$, clavate; 8 , 9, lamellate; 10 , serrate (Dorcatoma); 11, irregular (Gy rinus!; 1:3, two jointed antenna of Adranes cæecus. After LeConte.

ber, to four and three joints, and sometimes to two or one, and may even occasionally be wanting.

The larva of a beetle, especially those like the young maybeetle, is called a grub. 'The metamorpliosis is in beetles

$\alpha$

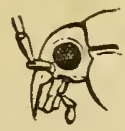

$b$

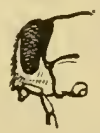

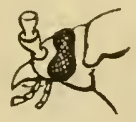

$d$

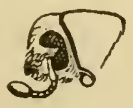

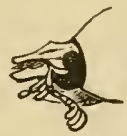

$f$

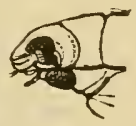

Fig. 86.-Head and eyes of beetles. $a$, Calosoma ; $b$, Chrysobothris; $c$, Prionus; $d$, Polygraphus; $e$, Geotrupes; $f$, Gyrinus, in which the eyes are divided. -From Judeich and Nitsche.

perfect. 'Those larre which walk freely about after their food usually have the body somewhat flattened, and the legs long; while those which bore into fruits or into wood have eylindrical, white bodies, and the legs are usually short, or, as in the larvæ of weevils, ete, they are legless.

The pupæ of beetles are nsually whitish, and have free limbs. 'They are either enclosed in cocoons of silk (Curcnlionide and Chrysomelide) or form a rude one of earth ; or, 
if wood-borers, live in rude cocoons of fine chips and dust, united by silken threads or a glutinous matter. Some Coccinellæ and Anthrenus transform within the old larvai skin. In most Coleopterons pupæ, the antennæ lie on each
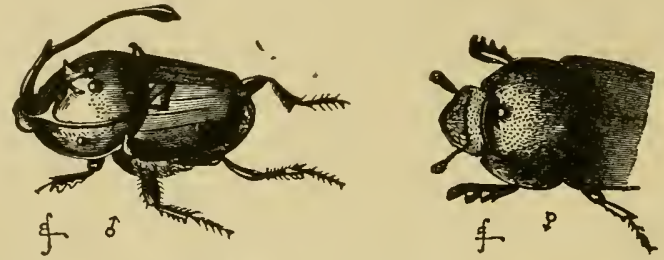

Fig. 8\%.-Onthophagus rangifer. $A$, male; $B$, fenale.-From Darwin.

side of the clypens, and the mandibles, maxillæ, and palpi appear as elongated tubereles. 'The wings are small and laid upon the posterior thighs, thins exposing the meso- and

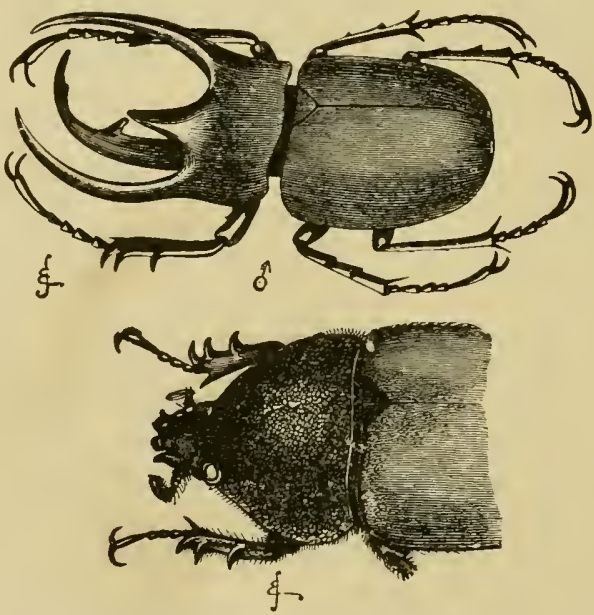

FIG. 88,-Chalcosoma atlas. Ujpper figure male, reduced; lower figure fomale natural size.-From Darwiu.

metathorax to view. The tarsal joints lie parallel on each side of the middle line of the body, and in those pupa which transform in the soil the ablomen ends in a pair of horny hooks, which aid the pupal in reaching the surface. 
Many male beetles (especially Lamellicorns and Staphylinids, Canthon, etc., Fig. 8i $^{\prime}$ are ornamented with horns, which exist only as rudiments or are wholly wanting in the other sex; in the male Lucanus (Fig. 110) the mandibles are of great size (compare also Figs. 88 and 89). Darwin remarks that beetles belonging to many and widely distinct families possess stridulating organs. Certain musical weevils can be heard at a distance of several. feet or even yards; the apparatus varying much in position on the body, but usually consisting of a rasp or set of ribs, and a scraper; in many Longicorns the rasp is on the mesothorax, which is rubbed against the prothorax; but the apparatus does not differ much according to sex. (Darwin.)

Protected from harm by their hard shell-like skin and their thick wing - covers, and living, as grubs, as pupæ, and as beetles, quite different lives, it would be hard to exterminate them. Myriad as are their forms, every species has slightly different habits and surroundings from its allies, and thus fills a niche in the insect-world which it alone can occupy. And it is this wonderful power of adaptation to changes in circumstances, as well as their solid skins and complete
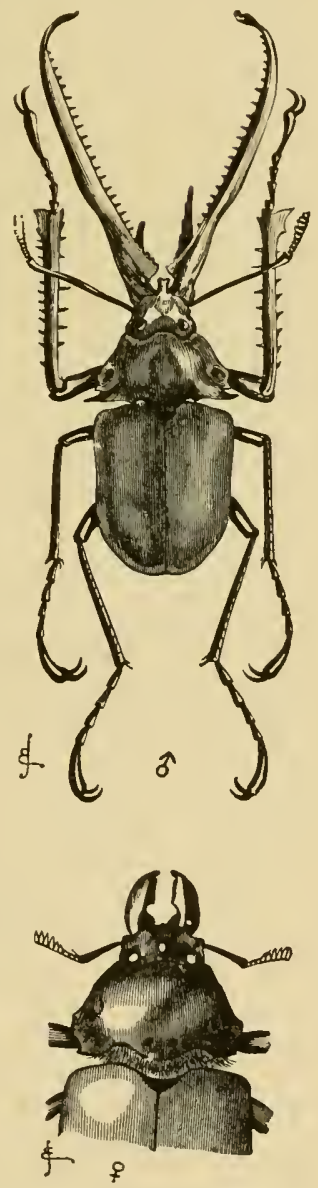

Frg. 89.-Chiasognathus grantii, reduced. Upper figure male, lower figure female.After Darwin. metamorphosis, which has enabled the great beetle order of over 100,000 kinds to become so abundant and prominent 
a group. They are preyed upon at different times of life by different enemies. Worms, parasitic mites, and birds and beasts constantly make war upon them, bnt these enemies only confine their numbers within healthy limits; so that, after all the inroads made mpon them, there is still food enough and room enough for each species to exist in its own beetle-fashion in its own little beetle-world.

'The Coleoptera have been divided by LeConte into two great groups or sub-orders, viz.: the Rhynchophora or weevils, in which the head is beaked and the palpi are short and rigid, while the labrum is usmally absent, * besides other less apparent characters; and the gennine Coleoptera.

'The genume Coleoptera, again, are divided by the number of joints in their tarsi as follows:

1. Hind tarsi with the same number of joints at least as the others (exeept in a few Claricorns). IsomerA.

2. Front and middle tarsi 5-, hind tarsi 4-jointed.

Heterosera.

'The Isomera are divided by LeConte and Horn into five series, perhaps super-families:

A. Fourth and fifth tarsal joints not connate:

First three ventral segments comnate: first divided by the hind coxal cavities so that the sides are separated from the very small medial part. AnEPHAGa. First ventral segment visible for its entire breadth (except in Rhyssodidæ):

Antennæ clavate or capitate, very rarely serrate. ClavicorNia. Antennæ serrate, very rarely clavate or capitate. SERIRICORNIA.

Antemme with a lamellate chnb, the opposing surfaces with a very deliente sensitive strueture; legs fossorial. . . . . . . . . . . . LAMELLICORNIA.

B. Fourth and fifth talsal joints anchylosed; the former very small; antennæ filiform. larely serrate, or feebly thiekened externally........ PIn TOPHAGA.

* In the Anthribidie and Rhinomacerida the labrum is present and the palpi are not rigid. 


\section{Sub-order 1. Rhynchophora.}

Beginning with the lowest family and ending with the highest, we take up first the weevils or Rhynchophora, the definitions being taken from LeConte and Horn's "Classification of the Coleoptera of North America."

Family Anthribidæ.-Beak broad, flat; antenne straight, 11-jointed; labrum distinct; last spiracle nucovered. Anthribus cornutus Say.

Family Scolytidæ.-Body thick, cylindrical; beak short, often not apparent; pygidium surrounded at the edge by the elytra; tibia usually serrate. The family of bark-borers or timber-beetles is an extensive one. They burrow sometimes by thousands under the bark of trees, especially spruce and pine, cansing the death and rapid decay of the tree by arresting the flow of sap. Their galleries, burrows, or "mines" usually branch out at right angles from a single gallery; the female in this single gallery lays her eggs in notches at quite regular intervals along each side; the larvæ, on hatching, mine in a direction at right angles to the original gallery. In some cases the mine resembles a bird's track, the galleries radiating from a single point. The larva are cylindrical and footless. Dendroctonus terebrans Oliv., Tomicus pini Say, Dryocates affaber. The most injurious species to the spruce are Xyleborus Fig. 90.-Dryocoetes affaber. $a$, celatus (Zimm.), $\boldsymbol{X}$. xylographus (Say),
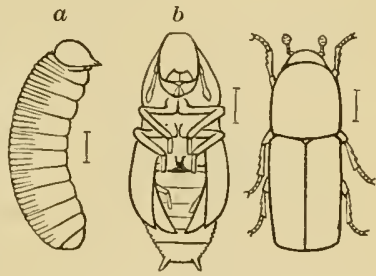
and Xyloterus bivittatus (Kirby).

Family Calandridæ.-Beak never narrowed behind the eyes;

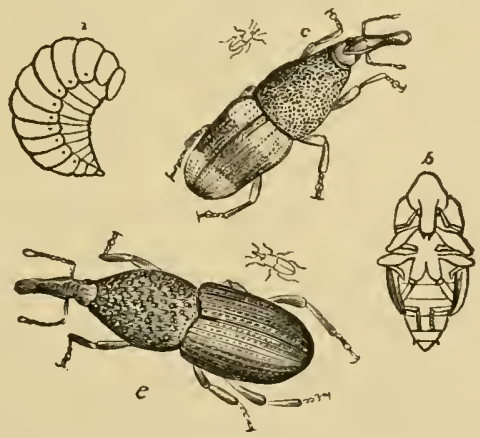

Fia. 91.-Calandra oryzae. $c$, rice weevil: $a$, larva; $b$, pupa. e, grain weevil. 
antennæ geniculate; labrum wanting; last spiracse not visihle. Rhyncophorus palmarum Linn. Here belong the rice, Citiatidru oryzu (Linu.), and grain weevils, C. granarius (Linn.); the latter so great a pest in granaries, the larva devouring the inside of the hull.

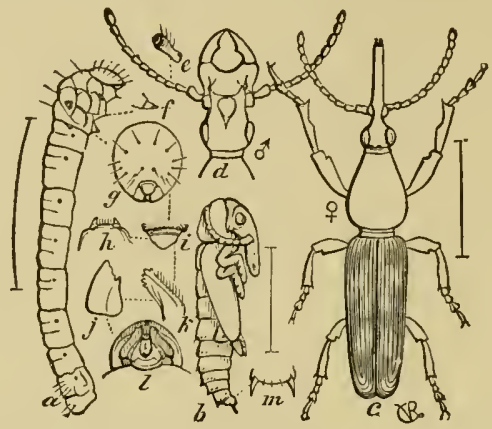

Fia. 92.-Northern Brenthian. $a$, larva; $b$, pupa; $c$, beetle, female; $d$, head of male; $e$, fourth antennal joint; $g$ - $l$, parts of larval head; $f$, leg.-After Riley.

Family Brenthidæ.-Head differing as to sex; narrowed behind ; antenne not geniculate; prothorax very long. The female of the northern Brenthian, Eupsalis minuta (Drury), bores a bole in the bark of the oak, pushing an egg into the hole; the males are very pugnacious (Fig. 92).

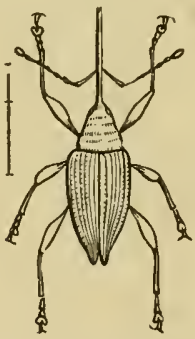

Fig. 93,--Hazel-nut weevil.

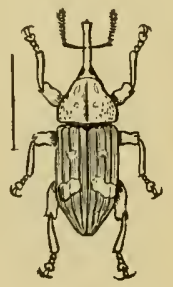

Fig. 94.-White-pine weevil. $a$, larva; $b$, pupa.

Family Curculionidæ.-Mandibles with no apical scar; beak variable in form and length; antenna usually geniculate These weevils form a family exceedingly numerous in species, which bore in the bark of trees, in nuts, seeds, etc. Bulaninus nasicus Say (Fig. 93); Pissodes strobi Peck (Fig. 94); Conotrachelus nenuphar Herbst, the plum weevil.

Family Otiorhynchidæ.—Mandiblẹs with a deciduous piece leaving 
a sear; beak variable, never long and slender ; antennæ geniculate,

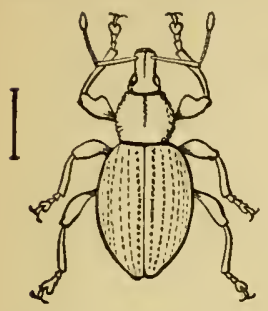

FIG, 95,-Otiorleynches sulcatus. 11-jointed. Otiorlyynchus sulcatus Fabr.; Entimus imperialis Forster, the diamoud beetle.

Family Byrsopidæ.-Tarsi setose; prostermum exeavated. Thecesternus Tumeralis Say; Byr'sopages cariuatus Mots.

Fimily Attelabidæ. - Beak short and stout, thickened at the end: maudibles stout, pincershaped. Attelabus rhois Bolı. rolls up an alderleat to form a cell for its eggs aud larva.

Finnily Rhynchitidæ. - Beak slender; mandibles flit; toothed on the inner and outer sicles. Rhynchites bicolor Fabr., a red weevil living on eultivated and wild roses.

Fimily Rhinomaceridæ.-Labrum distinet; beak as long as the prothorax. Rhinomacer elongatus Lec.

\section{Sub-order . Coleoptera genuina.}

\section{Section Heteromera.}

Fanily Stylopidæ. - By some authors referred to a distinet "order" (Strepsipter(t). In the males, which tly about, the mouth-parts are, except the matulibles and one pair of palpi, atrophied; the

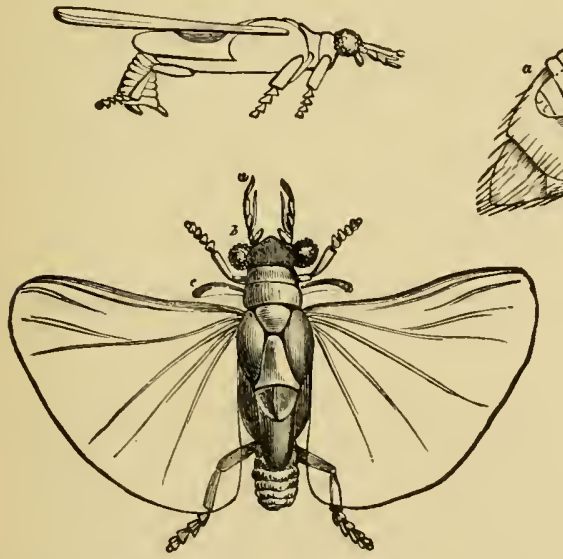

Fig. 96.

Fig. 96.-Stylops chilitien $i$, male, dorsal and side view.

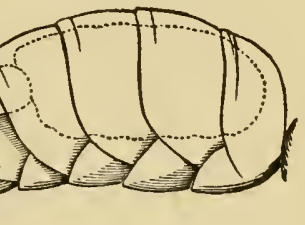

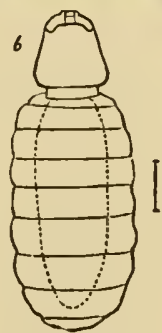

Fig. 9\%.

Fig, 97.-Female, ", in the abdomen of a bee (Andrena); $b$, the same remored.

pro- and mosothorax are very short, and the elytra reduced to slender, elub shaperl appendages, while the hind wings are well developed, the metathorax heing remarkably large and long, the abdomen heing small. The females are wingless, worm-like, with a fluttened tri- 
angulat head, and live within the abdomen of bees and wasps, though certain foreign genera are parasites in ants and Homoptera. The female is viviparous, giving birth to luundreds of very minute young, which are of very primitive form, with bulbous feet, the slender, hairy body ending in two long styles, and the intestine ending as a elosed sack. Stylops childreni Gray; Tenos peckii Kirby lives in a common wasp (Polistes metricus Say).

Family Rhipiphoridæ. - Tarsi with claws (those of Stylopids being clawless), elytra rarely covering the abdomen, as wide as the prothorax in front, usually narrowed behind, sometimes (Myodites) very small; rarely (Rhipidius) wanting in the female, in which case the wings are also wanting, and the body is larviform. Rhipidius pectinicornis is parasitic in Europe in Ectobiu germanica. This form is a connecting link between Stylopidx and other beetles. Metæcus paradoxus Linn. is a parasite in the nests of wasps (Vespa).
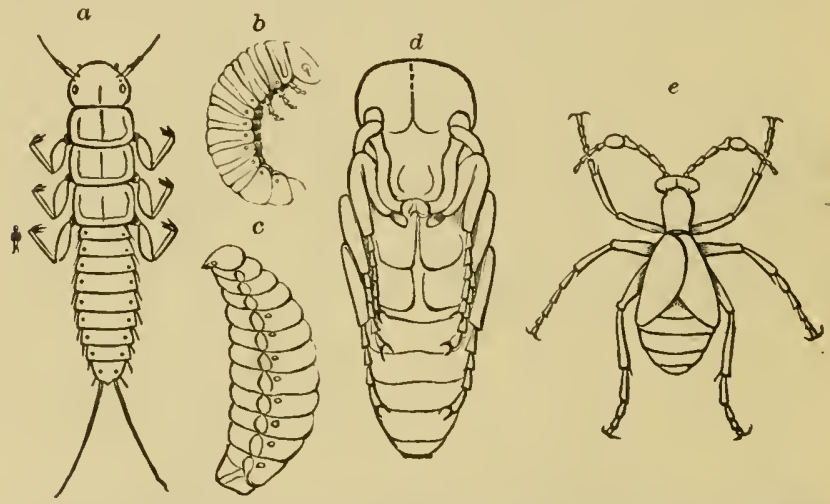

Fig. 98.- $a$, freshly-hatched larva of Meloë, first or Campodea-form stage ; $b$, second or carabidoid stage; $c$, coarctate, footless larva, third stage; $d$, pupa; $e$, inago, inale.

Family Meloidæ- - Prothorax narrower at base than the elytra, which are variable in form, in Meloe very short and pointed; claws eleft or toothed; front of head vertical. Larva primitive, Campodeaform, eertain species parasitic on bees; they mostly undergo a hypermetamorphosis, there being three larval stages (Fig. 98, $a, b, e$ ).

The blister-beetle or Spanish tly, Cantharis resicatoria Linn., is represented in the United States by the species of Macrobasis and Epicauta (Fig. 99, E. cinerea Forst.), which, with Horia, pass through a hypermetamorphosis in general like that of Meloe, the oil beetle (Meloë angusticollis Say).

Family Pyrochroidæ - Antennæ often ramose; hind coxæ large and prominent; claws simple; head horizontal; elytra wider than ablomen, rounded at tip. Pyrochroa flabellata Fabr.; Dendroides cunadensis Latr. 
Family Anthicidæ.-Hind coxe not prominent; anteuna rarely tibellate. Notoxus anchora Hentz.
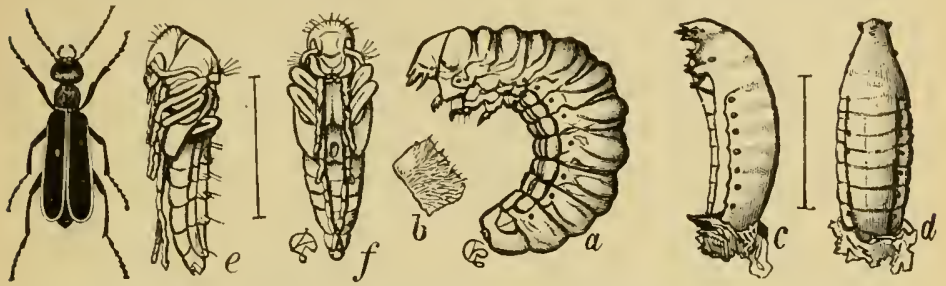

Fig. 99.-Epicauta cinerea. $a$, end of second larval stage; $c, d$, coarctate larva of $E$. vittata; $e, f$, pupa of $E$. cinerea.-After Riley.

Family Mordellidæ.-Antennæ filiform; hind coxæ laminiform; prothorax much narrowed in front; elytra narrowed behind. Mordella 8-punctate Fubr.

Family Cephaloidæ.-Head prolonged behind and gradually narrowed. Cephaloon lepturides Newman.

Family Edemeridæ.-Hiddle coxæ very prominent. Nacerdes melinurie (Linn.).

Family Pythidæ.-Antennæ free; thorax not margined; disk not impressed at base. Pytho niger Kirby.

Family Melandryidæ-Antennæe free; thorax margined at sides; disk with basal impressions. Melandrya striatu Say.

Family Monommidæ.-Antennæe received in grooves. Hyporhagus opaculus (Lec.).

Family Lagridæ.-Penultimate joint of tarsi spongy beneath. Arthromacra cenere Say.

Family 0thniidæ. - Ventral segments five, free; anterior coxæ small. Othnius umbrosus Lec.

Fimily Cistelidæ. - Tarsal claws pectinate. Cistela sericen Say.

Family Egialitidæ.-Ventral segments six, the last two closely united, the first two comnate. Eigialites debilis Mann.

Family Tenebrionidæ.-Tarsal claws simple; 5 ventral segments, in part connate; antennx usually thickened towards the end; anterior and middle tarsi 5-jointed; hind tarsi 4-jointed, the first joint almost always longer thin the second; wings often wanting. This very extensive fimily is difticult to dingnose. The larvie are slender, flattened, horny, resembling wire-worms, and the last segment of the body often bears two spines. The larva of Tenebrio molitor Linn., the meal-worm, occurs in corn and rye meal, and both beetles and larva feed on ship-biscuit. Other genera are Helops, Boletophagus, Blaps, Eleodes, Upis, etc.

\section{Section Isomera. \\ Phytophaga.}

This group is difficult to define, but all agree in feeding on vegetable matter.

Family Bruchidæ. -These beetles are "Chrysomelidie with the submentum distinctly peduncnlate;" front of liead prolonged into a 
broad square beak; anteunæ inserted in front of the eyes, variable in length, serrate or pectinate; tibial spurs distinct or obsolete. The larvæ live in the seeds of leguminous plants. Bruchus pisi (Linn.) infests peas, and $B$. obsoletus Say is the bean weevil.

Family Chrysomelidx. - The leaf beetles have the antenne of moderate length or short, not inserted upon frontal prominences; front small, oblique, sometimes (Hispini, Cassidini) inflexed; pronotum most frequently margined; tibial spurs usually wanting. This family includes the Colorado potato beetle and other species, which are injurious to garden vegetables. The potato beetle (Doryphora 10-
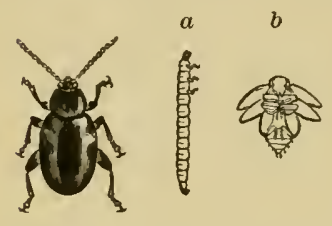

FiG. 100.-Turnip flea-beetle. $a$, larva; $b$, pupa.

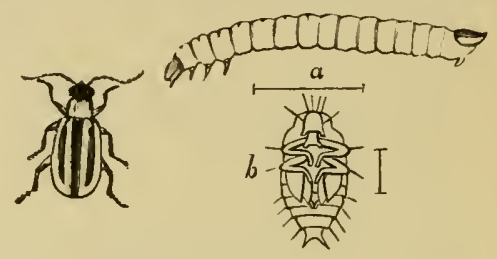

FIG. 101.-Squash beetle. $a$, larva; $b$, pupa.

lineate Say) finishes its transformations within a month after hatching from the yellow eggs which are laid on the under side of the potato leaves. In the Central States there are three broods, each of which pupate usually under ground, the first two broods remaining in the soil for ten or twelve days, while the third brood remain under ground throngh the winter, the beetles appearing late the next spring.

The flea-beetles (Haltica) are little dark jumping beetles which eat teuder and young beets, cucumbers, turnips, etc. (Fig. 100). The
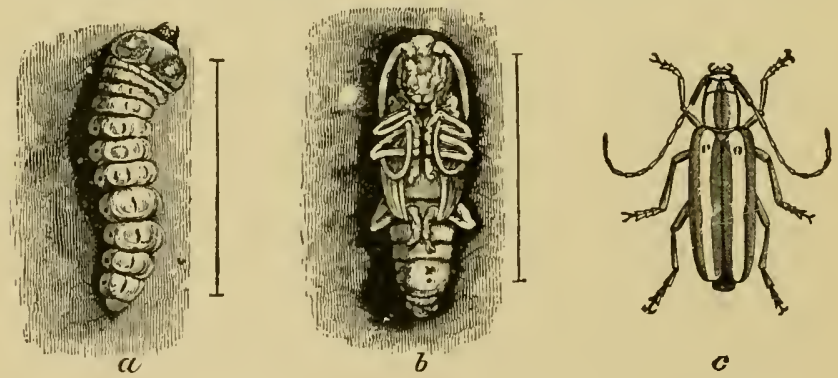

FIG. 102.-Apple-tree borer. $a$, larva; $b$, pupa; $c$, beetle.-After Riley.

squash beetle (Diabrotica vittata Fabr.) appears on squash and cucumber vines as soon as they are up, eating the young leaves. The elmleaf beetle (Galeruca xanthomelena Schr.) has of late years caused the leaves of that tree to wither and die, destroying the tree in towns 
and cities. There are in all from 8000 to 10,000 species of this family.

Family Cerambycidæ.--The longieorns are recognized by their usually long antennæ, by their large, broad heads, usually vertical, and distinct tibial spurs. While the Chrysomelida devour the leaves, the trunks of trees are tumnelled and finally destroyed by the larve of this family, ealled borers. The beetles thenselves are remarkable for their large size, rich eolors, and elegant forms. Over 7500 species are known, the most beautiful being from the tropics.
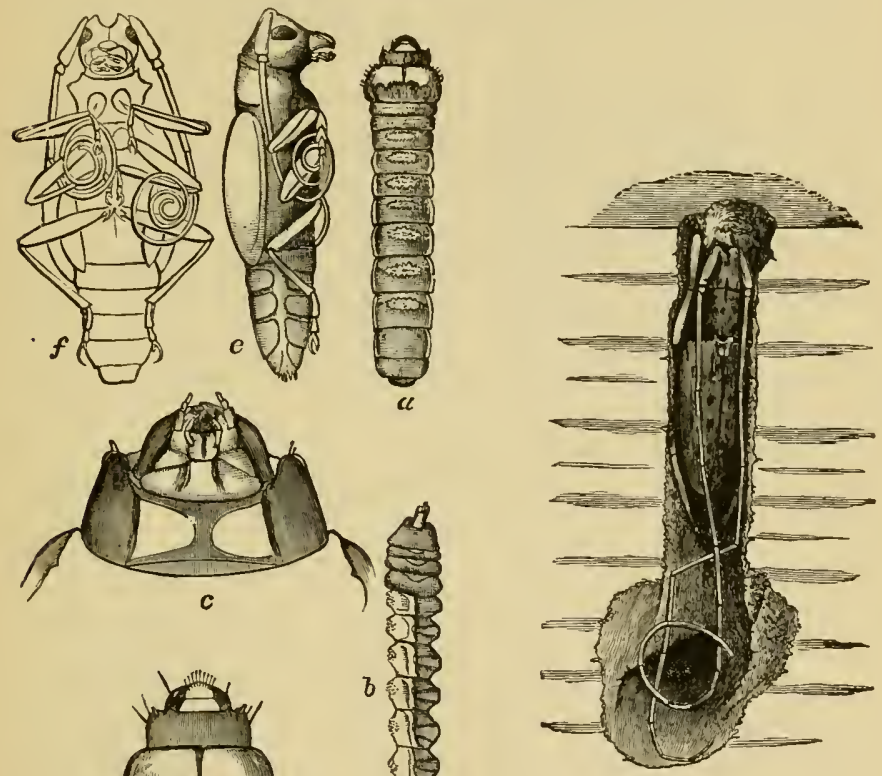

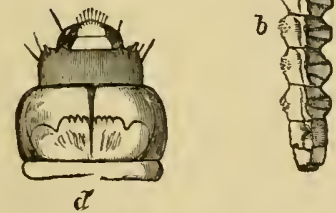

FIr. 103.-Larva of Monohammus confusor. $a$, top; $b$, side view, natural size ; $d$, upper. $c$, under, side of the head, enlarged; $e$, side, $f$, under side, of pupa.

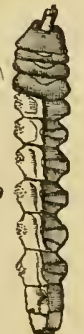

Beginning with Saperda, we recall the apple-tree borer, S. candida Fabr., which destroys living, especially young, apple-trees, the female laying her eggs by making gashes in the bark near the roots, the larva boring upwards into the wood, as it increases in size with age. Oncideres cingulatus (Say) places its eggs in small branches of hickory, ete, then gnawing through the bark below, so that the branch afterwards becomes broken off by the wind. 
Pine-trees are infested by the borer or larva of Monohammus con. fusor Kirby, which tunuels the tree, and injures the lumber made from it; the grub makes a creaking moise which may be heard some rlistauce from the tree in which it is at work. One of these beetles is known to have issued from the pine wood of a bureau wherein it must have lived fully fifteen years. The female lays her eggs in eurvilinear gashes in the bark in August, and the larva is two years in attaining its full size.

Living, healthy sugar-maples are gradually killed by the attacks of a beautiful yellow-banderl brown beetle (Plagionotus speciosus Say)

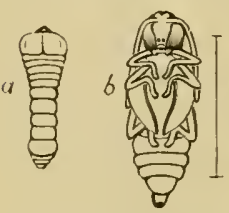

Fig. 105. - Common hickory borer. $a$, larva; $b$, pupa.

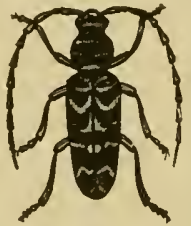

Fig. 106.-Male. which deposits its eggs in gashes in the bark, the eggs being laid late in July and in August. The hickory borer (Fig. 105) and a very closely allied species which rlestroys the locust-tree in the Northern States, are among the most injurious beetles of this family.

The sub-family Prioninu contains almost the largest beetles known; among them is Ortho. soma brunneum (De Geer). The species of Mallodon occur in the Southern and Western States, and M.melanopus Hald. bores in the roots of the young live-oak, dwarfing the tree.

Family Spondylidæ.-Tarsi not wirleued, and with no brush of hairs beneath. $P i$ randra brunnea Fabr.

\section{Lamellicornia.}

The beetles of this well-circumscribed group all agree in having the antennæ ending in a club composed of three, sometimes as many as seven, leaves or lamellæ, while the body is usually short and thick.

Family scarabæidæ.-Autennal lamellæ capable of being closely shut into a compact club. This group embraces the largest Coleoptera aud the most bulky of all inseets, viz., the gigantic Goliath aud Hercules beetles. Their larvæ are soft-skinned, thick-bodied, with rather long legs, and 4 -jointed anteunx; they live on roots, ete., and often transform in underground

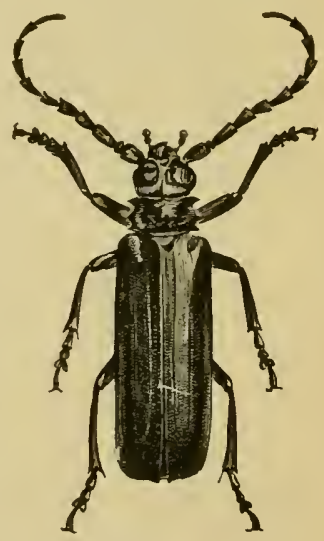

FIg. 10i. - The lesser Prionus Natural size.-After Riley.

cells; the beetles devour leaves and the pollen of flowers. There are nearly 7000 species. The Cetouix comprise very large and beautiful beetles; then comes our Southern Dynastes tityus Linn., an allied species in South America being D. hereules Linu. These are suc- 
ceeded by the grape beetle, Pelidnota punctata Linn., and the Goldsmith beetle, Cotalpa lanigera Linn. The May-bectle, or dor-bug, is a
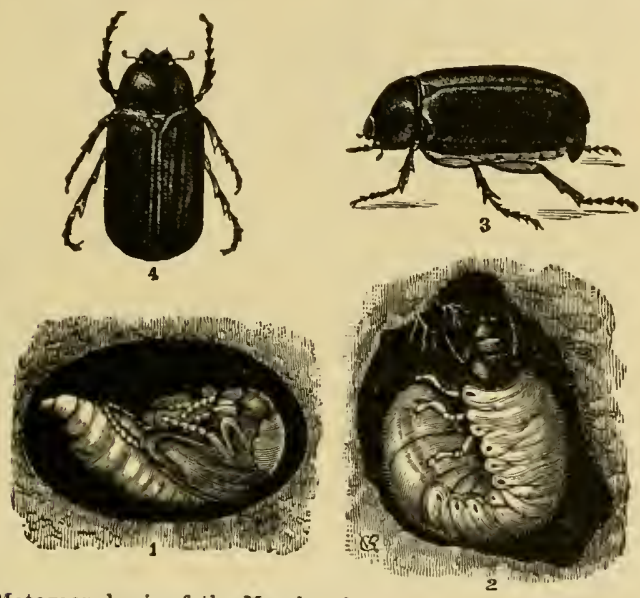

FIG. 108.-Metamorphosis of the May-beetle. 2, grub or larva; 1, pupa; 3, 4, beetle. Natural size.-After Riley.

very common species; its larva devours the roots of grass, sometimes injuring lawns, also the roots of seedling trees in plantations. Allied
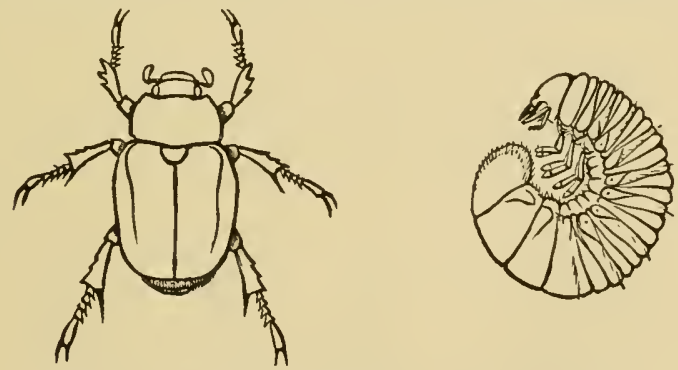

FIG. 109.-Goldsmith beetle and larva. Natural size.

to it is the rose-chafer, Macrodactylus subspinosus Fabr., while at the head of the family is the dung-beetle (Pheneus carnifex Linn.), and the sacred Scarabæus of Egyptian inscriptions.

Family Lucanidæ. - Club usually not flattened, leaves not capable of being closed. Lucanus dama Thunb., stag-beetle; Pussalus cornutus Fabr. occurs in all its stages in decayed harl-wood stumps in spring. 

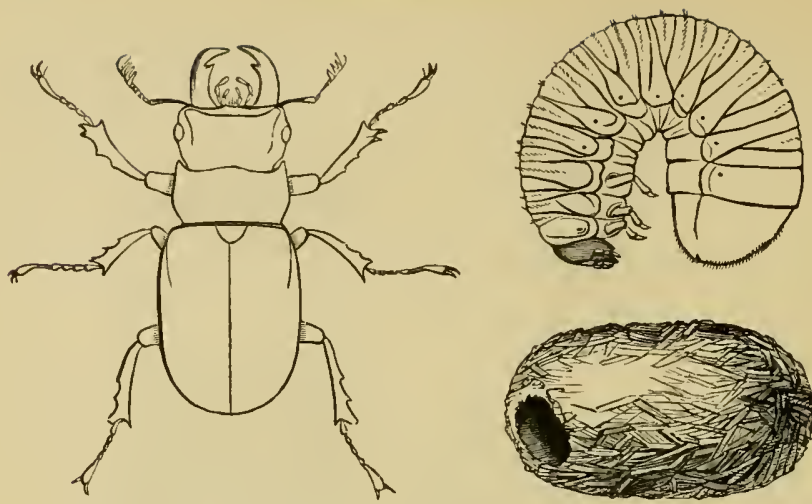

Fig. 110.-Lucanus dama. Fig.111.-Larva and cocoon. Natural size Serricornia.

In this group the antennæ are usually serrate.

Family sphindidæ. - Tarsi heteromerous, living in dry fungi. Sphindus americanus Lec.

Family Cioidæ. - Tarsi 4-jointed; antennæ clavate or flabellate. Cis fuscipes Mellie.

Family Lymexylidæ. Front coxæ conical, prominent; tarsi slender. Lymexylon sericcum. Harris.

Family Cupesidæ. Head narrowed behind; eyes smooth. Cupes capita ${ }^{+} a$ Fabr.

Family Ptinidæ.-Head not narrowed behind; eyes granulated; mesothoracic epimera not reaching the coxæ; antennæ with usually 9-11 joints, variable in form. Beetles mostly of small size, often living in partly decayed vegetable matter. Ptinus fur Linn. sometimes attacks museum colleetions. Anobium is the death-tick, and its ally, Sitodrepu punicea Fabr., has proved at times to be a museum pest.

Family Cleridæ. - Antennæ inserted at the sides of the front, usual

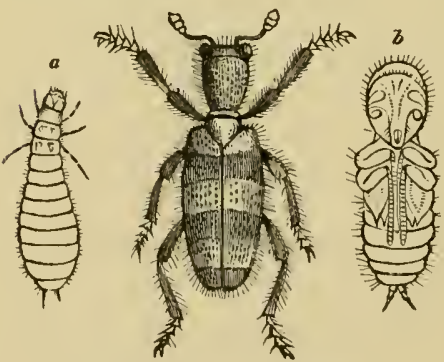

FIG. 112,-Trichodes apiarius. ly 11-jointed, rarely clubbed; tarsi 5-jointed, with membranous lobes beueath the four basal joints. The beetles of beautiful colors, occurring on plants or trunks of trees; the larva live under bark and are carnivorous, and those of Trichodes (Fig. 112) infest nests of bees in $\mathrm{Eu}$ rope. A few (Corynetes, Necro. bia) live on dead animal matter. Trichodes nuttallii Kirloy.

Family Malachidæ.-Ventral segments 5 or 6 ; antennæ inserted generally before the eyes.

Body with lateral, distensible vesieles. Malachius aneus (Linn.). 
Family Lampyridæ.-Ventral segments 7 to 8 ; antennæ serrate, rarely pectinate or tlabellate, inserted on the front; skin rather thin;
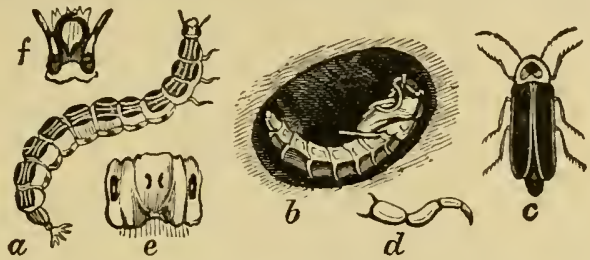

Fig. 113.-Photinus pyralis, fire-fly. Natural size. $a$, larva; $b$, pupa; $f$, head; $e$, uuder side of a Jarval segment.-After Riley.

found on plants. While the Phengodini are phosphorescent, the tribe Lampyrini embraces the fire-flies, which have phos phorescent organs at the end of the abdomen. In the species of Photuris both sexes are winged, but in Lampyris the females, called glow-worms, are larva-like and wingless. The larvæ are often carnivorous, living on suails, worms, te. The females of Phengodes and Zarhipis are not easily distinguishable from the larva, and are phosphorescent (Fig. 114).

Family Buprestidæ. - Skin very thick and solid; antennæ serrate; tarsi with membranous lobes as in the Clericlæe. Larva with a large, broad prothoracic segment, body behind slender, cylindrical; living under bark. This group is numerous in species, about 2700 being known. They usually have metallic reflections and ofteu rich colors; but are very injurious to fruit and shade trees (pines, oaks, etc.). Chrysobothris femoruta Oliv. is a common and destructive species; in Dicerca the tips of the elytra separate. Chalcophora virginiensis Drury bores into the trunks of pines. Melanophila drummondi (Kirby).

Family Throscidæ. - Resembling the next family, but with the prothorn $x$ fixed so as to be enabled to leap. Throscus constrictor Say.

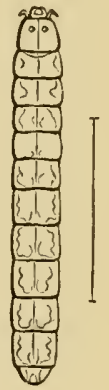

FIG. 114.Female (or larva?) of Phengodes.

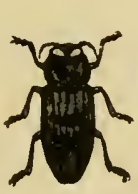

FIG. 115.-Chrysobothris femorata and larva.

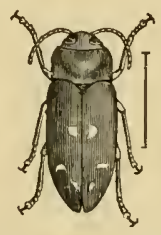

Fig. 116.-Drummond's Melanophila.

Family Elateridæ.-Prothorax loosely articulated, the prosteruum prolonged behind, forming a sharp spine which moves in a cavity in the mesosternum, so as to suddenly throw the beetle in the air 
if placed on its back. The group of snapping-beetles is very ex-

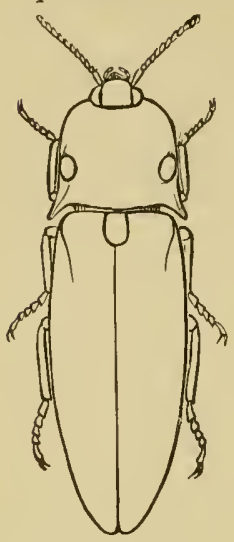

Fig. 117.-Fire-fly. Natural size. tensive, over 3000 species being recorded; the larvæ are called wire-worms from their hard, slender cylindrical bodies, and are known to live twe years before transforming; they are mostly herbivorous, a few larvæ, however, devouring the eggs of locusts. Here belongs the fire-fly of the West Indies, Pyrophorus noctilucus Linn. (Fig. 117).

Family Rhipiceridæ.-Antennæ serrate in the female, frequently flabellate in the males; onychium large and hairy. Sandalus petrophya Knoch.

Family Dascyllidæ.-Head not constricted behind; eyes granulated; mesothoracic epimera reaching the coxæ. Larvæ more or less aquatic. Prionocyphon discoideus Say.

\section{Clavicornia.}

In this group the antennæ are chlo shaped, while the tarsi vary in having frorn 1 to 5 joints.

Family Heteroceridæ.-Antennæ short, irregular; legs fossorial. Heterocerus pallidus Say.

Family Parnidæ. - Aquatic beetles, with a retractile head; last joint of tarsi long, claws large. Larvæ aquatic, hemispherical; that of Psephenus lecontei Lec. lives under stones in rapid streams; the pupa is formed under the larval skin which protects the insect beneath like the scale of a Coccus.

Family Georyssidæ.-Small, rounded, convex beetles, which cover themselves with mud; coxæ contiguous; prosternum semi-membranous. Georyssus pusillus Lec.

Family Byrrhidæ. - Pill beetles; head usually retracted under the prothorax; body oval or rounded and very convex; legs retractile. Byrrhus ameri-

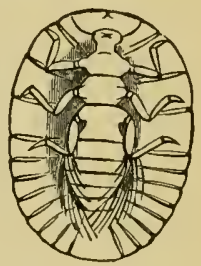

FIG. 118.-Larva of Psephenus lecontei. canus Lec.

Family Derodontidæ.-Anterior coxæ conical, transverse. Derodontus maculatus (Mels.).

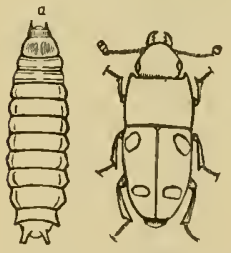

Fitg. 119.--Ips fasci. atus, $a$, larva.

Family Trogositidæ.-Antennæe straight; tarsi slender first joint short; living under bark or in fungi, while certain species are injurious to grain. Trogosita virescens Fabr.

Family Nitidulidæ.-Antennæ straight; tarsi more or less dilated, first joint not short. Larvie living usually in decaying matter. Nitidula bipustulata Linn., Ips fuscüutus Linn.

Family Histeridæ. -Body oblong and flat, or round, oval, globose, or cylindrical ; antenne geniculate; tibia usually all dilated. The species are scavengers, living under bark of trces, in excrements, and in carcasses. Ifister interruptus Bcauv. 
Family Dermestidæ. - Small oval or elongate beetles; borly usually scaly or pubescent. Dermestes lardurius Linn. in the larva state is destructive to musem collections, especially insects, as is that of Attagenus pellio, which also eats holes in carpets; while the worst

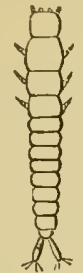

Fig. 120.-Larva of Hister merdarius.
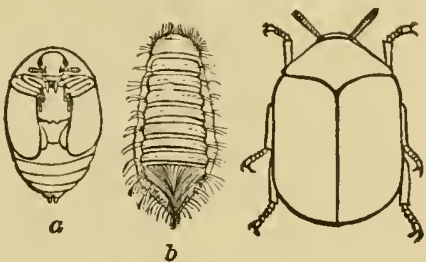

FIG. 121.-Museum pest. $a$, pupa; $b$, larra.

museum pest is Anthrenus varius Fabr. (Fig. 121). A. scrophulariue Linn. is the carpet beetle, introduced from Europe.

Family Mycetophagidæ.-Body flattened; head free. Living on fungi and under bark. Nycetophaguspunctutus Say.
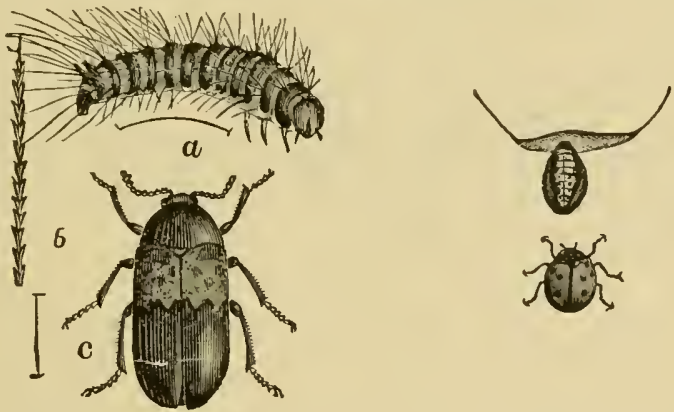

F1G. 122.-Dermestes lavdarins and larva. FIG. 123. " "Lady-bird" and pupa.

Family Cryptophagidæ. - Prothorax nearly or quite as wide as the elytra; bind male tarsi sometimes 4 -jointed. Antherophagus ochraceus Melsh.

Family Cucujidæ.-Boly very that and long; abdomen with five free segments. Living under bark, ants'nests, etc. Sylvanus surinamensis Linn. breeds in bran, rice, and wheat.

Family Rhyssodidæ.-liesembling Carabidx; head with a distinet neck; living under bark. Rhyssodes extrutus Ill.

Family Colydidiæ. - Small inseets, usually of an elongate or cylindrical form; with regular antenna; tarsi 4-jointed, simple; legs not fossorial. Living under the bark of trees, in fungi, or in the earth. Colydium lineola Say. 
Family Erotylidæ. - Tarsi more or less dilated and spongy beneath.

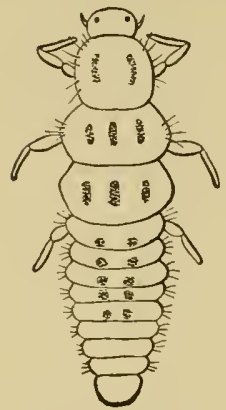

FIG. 124.-Larva of "Lady-bird." Erotylus; Dacne 4-muculatu (Say).

Family Endomychidæ.-Tarsi 4 -jointed, or, from the atrophy of the third joint, apparently 3-jointed; claws simple. Endonychus biguttatus Say.

Family Coccinellidæ. - Hemispherical beetles with the head deeply immersed in the prothorax; tarsi with the second joint dilated; claws appendiculate or toothed, sometimes simple: larvis of great benefit to agriculture from devouring Aphides. When about to pupate, the larva attaches itself by the end of the body to a leaf, and either throws off the larva skin, which remains around its tail, or the cast skin is retained, loosely folded about the pupa as a rude sort of cocoon. Coccinella novem-notata Herbst (Fig. 123); Psyllobora 20-maculata Say (Fig 124).

Family Corylophidæ. - IVings fringed with long hairs; a loose antennal club. Corylophus truncatus Lee.

Family Phalacridæ.-Body oval, convex; sentellum larger than usual. Phalacrus oralis Lee.

Family scaphidiidæ.-Body oval, convex; elytra broadly truncate behind; tarsi long and slender. Scaplidium quadriguttatum Say.

Family sphæridæ.-Wings fringed with long hairs; abdomen with 3 ventral segments. Splutrius politus Horn.

Fannily Hydroscaphidæ.-Antennæ short, not verticillate; abdomen prolonged. IIydroscuplu natans Lee.

Family Trichopterygidæ.-Antennæ slender, verticillate; abdomen not prolonged; the smallest beetles known. Trichopteryx aspera Haldeman.

Family Staphylinidæ.-Elytra very short; abdlomen entirely corneous, with 7 or 8 visible segments. The rove-beetles, recoguized by their narrow, long bodies and upturned abdomens, are ofteu minute, living under stones, in mamure-heaps, fungi, moss, and in ant-hills. Straphylinus vulpinus Nordm.

Family Pselaphidæ.-Very small; head and prothorax narrower thau the elytra and abdomen, the latter obtuse at tip. Pselaphus erichsonii Lec.

Fanily scydmænidæ.-Differing from Pselaphids by the long elytra. Scydmenus mariue Lec.

Family silphidæ. - The burying beetles have the antenux clubbed, sometimes nearly filiform; larva broad, sides of body serrated. Necrophorus americamus Oliv., Silpha lapponica Herbst, S. surinamensis Fabr. Adelops hirtus Tellk. is a blind cavebeetle.

Family Leptinidæ. - Eyes absent or imperfect. Loptinus testuceus Mïll. is parasitic on mice, ete.; Leptinillus validus Horu ou the beaver. 
Family Platypsyllidæ.-Body flat, like a cockroach; eyes and mandibles wanting. Platypsyllus castoris Ritsema is, both in its larval and adult stages, a parasite of the beaver.

Family Hydrophilidæ.-Body oblong, oval, convex, or hemispheri-

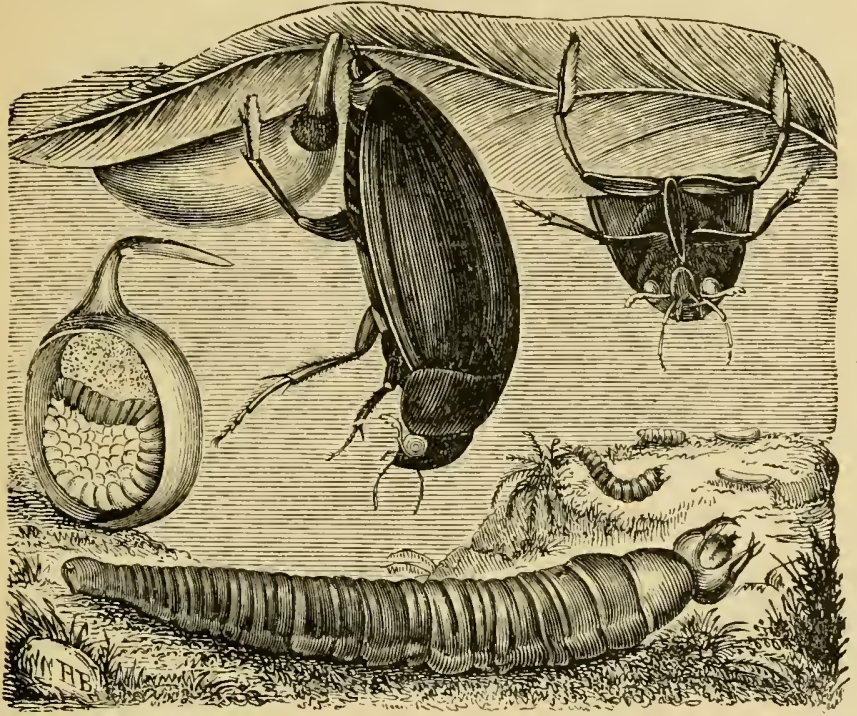

FIG. 126.-Hydrophilus; its egg-case and larva. Natural size.

cal; palpi often very long; mostly aquatic; larvæe carnivorous. $H y$ drophilus trüengularis Say; Spharidium scarabaoides (Linn.).

\section{Adephaga.}

This group has been already briefly defined on p. 9. 'I'he water and ground beetles are usually carnivorous both in the larval and adult stages, though many are phytophagous.

Family Gyrinidæ.-Body oval; antennx irregular, very short; eyes divided so that they appear as four. The whirligig beetles are seen in groups gyrating and circling on the surfice of ponds and streams, and when caught give out a disagreeable milky . fluid. Gyrinus borealis Aubé.

Family Dytiscidæ.-Like Carabids, except in those characters which adapt
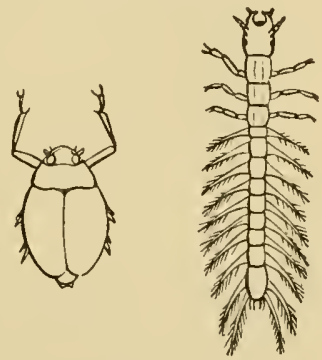

Figs. 1:7, 1:8,-Gyrinus borealis and larva of another species. 
them for an acuatic life; body oval, broad, and flattened; legs Hattened, oar-like, and fringed. The larva are called water-tigers from their fierce habits and long; slender jaws; when about to pu. pate they leave the water, and form a round cell in the bank. Dytiscus fasciventris Say; Acilius mediatus Say.

Family Haliplidæ. -Antennæ 10-jointed; small yellowish waterbeeties, spotted with black. Haliplus fusciatus Aubé.
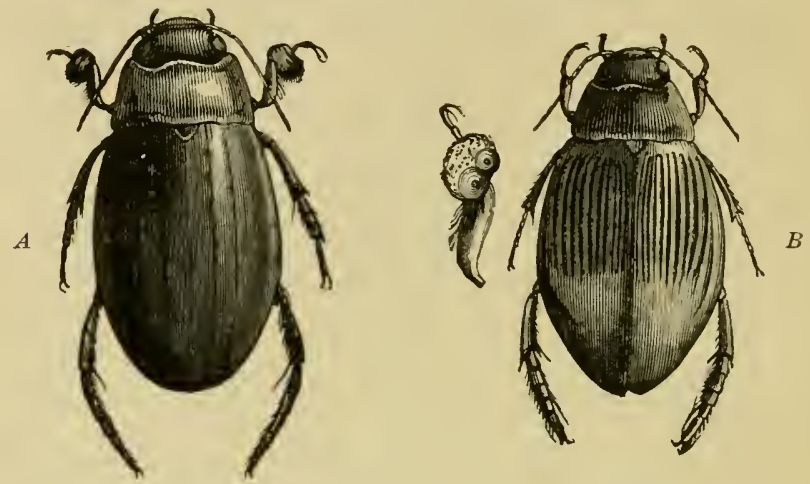

Fig. 129.-Dytiscus marginal is, from Europe. $A$, male, with smooth elytra and fore tarsi expanded into suckers; $B$, female.

Family Amphizoidæ.-A(puatic beetles of singular structure, with the legs adapted for walking. Amplizoc insolens Lec.
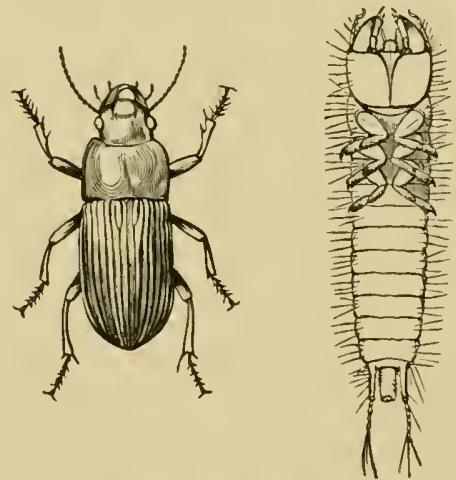

Fig. 130.-Harpalus caliginosus, natural size; larva of undetermined species, enlarged 3 times.

Family Carabidæ. - The ground-beetles have the an tennæ arising at the side of the hear between the base of the mandibles and the eyes. The species are very numerous; their larva are carnivorous, and live under stones, etc., in the same situations as the parents. In Harpalus the body is broad, while in Casnonia the head and prothorax are very slender. Brachinus, the "bombar dier" beetle, is remarkable for discharging from its anal glands, with an explosion, a pungent fluid. Currebus serre. tus Say is a typical form, as is also Culosomit culidum Fabr., which climbs trees after cat. erpillars. Platynus cupripenne Say; Brachinus fumans Filhr.

Family Cicindelidæ. - Antennæe on the front above the base of the mandibles; ligula small; female abdomen with 6 , male with $\%$, seg ments. 
The tiger-beetles not only run with agility, but have a light, swift

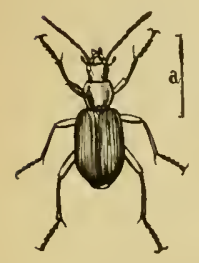

FIG. 131. - Platynus cupripenne.

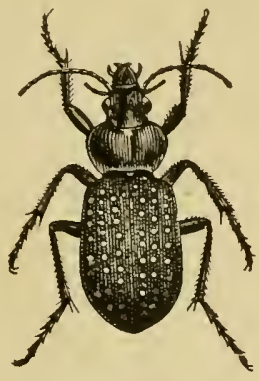

FIG. 132, - Calosoma calidum. Natural size.

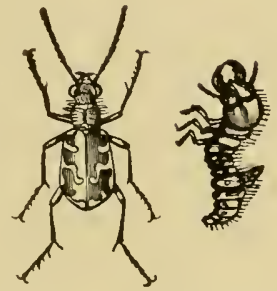

FIG. 133.-Cicindela hirticollis. Larva of an un. known species.

flight. Their larva bore into sand, propping themselves up in their holes by two dorsal hooked projections on the ninth segment. Certain South American forms climb trees like ants, which they resemble. Cicindele vulguris Say, C. hirticollis Say.

\section{Order XIII. Siphonaptera* (Aphaniptera, Fleas).}

Although the fleas resemble flies in their larval stage and in the mode of derelopment of the embryo, yet the adults are now thonght to present such a combination of characters as to throw them out of the great order of Diptera, where they have been allowed to remain by many authors. $\nmid$

\section{* Selected Works.}

Guyon, M. Histoire naturelle et médicale de la Chique (Rhynchoprion penetrans). (Rev. et Mag. de Zool., 1865-68. Paris.)

Karsten, H. Beitrag zur Kenutniss des Rhynchoprion penetrans. 1864.

Kraepelin, K. Ueber die systematische Stellung der Puliciden (Hamburg, 1884).

Landois, L. Anatomie des Hundeflohes (Pulex canis). (Dresden, 1866.)

Packard, A. S. Development of Pulex canis (Mem. Peab. Acad. Sc. Salem, 1872). Also the writings of Weismann and Balbiani. Taschenberg, 0 . Die Flöhe (Halle, 1880).

+ Although we have held the view of Haliday and Osten Sacken that the fleas have aftinities to the dipterous family Iycetophilida, yet, in deference to the researches of Kraepclin and the opinion of Brauer, we refer them to a separate order; though in their embryology and transformations fleas closely resemble flies like Myceto. phila, Simulium, Chironomus, etc. 
Besides being wingless, the antennæ are $3-14$ jointed, lodged in a cavity behind the eyes; their mandibles are long with serrate edges; the maxillæ are short, the palps being 4-jointed, and the labial palps are also 4-jointed. The labrum is distinct, bnt there is no hypopharyux. The body is ovate and much compressed; there are only two simple eyes, no compound or faceted eyes. The edges of the head and prothorax are armed with stont spines directed backwards, and the entire form of the body and arrangement of parts are in adaptation to the peeuliar mode of life of these insects, which live under or among the hairs of man and certain mammals and the feathers of certain birds.

The cat-flea lays eight or ten eggs, which fall on the floor
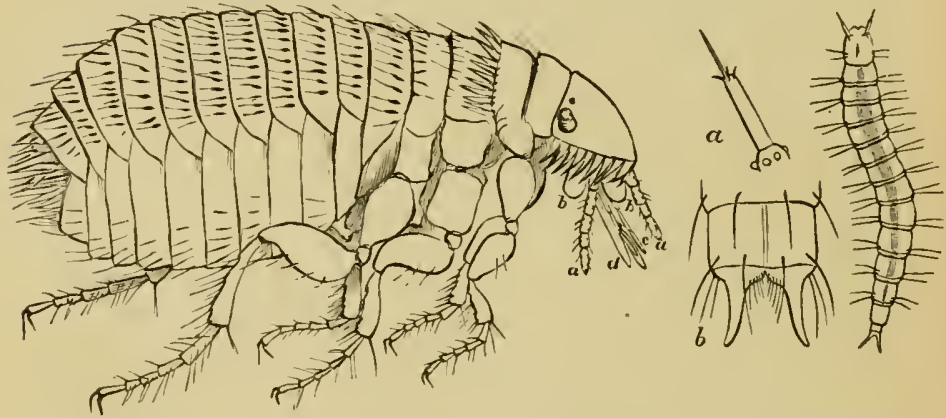

FIG. 134.-Dog or cat flea (Pulex canis). $a$, maxillary palpi ; $b$, maxillæ (should be longer and pointed): $c$, labial palpi; $d$, mandibles. Larva of the cat-flea: $a$, antenna; $b$, end of the body.

and there hatch, the larræ living in the dust and dirt on the floor, and feeding on it. In about twelve days after hatching the larva spin a silken cocoon, the pupa being inactive, and remaining in this state from eleven to sixteen days.

A serious torment of sandy, hot regions in the tropies is the jigger, ehigoe, chique, or pique, Surcopsylla penetrans, which during the dry season bores into the toes of natives, especially uncler the nails, catusing a distressing sore.

Family Pulicidæ. - With the characters of the order. Pulex irritans Linn., the human flea; $P$. canis Dugès, the flea of the dog and cat. 
An English observer has seen Heas sucking the blool of caterpillars. Ir. L. O. Ifoward states that a species of tlea, possibly Pulex gallince
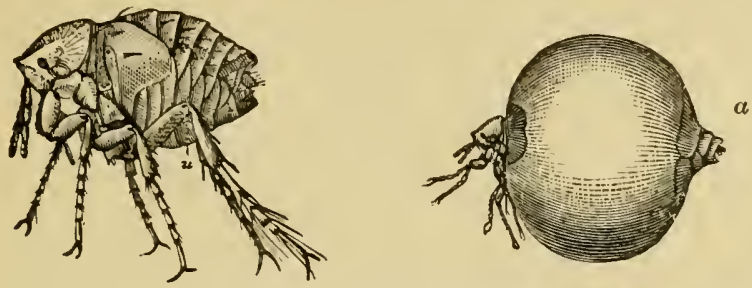

FIG. 135.-Jigger-flea. $a$, female distended with eggs.

Bouché, kills chickens in Florida, puncturing especially the heads of very young, downy individuals.

\section{Order XIV. Diptera* (Flies).}

Any species of this order may be at once recognized by

\section{* Selected Works.}

Becher, E. Zur Kenntniss der Mundtheile der Dipteren (Denk. Akad. d. Wissens. Wien, Bd. xlv., 1882).

Brauer, F. Monozraphie des 0estriden (Wien, 1863).

- Systematisehe Studien auí Grundlage der Dipteren-larven, etc. (Akad. d. WVissens. Wien, Bd. xlvii., 1883). (Figs. and deseriptions of dipterous larvæ, and list of all works and articles referring to the metamorphoses of Diptera.)

Dimmock, G. The anatomy of the mouth-parts and of the sucking apparatus of some Diptera (Boston, 1881).

Loew, H., and Osten Sacken, C. $R$ von. II onograph of the Diptera of North America, 1862-73 (Smithsonian Inst). Also other essays and papers.

Hammond, Arthur. On the thorax of the Blow-fly (Musca vomitorite). (Linn. Soc. Jouru.-Zoology, vol. xv., 18i9.)

Hansen, H. J. Fabriea oris Dipterorum (Copenhagen, 1883).

Kraepelin, K. Zur Anatomie und Physiologie des Rüssels von Musca (Zeits. f. Wissen Zool., xxxix., 683, 1883)

McCloskie. G. Kraepelin's Proboseis of Musca (Am. Nat., xviii., p. 1234, 1884).

Lowne, B. F. The anatomy and physiology of the Blow-fly, Musce vomitoria (London, 18 $\pi^{\circ}$ ).

Macquart, J. Diptères exotiques noureaux on peu connus (2 vols, en 5 parties, et 5 supplements. Paris, 1838-55).

Meigen, F. W. Systematisehe Beschreibung der bekannten europäischen zweitlügeligen Insekten ( 7 vols. Aachen and Hamm, 1818-35).

Meinert, F. Trophi Dipterorum (Copenhagen, 1881). (In Danish, with abstract in Latin.)

- Sur les larves eucéphales des Diptères (Copenhagen, 1886). (In Danish, with French résumé.) 
its having but a single parr of wings; the hinder pair being rudimentary, and forming the balancers or halteres. In many flies the antenne are short and 3-jointed, the last joint being furnished with a bristle, which in the house-fly and its allies is feathery; or, as in the mosquito and its allies, the antennæ are long and many-jointed.

Examining the honse-fly as a type of Diptera in general,

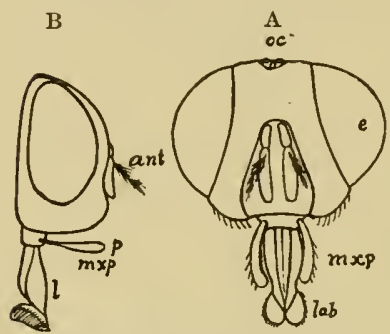

Fig. 136. $-A$, front, and $B$, side, view of head of house-fly. oc, simple, and $e$, compound, eye; ant, antenna; $m x p$, maxillary palpi; $l$, tongue; $l a b$, labellum. Magnified.

we notice that the 3-jointed antennæ, when not extended, lie in a carity in the face. The mandibles and maxillæ, so well developed in the mosquito and other piercing or biting flies, are aborted, thongh the maxillary palpi are present (Fig. 136, mxp; Fig. 13\%, $p$ ). On the other hand, the under lip, or so-called proboscis, ends in two flaps (labella), adapted for lapping liquid food. The structure of the proboscis is very curious. When the fly settles upon a lump of sugar or other sweet object, or even upon the back of our hand

Menzbier, M. A. Ueber das Kopopskelet und die Mundwerkzeuge der Zweifliugler (Bull. Soc. imp. Natur. Moscou, 1880).

osten Sacken, C. R. von. Catalogue of the described Diptera of North America (second edition. Washington, Smithsoniau Inst., 1878). Also numerous papers and monographs published by Smithsonian Inst., Am. Ent. Soc., etc.

Scheiner, J. R. Fauna Austriaca. Fliegen. (i, ii. Wien, 1862-64.)

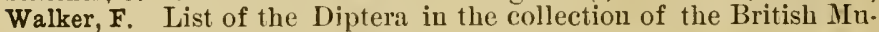
seum (7 parts, $12 \mathrm{mo}$. 1848-55).

Wiedemann, C. R. W. Ausseremropäische zweiflïgelige Insekten (2 vols. Hamm, 1828-30).

Williston, S. W. Synopsis of the North American Syrphidæ (Bull. 31, U. S. Nat. Mus: Washington, 1886).

- Dipterological notes and deseriptions (Trans. Am. Ent. Soc., xiii., 1886).

_- On the N. Am. Asilidæ (Trans. Am. Ent. Soc., xi., xii., 1884-5). Also articles by Bergenstamm and Loew, Bigot, Brauer, Burgess, Fitch, Gerstacker, Leach, McCloskie, Riley, Say, Shimer, Walsh, Westwood, and Williston. 
when covered with perspiration, it unbends its proboscis, extends it, and the broud knob-like end divides into two

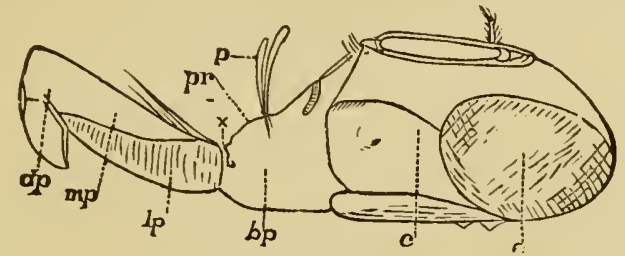

Fig. 137.-Head and proboscis of the blow-fiy. e, eye; c. epicranium; $b p$, basiproboscis; $p$, maxillary palpus; $p r$, chitinous ridges uniting with the rudimentary maxilla; $l p$, lower labial plate; $m p$, medi-, $d p$, disti-proboscis.-After Kraepelin.

flat, muscular leaves (Fig. 138, $B, l$ ), which thus form a broad sucker-like surface, with which the fly laps up
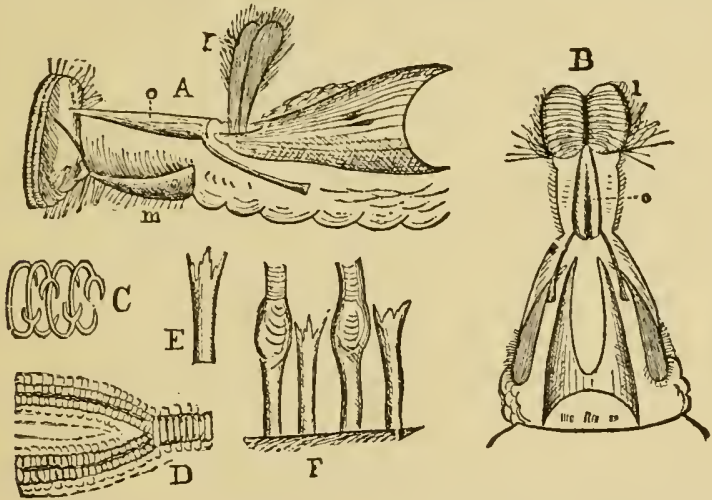

FIG. 138. - Proboscis of the house-fly. $A$, right-side view; $B$, view of the same from above; $C$, semi tubes of its false tracheæ; $E$, a tooth; $F$, arrangement of teeth between roots of false trachex: $D$, two of the false tracher with wrinkled membrane between. In $A$ and $B$ : $i$. labellum; $o$, operculum; $p$, palps; $f$, fulcrum; $m$, mentum. IIagnified.-A fter McCloskie.

liquid sweets, or any matter which seems good to the fly's mind.

The two flaps at the end of the proboscis are supported upon a framework of strong but delicate rods which act as a set of springs to open and shut the broad flaps. The inside of this broad, fleshy expansion is rough, like a rasp, and, as Newport states, "is easily employed by the insect 
in scraping or tearing delicate surfaces. It is by means of this eurious structure that the busy house-fly oceasions much mischief to the covers of our books, by scraping off the albuminous polish, and leaving tracings of its depreda-

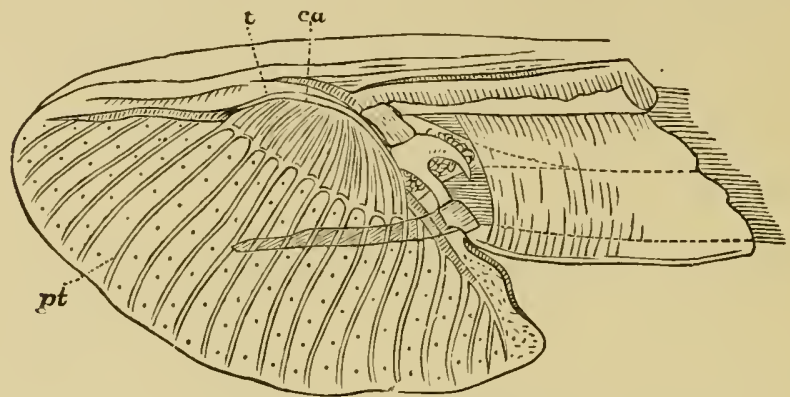

FJG. 139.-Side view of a labellum. $c a$, chitinous arch supporting the false tracheæ $(p t)$.-After Kraepelin.

tions in the soiled and spotted appearance which it occasions on them.

'The thorax is somewhat rounded, and though composed of three rings, yet these are so eonsolidated that it is at first hard to identify them. The prothorax is rudimentary, the

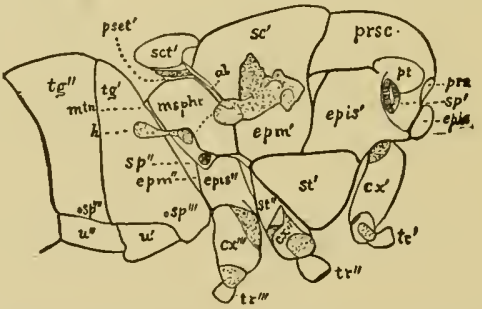

FIG. 140.-Thorax of the house-fly. prn, pronotum; prsc, præscutum; $s c^{\prime}$ mesoscutuin; sct', mesoscutellum; psct', postscutellum; $a l$, insertion of tegula, extending to the insertion of the wings, which have been removed; msphr, mesophragma: $h$, balancer (halter); $p t$, patagia; $m t h$, metanotum; epis, epis', epis', episternum of pro-, meso- and meta-thorax; epm', epm', meso- and meta-epimerum; $s t^{\prime}, s t^{\prime \prime}$, meso- and meta-sternum; $c x^{\prime}, c x^{\prime \prime}, c x^{\prime \prime \prime}$, coxæ; $t r^{\prime}$, $t r^{\prime \prime}, t r^{\prime \prime \prime}$ trochanters of the three pairs of legs; $s p^{\prime}, s p^{\prime \prime}, s p^{\prime \prime \prime}, s p^{\prime \prime \prime \prime}, s p^{\prime \prime \prime \prime \prime}$, first to fifth spiracles; $t g^{\prime}, t g^{\prime \prime}$, tergites of first and second abdominal seg: ments; $u^{\prime}, u^{\prime \prime}$, urites.

thorax being almost wholly formed of the middle ring (mesothorax). 'The latter consists of three large upper 
pieces, the prescutum, scutum, and the triangnlar or shield-shaped scutellum (Fig. 140, sct'). 'T'o the sides of this segment are attached the wings. 'The third ring (metathorax) is but partly formed, and cannot be seen from above. It supports the balancers (Fig. 140, $h$ ). There are also broad covering scales under the base of the true wings, called the teguld. 'The fly's wing is broad, thin, and transparent, and strengthened especially along the front edge by slender, hollow rods called veins. There are six principal veins, some of which are branched, and they are in most cases connected by a few cross-veins. The wings move with great swiftness. The house-fly, when held captive, moves its wings 330 times a second, and the tip of the wing describes a figure 8 in the air.

The hum of the fly is its roice. There are three different tones in the fly's hum. While flying the tone is rela-
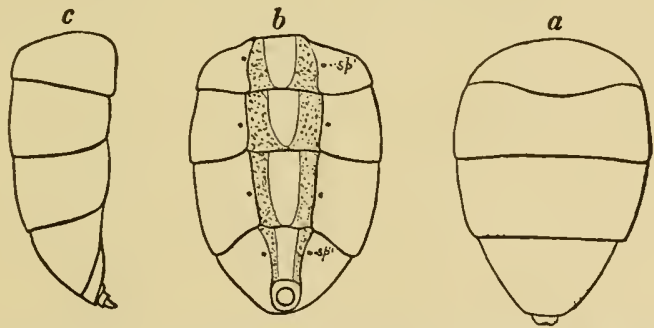

Fia. 141.-Hind body or abdomen of house-fly. $a$, dorsal, $b$, ventral, $c$, side, view; $s p^{\prime}-s p^{\prime \prime}$, the four pairs of abdominal spiracles. Magnified.

tively low; when the wings are held so as to prevent their vibrating, the tone is higher, and a higher one still when the fly is held so as to prevent all motion of the external parts. The latter tone is the true voice of the fly, and is produced by the spiracles or breathing-holes of the thorax. Thus, the humming sound is not produced by the motions of the wings alone. The hind body (Fig. 141) is broad and somewhat conical in shape, and there are seen to be only four segments when seen from above or below; but in the living fly three more may be detected, which can be thrust 
out of the body like the joints of a telescope, and form a sort of egg-layer (ovipositor). Flies have no sting, though certain kinds ean bite and stab with their month-parts.

'The legs are long and slender, and, like the body, they are covered with fine but stiff bristles. There are five toejoints, the last one with two claws. Beneath the elaws is a cushion divided into two lobes or divisions, and armed with hairs, which are tmbular, and secrete a sticky fluid, which aids the fly in walking upside-down on glass windows 01 the ceiling of a room.

Honse-flies are attracted to horse-manure, in which the young live in great numbers. On placing a fly in a glass

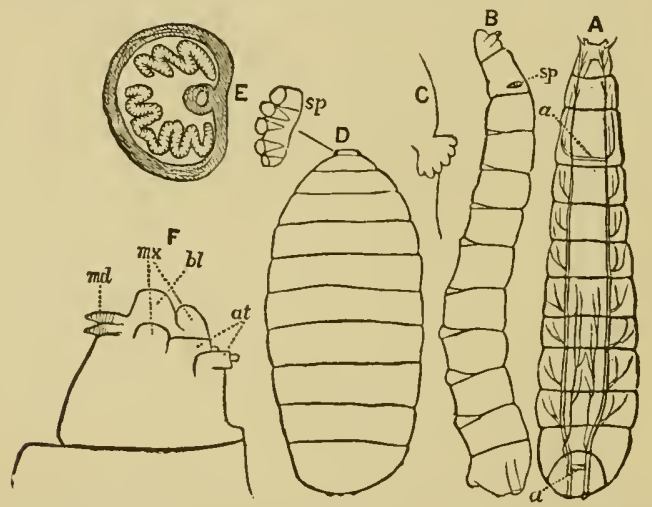

Fig 142.-The early stages of the common house-fly. $A$, dorsal, and $B$, side, view of the larva; $\alpha$, air-tubes: $s p$, spiracle. $C$, the spiracle, enlarged. $F$, liead of the same larva, enlarged: bl, labrum (?); $m d$, mandibles; $m x$, maxillæ; $a t$, antennæ. $E$, a terminal spiracle, much enlarged. $D$, puparium; $s p$, spiracle. All the figures much enlarged.

bottle, she laid, between 6 P.м., Angnst 12th, and 8 o'clock the next morning, 120 eggs, depositing them in stacks or piles.

The egg is long and slender, cylindrical, and .04 to .05 of an inch long and abont one fourth as thick. In twentyfour hours after it is deposited the larva or maggot hatches, and is as represented in Fig. 142, $A$. It is a footless, smooth, round, white worm, with the merest rudiments of 
mouth-parts, as seen at $F$. In a day it grows too big for its skiu, which bursts and peels off; this is again repeated a day later. The maggot thus sheds its skin twice, and consequently there are three larval stages; the third stage lasts three or four days.

When abont to transform into a pupa or chrysalis, the body contrats into a barrel-shaped form, as seen in Fig. $142, D$; its skin turns brown and hard, forming a case (called puparium) within which the larva changes to a chrysalis. Remaining in this stage for about a week (five to seven days), the fly is formed, and, pushing off one end of its pupa-case, walks nervonsly about, until its soft, baggy wings expand and become dry, when it takes to flight. It thus lives a fortnight before acquiring wings, and, as a fly, may live a few weeks, perhaps until frost; but in a few cases may pass the winter within the house, or in protected places ontside, and appear out of doors in the spring.

'There are probably 10,000 species of the order of Diptera in the United States alone, but to a large proportion of them the preceding description will in general apply. Hence, by studying thoroughly one fly, we can obtain a good idea of the general strueture of all.

In certain flies (Blepharoceridx) there are two kinds of females-one kind with month-parts adapted for piercing the skin of animals and sncking their blood, and the other with mouth-parts like those of the male, the maxillæ being absent. In the females of otler flies which suck blood, the males feed on honey.

In the flies, whose mouth-parts vary astonishingly in structure, so that some are piercers and biters, and others suckers and lappers, there is also a great variety of larval forms, different modes of metamorphosis, and consequently great powers of adaptation to different stations in life. A few species live in the sea, many in fresh water, and many, as the Tachina, are parasites in the bodies of caterpillar's and other insects. 'There is everywhere a wonderful har- 
mony between the different kinds and their surroundings, and thus the order is rich in species and individuals.

Darwin says that the sexes of Diptera differ little in color; the greatest difference being in some speeies of Bibio, in which the males are blackish or quite black, and the females obscure brownish orange. In Elaphomyia of New Guinea the males are horned.

Dr. Williston writes ns, however, that there are, upon the whole, more sexual differenees, aside from those in the genitalia, among the Diptera than in any other order. In the majority of species one finds but little difficulty in distinguishing the sexes by secondary characters. In a large proportion, also, there are minor colorational differences. Secondary sexual characters oceur with extreme rarity in the female, and in the male are chiefly confined to the head and legs.

Sub-order 1. Pupipara.-These are mostly wingless, degraded forms, which are born as pupæ from the body of the parent, the egg and larval state having been passed within the oviduct. The wingless species are remarkably spiderlike, the names bat-ticks and bird-ticks implying a resemblance to the ticks.

Family Braulina. - Wingless, eyeless, minute insects with a large head. 'The Bee-louse, Braule ceece Nitzsch.
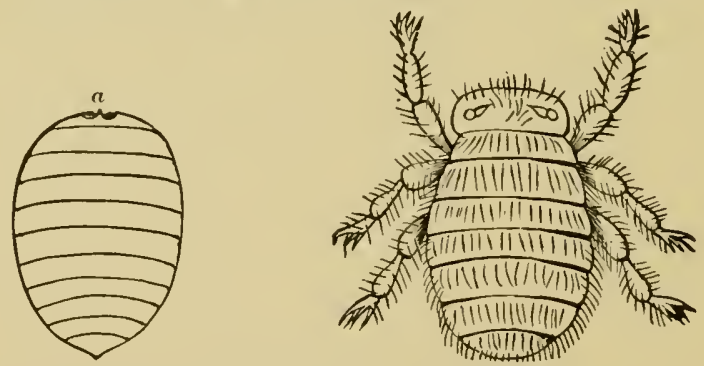

FIg. 143.-Bee-louse; $a$, its puparium.

Family Nycteribidæ.-The bat-ticks are spider-like, eyeless, or with four ocelli; with a small head. They live on the fruit-bats. Nycteribia westwoodii Guerin (Fig. 144). None exceel two lines in length. 
Family Hippoboscidæ. - The sheep-tick andi horse-tick are known by the flattened head and body, and by the stout proboscis. The

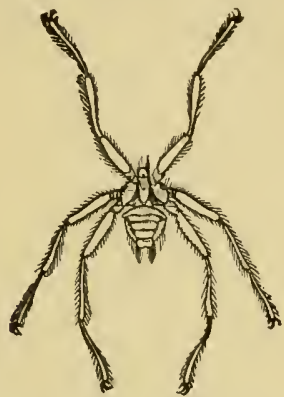

FIG. 144.-Bat-tick.

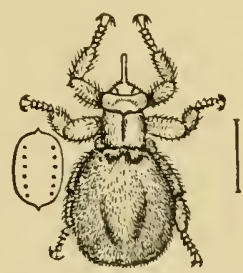

FIg. 145. - Sheep-tick and puparium.

sheep-tick, Melophagus oxinus Linn., is often very troublesome to sheep. The horse-tick (Hippobosca equina Linn.) is winged, with large claws.

Sub-order 2. Cyclorhapha. - This name has been given to this subdivision of fiies from the fact that the perfect flies escape from the pupa-case through a circular orifice. The word "maggot" is especially applicable to the larvæ of this group, since they are worm-like, whitish, without a definite head, and are footless. When about to pupate their bodies shrink into a barrel-shaped form, and the skin, instead of being cast off, forms a dense case for the protection of the soft-bodied, white pupa within.

The types of the sub-order are such insects as the houseand flesh-flies, as well as the Syrphus flies. The body is short and thick, the abdomen conical and composed of from fire to eight segments.

The arrangement of the families here adopted is that of Osten Sacken's "Catalogue of North American Diptera" (second edition, 18\%8), while the characters of the families are taken from Loew's "Monographs of the Diptera of North America," Part I., though the order of succession has been reversed, the enumeration beginning with the lowest and ending with the highest family. Certain of the smaller, unimportant families are mentioned only by name. 
Family Phoridæ.-Anteunæ 1-jointed, with a long bristle; femora tlattened. Phorce incrassata Meigen, of Europe, lives in hives on decaying bee-larve, and different species feed on both living and dead insects, and sometimes decaying vegetable matter.
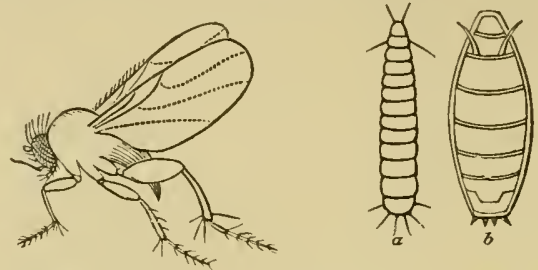

Fig. 146.-Phora incrassata. $a$, larva; $b$, pupa-case.

Family Asteidæ.-Front bristly above. Asteiu tenuis Walker.

Family Phytomyzidæ. - Front bristly. Plytomyza clematidlis Loew.

Family Agromyzidæ. - Front with strong bristles; middle tibix with a terminal spur. Agromyze coroncete Loew.

Family 0scinidæ. - Front without bristles, the crown having only a few short ones; border of the mouth without vibrissa, which, however, are represented sometimes by a small hair on each side. Middle tibix with small spurs; all the tibia without an erect bristle on the outer side before the tip. Costa of the wings without bristles. The anxiliary vein is completely wauting; the anterior of the two small basal cells is united with the discal cell, the posterior one is totally wanting. The species of Chlorops are injurious to cereals, the maggots living in the stalk. Meromyza americana Fitch.

Family Drosophilidæ. - Front with bristles above; face with distinct sub-antennal furrows; at the border of the mouth there is a feeble, frecuently rather indistinct small vibrissa. Middle tibix with rery feeble spurs; on the outer side of the tibix there is either a very small or no erect bristle before the tip. Wings without bristles on

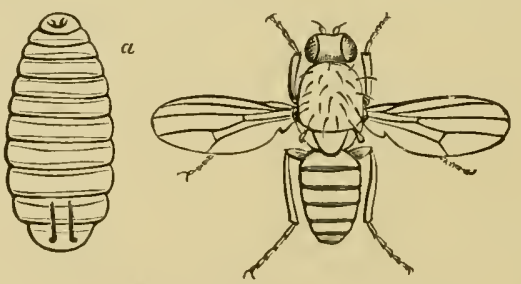

Frg. 147,-Apple-worm and its fly.

the costa; the first longitudinal vein is exceedingly abbreviated; of the auxiliary vein there is only a rudiment; the discal cell is usually. but not in all genera, mited with the foremost of the two small basal cells. Claws and pulvilli very small. The larra of an undetermined species of Drosoplita (Fig. 14t) injures stored apples, while Drosophilu rempelophila Loew infests pickled fruit.

Family Geomyzidæ.-Vibrissæ distinct. Diastata pulchra I-opw. 
Family Ephydrinidæ. - Face convex, with no distinct furrows for the reception of the antennie, and without vibrissie, though frequently beset with hairs or bristles; clypeus very much developed; opening of the mouth lirge; proboscis thickened, with a swollen
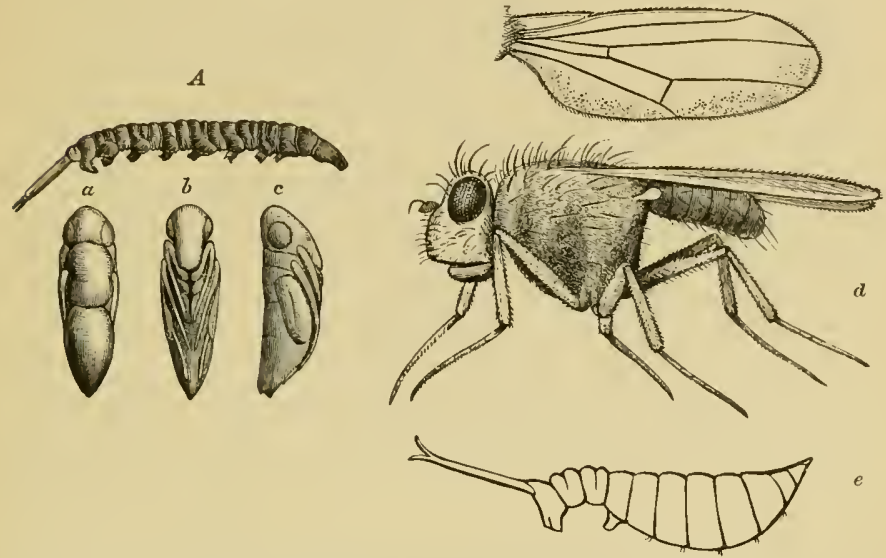

Fıg. 148.-A, larva of Ephydra coliformicn: $a$, dorsal, $b$, under, $c$, side, view of the pupa. d, Ephydru halophila; $e$, its pupa-case.

chin. Venation of the wings incomplete; the auxiliary vein distinct only at its base; the foremost of the two small basal cells reunited with the discal cell. Middle tibiæ with spurs. The sin-
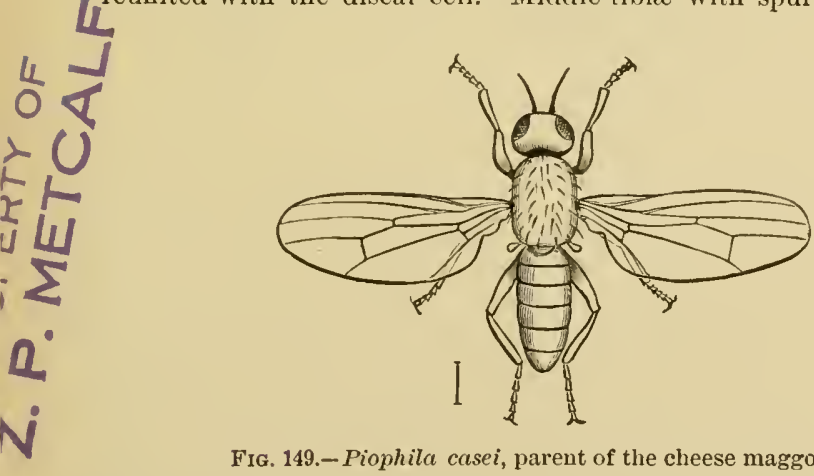

FIG. 149.-Piophila casei, parent of the cheese maggot.

gular larvæ are provided with a long eaudal respiratory tube. $E$. halophila Pack. lives in the brine of the Equality Salt Works, 
Illinois; $E$. californica Pack. in Clear Lake, Cal.; while E. gracilis is abundant in Great Salt Lake, Utah. The larve and pupa-cases of $E$. culfornica, which inhabits Mono Lake, are eaten in large quantities by the Indians.

Family Diopsidæ.-Eyes situated on long lateral projections. Sphyracephala brevicornis Say.

Family Piophilidæ. - Front with some small bristles above only; elypeus rudimentary, legs rather stout. Piophila casei Linn.

Family sepsidæ.-Head rounded; front bristly; border of the mouth more or less hairy, the foremost hair often imitating a vibrissa; clypens rudimentary; proboscis short; palpi exceedingly small or wanting Abdomen tapering towards the base. Middle tibiæ with distinct spurs; elaws and pulvilli small; venation of the wings complete; the auxiliary vein distinctly separated from the first longitudinal vein; the two posterior basal cells rather large. Sepsis similis IIaequart.

Family Opomyzidæ. - Opomyza signicosta Walk.

Family Heteroneuridæ. - Front with long bristles; clypeus not developed; palpi broad and proportionately large; legs slender. Heteroneura albimana Meigen.

Family Phycodromidæ. - Thorax and abdomen flat. Coelopa frigidu Fallen. Enrope and North America.

Family Sapromyzidæ. - Venation complete; auxiliary vein of the usual structure, frequently very near the first longitudinal vein; costa of the wings without bristles or a marginal spine; longitudinal veins without peculiar hairs; posterior basal cells small. Front with a single row of bristles on each side; no vibrissa on the border of the mouth; clypeus rather rudimentary. Only the middle tibix
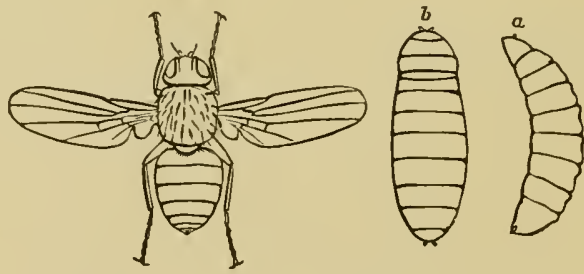

Fig. 150.-Louch:æa. $a$, larva ; $b$, pupa-case.

have terminal spurs; all the tibix with a small ereet bristle on the outer side before the end. Ovipositor of the female not horny. Sapronyza vulgaris Fitch.

Family Lonchæidæ.-Like the Sapromyzidie, but the female las a horny, 3-jointed ovipositor. The species bore in the bark of willows, ete. Lonchere polita Say.

Family Trypetidæ. - Venation eomplete; the end of the auxiliary vein ruus steeply to the border of the wing and becomes obsolete; first longitudinal vein always with bristles, the third frequently, the tifth sometimes; two posterior basal cells rather large, the hindmost 
often prolonged to a point. Front on each side with two rows of bristles, one of which is sitnated more above and in front, the other below and exteriorly. Border of the month with no vibrissse. Clypeus none or rudimentary. Proboseis never thickened. Only the middle tibia with spurs; all the tibire without an erect bristle on the outer side before the tip. Ovipositor horny, consisting of three elongated retractile segments like the drawers of a telescope, the last of which ends in a simple point. Trypeta florescentice Linn. Europe and North America.

Family Ortalidæ. -Venation of the wings complete; auxiliary vein separated from the first longitudinal vein, and running to the border of the wing in the usual way, under an acute angle, and remaining perfectly distinet in its whole length; third longitudinal vein generally with coarse hairs; two posterior basal cells large, and the outward one frequently prolonged in an acute angle. Front with bristles on the npper part only; no vibrisse at the border of the mouth; clypeus commonly very mueh developed, and proboseis often very mnch thickened. Middle tibia alone with spurs; no tibiæ with an erect bristle on the exterior side before the tip. Ovipositor of the female rather flattened and horny, consisting of three elongated segments, forming three drawers like those of a telescope, and ending in a simple point. Pyrgota undata Wied., Tritoxa flexa Wied.

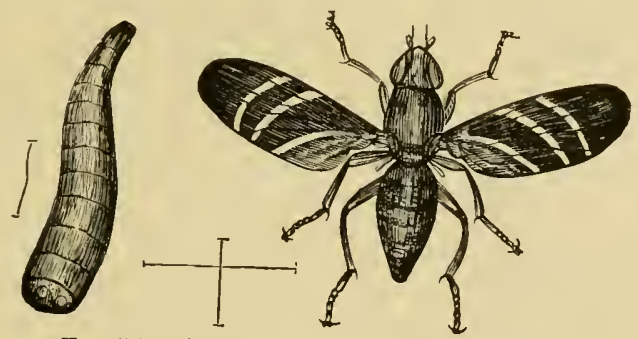

Fig. 151.-Tritoxa flexa, onion fly, and maggot.

Family Micropezidæ.-Body loug and slender; legs short; front with bristles near the crown. Calobate antennipennis Say.

Family Psilidæ.-Body slender; face receding, mouth small. Psila bicolor Meig. Europe and North Ameriea.

Family Sciomyzidæ. - Front with two bristles, one behind the other, on the side before the vertical bristles; middle tibia with a greater number of bristles at the tip. Sciomyza albocostata Fallen. Europe and North America.

Family Helomyzidæ. - Front bristly on the upper half only; all the tibiæ spurred. Helomyzn apicalis Loew.

Family Cordyluridæ. - Venation of the wings complete; both posterior basal cells of considerable size; auxilimy vein well separated from the first longitudinal vein, which is bare. Entire side of the 
front bristly; anterior border of the month with strong, usually numerous vibrissæ. Tibiæ with spurs. Scatophaga stercorarü Linn.

Family Anthomyidæ. - Thorax with a complete transverse suture. Fourth lougitudinal vein straight or nearly so, hence the first pos-

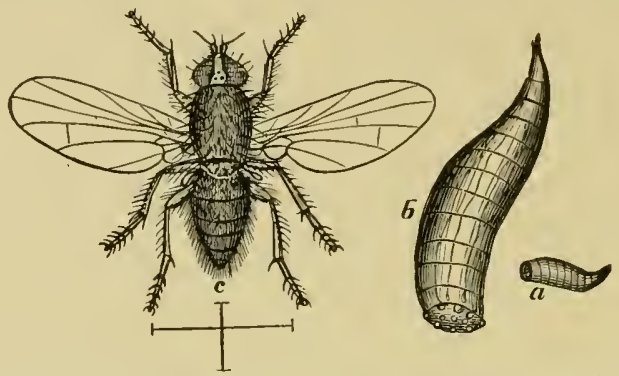

FIG. 152.-Onion fly, $a$, larva, natural size; $b$, the same, enlarged.

terior cell is fully open. Tegula rather well developed. IHorbin ceparum Meig. (Fig. 152). IIomalomyut scalaris (Fabr., Fig. 153) is the privy-fly; the maggots of this and $H$. cunicularis are sometimes discharged from the human intestines and urethra.

Family Muscidæ.-Bristle of the antennæ entirely plumose
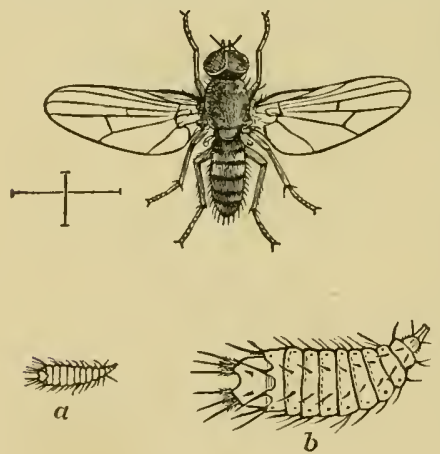

Fig, 153.-Homalomyia scalaris (?). a, larva, natural size; $b$, enlarged.-After Curtis.

red fluctuating tumors; its maggot (Musea) or pectinated (Stomoxys). Body never slender; thorax short; wings with the first posterior cell only slightly opened, or else closed at the border of the wing; tegulie large; legs stout. All the foregoing families, with the three following, are by many authors placed in one great family Muscide"; but, to accord with onr present imperfect knowledge, Loew and others have provisionally divided them into a great number of small families. Musca domestica Linn., the house-fly; Lucilin macellarie Fabr. sometimes lays its eggs in wounds in the skin of man, producing hard ( one case 300 of these maggots were found in or dropped from one man's nose or uasil cavities, where it had destroyed the soft parts, causing death. L. copser Linn., the blue-bottle tly; Calliphora erythrocephala Meig., the meat-fly; Stomoxys calcitrans Linn. bas a long, slender, hard proboscis; it breeds in or about stables, and bites horses and human heings. 
Family Sarcophagidæ.-Bristle of the antennæ plumose or hairy,

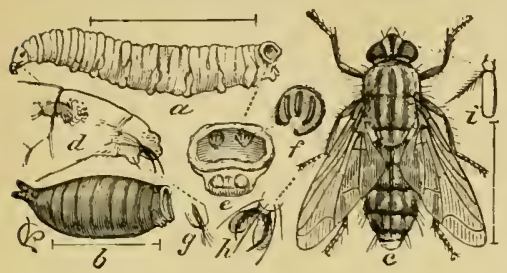

FIG. 154.-Sarcophaga sarracenice. $c$, fly: $a$. larva: $b$, pupa-case $d, g$, head : $e$. end of body; $f$. spiracle of larva; $i$, antenna; $h$, foot of fly.-After Riley. with the apex bare. First posterior cell only slightly opened or else closed; tegulæ large; legs stout. Surcophaga carnaria Linn., the flesh-fly of Europe, is black, with the thorax streaked with gray, and the abdomen checkered with whitish; it is viviparous, the eggs being hatched before they are laid. S. sarracenice Riley.

Family Tachinidæ.-Bristle of the antenna bare, or with a very short pubescence; thorax short; first posterior cell elosed or only slightly opened; legs short. Larvæ parasitic in caterpillars
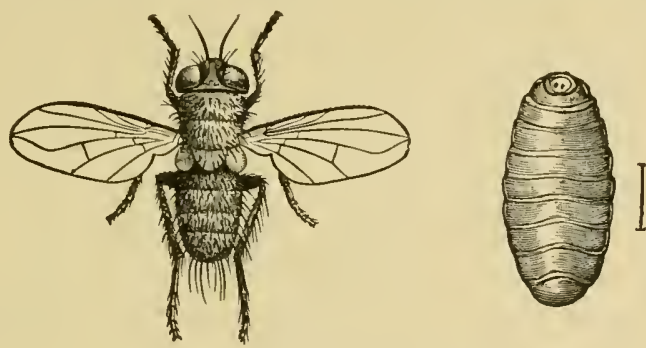

FIG. 155.-Tachina fly, and larva.

and other insects, living on the fat and juices of their host; many injurious caterpillars being destroyed by these useful tlies.

Family Dexidæ. - The species differ from those of the Tachinidx in having the bristle of the antenne either pubescent or plumose; and from the Muscicle in having the abdomen bristly above. Dexia analis Say.

Family Estridæ. - Antennæ inserted in rounded pits; the middle part of the face exceedingly narrow; the opening of the mouth very small; the mouth-parts rudimentary. Larve usually very thick, with a spiny skin. The ox bot-fly (Hypoderma bovis De Geer) appears from June to September, the worms occurring during May and in the summer in tumors on the backs of cattle, until in July they fall to the ground; they remain in the pupa-case $26-30$ days. The maggots of the horse bot-fly (Gastrophilus equi Fabr.) hang by their mouth-hooks to the walls of the horse's stomach.

Family Platypezidæ. - Antennæ with an apical bristle; hypopygium symmetrieally turned under the abdomen; middle tibia with spurs; empodium wanting. Platypeza anthrox Loew.

Family Pipunculidæ. - Small Hies with the head almost entirely occupied by the eyes; face very narrow. Pimenculus cingulatus Loew.

Family Conopidæ.-Wasp-like, with a long abdomen; eyes broadly separated; proboscis much prolonged; third joint of the antenna 
with an apical style or a thick dorsal bristle; parasitic in the abdomen of wasps and bees. Conops tibialis Say.

Family Syrphidæ. - A spurious longitudinal vein between the third
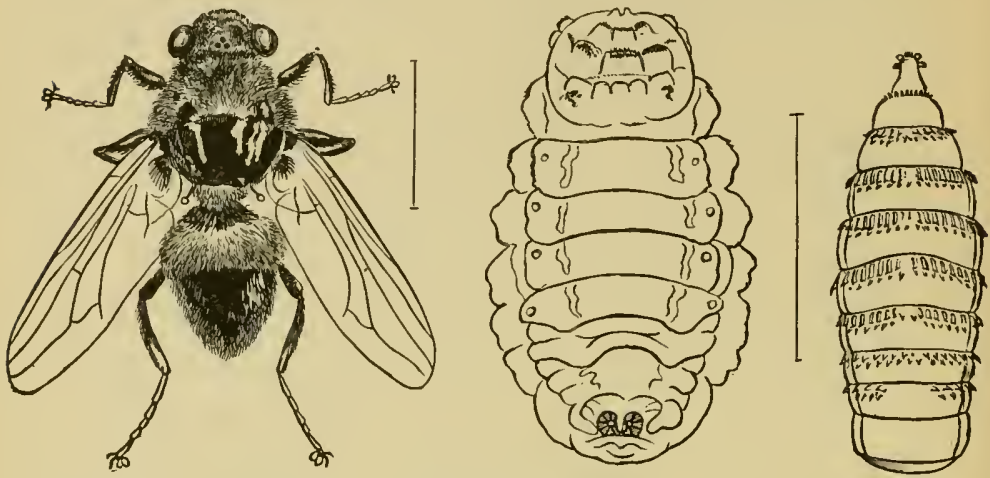

Fig. 156.

a

Fig. 157.

Fig. 156.-Bot-fly of the ox. a, larva. Fig. 157,-Horse bot-worm, enlarged. and fourth longitudinal veins; first posterior cell closed; no depression in the face for the antennæ. Often wasp- or bee-like in shape
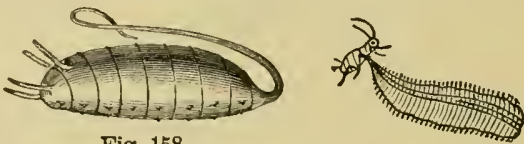

Fig. 158.

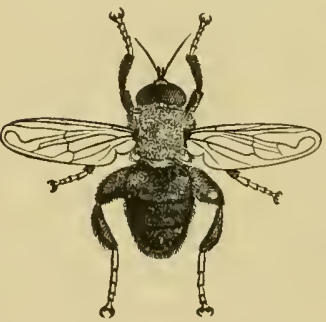

Fig. 159.

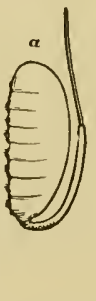

Frg. 158. - Rat-tailed pupa-case of Eristalis.

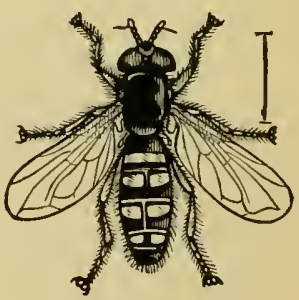

Fig. 160 .

FIG. 159.-Merodon posticata. $a$, its pupa-case.

FıG. 160.-Syrphus (Mesograpta) politus, and Aphis-maggot, natural size. and coloration (Williston). The larvæ of many species devour Aphides, etc., and may be observed among their colonies. The larva of Eristalis, which lives in stagnant, brackish, or excrementitious water, breathes by a long caudal filament.

Sub-order 3. Orthorhapha.-In this group the pupa is usually free, not coarctate, and escapes from the larval skin 
through a 'T'-shaped opening, or rarely throngh a transverse rent between the seventh and eighth abdominal segments. The following families, to and inchuding the Xylophagidx, belong to Section 1, Brachycera, in which the antennæ are short and 3-jointed:

Family Lonchopteridæ. - Wiugs with the three basal cells of moderate size, and of nearly equal length; antemne with an apical bristle. Lonchoptera riparia IIeig.

Family Dolichopodidæ-First basal eell rather short, the second united with the discal cell, the third small; auxiliary vein running into the first longitudinal vein; third longitudinal vein simple, the fourth sometimes fureate; no intercalary vein. Hypolygium symmetrieal, bent under the abdomen; empodium small, membranaceous, linear. Generally metallic green, brisk, small, restless flies which devour other inseets. Dolichopus cuprinus Wied.

Family Empidx.-Body rather loug; head rounded, the eyes in the males touching each other above; third joint of antenne simple, with a terminal style, or a terminal or dorsal bristle. These flies are voracious, attacking other tlies. Empis armipes Loew.

Family Cyrtidx.- Head of ten minute, the eyes very large and meeting above; thorax and abdomen much inflatel; tegulæ vaulted, very large; proboseis of ten very long. Certain of the larva are parrasitic in spiders or their cocoons. Acrocera bimuculate Loew; Lasid klettii O. Sacken.

Family Scenopinidæ. - Three basal cells very large; third joint of the short antennæ without style or bristle. Larva very long and slender; occurring under carpets, and probably feeding on carpetmoths and Psocids.

Family Therevidæ.-Differing from Asilidæ in the labella being not horuy, but fleshy; antennæ short, with at terminal style of variable form, sometimes wanting. Larvie like those of Scenopinus, with the segments in most of them eonstricted, the body appearing as if composed of nineteen segments behind the head. Thereva albiceps Loew.

Family Bombylidæ.-Three basal cells of the wing much prolonged, with usually four posterior cells, and the third joint of the antennæ not ringed; the proboscis is long, and the body is in most of the species densely hairy. They are mostly very swift on the wing, often hovering motionless in the air, and then darting away as quick as a flash. The larvæ of Bombylins are parasitic on bees; those of Systrechus oreas O. Sacken and Aphobantus mus O. Sacken feeding on the eggs of locusts (Camnula and Caloptentis).

Family Nemestrinidæ. - Many have wings with numerous crossveins, so as to be almost net-veined. In the African Megistorhynchus longirostris, a fly only about two-thirds of an inch in length, the proboscis, which it uses to suck the neetar from the flower of Gladioli, etc., is nearly three inches long. The European Hirmoneurt obscura deposits her eggs within the burrows of Anthaxia, a Buprestid beetle; the freshly hatched larva differing very singularly from older larvæ, the sixth to twelfth segments being each providerl with a pair of hooks, and they are supposed to attach themselves to 
a large beetle (Rhizotrogus), on which secondary hosts they are apparcently parasitic:

Family Midasidæ.-Antenuæ club-shaped, the third foint eomposed of several distinct joints. Mides cletatus Drury.

Family Asilidæ. - The robber-tlies are large insects, one species being two inches long; third joint of antenna simple; with or without bristle or style; and the under lip horny; they are the most savage and rapacious of all tlies, their beak being well developed. Promachus fitchii $O$. Sacken was once observed to destroy one hundred and forty-one honey-bees in a day; Laphria resembles humble-bees. Asilus nove-scotice Macq.; Erax bastardii NIacq. (Fig. 161, b, pupa).

Family Leptidæ. -Antennæ with the third joint simple, with a simple or thickened styliform bristle; three membranous pads below the claws. Leptis albicornis Say.

Family Tabanidæ. - Third joint of the anteunæ annulate, and always without style or bristle; eyes large; tegulæ large. The females of the horse-tlies alone bite, the jaws and maxillie being awl-like, rendering the bite painful. Tubanus lineola Fabr., Chrysops niger Maeq.

Family Acanthomeridæ.-Very large fiies,

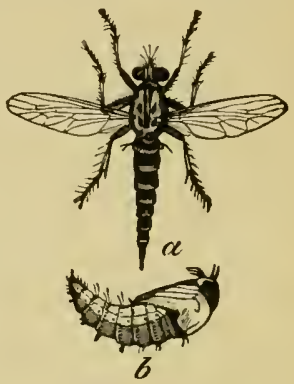

FIg. 161.-Robber-fly, Erax bustardii.-After Riley.

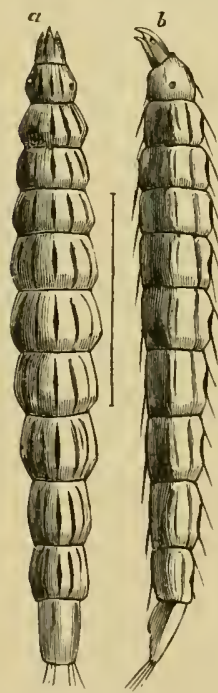

FIf. 162. - Larva of Stratiomyia. with mouth-parts consisting, even in the males, of four bristles. Acanthomera bellardii Bigot.

Family stratiomyidæ. - Third antennal joint annulated; costal vein only reaching the middle of the wing; tibia not spurred. The larvæ live in water, earth, or decaying wood. Fig. 162 represents a larva found living in abundance in the alkaline waters of Clear Lake, Cal. Stra. tionyia picipes Loew, Sargus decorus Say.

Family Cœnomyidæ.-Cenomyia pallida Say.

Family Xylophagidæ.-Third antennal joint anuulated; costal vein encompassing the whole wing. Xylophagus rufipes Loew.

The succeeding families belong to Section 2, Nematocera, in which the antennæ are long and many-jointed.

Family Rhyphidæ.-Tliree oceIli; wings with a perfect discal cell. Rhyphus alternutus Say.

Family Di-idæ.-Dixa claveta Loew.

Family Tipulidæ.-No oeelli; legs very long. The crane-flies form an extensive group whose larvæ live in soil, mould, fungi, and sometimes in the water; they are represented by Trichocera regelation is Linn., Tipula trivittuta Say, etc.

Family Psychodidæ.-Body with long coarse hairs; wings very short and broad. Very small thes seen flying and leaping on windows, etc. Psychodes alternata Say. 
Family Orphnephilidæ. -Orphnephilu testecen Ruthe.

Fumily Chironomidæ.-Body very slender; antenue plumose; larve anuatic, slender-lodied, of ten blood-red. A species of Ceratopogon is the milge, the "Simulinm nocivum" of Harris. Tunypus enmulutus sily, Chironomus nizoriundus Fiteh.

Family Culicidæ.-In the mosquitoes the females have the mouth parts very long and slender, and highly developed, while the mandibles of the males, ending like a parldle, are not adapted for piercing; the hypopharyux is perforated at the end for the exit of the poison, the openung connecting, according to McCloskie, with a duct leading from the poison-glands in the prothorax. The wings
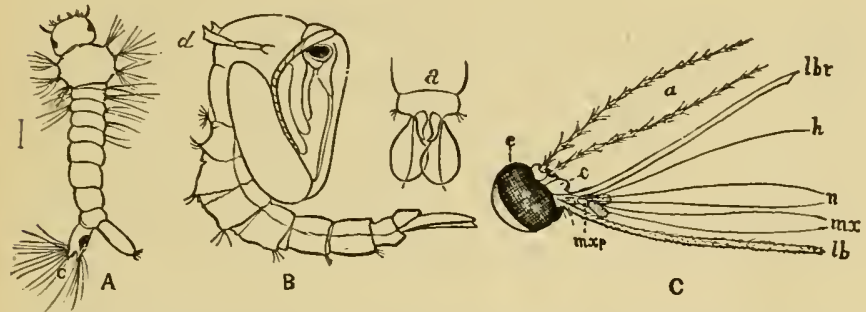

Fig. $163-A$, larva; $B$, pupa; $a$, end of $B$ of mosquito,-Burgess del. $C$, Head and mouth-parts of mosquito; $e$, eye; $\alpha$, antennæ; $l b r$, labrum; $h$, hypopharynx; $m$, mandibles; $m x$, maxillæ; $m x p$, maxiltary palpus; $l b$, labium; $c$, clypeus.-After Dimmock.

are fringed, and the veins covered with scales. The litrve are aquatic, breathing by a respiratory tube $(c)$ at the end of the body and bearing a tuft of bristles, while the pupæe are aided in swimming by two broad thin paddle-like caudal appendages, and respire by two thoracic tubes $(d)$. The larva of Corethra is beantifully transparent, thus escaping destruction by its enemies, and when quiet rests in a lıorizontal position. Culex cilictus Fabr.

Family Blepharoceridæ.-Body long and slender, like a large mosquito in greneral appearance; wings broad, but naked. The larve are of remarkable shape, and at first do not look like those of a tly, since the body is divided into six divisions somewhat like an Asellus, or water sow-bug. They adhere to smooth rocks in swift streams by six suckers arranged in a line along the under side of the body, and breathe by five pairs of filamental gills. The pupe are that beneath, with two sets of club-shaped breathing appendages situated on the thorax. There are, moreover, two kinds of females, one being like the male, not sucking blood. Blephurocera fusciata Westwood is native to this country, and Paltostoma torrentium Müller to Brazil.

Family Bibionidæ.-Prothorax much developed; wings without a discul cell; coxie not prolonged. Larva cylindrical, often injuring lawns from feeding on the roots of grass. Bibio albipen nis Sily.

Family Simulidæ.-Body short and thick; head bent under the 
large humped thorax; the mouth-parts, jaws, ete., well developed,
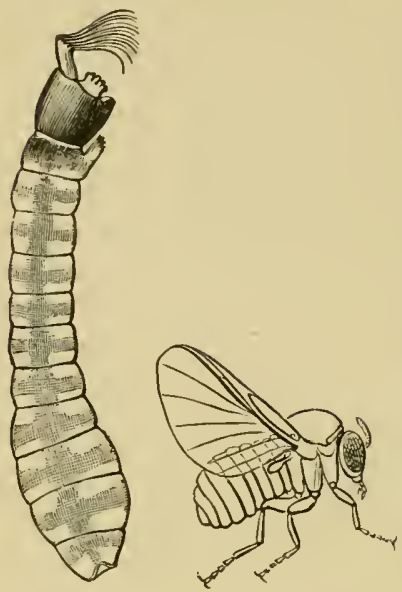

Fig. 164.-Black fly and larva. the fly giving sometimes a sharp bite, but often leaving behind a clot of blood without giving pain. The larvas live in rumning streams, and when about to transform make conical pouch-like cases attached to eel-grass, etc., wherein they pupate. The black fly (Simulium. molestum Harris) abounds in the Northern States, and probably extends to the arctic regions. The southern buffalo-guat (S. pecuarum Riley) and the turkey-gnat (S. meridionale), owing to their severe bite and the great multitudes of the females, oceasionally, along the Mississippi River from St. Louis to the month of the Red River, kil] mules, horses, cattle, sheep, hogs, dogs, cats, setting turkeys and hens, while three cases of death to human beings are recorded.

Family Mycetophilidæ.-The fungus-gnats have a rather slender body, with long legs and coxæ, while the wings have but few veins and no discal cell. Sciara mali (Fitch) lives in apples; the larva of another species of Sciara, called the
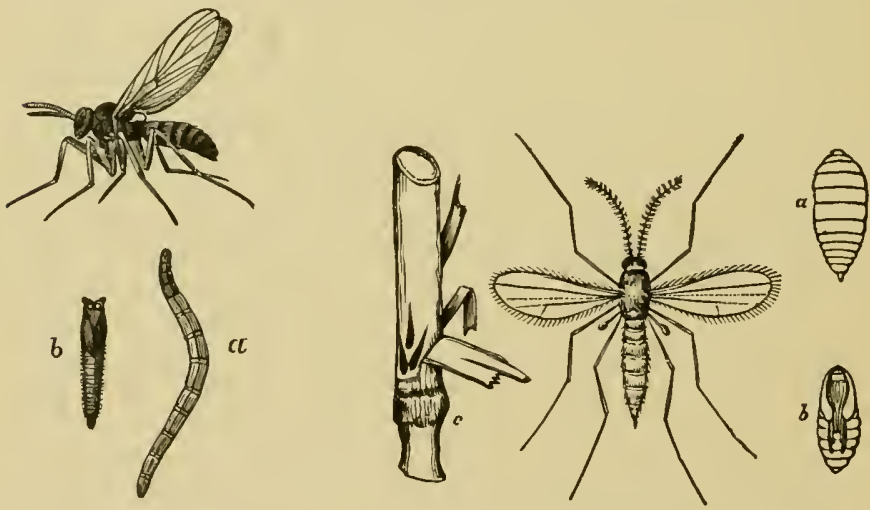

Fig. 165.-Mycetobia sor. dida. $a$, larva; $b$, pupa.

Fig. 166.-Hessian fly. $a$, larva; $b$, pupa After Fiteh.

"army-worm," living under the bark of trees, will, when about to pupate, form processions four or five inches wide and ten or twelve 
feet long. Mycetobin sordidu Pack. lives in sour sap in cracks of the birk of elm-trees.

Family Cecidomyidæ. -This great family of gall-guats comprises mostly minute tlies, which have but few veins in the wings, short coxie, the femora slender, and the tibia without spurs. They insert their eggs in the leaves of trees and stems of plants, raising a gall or tumor within which the maggots, often pink in color, live. The larva of Miastor produces young, living larve. Examples of the family are the wheat milge, Diplosis tritici (Kirby, Fig. 238), and Hessian fly (Fig. 23\%). Cecidomyin grossularice Fitch causes the gooseberry to turn prematurely red.

\section{Order XV. Lepidoptera * (Moths and Butterflies).} 'The beginner in the study of insects, after dissecting a

\section{* Selected Works.}

Abbot, J., and J. E. Smith. The natural history of the rarer lepidopterous insects of Georgia (i., ii. London, 1797. Fol. Many plates).

Boisduval, J. A., et Guenée. Sipécies générales des Lépidoptères (8 vols., 8vo. Suites ì Buffon. Paris, 1863-i4).

Breitenbach, w. Der Schmetterlingsrïssel (The butterfly's tongue). (Jena. Zeits. f. Naturw., 1881.)

Burgess, $\mathbf{E}$. Contributions to the anatomy of the milk-weed buttertly, Danais archippus (Mem. Bost. Soc. Nat. Hist., 1880).

Chambers, $\mathbf{\nabla}$. T. Index of described Tineina of North America (Bulletin Hayden's Survey, 1877). Also other papers in same Bulletin; Can. Ent., etc.

Clemens, B. Synopsis of North American Sphingidæ (Journ. Acad. Nat. Sc., Phil., iv., 1859).

Tineina of North America. Edited by Stainton. (8vo, London, 18\%2. A collection of all his papers on the subject.) Also papers in Proc. and Journ. Acad. Nat. Sc., Phil., 1859-62.

Cramer, P. Papillous exotiques ( 4 vols., 4 to, 442 plates. Amsterdam, 1789-91).

Edwards, H. Pacific coast Lepidoptera (i.-xxx. Proc. Cal. Acad. Se., $1873-78)$.

- Catalogue of U. S. described lepidopterous larvæ of North Ameriea (Bull. Eut. Div. Dept. Ag., Washington, 1888). Also numerous papers in Papilio, i.-iii. ; Eut. Amer., ete.

Edwards, W. H. Butterflies of North America (i.-iii., many pls. Pliila., 1868-1888).

Fernald, C. H. A synonymical catalogue of the described Tortricidæ of North America (T'rans. Amer. Ent. Soc., x., Phila., 1882). Also papers in Can. Ent., Amer. Nat.

French, G. H. The Butterflies of the Eastern United States (Philadelphia, 1886).

Grote, A. R. An illustrated essay on the Noctuidæ of North America (London, 1882). See also numerous short papers in Trans. Amer. Ent. Soc., Bulletin Buff. Soc., Bulletin Hayden's Survey, Canadian Entomologist, etc., 1863-1887 (containing descriptions of about 1000 species). 
locust, could not do better than to examine a common

Grote, A. R. New clieck-list of North Ameriean Moths (188:).

Guénée, A. Spécies générales des Lépidoptères (Noctuidie, Phalınidæe, and Pyralirla). (Suite à Buffion. 8vo. Paris, 1852-57).

Herrich-Schäffer, G. Lepidoptera exotiea nova (Regensburg, 1850-58).

Hübner, J. Sammlung exotischer Schmetterlinge (5 vols., 4to, plates. Augslourg, 1806).

Kirby, F. Symonymie eatalogue of diurnal Lepidoptera (of the world), with suppl. (London, 1871-r7).

Lederer, J. Versuch die europaeischen Lepidopteren in möglichst natiorliche Reihenfolge zu stellen (Verh. Zool. bot. Ges. Wien, $1852-53)$.

- Die Noetuinen Europas (Wien, 185\%).

Lintner, J. A. Entomological contributions (i.-iv. Albany, 1872-79).

Morris, J. G. Syuopsis of Lepidoptera of North America, Part I. (all published). (Smitlisonian Misc. Coll., iv., 1862.)

Packard, A. S. Notes on Zyganidxe (Proc. Essex Inst., iv., 1864).

- Synopsis of the Bombycidx of the United States (Proc. Ent. Soc., Plila, 1864).

Monograph of the Phalænidæ of the United States (Hayden's U. S. Geolog. Survey). (4to, 13 plates. Washington, 1876.)

Scudder, S. H. Symonymie list of North Ameriean butterflies (Bulletin Buffalo Soc. Sc., 1875-76). Also numerous other papers in Proc. and Mem. Bost. Soc. Nat. Hist., 1860-88.

- Butterflies : their structure, changes, and life-histories (New York, 1881).

- The Butterflies of the Eastern United States and Canada, with special reference to New England (4to, many plates. 1888-89).

Smith, J. B. Symopsis of the genera of the Noctuidae of North Ameriea (Bull. Brooklyn Ent. Soc.. 1882-83).

Stainton, H. T. The natural history of the Tineina (i.-xiii. 8vo, with many plates. London, 1855-73).

Staudinger, 0. Catalog der Lepidopteren des europaeischen Faunengebiets (Dresden, 18\%1).

Stoll, Casper. Supplement to Cramer's Papillons exotiques (4to. Imsterdam, 1787-91).

Strecker, H Lepidoptera, indigenous and exotic (Reading, Pa, 1872).

Stretch, R. H. Illustrations of Zygænidæ and Bombycidæ (8vo, plates. San Franciseo, 1874).

Walker, $\mathbf{F}$. List of the specimens of lepidopterous insects in the British MIıseum (London, 1848-6\%).

Walsingham, Thomas, Lord. Illustrations of typical specimens of Lepidoptera Heterocera of the British Iuseum. Pt. IV., N. A. Tortricidx. (London, 1879.)

- Pterophoridze of California and Oregon (London, 1880).

Walter, A. Palpus maxillaris Lepiclopterorum (Jen. Zeits. f. Naturwissens., Bd. xviii. N. F., xi. 13d. Jena, 1884).

- Beitrüge zur Morpliologie der Sehmetterlinge (Jen. Zeits. $\mathbf{f}$ Naturwissens., Bd. xviii. N. F., xi. B(l. Jena, 1885).

weismann, A. Studies in the theory of Descent. Translated by $\mathbf{R}$ Meldola. (London, 1881. Plates.) 

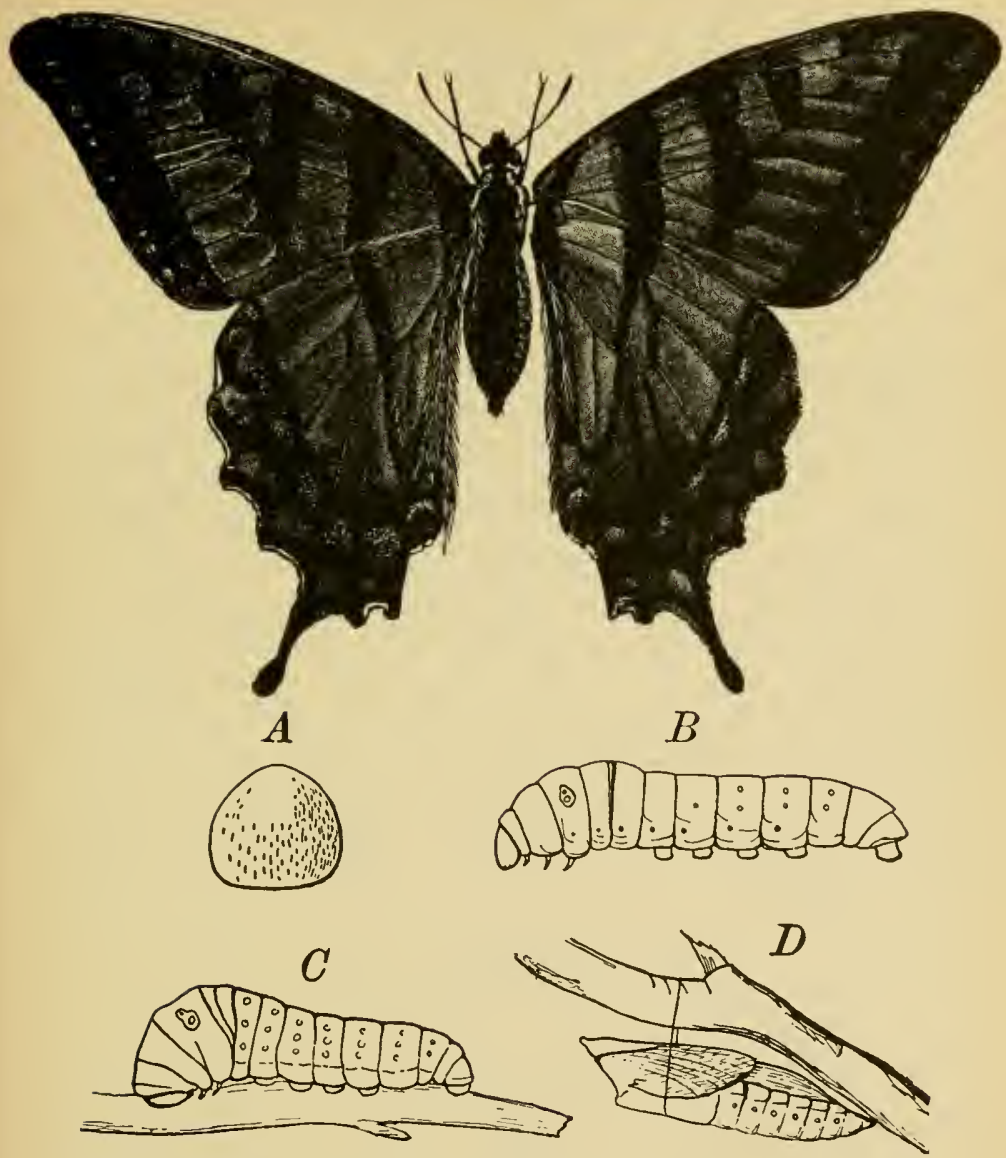

Fig. 167.-Papilio Turnus. $A$, egg, magnified; $B$, caterpillar; $C$, the same just before pupating; $D$, pupa or chrysalis. Natural size.

Westwood, J. 0. Monograph of the Castniidæ, etc. (Trans. Linn. Soc., London, 1877).

- Synopsis of the Uranida (Trans. Zool. Soc., x., 1879).

Zeller, P. C. Contributions to a knowledge of North American Heterocera (Verh. Zool. Bot. Ges. Wien, 1872-74. Ger.). See numerous other papers in Isis, and publications of Stettin, Berlin, and Vienna societies.

Also articles by A. G. Butler, Comstock, H. Edwards, Harris, Hulst, Moeschler, Morrison, Packard, Riley, Robinson, J. B. Smith, Walsh, and others. 
butterfly and watch its transformations from the caterpillar to the winged state.

We will select for study one of our largest and most common butterflies, the yellow and black swallow-tail (Pupilio Turnus) (Fig. 16\%). It may be found flying about lilacs, ete., from the first of June until midsummer.

We shall see in this, as in most bntterflies, how large the wings are in proportion to the body, and that they are so thickly covered with microscopic scales as to be opaque, while the body is also covered with fine slender scales like hairs. We shall see, also, that the form of the body is more or less spindle-shaped, well adapted for flying rapidly through the air. 'The head is small, not wider than the mid body, while the hind body is narrower than the mid body and tapers to a rounded point.

Now, looking at the head, which in front and above is thickly covered with hairs, we notice the

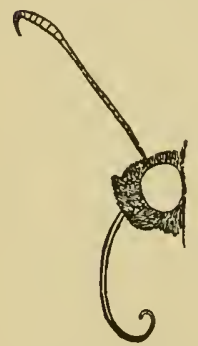

FIG. 168. - Side view of head of a buttertly (Eudamus Tityrus) showing antenna and tongue. large compound eyes, and that from between them arise the antennæ. These are very slender, and end in a knob. 'There is in many butterflies a naked space on the under side of the knob, in which are minute pits, which are probably organs of smell. There is but a single pair of month-feelers (palpi) in the butterflies, though two pairs exist in many moths. 'These are the palpi of the under lip, which are held up in front of the face. Between them is the tongue, which is a long slender black tube, which at rest is coiled up like a watch-spring between the feelers. If one will watch a butterfly at a flower, it may be seen unzolling its tongue in order to probe the bottom of the corolla.

The tongue is the only means by which the butterfly can obtain food. It sips or sucks up the nectar of flowers, or drinks water, imbibing it throngh this tube. 'The jaws are absent, except in the 'Tineids, where they are, however, 
rudimentary. Moreover, the butterfly needs little food; it only lives long enough to lay its egge, when it dies.

By looking at our specimen after the scales have been rubbed off the head, which may be done by a stumpy hair-

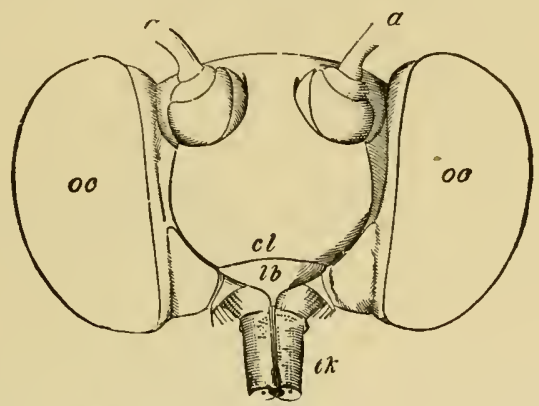

Fig. 169.-Butterfly's head, denuded of scales.-After Burgess.

pencil, it will appear somewhat as in Fig. 169 of the Archippus butterfly. 'This represents a front view of the head: $a, a$ are the antennæ; oc, the eyes; $c l$ is the front or clypens, and $l b$ indicates the upper lip, while the jaws are wanting; $t k$ is the tongue, cut off to show the tube in the middle. How the latter works can be seen by looking at

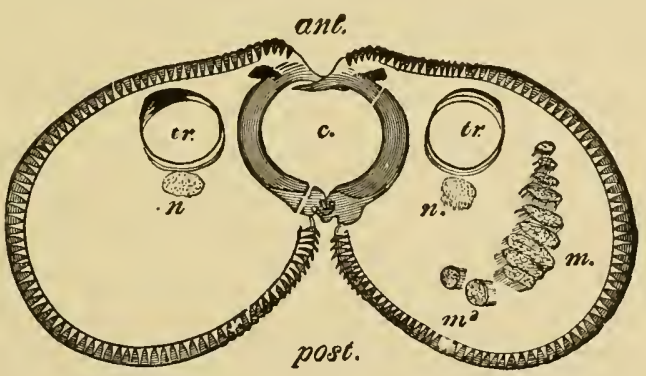

Fig. 170.-Section through the tongue of a butterfly.-After Burgess.

Fig. 170, which represents a cross-view of that of the Danais butterfly. The maxillæ in some moths, such as the great, green, tailed Luna moth, are short and separate, like 
a pair of blades. Now the tongue or proboscis of the butterfly is formed by the union of these two blade-like maxillæ; and they are so closely united together as to form a hollow tube or proboscis $(c)$, through which the nectar is

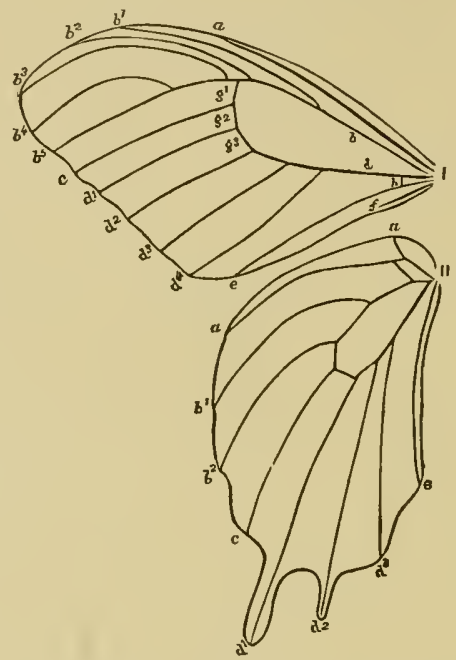

Fig. 171.-Fore and hind wings of a butterfly, showing the venation. $a$, costal vein; $b$, subcostal; $b^{1}, b^{2}, b^{3}, b^{4}, b^{5}$, the five subcostal veinlets; $c$, the independent vein (it is sometimes a branch of the subcostal and sometimes of the median vein); $d$, median vein; $d^{1}, d^{2}, d^{3}, d^{4}$, the four median veinlets; $e$, sul)median vein; $f$, internal vein; $h$, interno-median veinlet, rarely found; $b$ and $d$ are situated in the "discal cell." Lettering the same in both wings.

sucked with the aid of the pharyngeal sac, which serves as a pumping organ to suck the liquid food through the proboscis, and force it backwards into the digestive canal.

The wings of butterflies are beautifully painted and ornamented. If, however, we examine the scales separately under the microscope, we shall see that they are colorless. The variety of color on the different spots and bands is due to the arrangement of the scales, i.e., to the interference of the rays of light passing through them.

In the butterfly, as in the house-fly, it will be seen that the front edge of the fore wings is strengthened by two 
veins, one of which has three branches running parallel with the edge. As the weight or pressure of the air while mak. ing the stroke is borne chiefly by the front of the wing, it needs these rods to strengthen it.

The scales of a butterfly's wing differ much in shape on different parts of the body. On the wing of the Cecropia moth the hairs of the body and base of the wing are scen to pass into broad scales, represented in Fig. 17\%. They
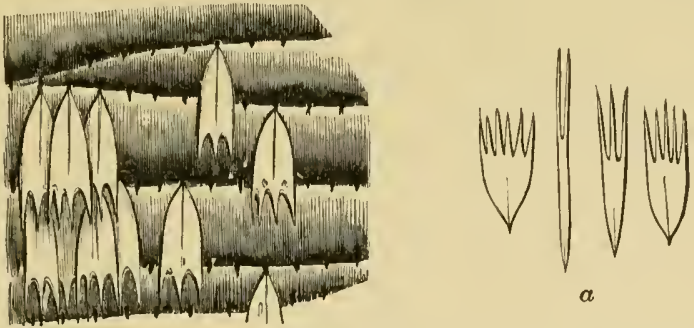

FrG. 1\%2.-Arrangement of the scales on a moth's wing. a, some enlarged.

are attached to the wing and laid partially over one another like the tiles on a roof, being inserted in irregular rows.*

The caterpillar or larva of the Turnus butterfly may be found on the apple or birch and other trees. In July the butterfly lays a nearly round egg (Fig. 16\%, A) upon the leaf, and by the end of summer one may find the great green worm in the same place. The body is romud, fat, and smooth; there are twelve seginents behind the head. From the top of the segment next to the head is projected,

* Acenrding to Dr. Royston-Piggott, the foot-stalk or perlicel of a scale consists of two membranes united to form a tube which gathers up and distributes the nourishing fluid among the striations or ribs of the seale. The scale has been resolved into a series of latticed ribs, connected by irregular eross bars: each rib displaying double black margins, and the cross-bars often beaded. The scales of Lepidoptera make admirable tests for the lighest powers of the microsene.

In the scales of Morpho cypris " the cross-laar structure, like all these azure blues, is most delicate, and produces glorious color." Pupilio troilus "is worth close investigation for reticulated bars." (Microscopical Advances, xxvii.; English Mechanic, Nov. 11, 1887.) 
when the caterpillar is disturbed, a singular V-shaped

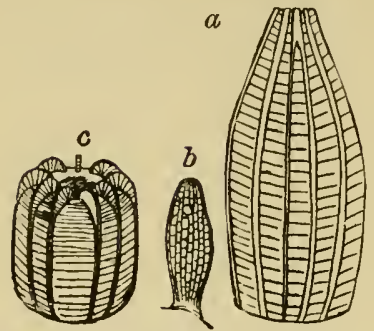

Fia. 173.- $a$, egg of Pieris oleracea; $b$, Colias philodice; $c$, Vanessa atalanta. - After Scudder. yellow organ, which sends out a disagreeable smell, and is thought to be repugnant to birds, ichneumon insects, etc. On each side of the third segment is a large eye-like spot, peculiar to this species. There are along the body nine pairs of spiracles, one on the segment next to the head, and eiglit pairs on the fourth to eleventh segments, or what correspond to the first eight abdominal segments of the butterfly, the latter having, however, but seven pairs of spiracles on the lind body.

The caterpillar's eyes are minute, simple eyelets, three or four on each side of the head, and only useful, probably, in distinguishing day from night. This is useful information, considered from a caterpillar's staudpoint, as most of them hide by day and feed by night. That caterpillars are very hearty eaters goes without saying. They perform prodigies of gastronomic skill. Did all the caterpillars which are born into the world survive the various ills and enemies they are heirs to, not a green thing would be left on the face of the earth. The locust's mission would be ended. It appears that when there are several broods of caterpillars, those of the later broods are hardier than those of the first generation.

The jaws of the caterpillar are large, black, horny appendages, and are toothed on the cutting edge, so as to pass through a leaf somewhat like a circular saw (Fig. $174, m d)$.

The silk is spun through the tongue-like projection of the under

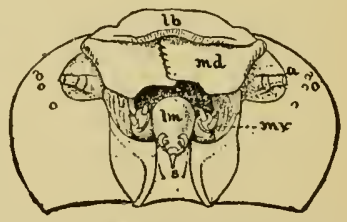

FIG. 174.-Mouth-parts of caterpillar. $a$. antennæ: the ocelli placed outside; $l b$, labrum; Im, labium: $m x$, maxilla.After Burgess. lip (Fig. 174, s). It is secreted in two long sacs within 
the body. The third is drawn out by the two fore feet, which are three-jointed and end in a single claw. 'The legs on the lind body, sometimes called prop-legs, are fleshy, not jointed, and end in a crown of hooks which curve outward, enabling the caterpillar to firmly grasp the edge of the leaf or twig of its food-plant.

Most caterpillars are more or less hairy or spiny, rendering them, when especially so, disagreeable to birds; besides this, they are bright-colored, so that birds readily recognize them and waste no time over them, but search for the common green smooth-bodied ones, which are, however, so difficult of detection by the birds that plenty are left to become moths or butterflies. Certain caterpillars, as the currant-worm, though smooth-bodied, are brightly spotted; these, however, the birds find, have a disagreeable taste. The bright colors are thus danger-signals, hung out to warn the birds.

We will now suppose that the caterpillar has got its growth, and is about to change to a chrysalis. When fully fer the caterpillar stops eating, and in a day or two throws off the caterpillar's skin and becomes a pupa or chrysalis. The latter word is derived from the Greek, meaning golden, in allusion to the golden spots which adorn the chrysalids of some butterflies. Our 'Turnns caterpillar, before pupation, as the act of becoming a pupa may be called, becomes short and thick, with the head drawn in. It spins an open-work platform of silk on the under side of a leaf; its tail is firmly anchored in the mass of silk by certain hooks at the end, and meanwlile it throws around its body near the head a strong silken cort as a support. Our Turnus chrysalis is not bright-colored, but allied in color to a dry leaf or piece of wood, so as to be easily overlooked by birds. Here it remains through the winter until the end of the succeeding May or first of June, when the butterfly within, which has been growing rapidly during the preceding warm days, by its convulsive struggles bursts the pupal skin on the back, forcing the covering of the head and mouth-parts aside, and 

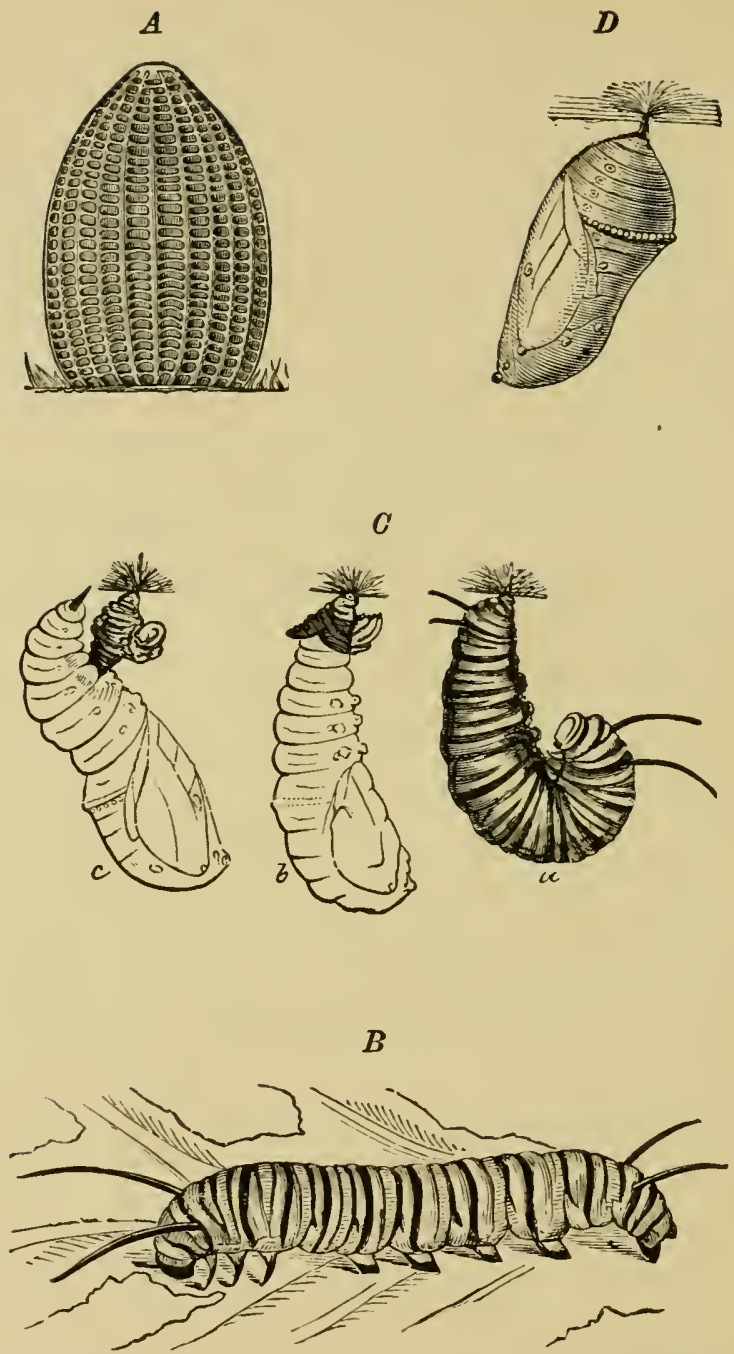

FIg. 175.-Transformations of Danais archippus.. $A$, egg, enlarged; $B$, larva; $C, a, b, c$, semi-pupal stages; $D$, pupa.-After Riley. $\quad$ (To face page 147.) 


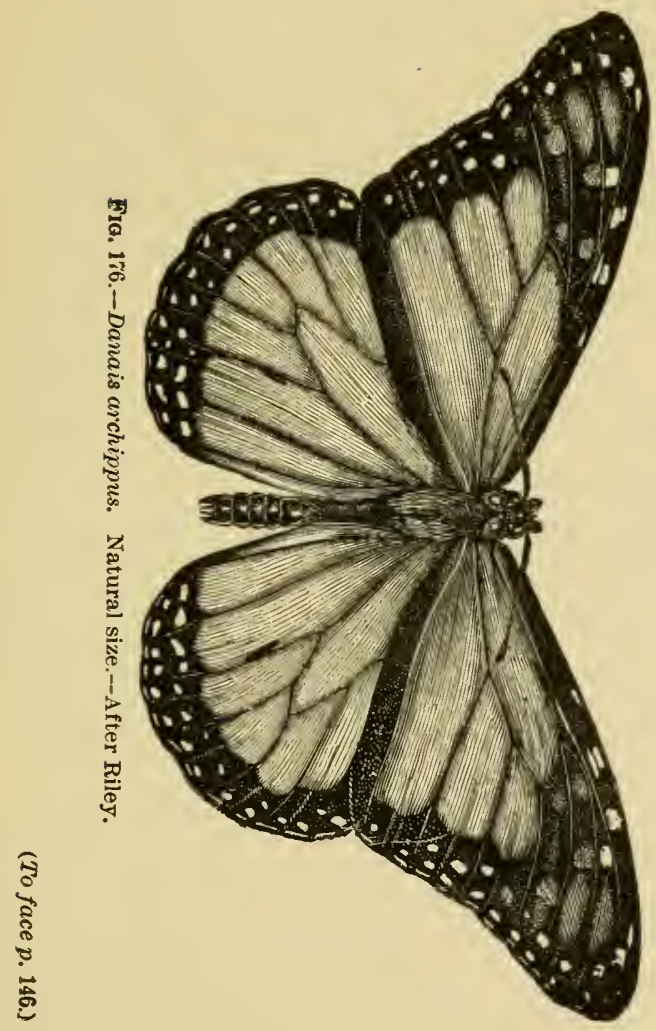


draws itself out of the rent. It stands on its feet for a few minntes, while its wings expand, and then takes flight and sails gracefully through the air on its broad wings.

Figs. 175 and 176 illustrate the metamorphosis of Danais archippus from the egg to the butterfly; but Fig. 175, c, is ineorrect so far as it shows how the partly formed ehrysalis is suspended. According to Riley's latest observations and figures, after the caterpillar has spun the little button-like mass of silk, as at $\alpha$, it entangles in the silk the hooks both of its last pair of legs, and those of the "supraanal plate," sitnated above the legs, and which becomes the stout spine at the end of the chrysalis, called the "eremaster." 'The eaterpillar then works its skin back to the end of the body, as at $b$. 'The anal legs of the larva are represented in the chrysalis by two sustaining knobs which cateh in the retaining membrane, and with the aid of a rectal ligament suspend the pupa, and prevent it from falling at the eritical point when the eremaster is withdrawn from the larval skin. Finally, while temporarily supported by the two elastie suspensory membranes, the ehrysalis so twists and turns itself that the hooklets of the eremaster become securely fastened in the silk button, and the old larval skin is disearded, the ehrysalis appearing as at $D$.

In most Lepidoptera the males emerge and fly about for some time before the females. Darwin infers that the adult males of most Lepidoptera generally exceed the females in number, "whatever the proportion may be at their first emergence from the egg" (Descent of Man, i. 305).

'The "assembling" of moths is a curious fact. If a virgin silk-worm moth be exposed in a eage, great numbers of males will collect about the hox. It is so with some beetles, as Prionus breveornis and probably other longicorns.

The wings of the two sexes of Lepidoptera often differ in venation, and usually in outline; while the males of certain South American lutterflies have tufts of hair on the edges of the wings, and horny excreseences on the disks of the hinder pair. 'The males of eertain butterflies 
are in parts elothed with peculiar hairs, called androconia (Fig. 178). Fritz Müller has shown that the males of certain butterflies are renclered attrietive to the other sex by secreting odorous oils of the ether series.

Certain hair-like scales on some butterflies give off an odor, in Pieris nupi like that of eitrons, while P. rapce is slightly odorous; and Müller has observed in the male of Didlonis biblis three different odors in different parts of the body. The females of Callidryas have in the end of the body highly odorous glands, while the males give off a musk-like odor from the same parts.

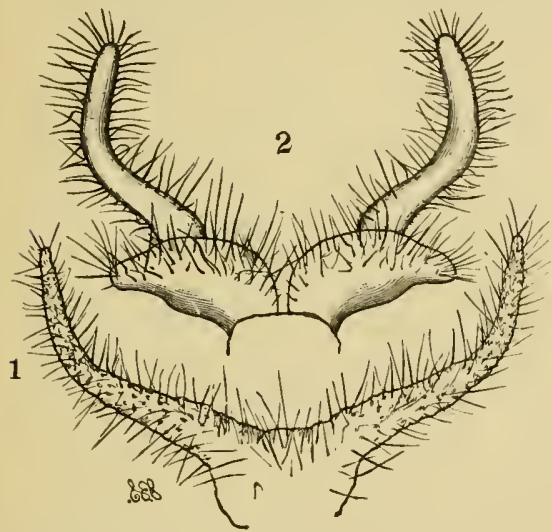

Fig. 177.-Scent-tufts of moths. 1, Leucarctia acroea; 2 , Pyrrharclia isabella.-After Smith.

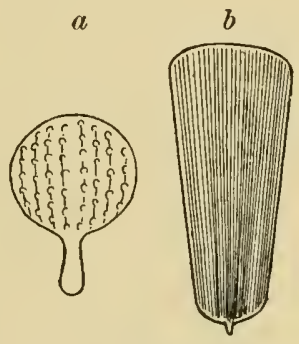

Fig. 178,- $a$, scent-scales or androconia; $b$, ordinary scale of Lycena butterfly. Highly magnified.After Scudder.

Peculiar white or orange-colored, liairy, thread-like processes have been found protruding from narrow openings near the end of the hind body of certain moths (Fig. 17\%), which give out, according to Mr. J. B. Smith, "an intense odor, somewhat like the smell of laudanum."

While there is great uniformity in the shape of the body of butterflies and moths, their habits are, within narrow limits, quite diverse. Some fly by day, others at dusk, others by night. The great number of species, of which there are estimated to be 25,000 , is undoubtedly due to the variety in the food-plants on which the caterpillars feed. Nearly if not every species of plant affords room and board 
for one or more species of caterpillar. The oak nourishes in this country alone about 200 species; nearly 100 different kinds feed on evergreen trees, eating the buds and leaves, boring in the branches, and, in short, attacking the tree in a variety of ways, so that there is a place and abundance of food for each kind of caterpillar. In their chrysalis state they are comparatively safe from harm. Nature has thus favored the Lepidoptera above all other insects except the flies, beetles, and Hymenoptera. From their number and variety, their beauty of color, attractiveness of form, and the ease with which they can be collected and their caterpillars reared, the butterflies and moths are the favorites of entomologists.

The larger moths and the butterflies are for convenience called Macrolepidoptera, and the species of the lower families, from the Pterophoridæ to the Pyralidæ, are called Microlepidoptera.

Family Pterophoridæ.-The plume-winged moths are recognized by

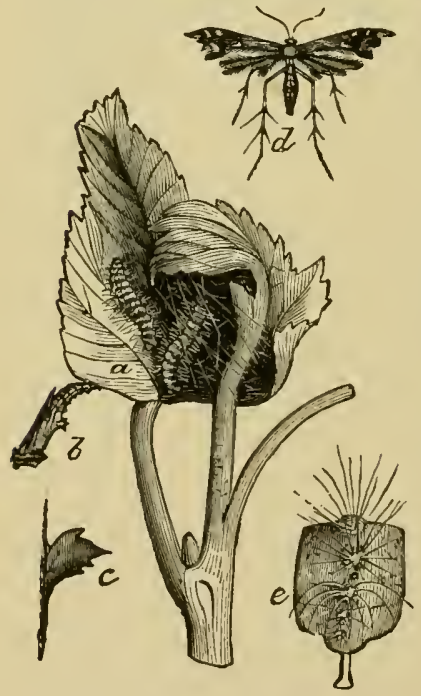

Fig. 179. - Grape Pterophorus. $\alpha$, larva; $b$, pupa; $d$, moth. their fissured and plume like wings; the body is unusually slender, with long antennæ and legs. The larvæ are spindle-shaped, rather hairy; the hairs are often hollow and sccrete a viscid fluid which exudes in a dew-like clrop from the end. They spin no cocoon, but, fastening themselves within a curled leaf by their tail, shed their larval skin and appear in the chrysalis state. Pterophorus periscelidactylus Fitch abounds on the grape-vine, eating the joung leaves and fruit-buds.

Family Tineidæ.-This great group (which is perhaps rather a super-family with several families included in it) is characterized by the slender body, long, narrow, often pointed wings of both pairs, with long fringes, by their usually minute size, and their rich, often metallic markings. Those with broad, blunt wings, like Tortricids, may be distinguished by the long, slender, pointed labial palpi. It is difficult to give the family characters of the larvæ; usually slender and slightly spindle-shaped, it is almost impossible to separate them 
from slender-bodied Tortricid caterpillars; those which "mine" the leaves of plants are much flattened. Some Tineid caterpillars feed in the stems or roots of plants, a few produce galls, while many live in solded leaves of herbs and trees.
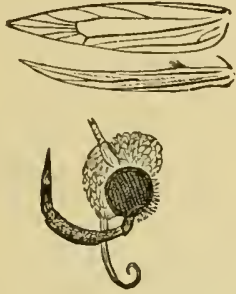

Fig. 180.-Wings and head of a Tineid: Batrachedra.
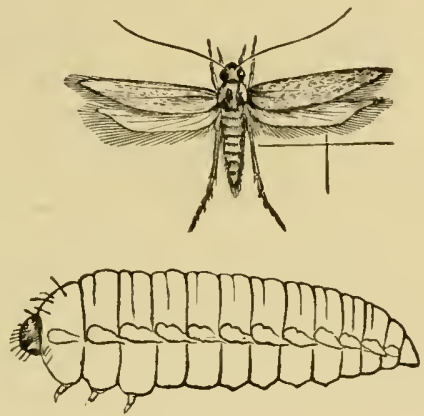

FIG, 181.-The Angoumois grain moth and larva.

The genus Nepticule contains the smallest known moths. The Angoumois grain moth (Fig. 181) eats the interior of wheat-grains in granaries; it is grayish yellow, with two or three darker spots on the fore wings. Tinea pellionella Linn., the clothes moth (Fig. $\left.18^{2}\right)$, as a caterpillar makes a case of woolly fibres, anl is a universal pest. So also is Tinea tapetzella Linn., which is black on the basil half of the fore wings, but white on the outer balf; destroys woollens. Tinea biselliella is a pale yellow-
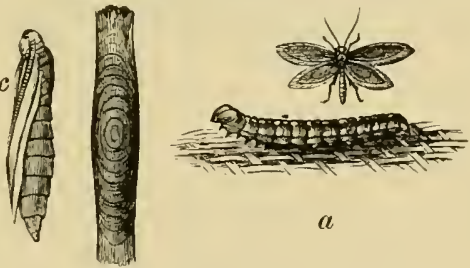

$\boldsymbol{\alpha}$ ochre moth, with a reddish-FIG. 182.-Clothes moth. $a$, larva; $b$, its ochre head; its caterpillar case, and $c$. its pupa.

makes no case, though destructive to woollens, fur, dried insects, etc. Tinea granellı Linn. (Fig. 183) is a universal wheat pest.

Family Tortricidæ. - The leaf-rolling moths are rather stout-bodied, with wide, oblong wings, the costal edge of the fore wings being often sinuous; the antennæe are simple. or tinely eiliated, and very rarely pectinated; the palpi are curved up against the front of the head, or extended forwards, and are sometimes two or three times as long as the head; the head above is rough with erect scales, while the wings are often crossed with irregular lines of tufts, and there is a noticeable tuft at the end of the abdomen. The legs are of medium size and length, and in a few species the hind tibix are densely clothed with hair-like scales, while in some cases the males have a long tuft of hairs lying in a groove along the inside of the hind tibie (Fernald).

The cates pillars are called leaf-roilers from their eommon habit of folding or rolling over a portion and lining the interior with silk; 
others feed on buds, or live in seeds and fruits, or bore in the stems of plants.

The spruce-bud Tortrix ( $T$. fumiferana Clemens), usually rare, at
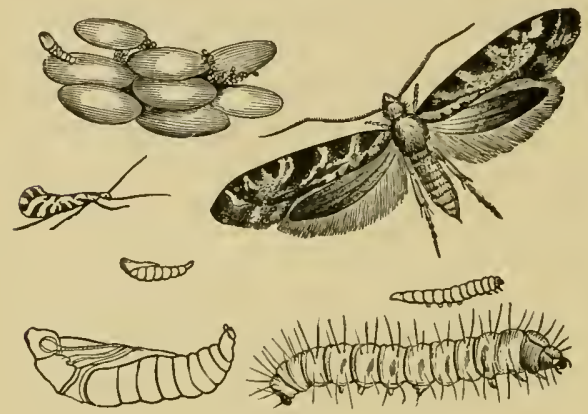

Fig. 183.-Grain Tinea, with larva and pupa. Natural size and enlarged.

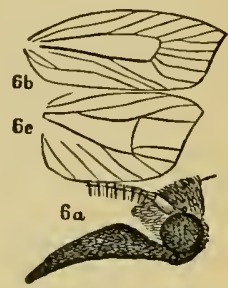

Fig. 184. - $a$, head and palpi; $b$, fore wing; $c$, hind wing, of Enectra xanthoides.

times has defoliated spruce and firs over extensive tracts on the coast of

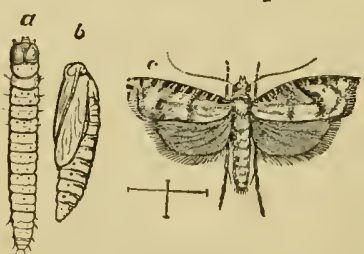
Haine; the moth lays about thirty eggs which are flat, scale like, slightly convex above, with a thin shell; the worm feeds on the buds and terminal shoots in June. Our most common leaf-roller is Cacacia rosaceana Harris, whose green larvæ, with a black head and prothoracic shield, fold the leaves of the apple, plum, cherry, rose, and other plants. The cranberry worm (Rhopo-

Fig. 185. - c moth of cranberry- bota vacciniana Pack.) often injures worm $(a) ; b$, pupa.

the cranberry plants. The strawberry leaf-roller, Phoxopteris fragarice (Walsh and Riley), folds the leaves.

Family Pyralidæ. - The moths of this group have slender bodies and legs, the fore wings are usually narrow, the hinder pair broad and somewhat pointed at the apex; the palpi are often held straight out, and are usually long and slender. The larve are easily confounded with the leaf-rollers, but are usually more or less striped, those of the Pliycids being often brownish. There are three subfamilies, viz., the Crambine, Phycince, and Pyraliner.

The species of Crambus are often very destructive to grass. The larva of $C$. vulgivagellus Clemens (Fig. 186), which ravaged the pastures and meadows of New York in 1881, is pale purple green, with a black head; it forms a silken tube near the roots of grass, and pupates in thin, slight cocoons just under the surface of the ground. To this group belongs the bee-moth (Galleria melonella). Among Phycine, the currant and gooseberry fruit-worm (Dakruma con. volutella Hübner) is noteworthy. Of the Pyralinx, Asopia farinalis Harris in the larval stage feeds on meal, ete.; other typical forms are the species of Botys, while aquatic larva, living in cases, are species of Hydrocampa, Cataclysta, and Paraponyx. 


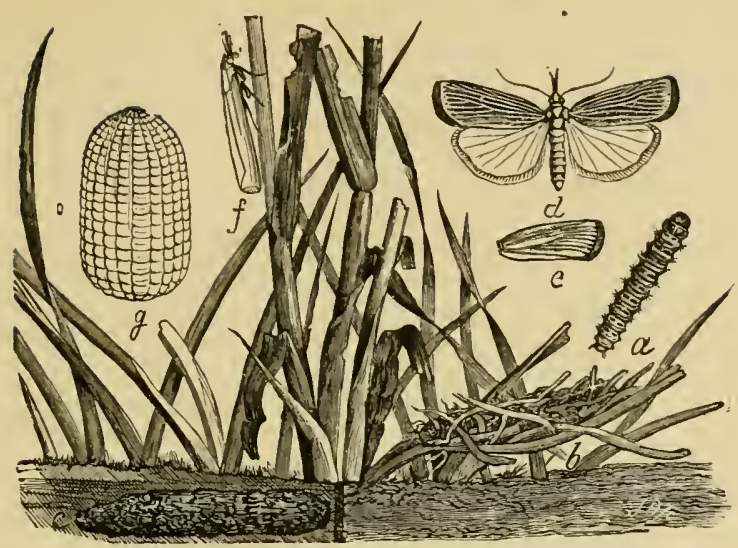

FIG. 186.-Vagabond Crambus. $a$, larra; $b$, tube; $c$, cocoon in the ground; $d, f$, moth; $e$, wing of a lighter specimen--all natural size; $g$, egg, enlarged.

Family Phalænidæ (Geometridie).-The geometrids, measuring-or span-worms, are at once known by their looping gait, due to the absence of the two front pairs of abdominal legs, so that in walking the body is arched upwards; when motionless they resemble twigs and stems of the trees they inhabit. The moths have slender bodies and very broad wings, with usually pectimated antennie; the palpi are short and slender, and the tongue short and weak. When about to pupate, the caterpillars often spin an open loose cocoon, but where the inseet

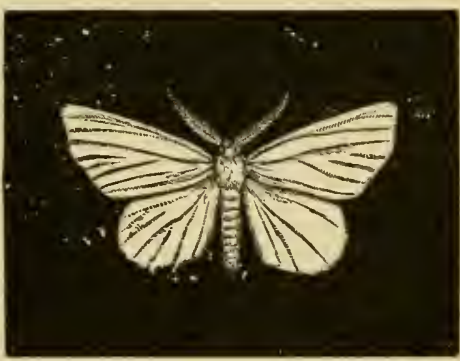

F1G. 18\%.-Eudalimia subsignaria.

hyberuates in the pupa state, as the eanker-worm, it buries itself in the ground; a few hang naked and suspended by the tail.
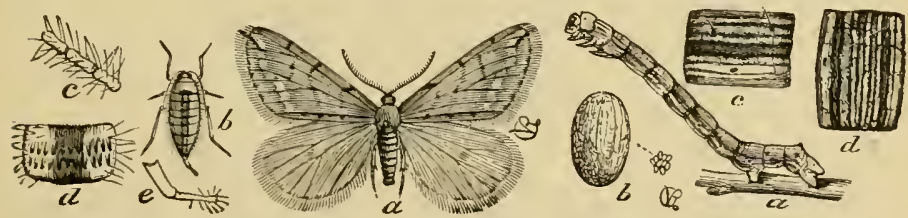

Fio. 188.-Spring canker-:orn. $a$, male moth; $b$, wingless female, natural size; $b$, egg; $a$, larva; $c$, side, $d$, tnp, of a segment.-After Riley.

The pupæ are rather smooth and slender, either pale brown and 
spotted, or mahogany brown. The more destructive forms are the spring canker-worm, Anisopteryx vernata, in which the females are wingless, and lay their eggs in patches on the bark, the worms appearing when the trees leaf out. In cities the caterpillars of Endalimia subsignaria Hübner defoliates elms and other shade-trees.

Family Noctuidæ. - The owlet moths number upwards of 1500 species in this comntry, many of which are destructive to crops. The noctuids in general differ from other moths in their thick bodies, the thorax often being crested, by their stont palpi, and the usually simple antennæ, though these are in some cases pectinated. The fore wings are rather narrow, with usually a dot and reniform spot in the middle of the wing, while the hind wings are large. They mostly fly by night. The caterpillars are usually smooth, without hairs or spines, the body tapering towards each end, and more or less striped; the number of fect is nsually sixteen, except the lower genera with broad wings, such as Cato-
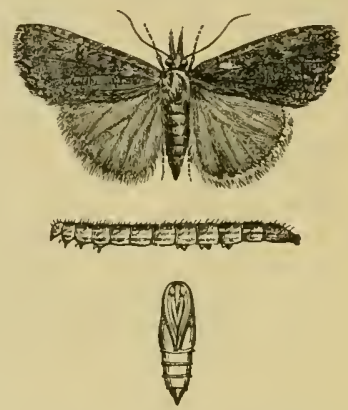

Fia, 189.-Hop-snout moth, $\mathrm{Hy}$ pena humuli. Natural size. cala, which are semiloopers, having but perteen feet. The pupwe are usually subteranean.
fourteen

The lower forms, called Deltoids, have very long palps, and the larva are slender, glassy green, and fall wriggling to the grome when disturbed. Such is Hypent humuli Harris. The species of Catocala have very broad fore wings and often bright red hind wings, the caterpillars living on trees. The great Erebus odor'a Drury,

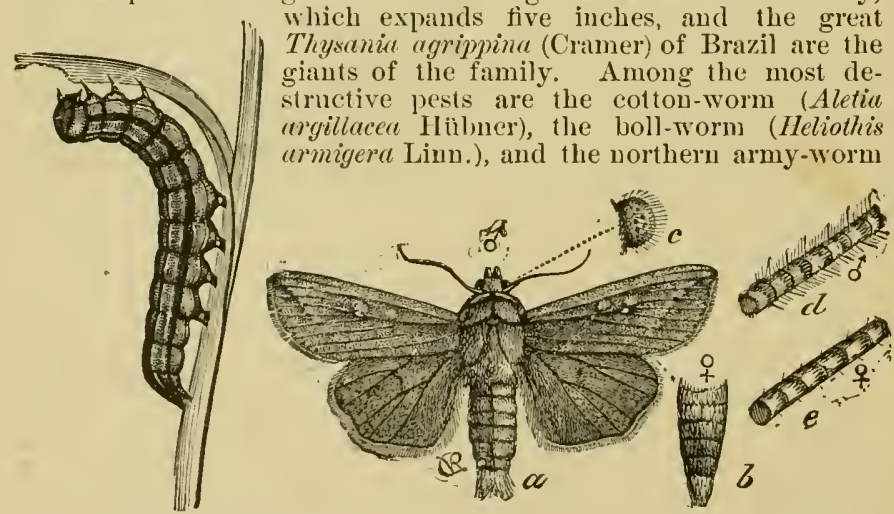

Fig. 190.-Army-worm and moth, $a$, male moth: $b$, abdomen of female-nat. size; $c$, eye; $d$, base of male antenna; $e$, base of female antenna, enlarged.

(Leucania unipuncta Haw., Fig. 190). Universal pests are the cutworms, which like most of the other larvae of the group feed by night, hiding by day. Their eggs are laid on the leaves of grass, and the 
caterpillars guaw off the stems of succulent plants. The larve cf the species of Apatela are hairy, and so closely resemble certain Notodontian caterpillars as to be easily mistaken for them.

Far:ily Bombycidæ. - The species of this family differ in the usually thick, hairy body, small head, pectinated antenna, and long, large clypeus; in the weak palpi and often small, weak tongue; while the caterpillars are usually hairy, and more or less tufted, or spiny. They spin a cocoon, more or less dense, and the chrysillids are nnusually short and thick. The group is divided into a number of sub-families, regarded by some authors as families.

The Lachneides (Lasiocampina) embrace the genera Clisiocampa, Gastropacha, etc. The larva of Clisiocampa americana Harris is called the American tent-caterpillar; its webs are seen in apple and cherry trees.

The Ceratocampince are represented by Anisota senatoria (AbbotSmith), whose spiny black-and-red-striped larva strip oaks; also by two very large moths, (itheronia regalis (Fabr.) and Eacles imperialis ;Drury); the Hemileucini by Hemilenca maia and Hyperchiria io Fabr.; while the giants of the family belong to the Attaci, which embrace the American silk-worm, the caterpillar of Telea polyphemus (Cramer); Ac.
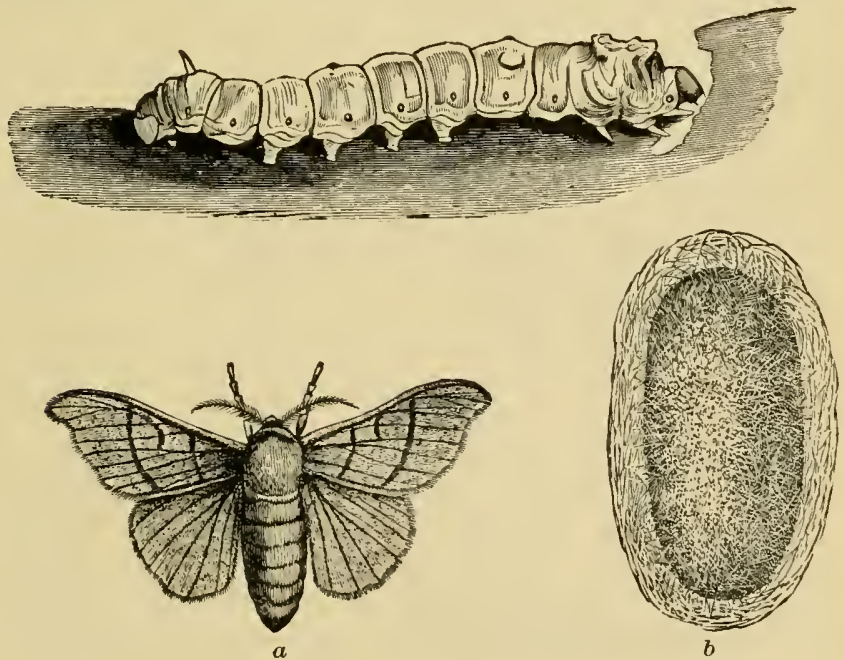

F1G. 191.-The Chinese silk-worm. $b$, cocoon; $a$, moth. Natural size.

tuas luna (Linn.), Platysamia cecropia Linn., and Callosamia promethers (Drury). The Bombycince are represented by the Chinese silk-worm, Bombyx mori Linn, and this group is suceeeded by Platypterices, of which Platypteryx arcuata Walk. is a type. This group is succeeded by the Notodontians (Ptilodontes), of which Schizura unicornis (Abbot 
and Smith) and Notodontu strugulu Grote, as well as Nerice bidentata Walk. (Fig. 192), and Eidema albifrons Abbot-Sinith, are examples.

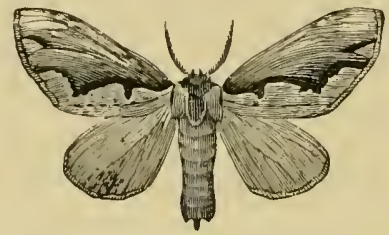

Fig. 192.-Nerice bidentata. Nat. size. Fig.193.-Edema albifrons. Nat. size.

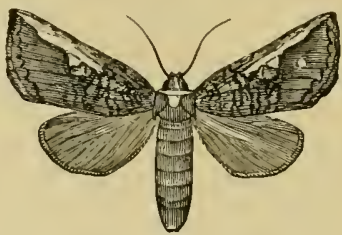

These are succeeded by the Cochlidiue, of which Limacodes scapho Harris is the most familiar form. This group is followed by the

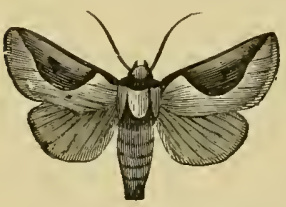

Fig. 191.-Limacodes scapha, moth and larva. Natural size.
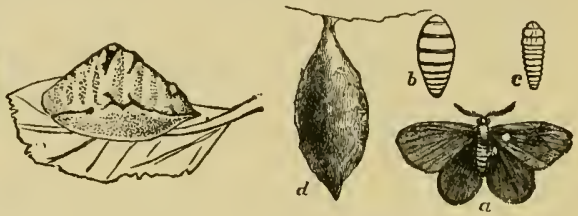

Fig. 195.-Basket-worm, Platoeceticus gloverii Pack. Nat, size.

Psychinip, represented by the basket-worms, Thyridopteryx ephemerceformis Steph., Psyche confederata Grote, and Plataceticus gloverii.

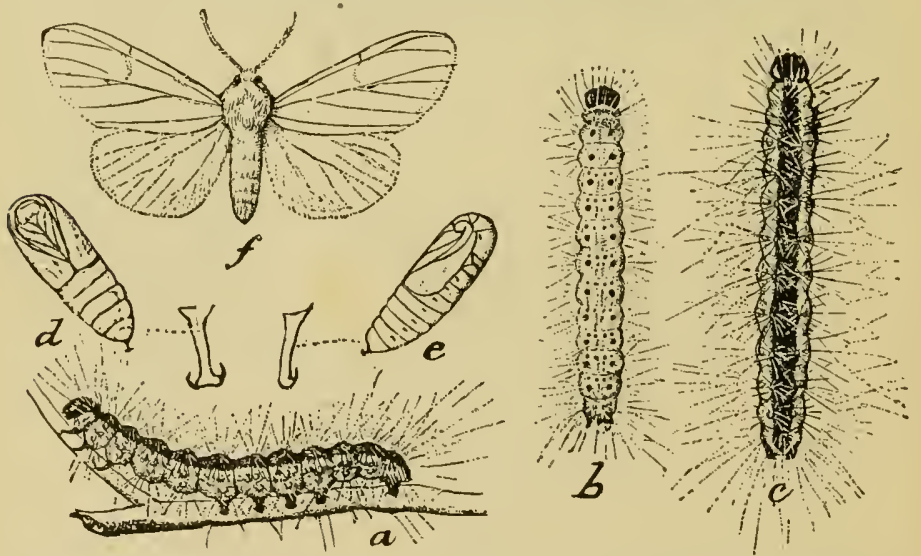

FIg. 196. - Hyphantria cuner. $a$, dark larva, seen from side; $b$, light larva from above; $c$, dark larva from above; $d$, pupa from below; $e$, pupa from side; $f$, moth.

The Dasychirce (Liparinæ) are represented by Orgyia leucostigma (Abbot Smith) or tussock-caterpillar, so destructive to shade-trees.

The Arctiine are a large group, the species of Aretia being nu- 
merous, the more common and destruetive species being Spilosomr virginica (Fabr.) and the fall web-worm, Hyphantria cunea (Drury, Fig. 196). The last sub-family is the Lithosite, in which the body is

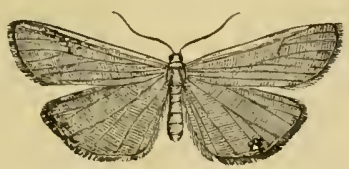

Frg. 197.-Lithosia bicolor. Nat. size.

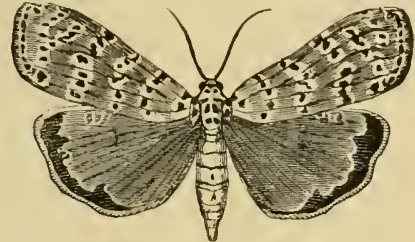

FIs. 198.-Utetheisa bella. Nat. size

slight, not very hairy, and the antenna not pectinated. Lithosia $b i$ color Grote (Fig. 197) and Utetheise bella (Limn., Fig. 198) are typical forms.

Family Zygænidæ.-The beautiful moths of this group are recognized by the pectinated antennx, their usually rather narrow wings, rounded at the apex, the Arctian-like venation, and by their hairy caterpillars, which transform in cocoons of silk or mostly hair. It is divided into the Zygrenina, represented by Zygsena in Europe, and in this country by the species of Procris, Harrisina, etc., as well as Lycomorpha pholus Drury; and the Glancopince, exemplified by Ctenucha virginica Charp.

Family Agaristidæ.-Formerly associated with the preceding family, the species of this group differ in having simple antennæ, a sub-costal cell, and the caterpillars are naked, more or less humped on the eighth abdominal segment, and do not spin a silk cocoon. The types are Eudryas grata Fabr., E. unio Hïibn., and Alypia 8-maculata (Fabr.).

Family Castniadæ. - The species are tropical, mostly very large moths with simple antennæ thickened towards the end, and the head narrow between the eyes (the scales are in Castnia larger than in any other Lepidoptera); the larve are Fig. 199.-Alypia of grape. a, larva; 1 , naked, boring in the stems of side of a segment,enlarged.-After Riley. orchids, etc. As in the two foregoing families the moths are day flies. Crastnir licus (Fubr.), South America: Synemon sophia (White), Australia. A species of the Australian genus Hecatesia, the males of which have a vitreous spot on the fore wings, makes a whizzing noise like the humining of a top.

Family Hepialidæ. - These are brown moths with silver marklngs, whose antennie are short, and either simple or sub-serrate; the tongue is wanting, the clypeus short, and the larvæ are borers. Hepialus mustelinus Pack. occurs in the Northeastern States.

Family Cossidæ. - Large moths with the antennæ well pectinated; 
a sub-costal cell, and a strong vein dividing the discal cell longitudinally into two cells; larve boring in solid wood. Prionoxystus robinue Peek. is the oak and locust tree-borer.

Family Thyrididæ. - Small, richly colored moths with simple antennæ, the wings small, the hinder ones more or less angular; the discal cell of the fore wings open. Thyris maculata Harris, $T$. lugubris Boisd.

Family Sesiidæ.-Small moths with brilliant colors, long, narrow, more or less transparent fore and hind wings, and thickened antenmæ; larvæ boring in the stems of shrubs and trunks of trees. Sesia pyri(Harris); Melittin ceto Westw., the squash-vine borer.

Family Sphingidæ.-The hawk-moths are large insects with thick bodies, spindle-shaped antennæ, thick palpi; usually a very long tongue; the fore wings are rather narrow, the apex sharp, and they have a small, short diseal cell. Caterpillars with a smooth or gramulated skir, and a hump or horn on the eighth abdominal segment; usually pupating in the earth, the pupa often with the tongne-case large and free. In ll emaris the body is bright-colored, and the wings transparent in the milldle (II. thysbe Fabr.). The larva of Thyreus abbotii has a disk-like hump instead of a horn. In Smerinthus the tongue is short and weak; S. excreatus Alb. and Sm. In Chroroeampa and its allies (Cherocampince) the thorax is not tufted, and the outer edge of the wings is more or less hollowed out; in the Splingine the thorax is tufted; the tongue long and the outer edge of the wings convex; Splinx celeus Hitbner is the potato or tomato worm, and $S$. carolina Lim., the tobaceo worm of the Southern States. The larve of Ellema have no hom; Ellema harrisii Clemens.

The butterflies appear to form a super-family, the Rhopalocerc, and are divided into four families. They differ from moths in their club-shaped antennæ; in the wings being elevated when at rest, and their peculiar venation; the lack of a bristle connecting the two wings; and from their day-flying habits are ealled diurnal Lepidoptera. The larvæ vary greatly in form and oruamentation, but with rare exceptions (a very few Hesperians) they are not borers, and none of them spin a perfect cocoon, the chrysalis either being fixed by the tail head-npwards and held in place by a silken thread passing around the body, or it hangs suspended by the tail; others (Lyeenidæ) generally fasten themselves longitudinally upon the leaf or stem of a plant, while the Hesperidx lie inside of a rolled leaf, with silken threads around the body.*

* The definitions of the five families of butterflies are in part copied from H. W. Bates's "Lepidoptera of the Amazon Valley" (Trans. Linn. Soc., London, 1862). 


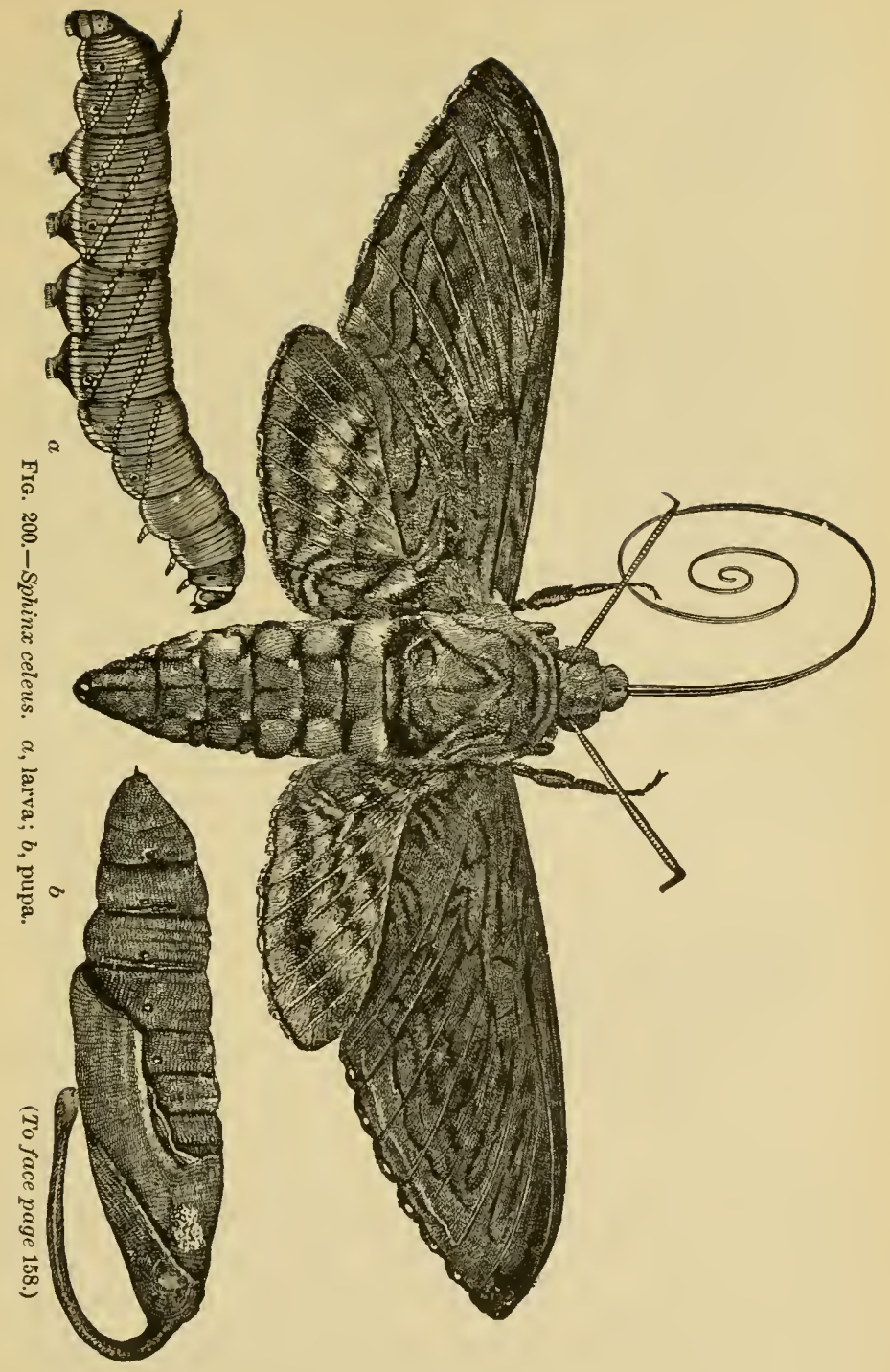


Family Hesperidæ.-Head very wide between the eyes; antennæ ending in a hook; hind tibiæe usually with two pairs of spurs. Larva

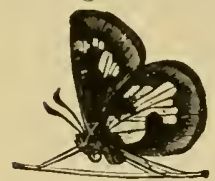

Fig. 201. - Hes peria. naked, with a large head, rarely boring in plants, usually living in a rolled-up leaf; pupa secured by many threads, or enclosed in a slight, imperfeet cocoon. The Hesperids connect the true butterflies with the moths, Megathymus yucce Boisd. and LeConte boring in the roots of Yucca, and bearing a superficial resemblance to the Castniidx, being more moth-like than any other butterfly, while the species of Synemon, with their bright colors and club-shaped antennx, simulate the Hesperids. Examples of the family are Hesperia tessellata Scudd., Nisoniudes trizo Bois. and Lec., Eudamus bathyllus (Abbot and Smith), and 'Thymele proteus (Linn.).

Family Papilionidæ.-Wing-cells (at least, of the hind wings) closed; hind tibiæ with one pair of spurs; a leaf-like appendage to the fore tibiæ, as in mofhs and Hesperids. Larva with a retractile scent-organ on the segment next to the head. Pupa fastened in an upright position by the tail and a girdle across the middle. Pieris rape Linn., the imported cabbage butterfly, and $P$. oleracea Harris, as well as Colias philodice Godart, represer.t the sub-family Pierince, while Parnassius and Papilio turnus Linn. represent the sub-family Paplionina.

Family Lycænidæ- - Six perfect legs in the females, four in the males. This group is subdivided into two sub-families, the first of which is the Lyconince, in which the fore tarsi lack the tarsal claws, but are densely spined beneatl. Wing-cells (except in Eumæus) not closed by perfect veins. Larva oval and flattened, head small, and the feet very small. Pupa short, obtuse at each end, smooth, fastened by the tail and a girdle. Lycana pseudargiolus Boisduval and LeConte; Chrysophanus thoe Bois. and Lec. In the sub-family
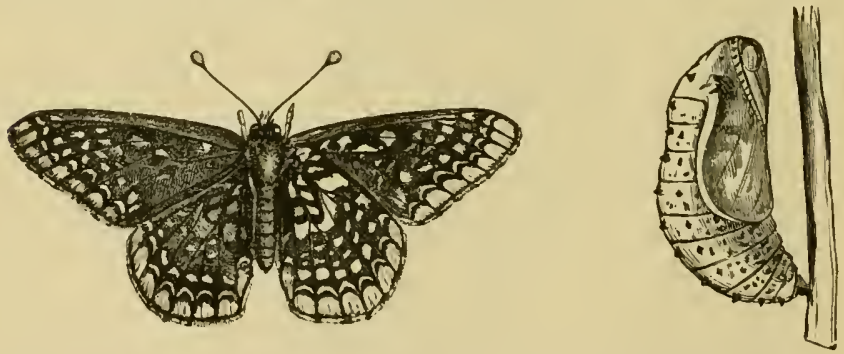

F1G. 202.-Melítoe $a$ phaeton (under surface on right side); $a$, pupa, enlarged

Erycinine, the legs are as in Lycæninx, the fore tarsi consisting of only one or two joints, and being spineless. Larva either not spined, or with bristles and hairs; pupa either with a girdle (Erycina), or fastened rigidly by the tail without a girdle (Stalachtis), or, as in Libythea, suspended freely by the tail.

Family Nymphalidæ. - Fore legs imperfect in both sexes; in the female wanting the tarsal claws; in the male the fore tarsi are aborted, consisting of one or two joints. Discal cell usually open. 
Larva long, cylindrical, with spines or fleshy processes. Pupa suspended freely by the tail, stont, either smooth and rounded, or angular in outline. This is by far the largest group of butterflies. Ageronia feronia Linn., a Brazilian butterfly, also an inhabitant of Mexico, according to Darwin makes a clicking sound while on the wing. Dione vanille (Linu.) inhabits Florida, the Gulf States, and extends across the continent to southern California. The speeies of Argynnis (ex. A. aphrodite Fabr.) are notable for the silvery spots

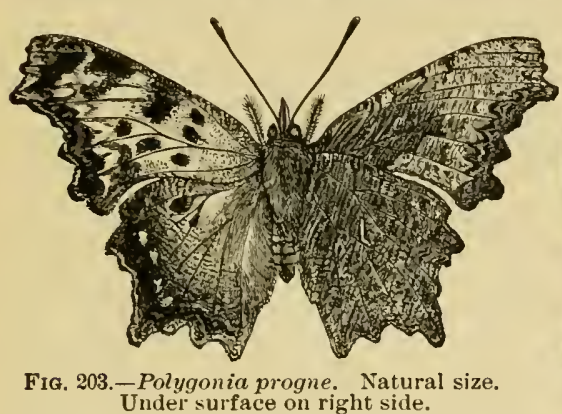

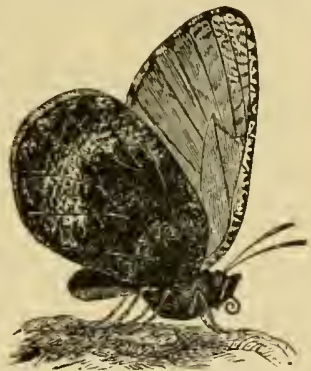

FIG, 204-Cneis semidea. Natural size.

on the under side of the hind wings. Allied to them are the species of Melitiea ( $\boldsymbol{M}$. phaeton Drury). In Vanessa ( $\boldsymbol{Y}$. antiopa Linn.) and Polygonia ( $P$. progne Craner) the outer edges of the wings are notched. The highest of the butterflies appear to be the species of Heliconia, of Cercyonis ( $C$. alope Fabr.), and the interesting arctic and alpine genus (Eneis (O. semidea Say).

Order XVI. Hymenoptera* (Saw-flies, Gall-flies, Ichneumons, Ants, Wasps, and Bees).

In order to perceive the distinctive features of this exten-

$$
\text { * Selected Works. }
$$

Aaron, S. F. The North American Chrysididæ (Trans. Amer. Ent. Soc., 1885).

Blake, C. A. Monograph of the Mutillidæe of North America (Trans Amer. Ent. Soc., xili., 1886).

Cheshire, F. R. Bees and bee-kecping. I. Scientific (Anatomy of the honey-bee). (London, 1886.)

Cresson, E. T. Synopsis of the Hymenoptera of America, north or Mexico (Philadelphia, 188i). Also papers on Ichneumonidæ, bees, etc., in Proc. Phil. Aead. Sc., and Trans. Amer. Ent. Soc., Canadian Entomologist, Proc. Bos. Soc. 1863.

Forel, A. Les Fourmis de la Suisse (Geneva, 1874).

Howard, L. 0. (Artieles on Chaleids in reports and Bnli. of U. S. Entomologist, 18:9-1888.)

A generic synopsis of the hymenopterous tamily Proctotrupida (Trans. Amer. Ent. Soc., xiii., 1886).

Lepelletier, St. Fargeau et Brulle. Histoire naturelles des insectes hymenoptères (Suites ì Buffon, i.-iv. Paris, 1836-45).

Lubbock, J. Ants, Bees, and Wasps (New York, 1882). 
sive order one should examine a honey-bee. Those that we see in our gardens are the workers; the males, or drones, and the females, or queens, are rarely seen out of the hive.

In the first place, see how well-proportioned are the three regions of the body; the head is large in proportion to the

A
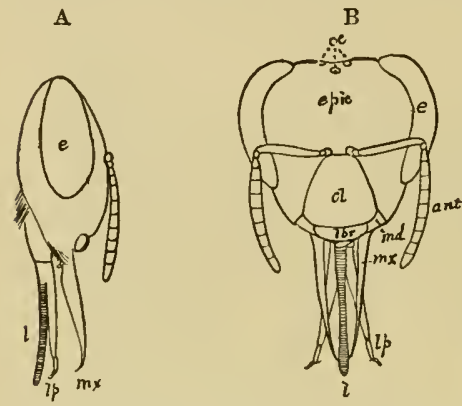

Fic. 205.-Head of a worker hive-bee. $A$, front, and $B$, side view; $o c$, simple, $e$, compound, eyes; epic, epicranium; $\mathrm{cl}$, clypeus: $l b r$, labrum; md, mandible; $m x$, maxilla; $l$. lingua or tongue; $l p$, labial palpi. Magnified.

thorax, which is nearly spherical; and the hind body, which has six visible segments, is short, conical, and attached by a slender waist to the chest. The three regions are more equally developed than in any other order of insects. Moreover, Hymenoptera differ from all other insects in the thorax (in ail except the Tenthredinidx), consisting of four segments, the first abdominal during pupation being transferred to the thorax.

McCook, H C. The natural history of the agricultural ant of Texas (Philad., 1879).

- The honey-ants of the Garden of the Gods, and the occident ants of the American plains (Philad., 1882). Also papers on other ants (Trans. Amer. Eut. Soc., 18\%6, and Proc. Acad. Nat. Sc., Phila., 1877-84).

Mayr, G. Formicina Austriaca; Die Formicicien der Verein. Staaten in Nordamerika, 1886; and others papers in Verh Zool. Bot. Ges, Wien, 1855-86.

Moggridge, J. T. Harvesting ants and trap-door spiders (London, 18\%3-74).

Packard, A. S. Revision of the fossorial Hymenoptera of N. A. (Proc. Ent. Soc., Phila., 186\%- ).

Humble-bees of New England and their parasites (Proc. Essex Inst., iv., 1864).

Saussure, $\vec{H}$ de. Studies of the family Vespidæ (3 vols., 8vo, 75 pls. Geneva, 1852-58).

Synopsis of American solitary Wasps (Smithsonian Misc. Coll., Washington, 1875).

Smith, F. Catalogue of Hymenoptera in British Museum (7 parts. London, 1853-59). (Sce also other papers in Trans. Ent. Soc., London, 1853-59.)

Also the papers of Ashmead, Bassett (on Cyuipidx), Norton (on saw-flies), Patton, Riley, Say, and Walsh (on Cynipidx, etc.). 
Looking at the head, which is carried vertically, the compound eyes are seen to be very large, while the three simple eyes (ocelli) are arranged in a triangle on the top of the head. The antemnx are slender, and elbowed or bent at the end of the long second joint. The large clypeus is succeeded in front by the short, movable upper lip (labrum).

'The mouth-parts are rather complicated, and it is their complexity or high degree of specialization which for the most part gives the bee and others of its order their superior position over other insects.

The jaws are rather large, and eross each other in front, and are much as in beetles and grasshoppers, being adapted for biting. On the other hand, the accessory jaws, or maxillæ, are different from those of any other insects. 'They are long and slender, and, with the under lip, bent under the head. They consist of three joints, the last forming a long flat blade. From the second joint arises a minute two-jointed feeler (palpus).

The under lip is, lowever, the most pecnliarly modified. It consists of three parts; the two outer forming the feclers, and ending in three small joints, while the middle division is the so-called tongue (Fig. 205, l). It is a thin-skinned, long, grooved, rery hairy rod, ending in a spoon-shaped button; extending this into flowers, the bee gathers the nectar. The mouth-parts are thus a set of complicater tools, - the jaws for biting and for use as trowels in making its waxen cells, the sharp lancet-like maxillæ for piercing flowers, and the tongue a sort of writhing, hairy rod, for gathering the sweet liquid secreted at the bottom of flowers.

The wings are seen to be clear and perfectly transparent, with no scales. They are formed of a clear membrane, hence the nanie of the order to which the bee belongs, i.e., Hymenoptera, or membrane-winged. The veins are few, irregular, inclosing a few cells. The hinder pair of wings is less than half as large as the front pair.

The legs are not very long, but very hairy, and the hinder ones have flattened slinnks, while the first toc-joint 
is very broad and flat, with the inner surface covered with dense stiff hairs, upon which the pollen of flowers is stuck, or piled up, so as to form a yellow heap which is borne to the hive.

The sting is formed of three parts, i.e., a sheath or "awl" and two barbed darts. Each dart is grooved, and slides up and down on a corresponding projection or "guide-1"ail" of the awl.

In their moutli-parts Hymenoptera are wonderfully specialized; they can bite, pierce, cut, suck, or lap. They are swift on the wing; their habits are related to their

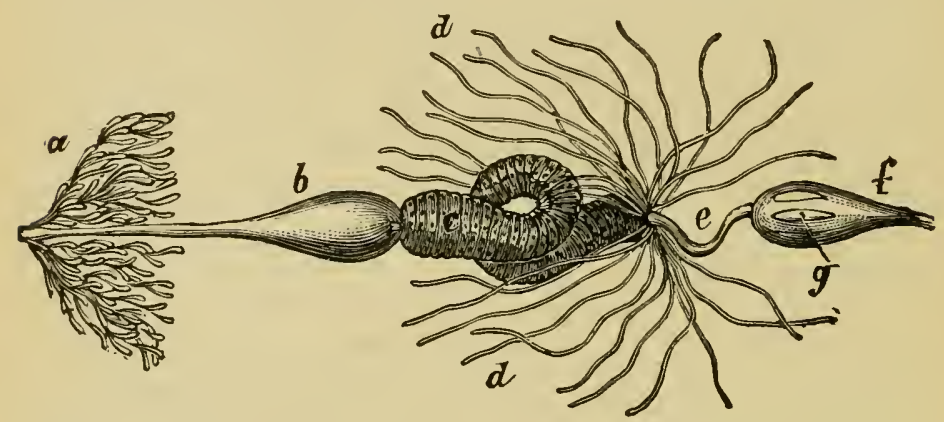

F1G. 206.-Digestive canal of the honey-bee. $a$, salivary glands; $b$, cesophagus; $c$, stomach; $d$, the numerous urinary tubes opeuing into the intestine, $e ; f$, rectum; $g$, rectal glauds. - After Dufour.

great range of station. Their metamorphosis is the most complete of all insects, the young wasps and bees being footless and fed by the parents. From these and other causes the order has flourished to a wonderful degree.

In this order, says Darwin, "slight differences in color, according to sex, are common, but conspicuous differences are rare except in the family of bees." In the Ichneumonidæ the males are almost al ways lighter colored than the females; while in the Tenthredinidæ the males are generally darker than the females. In Tremex columba the female is much brighter colored than the male. In the ants the males of several species are black, the females being testaceous. The sexes of bees often differ in color, the males generally being 
the brightest, and in Bombus and $A$ pathus they are much more variable in color than the females; in sereral species of Xylocopa, while the females are black, the males are bright yellow. (Descent of Man, i. 354.)

The gronp Terebrantia includes those families in which the ovipositor is normal, being adapted for boring, or so modified as to form a saw-like apparatus; while the Aculeata, including the ants, wasps, and bees, have a true sting.*

Family Tenthredinidæ.-Abdomen sessile, not narrowed at the base; ovipositor saw-like; anterior tibie with two apical spurs; the
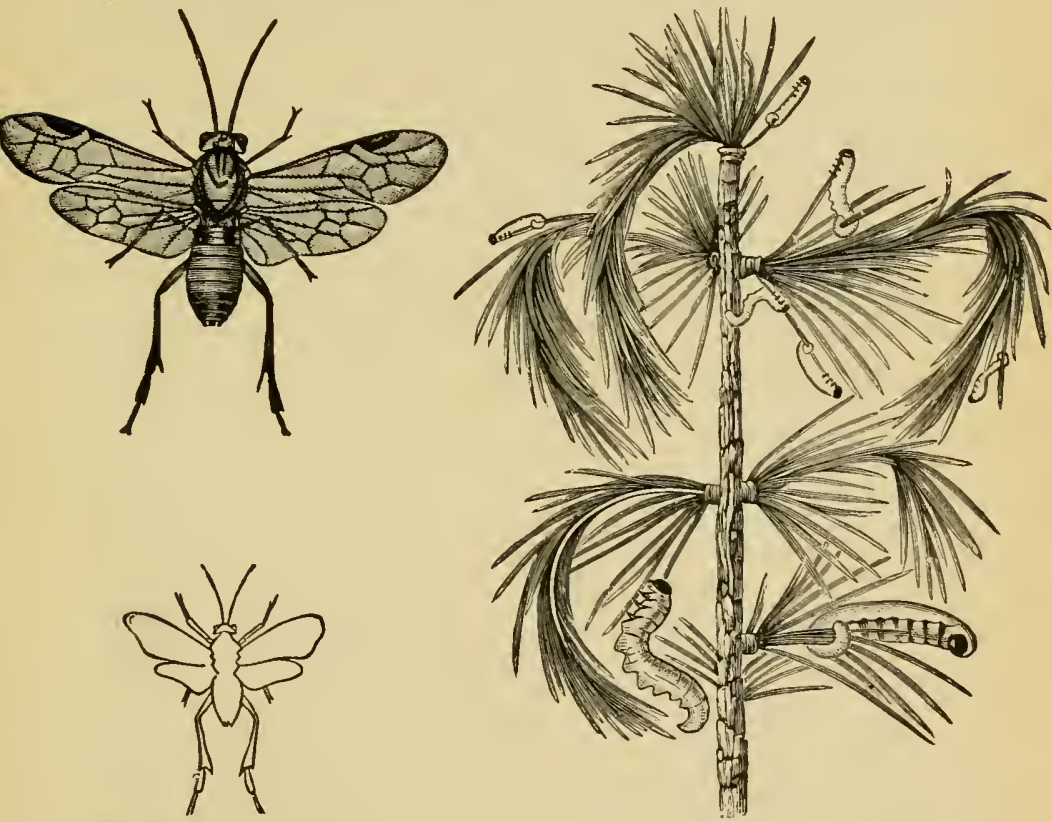

FiG. 207.-The larch saw-fly, natural size and enlarged, with the larch worm of different ages, natural size.-Miss L. Sullivan del.

head is short and transversely oblong, with short, not elbowed, usually simple, sometimes clavate or pectinate antennæ. The larvæ

* In preparing the synopses of the characters of the families, the author has often copied nearly verbatim from Cresson's "Synopsis of the Hymenoptera of America, north of Mexico"' (Phila., 1887). It is not improbable that some of the "funilies" are merely sub-families, as for example in the ants and wasps. 
closely resemble eaterpillars, having from six to eight pairs of

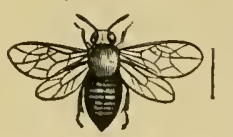
abdominal legs (in Lyda there are no abdominal legs, but a pair of singular, jointed terminal appendages); they are usually of some shade of green, and usually moult four times. Most of the larva secrete silk and spiu a dense, tough

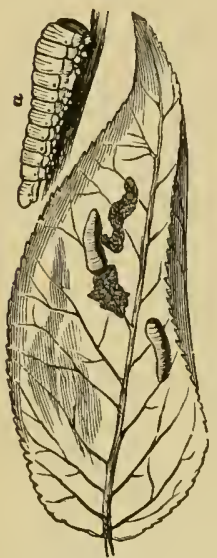

Fig. 208.-Pear slug. worm ( $\alpha$ enlarged), and its saw-fly. cocoon within which the half-formed pupa resides through the winter, finishing its change into the pupa state in the spring. With its sawlike ovipositor the saw-fly punctures twigs and leaves; as in the ease of the lareh saw-fly (Nematus erichsonii Hartig), the two sets of serrated blades of the ovipositor are thrust obliquely into the shoot by a sawing movement; the lower set of blades is most active, sliding in and out alternately, the general motion of each set of blades being like that of a back-saw. The species of Lophyrus have pectinated antennæ, and are destructive to coniferous trees.

The pear slug-worm (Selandria cerasi Peek) and the currant saw-Hy (Nematus ventricosus Klug) deposit their eggs in rows on the under side of the leaves, and there are suceessive broods of worms throughout the summer, the females of this species being agamous. The largest of our saw-flies is Cimbex americana Leach, whose antenuæ are knobbed at the end; while its larva as it lies coiled up on a leaf resembles a helix shell.

Family Uroceridæ. - The species differ from those of the preceding family in the loug, large, exserted borer, adapted for boring into solid wood, and in the fore tibia having but one apical spur. The larvæ are called horu-tails, and bore in pine or hard-wood trees; they are without abdominal feet, and when about to transform spin thim silken cocoons. The species of Cephus bore in the stems of wheat, ete., while Tremex columba Liun. infests elm, maple, and other shade trees, making large, smooth round holes in the tree.

Family Cynipidæ. - The gall-flies are all of small size, the head generally small and transverse, with slender, straight, 12-16-jointed antennæ; the thorax is usually thiek, oval, with a large seutellum, and the wings (sometimes wanting) are without a complete costal vein and stigma, and there are few veins; the abdomen is short, generally oval, more or less compressed, rarely knifeshaped; the second or third segment is the largest, while the ovipositor is spiral and eoncealed within two sheaths. The larva is a short, thick, fleshy, footless grub; and those of many speeies transform within their galls, or enter the earth to pupate.

The egg is deposited in leaves or branches, especially of the oak, rose, vaccinium, etc. Its presence, with pos-

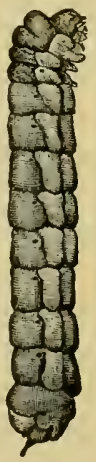

Fig. 209. Hor n tail: la rva of Tremex co. lumba.

Nat. size. 
sibly a slight amount of poison conveyed by the ovipositor, causes an abnormal growth of the plant-cells, until a tumor or gall is formed within which the larva hatches and lives. Each species of fly produces a peculiar gall, which is characteristic of that species. Great numbers of female gall-tlies are agamous, i.e., are produced from unfertilized eggs, there being no males in existence. Thus Cynips quercus-aciculate $O$. Sack., which produces a large gall in the autumu, in the spring of the year succeeding lays eggs which produce galls disclosing a dimorphic form,

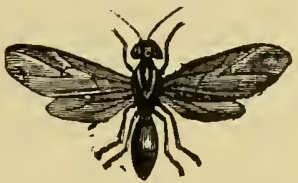

Fig. 210.-Gall-fly of oak. originally thought to be a distinct species, and named $C . q$. spongi. fica by Osten Sacken. The autumn brood of this Cynips consists entirely of agamous females, while the spring brood consists of both males and females; there is thus an alternation of generations, and this is the case in many species. In some cases the two generations belong to what were originally described as separate genera. Thus Adler observed that the European Neuroterus lenticularis produces galls of a certain form on the under surface of oak-leaves, the galls falling off in the autumn, and the fly appearing in the early spring. It then deposits its eggs on the buds of the oak, which produce upon the leaves and stalks of the male flowers galls unlike those of the preceding autumn. Moreover, the fly which emerges from them has been referred to a separate genus as Spathegaster baccarum. This in turn lays eggs which produce the original Neuroterus form; and the Neuroterus generation consists of females alone, while the Spathegasters are of both sexes.

The gali-tlies fall into two sections, the first containing the true

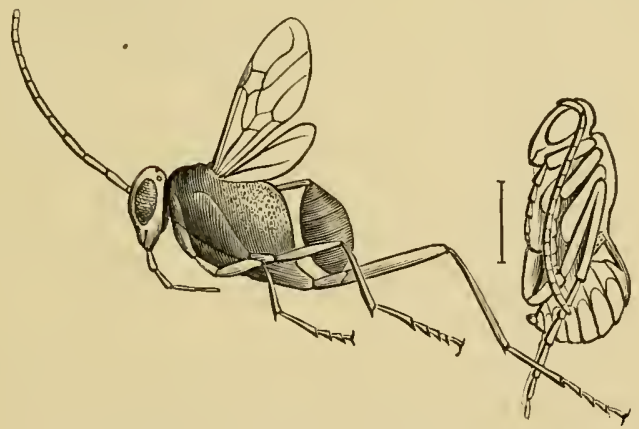

Frg. 211.-Evania lœvigata, male, and pupa.

gall-flies (Psenides) and the guest gall-flies (Inquilines, which are commensals or boarders living at the expense of the true gall-flies), with the peculiar genus Ibalia, while the second includes the Figitides, which are parasitic. In the sub-family Figitinæ the abdomen is elongate-ovate, compressed, with the apex more or less pointed. 
Family Evaniidæ. - These are insect-parasites, and are characterized by the abdomen being attached to the disk or near the base of the metathorax, and not at the apex as is the case in the other families. The abdomen is petiolate and more or less compressed. Evanü lavigata Olivier is parasitic in the eggs of the cockroach (Periplaneta). Fænus jaculator Linn. in Europe lays its eggs in the larvæ of Crabronidæ.

Family Trigonalidæ. - Costal and sub-costal veins separate and distinct, the costal cell being present. Abdomen sub-sessile, short, ovate. Trigonalys.

Family Ichneumonidæ.-In this great family the costal and subcostal veins are confluent, the costal cell therefore absent, while the

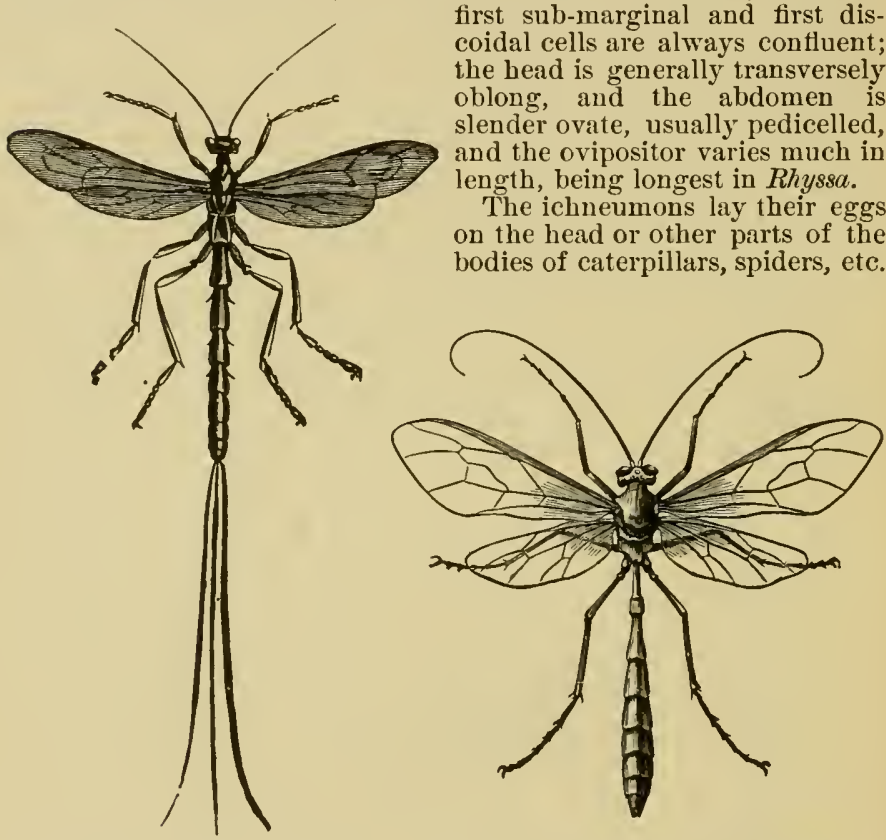

FıG. 212.-Rhyssa. Nat. size. FIG. 213.-Ophion macrurum. Nat. size.

On hatching, the larva, which is a soft, fleshy, footless grub, bores into the body-cavity of its host, and lying there absorbs the blood flowing around it, and thus weakens the caterpillar, so that it dies, or the insect does not live beyond the pupa state. Typical genera are Ichneumon, Ophion, Cryptus, Pimpla, etc.

Family Stephanidæ.--In this very small group the head is globose, the vertex tuberculate and rugose; the costal and sub-costal veins separate and distinct, the costal cell being present. Stephanus cinctipes. 
Family Braconidæ.-The spccies of this numerous group differ from the Ichnenmonidie in slight respects, i.e., in "the absence of the second recurrent vein of the fore wings, and by having the first submarginal cell generally, though not always, separated from the first discoidal cell, and, with the exception of one sub-family, the Aphidine, by the non-existence of a real articulation between the second and third abdominal seg. ments" (Cresson). In their habits and general appearance they do not differ from ordinary Ichneumonids, though, as a rule, of smaller size. The group is represented by Bracon and Nicrogaster; the species of the latter spin their cylindrical cocoons either within the bodies of caterpillars, or fasten them in a thick mass to the exterior. The species of Aphidius are parasitic in Apliides.

Family Chalcididæ. - The fore wings are nearly veinless; the posterior margin of the prothorax not reaching the tegula; while the ovipositor issues from before the end of the abdomen. The Chalcids are generally minute: many of them of beautiful shades of green, with metallic reflections. A goodly proportion of them are
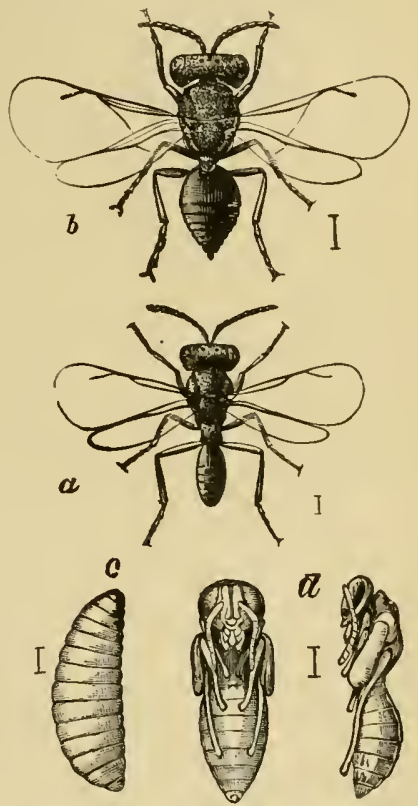

Fig. 214.-Parasite of the cabbage butterfly, $a$, male; $b$, female; $c$, larva; $d$, pupa. secondary parasites, viz., are parasitic on other Chalcids; some deposit their eggs in galls. Typical genera are Pteromalus ( $P$. puparum Linn., Fig. 214), Semiotellus, and Chalcis. Eurytoma hordei Harris is the wheat joint-worm, not being carnivorous.

Family Proctotrupidæ. - In these minute egg-parasites, as many of them are, the protborax extends to the tegulæ, and

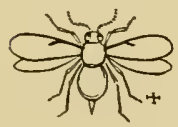
the ovipositor issues from the end or apex of the abdomen. The wings are also almost veinless, and in the minuter forms they are lobed or fissured with long fringes. Many species, as those of Mymar, Teleas, and Platygaster (Fig. 215), lay their eggs in Fis. 215. - Egg- those of other insects, and hence they are the iniparasite if nutest of Hymenopteri. Pteratomus putnami Pack. is but one-ninetieth of an inch long.

Family Pelecinidæ.-In the single genus representing this group the antenne are long, not elbowed, and thread-like; and the male abdomen is clavate, while that of the female is remarkably long and slender. Pelecinus polycerator Drury. 
Family Chrysididæ.-In the species of this interesting group, there

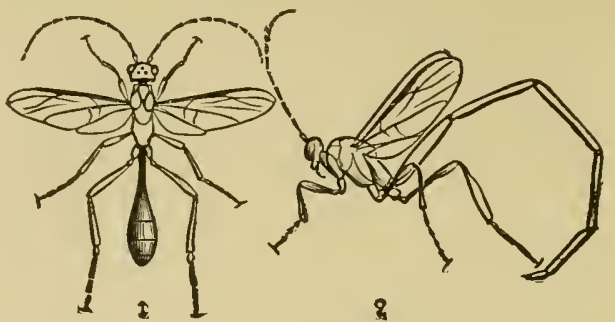

Fig. 216.-Pelecinus, male and female. Natural size.

are only from three to five complete abdominal segments, the

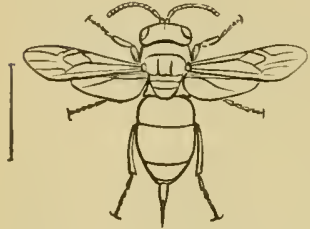

Fra. 217.-Chrysis hilaris. remainder forming a telescopic, retractile tube, containing a sting-like ovipositor.

The Chrysis tlies are blue, green, and ruby-red, with rich metallic reflectious. The females, cuckoo-like, lay their eggs in the already provisioned nests usually of solitary wasps and bees, the larvæe eating the food stored up, causing starvation and death to the young of their hosts. Typical genera are Cleptes, Elampus, Hedychrum, Chrysis and Parnopes.

The ants, formerly all included in the old family Formicidæ, are now regarded as forming a section or super-family Heterogyna, which is characterized by the petiole of the abdomen having one or more scales or nodes; while the antennæ are elbowed. Ants live in societies consisting, besides males and females, of workers. There are five families, characterized as follows:

Family Formicidæ. - In this (and the three following families) the petiole has but a single joint; the abdomen proper (not including the petiole) is not coustricted between the first and second segments, while the mandibles are inserted wide apart. The clypeus is always distinct and often very large; the frontal crest is more or less long, not surrounding the insertion of the antennx, and the petiole is almost always surmounted by an erect scale. Most of our ants belong to this group; their larvæ usually spin a thin but tough cocoon. Ants are fossorial, digging mines and galleries underground, or excavating them in old stumps and trees. A complicated society or nest of ants is called a "formicarium;" the work of which is carried on by the wingless individuals, called workers.

Certain ants enslave other species; have herds of cattle, the aphides; tumnel broad rivers, lay up seeds for use in the wintertime, are patterns of iudustry, and exhibit a readiness in overcoming extraordinary emergencies which shows that they have sufficient 
reasoning powers to meet the exigencies of their life; their ordiaary acts being instinctive, viz., the results of inherited habits. Typical genera are Camponotus, Polyergus, Formica, Myrmecocystus, and Tapinoma.

Family Odontomachidæ.-Mandibles very long and suddenly recurved within at tip, inserted close to each other. Odontomachus.

Family Dorylidæ.-Ants with a very small or even indistinct

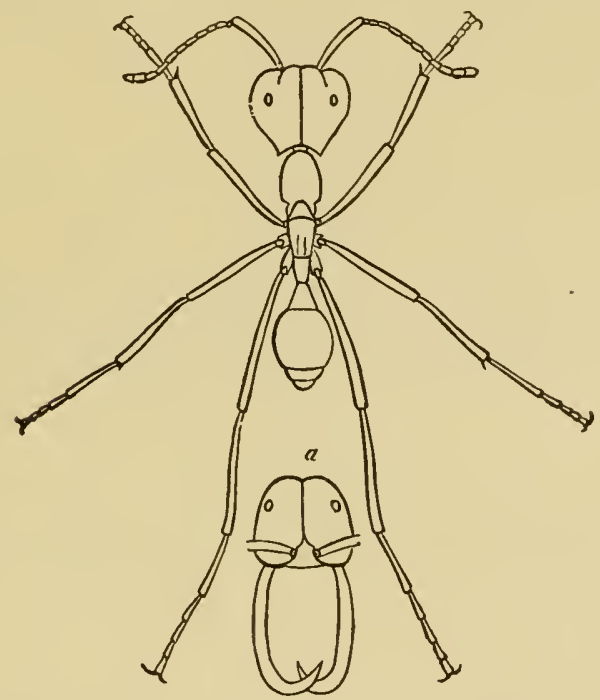

FIG. 218.-Eciton mexicana; worker-major; $a$, front view of head.

clypeus; frontal crest very short; petiole depressed, nodiform. Represented by a single genus, Labidus, of which only the males are known; and they are supposed to be the males of Eciton.

Family Poneridæ. - Abdomen proper constricted between the first and second segments. Ponera.

Family Myrmicidæ. - In the stinging ants the petiole consists of two joints. Myrmica molesta Say is found all over the world; other typical genera are Atta, Eciton, Pseudomyrma, Pogonomyrnex, and Pheidole. The workers are divided into two sets; those with large heads are called worker-majors or soldiers, and the smaller ones worker-minors.

The group of Fossores, or fossorial Hymenoptera, consisting of the sand-and wood-wasps, etc., is divided into a number of families, some of which may yet be united. The petiole is simple, i.e., not formed into scales or nodes; there are no workers, though the females of the Mutillidæ are 
always wingless. The legs of the females are adapted for burrowing, and not fitted for collecting pollen.

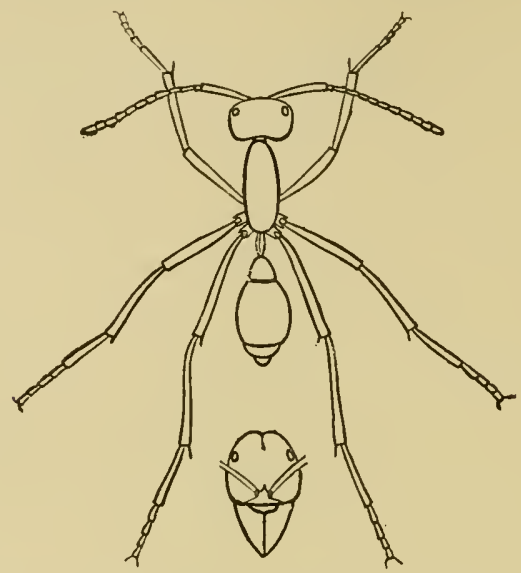

FIG. 219.-Eciton mexicana; worker-minor.

Family Mutillidæ. - Females wingless; in this as atso in the three following families the prothorax is produced behind, so that the hinder angles reach the tegulie. The intermediate tibix have two apical spurs. In this group, as well as in the Scoliidæ, the first ventral segment of the abdomen is distinctly separated from the second by a more or less deep constriction. The Ifutillids are usually scarlet, or scarlet and black, and the body is more or less hirsute; they sting

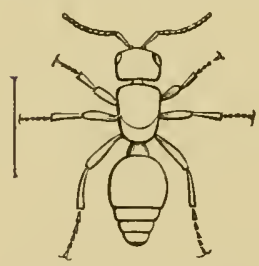

Frg. 220.-Mutilla, female.

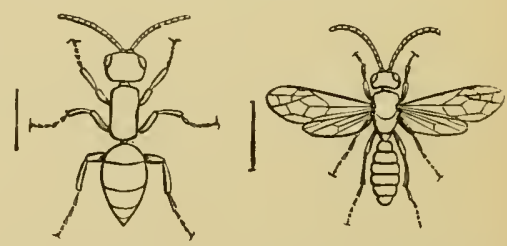

Fig. 221.-Myrmosa, male and wingless female.

badly, and store their burrows in the sand with flies and other insects. Mutilla ferrugata Fabr. (Fig. 220); Myrmosu unicolor Say (Fig. 221).

Family Scoliidæ.-The females are always winged, and the middle tibix have but one apical spur. The head is broad in front, the eyes indenterl, while the female antemue differ from those of the males in being short, thiek, and elbowed. The species of Scolia are black banded with yellow, and live as parasites in the grubs of beetles. Tiphia inornata Say is a common black species. 
Family Sapygidæ. - In these sand-wasps there is no constriction between the first and second segments of the abdomen; the lind legs are short, and the eyes indented. The species enter the burrows of Osmia and other bees, depositing their eggs in the cells of their hosts. Sapyga martimii Smith.

Family Pompilidæ.-The body of these often very large sand-wasps is oblong and more or less compressed; the antennie are not elbowed, and the hind legs are long, reaching beyond the end of the abdomen, while the eyes are not indented. These active, black wasps storc

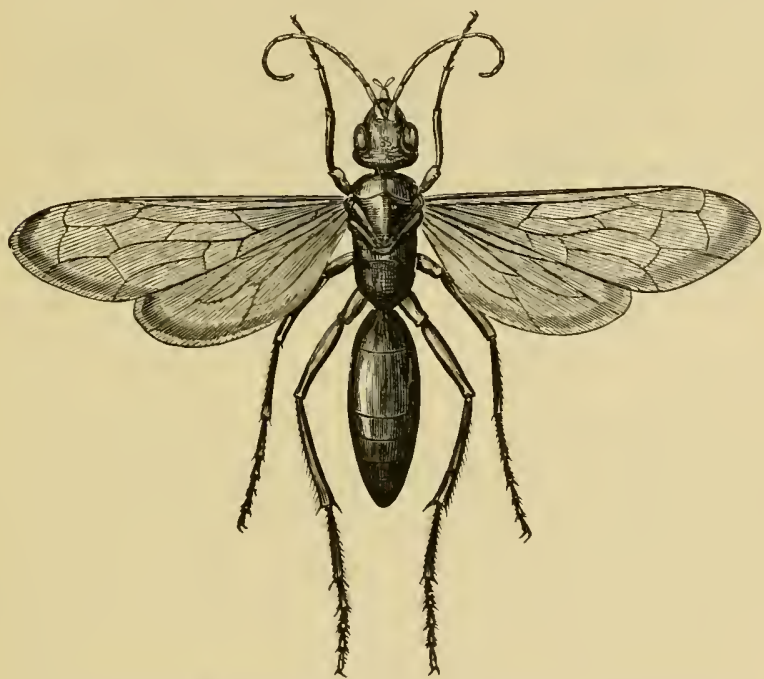

FIa. 222.-Pompilus formosus, the Tarantula-killer. Natural size.

their burrows, made in the sand, with spiders. One of the largest species is Pompilus formosus Say.

Fimily Sphecidæ. - Very rapacious wasps with a pedicelled abdomen, the petiole slender, cylindrical, smooth; flagellum slender at the end; middle tibia with two apical spurs. They rapidly dig in gravel-paths and sand-banks, provisioning their vests with caterpillars, grasshoppers, or spiders, which they sting between the joints of their body, paralyzing them so that they live on until their own larve hatch and eat them. Sphex ichneumonea Linn. fills its burrow with grasshoppers. The species of Pelopæus are called "muddaubers," as they build their cells of dabs of mud on the walls of houses, etc.

Family Ampulicidæ.-Prothorax long and narrow, ending in front in a neck; metathorax long, truncated behind; clypens kecled, beak-like. Rhinopsis crnaliculutu Say; Ampulex sibiricu Fabr.

Family Larridæ. - Wasps of this group have the mandibles notched on the ontside near the base; the labrum is concealed; the abdomen is oval conical. They burrow in sand-banks, provisioning their 
cells with locusts, grasshoppers, etc. Larrada semirufa Cresson preys on young locusts.

Family Bembecidæ.-The labrum in this family is disinet, exserted, and sometimes long and beak-like. Stizus speciosus Say

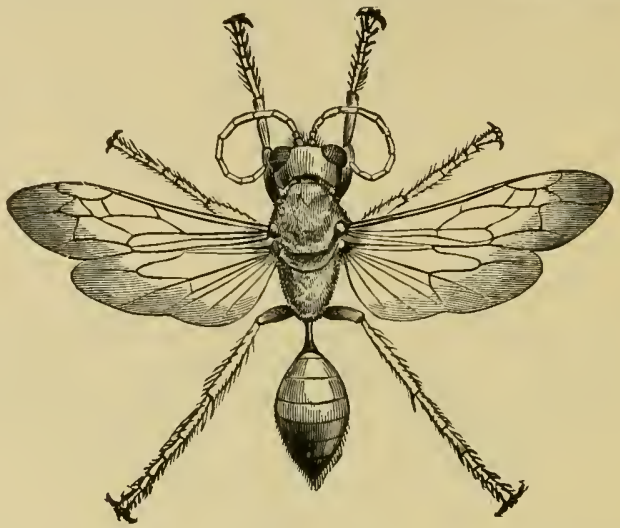

FIG. 223.-Sand-wasp, Sphex ichneumonea. Natural size.

preys on the Cicada; the species of Bembex seize flies, bearing them to their nests; our common speeies is Bembex fasciata Fabr.

Family Nyssonidæ. -Labrum short, either not or scarcely exserted. Nysson lateralis Say; Gorytes flavicornis Harris. These saud-wasps prey on flies, Tettigoniæ, ete.

Family Philanthidæ. - In these wasps the prothorax is very short, transverse, not extending back to the tegulie; the fore wings have

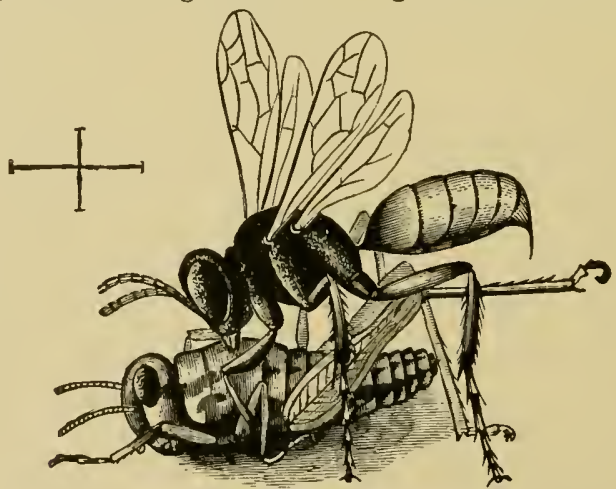

FIG. 224.-Larrada grasping a young locust, and about to sting it.

three complete sub-marginal eells, and the abdomen is eithcr sessile or sub-sessile. Philenthus vertilabris Say; Cerceris deserta Say. These wasps provision their nests with the grubs of weevils and Buprestids, and adult beetles, as well as honey-bees. 
Family Mimesidæ-Abdomen petiolate, the petiole flattened and usually furrowed above; antenna clavate; middle tibiæe with but one apical spur. Mimesa cressonii Pack.; Psen lencopus Say.

Family Mellinidæ. - This group is represented by a single genus, in which the abdomen is petiolate; the head cubical, front very broad, eyes indented; and the first sub-marginal cell receives a recurrent vein. Mellinus bimaculatus Say.

Family Pemphredonidæ. - Wood-wasps, in which the anterior wings have two complete submarginal cells; prothorax short, transverse; metathorax short, rounded posteriorly; clypeus not carinate or beak-like. Stigmus fraternus Say mines the stems of the Syringa; Cemonus inornatus Harris burrows in the elder; Passalacus mandibularis Cresson burrows in company with the two preceding species.

Family Crabronidæ. - These wood-wasps are easily recognized by their cubical heads; short and wide clypens; and by having but one submarginal and two discoidal cells. The habits of the species are extremely interesting. Crabro sex-maculatus Say mines decaying wood, and $C$. singuluris Smith bores in posts. In the males of Thyreopus the fore legs have shield-like expansions which are either striped or dotted with b]ack. Rhopelum pedicellutum Pack. bores into the stems of the rose, Corcorus, Spirara, etc.

The section or super-family Diplopteryga, corresponding to the Vespidæ of early authors, comprises the true wasps, in which the wings when at rest are folded lengthwise. The prothorax reaches back to the base of the wings, the eyes are kidney-shaped, and the legs are smooth, not spiny or bristled.

Family Masaridæ.-Antennæ clubbed at tip. Mrasuris vespoides Cres.

Family Eumenidæ. - In this and the next family the antennæ are filiform. Middle tibiæ with one spur at apex; tarsal claws onetoothel; solitary; no workers. The solitary wasps are represented by the genera Eumenes, Odynerus, etc. Eumenes fraterna Say constructs a round cell of pellets of mud, as big as a cherry, which it fills with small caterpillars; Odynerus albophaleratus Saussure also preys on small caterpillars, which it stores in round mud-cells.

Family Vespidæ. - In the social or paper wasps, the republic is a numerous one, there being many workers. They all have two spurs at the end of the middle tibix. $P_{0}$ listes americanus Fabr. and other species build nests consisting of few cells in one row, attached mouth downwarl to bushes. The species of Vespa build several tiers of cells, arranged mouth downward, and enveloped by a wall of several thicknesses of paper. Our commoner species are Vespa arenuria Fabr. and a larger species, the FIG. 225.-Vespa maculata. Nat. size. white-faced wasp, Vespa maculeta Linn. The females found the colony, and raise a brood of workers, which early in the summer assist the queen in completing the nest. 
The bees, formerly included in the family Apidæ, belong to the section Anthophila, which is divided into two families. In all bees the basal joint of the hind tarsi is (ex-

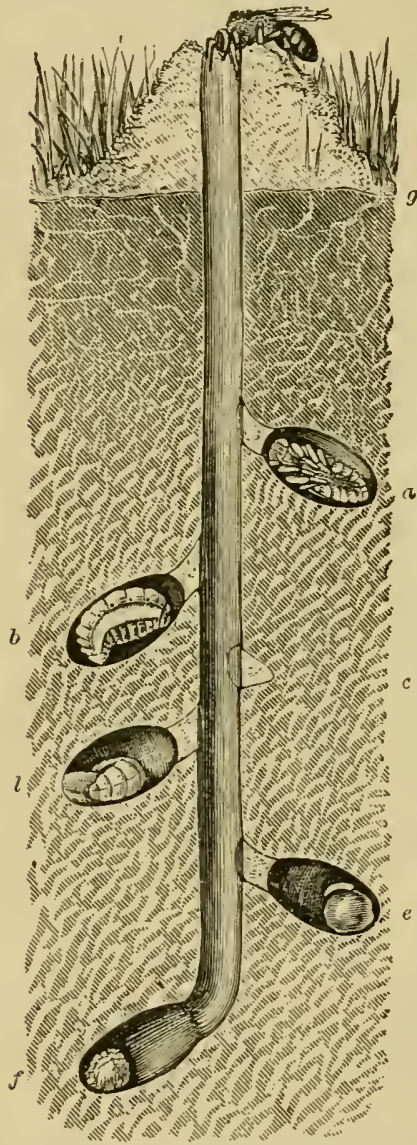

Fig 226.-Nest of Andrena. g. level of ground; $a$, first made cell, containing a pupa; $b, i$, larvæ; $e$, pollen-mass with an egg laid on it; $f$, pollenmass freshly deposited by the bee. Natural size.-After Emerton. cept in the parasitic species of Nomada, etc.) broad and flat, generally bristly, and adapted for carrying pollen.

Family Andrenidx.-Solitary bees with the labium flattened, shorter than the mentum. Halictus parallelus Say excavates in fields nests like those of Andrena ricina Smith (Fig. 226).

Family Apidæ. - In the social bees, where there are, as in Bombus and Apis, numerous workers, the labium is slender, not flattened, and is longer than the mentum; the basal joints of the labial palpi are longer than the others.

The queen humile-bee hiber. nates, and in the spring founds her colony by laying up pellets of pollen in some subterranean mousenest or in a stump, and the young, hatching, gradually eat the pollen, and when it is exbausted and they are fully fed they spin an oval cylindrical cocoon. The first brood are workers, the second males and females. The partly hexagonal cells of the stingless bees of the tropics (Melipona) are built of wax or elay, while the hexagonal cells of the honey-bee are made by the bees from wax secreted by minute subcutaneous glands in the abdomen. Though the cells are hexagonal, they are not built with mathematical exactitude, the sides not al ways being of the same length and thicksess.

The cells made for the young or larval drones of the boney-bee are larger than those of the workers, and the single queen cell is large and irregularly slipper-shaped. Drone-eggs are supposed by Dzierzon and Siebold not to be fertilized, wuuc the rucen-ber is the only 
animal which can produce either sex at will. Certain worker-eggs have been kuown to transform into queen-bees. On the other hand, worker-bees may in rare cases lay drone-eggs.

The egg from which the queen develops is like that of a worker, the difference arising in larval life, owing to a change of treatment of the larva by the nurses, its food, derived from pollen by digestion,* being different from that provided for the worker. The first or old queen, when the population of the hive becomes excessive, leaves the hive to establish a new colony. This is called "swarming." The queen is very fertile, having the power of laying between 2000 and $3000 \mathrm{eggs}$ a day, or " $t$ wo eggs per minute for weeks in succession." Cheshire states that the larva feeds four days, moulting probably six times; and finally, when it stops eating, lines its cell with a silken cocoon, though before this can be spun a cover or "sealing" is put over the call by the workers, there being minute openings in the cover for the passage of air into the ccll. A strong colony or "stock" may contain as many as 12,000 larve, all of which are fed by the nurses or workers with pollen and honey. In about a fortnight from the time of seal. ing, the bee bites through the sealing, and twenty-four hours after drying and preening itself, enters upon the duties of the hive.

* Cheshire says: "The secretion, commonly, though, as I hold, erroneonsly, called 'royal jelly,' is added unstintingly to the end." The first brood food "is a highly nitrogenous tissue-former, derived from pollen by digestion, and having apparently a singular power in developing the generative faculty; for I find drone larva receive much more of it than those of workers, to whom any accidental excess possibly gives the power of ovipositing, as we find it in the abnormal fertile worker." He thinks also that the queen, if not always, at least during the time of egg-laying, is fed by the workers from the secretion of the chyle-gland (No. 1), with probable additions from some of the other three, there being four kinds of glands, in all, in the bead and thorax. (Cheshire's Bees and Bee-keeping, p. 82.)

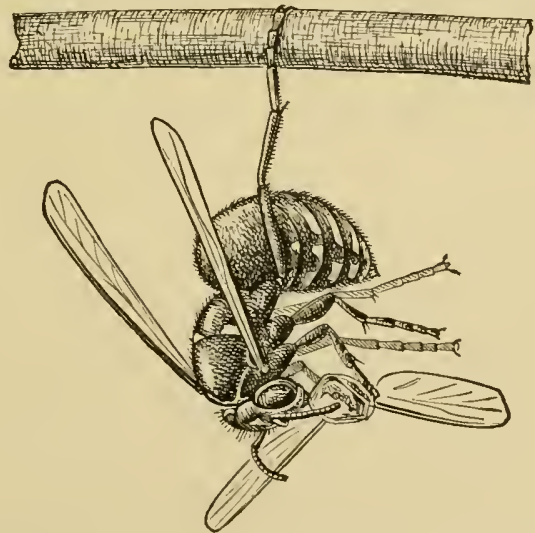

Wasp hanging by one foot, and eating a fly.-After Emerton. 


\section{CHAPTER IV.}

\section{INSECT-ARCHITECTURE.}

MANY young naturalists are deterred from studying in. sects by the lack of books enabling them to readily identify the species they collect; bnt if handicapped in this direction, they can nevertheless observe the curions habits of insects, and form most interesting collections of their cocoons, nests, and various contrivances for concealment from their enemies.

Man's earliest, most primitive attempts at architecture were undoubtedly in the direction of obtaining shelter from too great heat or cold, from rain and snow, and from hostile beasts and more hostile men. For the same reason insects make shelters of various sorts, both for their eggs, their young, and themselves. More unconscious (and often, perhaps, semi-conscious) ingenuity is expended by insects, especially the social kinds, than by any of the higher animals, not even excepting the birds. We know that fishes in rare instances build rude nests, and show some slight degree of care for their progeny; squirrels and mice faintly imitate birds in nest-building: but where even among birds do we find nests so complex and eumningly contrived as those of ants, paper-wasps, and social bees? Do we really know that birds and beasts, the domesticated species excepted, are, as regards architectural skill and general reasoning power, any higher in the intellectual scale than the social insects, with their different kinds of individuals assigned to this or that duty, their laborers and soldiers, and, in the case of ants, their system of slave-labor, their herds of mileh-eows (the Aphides), and genins for honsekeeping, nursing, and eivie police duties? But not content 
with generalities, let us look at a few instructive examples of insect-architecture, begimming with the simpler and ending with the more complex.

Perhaps the first impulse of an insect in endeavoring to escape from some enemy is to burrow in the soil, or, if aquatic in its habits, to bury itself in the mud at the bottom of the pool or stream it inhabits. Snch habits once

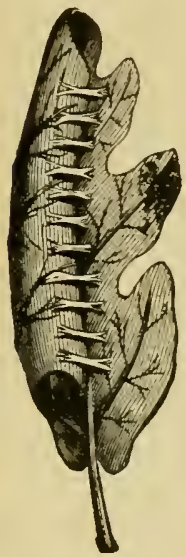

F1G. 227.-Oak-leaf rolled sidewise.

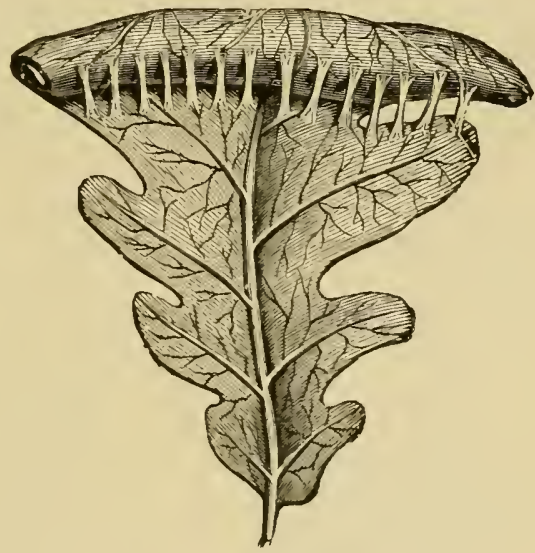

Frg. 228.-Oak-leaf rolled at the end.

acquired and transmitted wonld lead a wood-eating or leafgnawing insect to save its life by burrowing into and mining leaves or bark, or even rolling over the edge of a leaf and hiding under it; and such insects after a number of generations, meeting with success in the struggle for existence, without much doubt founded the insect-guilds, if we may so style them, of masons, carpenters, and builders.

When we consider how many kinds of leaf-rollers there are among different orters of insects, we may perhaps regard this as the readiest and most simple method of forming a shelter. Among the caterpillars of the smaller moths there are multitudes which roll up portions of the leaf, whole leaves, or even bind several leaves together with silken cords. How this is done may be seen by 
Figs. 22\%-230, taken from the work of Réaunur; but any one can find similar examples, as we have done, on our

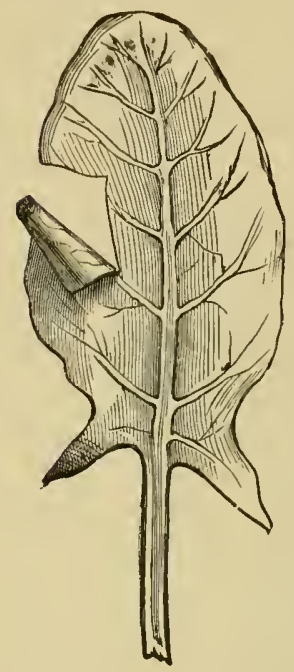

FIG, 229.-Sorrel-leaf cut walks!

by a caterpillar. own oaks and willows. By watching the little worm with a lens, one can realize how deftly the unconscious mechanic begins to turn over the point of a leaf, holding it in place by first attaching a single silken strand to a fixed point so as to give the first turn, and then gradually and with a good deal of pains hauling the rolled portion over, and attaching new strands until finally a well-shaped roll is made in which the insect can safely reside during its caterpillar existence. In a single season an industrious collector could make a most interesting collection of tents and rolls formed by caterpillarsand what a zest would it give to his

Another order of rolls are those made by the leaf-rolling weevils, whose very long snouts have short jaws at the end, to aid in the work; though, judging by the readiness with which they use their feet, there scems to be some intelligence lodged in those appendages. The singular thimble-like rolls of Attelabus rhois may be found in June and July on the alder. When about to lay her eggs, the female begins to eat a slit near the base of the leaf, on each side of the midrib and at right angles to it, so that the leaf may be folded together. Before beginning to roll up the leaf she gnaws the stem nearly off, so that, after the roll is made and has dried for perhaps a day, it is easily detiched by the wind and falls to the ground. Then folding the leaf, she tightly rolls it up, neatly treking in the ends, mitil a compact, cylindrical, solid mass of vegetation is formerl. Before the leaf is entirely rolled, she deposits a single egg, rarely two, in the 
middle, next to the midrib, where it lies loosely in a little cavity. While all this is going on her consort stands near by, and she occasionally runs to him to receive his caresses, again resuming her work. These rolls remain on the

A

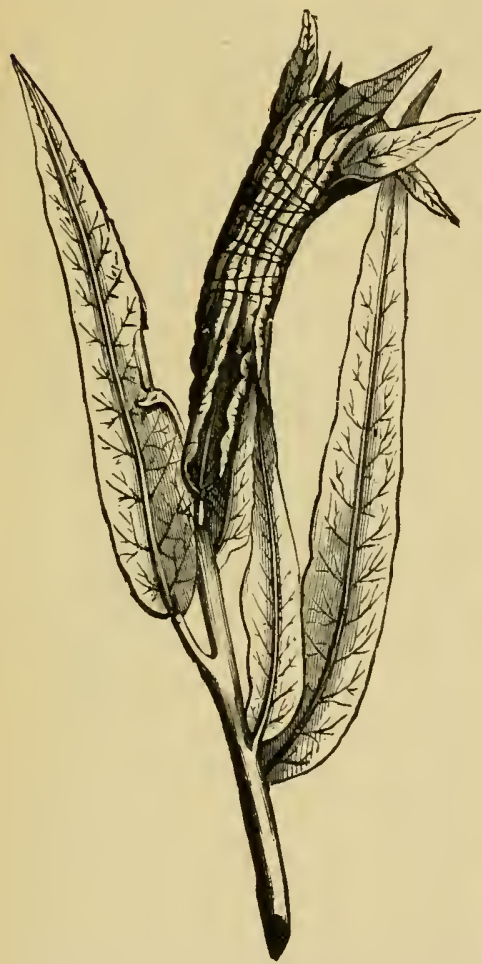
bushes sometimes for several days, but probably drop by the time the larva escapes from the egg; and it seems probable that the grub uses the roll for a shelter until it matures and is ready to enter on its transformations to a beetle. Another species found on the oak does not devote the whole leaf to a single roll, for three

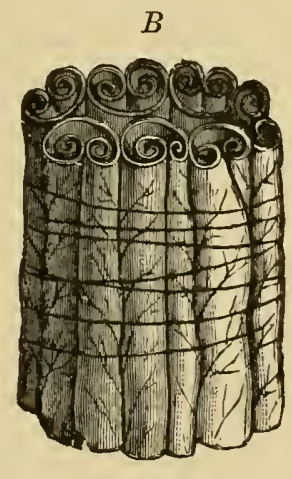

FIG. 230.-A, willow-leaves rolled by a caterpillar; $B$, willow-leaves rolled-seen in section.

or four small rolls may be found on one leaf.

The gall-makers are not the species of Cynips alone, but also certain gnats and Aphides, including the Phylloxera, which inhabit shelters, due to the morbid growth and multiplication of cells on the leaves and twigs, or roots, as the 
Case may be, stumg by the palent, whose instincts are exereised in selecting the proper plant, and portion of plant, to sting. Although the gall-flies are not the direct architects of the galls, no collection of insect-products would be complete without a series of galls, of which there are so many kinds.

Intermediate between leaf and wood miner's, and caseworms, are certain Pyralid moths which not only crumple and roll up the leaves of plants, but piece out their mines by tubular additions to the openings, which form eases in which the caterpillar securely hides. As examples are Acrobasis juglandis and Phycita nebulo. Another Pyralid (Phycis rubrifasciella) mines the buds and recently expanded young leaves of the pig-hickory, and also bores into the base of the leaf-stalks. It also builds out the mouth of its mine, adding a tube formed of grains of

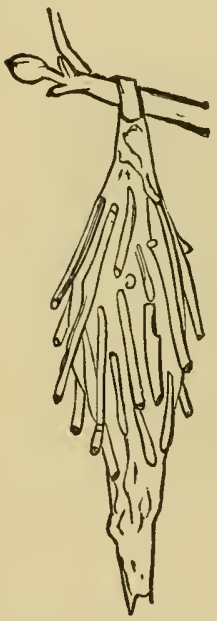

F1a, 231. - Case of the basket-worm. -After Harris. its excrement, in which it lives and finally transforms.

Besides mining leaves, which is one of the humblest kinds of architectural effort, certain Tineid moths construct flat, oval, or cylindrical silk-lined sacks or cases in which they live, and which, like Diogenes and his tub, they carry about with them. The clothes-moth in its larval stage constructs the too-familiar cases of felting, formed of closely-woven bits of woollen and lined with silk. A whole group of sackbearers (Psychids), small and large, build
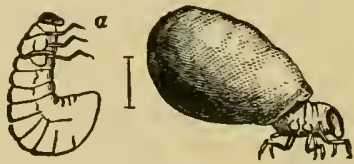

Fic. 232.-Larva and case of Chlamys.

spindle-shaped sacks covered with bits of leaves and twigs, which are so arranged as to resemble basket-work. One of 
these in Europe (Psyche helix) constructs a snail-like case. Beetle-grubs rarely construct such cases, but the little Chlamys is a genuine sack-bearer, as is another leaf-eater, Coscinoptera dominicana.

All the Caddis-flies are sack-bearers in their larval state, and the larvæ are from this habit called case-worms. 'The worm apparently builds them by adding grain after grain of coarse sand to the mouth of the tube, lining the interior with silk; if there is moss at hand, bits are fastened to the exterior, or large pieces of leaves. Fig. 233, $a$, represents
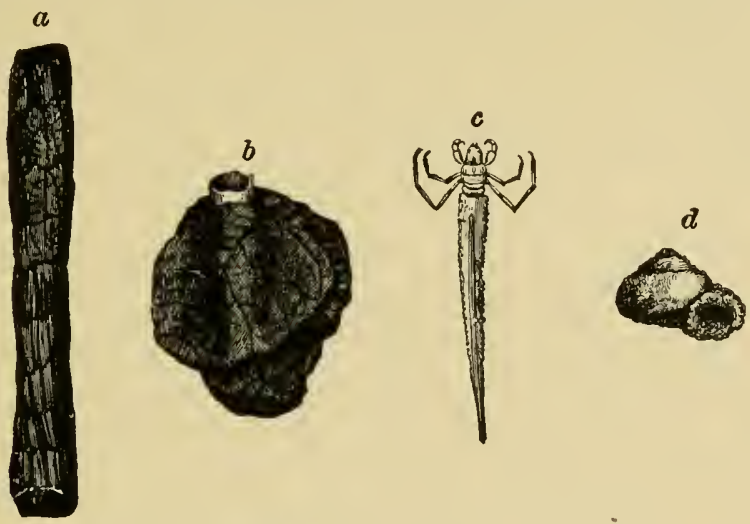

FIG. 233.-Different forms of cases of caddis-flies.

the case of the European Phryganea grandis; but we have a similar one, formed by cutting a leaf into a broad ribbonlike strip and then rolling it into a tube. Some are like horns, while the case of Helicopsyche (Fig. 233, $d$ ) has often been mistaken by shell-collectors for a fresh-water snail (Valvata).

As architects ants are preëminent, and they evince their skill in construction not by mounds alone, but also by digging deep wells and tunnelling broad rivers, as well as in laying out roads above and below ground.

While our native species are not known to form elaborate nests, a greenish ant in India (Ecophylla smaragdina) is 
said to form a nest, somctimes a foot in diameter, by drawing living leaves together without detaching them from the branch, and uniting them with a fine white web. We wonder at the instinct of the tailor-bird, but there are thousands of species of insects which show as much intelligence in sewing together their shelters. Another Indian ant makes a small nest, about half an inch or more in diameter, of some paper-like material, which it fixes on a leaf. In Brazil certain ants construct large nests, called "negro-heads," which resemble wasp-nests, being attached like them to the branches of trees, though on removing the onter wraps they are found to differ in having no regular cells, but consist of intricate curred galleries leading into the interior chambers and passages.

But it is in the nests of wasps and bees that we have constructions which attest the highest degree of architectural skill known in the animal creation, those of man alone excepted. It is to be observed, however, that here, as elsewhere, Nature does not make a leap. She does not present us at the outset with fully developed paper-wasps' nests and colonies, or the highly complicated nest and colony of the honey-bee. These were, without much doubt, gradual developments, the results of many failures and successes of which we have no record. There is a long series of wasps, for example, whose nests show different degrees of complexity, which gradually lead up to the nest of the paper-wasp with its numerous cells arranged in several stories, and all walled in by papery layers.

We have first simple holes excavated in the sand by the Sphex ichneumonea (Fig. 223). We have noticed a company of nearly a dozen of these large reddish wasps, whose bodies are covered by a rich golden pubescence. Each one for itself-for in these solitary wasps there is no combined action--began to dig its hole in a gravelly walk, removing the little stones and coarse grains of sand with its jaws; as the hole deepened it loosened the earth with its jaws, and threw it out of the hole both with its jaws and fore 
feet, and when the sand accumulated so as to be in its way it would retreat backwards and push the dirt still farther back from the mouth of its cell with its lind legs. In this way, working literally with tooth and nail, it dug a shaft five or six inches deep, and then flew away after grasshoppers to store it, finally filling the mouth so that no distinct traces of its work would remain.

A decided step upward is the lome of the inud-dauber. This wasp moistens the dirt with its saliva, forming pellets of mud, which it plasters on walls or rafters, storing the cell with spiders, etc. In our common yellow-legged muddauber (Peloperus flavipes) the cells are built of long pellets of mud placed in two rows, and diverging from the middle.

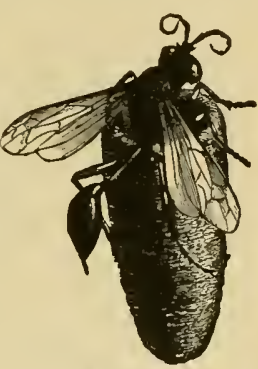

FIG. 234-An African mud-dauber.

'The wood-wasps excavate their burrows in the hollow stems of pithy plants, such as the elder, syringa, raspberry, or blackberry, the idea seeming to be to save as much labor as possible; some species going so far, or rather doing so little, as to refit old nail-holes for their nesting purposes.

Coming to the true solitary wasps, we find species of very different nest-building habits. While one kind of Odynerus builds separate cells of mud, placing them in oak-galls or in deserted nests of the tent-caterpillar, another bnilds several cells together under a common covering of sandy mud fastened to a stack of grass. More of an architectural effort is seen in the flask-shaped cells of mud which Eumenes fraterna builds, attaching several of them in a row to a branch, filling the interiors with little caterpillars.

Of a more advanced order is the nest of Icaria, which shows that each cell is built independently in regular hexagons; sometimes the cells are arranged in two or three rows; while in the nest of our Polistes annuluris, often to be found attached to bushes, the cells are crowded together in one plane or story. But in a delicate nest of a South 
American wasp (Mischocyttarus), which is suspended by a long pedicel, the cells, few as they are, are arranged in two stories. The transition from this form to the nests of Vespa and allied forms, which are covered in with walls of paper with a single entrance, is not great. The paperwasps begin to build in early summer, and we could then begin to form a series of nests in different stages of construction which would be very instructive.

From among the bees there can be selected a series, showing that at the ontset bees began, so to speak, in an uncertain and tentative way to build their homes. Withont much doubt the solitary bees preceded in geological history the social species, though at present the geological record is a blank, for species of Andrena, Xylocopa, Bombus, and Apis occur in amber and other Miocene deposits, and we know as yet nothing of the geological succession of bees, none being found in the Eocene Tertiary.

As with the wasps, we may begin our review of the evidences of the nesting skill of bees by first considering those that simply tunnel the soil, as Andrena, which makes its nests in pastures, consisting of a straight tubular well or shaft, from which diverge short passages leading into the brood-chambers (Fig. 226).

Certain other bees excavate tunnels or refit the hollows of elder and other pithy shrubs. The species of Osmia, little green and blue bees, build oval cells of mud, placing them in different situations, either under stones or in partly decaying trees. Osmia simillima, one of our commonest species, is shrewd enough to avail itself of the empty galls of a Cynips common on the oak, placing them in a row on the vanlted arch of this large oak-apple.

A step higher brings us to the leaf-cutter bees (Megachile), which cut out circular pieces of rose-leaves, a single bee sometimes building thirty cells, using during the process as many as a thousand pieces. With the pieces thus obtained she lines tubular hollows in trees, etc., and 
stores in each cell a mass of pollen, on which an egg is placed, for the food of the young grub.

Carpenter-bees are well named, as with their strong jaws
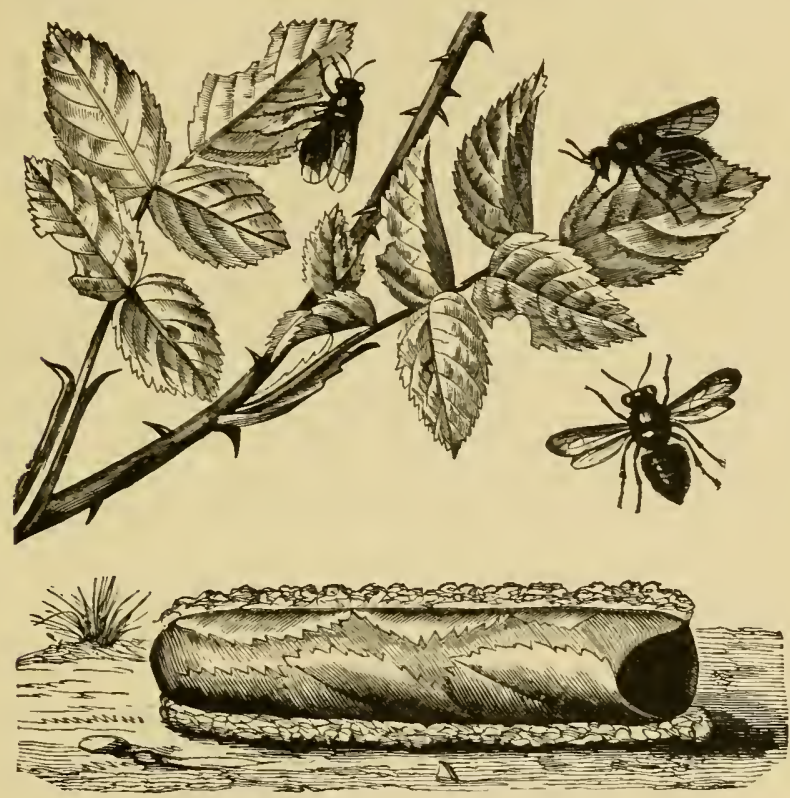

FIG. 235.-Leaf-cutter bee and nest.

they bore perfectly regular holes in pine boards, as straight as if made with an anger. The tunnel is sometimes made from 12 to 18 inches in length, and abont half an inch in diameter, so as to readily admit the bee. The industrious little carpenter, working as rapidly as she can, excarates her holes (in pine wood) at the rate of about a quarter of an inch a day. Mr. Angus says: "If I mistake not, it takes her about two days to make her own length at the first start; but this being across the grain of the woor may not be so easily done as the remainder. which runs parallel with it. She always follows the grain of the wood, with the exception of the entrance, which is about her own length." 
Passing over the humble-bees, which are not skilful architects, we come to the workers in wax, such as the stingless bees of the tropics (Trigona and Melipona), and the hive-bee, our only domestic insect. The cells of Melipona are hexagonal, but the honey-cells are irregular and larger in size. The cells of an Australian Trigona are arranged in combs similar to those of the common wasp. Hence these bees are a connecting link between the solitary bees and the honey-bee, whose elaborate style of architec ture has been so often recounted.*

* See, for an account of the cells of the honey-bee, the latest and best work on the honey-bee, "Cheshire's Bees and Bee-keeping" (2 vols., with numerous excellent illustrations; London, L. Upcott Gill, 1880 7 ); for essays on the cells of bees, and the mathematical principles and theory of construction, the writings of Maraldi, Réaumur, Huber, J. Wyman (Proc. Amer. Acad. Arts and Sciences, vii., 1866), S. Haughton, G. R. Waterhouse, F. Smith, Tegetmeier, Darwin, and the author's "Guide to the Study of Insects."

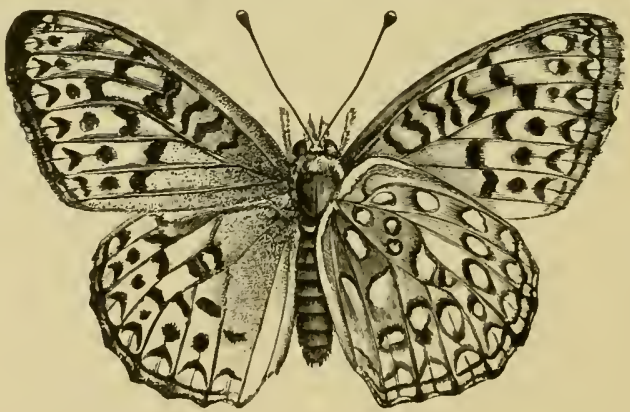

Argynnis aphrodite; under side shown on right. 


\section{CHAPTER V.}

\section{INSECTS INJURIOUS AND BENEFICIAL TO AGRICUL.}

TURE.

Economic Entomology relates to those insects which prey on our crops; it comprises a study of their habits. classification, and the remedies against their attacks; it also includes a study of insect-parasites of the domestic animals, of man himself, as well as household pests. In short, this branch of applied science treats of the habits and best means of destroying any insect which is in any way injurious to human interests. 'To succeed well in this applied science one must be a close, patient observer and of a practical turn of mind.

The number of injurious insects in the United States is large and increasing. Owing to the destructiveness of introduced species, ${ }^{*}$ the large areas devoted to special crops, and other causes, crops in this country seem far more liable to insect-depredations than in the old World, and the evil is perhaps especially felt in the more recently settled portions of the country.

Prof. J. A. Lintner, the State Entomologist of New York. in his first report remarks: "There is probably not a single

* The most obnoxious insects brought accidentally from Europe are the following: the wheat-midge and Hessian fly; eurrant-worm (Nematus ventricosus), oyster-shell bark-louse, apple Aphis, hop-louse, grain Aphis, and several other speeies of plant-lice; the eoddlingmoth, cabbage-butterfly (Pieris ropre), eabbage-moth (Ephestir interpuntella), currant-borer ( Egeria tipuliform is), asparagus-beetle, cloverroot borer, onion-fly (Phorbia ceparmin), and several other root-flies; also some of our eut-worms appear to have heen introduced from Europe.

On the other hand, we have unwittingly sent to Europe the grape Phylloxera. 
crop cultivated which the infesting insects do not diminish by at least one-tenth-an amount of injury which would hardly be noticed. They often injure crops to the extent of one-fourth or one-half, and occasionally entirely destroy them, as during the ravages of the wheat-midge in this State in 1854-185\%. One of our ex-Governors, in his agricultural addresses, has frequently urged that insect-depredations upon crops of one-fourth or one-half their value should be regarded as a direct tax of twenty-five per cent or fifty per cent levied upon their full value, and collected, perhaps, year after year, withont a show of resistance; but which each farmer could, and therefore should, resist, and thereby relieve himself from at least a portion of the burden."

The following estimates of the losses incurred by the people of the United States will canse one to realize how large a sum, much of which by proper care and foresight could be saved, is annually wasted. The agricultural products of the United States are said to amount annually to $\$ 2,500,000,000$; of this amount we probably annually lose by the attacks of insects not far from one-twentieth, or $\$ 100,000,000$. The losses from the ravages of the locust in the border or Western States in $18 \% 4$ were estimated at $\$ 45,000,000$; those occasioned by the chinch-bug in Illinois in 1864 amounted to over $\$ 73,000,000$, and in Missouri in 1874 to $\$ 19,000,000$. The average annual loss to the cottonraising States from the cotton-worm from 1860 to $18 \% 4$ was estimated as about $\$ 15,000,000$.

While it is estimated that each species of plant on the average supports three or four species of insects, very many plants, especially those in gencral cultivation, afford subsistence to many more; for many species which now attack garden regetables or fruits. before the settlement of this country lived on plants of different species, but now concentrate their attention on one. Thus the Colorado potato-beetle in its native state lived on a species of Solanum; and most if not all the other species now injurious to the 
potato, before its introduction lived on other plants. The insects of the apple and other fruit trees before those trees were introduced into America lived on certain forest-trees, such as the oak, elm, ash, mountain-ash, wild cherry, poplar, willow, etc.

Our forest-trees are also peculiarly liable to depredations from insects, certain species of which attack the roots, others the bark, others the wood, many the leaves, and a few the fruit or nuts. Thus the oak harbors between five or six hundred species, the hickory affords maintenance to one hundred and forty recorded species, the birch to over one hundred species, the maple to eighty-five, the poplar to seventy-two, while the pine yields food to over a hundred different kinds.

We will now very briefly notice the most common and formidable pests of some of our cultivated plants, referring the reader for further information to the list of works and reports on economic entomology at the end of this book.

\section{Insects Injurious to Field and Garden Crops.}

\section{Injuring Wheat.}

The Joint-worm (Isosoma hordei Harris).-A minute, footless, yellowish-white maggot often forms blister-like swellings between the second and third joints of the stalk, immediately above the lower joint in the sheathing base of the leaf; remaining throngh the winter in the stubble, straw, or harvested grain, and changing into a small, slender, black, fonr-winged insect, which deposits its eggs in the stalks of young wheat late in May and in Jume.

This is one of the Chalcididæ, and, unlike the majority of the family, lives on plants. When wheat or barley is from eight to ten inches high its growth becomes suddenly checked; the lower leaves turn yellow, and the stalks become bent. If the butts of the straw are now examined, they will be found to be irregularly swollen and discolored between the second and third joints, and, instead of being 
hollow, are rendered solid, hard, and brittle, so that the straw above the diseased part is imporerished and seldom produces any grain.

REMEDY.-Burn the stubble in the autumu or early spring for several years in succession.

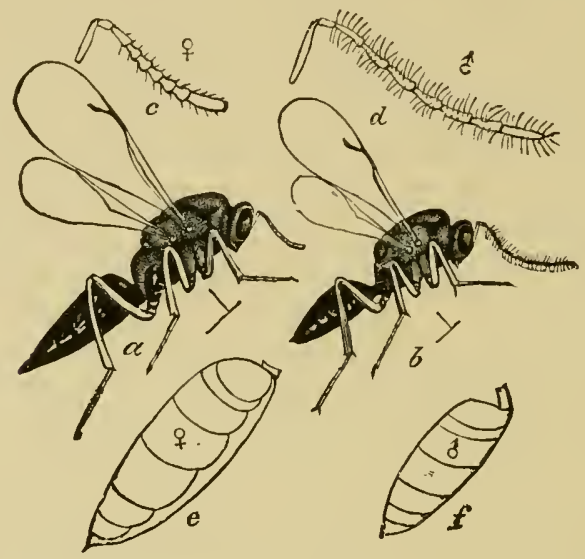

FIG. 236.-The joint-worm fly. $a, c, e$, female; $b, d, f$, male.-After Riley.

The Hessian Fly (Cecidomyia destructor Say).--Two or three small, reddish-white maggots embedded in the crown of the roots or jnst above the lower joint canse the stalks and leaves of wheat to wither and die; the maggots harden, turn brown, then resemble flaxseed, and finally ehange into little black midges with smoky wings, which lay from twenty to thirty eggs in a crease in the leaf of the young plant.

There are two broods of the fly, the first laying their eggs on the leaves of the young wheat from early in April till the end of May, the time varying with the latitude and weather; the seeond brood appearing during August and the early part of September, and laying about thirty eggs on the leaves of the young winter wheat.

'T'he eggs hatch in about fonr days after they are laid. Several of the maggots or larva make their way down to the 
sheathing base of the leaf, and remain between the base of the leaves and the stem near the roots, causing the stalk to swell and the plant to turn yellow and die. By the end of November, or from thirty to forty days after the wheat is sown, they assume the "flaxseed" state, and may, on removing the lower leaves, be found as little brown, oval, cylindrical, smooth bodies, a little smaller than grains of rice. 'They remain in the wheat until during warm weather; in April the larva rapidly transforms into the pupa within its flaxseed skin, the fly emerging from the flaxseed case about the end of April. 'The eggs laid by this first or spring brood of flies soon hatch; the seeond brood of maggots live but a few weeks, the flaxseed state is soon mdergone, and the autumn or second brood of flies appears in Angust. (In some cases there maly be two antumn broods, the earlier Angust brood giving rise to a third set of flies in September.)

There are several destructive ichneumon parasites of the Hessian fly, whose combined attacks are supposed at times to destroy aboit nine-tenths of all the flies hatched. Of these, the most important is the Chalcid four-winged fly, Semiotellus (Merisus) destructor (Fig. 23\%, i, much enlarged), which infests the flaxseed; and the egg-parasite, Plutygaster herrickii Pack.

REMEDIEs. - By sowing a part of the wheat early, and, if affected by the fly, ploughing and sowing the rest after September 20 , the wheat-crop may in most eases be saved. It should be remembered that the first brood should be thus circumvented or destroyed in order that a second, or spring, brood may not appear.

If the wheat be only partially aflected, it may be saved by fertilizers and careful cultivation; or a badly damaged field of winter wheat may thus be recuperated in the spring.

Pasturing with sheep, and consequent close cropping of the winter wheat in November and early December, may cause many of the eggs, larva, and flaxseeds to be destroyed; also, rolling the ground may have nearly the same effect.

Sow hardy varieties. The Underhill Mediterranean wheat, and especially the Lancaster variety, which tillers vigorously, should be sown in preference to the slighter, less vigorous kinds in a region much infested by the tly. The early (August) sown wheat might be Diehl; the late sown, Lancaster or Clawson.

Of special remedies, the use of lime, soot, or salt may be recommended, also raking off the stubble; but too close cutting of the 


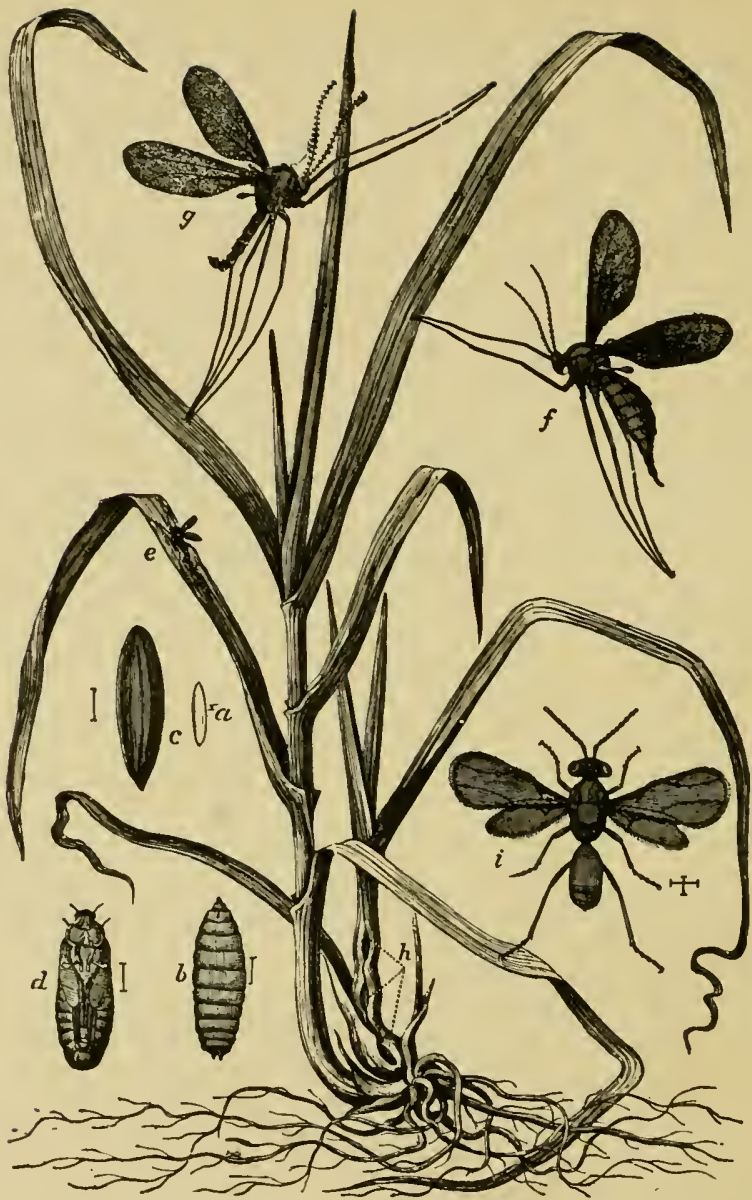

FIG. 237.-The Hessian fly and its transformations.

A healthy stalk of wheat on the left, the one on the right dwarfed and the lower leaves beginning to wither and tuin yellow; the stem swollen at three places, near the ground where the flaxseed $(h)$ are sitnated, between the stem and sheathing-base of the leaf. $a$, egg of the Hessian fly (greatly enlarged, as are all the figures except $e$ and $h) ; b$, the larva, enlargel, the line by the side, in this and other figures, showing the natural length; $c$, the flaxseed, puparium, or pupa-case; $d$, the pupa or chrysalis: $e$, the Hessian fly, natural size, laying its eggs in the creases of the leaf; $f$, female Hessian $H s$, much enlarged: $g$, male Hessian $\mathrm{H} y$, much enlarged; $h$, flaxseed between the leaves and stalk; $i$, Chalcid parasite of the Hessian fly, male, enlarged.-Fig. $b$ drawn by Mr. Riley; Fig. $d$ by Mr. Burgess; Figs. $a, c$, and $i$, by the author; $h, g$, $f$, drawn on wood by L. Trouvelot.

(To face page 195.) 
wheat and burning the stubble are of doubtful use, as this destroys the useful parasites as well as the flies.

The Wheat-midge ( $D i$ plosis tritici Kirby).This species injures the head. Several minute orange-red maggots, an eighth of an inch long, crowding around the kernels of wheat, cause them to shrivel and dry when ripe. The maggots descend into the ground and spin minute cocoons, from which in the following $J$ une emerge bright orange - colored midges. This insect is far less common and destructive than the Hessian fly.

Remedr. - Plough deep after harvest, and burn the "screenings" after threshing.

Chinch - bug (Blissus leucopterus Say). - This bug, while young, sucks the roots of wheat and corn, afterwards infesting in great numbers the stalks and leaves, puncturing them with its beak. It appears early in June, and there is a summer and an antumn brood, the adults hibernating in the stubble.

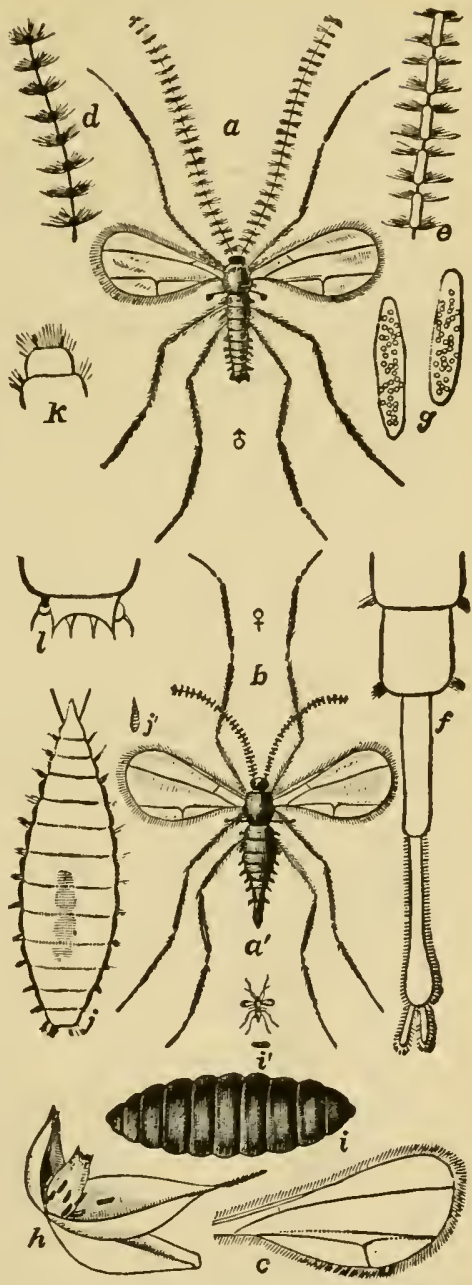

Fig. 238.-Wheat-midge. $a$, male; $b$, female; $c$, wing, enlarged: $d$, antennal joints of male; $e$ of female: $f$, ovipositor, with its two sliding tubes aud terminal appendages for guiding the eggs, $g: h$, larvæ on a kernel; $i$, the larva, enlarged; $i$, the same. natural size: $j$, the same crawling, with its antennæe extended; $k$, anterior, $l$, posterior, end.-After Fitch. 
ReMedies. - Burn the stinbble, old straw, and corn-stalks among weeds in fence-corners iu the early spring. Sow small grain early in the spring; fall plonghing and the nse of the roller upon land thai is loose and friable are recommended. Where irrigation is practised, fields may be tlooded for several days in sucission, and thus the insects driven off or drownerl. A kerosene emulsion, sprayed with the force-pump and cyclone nozzle, will destroy immense numbers; and deep furrows, with a $\log$ drawn through them to grind the soil into dust, will also prove useful in arresting their progress.

Grain Aphis (Aphis avence Fabr.).Multitudes of dark plant-lice, clustering on the heads of wheat in August; in

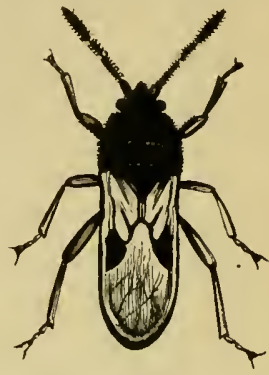

FIG. 239.-Chinch-bug. certain years blacken the fields of grain, and by sucking the kernels cause them to shrink in size and to diminish in weight.

The Northern Army-worm (Leucania unipuncta Haworth).-This caterpillar periodically ravages wheat and other grain fields in the Middle and Northern States, marching through them in great armies. 'The

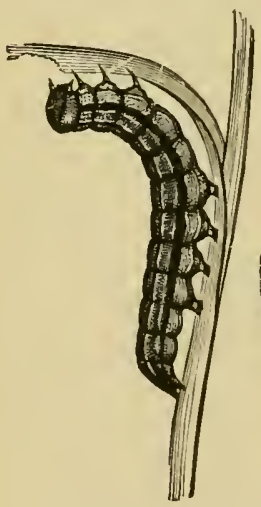
moth appears late in the summer or early in autumn, when it hibernates, after laying its eggs near the base of leaves of grasses; or farther south it

FIg. 240,-Northern army-worm. a, moth, with details.-After Riley.

hibernates in the chrysalis state, laying its eggs in April and May, but later northward. 'The eggs hatch, the young appearing eight or ten days after, and the worms are most 
destructive in a wet summer succeeding a dry one, at the time when the wheat is in the milk. The caterpillar state lasts a month; the chrysalis state two weeks, unless it hibernates.

'The caterpillar is an inch and a half long; the head is covered by a network of confluent spots, and along the middle of the face run two lines diverging at each end. $\Lambda$ light-colored waved line just above the legs is sncceeded by a dark one, then a light one edged with two thread-lines; while the upper part of the body is dark, with an interrupted white thread running along the middle of the back. The moth is rusty, grayish-brown, sprinkled with black specks; and the species is called unipunctu from the single white discal dot of the fore wings.

REMEDIES. - The best preventive remedy is to burn meadows and grass-lands, where the eggs are laid, in autumn. When the armies are in motion and threaten a field of wheat, the latter should be protected by a deep trench with steep or undermining sides, in which fires are kindled or kerosene is poured. The use of the ditches may be supplemented by dusting the grass or wheat for a few feet on each side of the ditch with Paris green.

The Wheat-head Army-worm (Lencania albitinea).-This caterpillar injures the heads of wheat, rye, and barley, beginning at the base, sometimes at the centre of the ear, sometimes hollowing out the soft grains, leaving nothing but the shell and the chaff. The caterpillar is like the foregoing species, but is striped with sulphur-yellow and light and dark brown lines. The insect is common from Maine to Kansas.

\section{The Wheat Thrips (Thrips tritici of Dr. Fitch).-} This is an exceedingly minute, active, long, narrow, leaping insect of a bright yellow or shining black color, occurring in numbers on the heads and stalks in Jme and July, puncturing and thus exhausting the juices of the kernels, and rendering them dwarfish and shrivelled. Another kind common on wheat in New York, in Jume, is the threebanded 'Thrips (Coleothrips trifasciate Fitch).

Other wheat-insects are certain species of Oscinis, Chlorops, 
and Meromyza, which injure the stalks and leaves. The roots are eaten by tho white grub, wire-worns, etc., while stored grain is destroyed by the caterpillar of the Angoumois moth (Gelechia cerealella), by the grain weevil (Sitophilus granarius), and by the grain Sylvanus (S. surinamensis).

\section{Injuring Corn.}

Cut-worms (Agrotis suffusa D. \& S. and other species). -Not corn alone, but other cereals, the grasses, and most garden vegetables are indiscriminately attacked by different species of caterpillars of Agrotis and allied genera, which are called cut-worms from their habit of gnawing or cutting off the leaves or heads of young succulent plants as they are coming up out of the ground. They are thick, with a distinct horny scale (prothoracic plate or shield) on the segment next to the head, and are usually marked with shining and warty, or smooth, spots of the same general color as the rest of the body, and are usually longitudinally striped. They are to be seen early in spring hiding under sticks, boards, and stones, having hibernated in this state. They

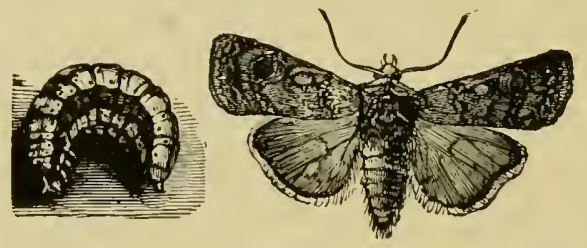

FIG. 241.-Cut-worm and its moth.-After Riley.

feed by night, hiding in the daytime, and the chrysalids are situated under ground. They transform into moths, sometimes called dart-moths, which may be known by their crested thorax and ciliated or (rarely) pectinated antennæ, while the fore wings are rather narrow, usually with a dark dot near the middle of the wing, and just beyond a reniform or kidney-shaped mark; there is usually a basal, median black streak. The moths appear in midsummer, and lay their eggs near the roots of grasses; these hatch in the 
autumn, the worms living on the roots and spronts of herbaceous plants, and on the approach of winter descending below the reach of frost.

REmedies, - Before planting, the seed-corn should be soaked in copperas-water; while late in autumn corn-land should be ploughed deep so as to turn up the half-grown worms, and expose them to winter colds and insectivorous birds. When the worms have begun their attacks, search should be made for them by digging up the soil around the plant. They may also be trapped in holes made by a stake in corn-hills, or near cabbage-plants, etc. According to Riley they may be destroyed by the wholesale by dropping between the rows of the crop to be protected, at nightfall, balls or masses of fresh-cut grass, clover, or turnip-leaves which have been sprinkled with the Paris-green or London-purple solution.

Wire-worms.-Eating the roots of corn, wheat, grass, etc., hard, cylindrical, reddish worms, tapering alike towards each end of the body, and changing into snapping beetles. (See family Elateridce, p. 109.)

Remedies. - They may be caught by plaeing slices of potato, turnip, or apple in the beds, and examining the under sides every morning.

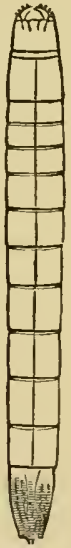

FIg. 242,-Wireworm.
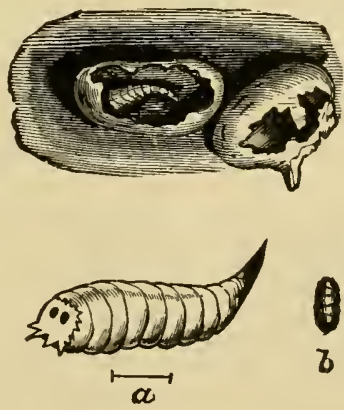

Fig. 243.-Corn maggot, $\alpha$, larva; $b$, pupa-case.-After Riley.

The Corn-maggot (Anthomyia zece Riley). - Gnawing seedcorn after it is planted, a maggot which sometimes abounds so as to nearly ruin entire corn-fields. 
The Corn-weevil (Sphenophorus zece Walsh). -Puncturing large holes in young corn near the base of the stalk, before it has spindled, and sometimes destroying whole fields of young corn, a rather large black weevil, nearly half an inch long.

The Spindle-worm (Achutodes zece Harris).-Boring in the stalk before the corn spindles, cansing the leaves to wither, a caterpillar an inch long, smooth and naked, with the head and last segment black. When the leaves begin to wither, cut open the stalk and remove the worm.

The Stalk-borer (Gortyna nitela Guenée).-Boring in the stalks of corn, potato, tomato, etc., a caterpillar of a pale livid hue, with light stripes along the body; also sometimes boring into the cob of growing Indian corn.

This worm also bores in dahlia and aster stalks, and may be cut out with a penknife, and the split in the stalk will heal by being closed with a piece of thread.

Besides these pests, corn is often attacked by the chinchbug, and sometimes by the boll-worm, as well as the caterpillars of the Io and Arge moths.

\section{Injuring the Cotton-plant.}

The Cotton Army-worm (Aletia argillacea Hübner).This caterpillar often feeds in vast numbers on the leaves of the cotton-plant. It has a looping gait; is slightly hairy,

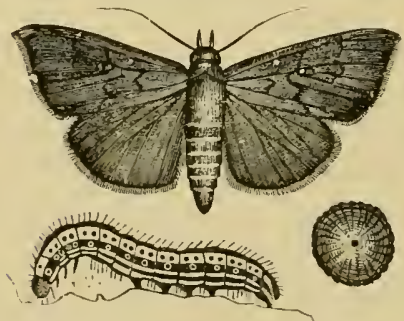
green, dotted with black along a subdorsal yellowish line, with black dots beneath; and changes to a pale-reddish-brown moth. The insect, as shown by Riley, "never hibernates in either of the first three states of egg, larva, or ehrysalis, and it survives the winter in the moth or Fig. 244. - Cotton-worm; egg and imago state only in the southern
moth. portion of the cotton belt." The moth, he adds, hiber- 
nates principally under the shelter of rank wire-grass in the more heavily timbered portions of the South, and begins laying its eggs ( 400 to $500 \mathrm{in}$ number) on the ratoon cotton when this is only an inch or two high. The localities where it hibernates, and where consequently the earliest worms appear, seem to be more common in the western part of the cotton belt ('Texas) tham in the Atlantic cotton States. It is inferred that from this region the moths emigrate east and north, laying their eggs later than the original 'T'exan brood, as in Alabama, Georgia, and northward. The recently hatched worms of different sizes were found late in March on ratoon cotton in southern Georgia and Florida, and in late seasons from the middle of April to the middle of May, though they do not attract the attention of planter's until the middle or last of June. In midsummer the period from hatehing to the time when the moth lay's her eggs is less than three weeks, while in spring and late antumn twice that time may be required. There are thus in the northern cotton States at least three "crops" or broods of caterpillars in a season, while in Texas there are at least seven annual generations. 'I'he first generation is only local, but in 'lexas, says Riley, "The third generation of worms may become, under favoring conditions, not only widespread but disastrous, and the moths produced from then so uumerous that they acquire the migrating habit. This generation appears in south 'Texas during the latter part of June, and in south Alabama and Georgia somewhat later," and this is the first brood which attracts general attention. When the worms are very abundant and the cotton well " ragged," the moths, driven by need of food for their progeny, and with favoring winds, migrate to distant points, and thus spread late in summer northward, and they have been seen as far north as Boston, Buffalo, and Racine, Wis. At the same time these northern specimens are so fresh that they are supposed to have been lored on some unknown northern food-plant. This point is not yet settled.

The earliest worms are confined to the low lands and to 
luxuriant plants; severe rains destroy them, as do late cold rains, while frequent summer rains favor their development, and hot, dry weather is destructive to them.

The natural enemies of the cotton-worm are numerous; birds, toads, lizards, and certain kinds of ants prey on them, besides ground-beetles, bugs, and a number of species of ichneumons, including an egg-parasite ('Trichogramma).

REMEDIES. - While many moths can be destroyed by lights, the universal remedies by which great numbers of the worms are destroyed are Paris green, petroleum emulsions, and Persian insect-powder; and among devices for applying the liquid insecticides the centrifugal or cyclone spraying-nozzle is the most efficacious.

The dry preparation is one pound of the green to from 20 to 35 pounds of cheap flour, or, instead of flour, land plaster (gypsum) or cotton-seed meal. The best preparation of Paris green consists of 1 pound to 40 gallons of water. London purple may be applied dry, using 2 pounds to 18 of flour, etc.; or wet, one half a pound to 50 or 55 gallons of water.

A fine spray of kerosene oil applied to the leaves will kill all the worms in a remarkably short time; but as petroleum in any form injures the plant, the oil must be so diluted as to injure only the worm and not affect the plant. Prof. Barnard suggested the use of milk as a diluent, and finally an emulsion was perfected by Mr. Hubbard for orange insects, which is now in general use. Cotton-seed emulsions are less efficacious than those made with petroleum.

Another important insecticide for field use against the cotton-worm is pyrethrum or Persian insect-powder, applied by a bellows, or in water solution, the powder heing simply stirred up in water (200 grains to 2 gallons of water), applied by means of a fountain-pump or an atomizer. The inventions for applying insecticides, both dry and wet, are very fully describel and illustrated in Riley's report on the cotton-worm, forming the fourth report of the U. S. Entomological Commission.

\section{Injuring the Potato.}

The Colorado Potato-beetle (Leptinotarsa 10-lineata Say). -Devouring the leaves, a large, thick-bodied, reddishorange grub, with black spots on the sides, changing usually under ground into a large hemispherical yellow beetle, about half an inch long, with ten wide black stripes on the back; three broods of the grub appearing in one season. Originally an inlabitant of Coloralo, this destructive beetle is a constant plague all over the Northern and Middle 
States, as well as Canada, New Brumswick, and Nova Scotia.

Remedies.-The universal remedy is Paris green, one part mixed with about twenty parts of cheap flour, and clusted with in ciredgingbox over the vines early in the morning while the dew is on the ground. As the dry powder blows about, and is a poison, Paris green being a

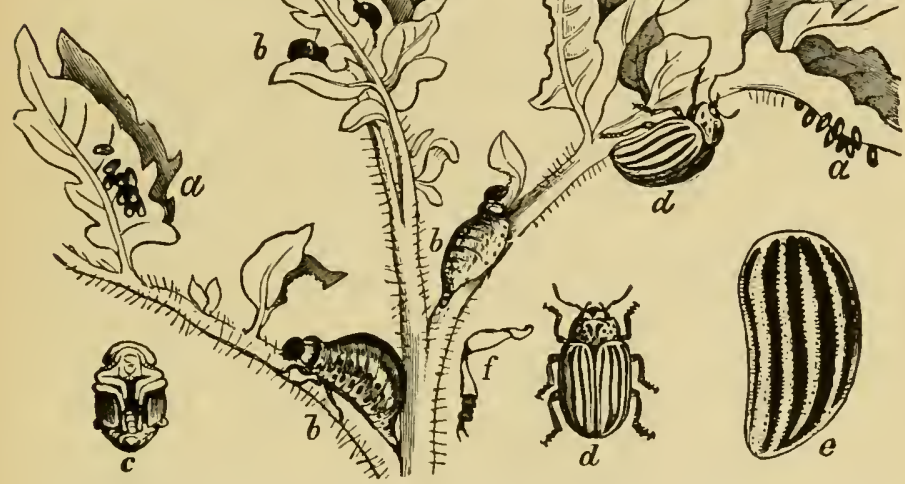

FIa. 245.-Colorado potato-beetle. $a$, eggs; $b, b, b$, larva; $c$, pupa; $d$, beetle.

preparation of arsenic, it is better to apply, with a spraying-machine or watering-pot, a liquid preparation, i.e., a mixture of Paris green and water. On small farms and in gardens near the dwelling-house Paris green should be used with caution, as it has been known to poison cows and horses.

Blistering-beetles (Macrobasis cinerea Fabr., Epicauta pensylvanica De Geer, etc.).-These insects do more or less damage to potato-leaves in certain years. The black blistering-beetle (E. pensylvanica) is commonest northward; it is totally black, and is a little smaller than the gray species (M. cinerea), which is ash-colored on the head, the prothorax, and under side of the body. 'The striped blisteringbeetle $(E$. vittata $)$ is longer and slenderer than the others named, and is clay-yellow, with six black longitudinal stripes. The remedies recommended for the Colorado beetle will destroy these and all other insects feeding on potato-leares. 
The Flea-beetle (Haltica cucumeris Harris).-Eating holes in the leaves of this and other garden vegetables, especially the cabbage, sometimes riddling them when young and cansing them to turn rust1 color, minute blackish beetles, which on being disFIG. 246.- turbed leap off like fleas. Watering the leaves
Fiea.beetle. with a solution of lime, or sprinkling them with wood-ashes, drives them away.

The Striped Garden-bug (Lygus lineolaris Beanrois).Puncturing and poisoning the leaves of the potato and all sorts of garden vegetables, cansing them to wither and turn black, a medium-sized bug with a yellowish head and a 5-lined thorax.

Remedies. - Sprinkle the leaves with alkaline solutions, such as strong soapsuds, or decoctions of tobacco and of walnut leaves, or dust the leaves with air-slaked lime or sulphur.

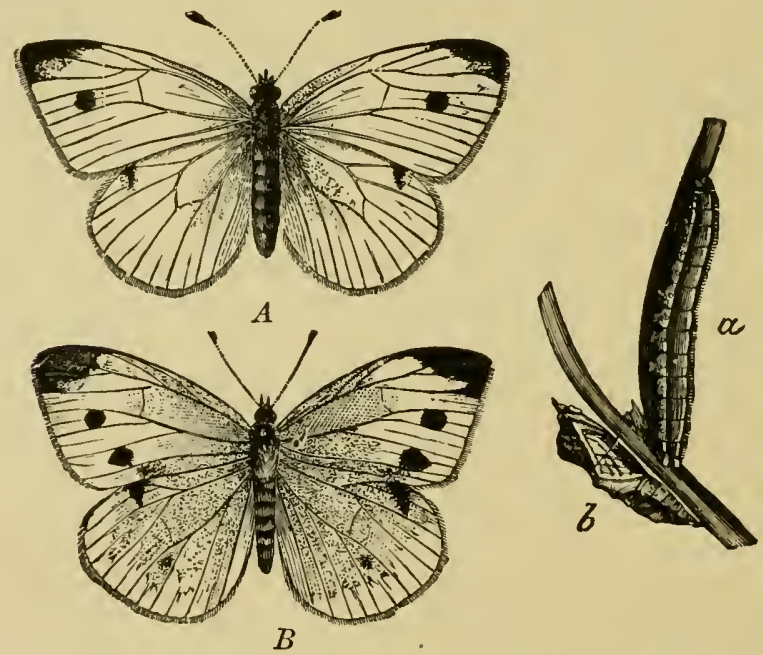

FIG. 247.-European cabbage-butterfly. $A$, male; $B$, female; $a$, larva; $b$, pupa. After Riley.

Besides the foregoing insects, potato-plants are often attacked by the great Sphinx or horned caterpillar, the grubs of the golden-helmet beetle (Cassida aurichalcea), 
while the stalks are sometimes tumnelled by the grub of a weevil (Baridius trinotatus Say), as well as the caterpillar of Gortyna nitela.

\section{Injuring the Cabbage, Radish, etc.}

The European Cabbage-butterfly (Pieris rapce Schrank). -Feeding not only on the outer leaves, but boring into the heads in all directions, a green, velvety caterpillar with a yellowish stripe along the back and side, and turning into a white butterfly with four (male) or six (female) conspicuous black spots. There are two broods of worms, the insect wintering as a chrysalis. It is held in check by a Chalcid parasite (Pteromalus puparum Linn.).

REMEDIES.-Destroy the butterflies by capturing them with a handnet; trap the chrysalids by placing boards slightly raised from the ground, under which the caterpillars may pupate; also sift over the cabbage-heads a powder composed of one part of pyrethrum diluted with twenty parts of flour, or sprinkle a saturated infusion of pyrethrum on the plants. Excellent remedies are applications of hot water, or a solution of one pound of whale-oil soap dissolved in about six gallons of water, or strong tar-water.

The Cabbage Plusia (Plusia brassicce Riley).-In Angust and September, gnawing large, irregnlar holes in the leaves; a rather large, pale-green caterpillar, marked with still paler, more opaque lines, and with threo pairs of abdominal feet, being a semilooper, and changing to a grayishbrown moth, whose wings are adorned with a distinct silver mark of interrogation. The moth lays her eggs singly

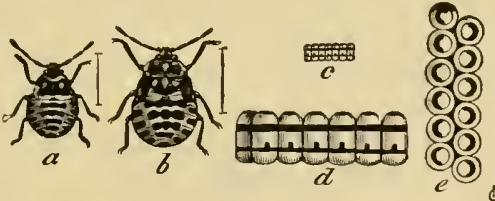
or in small clusters on either side of the leaf, the roung worms feeding first nu the ontside leaves, afterwards boring ashort distance into the heads. There are four broods a 
year, and both chrysalids and moths hibernate. Apply remedies like those suggested for the cabbage-butterfly.

The Harlequin Cabbage-bug (Murgantia histrionica Hahn).-Destroying, in the Southern States, by its punctures, cabbages, turnips, radishes, mustard, etc.; a black and orange-colored bug. The very young, as well as the old, combine to destroy the plant, which wilts as if poisoned.

Besides those already mentioned, cabbages are more or less injured by the web-moth (Pluiella xylostella Linn.), the zebra caterpillar (Hamestra picta Harris), the cabbage Aphis, the cabbage-weevil (Otiorhynchus picipes Fabr.), etc. All can best be destroyed by the use of py-

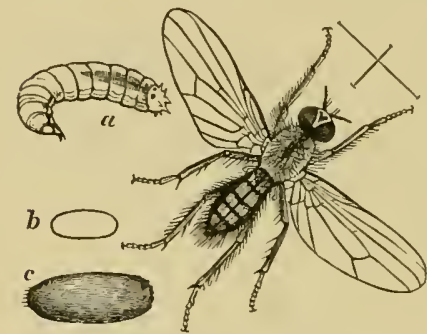

FIG. 249.-Radish-fly. $a$, larva: $b, c$, pupa-case, natural size and enlarged. a rethrum.

The Radish-fly (Anthomyia radicum B ou ché). - T' he chief pest of radishes is a small white maggot which attacks young plants raised in old soil. It changes to a pupa within a barrel-shaped pupacase, from which emerges -After Curtis.

about lalf as large as, the house-fly. The best preventives are early sowing in a light

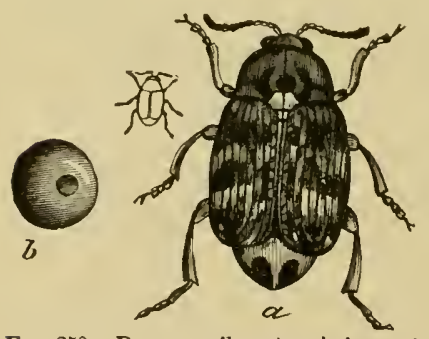

FIG. 250.-Pea-weevil, natural size and enlarged; $b$, pea containing a weevil. new soil, and the annual rotation of crops; also the application of hot water, salt, and lime.

\section{The Pea-weevil (Brichus} pisi Linn.).- The only serious pest of peas is the weevil, which spends its whole life in the pea, except when the plant is in flower.

REMEDIEs.-As a preventive against wormy seet-peas, they should be kept sealed up in tin eans over one year before planting; or soak the peas in boiling water for a few minutes before planting. Worm- 
eaten peas may be detected by placing the whole lot in water, when the infested oues will float on the surface. The weevils in peas may be killed by submitting the infested peas to the fumes of bisulphide of carbon in a closed vessel.

The Bean-weevil (Bruchus fabce Riley). - This is a smaller weevil than that of the pea, and injures beans in the same manner, except that the beans are tenanted by several weevils; it is, however, a more formidable pest than that of the pea.

The Squash-borer (Melittia cucurbitce Harris).--Squashvines are often killed by a borer in the stalk, a short, thick caterpillar, whitish, with adark head and horny patch just behind it. It changes to a beantiful, narrow-winged orange-colored moth spotted with black. The borer lives in the vine until the end of September, and pupates either in the vine or in the ground; hence if all the vines are collected
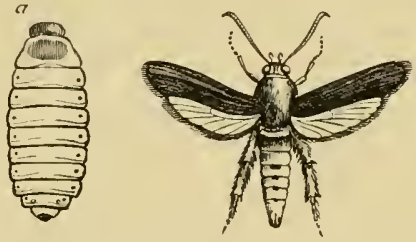

Frg. 251.-Squash-borer (a) and moth Natural size. and burned in the autumn, there will be less borers the following season. Vines planted late are less injured than early ones.

The Striped Squash-beetle (Diabrotica vittata Fabr.).-
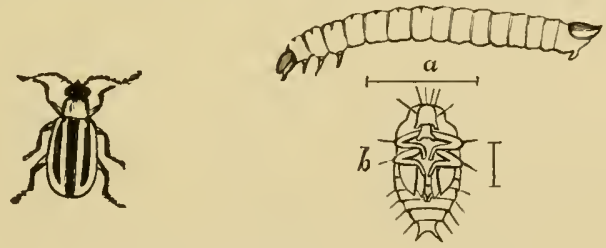

Fig. 252.-Squash-beetle. $a$, grub; $b$, pupa.

As soon as squash-, cucumber-, and melon-vines are up, the young leaves are eaten by a small yellow-striped beetle, whose larva is a long slender grub, which bores in the roots in June and July. The eggs are deposited on the root, at or just below the surface of the soil; the larva becomes fully 
grown in abont a month after the egg is laid; it remains in the pupa state abont two weeks, and the beetle probably lives several days before oripositing, so that one generation is in existence abont two months, and there are two or three generations in a summer. The beetle must hibernate, as it appears very early in the spring.

Revedies.-Sifting the ieaves with powdered oyster-shell lime or gypsum, hellebore or pyrethrum, is worth trying as a remedy, while covering the young vines with cotton or a high frame covered with fine muslin is the usual preventive.

The Squash-bug (Anasa tristis De Geer).-Numbers of

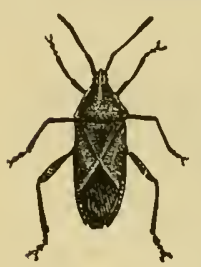
this great black bug are to be seen clustering about squash-vines, sucking the sap with their stout beaks. It is a large blackishbrown bing, dirty yellowish beneath. Towards the last of June the female lays her eggs on the leaves, and the young may soon be seen sucking the sap in the leaves. SucFig. 253. Squash- cessive broods appear during the summer. It
bug. Na tural size. can be controlled by hand-picking.

Another species sometimes injurions to squash-vines is the squash "lady-bird" (Epilachna borealis Thumberg), whose larva is a yellowish grub with long branched spines, arranged in rows of six on each segment, except the first thoracic, which has only four. The beetle is like a large Coccinella, and is yellowish, with seven large black spots on each wing-cover. The pickle-worm (Phacellura nitidulis Cramer) bores eylindrical holes in cncumbers and melons as well as squashes. It is a pale greenish-yellow caterpillar, with a pale reddish head. It spins a slight white cocoon, from which the moth issues eight or ten days afterwards.

\section{Injuring the Hop-vine.}

The Hop Aphis. - T'his plant-louse is a great pest of the hop, as it clusters in immense numbers on the branches and leaves, and is very difficult to extirpate. Prof. Riley 
has discovered that, like the European individuals, it lays its eggs at the approach of cold weather on plum-trees near by.

The Hop-worm (Hypena humuli Harris). - In June, and
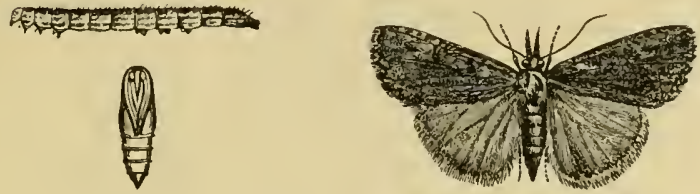

Fig. 254.-Hop-worm, pupa, and moth; all natural size.

again in July and Angust, hop-leaves are devoured by active, slender, grass-green caterpillars, with but four pairs of abdominal legs.

REMEDIES.-Hand-picking and vigorously shaking the vines twice a day, as well as spraying the vines with whale-oil soap, are advisable.

\section{Injuring the Grape-vine.}

The Phylloxera (Phylloxera vastatrix Planchon).-By
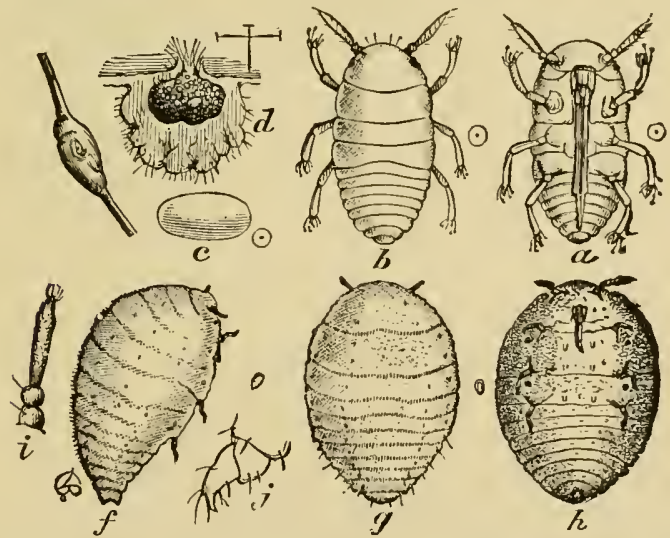

FIG. 255.-The Phylloxera, wingless leaf-form. $a$, under, $b$, upper, side of newlyhatched larva; $c$, egg; $d$, section of the leaf-gall containing the insects; $e$, swelling of tendril; $f$, side, $g$, upper, $h$, uuder, view of the mother gall-louse; $i$, antenna; $j$, two-jointed tarsus.-After Riley.

far the most destructive insect of the vine is this Aphid. It exists in two forms, one raising irregular galls on the 
leaves and the other forming small swellings on the rootlets. 'The root-form is both wingless and winged, the latter

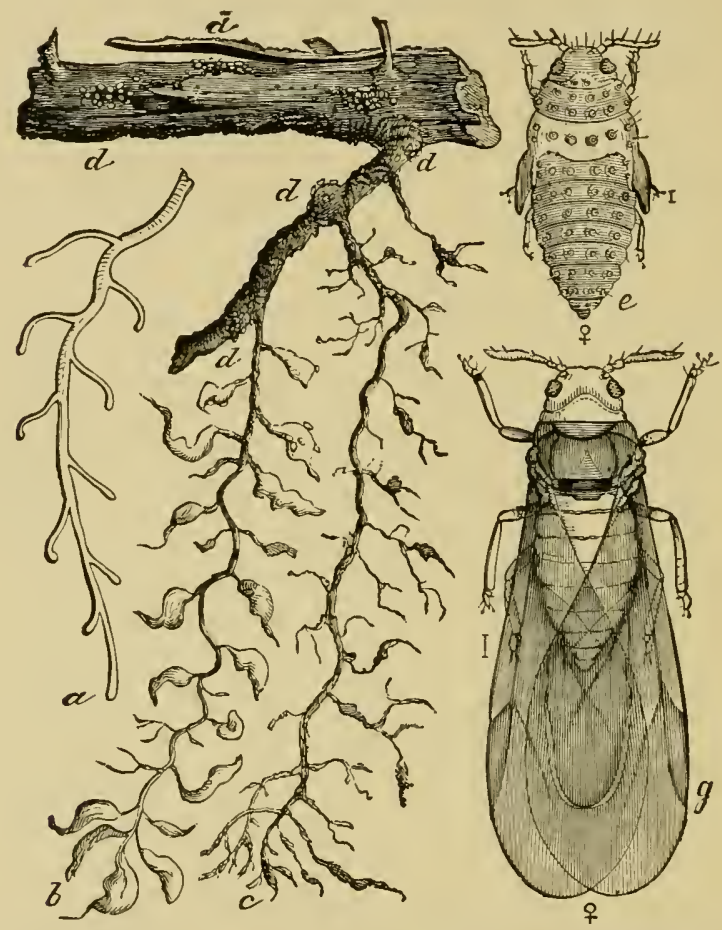

FIG. 256.-The Phylloxera, root-form: $a$, healthy root; $b$, one in which the lice are working, their punctures causing the swellings; $c$, a root deserted by them, the rootlets beginning to decay; $d, d, d, d$, lice of natural size on the larger roots: $e$, pupa of the female, $g$.-After Riley.

very rare; the leaf-form is said to be always wingless. The chief injury is done to the roots, which die under the attacks of this minute, insidions foe.

All direet applications of ehemieals, and the removal and burning of the bark of the vines, nsually result in failure to kill the few winter eggs to be found; Riley maintaining that the normal mode of hibernation of the species is as a 
roung larva upon the roots. It has been discovered that the insect can continue propagating mor ground for at least four years without the laying of fertilized eggs.

REMEdies.-In France and Southern Europe preventive remedies, such as the submergence of the vineyards, and especinlly the importation and use of American stocks, have been the chief means of success in dealing with this pest. The season, however, says Riley, in which insecticides (especially sulpho-carbonates) applied to the roots will do most good is in the interval between the hatching of the fertilized winter-egg and the appearance of the winged females, i.e., during May and June.

Other insects occasionally injuring the vine are the larva of the grape plnme-moth (Pterophorus), which, as the leares and flower-buds expand, eats them, in certain years materially lessening the crop. Tarious other caterpillars, as the "vine-dresser" (Everyx myron), which cuts off the leaves and sometimes the half-grown clusters of grapes (as does also the tree-cricket), also certain leaf-beetles, do more or less harm, while the fruit is at times infested by a leaf-roller (Lobesia botrana), and the seeds are sometimes tenanted by the little white maggot of a chalcid (Isosoma vitis), which causes the fruit to shrivel, withont maturing.

\section{Injuring Fruit-trees.}

Of insects injuring fruits, Mr. J. A. Lintner estimates that there are in the United States at least 1000 species; of these 210 are known to live at the expense of the apple-tree. We can only call attention to some of the most pernicious pests, referring the reader for further information to $\mathrm{Mr}$. W. Saunder's excellent book, "Inseets Injurious to Fruits."

The Apple-tree Borer (Saperda candida Fabr.).-This beetle (Fig. 10\%) flies abont the orchard in May and June in Missouri and Illinois, but in $\mathrm{Jul}_{\mathrm{y}}$ in $\mathrm{New}$ England, and the female lays its eggs in gashes in the bark. The larva or grub upon latehing bores upwarels into the wood, where it lires within a few days of three rears. Enlarging its burrow, it transforms in a cell lined with ehips, situated 

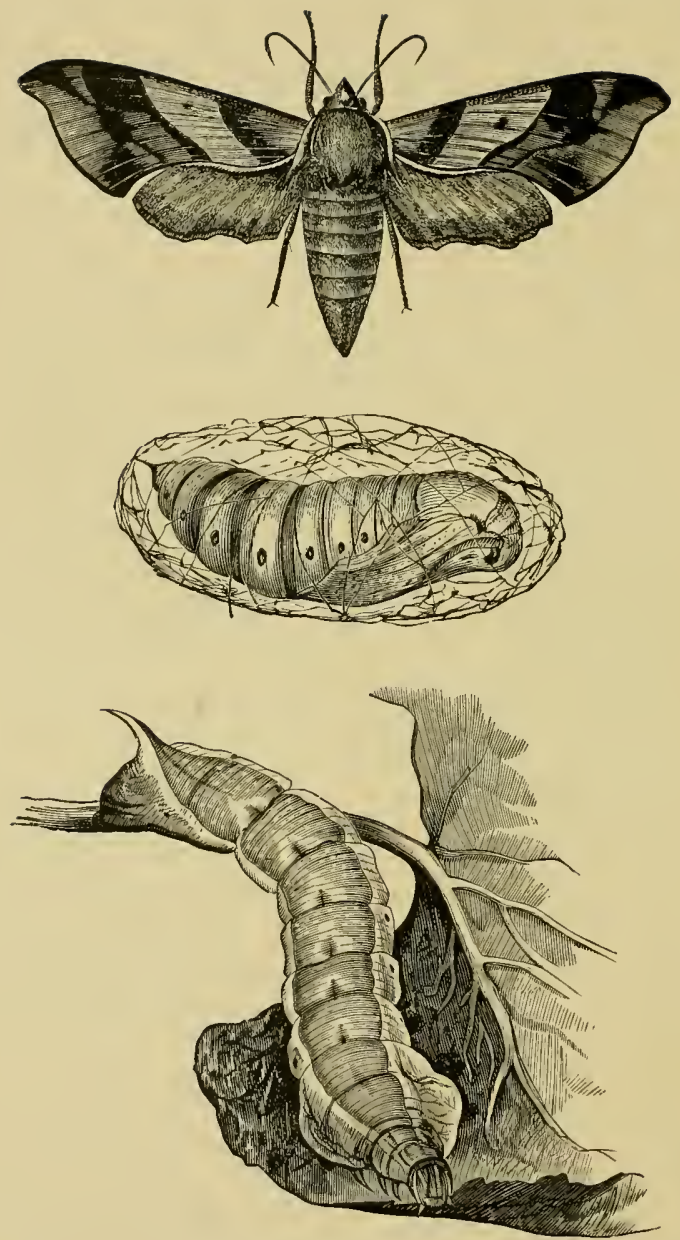

FIG. 257.-The Vine-dresser, with the chrysalis in its cocoon; and the moth. After Riley. 
eight to ten inches from its birth-place. It is notorious that this borer will kill both old and young living trees.

RENEDIEs. - In late summer and autumn the bark should be carefully examined for the gashes made by the beetle in laying its eggs, and the small grubs eut out of the bark or sap-wood. Young trees should also be scraped and soaped, and the trunk at base be surronuded by tarred paper to prevent the female beetle laying her eggs.

The Codding-moth (Carpocapsa pomonella Linn.).-Besides the canker-worm and tent-caterpillar, which are locally destructive, the universal pest of the apple-orchard throughout the United States, from Maine to California, is this insect. In the Northern States the moth flies in May, laying its eggs in the calyx after the blossoms fall, and in a few

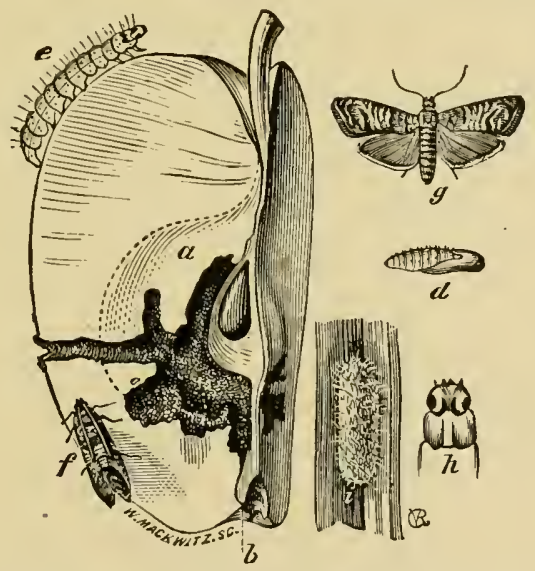

Fia. 258.-Coddling-moth. $a$, worm-eaten apple; $b$, point at which the egg is laid, and at which the young worm entered; $d$, pupa; $e$, full-grown worm; $h$, its head; $f, g$, moth; $i$, cocoon.-After Riley.

days the larva hatches, burrowing into the core, when in three weeks it becomes of full size, being a pale whitish caterpillar nearly an inch in length. As the result of its work, the apple prematurely falls to the ground, when the worm deserts it. It then usually creeps up the trunk of 
the tree, spins a thi $k$ cocoon in erevices in the bark, and in a few days a second brood of the moths appears; but most of the caterpillars hibernate in their cocoons.

REMEDIES.-The obvious preventive renedy is to gather the wind. falls each day as soon as they fall and feed them to the hogs, while fowl should be allowed to run in the orehard. The best direct remedy is to bind bands of hay or straw around the tree from July to the last of September, replacing them every few days by fresh ones, the old ones being burnt, so as to kill the caterpillars or chrysalids hiding loneath the bands.

Prof. Forbes, as the result of numerous experiments, finds that by once or twice spraying with Paris green, in early spring, before the young apples had drooped upon their stems, there was a saving of about 75 per cent of the apples exposed to injury by the coddlingmoth. It should be added that spraying with this poison after the apples have begun to hang downward, is muquestionably dangerous.

Another general pest, often destroying young orchards or separate trees, is the apple bark-louse, while stored apples are destroyed by the maggots of flies (p. 126).

The Plum-weevil (Conotrachetus nenuphar Herbst).-

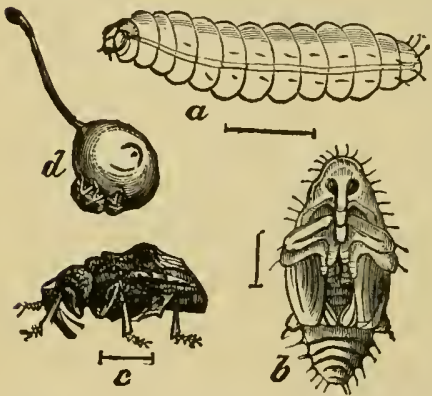

FIG. 259.-Plum-weevil. $a$, larva; $b$. piipa; $c$, beetle, enlarged; $d$, natural size, puncturing a plum.

with the larva within.

This weevil has well-nigh exterminated the plum in the Eastern States, and its attacks far outweigh in importance those of all other plum insects. It resembles a dried bud; when the fruit is set it stings the green plums, making with its beak a eurved incision in which a single egg is deposited. The presence of the grub eauses the fruit to prematurely drop plum, burrows into the ground, and during the last of summer becomes a beetle.

Remedies. - As a remedy the trees should be frequently shaken or jarred, and the weevils. falling into a sheet placed beneath the tree, shonld be collected and burnt. Forbes finds that about half the damage done by weevils may be prevented hy spraying the trees with Paris green early in the season, while the fruit is small. 
The Peach-tree Borer (Sunnina eriliosa Sily). - This borer ontranks all other insects as a destroyer of peachtrees. It lays its eggs in the bark near the ground, and the worm on hatching attacks the living trees, boring into the bark and sap-wood of the roots, or trunk, causing the

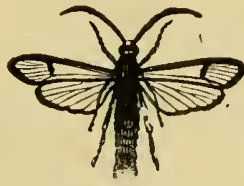

a

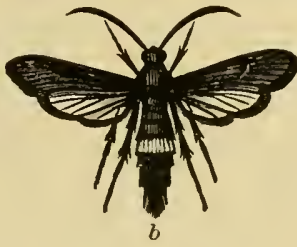

Fra. 260.-Peach-tree borer. $a$, male; $b$, female.

gum to exude, so that its presence may be easily noticed. When the caterpillar is one year old it makes a cocoon under the bark of the trunk or at the larger roots of the tree. To prevent its attacks heap the earth high around the trunk, or wrap tarred paper around the lower part of

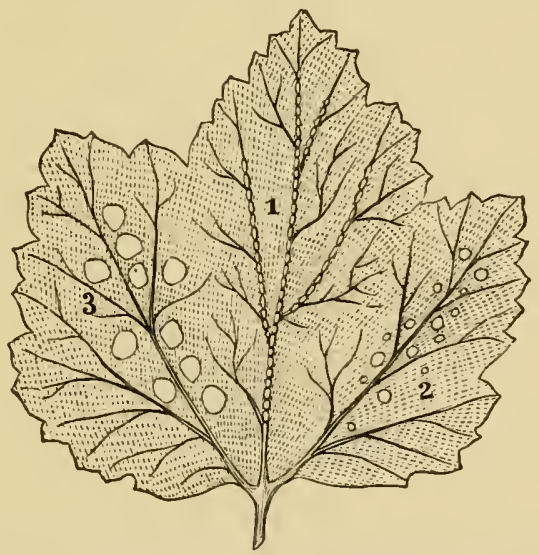

Fig. 261.-1, eggs of the currant saw-fly deposited along the midribs; 2 and 3 , the holes bored by the young worms.

the trunk; when the worm is fairly at work, cut it out, applying wax or clay to the wound. 


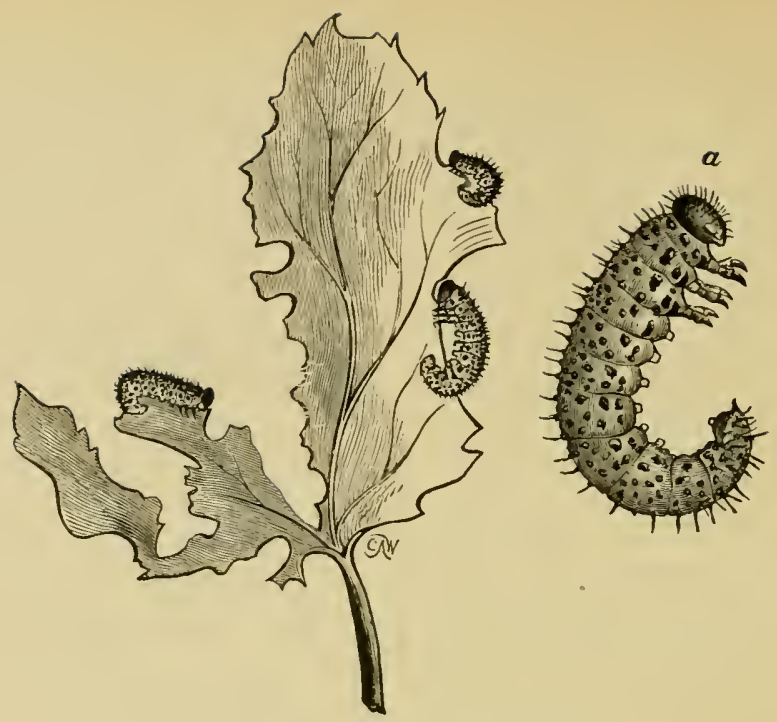

FIG. 262.-Currant-worm. $a$, enlarged.

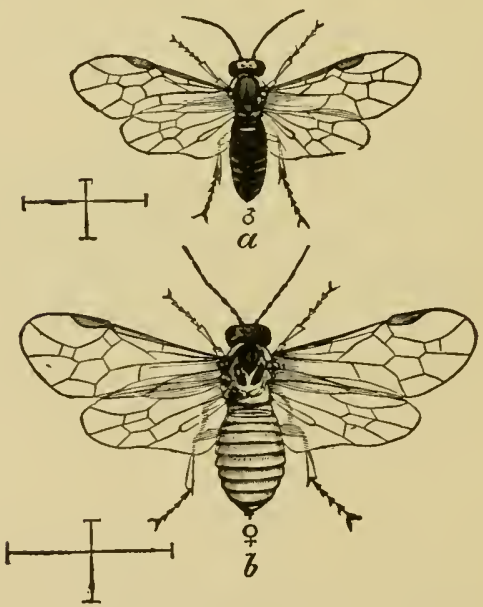

F1G. 263.-Saw-fly or adult currant-worm. $a$, male; $b$, female.

(To face page 217.) 
The Currant-worm (Nematus ventricosus Klug).-This Saw-fly larva or false eaterpillar is far more destructive than all other insects combined to eurrant and gooseberry shrubs, since the voracious larve appear in snceessive broods. 'The female, without having paired with the male, deposits her whitish eylindrical eggs along the under side of the midribs. In four days the worms hateh, and eight days after become fully fed, burrow into the gronnd, remaining in the pupa state about a fortnight.

REMEDIEs.-Powdered hellebore or pyrethrum mixed with four or five times its bulk of cheap flour will, if constantly applied, save the crop.

\section{INSECTS BENEFICIAL TO AGRICULTURE.}

In a great variety of ways certain insects are lielpful to man, and are especially efficacious either in ensuring his crops or in destroying those insects which would otherwise devour them.

Fertilizers of Fruit-trees. - A very important part in the production of abundant crops of fruit is played by bees and other honey- or nectar-gatherers, and pollen-feeding insects. It is now generally acknowledged that bees, especially the honey-bee, act as "marriage-priests" in the fertilization of flowers, conveying pollen from flower to flower, and thus ensuring the "setting" of the fruit. Orehards in which bee-hives are placed bear heavier erops than those not thus favored. Bees are in Europe profitably introduced into peach-houses in order to effeet the pollination of the flowers. Many wasps, as well as butterflies and moths, species of pollen-eating beetles, Thrips, and other insects, by uneonsciously bearing pollen from distant flowers, prevent too close in-and-in breeding. Indeed, as Goethe said, flowers and insects were made for each other. * Many plants would

* "For it is not too much to say that if, on the one hand, flowers are in many cases necessary to the existence of insects; insects, on the other hand, are still more indispensable to the very existence of 
not bear seeds did not insects fertilize them. Insects are in the first place attracted to flowers by their sweet scent and bright colors, and it is claimed that the lines and circles on the corolla of certiin flowers guide them to the nectary; thongh we do not see why the scent is not in the main sufficient for this purpose. According to Sir John Lubboek, "The visits of insects are of great importance to plants in transferring the pollen from the stamens to the pistil. In many plants the stamens and pistil are situated in separate flowers: and even in those cases where they are contained in the same flower, self-fertilization is often rendered difficult or impossible; sometimes by the relative position of the stamens and pistil, sometimes by their not coming to maturity at the same time. Under these circumstances the transference of the pollen from the stamens to the pistil is effected in various ways. In some species the pollen is carried by the action of the wind; in some few cases, by birds; but in the majority, this important object is secured by the visits of insects, and the whole organization of such flowers is adapted to this purpose." (l. c. 2.)

Hermann Müller believed that the peculiaritios which distinguish bees and most Lepidoptera, i.e., their month-parts and, in the case of bees, their legs, have been gradually produced in past ages by their visits to flowers.

Insects also are useful as pruners, checking the too-rapid growth of leaves and shoots, the result being the formation of a greater amount of seeds or fruit. Unfortunately this process in most cases exceeds healthy limits, and the plant, being almost wholly defoliated, is weakened or killed.

Parasitic Insects (Ichneumons and Tachince).-While insectivorous birds accomplish much towards reducing the

Howers:-that, if insects have been in many cases modified and adapted with a view to obtain honey and pollen from flowers, flowers in their turn owe their scent and color, their honey, and even their distinetive forms, to the action of insects. There has thus been an interaction of insects upon flowers, and of flowers upon insects, resulting in the gradual modification of both." (Lubbock's "British Wild Flowers considered in relation to Insects.") 
numbers of injurious insects, they often as likely as not eat the beneficial as well as the destructive kinds. Without doubt the leading fictor in preventing the undne increase of noxions insects are the parasitic kinds belonging to the hymenopterous families Ichnemmonida, Braconitæe, Chalcidida and Prototrupida, and the dipterous family 'Tachinidæ.

An iehneumon-fly lays its eggs either on the ontside of the caterpillar or bores under its skin, inserting an egg within the body. Mr. Poulton has earefully watched a Paniscus ovipositing on a caterpillar. It laid fourteen eggs, firmly attaching them to its skin, most of them in the sutures between the segments, and on the sictes of the body. An excess of eggs are laid, since some to not develop; for if all gave out larvæ, none conld arrive at maturity within the boty of the future host. The ichneumon lays a smaller number of eggs on small caterpillars than on large ones, and yet in all cases lays more than can develop.

The larva of the ichneumon upon hatching works its way into the interior of its host. Here it does not injure the muscles, nerves, or the vital parts of the caterpillar, but apparently simply lies motionless in the body-cavity, absorbing the blood of its host.

Many ichneumons are polyphagous, i.e., live on insects of widely different species belonging to different orders; others confine their attacks to a single species. Certain chalcids are secondary parasites, living in the larva of those parasitic in eaterpillars, etc. Most ichmeumons have but a single generation; a few are double-brooded. In Germany Ratzeburg observed a brood of Microgaster globatus early in May, and another early in August. Though there may be two broods of the hosts, there is as a rule but a single brood of ichneumons. Ratzeburg indeed found that certain ichneumons parasitic on saw-fly larvæ imitated the habit of the latter of living more than a year, i.e., they did not develop until the greater number of saw-flies had issued from the belated cocoons. On the other hand, Pteromalus puparum 
undergoes in Europe an extraordinarily rapid growth; it stings early in June the chrysalids of Vanessa polychloros, and by the middle of July the adults appear. Teleas ovulorum requires only from four to six weeks to develop; it, however, flies somewhat later, so as to find the young silk caterpillars on which to lay its eggs.

Ichneumons rarely develop within adult insects, but certain Braconids infest Coccinellæ. 'The small Chalcids (Pteromali) mostly inhabit the tender pupæ of bark-boring beetles and leaf-rollers. Among the smaller ichneumons several females usually inhabit a single host, while from 600 to r00 individuals of Pteromalus puparum may inhabit a single chrysalid.

Most ichneumons develop within their hosts, but many species of Chalcids live on the outside and suck the blood of their victims. Certain ichneumon larvæ living within their host undergo the most remarkable change as respects their mouth-parts. In the larva of Microgaster globatus (according to Judeich and Nitsche) there are in the early stages only the wart-like rudimentary sucking mouth-parts, but after the last moult they acquire ordinary biting mandibles, with which they can gnaw through the skin of their host.

The young of the Tachina-flies are true footless maggots, and take their liquid food by suction throngh the montll, the mouth-parts being very rudimentary. Tachina (Senometopia) militaris has been observed by Riley to lay from one to six eggs on the skin of the army-worm, "fastening them by an insoluble cement on the upper surface of the two or three first rings of the body." 'The young maggots on hatching penetrate within the body of the caterpillar, and, lying among the internal organs, absorb the blood of their unwilling host, cansing it to finally weaken and die. Usually but a single maggot lives in its host. Many grasshoppers as well as caterpillars are destroyed by them.

Insectivorous Insects.-There are very many carnivorous kinds which devour insects entire. Such are the ground- 
beetles, water-beetles, the larvæ of Tenebrionids and of lady-beetles (Coccinella), and those of the lace-winged flies (Chrysopa) which prey on Aphides, though the maggots of the Syrphus flies are more abundant and efficacious as Aphis-destroyers.

\section{Preventive and Direct Remedies Against the Attacks OF INSECTS.}

In applying any remedies against noxious insects, it is of prime importance to beeome thoroughly acquainted with the haljits and transformations of the pests with which we have to contend. It should be borne in mind that insects during their transformations lead different lives, and that practieally a caterpillar is a different animal from the chrysalis or the butterfly, with entirely different habits and surroundings; and so on throughout the other orders of insects.

Under the head of general or preventive remedies may be enumerated :

High enlture, with the use of plenty of manures and fertilizers.

Rotation of erops, and early or late sowing.

Raising crops to last for two years, such as peas and beans, to guard against weevils.

The breeding of inseet-parasites.

Burning grass and stubble for certain insects injuring field-crops.

Removal of dead trees or stumps near orehards or in forests.

Among direct remedies, besides hand-picking, is the use of the following inseeticides:

Paris green and London purple.

Kerosene emulsions.

Pyrethrum or Persian inseet-powder.

Bisulphide of earbon for the grape-root Phylloxera.

Carbolic-aeid soap; whale-oil soap.

Ammonia or chloroform for insect-bites. 
Sulphur tor mites; borax for cockroaches.

Ointments and carbolic soap for lice.

Salt, hot water, ashes, dust, soot.

Various devices and machines for applying powders or liquid preparations.

Paris Green and Londo? Purple.--These arsenical preparations may be used dry when mixed with cheap flour in the proportion of 1 to 25 parts, or wet mixed in the proportiou of $\frac{1}{2}$ to 1 pound of the powder with 40 gallons of water. The London purple is the weaker of the two powders; but is often preferred to Paris green from its cheapness, and because it is more easily diffused, and can be seen more distinetly on the leaves, though its effects may not be observed until two or three days after being applied.

Petroleum Emulsions.-Dilute 1 yuart of kerosene oil and 12 fluid ounces of condensed milk with 36 ounces of water. This is emulsionized by violent churning, aud before being used may be diluted from 12 to 20 times with water. Equal parts of kerosene and condensed milk may also be thoroughly mixed or churned together, and then diluted ad libitum with water.

Pyrethrum or Persian Insect-powder.-This powder is deadly to most insects, but harmless to plants and human beings, cattle, or horses. It may be applied (1) as a dry powder; (2) as a fume, being thrown on the stove or on a red-hot shovel or piece of sheet-iron; (3) as an alcoholic extract, diluted; (4) by simply stirring the powder in water; and (5) as a tea or decoction. As a powder it may be mixed with from 10 to 20 times its bulk of wood-ashes or flour, but before use should remain for twenty-four hours with the diluent in an air-tight vessel. (Riley.) One experimeuter dilutes the dry powder with only four or tive times its bulk of flour in applying to cabbages to kill cabbage-worms.

Spraying-machines.-Numerous inventions for applying these preparations on an extensive scale are described in the reports and bulletins of the Entomologist of the Department of Agriculture at Washington; among the most efficacions being spray nozzles* of different kiuds, being modifications of the old-fashioned sprinklers

* The eddy or cyclone uozzle consists of a small circular chamber with two flat sides, one of them screwed on so as to be readily removed. Its prineipal feature consists in the inlet through which the liquid is foreed, being bored tangentially through its wall, so as to cause a rapid whirling or centrifugal motion of the liquid, which issues in a funnel-shaped spray througb a central outlet in the adjustable cap. The breadth or height, fincness or coarseness of the spray depends on certain details in the proportions of the parts, and especially of the central outlet. The nozzle was invented by Riley and Barnard. In applying the fluid to trees, an ordinary barrel is used as a reservoir. in which is inserted a force-pump will antomatic. stirrer. A loug rubber hose extends from the pump, and is attached to the spraying apparatus. (Riley.) 
and sifters; machines for blowing dry poisons, squirters of thuid poisons and emulsions, the best of which are fountain-pumps. For spraying orchards, groves, and forest-trees, force- or fountain-pumps with a long hose, the end of which passes through a hamboo pole ending in a cyclone or eddy-chamber nozzle, are very efticient.

Remedies against Bots.-Those of cattle may be pressed with the thumb out of the tumors on the back after slightly enlarging the abscess with a knife or scalpel; otherwise, if the bot is burst within the tumor, inflammation will result.

Sheep-bots may be removed from the nostrils before they have penetrated far by inserting a feather anointed witl oil of turpentine, and gently moving it about. Dilute carbolic acid injected with a syringe is also beneficial. As a preventive, anointing the nose with coal-tar has been recommended, and salt-troughs are smeared with this substance to accomplisin this anointing more easily.

As a preventive against horse-bots, frequent currying and clipping the hair removes the eggs. This need be done only during the time when the flies are abont. (Riley.)

Miscellaneous Remedies - The clothes-moth is exterminated from furniture by soaking chairs, sofas, etc., in tanks of kerosene and then recovering them; carpet moths and beetles are very difticult to overcome; but they may be kept under to a great extent by ironing the edges, applying Persian insect-powder in closely shut rooms, or saturating the edges next to the wall with benzine, care being taken not to set the room on fire. A room or bedstead may, by the use of kerosene or of corrosive sublimate, be disinfected of bed-bugs.

Mites are generally destroyed by sulphur; the itch-mite by sulphurointment; lice on animals by carbolic soap. or kerosene-oil emulsions, or any oil or grease; lice on chickens may be dininished by whitewashing the coop, fumigating it with sulplur or washing with kerosene; cockroaches succmmb to equal parts of powdered borax and sugar placed in their way. The bites of moscunitoes, stings of bugs, bees, etc., may be treated locally with ammonia or chloroform, bee-stings with wet mud applied to the wound; while the bites of centipedes and the stings of scorpions may be treated with diffusible stimulants, such as ammonia taken in repeated doses internally, besides brandy or whiskey, to support the system until the patient recovers from the shock.

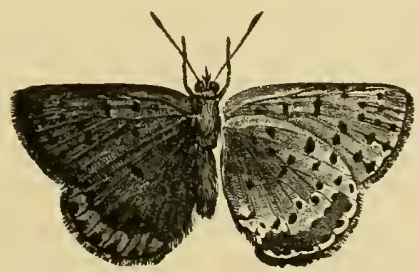

Chrysophanus thoe, right side as seen beneath. 


\section{CHAPTER VI.}

DIRECTIONS FOR COLLECTING, PRESERVING, AND REARING INSECTS.

Where to Look for Insects. - In collecting, whenever the two sexes are found united they should be pinned upon the same pin, the male being placed above. When we take one sex alone, we may feel sure that the other is somewhere in the vicinity; perhaps while one is flying about so as to be easily captured, the other is hidden under some leaf, or resting on the trunk of some tree near by, which must be examined and every bush in the vicinity vigorously beaten by the net. Many species rare in most places have a metropolis where they occur in great abundance. During seasons when his favorites are especially abundant the collector should lay up a store against years of scarcity.

At no time of the year need the entomologist rest from his labors. In the winter, under the bark of trees and in moss he can find many species, or detect their eggs on trees, etc., which he can mark for observation in the spring when they hatch out.

He need not relax his endeavors day or night. Mothing is night employment. Sknnks and toads entomologize at night. Early in the morning, at sunrise, when the dew is still on the leaves, insects are sluggish and easily taken with the hand; species fiy then that hide themselves by day, while at night many caterpillars leave their retreats to come out and feed, when the lantern can be used with success in searching for them.

Wollaston (Entomologist's Annual, 1865) states that sandy districts, especially towards the coast, are at all times preferable to clayey ones, but the intermediate soils, such as the loamy soil of swamps and marshes, are more productive. Near the sea, insects occur most abundantly beneath 
pebbles and other objects in grassy spots, or else at the roots of plants. In many places, especially in alpine tracts, as we have found on the summit of Mt. Washington and in Labrador, one has to lie down and look carefully among the short herbage and in the moss for Coleoptera.

The most advantageous places for collecting are gardens and farms, the borders of woods, and the banks of streams and ponds. The deep, dense forests, and open, treeless tracts are less prolific in insect life. In winter and early spring the moss on the trunks of trees, when carefully shaken over a newspaper or white cloth, reveals many beetles and Hymenoptera. In the late summer and autumn, toadstools and various fungi and rotten fruits attract many insects; and in early spring, when the sap is running, we have taken rare insects from the stumps of freshly cut hard-wood trees. Wollaston says: "Dead animals, partially dried bones, as well as the skins of moles and other vermin which are ordinarily hung up in fields, are magnificent traps for Coleoptera; and if any of these be placed around orchards and inclosures near at home, and be examined every morning, various species of Nitidule, Silphidce, and other insects of similar habits, are certain to be enticed and captured.

"Planks and chippings of wood may be likewise employed as successful agents in alluring a vast number of species which might otherwise escape our notice; and if these be laid down in grassy places, and carefully inverted every now and then with as little violence as possible, many insects will be found adhering beneath them, especially after dewy nights and in showery weather. Nor must we omit to urge the importance of examining the under sides of stones in the vicinity of ants' nests, in which position, during the spring and summer months, many of the rarest of our native Coleoptera may be occasionally procured." Excrementitions matter always contains many interesting forms in various stages of growth.

The trunks of fallen and decaying trees offer a rich 
harvest for many wood-boring larvæ, especially the Longicorn beetles; and weevils can be found in the spring, in all stages. Numerous carnivorous coleopterous and dipterous larvæ $d$ well within them, and other larvæ which eat the dust made by the borers. The inside of pithy plants like the elder, raspberry, blackberry, and syringa, is inhabited by many of the wild bees, Osmia, Ceratina, and the woodwasps, Crabro, Stigmus, ete., the habits of which, with those of their Chalcid and Ichneumon parasites, offer endless amusement and material for study.

Ponds and streams shelter a vast throng of insects, and should be diligently dredged with the water-net, and stones and pebbles should be overturned for aquatic beetles, Hemiptera, and Dipterons larvæ.

The various sorts of galls should be collected in spring and autumn and placed in vials or boxes, where their in-

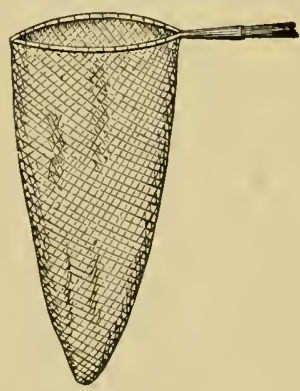
habitants may be reared, and the rafters of ont-houses, stone-walls, etc., should be carefully searched for the nests of mud-wasps.

Collecting Apparatus._First in importance is the net (Fig. 264). This is made by attaching a ring of brass wire to a handle made to slide on a pole six feet long. The net may be a foot in diameter, and the bag itself FIs. 261.-Collecting-net. made of muslin or mosquito-netting (the finer, lighter, and more durable the better), and should be about twenty inches deep. It should be sewed to a narrow border of cloth placed around the wire. A light net like this can be rapidly turned upon the insect with one hand. The insect is captured by a dexterons twist which also throws the bottom over the mouth of the net.

The insect should be temporarily held between the thumb and forefinger of the hand at liberty, and then pimed throngh the thorax while in the net. The net we use has a folding frame of stont brass wire, one side soldered to a 
stout brass tube, the other held in place by a screw in the end of the tube; it is simple and useful in travelling. The pin can be drawn throngh the meshes upon opening the net. The beating-net should be made much stouter, with a shallower cloth bag and attached to a shorter stick.* It is used for beating trees, bushes, and herbage for beetles and Hemiptera and various larvæ. Its thorough use we wonld recommend in the low regetation on mountains and in meadows. The water-net may be either round or of the shape indicated in Fig. 265. The ring should be made of brass, and the shallow net of grass-cloth or

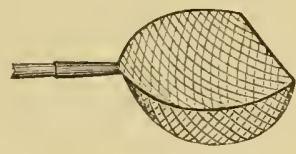

FIG. 265.-Water-net. coarse millinet. It is used for collecting aquatic insects. Mr. Schmelter recommends for collecting small waterbeetles, etc., a net made of ordinary mushin, with a bottom of the finest brass wire-cloth, the meshes of which do not exceed $\frac{1}{2} \mathrm{~mm}$.; the water will readily pass through this net, while the smallest insects will be retained. Herr Isenschmidt suggests in "Entomologische Nachrichten" a net constructed entirely of woven wire, but this would be clumsy to carry about, and Schmelter's net is preferable.

Various sorts of forceps are indispensable for handling insects. Small, delicate, narrow-bladed forceps, with fine sharp points, such as are used by jewellers, and made either of steel or brass, are excellent for handling minute specimens. For larger ones, long, curved forceps are very convenient. For pinning insects into boxes the forceps

* Schmelter uses one made of a strong wire ring of from one to one and a balf feet in diameter, with a bag of muslin attached of at least the same lepth, firmly fixed to the end of a stick about two to three feet long. In another form which is much used "the ring consists of different parts, two or three, wbich are connected by means of joints, and the ring ean be folded when not in use. By meins of a serew the ends of this ring are firmly fixed into a tube, which again fits tightly on the end of an ordinary walking cane. In any fishing-tackle store, rings of this or of a similar construction are for sale." (Bull. Brooklyn Ent. Soc., i. 26.) Dr. Bailey describes and figures a net with a folding frame in Can. Ent., x. 62. 
should be stout, the blades blunt and curved at the end so that the insects can be pinned without slanting the forceps much. The ends need to be broad and finely indented by lines so as to hold the pin firmly. With a little practice the forceps soon take the place of the fingers. Some persons use the ordinary form of pliers with curved handles, but they should be long and slender. A spring set in to separate the handles when not grasped by the hand is a great convenience.

Various pill-boxes, vials, and bottles must always be taken, some containing alcohol or whiskey. Many collectors use a wide-mouthed bottle, containing a sponge saturated with ether, chloroform, or benzine, or bruised laurel-leaves, the latter being pounded with a hammer and then cut with scissors into small pieces, which give out exhalations of prussic acid strong enough to kill most small insects.

Besides these the collector needs a small box lined with corn-pith or cork, and small enough to slip into the coatpocket; or a larger box carried by a strap. Most moths and small flies can be pinned alive without being pinched (which injures their shape and rubs off the scales and hairs), and then killed by pouring a little benzine into the bottom of the box.

Killing Insects for the Cabinet.-Care in killing affects very sensibly the looks of the cabinet. If hastily killed and distorted by being pinched, with the scales rubbed off and otherwise mangled, the value of such a specimen is diminished either for study or the neat appearance of the collection.

Besides the vapor of ether, chloroform, and benzine, the fumes of sulphur readily kill insects. Large specimens may be killed by inserting a pin dipped in a strong solution of oxalic acid. An excellent collecting-bottle is made by putting into a wide-mouthed bottle two or three small pieces of cyanide of potassium, which may be covered with cotton, about half-filling the bottle. The cotton may be 
covered with paper lightly attached to the glass and pierced with pin-holes; this keeps the insects from being lost in the bottle. This is excellent for small flies and moths, as the mouth of the bottle can be placed over the insect while at rest; the insect flies up into the bottle and is immediately suffocated. A bottle well prepared will, according to Laboulbène, last several months, even a year, and is vastly superior to the old means of using ether or chloroform. He states: "The inconvenience of taking small insects from a net is well known, as the most valuable ones usually escape; but by placing the end of the net, filled with insects, in a wide-mouthed bottle. and putting in the cork for a few minutes, they will be suffocated." For Diptera, Loew recommends moistening the bottom of the collecting box with creosote. Mr. J. A. Jackson recommends the use of a glass fruit-jar, one in which the cover screws dowu upon a rubber cushion or packing. Put a bunch of cotton in the bottom, retaining it in its place by pressing down upon it a circular piece of pasteboard, made to fit tightly in the jar, except that two or three notches should be left in the edge for the chloroform to run through to the cotton. The bottle is now ready for use; an insect dropped into it will die almost instantly. (Can. Ent. xix. 119.) A morphine bottle prepared in the same way will do for micros. Ether may be used in the same way, as we are accustomed to do, but chloroform is gencrally preferred. Prof. E. W. Claypole (Canadian Entomologist, xix. 136) kills Lepicoptera, etc., with benzine or gasoline, the latter only costing fourteen cents a gallon. With most moths it causes instant death, and can be poured on the bodies of large silk-worm moths, such as Cecropia, without injuring the scales or hairs. He carries it in an ounce phial having a cork through which passes a finely-pointed glass tube, the outer end of which is capped with a small India-rubber capsule; the whole may be bought at a drug-store for a few cents, under the name of a dropping-tube. Thus the tube is always full of liquirl ready to be squirted ont on an in- 
sect in the net, or even at rest in the open air, and the specinen is at once ready to be pinned and spreal. A chioroform bottle with a brush securely inserted in the cork is often convenient for small moths.

Pinning Insects. - The pin should be inserted through the thorax of most insects. The Coleoptera, however, should be pinned through the right wing-cover (Fig. 266); many Hemiptera are best pinned throngh the scutellum. The specimens should all be pinned at an equal height, so that about one-fourth of the pin should project above the insect.

'The best pins are those made in Germany, and are advertised for sale in American entomological journals. For very minute insects rery small pins are made. They may

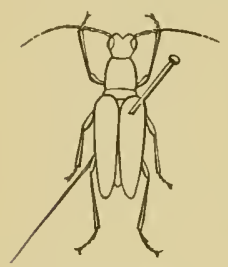

Fig. 266.-Mode of pinning a beetle. be used to impale minute insects upon, and then stuck through a bit of cork, or pith, through which a large, long pin may be thrust. Then the specimen is kept out of the reach of devouring insects. Still smaller pins are made by cutting off bits of very fine silvered wire of the right length, which may be thrust by the forceps into a picce of pith, after the insects have been impaled upon them.

Small insects, especially beetles, may be mounted on cards or pieces of mica through which the pin may be thrust. The French use small oblong bits of mica, with the posterior half covered with green paper on which the number may be placed. The insects may be gummed on the clear part, the two sexes together. The under side can be seen through the thin mica.

Others prefer triangular pieces of card, across the end of which the insect may be gummed, so that nearly the whole under side is risible.

Mr. Wollaston advocates gumming small Coleoptera upon cards. Instead of cutting the pieces of card first, he gums them promiscuously upon a sheet of card-board. "Having 
gummed thickly a space on your card-board equal to, at least, the entire specimen when expanded, place the beetle upon it, drag out the limbs with a pin, and, leaving it to dry, go on with the next one that presents itself. As the card has to be cut afterwards around your insect (so as to suit it), there is no advantage in gumming it precisely straight upon your frome, - though it is true that a certain amount of care in this respect lessens your after-labor of cutting off very materially. When your frame has been filled, and you are desirous of separating the species, cut out the insects with finely-pointed scissors."

For mending broken insects, i.e., gumming on legs and antennæ which have fallen off, inspissated ox-gall, softened with a little water, is the best gum.

For gumming insects upon cards, Mr. Wollaston recommends a gum "composed of three parts of tragacanth to one of Arabic, both in powder; to be mixed in water containing a grain of corrosive sublimate, without which it will not keep, until of a consistency just thick enough to run. As the gum is of an extremely absorbent nature, nearly a fortnight is required before it can be properly made. The best plan is to keep adding a little water, and stirring it every few days, until it is of the proper consistency. It is advisable to dissolve the grain of corrosive sublimate in the water which is poured first upon the gum.

Preservative Fluids. - The best for common use is lㅣohol, at first diluted with as much water; or weak whiskey, as alcohol of full strength is too strong for caterpillars, etc., since it shrivels them up. The spirits should afterwards be clianged for alcohol of full strength for permanent preservation. Glycerine is excellent for preserving the colors of caterpillars, though the internal parts decay somewhat, and the specimen is apt to fall to pieces on being roughly handled.

Laboulbène recommends, for the preservation of insects in a fresh state, plunging them in a preservative fluid consisting of alcohol with an excess of arsenic acid in frag- 
ments, or the common white arsenic of commerce. A pint and a half of alcohol will take about fourteen grains (troy) of arsenic. The living insect, put into this preparation, absorbs about $\frac{3}{1000}$ of its own weight. When soaked in this liquor and dried, it will be safe from the ravages of moths, Anthrenus or Dermestes. This liquid will not change the colors of blue, green, or red beetles if dried after soaking from twelve to twenty-four hours. Hemiptera and Orthoptera can be treated in the same way.

A stay of a month in this arseniated alcohol mineralizes the insect, so that it appears very hard, and, after drying, becomes glazed with a white deposit which can, however, be washed off with alcohol. In this state the specimens become too hard for dissection and study, but will do for cabinet specimens designed for permanent exhibition.

Another preparation recommended by Laboulbène is alcohol containing a variable quantity of corrosive sublimate, but the latter has to be weighed, as the alcohol evaporates easily, the liquor becoming stronger as it gets older. The strongest solution is one part of corrosive sublimate to one hundred of alcohol; the weakest and best is one-tenth of a part of corrosive sublimate to one hundred parts of alcohol. Insects need not remain in this solution more than two hours before drying. Both of these preparations are very poisonous and should be handled with care. The lastnamed solution preserves specimens from mould, which will attack pinned insects during damp summers.

A very strong brine will preserve insects until a better liquor can be procured. Professor A. E. Verrill recommends two simple and cheap solutions for preserving, among other specimens, the larvæ of insects "with their natural color and form remarkably perfect." The first consists of two and a half pounds of common salt and four ounces of nitre dissolved in a gallon of water and filtered. Specimens should be prepared for permanent preservation in this solution by being previously immersed in a solution 
consisting of a quart of the first solution and two ounces of arseniate of potash and a gallon of water.

M. H. Trois * gives the following formula for preserving caterpillars.

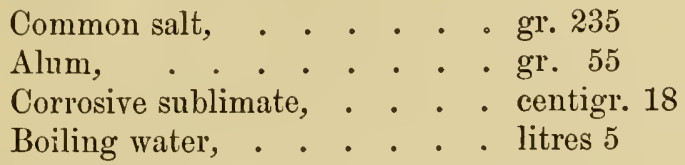

When the liquid is cold add 50 grains of carbolic acid. Let the liquid stand five or six days, and then filter. It is claimed that by means of this fluid the colors of caterpillar's can be preserved perfectly, even when exposed to a strong light.

The nests, cocoons, and chrysalides of insects may be preserved from injury from other insects by being soaked in the arseniated alcohol, or dipped into benzine, or a solution of carbolic acid or creosote.

Dr. J. L. LeConte has published in the "American Naturalist," iii. p. 30\%, some new directions for the preservation of insects which will apply to beetles as well as other insects. "Surgical art has given to us an instrument by which a poisonous liquid can be rapidly and most effectively applied to the entire surface of large numbers of specimens as they stand in the cabinet boxes, without the tronble of moving them. I refer to the 'atomizer.'

"Opinions may vary as to the nature of the liquid poison to be used, but after sereral trials I have found the following formula to be quite satisfactory; it produces no efflerescence, even on the most highly polished species, while the odor is quite strong, and persistent enough to destroy any larvæ or eggs that may be already in the box :saturated alcoholic solution of arsenious acid, eight fluid ounces; strychnine, twelve grains; crystallized carbolic acid, one drachm; mineral naphtha (or heavy benzine) and

* A litre is 33.81 fluid ounces, or a little less than an English quart; a gramme is 15.432 grains. 
strong alcohol, enough to make one quart. I have not stated the quantity of naphtha, since there are some varieties of light petroleum in commerce which dissolve in alcohol only to a slight extent. These should not be used. The heavier oils which mix indefinitely with alcohol are the proper ones, and for the two pints of mixture ten to twelve fluid ounces of the naphtha will be sufficient. Care should be taken to test the naphtha on a piece of paper. If it leaves a greasy stain which does not disappear after a few hours, it is not suitable for this purpose.

"The best form of atomizer is the long, plated, reversible tube; it should be worked with a gum-elastic pipe having two bulbs, to secure uniformity in the current. The atomizing glass tubes and the bottle, which usually accompany the apparatus, are unnecessary; a common narrownecked two-ounce bottle will serve perfectly to hold the fluid."

Preparing Insects for the Cabinet.-Dried insects may be moistened by laying them for twelve or twenty-four hours in a box containing a layer of wet sand, covered with one thickness of soft paper. Their wings can then be easily spread. Setting-bourds for spreading the wings of insects may be made by sawing deep grooves in a thick board, and placing a strip of pith or cork at the bottom. The groove may be deep enough to allow a quarter of the length of the pin to project above the insect. The setting-board usually consists of thin parallel strips of board, leaving a groove between them wide enough to receive the body of the insect, at the bottom of which a strip of cork or pith should be glued. The ends of the strips should be nailed on to a stouter strip of wood, raising the surface of the settingboard an inch and a half, so that the pins can stick through without tonching. Several setting-boards can be made to form shelves in a frame covered with wire gauze, so that the specimens may be preserved from dust and destructive insects, while the air may at the same time hare constant access to them. The surface of the board should incline 
a little towards the groove for the reception of the insect, as the wings often gather a little moisture, relax and fall down after the insect is dried. "For the proper setting of insects with broad and flattened wings, such as butterflies and moths, a spreading board or stretcher is necessary. One that is simple and answers every purpose is shown at Fig. 26\%. It may be made of two pieces of thin white-wood or pine board, fastened together by braces, especially at the ends, and left wide enough apart to admit the bodies of the insects to be spread: strips of cork or pith, in which to fasten the pins, may then be tacked or glued below so as to cover the intervening space. 'The braces must be deep enough

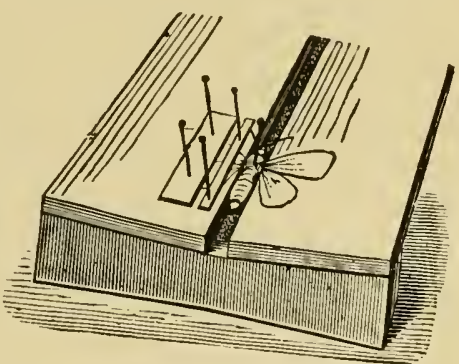

FIG. 20ิ์.-Setting-board.

to prevent the pins from touching anything on which the stretcher may be laid; and, by attaching a ring or loop to one of them, the stretcher may be hung against a wall, out of the way. For ordinary-sized specimens I use boards 2 feet long, 3 inches wide, and $\frac{1}{3}$ inch thick, with three braces (one in the middle and one at each end) $1 \frac{1}{2}$ inches deep at the ends, but narrowing from each end to $1 \frac{1}{6}$ inches at the middle. This slight rising from the middle is to counteract the tendency of the wings, however well dried, to drop a little after the insect is placed in the cabinet. The wings are held in position by means of strips of paper (Fig. 267) until dry." (Riley.) Others use strips of stiff, smooth cloth.

Moths of medium size should remain two or three days on the setting-board, while the larger thick-bodied sphinges and Bombycidæ require a week to dry. The wings can be arranged by means of a needle stuck into a handle of wood. They should be set horizontally, and the front margin of the fore wings drawn a little forward of a 
line perpendicular to the body, so as to free the inmer margin of the hind wings from the body, that their form

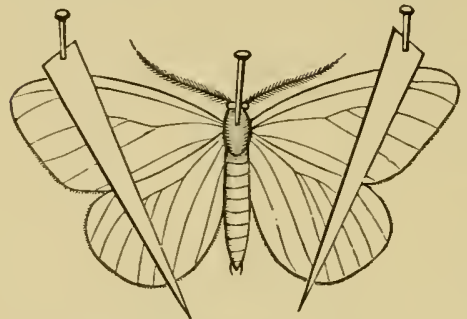

FIG, 268.-Mode of setting with card-braces the wings of a butterfly or moth. may be distinctly seen. When thus arranged, they can be confined by fine threads drawn over the wings, by pieces of card pinned to the board as indicated in Fig. 268, or, as we prefer, by square pieces of glass laid upon them.

After the insects have been tholoughly dried they should not be placed in the cabinet until after having been in quarantine to see that no eggs of Dermestes or Anthrenus, etc., have been deposited on them.

For preserving dried insects in the cabinet Laboulbène recommends placing a rare insect (if a beetle or any other hard insect) in water for an hour until the tissues are softened. If soiled, an insect can be cleansed under water with a fine hair-pencil, then submit it to a bath of arseniated alcohol with corrosive sublimate. If the insect becomes prune-colored, it should be washed in pure alcohol several
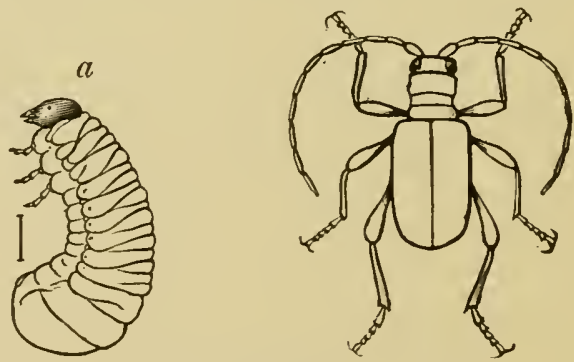

FIG. 269.-Ptinus fur. a larva.

times. This method will do for the rarest insects; the more common ones can be softened on wet sand, and then the immersion in the arseniated alcohol suffices. After an 
immersion of from a quarter of an hour to an hour, according to the size of the insect, the pin is not affected by the corrosive sublimate, but it is better to unpin the insect previous to immersion, and then pin it when almost dry.

For cleaning insects ether or benzine is excellent, applied with a hair-pencil; though care should be taken in using these substances, which are very inflammable.

After the specimens are placed in the cabinct, they should be further protected from destructive insects by placing in the drawers or boxes pieces of camphor wrapped in paper perforated by pin-holes, or bottles containing sponges saturated with benzine or oil of sassafras. The collection should be carefully examined every month; the presence of insects can be detected by the dust beneath them. Where a collection is much infested with destructive insects, * benzine should be poured into the bottom of the box or drawer, when the fumes and contact of the benzine with their bodies will kill them. The specimens themselves should not be soaked in the benzine if possible, as it renders them brittle. $\uparrow$

* The common museum pests are Anthrenus varius, A. muscorum, Attagenus pellio, Trogoderma tarsale, and Dermestes lardarius, besides Tinea pellionella, Megatoma, and Atropos pulsatorius; in California Perimegatoma variegatum has proved destruetive to collections. Ptinus fur (Fig. 269) is also liable to occur.

+ We find by placing a small piece of cyanide of potassium in an open short vial for a fortnight in an insect drawer that it may be thoroughly disinfected; for permanent use naphthaline cones are effective. Naphthaline cones, while not killing the larva, repel adult anthreni, etc., and should be kept constantly in boxes or drawers. Mr. Schwarz advocates the use of "white carbon," which is naphthaline sold in the form of small, square rods, costing only 8 cents a pound wholesale, and which is much purer than the naphthaline cones now in the market. When broken up into small pieces, and wrapped in thin paper, it ean be conveniently used in insect boxes or drawers. Mr. Akhurst uses a preparation consisting of 3 parts of creosote or crude carbolic acid and 1 part oil of pennyroyal, applied to the seams, grooves, and elges of boxes or drawers to keep out museum pests. MIr. J. B. Smith urges the use of bisulphide of carbon, which both serves to check the development of the eggs and to destroy the recently-hatched larve of museum pests. He finds that the only chances of safety from infection " consist in constant 
Insect-cabinet.-For permanent exhibition, a cabinet of shallow drawers, protected by doors, is most useful. A drawer may be eighteen by twenty inches square, and two inches deep in the clear, and provided with a tight glass cover.

For a permanent cabinet, says Mr. S. H. Scudder, nothing can excel the drawers made after the Deyrolle model, now in use by the Boston Society of Natural History. "I have tried them for six years, and find them entirely pest-proof. They are made with a cover of glass set in a frame which is grooved along the lower edge and thus fits tightly into a narrow strip of zinc set edgewise into a corresponding groove in the drawer; the grooves beyond the point of intersection of two sides are filled with a bit of wood firmly glued in place; it is hardly necessary to say that the sides of the drawer and the frame of the cover should be made of hard wood; soft wood would not retain the zinc

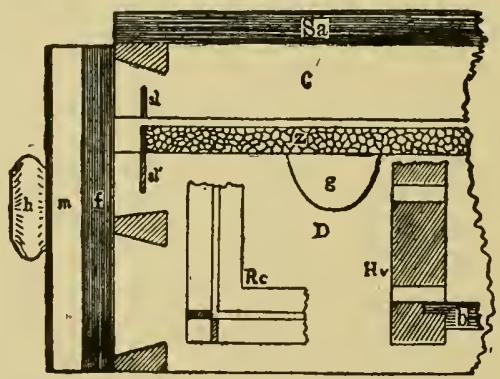

Fig. 250.-Model of the Deyrolle insect-drawer, side view of front end, with the cover raised. $D$, bottom of drawer; $C$, cover of same, raised a little; $f$, front piece, with moulding $(m)$ and handle $(h)$ glued to bottom piece; $s a$, sash; $s l$, slit in cover, into which the zinc strip $(z) \mathrm{fits} ; s l^{\prime}$, slit in bottom, into which it is fastened; $g$, bevelled groove, to allow the finger to raise the cover; $H v$, hind view of one end of the bottom to show the insertion of the bottom $(b)$; $R c$, reverse of one corner of cover to show the grooves filled beyond their junction. All the figures half size.

strip; the zinc should be perfectly straight, and the ends well matched; if this be done, nothing can enter the box

examination, tight boxes, and a free use of chloroform or bisulphide of carbon" (Proc. Ent. Soc. Washington, i. 115). 
when it is closed. A similar box with a wooden rabbet is used at the Mnseum of Comparative Zoology at Cambridge; but it cannot possibly be so tight, and requires hooks on the sides to keep the cover down; it has the advantages of greater cheapness, as it can be made of soft wood, but is at the same time chumsier. My own drawers are made of cherry sides, and have also a false front attached to them, furnished with monldings and handles so as to present a not inelegant appearance; and, exchusive of the cork with witich they are lined, cost $\$ 2.65$ each; they measure inside $18 \frac{3}{4}$ inches long, 14 inches wide, and $1 \frac{7}{5}$ inches deep, not including the cork lining."

In the drawers in use by the U. S. Entomologist at the Department of Agriculture there are on the sides within, deep grooves kept constantly filled with naphthaline.

For constant nse, boxes made of thin, well-seasoned wood, * with tight-fitting covers, are indispensable. For Coleoptera, Dr. LeConte recommends that they be twelve by nine inches (inside measurement). For the harger Lepidoptera a little larger box is preferable. Others prefer boxes made in the form of books, which may be put away like hooks on the shelves of the cabinet, though the cover of the box is apt to be in the way.

The boxes and drawers should be lined with cork cut into thin slips for soles; such slips come from the corkcutter about twelve by four inches square and an eighth of an inch thick.

Other substitutes are the pith of various plants, especially of corn; "pita" and palm wood; and "inodorous felt" is used, being cut to fit the bottom of the box.

LeConte recommends that, "for the purpose of distinguishing specimens from different regions, little disks of variouslycolored paper be used; they are easily made by a small

* Bass-wood, or that of the poplar, tulip-tree, or even mabogany, is better than pine, as the resin in the latter sends off exhalations whieh eventually combine with the fat of the specimens enclosed in the box and render them greasy (Psyche, i. 64). 
punch, and should be kept in wooden pill-boxes ready for use; at the same time a key to the colors, showing the regions embraced by each, should be made on the fly-leaf of the catalogue of the collection." He also strongly recommends that the "specimens should all be pinned at the same height, since the ease of recognizing species allied in characters is greatly increased by having them on the same level."

He also states that "it is better, even when numbers with reference to a catalogue are employed, that the name of each species should be written on a label attached to the first specimen 'Thus the eye is familiarized with the association of the species and its name, memory is aided, and greater power given of identifying species when the eabinet is not at hand." For indicating the sexes the astronomical sign o (Mars) is used for the male, and $q$ (Venus) for the female, and $P$ for the worker.

For exhibiting alcoholic specimens of insects in different stages, and preventing their remaining at the bottom of bottles on the shelves, Prof. Moebius places the specimens in a glass tube filled with alcohol and having a stopper of cotton-wool. He then puts the insects according to their age, eggs or larvæ lowest, in a stoppered npright bottle filled with aleohol, in the middle of which is a cylindrical glass which presses the glass tube against the side of the upright vessel (Zool. Anzeiger, vi., 1883, 52-3).

Transportation of Insects. - While travelling, all hardbodied insects, comprising many Hymenoptera, the Coleoptera, Hemiptera, and many Neuroptera, should be thrown, with their larvæ, etc., into bottles and vials filled with strong alcohol, with rubber stoppers. When the bottle is filled new liquor should be poured in, and the old may be saved for collecting purposes; in this way the specimens will not soften and ean be preserved indefinitely, and the eolors do not, in most cases, change. LeConte states that " if the bottles are in langer of being broken, the specimens, after remaining for a day or two in alcohol, may be 
taken out, partially dried by exposure to the air, but not so as to be brittle, and these packed in layers in small boxes between soft paper; the boxes should then be carefully closed with gunl-paper or paste, so as to exclude all enemies."

Lepidoptera and dragon-flies and other soft-bodied insects may be well preserved by placing them in square pieces of paper folded into a triangular form with the edges overlapping. Put up thus, mnltitudes can be packed away in tin boxes, and will bear transportation to any distance. In tropical climates, chests lined with tin should be made to contain the insect-boxes, which can thms be preserved against the ravages of white ants, etc.

In sending live larvæ by mail, they should be inclosed in little tin boxes; and in sending dry specimens, the box should be light and strong, and directions given at the post-office to stamp the box lightly. In sending boxes by express, they shonld be carefully packed in a larger box having an interspace of two inches, which can be filled in tightly with hay or crumpled bits of paper. Beetles can be wrapped in pieces of soft paper. Labels for alcoholic specimens should consist of parchment, with the locality, date of capture, and name of collector written in ink. A temporary label of firm paper, with the locality, etc., written with a pencil, will last for several years.

Preservation of Larvæ.-Alcoholic specimens of insects, in all stages of growth, are very useful. Few collections contain alcoholic specimens of the adult insect. This is a mistake. Many of the most important characters are effaced during the drying process, and for purposes of gencral study alcoholic specimens, even of bees, Lepidoptera, Diptera, and dragon-flies, are very necessary.

Larvæ, generally, may be well preserved in vials or bottles of alcohol with rubber corks.* They should first be put

* Although rubber stoppers are more expensive than the best cork stoppers, they are more clurable, and prevent evaporation vastly better; in corking, run an insect-pin down by the cork, allowing it to remain in for a while, thus allowing the air to escape and preventing the 
into whiskey, and then into alcohol. If placed in the latter first, they shrivel and become distorted. Mr. E. Burgess preserves caterpillars with the colors unchanged, by immersing them in boiling water thirty or forty seconds, and then placing them in equal parts of alcohol and water. It is well to collect larvæ and pupæ indiscriminately, even if we do not know their adult forms; we can approximate to them, and in some cases tell very exactly what they must be.

\section{Rearing Aquatic Larver.}

Many insects pass their early stages in brooks or ponds. I'hey can be dredged with the water-net, and reared in pans or jars of water in which a few water-cresses, mosses, or other aquatic plants may be kept to oxydize the water and keep it pure. In this way the larvæ or nymphs of Perlidæ, may-flies, dragon-flies, caddis-flies, aquatic beetles, Diptera, and moths may be reared with more or less success. By collecting such larve in Mareh, April, and May, a good many species maty be brought to maturity within a few weeks' time.

Any glass jar, or even a deep earthen pan, may suffice for an aquarium, in place of more elaborate glass and iron structures.

Mr. Lugger has invented an aquarium which he finds very eonvenient for rearing aquatic insects; it consists of a tin box one foot square in front and about three inches thick, with a glass front. Over this glass front slips a round-oval picture-frame. If the inside is painted and filled with water, the whole looks like a suspended picture of rather unusual thickness. Several such aquaria can be grouped together like so many pictures. If connected by siphons carefully graded, a constant flow of water can be obtained, which produces the necessary current and sup-

strong compression of the alcohol, which tends to force the cork out. See Dr. Hagen on the use of rubber stoppers, Can, Ent., xviii. p. 1. 
plies the needed amount of oxygen. In such aquaria aquatic larvæ and insects can be studied with great convenience. The addition of some water-plants adds greatly to the beauty of these aquarial pictures. (Proc. Ent. Soc. Washington, i. 3\%.)

\section{REARING INSECTS IN GENERAL.}

More attention has been paid by entomologists to rearing caterpillars than the young of any other orders of insects, and the following remarks apply more particularly to them, but very much the same methods may be pursued in rearing the larvæ of Neuroptera, beetles, flies, and Hymenoptera. Subtermanean larva have to be kept in moist earth, aquatic larvæ must be reared in aquaria, and carnivorous larvæ must be supplied with flesh. The larvæ of butterflies are nsually rare; those of moths occur more frequently, while their imagos may be scarce. In some years many larvæ, which are usually rare, occur in abundance, and should then be reared in numbers. In hunting for caterpillars, bushes should be shaken and beaten over newspapers or sheets, or an umbrella; herbage should be swept, and trees examined carefully for leaf-rollers and mincrs. The best specimens of moths and butterflies are obtained by rearing them from the egg, ${ }^{*}$ or from the larva or pupa. In

* Lepidoptera lay on the average from 100 to 700 eggs: those of butterflies should be looked for on the herbs, bushes, or trees about which they fly; those of sphinges on the flowers apt to be visited by them. The eggs will be founcl after patient search by turning up the leaves of willows, azaleas, and other plants. As a rule a butterfly or moth follows a path or fence side when laying; so upon fincling the first egg or larva we more minutely examine each shrub, for they are very apt to lay an egg on each prominent one as they go along. "And it is not difficult to follow the path of the parent for quite a distance; and so the finding of one egg means almost surely the fincling of more." G. D. Hulst (Bull. Brooklyn Ent. Soc., ii. 13.)

The same is the ease with the search for rare caterpillars; our best breeders of rarities search patiently by turning up one leaf after another for them. For want of time, and especially when the branches are high, we use a stick and umbrella, and beat the branches or leaves 
confinement the food should be kept fresh, and the box well ventilated. 'Tumblers covered with gauze, pasteboard boxes pierced with holes and fitted with glass in the covers, or large glass jars, are very convenient to use as cages. The bottom of such vessels may be covered with moist sand, in which the food-plant of the larva may be stuck and kept fresh for several days. Larger and more airy boxes, a foot square, with the sides of gauze, and fitted with a door through which a bottle of water may be introduced, serve well. 'The following extract from Riley's "Fifth Amual Report on the Injurious Insects of Missouri" Illustrates his style of vivarium:

"For larger insects I use a breeding-cage or vivarium of my own devising, and which answers the purpose admirably. It is represented in Fig. 271, and comprises three distinct parts: 1st, the bottom board (a), consisting of a square piece of inch-thick walnut with a rectangular zine pan (.ff), four inches deep, fastened to it, above, and with two crosspieces $(g g)$ below, to prevent cracking or warping, facilitate lifting, and allow the air to pass underneath the cage. $2 d$, a box $(b)$, with three glass sides and a glass door in front, to fit over the zinc pan. 3d, a cap $(c)$, which fits closely on to the box, and has a top of fine wire ganze. To the centre of the zine pan is soldered a zine tube $(d)$ just large enongh to contain an ordinary quinine bottle. The zinc pan is filled with elean sifted earth or sand $(e)$, and the quinine bottle is for the reception of the food-plant. The cage admits of abundant light and air, and also of the easy removal of the excrement and frass which fall to the ground; while the insects in transforming enter the ground or attach themselves to the sides or the eap, according to their habits. 'T'he most convenient dimensions I find to be twelve inches square and eighteen inches high: the cap and the door fit closely by means of rabbets, and the former has

into the outspread umbrella; this method is successful for fir, spruce, and pine trees, as well as forest trees in general. 
a depth of about four inches to admit of the largest cocoon being spun in it without touching the box on which it rests.

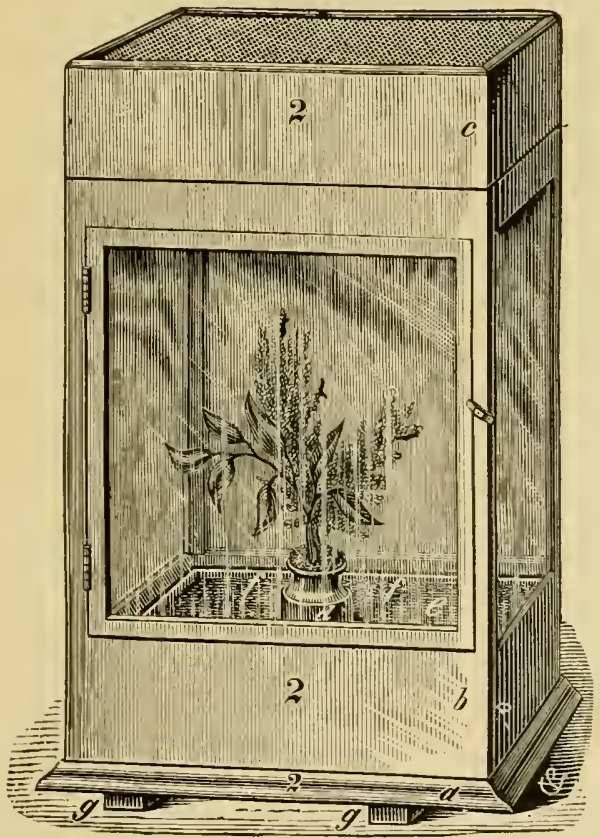

Fia. 271.-Breeding-cage.

The zinc pan might be made six or eight inches deep, and the lower half filled with sand, so as to keep the whole moist for a greater length of time.

"A dozen such cages will furnish room for the annual breeding of a great number of species, as several having different habits and appearance, and which there is no danger of confounding, may be simultaneously fed in the same cage. I number each of the three parts of each cage, to prevent misplacement and to facilitate reference; and aside from the notes made in the note-book, it will aid the 
memory and expeclite matters to keep a short open record of the species contained in each cage, by means of slips of paper pasted on to the glass door. As fast as the different specimens complete their transformations and are taken from the cage the notes may be altered or erased, or the slips wetted and removed entirely. To prevent possible confounding of the different species which enter the ground, it is well, from time to time, to sift the earth, separate the puyse and place them in what I call imago cages, used for this purpose alone and not for feeding. Here they may be arranged, with reference to their exact whereabouts."

The object is to keep the food-plant fresh, the air cool, the larva out of the sun, and in fact everything in such a state of equilibrinm that the larra will not feel the change of circumstances when kept in confinement.

Sugaring for Moths. - We may set bait or "sugar" for moths, smearing the mixture of sugar and rinegar on the bark of a tree, and visiting the spot by night with the lantern and net. A mixture of cheap brown sugar mixed with a little hot water and beer, or one of some beer and molasses in equal parts, flarored with a little rum or brandy, may be applied with a paint-brush before dusk to stumps, trunks of trees, or fences; some prefer to lay it on in long and narrow streaks rather than in broad patches. With a dark-lantern hanging from a strap around the waist, the collector may visit the trees several times during an evening, especially a warm, damp, foggy, still night.

Mr. O. S. Westcott advises the night collector to have two wide-mouthed bottles, each with a chloroform sponge tacked on the bottom of the cork; also two cyanide of potassium bottles, to which the temporarily anæsthetized moths may be transferred (Can. Ent., viii. 12).

Traps for Moths, etc. - T'aking advantage of moths flying to lights, * many can be collected about gas or electric lights.

* It is a curious fact that in general the males alone are attracted to light; the same is probably true of beetles, at least the June beetle. 
Indeed, the electric lights now make the best collecting places, and they attract moths and beetles to such an extent that almost nothing can be taken at sugar or gaslamps where these lights are situated. A light trap may be made by a lantern combined with a reflector, suspended out of doors: under the lantern a funnel several inches larger than the lantern may reach down into a box or bottle containing the fumes of chloroform or ether, or benzine, or, if the lintern is nsed for beetles, into a bottle filled with dilute alcohol.

It should be borne in mind, as Mr. Thaxter observes, that Noctuids always fly against the wind, and unless the light is so placed that they can fly thus to get to it, one's success will be slight.

We will now describe the methods of rearing and preserving insects of different orders.

\section{Rearing Caterpillars.}

The best specimens of moths and butterflies are obtained by rearing them from the egg, or from the larva or pupa. Besides merely breeding catervillars in order to procure good specimens for the cabinet, the modern student of entomology who desires to trace the genealogy of Lepidoptera should study the freshly-hatched larva, and compare it and the other early stages with the full-grown larva, so as to obtain a complete life-history, with colored illustrations, of each stage. Hence a good deal of care must be exercised in breeding and describing caterpillars. In confinement the food should be kept fresh, and the breeding cage or box well ventilated. 'Tumblers covered with gauze, pasteboard boxes pierced with holes and fitted with glass in the covers, or large glass jars-but better still, tin boxes of different sizes, in which the food remains fresh for several days-are very convenient to use as cages. The bottom of such vessels may be covered with moist sand, in which the food- 
plant of the larva may he stuck and kept fresh for several days. In rearing from the egg, says Scudder, the greatest difficulty is during early life; young caterpillars must have the freshest and tenderest food and not too much confinement. With all precautions many will be lost, for they are so small that it is difficult to keep track of them, and some are very prone to wander when their food does not snit them. They are best reared in some open vessel covered with ganze, with the growing plant, placed in the light, but not in the sun. Most caterpillars change to pupæ in the autumn; and those which transform in the earth should be covered with earth, kept damp by wet moss, and placed in the cellar until the following summer. The collector in seeking for larve should carry a good number of pill-boxes, and especially a close tin box, in which the leaves may be kept fresh for a long time. The different forms and markings of caterpillars shonld be noted, and they shonld be drawn carcfully together with a leaf of the food-plant, and the drawings and pupa skins, and perfect insect, be numbered to correspond. Descriptions of caterpillars cannot be too carcfully made, or too long. The relative size of the head, its ormamentation, the stripes and spots of the body, and the position and number of tubercles, and the hairs, or fascicles of hairs, or spines and spinules, which arise from them, should be noted, besides the general form of the body. The lines along the body are called dorsal if in the mirdle of the back; subdorsal if upon one side; lateral and ventral when on the sides and under surface; or stigmatul if including the stigmata or breathing-pores, which are generally parti-colored. Indeed, the whole biography of an insect should be ascertained by the observer; the points to be noted are:

1. Date when and how the eggs are laid; and number, size, and marking of the eggs.

2. Date of hatching, the appearance, food-plant of larva, and number of days between each moulting; the changes 
the larva undergoes, which are often remarkable, especially at the first monlting, with drawings illustrative of these; the habits of the larva, whether solitary or gregarious, whether a day or night feeder; the ichneumon parasites, and their mode of attack. Specimens of larve in the different moultings should be preserved in alcohol. The appearance of the larvæ when full-fed, the date, number of days before pupating, the formation and description of the cocoon, the duration of larre in the cocoon before pupation, their appearance just before changing, their appearance while changing, and alcoholic specimens of larvæ in the act, should all be studied and noted.

3. Date of pupation; description of the pupa or chrysalis; duration of the pupa state, labits, etc.; together with alcoholic specimens or pinned dry ones. Lepidopterous pupæ should be looked for late in the summer, or in the fall and spring, about the roots of trees, and kept moist in mould until the imago appears. (Many Coleopterous pupæ may also occur in mould and, if aquatic, under submerged sticks and stones, and those of borers under the bark of decaying trees.)

4. Date when the insect escapes from the pupa, and method of escape; duration of life of the imago; and the number of broods in a season.

Drawing Caterpillars.-After some practice any one can make a recognizable drawing of even an insect, especially of a caterpillar, and after a little experieuce even a sketch in water-colors. Drawing in natural history is all-important to the beginner; it trains the eye to observe closely, and good sketches of the early stages of insects are especially needed in this country. Various cameras have been contrived to enable the artist to get a correct ontline of objects, while for flat, microscopic objects the use of the camera lucida is invaluable; after a few trials it can be used both for drawing outlines and filling in details. In this way the larvæ of the Micro-lepidoptera monnted on glass slides may be drawn. 
Managing Caterpillars in Confinement.-They may be enclosed in ganze bags tied over the smaller branches of the food-tree, yet they have to be watched; they need attention after heavy showers or storms; and some will eat their way through just before pupation. For caterpillar's in confinement air and light are necessary, though many do well bred in small tin boxes without ventilation. The boxes should be clemed every day; removing the castings and hits of leaves, as well as sick or dead larva. If any contagions disease appears, all the sick caterpillar's should be burnt and the box cleansed with dilute carbolic-acid water. 'The food should be renewed every day, and if possible put into a bottle of water elosed with cotton to prevent caterpillars from falling in. 'Too much food in a small jar or box fouls the air and hastens its own decay. After beginning to feed larva with one kind of food-plant, it is dangerous to change it for another; hence they should be fed on the kind of plants on which they are first found.

Dr. Knaggs has, in the "Entomologist's Monthly Magazine," given some directions for managing caterpillars. Very young caterpillars, which will not eat the food provided, and become restless, should be reared in air-tight jam-pots, the tops of which are covered with green glass to darken the interior of the vessel. When small larve hide themselves by mining, entering buds, and spimning together leaves, they should have as small a quantity of food as possible. In changing larvæ from one plant to a fresh one, a slight jar or puff of breath will dislodge them, and they can be transferred to the jan-pot; or the glass eylinder, covered at one end with muslin, can be turned muslin end downwards for them to crawl upon. The duplicate breeding-cage, pot or tube, should be "sweetened" by a free current of fresh dry air and then stocked with fresh food.

Dr. Knaggs advises that "hiding-places" or bits of chips, etc., be provided for such Noctnid larva as natnrally lie concealed, such as Orthosia, Xanthia, Noctua, ete., "while 
for Agrotis and a few others a considerable depth of fine earth or sand is necessary." *

"Larvæ, which in nature hibernate, must either be stimulated by warmth and fresh food to feed up umnaturally fast, or else through the winter must be exposed to out-door temperature." Mibernating, hairy larva must be kept dry during winter. For such larve as begin to eat before the trees are leavel ont, the leaves of erergreens must be provided, pine leaves, chiekweed, grasses and mosses. On the other hand, Mr. W. H. Edwards has fed belated larvæ of Papilio cresphontes on dried leaves of priekly ash, softened in water. He also fed another belated lot with leaves of the hop-tree which had been gathered for two years. These he soaked overnight, laid between blotting-paper, and the larvæ ate them readily. Larve from other countries may be fed in the same mamer, the foodplants being sent by mail. Mr. Greene describes what he ealls his "larvarium, viz., a very large box, say three feet square and about the same in depth, filled partly with mould covered with moss." The edges of the top of this box must be smoothly shaved to suit the lid, which is like the frame of a slate, the slate being knocked out. This is then eovered with gauze. In a box of this size small branches may be held in bottles of water, and two or three dozen larvæ safely housed. If placed in a cool room, with plenty of air, they will grow almost as large as if in freedom. Mr. Gibson strongly reeommends that during the winter all eages eontaining larva be placed in front of a window facing the east or northeast, so that the inmates may be kept as cool as possible.

When the moth is fairly out of the pupa, as remarked by Mr. Sanborn, their wings often fail to properly expand on

* Many larvæ require earth during all their entire existence as such, and very many more require it for pupation. The Noctuids, especially, burrow in the earth during the day, and the Catocalæ, as well as many others, must have clean litter in which to hide, for thcy feed only at night, and lie concealed under bark, in crevices, and among grassroots and leaves during the day. 
account of the want of moisture, "the insect being unable to expand its wings in a heated, dry room. He has avoided this difficulty ly placing the inseet just emerged, or about to come forth, beneath a bell-glass, within which he had placed moistened pieces of bibulous paper."

By taking advantage of the habit of many tree-feeding eaterpillars of changing to pupa (pupating) in the soil elose to the trunk of the tree, many rare moths an with little trouble be raised from the chrysalides thus found. As the Rev. Joseph Greene ("The Insect-lnunter's Companion," London, 18\%0) advises, the dirt around the trunk sloould be dug up with a trowel, and carefully examined for chrysalides. He adds that "pupæ may be found almost anywhere and everywhere, under moss on large stones and boulders, in the deeayed stumps of old trees, behind the loose bark on palings, between dead leaves, under moss on banks, etc., etc."

Hibernating Larvæ.-These are very apt to die when artificially hibernated. If kept too dry they die from lack of moisture; if kept too moist they are apt to be attacked by fungi. 'The effort should be to keep them at a temperature as steady as possible and below the freezing point. If placed in a cellar with the window open, or among leaves out of doors in a box protected from rain and snow, in conditions as nearly as possible to nature, they may be in many cases successfully carried over through the winter.

Management of Pupæ.-Mr. S. Lowell Elliott, who has been remarkably successful in rearing butterflies and moths, breeding them by the hundreds and even thonsands, las a pupa-box of the following description: It is about $20 \times 16$ inehes, and 8 inches deep, with a bottom of coarse wire cloth placed about 2 inches from the bottom, so that the box can be set over a flat earthen pan of water; it is divided by thin wooden partitions into four compartments, the bottom of each of which is covered with a thick layer of baked Sphagnum moss which has been pulled into fine bits. 'The pupæ are laid on this floor of moss, and covered over 
with a thick layer of moss prepared in the same manner as that beneath. 'The box is covered by a glass plate kept in place by projections from the sides. During the winter the pan of water may be dispensed with, and the box put into a cellar-room with the window partly open, so that the fresh moist air may penetrate, or in a cool attic; or, better, placed in such a situation outside of the house that the box will not receive injury, while the pupa will be kept cool and not too damp. We have found that sneh a box, with water in course of evaporation under it, is by far the best place to keep pupæ both in summer and winter.

When the moths emerge, they are transferred by Mr. Elliott to another box (or rather a series of them, for keeping numerous specimens at the same time), with a glass top, and a stick introduced on which the moth may hang suspended by its feet until the wings are fully expanded and the body sufficiently dried; they are then transferred to the poisoning-box, and the insect is finally set, before a wing has fluttered.

Pairing or Mating Lepidoptera in Captivity._- "It is common enongh," says Mr. W. H. Edwards, "for certain Sphinges and Bombycidæ to mate in boxes and immediately after leaving the pupæ. This may happen when the eggs are mature at the birth of the insect. With many species of butterflies the eggs do not mature for several days after leaving the chrysalis, as is the case with the large Argynnids; but with others, as Phyciodes tharos, nycteis, and myrina, they are mature from the start. I have not experimented in this direction, but from what Miss E. L. Morton, of Newburgh, N. Y., tells me, it may be possible to induce butterflies of some species to mate and so to obtain eggs, for the eggs are laid very shortly after copulation, as I have several times observed. Miss Morton had by mistake placed a male Satyrus alope under a bag of netting on grass. 'Three days later she introduced a female, which up to that time was supposed to be the second female. Almost immediately the pair mated, and 
a few hours later eggs were laid. In attempting to get eggs in this manner, it would be best that a male caught in the field should be introduced to a female just from the chrysalis, for in the field it is these last which are sought by the males. Almost always, when a pair of butterflies in copulation are taken, the male will be found worn or broken, while the female is uninjured in wing and therefore must have lately left the chrysalis" (Can. Entomologist, xviii. 1 \%).

Mr. S. Lowell Elliott very successfully mates Bombyces, etc., by placing the sexes in a gauze mating-bag suspended in a room through which passes a current of air from out of-doors.

Mr. Edwards also covers a branch of the food-plant with a bag of fine netting, placing the female within, so that she can move freely about; she should have plenty of light, though not exposed to the direct rays of the sun. If the plant is a small one it may be covered with a headless keg, covered at one end with ganze.

Treatment of the Eggs. - They should be kept in a not. too dry or overheated atmosphere, and should be so placed that at its birth, without effort, the larva at once finds fresh food.*

Collecting and Rearing Micro-lepidoptera. - For collecting and preserving these minute and delicate moths, which are called by collectors Micro-lepidoptera, especial instructions are necessary. When the moth is taken in the net, it can be blown by the breath into the bottom. "Then by elevating the hand throngh the ring, or" on a level with it, a common cupping-glass of about two inches in diameter, or a wine-glass carried in the pocket, is placed on top of the left hand over the constricted portion, the grasp relaxed, and the insect permitted to escape through the opening into its interior. The glass is then closed below by the left hand on the outside of the net, and may

* Hulst and Thalenhorst in Bulletin Brooklyn Ent. Soc., ii. 63; other hints are taken, sometimes verbatim, from this article. 
be transferred to the top of the collecting-box, when it can be quieted by chloroform." (Clemens.) Or the moths may be collected in pill-boxes, and then carried home and opened into a larger box filled with fumes of ether or benzine or cyanide of potassium. In pinching any moths on the thorax, as is sometimes done, the form of that region is invariably distorted, and many of the scales removed. In searching for Micros we must look carefully on the lee side of trees, fences, hedges, and undulations in the ground, for they avoid the wind. Indeed, we can take advantage of this habit of many llieros, and by blowing vigorously on the trunks of trees start the moth off into the net so placed as to intereept it. 'T'his method is most productive, C. G. Barrett states, in the "Entomologist's Monthly Magazine," while a steatly wind is blowing.

The larvæ vary excessively in the number of legs, sixteen being the usual number, but in several genera (Gracilaria, Lithocolletis, etc.) we only find fourteen : in Nepticula, though the legs are but poorly developed, they number eighteen; on the other hand, the larve of a few of the smaller genera (Antispila, T'inagma, ete.) are absolutely footless.

In seeking for the larræ, we must remember that most of them are leaf-miners, and their burrows are detected by the waved, brown, withered lines on the surface of leaves, and their frass, or excrement, thrown out at one end. Some are found between united leaves, of which the upper is crumpled. Others construct portable cases which they draw about the trunks of trees, fences, etc. Others burrow in the stems of grass, or in fungi, toadstools, and in the pith of eurrant or raspberry bushes. Most are solitary, a fow gregarious. A bush stripped of its leaves and corered with webs, if not done by Clisiocampa (the American tent-caterpillar), will witness the work of a Tortrix or Tineid. Buds of unfolded herls suffer from their attacks, such as the heads of composite flowers which are drawn together and consumed by the larvæ. 
After some practice in rearing larvæ it will be found easier and more profitable to search for the leaf-miners, and rear the perfect, fresh, and uninjured moths from them. In this way many species never found in the perfeet state can be secured.*

In raising Micro larve it is essential that the leaf in which they mine be preserved fresh for a long time. 'Thus a glass jar, tumbler, or jam-pot, the top of which has been ground to receive an air-tight glass cover, and the bottom covered with moist white sand, will keep a leaf fresh for a week, and thus a larva in the summer will have to be fed but two or three times before it changes ; and the moth can be seen throngh the glass without taking off the cover; or a glass cylinder can be placed over a plant inserted in wet sand, having the top covered with ganze. Dr. H. G. Knaggs, in treating of the management of caterpillars in breeding-boxes, enumerates the diseases, besides muscardine and cholerine (and we might add pebrine), to which they are subject. Among direct injuries are wounds and bruises, which may be productive of deformities in the future imago; the stings of ichneunon flies, whose eggs laid either npon or in the body may be erushed with finely pointer scissors or pliers; frost-bites; and suffocation, ehiefly from drowning. If the caterpillar has not been more than ten or twelve hours in the water, it may be recovered by being dried on a piece of blotting-paper and exposed to the sun. Larve may also starve to death, even when food is abnndant, from loss of appetite, or improper ventilation, light, etc.; or they may eat too much, become dropsieal and die. Caterpillars undoubtedly suffer from a

* "In general, it may be said, the mines of the leaf-miners are characteristic of the genus to which the larva may belong. A single mine once identitied enables the collector to pronounce on the genus of all the speeies he may find thereafter. This, added to the ease with which the larva are collected, and the little subsequent care required to bring them to maturity, except to kecp the leaves in a fresh and healthy state, makes the study of this gromp, in every respect, pleasant and satisfactory to the entomologist." (Clemens.) 
contagious disease analogous to low fever. Many die while moulting, especially the larva of bntterflies, splinges, and bombycids; others are carried off by diarrhou, which is generally caused by inıproper feeding on too juicy or relaxing food, when oak leaves or dry stunted folinge shonld be given them. 'T'o relieve constipation they should be fed with lettuce and other natural purgatives: and lastly, they may be attacked by fungi, especially, besides those previously mentioned, a species of Oidium. Such patients should be put in direct sunlight or dry currents of air. (Fntomologist's Monthly Magazine, June, 1868.) 'The pupæ easily dry up ; they should be kept moist, in tnbes of glass closed at either end, through which the moth ean be seen when disclosed.

In setting Micro-lepidoptera: "If the insect is very small I hold it by its legs between the thumb and finger of the left hand, whilst I pierce it with the pin held between the thumb and finger of the right hand; if the insect is not very snall I use a rough surface, as a piece of blotting-paper or piece of cloth, for it to lie npon and prevent its slipping abont, and then cantionsly insert the point of the pin in the middle of the thorax, as nearly as possible in a vertieal direction. As soon as the pin is fairly throngh the insect, remove it to a soft piece of cork, and, by pressing it in, push the insect as far np the pin as is required.

"For setting the insects I find nothing answers as well as a piece of soft cork, papered with smooth paper, and with grooves cut to admit the bodies. The wings are placed in the required position by the setting-needle, and are then retained in their places by a wedge-shaped, thin paper brace, placed over them till a square brace of smooth card-board is placed over the ends of the wings." (Stainton.) A small square of glass can also be laid on the wings to keep them expanded, and thus serve the sime purpose as the paper braces.

Linnæus first set the example of having the specific names of the Tortricids end in ana, and of the 'lineids in ella; and 
at the present day the rule is generally followed by entomologists, who have also given the same terminations to the names of the smaller species of Pyralides, such as Pempelia, Crambus, and allied genera.

We may also add Lord Walsingham's directions for collecting Micro-lepidoptera, published in the "American Naturalist" (vol. vi., No. 5):

"I go out with a coat provided with large pockets inside and out, containing an assortment of pill-boxes (generally of three sizes, glass-bottomed pill-boxes preferred), a bag slung over my shoulder, and a net. Unless searehing for particular day-flying species, I prefer the last three hours before dark. As the sun goes down, many species move which do not stir at other times. I wateh the tops of the grass, the stems of the flowers, the twigs of the trees; I disturb leaves and low-growing plants with a short switch, and secure each litthe moth that moves, taking each out of the net in a separate pill-box, selected according to the size of the insect, as he runs up the net to escape. Transferring the full boxes to the bag, I continue the pro. cess until moths cease flying or night sets in. Many species can be taken with a lamp after dark.

"Returning to eamp, I put a few drops of liquid ammonia on a small piece of sponge and place it in a tin canister with such of the boxes as do not contain the smallest species, and put these and the remainder away until morning in a cool place. In the morning I prepare for work by getting out a pair of scissors, a pair of forceps, my drying-box containing setting-boards, a sheet of white paper, and some pins.

"First, I cut two or three narrow pieces of paper from three to six lines wide, or rather wider, aecording to the size of the largest and smallest specimens I have to set. I then double each of these strips and cut it up into braces by a number of oblique cuts. Now I turn out the contents of the canister and damp the sponge with a few drops of fresh ammonia, refilling with boxes containing live insects. Those which have been taken out will be found to be all dead and in a beautifully relaxed condition for setting. Had the smallest specimens been placed in the canister overniglat, there wonld have been some fear of their drying up, owing to the small amount of moisture in their bodies.

"If the weather is very hot there is some danger of killed insects becoming stiff while others are being set, in which case it is better to pin at once into a damp cork box all that have been taken out of 
the canister; but under ordinary circumstances I prefer to pin them one by one as I set them.

"Taking the lid off a box, and taking the box between the finger and thumb of the right hand, I roll out the insect on the top of the left thumb, supporting it with the top of the forefinger and so manipulating it as to bring the head pointing towards my right hand and the thorax uppermost. Now I take a pin in the right land, and resting the first joint of the middle finger of the right against the projecting point of the middle tinger of the left hand to aroid unsteadiness, I pin the insect obliquely through the thickest part of the thorax so tbat the head of the pin leans very slightly forward over the head of the insect. After passing the pin far enough through to bring about one-fourth of an inch out below, ${ }^{*}$ I pin the inseet into the middle of the groove of a setting-board so that the edge of the groove will just support the under sides of the wings elose up to the body when they are raised upon it. The board should be chosen of such a size as will permit of the extension of the wings nearly to its outer edge. The position of the pin should still be slanting a little forward. The wings should now be raised into the position in which they are intended to rest, with especial care in doing so not to remove any scales from the surface or cilia of the wings. Each wing should be fastened with a brace long enough to extend across both, the braces being pinned at the thiek end, so that the head of the pin slopes away from the point of the brace; this eauses the braces to press more firmly down on the wing when fixed. The inseet should be braced thus : the two braces next the body should have the points upwards, the two outer ones pointing downwards and slightly inwards towards the body, and covering the main portion of the wings beyond the middle. Antennæ should be carefully laid back above the wings, and braces should lie flat, exercising an even pressure at all points of their surface. The fore wings should slope slightly forwards so that a line drawn from the point of one to the point of the other will just miss the head and palpi. The hind wings should be close up, leaving no intervening space, but just showing the upper angle of the wing evenly on each side. I can give no more precise directions as to how this desirable result may most simply and speedily be attained; no two people set alike. Speed is an object; for I have often had to set twelve dozen insects before breakfast. A simple process is essential, for a man who is always pinning and mov.

* The English mode of pinning low down on a short pin presents so many disadvantages that we wonld cantion collectors to pin high up on a long German pin so that three-fourths of its length should project below the body.-A. S. P. 
ing pins, and learranging wings and legs, is sure to remove a certain number of scales and spoil the appearance of the insect, besides utterly destroying its value. I raise each of the fore wings with a pin, and fix the pin against the inner margin so as to keep them in position while I apply the braces. Half the battle is really in the pinning. When an insect is pinned through the exact centre of the thorax, with the pin properly sloped forward, the body appears to fall naturally into its position on the setting-board, and the muscles of the wings, being left free, are easily directed and secured: but if the pin is not put exactly in the middle, it interferes with the play of the wings. Legs must be placed close against the body or they will project and interfere with the set of the wings. Practice, care, and a steady hand will succeed. When all the insects that have been killed are set, the contents of the camister will be found again ready, twenty minutes being amply sufticient to expose to the fumes of ammonia. Very bright green or pale pink insects shonld be killed by some other process, say chloroform, as ammonia will affect their colors.

"Insects should be left on the setting boards a full week to dry ; then the braces may be carefully removed and they may be transferred to the store-box.

"Having given some account of the process each insect goes through, I will say a word as to the apparatus required.

"First as to nets. The simplest net is a strong, circular iron wire hoop with a bag of book-muslin attached, fastened into a light deal or other handle.

"I use a small pocket net about nine inches in diameter, made to fold up, with a jointed wire frame and a screw to fit into a brass socket in a short cane-handle. To counteract the strain of the net upon so slight a frame the three wire joints are made flat, the two side joints flattened across the strain, the upper one the reverse way ; but to prevent this upper joint from coming into play when the net is fixed, the upper part of the screw which holds the frame to the handle is welded squarc and fits a corresponding square socket in the other end of the wire frame, holding all tight when screwed down. A small green silk or other net can be slipped on or off this frume as required.

" $\Lambda$ n umbrella net with stont steel rim and canvas edging is useful for sweeping tall grass and herbage, or to beat branches iuto, by which means many small and beantiful species of retired habits may be obtained.

"I use pill-boxes with glass bottoms, which can be obtained of varions sizes. They are convenient in almitting of the examination of each specimen, so rare species can be especially searched for, and damaged ones permitted to escape; but they are expensive, and for ordinary 
purposes card-board boxes answer sufticiently well. It is a good plan at the beginning of a season to strengthen all your boxes by a crossed strap of tape or calico tirmly glued at the top and botton. For a killing-box any tin box or canister, with a closely-fitting lid, capable of containing one hundred pill-boxes will be found to answer.

"Setting-boards can be bought realy-made of the smallest sizes. They are made by gluing a strip of thick cork on a thin slip of deal ; the cork must be thick enough to enable a groove to be cut into it, deep enough to hold the bodies of the insects to be set, and to leave suflicient depth for the pin to hold tirmly without reaching the deal. The cork on each side of the groove should be smoothed off with a gentle curve, so that the wings dry in a good position. The deal backing projects beyond the cork so as to slide into a groove if required, and it is convenient to have a deal cupboard of drying-boxes with handle at top and perforated zinc door, having grooves on each side in to which the setting-boards can be slid. Each board should be papered with thin white paper.

"At the beginning of a scason setting-boards may be washed or brushed over with advantage with a weak solntion of oxide of zinc ; it fills up old pinholes and makes them look clean.

"Always set your insects as soon as you kill then; they are then much more easy to set, and retain their position better when dry.

" When pill-boxes are filled, keep them cool to prevent the insects from fluttering; if glass boxes, keep them also in the dark.

"Many species when first taken will flutter in the boxes and injure themselves; for these it is well when collecting to carry a small phial of chloroform and a zinc collecting-box, cork-lined, into which you can at once pin your captures; the cork should be damped to keep them fresh. Touching a pill-box with a finger moistened with chloroform will kill the insect inside. Too much chloroform is apt to stiflen the nerves of the wings and interfere with setting.

"By breeding Micro-lepidoptera, many species not otherwise easily obtainable may be added to a collection, and the habits of others in the larva state may be studied with much interest. For this purpose a few wide-mouthed glass bottles should be obtained with corks to fit, so that the small larvæ can be placed in them with fresh food and the food kept fresh by exclusion of air. If mould should appear, the cork can be replaced by muslin or a net tied over. I would hardly advise a travelling collector to attempt this method, although I have adopted it with some success; but in a stationary camp it is most interesting and comparatively easy.

"Cork-lined store-boxes are of course required into which to remove the insects when sufticiently dried on the setting-boards. These, as well as the pins and setting-boards with drying case to hold them, 
and the net frames of the folding and umbrella patterns, will be best obtained from some dealer in such things.

"To pack Micro-lepidopter for travelling, pin them firmly close together into a cork-lined box, so that each specimen just gently holds down the body of the one above it. This cannot be done with very minute species. Put your box into another larger box, and let the outer one be sufliciently large to leave a good clear six inches all around the inner one. Pack this intervening space with hay, not crammed too tight; it will act as a spring and reduce the effect of shaking; the whole parcel should be made thoroughly secure against damp."

In collecting Tortricids, Prof. C. H. Fernald, the best anthority on this family, does not use the cyanide bottle, as a roll over the bottom destroys the thoracic tnfts, etc., but he puts the moths alive into pill-boxes. They can then be taken home and killed in the cyanide bottle or with chloroform. In pinning, the moth should not be touched with the thumb and finger, but should be handled with a pair of fine forceps, laid upon a piece of pith held between the thumb and finger, and the pin passed through the thorax so as not to injure the thoracic tuft. He prefers for the larger species japanned pins, and for the smaller ones silver wire, inserted in one end of a neatly-cut piece of fungus, through the other end of which a large pin may be thrust. (Can. Ent. x. 82.)

The following excellent directions for rearing the larvæ of 'Tortricidæ, by Charles G. Barrett, are copied from the “Entomologist's Monthly Magazine," Jan., 1883:

"There is no great difficulty in rearing the leaf-rolling species of the genera Tortrix, Lozotænia, and part of Pœcilochroma (of Wilkinson's 'Tortrices' and Stainton's 'Manual'), nor those which draw together leaves either flatly or by folding or spinning several together, such as Peronea and its allies, Phlœodes, Pœdisca, Coccyx, etc., because they mostly feed on the comparatively dry and firm leaves of trees or bushes, and are in consequence but little subject to the annoyance of mouldy food. All that is necessary is to put the rolled, twisted, or joined leaves containing the larvæ into large tins or gallipots, closely tied down and covered with glass, and to open them daily for ventilation, supplying fresh food when necessary. Particular care, however, must 
be taken never to introduce any food in a damp state, from either dew or rain, or mould will be the immediate result. These species will spin up among their food-plant, and emerge in many cases in a fortnight, in all cases within the same season. The few species in these groups, such as Tortrix icterana and viburnana and Fnectra pilleriana, which generally feed on succulent low-growing plants, should have plenty of air, not being covered with glass unless the food begins to wither, such plants becoming very quickly rotten if covered elosely down. This is also the ease with the curious balls of young bramble leaves twisted up by the larva of Notocelia admanniana.

"In the cases of the very numerous species which feed in the slioots of shrubs and low plants, eating out the young leaves, such as the larger species of Antithesia, Hypermecia, Brachytæuia, Pardia, Spilonota, Hedya, Steganoptycha, parts of Paramesia, Semasia, and Poeilochroma, much judgment must be used. Where the shoots are of hard-leaved bushes and plants, and the larva does not pack its domicile with frass, tins or gallipots may be used and covered with glass, or wholly or partially uneovered, as seems necessary from the state of the weather or the condition of the food; but shoots of soft. leaved low-growing plants, and those which, as in the case of Steganoptycha navana, are apt to be full of frass, should be put into ordinary rough flower-pots and tied tightly down with calico, old lining, or any close-textured material that comes to hand. These pots allow a good deal of evaporation, and if dry moss is introduced it will also absorb some of the superfluous moisture, so that glass may be laid either completely or partially over these also, to keep the food from withering, but it must be frequently removed and the food stirred up and examined and prevented from becoming mouldy or rotten. The same should be done with larvæ of Sericoris, some of which feed in flower-spikes as well as young shoots, and are therefore still more liable to injury from mould or decay. But of all the low-plant f $\_$zders the most difficult by far to rear are the Sciaphilæ. It is barlly possible to keep the solid composite flowers in which S. perterana and S. icteriana feed from becoming mouldy, and the larvæ do not willingly move to fresh flowers. Perhaps the best plan is to tie up the infested flowers with others in close bunches, so that air can get round them, and then tie them down in flower-pots. The sboots and curved leaves in which virgaureana and other speeies feed can only be treated as before described. But the diffieulty of keeping the fool in good condition is as nothing compared to the difficulty of keeping the larvæ in any sort of confinement. They seem beyond measure impatient of imprisonment, and as soon as they discover the least eloseness in the air, or change of condition in the food, begin to wander round the vessel, and try by every possible means to escape. If it is not very 
tightly tiel down they force their way under the string, perfectly in different to a squeezing that, while in operation, completely flattens them; and if the string is too tight, they will force their way between the covering and the pot, or into the smallest fold, and there die, after reducing themselves to the thickness of brown paper. To frustrate their efforts the covering must be of strong calico or cloth, and must be tied down with thin string, which must be wound five or six times round the pot and strained tight at each round, and the corering material then pulled tight. No larva cau then force its way under the string, and they cannot easily get between the calico and the pot; but, to completely prevent this, the best plan appears to be to rub a little lard or other form of grease round the edge of the pot. This they detest, and will not willingly touch, and it does seem to circumvent them. If by these devices the larvæ can be compelled to remain in the pot, they will spin up among the food-plant or in the moss; but so much sulkiness remains in their disposition that the moths, on emerging, will often remain among the rubbish at the bottom until spoilerl. The best plan is to examine the food and pick out the pupæ, which do well if placed on soft material iu a chip or card box. If however, when full-fecl, the larvæ are allowed to force their way with difficulty out of the pot, they appear quite satisfied, and will spin up in the first available place; so that I have obtained numerous pupæ by simply laying a squeezed-up piece of gauze or leno, or even some dry moss, loosely on the top of the pot.

"There are a very few leaf-feeders, such as Stigmonota weirana and S. nitidana, which hibernate in a cocoon between the leaves on which they have fed. These give little trouble, and only require to be kept cool.

"The species of the genus Retinia, which feed in fir-shoots, are tolerably easy to rear if the shoots are not allowed to get tco dry, as they do not readily become mouldy, and the larvæ will move freely to fresh shoots. A common flower-pot covered with glass is the best for them.

"Some of the species of Anchylopera, which feed on the leaves of shrubs and make themseives domiciles in which to pass the winter, are rather difficult to rear, and must bave winter exposure, but those which feed in early spring on clover, etc., are easily managed.

"Except the Sciaphilæ, no Tortrix larvæ are so hard to rear as the various groups of seed-feeders. There certainly are exceptions, such as Antithesia gentianana and marginana, Asthenia strobilella, and Eupacitia roseana, which obligingly remain in their respective seedheads all the winter, requiring only to be kept cool and not too dry, and not even needing to be wintered out of doors. The feelers on Papilionaceous seeds, such as Stigmonota orobana and dorsana, after 
leaving the seed-pods, will spin their tough cocoons on rotten wood or calico, and may also be wintered indoors. But it is quite otherwise with the genera Catoptria, Endopsia, Carpocapsa, and parts of Grapholitha, Semasia, Eupœcilia, etc. Most of these feed up with very great rapidity, becoming full-fed almost before the parent moths have ceased to fly-say, within a month or six weeks of the time of the egg being laid-and remain for nine or ten months in cocoon in the larva state, in most cases leaving their food and spiuning up among débris, or under stones, or other suitable places. Having to arrange for so long a repose, it is natural that they should wish to choose a suitable and comfortable spot, but some seem unnecessarily fastidious. All that I have recorded of the restless, obstinate, and suicidal tendencies of Sciaphila larvæ applies equally to these. They must be tied down in flower-pots tightly, and the covering material strained, as already suggested-not omitting to grease the edge-and when they find that they cannot really escape they may generally be tempted to spin up by the introduction of pieces of rotten wood, cork, hollow sticks, folded paper or rag, or the stems of their food-plants. Sometimes nothing will give satisfaction; and the larvæ, after sulking for weeks, will actually dry up and die without any material alteration in their appearance. I have known dozens of larvæ of Catoptria cemulana to die in this way after leaving their food-the seeds of the golden-rod. On the approach of winter, the pots containing larvæ of any of these groups must-the hole in the bottom being first stopped, so as to exclude insect focs, but allow drainage-be placed in the open air, exposed to the influences of any weather that may come. It is well to look at them occasionally, lest the covering gets rotten and broken, or the pot is rolled over by some active cat; but, making allowance for accidents, larvie kept in this mauner out of doors until the end of April, or even into May, will generally produce a fair proportion of moths.

"The internal, stem, and root-feeding species require very various treatment. The succulent stems in which the Halonote principally feed require to be kept alive in moist earth until the larva are fullfed; and care must afterwards be taken that the stems do not ferment from lying too close together, or dry up before the moths emerge. The species, such as Grapholitha pupillana and the Dicroramphæ, which feed in the stems of harder plants, also thrive better if the roots are kept in moist earth; and this precaution must, of course, Je taken with the root-feeding Euchromiæ, Orthotæniæ, and Xanthosetiz. Most of these species are best collected in the spring, as the larvæ are slow feeders, and not easily discoverable until tolerably well grown. Most of them turn to pupa in the stems, though $G$. pupillana 
follows the custom of its allies in wandering away and spinning up elsewhere.

"The larvæ of Antithesia fuligana, A. nigricostana, and several of the Eupœcilix aud Argyrolepiæ, which feed in the soft stems of lowgrowing plants, must be collected in the autumn before the dead stems are broken and scattered by the winter storms. The stems must be kept fresh in moist earth until they naturally die down, by which time the larva have generally spun up, and the stems may then be kept in pots, jars, or even bottles, eare being taken that they do not get either mouldy or too dry, and will do as well in a cool room as out of doors."

Preserving Micro-larvæ in Alcohol,-Dr. H. Dewitz mounts the larve aud pupæ of Micro-lepidoptera, and also the early stages of other smill insects, in the following way: The insects are put into a bottle with 95 per cent alcohol. Many larvie turn black in alcohol, but boiling them in alcohol in a test-tube will bleach them. They may then be fiually placed in glass tubes as small and thiu as possible, varying from 0.003 to 0.006 metre in diameter, according to the size of the insects. About 0.07 metre's length of a tube is melted over a spirit-limp, and the tube filled three-quarters full with 95 per cent alcohol, the insects placed within, and the contents of the tube heated at the end still open, and then closed by being pulled out with another pisce of glass tubing. After the glass has been held a few minutes in the hand until it is slightly cooled off, the end closed last is once more leeld over the lamp, so that the points may be melted together, and this end of the glass may be finished. During the whole time from the

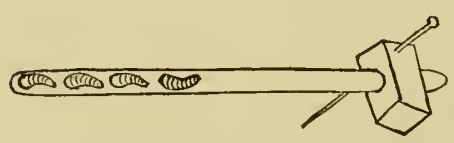

FIG. 272.-Method of preserving minute larvæ, upper end; for if the tube is etc.-After Dewitz. closure of the tube until the complete cooling of the glass, it should be held obliquely in the hand, so that the alcohol may not wet the too full, it is difticult to melt it, as the steam quickly expanding breaks through the softened mass of glass. The tube may be mounted by boring a hole through a cork stopper of the same diameter as the glass. The stopper is cut into the shape of a cube, a strong insect-pin put through it, and the glass tube inserted into the hole. It ean then be pinned in the insect box or drawer, near the imago, so that the free end of the glass may touch the bottom, while the other end stands up somewhat; while to keep the tube in place the free end resting on the bottom may be fasteued with two strong iuseet-pins. The specimens thus put up can be easily examined with a lens, and if they need to be taken out for closer exami- 
saricn, the tube can be opened and closed again after a little practice (/)eutsche Ent. Zeits., xxxi., 1887, heft 1).

Preserving Larvæ Dry.-A good method of preserving larvæ dry, adopted at Dresden, is to squeeze ont the intestines through a hole made near the anal extremity of the larva, then to insert a fine straw, after which it may be put in a glass vase, which is placed in a tin ressel and held orer a lamp; the larval skin is blown while suspended over the lamp, by which the skin dries faster. It may be done with a small tube or blow-pipe fixed at the end of a bladder, held under the arm or between the knees, so as to leave the hands at liberty; and the straw which is inserted into the body of the larva may be fastened by a cross-pin stuck through the skin, and thus retained in its proper position throughout the process of blowing.* M. P. Chrétien, of Paris, who has had wide experience in preparing caterpillars, writes me describing his method of emptying larvæ as follows: It is sufficient to make with the point of a pair of scissors a very small cut in the anus of the caterpillar, between the last pair of legs; then to extend the caterpillar upon a piece of old linen for the purpose of soaking up the fluids of the larra; then to press the caterpillar, begin-

* Mr. F. A. Wachtel fastens the skin to the fine point of a glass tube in blowing, and by this method the last abdominal segment preserves its form. His method is described and the apparatus figured in the Bulletin of the Brooklyn Entomological Society, i. 94. See also "Scudder's Butterflies" (H. Holt \& Co.); Can. Ent. vi. 107; or Amer. Nat., viii. 321. For the serious study of larvæ, alcoholic specimens should supplement the blown ones; for in many caterpillars, notably the Geometrids, the characters of the anal legs and supra-anal plates , (distorted or lost in blown specimens) are only to be observed in living or alcoholic examples. Mr. A. W. P. Kramer, after drawing out the intestines, etc., takes those protruding parts between his fingers and inserts the point of a finely drawn-out glass tube till it enters the vent two or three millimetres, then secures the intestine to the tube with a thread, and makes the juncture air-tight with a little collodion. He then fills the larva with air, and lets it dry for from one to six days. The advantages claimed for this process are that no heat is required, and that one has greater facilities for giving the larra a natural position. The air-pressure can be obtained with a toy red-rubber balloou. Bull. Brooklyn Ent. Soc., vii. 93. 
ning at the head, by means of a little glass roller, or even a pencil or pen-handle; then, by rolling the caterpillar's body, all the contents may be pressed out; this process may be aided by drawing out the parts with fine pincers. He also suggests that the empty skins of larvæ, if piaced in alcohol of a strength of $48^{\circ}$, may be sent by mail from one country to another, or preserved for a few weeks and then blown. Blown specimens need only to be protected from the attacks of museum-pests and from dampness. Small larvæ, such as those of the Micros, may be put alive into a hot bottle, baked until they swell to the proper extent and dry, when they can be pinned with all their contents inside.

Bleaching the Wings for the Study of the Venation.-In order to study the venation of the wings of butterflies and the larger moths, we usually remove the scales with a stiff camel's-hair brush, and then the venation can be drawn under a $2 \frac{1}{2}$ - or 4 -inch objective with the aid of the camera lncida, and an exact sketch be made. Others prefer to "bleach" the wings by caustic alkaline solutions. Dr. Dimmock, however, suggests a modification of the chlorine bleaching process, commonly employed in cotton bleacheries. After soaking the wings for a few moments in pure alcohol, in order to dissolve the oily matter in them, they can be removed to a solution of common bleaching-powder, which is sold as "chloride of lime," but which is really a mixture of calcic hypochlorite, calcic chloride, and calcic hydrate. Ten parts of water dissolve the first two compounds, leaving nearly all the third suspended in the solution, which should be made with cold water, filtered, and kept in a tightly-corked bottle till required for use. After the color has sufficiently disappeared from the wings, they should be transferred to a wash composed of one part of strong hydrochloric acid to ten parts of water. The wings may then be gummed on cards, or upon glass by the proper transfers throngh alcohol and chloroform to Canada balsam.

A solution of sodic hypochlorite, known as eau de $L a-$ 
barraque, or a solution of potassic hypochlorite, known as eau de Javelle, enables one to dispense with the wash of dilute acid. "These bleaching processes preserve the most delicate wings unbroken; and when the specimens are of rare species, rubbed wings can be used, the absence of the scales not being evident after bleaching" (Psyche, i. 97). Legs and other parts of insects may be treated in the same way.

Mr. Chambers suggests (Can. Ent. viii. 39), for Micros, placing the wing upon a glass microscope-slide in from one to three or four drops of a strong solution of potash, and after putting a cover-glass over the wing, holding the slide over a flame until it begins to boil, removing it at the first sign of ebullition, when the wing will be found to be denuded; it may then be drawn with the camera, and afterwards mounted for permanent preservation.

Mounting the Wings of Microlepidoptera.-Prof. C. H. Fernald mounts the wings of Microlepidoptera in cold glycerine; after having been bleached by Dimmock's method (which, for bleaching, is to be recommended), the wings are transferred to the slide direct from the water in which they are washed, then allowed to dry (sometimes hastened by holding the slide over the flame of a lamp); and, when quite dry, a drop of glycerine is to be added, and the cover at once put on. When the glycerine has penetrated around the edges so as to completely saturate portions of the wing, the scales at once become transparent, and the structure is clearly apparent.

By holding the slide over the lamp till ebullition takes place, the glycerine will be found to replace the air under the concave portions of the wings, withont any injury to the structure; and even in those refractory cases where the glycerine has been allowed to boil for a considerable length of time, no injury was found to be done to the wing-membrane. (Amer. Month. Micr. Journ., i. [1880] p. 172.)

Mounting the Wings of Macro-lepidoptera.-Dr. H. Dewitz of Berlin removes the colors and scales, for the purpose of studying the venation, by means of eau de Jacelle, cutting off both wings on one 
side close to the body and placing them in the fluid. It is well to soak them beforehand in alcohol, as saturation by the ear: de Javelle will then take place much more quickly. Then as soon as the wings lose their color, so that the venation is plainly perceived, they are soaked in water for an hour. A glass slide is then pushed under the wings and they are lifted out of the water. This is done so as to make the upper and lower wings lie close together in the middle of the slide, which is then dried. The bases of large wiugs can be fastened with a drop of warm liquid solution of isinglass. After the wings are entirely dry, a thin rectangular piece of glass, somewhat larger than the extent of the wings, is placed over them. According to the thickness of the wings, very slender strips of cardboard or pasteboard may be so glued to the slide as to make a square frame, thus forming a cell to hold the wings.

He imbeds small wings in Canada balsam, by dropping the balsam on the wings and covering them with a thin glass, such as is used by microscopists. The slide thus prepared should lie horizontally for a few months, and then be preserved in a box made to hold such slides, those made for holding ordinary microscopic slides serving for the preparations of wings of Lepidoptera of medium size. (Entomologische Nachrichten, 1887, pp. 164, 165.)

To Remove Grease.-Mr. Henry Edwards removes grease from moths and butterflies by submerging them in a vessel of ether for twelve hours; then taking the insect out and draining off the ether, he places the butterfly on plaster-ofParis powder for twelve hours, after which time the powder is blown off and the insect is reset.

Mr. Ph. Fischer places greasy specimens in a fluid composed of one part of ether to two of the strongest alcohol, leaving them therein for about twenty-four hours. After being taken out and dried, they are spread. Where only the wings are oily, the specimen is put on the spreading-board, under side up, without fastening it in any way, and the purest spirits of turpentine poured on it to fully soak the wings, after which finely-powdered pipe-clay is strewn thickly over the affected parts, and this left to dry. Should the clay, after becoming dry, be yellow, the oil is not all out of the wings, and the process must be repeated. To remove the clay, hold the specimen on the upper part of the pin, and give the pin a little jerk near the point, and the clay, 
being brittle, will easily fall off; after it is all remored, the specimen may be brushed with a fine camel's-hair brush until clean. Specimens treated in these ways will never again become oily. (Can. Ent., xviii. 78.)

\section{Collecting and Preserving Coleoptera.}

Beetles shonld be pinned for the cabinet through the right wing-cover (Fig. 266). They are found in every variety of sitnation : on plants, in decomposing animal and regetable matter, in mushrooms, under bark of trees, under stones, especially in moist and shady situations; many are found creeping on the ground, in desert and other arid spots in western America. Some are attracted by candles at night ; a lighted candle may be fastened in a piece of gliss tube just above a fumnel, the lower extremity of which ends in a bottle of alcohol. By using a piece of cyanide of potassium in place of the alcohol in the bottle, other insects may be captured (snch a trap may be set out throngh a still night for moths). A similar apparatus has been used with success in collecting beetles in fungi, the latter being held over a funnel and rapped a few times, causing the beetles to run ont and drop into the month of the funnel and thence into the bottle; while others (in all parts of the country) fly actively on being approached and light again on the ground a few paces off.

Mr. F. G. Schanpp collects on the sandy banks of rivers large numbers of small ground-beetles, by pouring water over the small holes in the sand and on the plants growing at the edge of the water ; this canses them to run out of their retreats by the hundreds. Clivina and Dyschirins live in holes in the sand, Omophron and Heterocerus under the plants, the rest hide nuder the small stones on the banks. He also cuts ont pieces of turf by the water's edge and places them in water, thus collecting both beetles and their larvæ and pupæ.

Burying-beetles may be attracted by placing small pieces 
of meat under stones, boards, etc.; this is a more pleasant way of collecting them than by turning over carrion. Mr. Schanpu also collects coprophagons beetles (Hister, Aphodins, and Staphylinids) by shovelling the dung of cows, horses, sheep, etc., into a pail of water; the dung sinks, and in a few moments the insects living in it rise to the surface and are easily captured.

An excellent trap for small Silphicls, Catops, Colon, etc., is made by putting a rabbit's foot or any similar object in an ale bottle, and burying it up to the mouth in earth. These small nocturnal species will, in the pursuit of the odor-giving food, fall into the bottle, from which they can not escape (LeConte). This is also an indispensable method to follow in colleeting care-beetles.

"Many peculiar species, not fourd in other situations, live under material cast up by the ocean ; others are found along the shores of lakes and rivers; many also are found living in the water." (LeConte.)

Mr. Edward Newman says that "moss is a great resort of beetles in the winter; whenever you have the opportunity, go into the thickest woods, and pulling up the moss by handfuls cram it into a canvas bag, which you have taken with you for this especial object. Then on a winter's day, when nothing tempts you abroad, shake out your moss, bit by bit, on a white cloth, and you will soon possess yourself of wonders."

"A large number of species are very mimnte, and are usually found in abundance; these should not be neglected, as to scientific men they possess quite as much interest as the larger species. The speeimens should be thrown into strong alcohol ; if this cannot be procured, common whiskey will answer very well, but must, when the specimens are numerous, be replaced by fresh liquor. The smaller specimens should be kept in a separate bottle. Whe.1 the bottle is full, the liquor should be poured off and replaced by fresh alcohol or whiskey, and closely corked. If there is much danger of breaking in transportation, the specimens, 
after being well soaked with the alcohol, may be allowed to dry partially, but not so as to become brittle, and then packed in small pasteboard boxes, taking care, by sluaking the box well before finally closing it, to pack the specimens so closely that they camnot be broken by moving about; the box may then be closecl by pasting a small strip of paper around it, and the locality, date of collection, etc., written on the top." (LeConte.)

We copy from a chapter on collecting Coleoptera, by Edward Newman, in Greene"s "Insect Hunter's Companion" (London, 18\%0), an account of Mr. Crotch's plan of killing and preserving beetles, of especial use while on a long journey.

"The following method has now been in use some time, and hence has been fairly tested. Its advantages are very great, so that I make no apology for introducing it to the notice of your readers. The first idea of the process is ảue, as far as I know, to M. de Vuille-froi, who used it with me in Spain, some years ago, with great success. The specimens may be collected in two ways, according to the size and the convenience of the collector. The first and best way, for small species, is by putting them into a bottle containing about half an inch of dry pine-sawdust, in which bas been previously placed a small piece of cyanide of potassium about as lig as a pea; they will then die instantly. Larger species and small species which do not fly readily may be put into spirits in the ordinary way, but the Staphylinida and others generally open their wings in this process. The sawdust should be pine-wood and sifted free from chips on the one hand and from dust on the other, so as to be of an uniform size. For storing the species thus collected, a few tin canisters will be found most $\mathrm{em}$ venient; a layer of sawdust is placed at the bottom, and then beetles, and so on alternately to the top. The sawdust used in the tins should be clamped (not retted) with a mixture of spirit and one-twenticin part of carbolic acid, which will effectually prevent mould or mites and will bring the specimens home perfectly fresh and clean. Sncill species, or specimens from a particular locality, should be wrapped in a piece of rag or tissue-paper, with a little sawdust, and the name of the locality. The specimens collected in spirits should be removed as soon as possible (in a few days at farthest), and transferred to saw dust. When the tins are full, some more spirit and carbolic acid should be poured in and the top soldered down: they will then keep 
for two years at least. The advantages of this method are manifest, especially in the absence of any danger of breakage or leakage; and it is more than probable that a similar plan might be employed with reptiles, fishes, etc., but for these chloride of zinc suggests itself as the agent most likely to be of service. As the insects do not become rotten by the above process, it is somctimes not so easy to set their legs in the peculiar manner in vogue in this country, but they will have as a set-off the advantage of being thoroughly fit for study. When by any chance spirit cannot be obtained, they will keep perfectly in dry sawdust, if the specimens are dried in the air for a few hours first; all that is necessary afterwards being to relax them in the sawdust instead of removing then from it. Jars or wide-mouthed pickle-bottles may of course be used instead of tins, and are more air-tight, but liable to break."

"That eminent and most excellent entomologist, Mr. E. W. Janson, indorses MIr. Crotch's recommendation, and adds a few hints on the subject of collecting beetles abroad, as follows :

" "The sawdust plan, now almost universally adopted by ccllectors, I can recommend both on account of its simplicity and efficiency. The sawdust should be that of some white or yellow wood without coloring matter-pine is perhaps the best; it should be sifted over fine muslin, and the dust and minute particles rejected. In collecting, wide-mouthed bottles should be used; these should be about one fourth filled with dry sawclust, adding beneath a piece of cyanide of potassium of the size of a large pea or haricot bean. On reaching home after collecting, the contents of the collecting bottles should be sbaken out on a large shect of paper, and the insects transferred to the stockbottle or jar, and the cyanide and sawdust returned to the collectingbottles for future use. Any description of wide-mouthed bottles, such as pickle-jars, may be used as stock-bottles; they should, however, have tightly-fitting corks or rungs. Before putting the insects collected into the stock-bottle, throw into it sawdust a quarter of an inch in thickness, slightly damped, not moistened, with a mixture made of alcohol (methylated spirit will answer admirably; brandy or strong whiskey, if unsweetened, will suffice, but sweetened gin and rum must be aroided), or, still better, benzine or benzoline, and carbolic or phenic acid. These should be mixed in the proportions of nineteen parts of alcohol or benzine and one part of carbolic acid. On the sawdust damped with this mixture place a layer of insects; over them a second stratum of damped sawdust, then a second liyer of insects, and so on alternately until the stock-bottle or jar is tilled; take care that it is always kept well closed. When it is filled it may be packed with any other objects in sawdust, liny, moss, or any other clastic substance, and forwarled to its destination." 
Special attention should be given to the collection of the larva of beetles, called grubs. 'They are found in soil, under the bark of trees, in nuts, etc., and in fresh-water pools.

A ready method of collecting beetles, etc., in autumn, winter, or early spring, is to sift the leaves collected in hollows in the gromnd and near the edge of woods. Mr. H. Schmelter uses a sieve consisting of a wire ring of about one foot in diameter, to which a bag of coarse muslin of about the same length is sewed, the bottom of which is formed of a piece of brass-wire eloth about 10 inches in diameter, and with spaces about $5 \mathrm{~mm}$. square. 'The sifting ean be done over a sheet of white muslin or paper or, better, by placing the sieve in a bag $1 \frac{1}{2}$ feet in length, fastened to a ring of the size of that of the sieve. 'The sifted matter' will fall into the outer bag, and can be examined at one's convenience.*

Wood-boring beetles, such as longicorns, etc., may be captured, says Schmelter, often in large numbers, by sawing off the dead branches of trees in spring, gathering plants with pithy stems, such as the elder, reeds, etc., and piling up these materials in an empty room with the door and windows tightly closed, the latter best made of wire screen, so as to admit of a free circulation of air. "If a special room for this purpose is not at one's disposal, a large box connected with a small one, of which several sides should be made of glass, will answer. 'The insects, after having made their way out of the wood during spring and summer, will be attracted by the light to the windows of the room or into the smaller box, and there be easily captured.” (Bull. Brooklyn Ent. Soc., i. 33.)

A writer in "The Entomologist" (London) finds that coarse tufts of grass which are to be found in almost every field "are very productive if ent round with a sharp knife, lifted gently, and then inverted and shaken over 
paper." This work can be done in the autumn and early spring, as the tufts are favorite libernating places, Staphylinidx most commonly taking refuge in them.

Beetles may be kept soft and flexible so as to be sent throngh the mail in boxes withont being pinned and without danger of breaking, by being prepared in the following manner, as recommended by Mr. J. B. Smith. They should be soaked for a week or more in a fluid composed of 100 grams of alum, 25 of salt, 12 of saltpetre, 60 of potash, and 10 of white arsenic dissolved in 3000 grams of boiling water. This solution should be filtered, and when cold add to every ten parts, four of glycerine and one of methyl alcohol. (Psyche, iv, 140.)

Rearing Tiger and Ground Beetles.-Mr. F. G. Schaupp, who had good success in raising tiger and ground beetles from the larva, pursued the following method: For Cicindelæ he made a box of wood $\left(2 \times 1 \frac{1}{2} \times 1\right.$ foot), with openings covered by glass and woven wire, such as is used for fine screens, and filled it with sand half a foot deep, making here and there a few miniature hills, and in the middle of the box a valley, in which he placed a flat tin pan filled with water, while at the two sides he placed pieces of turf to represent a meadow. He fed the larvæ with different kinds of soft grubs, such as those of small Chrysomelids (Criocerus asparagi and Diabrotica, etc.), and kept the Cicindela beetles for over two months, when they mated and dug holes in the sand; in srch a box the eggs may be laid and the larve reared. For raising beetles from the eggs he also used boxes of zinc, the two longer sides and the cover of glass, the two smaller sides of wire cloth.* He succeeded in obtaining larvæ from Cucujus clavipes. He fed the beetles and larvæ with sngar-water, with which he soaked small thin pieces of wood. 'The species of Cychrus were fed on snails, but they also readily feed on the soft

* He also used empty tomato or fruit cans, with the upper edge cut smooth and covere? by fine wire cloth, fastened by a cord or tin ring. 
grubs of wood-borers. "Carabus, Chlanius, and Galerita are fed with veal, and it is very interesting to low at the twelve Carabus limbatus (six males and six females) while devoming the meat, tearing and lifting it, all standing around it like the members of a poultry-yard around a trough."* He bred Dicclus dilatutus from the larva by placing them in a bottle half filled with dry earth, wetting it daily with three or four drops of water.

All the materials put in the cage, viz., sand, earth, rotten wood, moss, etc., should be baked or passed through a bath of boiling water to destroy any insect-life (eggs or minute larvæ) that might be present, and thus lead to mistakes or result in injury to the creatures being bred. When a sufficient number of eggs are laid in the breeding-box the beetles should be removed. 'The beetles, while in confinement, should be kept during the day in a dark, cool place, and their cage should be placed during night before the window in the open air, Cicindelæ of course excepted. The larvæ of the latter must be reared singly, as they otherwise would destroy one another. Also cover the box with tin eloth and place it in a dark closet or large box, or else flies and ichneumons will destroy then. 'The larvæ feed for four or five weeks, while the pupæ require for their development about ten days. The best food for Cicindela larvæ is beheaded wood-boring grubs, which will not bite. All remnants of food should be carefully remored from the breeding-box, as any decaying matter is harmful. 'The earth should be moistened only once or twice a week.

In raising Carabids, place earth in the cage in which the young may burrow for protection from each other. A few days after mating the males should be remored, and a few days later still the females should be put in another cage,

* Bulletin of the Brooklyn Entomologieal Society, i. 2. Mr. Schaupp suggests that to procure food for carnivorous larva a piece of meat be left for a while in the cage, with flesh-flies deprived of their wings ; these will lay eggs, and the maggots will at once hatch and serve as food for the larval beetles. 
as they will eat their own offspring, thus differing from dung-beetles and carrion-beetles (Necrophori), which take great eare of their young. By using very black earth for the cages, the eggs and young larve may be more easily detected. As a matter of course, as soon as the larvæ are a few days old, each one should be placed in a separate box. Clusters of eggs found under stones, boards, and leaves may be also taken home and placed in boxes.

Rearing of Burying-beetles (Necrophor'us and Silpha).These are easy to raise. In a soap-box half filled with loose, moist earth place pieces of poor meat and a dozen specimens of Necrophorus and Silpha. Cover the box with fine wire cloth, and place it out of the way till the worst smell is over; it should be kept in the dark to prevent flies from depositing their eggs therein. In two weeks there will be plenty of larvæ; soon after the pupæ, and in two weeks more the beetles may be found. The pupæ are apt to be infested by small parasites which hide beneath the antennæ and legs; to remove them, says Schaupp, take a very fine hair-pencil, dip the point into benzine and touch the parasite, which will become dizzy and can be easily removed.

As the larve of Silphæ are very voracious and cannibalistic, as soon as they are obtained they should be separated as early as possible, placed singly in a separate small box and fed with small pieces of fresh meat, sufficient for one day's rations. On feeding them the following day, the remnants of the former repast should be removed.

Rearing Wood-boring Larvæ, Longicorns, etc.-For the most part, says Schaupp, Lamellicornia, Longicornia, Elateridæ, Buprestidæ, and Curculioniclæ are comparatively easy to raise, but care has to be taken that only specimens of the same species are confined in the same box. Large boxes should be used, so that large pieces of wood containing the larvæ may be placed in them. These may be treated as follows: Take a piece of wood four eubic inches in size ; split it in two, and make on the inside a cavity just large enough to receive the grub and allow it to easily move in it, then fasten 
the two hilves together with a strong rubber hand. Slightly moisten the wood in the box twice a week, and if the larra eseapes by boring a hole throngh the wood, replace it in the central cavity by filling the hole with a plug. Mr. Siewers raised the larra of borers in tin or glass on wet hard-wood or poplar sawdust; he kept them for six or eight months, changing the sawdust once a month.

Certain larræ, especially those of Lamellicorns and Elateridæ, before transformation enter the earth. For such species place some earth in the box, but not before the larve show a decided wish to go there by quickly boring holes straight downwards; for the earth in contact with the moist wocd rapidly forms a deadly fungus. Of course the earth for the breeding-boxes must be thoroughly baked, so as to destroy all insects, etc., destructive to the helpless soft-skinned pupæ; the larvæ and pupæ should also be kept in darkness.

Rearing of Bark and Bast-boring Beetles.-Such insects, especially Longicorns, Buprestids, Scolytidæ, etc., may be reared by cutting out with the saw and hatchet pieces of the infested tree, with the bark on, about six inches square and one inch thick. The castings and sawdust, together with the larvæ, should be placed under the bark. Several pieces of bark tied together with the bast-sides opposite will sometimes answer the purpose, but the better way is to leave the larvæ in the wood until they are nearly fullgrown; then, in general, the transformations are completed in about two weeks.

Rearing Larvæ of Dung-beetles.-These may be taken home with a part of the earth above which they live and part of the nearly dried and inodorons cow-droppings under which they hide. "But here the greatest care has to be taken not to overlook the very numerous small Staphylinidæ and carabidous larvæ that live with-or rather on-those scarabæidous larvæ." *

* F. G. Schaupp in Bulletin Brooklyn Ent. Soc., iv. 17-19. 
Cleansing Greasy Beetles.-To clean greasy beetles, etc., dip them for a half to a whole minute in spirits of ammonia (liquor ammoniæ), and wash them in water (the hotter the better). A longer stay in ammonia and a careful washing dissolves the verdigris on pins (John Hamilton). Others soak them in benzine, but they should not be left too long in it, as they thereby become very brittle. Dubois removes verdigris from insect-pins by immersing them in benzine for several hours. Primrose-beetles are the only ones that the benzine bath can alter.

To Wash 0ld, Soiled Specimens.-Place the specimens in a tin kettle three quarters filled with moist sand, to soften them; small species should remain therein overnight, larger ones for twenty-four hours; then wash them with cold water, using a small stiff paint-brush, and if not sufficiently clean apply soap, rubbing with the brush and then washing them with cold water. On species of Trox, Lachnosterna, etc., covered with a layer of mud on the wings, the soap should be allowed to remain for a few hours, and then washed off with cold water (Bull. Brooklyn Ent. Soc., vi. 24).

\section{Collecting and Preserving Hemiptera.}

This group of insects has been much neglected, though no group will yield more novel discoveries than this. By sweeping grass and herbage, as for beetles, in the latter part of summer, large numbers occur which can best be obtained in this way. Hibernating species are found under leaves in hard-wood forests, and can be obtained by sifting the leaves. The large carnivorous kinds are sometimes found on bushes with caterpillars transfixed on their beak. Aquatic species shonld be taken ont with the water-net by thrusting it suddenly under surface-swimming species, or by pushing it among submerged grass or weeds where the smaller forms may be lurking; several kinds occur under submerged logs, sticks, etc. 
The soft-bodied species of $\Lambda$ phis or plant-lice should be preserved in alcohol, glycerine, or Canada balsım. They should be carefully watched for their parasites, and can be easily kept in slender glass vials, through which they can be observed.

All the bugs should be pinned through the distinct triangular scutellnm, situated in the middle at the base of the wings (Fig. 2\%3). The small, hard species of piming a bug.

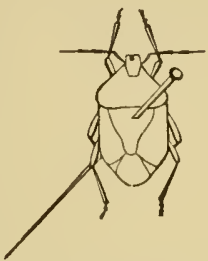
leaf-hoppers should be pinned through the right wingcover. Various quadrupeds should be carefully examined for lice, which may be preserved in alcohol, or mounted on slides for the microscope.

Examining Live Aphides.-Mr. H. J. Slack says that when we want live aphides to examine under the microscope in a vigorous condition, we must handle them with extreme gentleness, or their soft and delicate bodies will be injured and the creature killed. Their slightness of structure is, however, accompanied with great enclurance of conditions that would be quickly fatal to many siouter organisms. MIost insects would be rapidly killed by immersion in paraftine oil; but young and vigorous aphides will of ten live for some time, and occasionally for hours, in this fluid, such as is burnt in lamps. If two or three of the insects are very carefully placed in a little cork cell,** filled with paraffine oil, and covered with thin glass, they are in a handy condition for examination. The result of mumerous experiments marle with the best American petroleum oil, commonly called crystal oil in the lanjp shons, is that the survivals are very uncertain, but sufficiently frequent for the process to be well worth trying. They kcep pretty quiet in the fluid, and it enables higher powers to be used with convenience. $\quad \mathrm{A} \frac{1}{2}$. inch objective, magnifying about 100 linear, with a full-sized instrument, is very handy. The illumination should be varied; but one of the best ways is to use both an achro matic condenser and a lieberkuhn, or little silver reflector, at the end of the objective. The largest hole and central stop of the condenser will give a fine dark-ground illumination. When used in combination with the lieberkubn, it lights up the inside of the object, while the less transparent parts receive reflected rays from the silver surface. The student will find a great many cases in whicb this mode of treating a refractive and reflective object produces the liest results. The eyes of the Aphis, seen in this way, are like lalf mulberries, and the little eye projecting from the corner of the larger group is well dis-

* A vial-cork $\frac{5}{5}$ inch in diameter cut across so as to make a disk 1 inch thick, with an oblong hole in the centre, and gummed on a slide. The gum is not dissolved by paraftine oil. 
played. Where the view of the compound eyes is a full-face one, the darker pigment is seen so strcngly that its true position is concealed. A profile view shows the little lenses to be clear, like glass, and the pigment to be behind them. (Knowledge, iii. (1883) p. 246.)

\section{Preservation OF ORThOptera.}

Orthoptera can be easily preserved in strong alcohol, and may afterwards be taken out and pinned and set at leisure. If preserved dry they can be killed with cyanide of potassium, or ether, without losing their colors, as they would do after remaining long in alcohol. They should be pinned through a little triangular spot between the bases of the elytra, or fore wings, when the wings can be spread to advantage. They are also often pinned through the right wing, as in Coleoptera. In pinning these insects for transportation, care should be taken to put in additional pins, crossing each other on each side of the abdomen, and in like manner to steady the hind legs, which are very apt to fall off if too much jarred.

\section{Preservation of Dragon-Flies, May-flies, Caddis-Flies, STONE-FLIES, ETC.}

These net-veined insects of different orders, the young of which frequently live in fresh-water ponds and streams, should be pinned through the centre of the thorax; the smaller and more delicate kinds immediately on capture should be pinned in the collecting-box.

As regards the preservation of the dragon-flies, Mr. Uhler states that "the large, brilliant green dragon-flies (Cordulina), as well as the yellow, brown-striped Gomphina, having the eyes wide apart, will furnish new species in almost all parts of the country. In order to preserve specimens in the neatest manner it is well to slip them immediately when canght into paper bags of suitable size, first taking care to lay back the wings so that they will be applied together, to prevent mutilation. These paper bags 
may be placed loosely in a box carried for the purpose. 'The specimens can thus be taken out at leisure, killed by applying a camel's-hair pencil dipped in ether, chloroform, or benzine to the under side of the body, and then spread on the setting-board. In most species the colors change after death, hence it is important to make short descriptions of the colors before killing the specimens." The smaller, more slender, and delicate Nemroptera shonld be pinned directly in the collecting-box. Many species are eaught by a light in the night-time, such as Polystoechotes nebulosus and the caddis-flies (Neuronia semifasciata, etc.); and a bright light placed in damp situations by streams, etc., will attract large numbers, the smaller species, like moths, being attracted a great distance by light. Other species of this group, so numerous in the Northern States, are found in great numbers floating on lakes and ponds. For the proper study of the genera of these insects, and often of the species, they shonld be collected in alcohol, so as to be studied in a flexible state.

The aquatic larvæ and pupæ can be reared in aquaria in jars and tumblers, taking care that the weaker species are separated from those more powerful and bloodthirsty. The little Entomostraca, or water-fleas, serve as food for the smaller species. With care many species can be reared in this way; and so little is known of their transformations that figures and descriptions would be of great valne. 'The interesting and varied habits of the different families can also easily be noted.

Preparation of May-flies (Ephemeræ). - The wings of dried specimens, says Rev. A. E. Eaton, in his monograph of the group (page 326), in some of the genera are apt to be completely shrivelled up. When such is the case, recourse may be had to the following method of preparing them for examination: The wing detached from the specimen is first of all floated upon scalding water, and induced to expand as fully as possible whilst it is floating. It is next 
taken up upon paper or a strip of glass and transferred to cold water, and then spread out to dry upon paper or glass. If npon paper, the wing can presently be separated therefrom by bending the paper away from it, and it can either be mounted permanently as an object for the microscope, or be placed temporarily for examination within a compresscell, care being taken to flatten it out by only vertical and gentle pressure. If the result be then unsatisfactory, the whole process can be repeated.

\section{Collecting and Rearing Diptera.}

For collecting flies, Dr. Williston states that June in New England is the best season, so that April in the cotton States, May in the Middle and Southern-Central States, world be the best time for those regions. In May and the early part of June, beating will give excellent results. A little later, patches of blackberry, wild cherry, dogwood, Canada thistle (Cirsium), or other melliferous blossoms, will afford desirable specimens. "It is better to let specimens come to the collector than to go hastily about looking for them. I have spent six hours abont a patch of Cornus paniculata not ten metres in diameter, and been amply repaid. But few specimens are found in shady woods; those few are to be sought for there. The favorite places for Tabanidæ, as indeed for most flies, are on the borders of woods, open glades, meadow-lands, etc."

Dr. Williston advises the use of eyanide bottles of the following description, as specimens collected in ordinary cyanide bottles are worthless for scientific purposes. "I select," he says, "several one- or two-ounce wide-mouthed bottles of the same form, and carefully line the bottom and sides with a good quality of blotting-paper. Good, firm corks are selected which are interchangeable in the different bottles: in one of these corks a small hole is made, in which it is better to fit a small metallic ferule; a strip 
of blotting-paper is then coiled within this cavity, and it is over this that a few drops of a solution of cyanide of potash is poured."*

It is useless to collect flies in a bare bottle; the insects soon exhale moisture sufficient to ruin them. 'The blottingpaper prevents this, and the cork can readily be removed from one bottle and put into another when a sufficient quantity of flies is collected. $\dagger$ Moisture of any kind injures flies.

"In the earlier part of the season many rare specimens of Diptera may be obtained by beating. For this purpose I employ a rather heavier net-wire, to which a pointed net of cheese-cloth is attached. On such occasions it is necessary to carry with one a larger bottle with a little cottonwool in the bottom for chloroform, and a vial of the latter in the pocket to be poured into the larger bottle. By thrusting the end of the net, with its contents, for a few seconds into the chloroform bottle, one can then remove the specimens undisturbed. Mik advises that minute flies should be preserved alive in small bottles filled with paper clippings, through the cork of which a small glass tube is thrust nearly to the bottle. For a collecting-net, after many experiments and failures, I have found most serviceable a simple, rather light, brass wire, soldered together to form a ring about $28 \mathrm{~cm}$. (10-11 inches) in diameter, and firmly attached to a light handle about one metre long. The net is made of very coarse bobbinet lace, the most serviceable and, in the end, the cheapest material. The net should be readily handled with one hand.

"Specimens should not be allowed to remain overnight unpinned. The large specimens may be pinned through

* Dr. Williston writes me: "I notice that a good many collectors now use such a bottle for all kinds of insects."

† "If one," says Dr. Williston in a letter, " is so situated that he cannot carry a box to pin specimens in, he should put cotton-wool or paper clippings (rice paper) in his cyanide bottle to prevent the shaking about of plose specimens." 
the thorax, preferably with japanned iron pins. * They should be placed on the pin only low enough so that the head may be grasped with the thumb and forefinger without danger to the specimen. The wings should never be spread. Spreading not only renders the specimens more difficult to study, but it spoils the natural appearance of the insects, and is a positive injury to them for the cabinet. All that is necessary is to push aside the wings so that they will not conceal the abdomen. Minute specimens should be pinned with fine iron wire from the under side, and then pinned upon small strips of thin cork, the upper surface of which has been covered with white paper, and throngh the other end of which a pin is thrust. Small specimens should never be glued to bits of cardboard, as is commonly done with Coleoptera. Only one specimen should be placed on the piece of cork.

"The greatest enemy to dipterological collections is dust: insects can be guarded against, but it is difficult to exclude dust, unless tight cases are used. Dampness and mildew do often much mischief.

"A good dipterological specimen must be unrubbed, unmoistened, not dusty nor greasy, and with the wings unspread. It is quite as easy to collect good specimens as poor ones, and much more satisfactory." (Psyche, iv. 138.)

Dr. Williston writes me that for the collection of Bombylidæ and similar hairy flies "my present custom is to pin the fly while in the net, without directly touching it, and then to remove it, and either kill it in the cyanide bottlef or with a match, then pinning it in a box. The specific characters of many Bombylids are in the hairs, which are very easily rubbed off. It is almost impossible to collect them in a bottle and get good specimens."

In an elaborate paper J. Mik, the Austrian dipterist,

* Dr. Williston writes me that he does not like japanned pins so much as formerly, as they bend so easily.

† Dr. Williston prefers 1-oz. cyanide bottles. 
gives full directions, in which the chief points are that they must not be pinned in the middle dorsal line of the thorax; and that they should not be killed with alcohol, while killing with potassic cyanide is not recommended.

Very small Diptera should not be killed when they cunnot be immediately pinned; too much material should not be collected in the net at one time; and hairy flies should not be taken in the hand to pin, but handled with fine forceps, while lacquered-iron needles or lacquered-iron wire should be used for pinning instead of common insect-pins or silver wire (which contain copper and are therefore liable to corrode); wire should be used for all flies under $3 \mathrm{~mm}$. in length. (Abstract in Psyche, iii. 226.)*

Aquaria are necessary for the maintenance of aquatic larvæ. If quantities of swamp-mud and moss with decaying matter are kept in boxes and jars, multitudes of small flies will be hatched out. Leaf-mining and seed-inhabiting species can be treated as Micro-lepidoptera, and earth-inhabiting larvæ like ordinary caterpillars. Dhing, mould in hollow trees, stems of plants and toadstools, contain mumerous larvæ or maggots, which must be kept in damp boxes.

\section{Collection and Preservation of Hymenoptera.}

These insects are exceedingly abundant, and especial attention should be paid to collecting the smaller species. They should be pinned through the thorax, high up on the pin, and those that are not hairy collected in alcohol. In fact, as much depends on the study of the softer parts of the mouth-appendages, specimens of each species so far as

* Dr. Williston tells me that "Prof. Mik advises ordinary sulphurmatches to kill specimens, and the process has some merits, though I think it is inferior to a lined cyanide bottle. He uses an oval tin box, in which there is left an opening between the opposing edges that will admit a match. The fly is put in the box, the match struck and inserted till the sulphur is consumed, then withdrawn and the cover fully closed till the fly is dead." 
possible should be placed in alcohol, as it is difficult, if not impossible, to examine the under lip, etc., in dried specimens. 'The hairy species of bees should be pinned while in the net. The minnte ichneumon flies should be gummed like small beetles upon cards, or preserved in small pill-boxes. The nests of bees, wasps, and ants, and the young in the different stages of development, should be collected, and the latter placed at first in weak and afterwards in strong alcohol. 


\section{CHAP'TER VII.}

\section{MODE OF DISSECTING INSECTS.}

The External Anatomy.-For this purpose alcoholic specimens are necessary, the chief drawback being that the alcohol causes the muscles to so contract that the joints of the palpi and other appendages may be retracted; specimens killerl with cyanide of potassium and then placed in alcohol may prevent contraction. With a lens mounted in a holder, so that both hands can be used, the student can, with a pair of fine forceps and a needle momnted in a handle, remove the appendages of the month, the antenuæ and legs, and with a pair of fine scissors ent off the wings. For examining microscopically the ends of the antenna and palp: to discover the external parts of the sense-organs, the appendages should be carefully cleaned and then soaked in eau de Javelle, or in dilute liquor potassæ, in order to render the parts transparent. It should be borne in mind that the liquor potassæ dissolves the muscles, nerves, etc., leaving only the external integument. 'The head with its appendages, the segments of the thorax, and the abdomen may in most insects be dissected, the parts poisoned with corrosive sublimate and gummed to a card, in the manner represented by Fig. 1. Dried beetles and other insects may be relaxed by being placed overnight on wet sand, or placed in warm water, in alcohol, or in glycerine. Hairy or scaly insects, such as Lepidoptera, should be denuded with a stiff camel'shair brush: this of course is necessary in examining the head of Lepidoptera.

The Internal Anatomy.-The dissection of the internal organs of insects is exceedingly difficult and nice work, requiring delicacy of manipulation and untiring patience, 
The prince of entomotomists was Straus-Durckheim. Professor Agassiz once told us that it was Straus's habit, before beginning his day's work, to eat a light breakfast and abstain from coffee, so that his hands should not shake. Straus's great work on the anatomy of the cockchafer and his "Traité pratique et théorique d'anatomie comparative" are models of what such work is and how it should be done. 'The indispensable instruments for entomotomy are a flat tin dish, with braces soldered within near the bottom to hold down a piece of thin cork, to which the insect may be pinned,* or a flat glass or porcelain dish, in which melted wax has been poured; for microscopic dissection a large glass cell a fourth of an incl thick, in which melted wax has been poured. Other tools are delicate forceps, scissors, straight and curved (also delicate spring-scissors, being a pair of scissors attached to a long handle, with one blade moving on a spring, we find very useful); needles of different sizes mounted in landles, some of them ground to a knifeedge, and fine narrow scalpels and eye-knives; also an injecting-syringe, with fine points of different sizes, and pipettes; though an ordinary hypodermic syringe will answer. The beginner should select for his first attempt at insect anatomy the dissection of a large locust, such as Acrydium americanum or Edipoda carolina, or a katydid, with the aid of the description of the internal anatomy of Caloptenus on pp. $7-1 \%$ By carefully cutting along

* "In dissecting insects and other small forms one oceasionally experiences considerable difficulty in fastening the object in the dissecting-pan. Pins are inconvenient as they are in the way, and besides they frequently injure portions of the specimen. These difticulties may, however, he avoided by partially imbedding the objeet in wax or parattine, which, however, should not extend above the middle line of the body. The parattine and the embedded object may then be readily fastened in the dissecting-tank, or, when it is necessary to stop operations, the parafline aud object may be placed in alcohol. (J. S. Kingsley in Science Record, ii. 86.) Prof. C. H. Stowell uses an empty blacking.box, filled to the depth of about $\frac{1}{8}$ ineh with melted beeswax, in which while melted a grasshopper, etc., is placed in the desired position, and the whole left to cool, when hard water is poured in and the dissection begun. (The Microscope, iv., 1884, 277.) 
each side of the back with fine seissors, the dorsal portion of the integument can be carefully removed so as to leave the inner cellular layer (hypodermis) untouched; this should then be raised, disclosing the delicate tubular dorsal vessel or heart. Below it lies the alimentary caual, which passes through the middle of the body. The nervous system can be seen upon removing the alimentary canal, as it lies loosely on the floor of the body; but in order to work ont the ganglia in the head, it is better at first, with a sharp, thin scalpel, to cut a well-hardened locust in two longitudinally, the section passing through the brain and subœsophageal ganglion. Indeed, a "sagittal" or longitndinal section of a well-hardened locust or grasshopper can be easily made, and when floated out in a shallow pan of water and examined with a Coddington lens attached to the movable arm of the lens-holder can be studied and then put away in a wide-mouthed bottle for future observations.

Mr. Frank Cheshire has in lis work on the honey-bec given some useful hints on the dissection of that insect. In order to dissect the salivary glands of a worker-bee, lie adopted the following method:

"By inserting a needle into the mouth of a worker-bee, and passing it upwards, behind the front wall of the head, the latter may be so opened that its salivary (?) glands, in a partly broken condition, may be obtained for examination; but if the attachments and entire forms are to be investigated, we must proceed as follows: Partly fill some shallow receptacle, such as a pomatum-pot, or large pill-box, with melted bee's or paraffine wax. When cold, with a hot wire melt a little bath in the centre of the waxen surface, and then insert the bee we wish to dissect, so placing in this case that one side of the head is submerged. By a second application of the wire, re-melt the wax in the neighborhood of the head, using no more heat than is necessary to secure thorough adhesion, and now cover with water or glycerine. A powerful light and a good watch-maker's eye-glass (secured round the operator's head with a tape, when it ean be pushed up on to the forehead if not required) will permit of reasouably good dissection, although, of course, better results can be reached by using a Stephenson's erecting binocular microscope-the instrument with which all the disseetions for this work have been made. The bee thus securely held by the wax, both hands are frce to manipulate. Now, with a needle-knife (made by heating a large needle, beating it Hat, and afterwards sharpeniug upon a lione, and inserting into a wooden handle) cut carefully round the compound eye, and lift it 
off. Curiously folded, and passing round the optic ganglion, we have a long whitish body, which a facetions friend compared to ropes of onions. It is one side of the system No. 1 of Siebold (Fig. 16). Behind this, and extending from the top of the head downwards, we find packed inimitably a second gland system (No. 2), consisting of many pouches, joined by canals to a common duct, which may be followed until it is discovered to enter another duct (b, Fig. 16), ruming backwards and forwards in the body. Tracing this channel towards the thorax, we see it enter the neek, and immediately after bifurcate or fork (c, Fig. 16). Following the line of one of the two ducts, we come upon a reservoir $(s c)$, leading backwards to another gland system (No. 3), of singular structure, with two lobes, lying in the front of the thorax on each side of the body. The position of all these systems is well seen in Plate I. The operation here described is not likely to be accomplished with one bee, and I spent many days, and spoilt many specimens, before getting the glands in their entirety, with their connections; but I have good reason for supposing that these successful dissections are unique." (pp. 74-76.)

Cheshire also examines the "stomach-mouth," as seen through the transparent walls of the honey-sac, in the following way: "The œsophagus, honey-sac, and chyle-stomach slonld be removed together (from a recently killed bee), aud placed on a glass slip, the microscope stage being made horizontal. No cover-glass should be used, but sufficient very weak salt and water added. The whole object will exhibit, for at least fifteen minutes, muscular contractions of a most instructive kind, while the gaping and snapping of the stomach-mouth, and the passing onwards of food, is often noticed. If the bee operated upon has just previously been fed with honey stained with some aniline dye, the effect is enhanced. By closing the oesophagus I have frequently succeeded in getting not only food, but even bubbles of air, gulped down into the chyle-stomach, and, by carefully pressing upon the stomach-month with the side of a needle, the lips may be forced open, and food passed on into the stomach beyond." (Bees and Bee-keeping, p. 66.)

Dissection of Aphides.-G. B. Buckton says that " in the dissection of Aphides much assistance may be often got by a selection of liquids. Some of these are best suited for the purpose of hardening the tissues, so that they may bear separation and tearing asunder without their destruction. Others are used for coloring the transparent organs, so as to make them more visible. These organs of Aphides are so delicate that pure water will in a great measure destroy them. In such cases a weak solution of common salt, or very dilute glyeerine, or sugar and water, or albumen and water, all of which should nearly approach the density of the juices of the insect, will be found a eonsiderable help.

"Some Aphides are so large, so full of liquid, and so charged with oil-globules that some treatment is necessary to reduce their bulk, and to allow of a sufficiently thin stratum of balsam for mounting.

"In such eases the Aphicles may be placed in spirits of turpentine, and just raised to the boiling-point in a small test-tube. After soaking in the turpentine for a few hours, all the oil-globules will be 
cemoved, and the insect by this treatment will have become transparent, and the arueons parts will not then chill the balsam.

"To prepare Aphides for dissection, liquids may be divided into those used for hardening the tissues and those employed for coloring the same. For bardening, a digestion for several hours in weak alcohol will be of advantage. The alcohol must not be too strong, or the albuminous portions will be congulated and becone too opaque.

"Weak acetic acid will render some portions tough, and the same action is also well effected by a weak solution of phosphoric or of nitric acid.

"The action of ordinary ether upon Aphides is not well understood. Their bodies are speedily destroyed by plunging them into the liquid. At the same time a considerable stream of air-bubbles contained in the trachea is expelled, and of such a volume as would lead to the supposition that much of this air must be in some state of solution in the body-juices.

"The reaction of weak potash has been before noted. As a rule, the germinal matter resists its action for a considerable time. Simultaneously this reagent usually stains it a bright gamboge yellow. In some genera (notably Lachnus and Dryobius) potash deepens very markedly the violet dye natural to these Aphides. In other cases I have found potash to evoke the violet shade from specimens otherwise colorless. This dye is fugitive, and if discharged by an acid cannot be again recovered by the action of an alkali. Soda and ammonia also bring out this color.

"Advantage may be taken of the fact that there is a certain order in which the tissues resist the intrusion of a forcign matter such as a dye. Thus the germinal and most vitally endowed organs reject dying by carmine, logwood, and such coal-colors as magenta; whilst the portions in process of exfoliation and decay absorb it the most readily. For such purposes, weak alcohol may be made slightly alkaline by ammonia, and tinged with a little carmine or cochineal solution. Dilute ehromic acid both tinges the tissues yellow and renders them tough. Solutions of osmic acid also may be used to advantage, and, in short, the usual reagents employed for conducting minute anatomy may be taken with due circumspection and tenderness.

"For labelling specimens, paste will be found much more adherent than gum. 'The former may be preserved for some mouths in a well-closed bottle, if a little aqueous solution of corrosive sublimate be stirred into it." (“Monog. British Aphides," iv. (1883) pp. 193-5.) 


\section{CHAPTER VIII.}

\section{CUTTING AND MOUNTING MICROSCOPIC SECTIONS, AND MOUN'TING INSECTS WHOLE.}

AFTER becoming familiar from careful dissections with the gross or general anatomy of insects, and having perceived the relations of the various viscera to one another and to the walls of the body, the student is prepared to appreciate serial microscopical sections of insects, or of selected portions of their bodies. These can be made by the aid of the microtome, and an insect whose integurnent is not too thick can with this instrument be cut from head to tail into several hundreds of slices from $\frac{1}{100 \overline{0}}$ to $\frac{1}{50 \overline{0}}$ of an inch in thickness. In this way the histology or fine anatomy of the hypodermis, and the epidermal glands of the nervous ganglia, alimentary canal, the crop with its teeth, the stomach and intestine, etc., can be examined.

The following directions, which apply to soft organs, or portions of them, of animals in general, have been taken from Lee's "Microtomist's Vade Mecum," * while extracts from other authors, relating to special points, are added.

In order to prepare sections of entire insects, or of separate organs, the insect to be studied should be first carefully killed, and the tissues "fixed," then stained, finally washed out or dehydrated with alcohol, and sections cut with the microtome and mounted in balsam or glycerine jelly.

In general, larvæ and other soft-bodied insects should be killed by being thrown into weak or 50 per cent alcohol, so that the body or the separate soft parts will not contract

* A. B. Lee's “ Microtomist's Vade Mecum" (London, 1885). See also Whitman's excellent "Methods in Microscopical Anatomy and Embryology" (Boston, 1885), Prudden's " Histology," and especially Stöhr's "Lehrbuch der Histologie." 
too mueh, and then after, say, twelve hours transferred to stroug, 90 per cent, and in some cases absolute, alcohol. After being transferred to 90 per cent alcohol, the speeimens shonld be again placed in fresh aleohol, in roomy vials not too elosely erowded, and shonld rest on a mass of cotton so as not to lie directly on the bottom of the bottle.

Fixation of the Histological Elements. - T'wo things, says Lee, are implied by the word "fixing;" first, the rapid killing of the element, so that it may not lave time to change the form it had during life, but is fixed in death in the attitude it normally had during life; and second, the hardening of it to such a degree as may enable it to resist without further change of form the aetion of the reagents with which it may subsequently be treated.

'The most convenient fixing agents are picro-sulphurie aeid (Kleinenberg's or Mayer's formula) and corrosive sublimate. After treating the structure with one of these, it should be washed so as to remove from the tissues all traces of the fixing reagent. If eorrosive snblimate, or osmic acid, or a solution into which ehromie acid or a chromate enters, has been used for fixing, the washing may be done with water; but if picrie aeid has been used, the washing should be done with aleohol.

Dehydration.-As soon as the fixing agent is removed, the water of the tissnes must be removed; this is done by plaeing the object gradually in aleohol, at first in 50 per cent alcohol for two hours, 60 per eent for six to twenty-four hours, 80 per cent several hours, 95 per eent two or three hours, and absolute alcohol time enough for complete satmration.

For inseets, especially, Mayer's fluid seems preferable. He prepares it as follows: distilled water 100 vols., sulphuric acid 2 vols., pierie acid, as mueh as will dissolve; filter. As this fluid does not diffuse very rapidly through thick chitin, Mayer direets that inseets should be opened witl scissors, and the borly-cavity at onee filled with the solution by means of a pipette. $\Lambda$ large quantity of the solution 
shonld be employed in all cases, and it should be changed as often as any eloudiness arises in it. Washing-out is done with $\% 0$ per eent alcohol, and warm alcohol extracts the acid much more quiekly than cold.

Embedding, Staining, and Cutting.-'The water having been completely removed, the object is placed in good ehloroform for a few minutes until saturated. 'The chloroform, adds Lee, is now to be gradually saturated with paraffine. "This is done by placing it, with the object, on a water-bath, heating it to the melting-point of the paraffine employed, and dropping into it from time to time small piees of paraffine. When it is seen that no more bubbles are given off from the object the addition of paraffine may cease, as that is a sign that the paraffine solution has entirely taken the place of the ehloroform in the objeet. 'This displacement having been gradual, the risk of shrinkage of the tissues is reduced to a minimum. The heating is then continued (at the melting-point of the pure paraffine) until the whole of the chloroform has been driven off, which may be conveniently tested by the smell." "The object is then embedded in the desired position, and sections cut with the microtome.

'The sections, cut dry, are mounted in series on a glass slide. To fix collodion sections in serial order, preparatory to mounting, Minot advises their arrangement on the slide in 95 per cent alcohol. Then the alcohol is ponred off, and a drop of alcoholie shellae placed on each section (just enough to cover the section completely). The slide is next placed in the oven of a water-bath at $40^{\circ}$ for a few minutes (5-10), until dry. The sections are then ready for clarifying in elove-oil, and mounting in balsam.

Another and perhaps better collodion fixative is that tried by Sehällibaum, whose solution is prepared by dissolving one part collodion in three or four parts clove oil, which is applied to the slide by means of a fine brush at the time of using. The sections having been arranged, the slide is warmed for a few minutes $(5-10)$ in the oven of 
a water-bath, in order to evaporate the clove oil. 'The sections may next be freed from the emberding mass and colored according to desire. Gage recommends that the collodion and clove oil be applied separately.* "The paraffine is now removed and the sections are stained, generaily with borax-carmine, which two operations are performed as follows: $A$ series of glass-tubes large enough to hold a slide is filled with the following reagents, and arranged in the following order: 'Turpentine (or naphtha); absolute alcohol; 90 per cent alcohol; 80 per cent alcohol; alcoholic borax-carmine; 70 per cent alcohol acidulated with HCl; 90 per cent alcohol; absolnte alcohol. 'The slide, having been warmed to the melting-point of the paraffine, is plunged into the turpentine, which removes the paraffine; then passed through the tubes with the successive alcohols into the stain, from which it is bronght into the snccessive alcohols of the ascending series, which wash out the stain and dehydrate the sections. Nothing more now remains to be done but to treat the sections with a drop of benzol or turpentine, and to add Canada balsam and a coveringglass."

When the objects are small and sufficiently permeable, the sections can be stained on the slide. "In this case the object after having been fixed and washed out is taken while still on its way through the lower alcohols (it should not be allowed to proceed to the higher grades of alcohol before staining) and passed throngh a bath of alcoholic borax-carmine (or other alcoholic stain) of sufficient duration, then dehydrated with snccessive alcohols, passed throngh chloroform into paraffine, and cut as above described." $\uparrow$

* See Whitman's Methods of Research in Microscopical Anatomy and Embryology, pp. 121, 122.

tIf the objects have already been soaked in clove-oil, or other essential oil, for the purpose of clearing, they may either be embedded direct from the clove-oil, or this may be removed by means of chloroform, which is the better practice (Lee). 
For staining, alcoholic cochineal (Mayer's formula) is recommended for insects on account of its high penetrating power, since the chitinous skin of insects is but slightly permeable by aqueons solutions of carmine.

To embed an object, as a small insect, or portion of an insect, make a little tray, box, or thimble out of paper, which can be filled with melted paraffine, the paper being removed before cutting; the cast thus made can be inserted directly in the jaws of a Thoma microtome, or cemented to a piece of cork which is held by them. Besides paraffine, wax and oil and naphthaline serve as embedding-masses. A bit of soft tissue, says Prudden, may be embedded in a mixture of equal parts of white wax and paraffine melted together, with the addition of a sufficient quantity of olive-oil to give the mass the proper consistence for cutting when cold.

Celloidin is also recommended for use as an embedding material. It may be obtained of dealers in micro-supplies. It is sold in the form of plates and shreds (the shreds being more convenient for use) put up in ounce packages. A saturated solution of celloidin is made in a mixture of equal parts of sulphuric ether and alcohol (97 per cent). This requires about twenty-four hours with occasional agitation.

If the object to be cut is loose in structure or porous, it should be transferred from strong alcohol to a mixture of equal parts of alcohol and sulphuric ether and allowed to remain for a short time, and then placed in a small quantity of the celloidin solution and allowed to remain until the celloidin has thoroughly penetrated the object. If the piece is small, a drop of the celloidin solution may be placed on one corner of a slightly greasy glass slide, and the object set up in it with the face to be cut placed next the glass. More of the solution is dropped on to the object until it is covered by a lump or pile of the celloidin; when it has set sufficiently to allow it to be handled withont displacement, immerse the slide with its little pile of celloidin 
in strong alcohol and allow it to remain until it is hard enough to cut, changing the alcohol if necessary.

When ready to cut, place the corner of the glass slide over the well of the microtome, with the object hanging in the well, and fill the well even to the surface with the paraffine embedding mass. As soon as the paraffine hardens, the glass slide can be easily removed with a sliding motion which leaves the surface to be cut parallel to the surface of the microtome.

Cut away the embedding mass of paraffine in such a manner that the front and back sides shall be parallel and leave enough to support the object to be cut, and then slice with a razor or the knife of the microtome. The parallel edge of the first section adheres to the edge of the succeeding section, and the series of sections can be removed from the knife, placed in order on the slide, and secured in position. The superfluous paraffine can be removed with warm turpentine, and the turpentine with alcohol if it is desirable to stain the sections on the slide.

If the piece to be sectioned is large, after treating with the solution of celloidin it can be embedded in a small folded paper box, as directed for embedding in paraffine.

As both absolute alcohol and oil of elores dissolve the celloidin, in dehydrating use alcohol of 96 per cent, and in clearing oil of bergamot, oil of sandal, or oil of origanum.*

Dr. L. Lowe's mixture for embedding is the following:

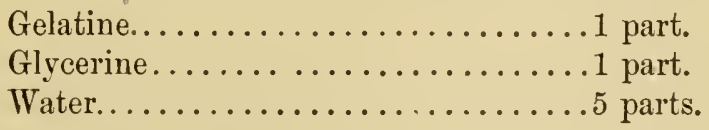

This is put upon the water-bath and thoroughly dissolved and afterwards strained. After coloring the animal preparation it is well washed with water and then submerged in the gelatine at a temperature of not more than $122^{\circ} \mathrm{F}$.

* Contributed by N, N. Mason, Esq. 
At this temperature the preparation remains until it is completely saturated with the gelatine (from 1 to 3 days), and is then taken ont. A piece of hollow pith or several pieces side by side are cut flat upon one side and the preparation laid upon it or them, the gelatine being dropped upon the latter so as to cover the preparation and fix it to the pith. After cooling for a few minutes the whole is placed in absolute alcohol, where it is to remain for a few days, the longer the better, and it is then ready for the microtome. The microtome having been filled with melted wax, the preparation is immersed in it. After cooling, the wax is cut away so that the knife does not come in contact with it in cutting. Before making each section a drop of oil of cloves is applied to the preparation and the subsequent cut is ready for the slide. Mount using dammar or balsam in benzole, or, better, clear balsam.

Mounting Sections.-The process of mounting is simple. After the slices are arranged on the glass slide, a little balsam or glycerine jelly is placed on the objects, the slide being held over the flame of a candle so as to slightly heat it and drive off the fluids as well as to liquefy the balsam or jelly, and then a thin cover-glass is placed over the object, and a covering of Brunswick black varnish placed with a brush around the edge of the cover-glass, to prevent the penetration of air or leakage of the fluid within, and allowed to dry for a day or two before being used.

Dr. Kingsley states that one great difficulty in rapidly mounting in glycerine is in fastening the cover-glass firmly. " Various modes of procedure have been described, possibly the best the writer has seen in print being that which employs paraffine. A still better method is to use a very small amount of glycerine, so little in fact that when the cover is applied the margin of the glycerine does not reach the edge of the glass. Then, with a fine brush, balsam or dammar dissolved in benzol is allowed to rmn in under the edge of the cover-glass, and after becoming lard the 
superfluous balsam is cleaned off, and the slide finished in any desired mamner." (Science Record, ii., 1883, 1\%.)

To Render Small Insects or Larvæ Transparent._While some dipterons and hymenopterous larvæ are naturally transparent, the nervous system can be more clearly brought out by the use of acetic acid, which can be dropped on the object while in the animalcule or live box or on the glass slide.

Glycerine or glycerine jelly is an excellent article for rendering the body transparent, and can be used in observing living Aphides and similar insects, as it renders the chitinous integument more transparent.

Dr. Looss has found that a solution of sodic hypochlorite (eau de Labarraque) of the druggists, or of potassic hypochlorite (eau de Javelle), is a fine solvent for chitin in making microscopical preparations. "The liquid, as bought, completely dissolves, when heated, even the solidest and hardest chitinous parts of insects in a short time, first making them glass-like, transparent, and entirely colorless. If the liquid is diluted with six or seren times its volume of water, and the chitinous parts, either fresh or after they have been hardened, are put in it for twenty-four hours, or even longer according to size, the chitin will be altered, although not noticeably externally; it loses much of its original brittleness, and above all things is more permeable to staining solutions. The objects require for complete staining greater or less time according to size, but the coloration is beautiful and distinct with either alcoholic or aqueous staining reagents. In our institute Pediculidx and Mallophaga have been prepared by this method which show, besides their transparency, complete and clear coloration." (Psyche, iv. 286.) This fluid may also be used to make the eggs of insects more transparent.

Mounting Transparent Aquatic Insects.-Mr. O. Luggel describes a new method of preserving and mounting transparent aquatic insects for the microscope. For observing them while alive a common life-cell is all that is required, 
but for permanent preservation he mounts them in a neat and very useful cell devised by Dr. T. Taylor, which is easily made of common beeswax, and can quickly be built up to any desired height. "To make the cell harder, and to raise the melting-point, a slight amount of powdered resin is added. Both materials are heated together in a small porcelain dish, so as to thoroughly combine them into a homogeneous mass. If required for use, the dish is simply heated, and the cell is made in the usual way upon a turntable. Since both turn-table and slide are colder than the wax, the cell becomes visible at once, and, by repeated applications with the brush, it can be made of any required depth. If too high, or if too sloping towards the centre, the wax can be readily removed upon the turn-table by the application of a knife; a groove for the reception of the cover-glass is also very readily made. The cell is now ready for most purposes, and is an excellent one for mounting with glycerine jelly and Canada balsam. If another material-oil, for instance-is to be used which would dissolve the wax, the inside of the cell should first be coated with any of the usual varnishes, such as Brunswick black. The same varnish should also be used from the outside to seal the completed and filled cell. I have found such cells of great utility in enclosing aquatic larvæ. To do so satisfactorily, I make with a knife a shallow cut across the cell, and fill the latter with water in which the larva to be preserved has been placed. By gently pressing down with a cover-glass, I can secure the still living specimen in any desired position. Now I remove with a piece of blottingpaper a very small quantity of the water through one of the cuts previously made, and allow at the other cut the pyroligneous acid to enter. As soon as this acid has reached the larva, this dies at once in the position occupied at the time. The cell is now sealed in the usual way; but previous to doing so the sides of the two cuts are pressed together.

"Specimens thus treated remain unchanged for a long 
time; for how long I do not know as yet, but possibly for an indefinite time, if not exposed to the sunlight."

"With this method of preserving transparent aquatic larve can be combined the staining of them at the same time. For this purpose aniline-blue or fuchsine should be used, which are soluble in water. One part of the color, dissolved in 200 parts of distilled water, is mixed with 800 parts of the rectified pyroligneous acid. The mortus operandi is the same. In the course of several hours the object has become uniformly stained, and can be sealed after the addition of another drop of the acid. If stained too dark, a current of the diluted acid will soon remedy this fault." (Proc. Ent. Soc. Washington, i. 101.)

Transmission, Preservation, and Mounting of Aphides and Similar Insects. -G. B. Buckton gives the results of his experience as to the best mode of transmitting living Aphides, and also the best method for killing and preserving similar insects for future examination.

As to transmission, the chief thing to be guarded against is desiccation, and no plan seems to be so successful as their enclosure in ordinary quills stopped by plugs of cork or pellets of beeswax. The substance of the quill is sufticiently porous to prevent mildew on the one hand and a rapid evaporation on the other. In this way small insects may be sent throngl the post, and in a far better condition than can be secured in any tin boxes, even though they be filled with leaves. If a slip of some succulent leaf be rolled round each quill, to retain moisture, a bundle will conveniently pass through the post.

For preservation (other than on a slide) the best plan is to drop the insects into small thattened glass tubes partially filled with a suitable liquid, then draw the tube to a fine point, break the end off, and warm the empty space (or, better, expel the air by a pump), and the tube can be entirely filled with liquid, and then sealed with the blow-pipe.

For mounting microscopically, five or a dozen spots of fluid Canada balsam should be dotted on a slide from the head of a pin, and by means of a hair-pencil as many living insects transferred to them. "The specimens at once adhere, and if the spots are small the insects spread out their limbs naturally, with a view to escape. They may be fixed on their backs or otherwise, according to the views desired.

" $\boldsymbol{\Lambda}$ very thin glass cover, or, if very high magnifying powers are wanted, a small disk of clear mica, is laid over the insects, and then 
one or more drops of the fluid balsam are delivered from a glass rod at one of the sides of these corers. The balsam runs slowly under by capillarity, and it drives all the air before it, the small weight of the cover assisting it to spread, until the whole area is tilled. No pressure is to be used, or the elastic bodies of the Aphides will chauge shape; and besides this, the juices will be forced through the cornicles and pores. If the balsam is thick, a very gentle heat, hardly exceeding that of the cheek, may be applied, but as a rule the temperature of a room is better than that which exceeds it. The insects die immediately if they are cut off from air, and in almost every case their position will be good for examination. To spread the wings of a small insect, the above-mentioned small dots may be spread in a row. The belly of the specimen is applied to the middle spot, and by a bristle one wing may be applied to the dot on the one side, and the other wing to the third dot. The cover is then placed as before, and when the balsam runs in it will not disturb the position of the spread wings.

"It will be noticed that very soon after live insects have been mounted in a resinous substance that will not mix with water, a white cloudiness forms around each specimen. This is caused by the watery juices of the insect, which 'chill' the medium and make it opaque.

"This cloudiness, however, entirely disappears after perhaps a month, the moisture being carried slowly onwards. The same is to be said of stray air-bubbles. The oxygen of the air unites with the balsam, and thus hardens it; but what combination is effected with the nitrogen is not so clear. Howerer, air-bubbles in balsam disappear in time, provided the former is not in too hard a condition.

"In cases where the above small pressure is undesirable, small circles, cut by round punches of different sizes out of very thin sheet lead, will be found more convenient to insert between the glass slip and its cover than circles of card, which are sometimes recommended. The thin sheet lead from the Chinese tea-chests is rery suitable for punching, and as it is not porous like card it yields no air-bubbles br heat.

"D. Tou Schlechtendal * has described a method by which it would appear that all the characters of form and color (?) may be preserved in Aphides and other insects. The method consists of a rapid death and drying of the insect by means of a current of heated air. The Aphis, previously attached to some suitable support, is suddenly and momentarily subjected to the heat of a spirit or other flame, by which it is immediately killed and caused to retain its natural posi-

*Entomol. Nachrichten, iv. p. 122. 
tion. Several examples are then carefully rossted in a current of bot air, such as that passing through an inclined glass tube duly made bot, or dried on a sheet of paper mored orer a heated metal plate.

" When dry, the specimens are mounied on card by aitachment with gum tragseanth; or, as Mr. J. W. Douglas suggests, more conteniently on mica, called 'tale' in the shops, which, ss it is incombustible, is well suited for a support both before and after drying.

"This method is rouched for as good br Drs. Giebel, Taschenberg. Marer, and Rudow.

"I have not tried this roasting process, but it must require some address to prerent the shrirelling of wings in such delicaiels-iormed insects, and to proride against the bursting action of the boiling juices-

"A more complete history of the process than the foregoing was giren by Mr. Douglas in 12 is.

" I. Lichtenstein has mang times heen good enough 10 forward in letters to me preparations of Aphides which hare been secured hetween two films of mica. The insects, he explains, sre immersed in a solution of resin ia turpentine, 'a nstural amber,' and, when all are in due position, the mica tilms are placed orer sperums in card, and then gummed papers, similarly perforated, are pressed upon them. This arrangemeni secures all in their places.

"Methods and operations in science, like erents in hisiory. repea: themselves. Fifty years ago tilm, of mica were used to cover objects for the microscope, sad betore the manufacture of the thin slass now so commonly used it admirably acswered its purpose. Thder deep magnifring powers, such as $\frac{1}{12}$ in., it will be found eren now of great service. The mineral may be split by the lanct into tilms much thinner than glas can be blown in a tai siste. =mall unscratched pieces mar be selected which are perfectls inan=parent, and their cost is quite tritling.

"On account of the high refracting power of Canada halsam. the colors of recentlr-immersed Aphides shuw themselres rery brighily; and it sometimes happens that tints, quite lost through irradiatiun $\mathrm{C}$ : glance on the surfaces, become disinct by ireatmen with this resin.

"The bright color and marking of some species are due to the hue of the internal juices of the invects. These cannot be preserved by balsam, but it is otherwise with the pigments which stsin the somewhat horny corerings of the thorar and abdomen. These color are persistent." ("Monog. British Aphides," ir. I\$S3/ pp. 18593.

Thouss W. Stsrrs Yetkod of Preparizg azd Youting. Witb Pressure, Insects Entire ss Irsaspare: 0 bjects." - Aftet procuring the insect,

* This, with the three following zotes, were kindir communicsted by .. .. Msson, Esq. 
place it under a tumbler with a few drops of ether. When dead wet it with alcohol and place it in 'liquor potasse,' U. S. P., and let it soak until the skin is soft, and until on slight pressure the contents of the intestine can be pressed out through the natural or, if necessary, an artificial opening. This is best done under water in a white plate.

When this is effected the object is to be cleaned. Have a camel'shair brush in each hand; with one hold the object, and with the other brush every part of the insect on both sides, float it on to a glass slide, and dispose each part in a natural position, either creeping or flying. Cover this with another glass slip of the same size and press gently together, using only sufticient force to make it as thin as possible without crushing or destroying it. Confine the glasses with the insect between them with a fine brass wire, and place them in clean water to remain 24 or 36 hours; this will give the insect a position which is not easily changed, and it is therefore proper that the position be such as you desire when the insect is finished. Remove the wire and open the glasses carefully under water and float the insect off, give it another brushing, and let it remain a few hours to remove the potassa. Transfer to a small but suitable vessel containing the strongest alcohol that can be obtained, pursuing the same course as with the water, placing the specimen between glass slips tied together, and let it remain about 24 hours.

Transfer to a vessel containing spirits of turpentine; it is to remain in this, kept between the glasses, until all the water is removed. While in the spirits of turpentine, the insect is to be released several times, and the moisiure removed from the glasses, and the insect again confined. When no moisture is seen to surround the insect, heat the glass slips containing the insect over a spirit-lamp until the contained turpentine nearly boils, when, if any moisture is present, it will show its presence when the glasses are cold.

If free from moisture it is ready for mounting. Float it outo a suitable slide from the turpentine, drop a sufticient quantity of balsam upon it, examine and see that no foreign substances are present, heat the cover slightly, and apply in the usual way. After a day or two heat the slide moderately and press out the surplus balsam, and place a small weight upon the cover while drying. After the lapse of a suitable time, remove the surplus balsam and clean the slide.

In all the operations the utmost cleauliness is essential. The liquids used should be frequently filtered and kept from dust, and a large share of patience will be found necessary.

After sufficient time has been given to allow the balsam to harden su that the cleaning will not displace the cover, remove the surplus 
from around the cover-glass with a warm knife, and then moisten a soft tooth-brush with a mixture of equal parts of alcohol and aqua ammonia, and a slight rubbing will clean the slide with very little danger.

After removing the superfluous balsam and cleaning the slide, finish by spinning a ring around the cover with the cement made from the following formula:

Gum dammar................... 75 grains.

Gum mastic...................... 45 "

Canada balsam, evaporated to dryness..... 45 "

Chloroform.......................... "

Spirits turpentiue................. "

Mix and dissolve.

Method of Preparing Minute Entomostraca, Mites, Spiders, Insects, etc. - "The specimens should be killed by adding a few drops of osmic acid to the water; when they fall to the bottom they are to be taken up and placed in alcohol of 30 per cent, from which they are to be transferred to alcohol of 50 per cent, then to cochineal solution in 70 per cent alcohol, then washed repeatedly in 70 per cent alcohol, then placed in 90 per cent alcohol, and finally in absolute alcohol. Then a small quantity of oil of cloves is poured into the alcohol, and at the line of juncture of the two liquids the specimens become permeated with the oil. They are then to be transferred to clear oil of cloves, and finally when perfectly clear mounted in Canada balsam, or embedded in paraftine and cut into sections. By this method specimens can be obtained with absolutely no shrinking of the protoplasm." (M. M. Hartog, Journ. Royal Microscopical Society, London.)

Carbolic Acid in Balsam Mounting.-Put the living insect into carbolic acid;* this in a few minutest clears the object, rendering it transparent and apparently wholly destitute of viscera, but exhibiting clearly the sexual organs. Drain off the superfluous acid and mount without pressure in moderately thick balsam. The acid does not harden the object, but it remains perfectly flexible for a long time. (C. M. Vorce, Science Gossip, June, 1880, p. 139; also Jour. Roy. Micr. Soc., 1881, 139.)

Killing and Preserving Insects.-Mr. G. W. Vickers approves of Mr. Vorce's method stated above, and describes his own mode of procedure. "Place a drop of the [carbolic] acid (pure crystallized

* Liquefied crystals. - N. N. MI.

t Some insects should remain for a day or more.-N. N. M. 
with just sufficient water added to keep it fluid) on a slide, and drop into it the living insect; it will be seen to struggle for a second or two, then the limbs, wings, and tongue become extended; it then becomes beautifully clear and transparent. The acid should now be drained away, a drop of balsam put on, the cover applied. ..." (North. Microscopist, ii., 1882, 227.)

Bleaching Fluid for Insects.-W. Sargent recommends the following: Hydrochloric acid, 10 drops; chlorate of potash, $\frac{1}{2} d r$; water, $1 \mathrm{oz}$. Soak the insect in it for a day or two, then wash well. (Journ. R. Micr. Soc., 1883, 151.)

To Clear Objects for Balsam Mounting. -Dr. J. J. Mason uses a mixture of carbolic acid, one part, and oil of turpentine, four parts, mixed. When the object is perfectly clear, drain off the superfluous mixture and mount in balsam.

Mounting Insects in Balsam without Pressure.-Mr. H. Chadwick gives the following directions:

Preparation.-I. Soak the specimens in liquor potassa until they are transparent. Wash well in distilled water, using a pipette and camel-hair pencil. Transfer to 50 per cent spirit, then to a small quantity of pure spirit in a watch-glass or soaking-bottle, and allow them to macerate. By this method the formation of air-bubbles in the interior of the specimens may generally be avoided.

II. Wash well in distilled water. Soak in pure spirit or alcohol for some days. Transfer to carbolic acid until sufliciently transparent. Then transfer to oil of cloves, but many persons do not consider this necessary. This method should be used in all cases where the integument is too opaque to allow light to pass through it before treatment, and it is especially useful in the study of the muscles.

Mounting.-Take a clean $3 \times 1$ slip, having a sunken cell in its centre. Just inside the edge of the cell, equidistant from each other, eement three white glass beads with hardened balsam. Put a small quantity of soft balsam in the centre of the cell, and gently warm it over a spirit-lamp. Take the object, a wasp's or blow-fly's hearl, for example, and place it upon the previously warmed balsam, arranging it in the required position. Now take a clean cover-glass, the diameter of which should be a little less than that of the cell, and holding it between the points of a pair of forceps, place a large drop of balsam in its centre, and allow it to fall upon the object. The edge of the cover should rest upon the three beads. If the quantity of balsam under the cover-glass is not sufticient to fill up the whole of the space between it and the slicle, a little more must be allowed to run in, and if the object has become displaced, it may be rearranged by means of a fine blunt needle, introduced beneath the cover-glass. 
A clip should be used during the last operations, but only to prevent displacement of the cover. The slide must now be put aside in a warm place, until the balsam is hard enough to allow the superfluous portion to be removed safely. Sufticient balsam should be left to form a sloping edge around the cover-glass, and it should be hardened for a few days after cleaning. Be sure that the balsam is quite hard before applying brown cement. The ease with which an object can be rearranged, or a chance air-bubble removed, without disturbing the cover-glass, constitutes the chief advantage of using beads. A supply of different sizes should be kept, and the size used must be regulated by the thickness of the object. Pure balsam in collapsible twbes is to be strongly recommended, on account of the nicety with which the quantity of balsam required for mounting a slide can be regulated. The neck of the tube should be wiped with a clean cloth moistened with benzole before the screw-cap is replaced, in order to prevent the possibility of a little balsan hardening in the screw, and so prevent the easy removal of the cap when next required. (Scientific and Literary Gossip.)

Preparing and Mounting Dissections of the Appendages, etc.-A. C. Cole's method in dealing with the parts of spiders will also apply to insects. The spinnerets, legs, and falces having been respectively removed are placed separately in liq. pot. for 24-36 hours; then soaked in water to remove the potass; then placed in acetic acid (in which such parts of insects, etc., may always be preserved until required for mounting); then again soaked in water; then placed in strong alcohol for a short time; then cleared by means of oil of cloves, and, lastly, transferred to turpentine, and mounted without pressure in cells. (Studies in Microscopical Science, III. sect. iv.)

Mounting Minute Insects and Acari in Balsam.-Mr. A. D. Michael describes his process as follows: He first kills the creatures in hot water or spirit. Hard insects and Acari are best killed in hot water, which causes them to expand their legs, but water rather injures minute flies, and spirit is better for them. Next wash the objects thoroughly in spirit and clean with a badger's hair, clean mechanically and by washing in spirit. Place the object on a glass slip and arrange it with the hair, leave it in spirit for such a time as experience suggests, tilt the slip so as to drain off the spirit, but not to dry the object, which should never be allowed to dry from the first process to the final mounting. Having drained off the spirit, drop on the object a little oil of cloves, which is better than turpentine; slightly warm the slide and put on a thin cover-glass, which must be supported so as not to touch the object; leave it until thoroughly soaked. If necessary, remove to a clean slip for the final mount. It may be necessary to arrange the object more than 
once. Drain off the oil of cloves and put on a small quantity of Canada balsam, or preferably balsam and benzole. Arrange the creature on the centre of the slicle. Let the balsam harden a little, then the object will not float off, as happens sometimes when a quantity of balsam is used at once. Lower the cover straight dowu on the object; do not try to drive out a wave of balsam as is recommended in the text-books. It is better not to put enough balsam at first to fill the space under the cover, as the balsam supports the rover if it does not reach the edge; but if the balsam reaches the erlge of the cover it is apt to draw down the cover and crush delicate objects. A few pieces of thin glass to support the cover are a great protection to the object, or better still, a few tiny glass beads. Finish the slide with a ring, Bell's cement or something of the kind, but that must not be done unless the cover be supported in some way. (Journ. Quek. Micr. Club, i. (1883), pp. 241-2.)

Sections of the Brain.-In studying the brain of insects it is better to begin with that of some of the lower forms, such as the cockroach or locust, as they are on a simpler plan than that of ants, wasps, and bees. In the sections of the brain, made by Mr. N. N. Mason in 1879 , it was thought better to cut the entire head so that the muscles and integument should support the soft parts within, including the brain. The head therefore was cut with the microtome into sections from $5 \frac{1}{500}$ to $\frac{1}{1000}$ inch in thickness, after having previously been hardened in absolute alcohol for two days or more, and then kept in melted paraftine for one or two or more days. It was then embedded in a preparation of paraftine, swcet oil and wax, or, in some cases, in soap. After the sections were cut they were stained with picrocarmine, or with osmic acid and picrocarmine. Finally, the slices were mounted in glycerine jelly for study under the microscope. 'The sections were in most cases frontal ones, namely, cut transversely from the front of the liead or brain backwards, while a few were longitudinal (vertical or sagittal) ones, viz., cut parallel to the median line of the body.

MI. H. Viallanes, in bis work on the brain of the locust (Edipoda and Caloptenus), published in 1887, deseribes his method as follows: He separates the head from the living animal, then with the scissors removes the labrum and mouth-parts and all of the integument behind the compound eyes. He then removes the muscles of the mandibles, the tracheæ and fatty masses, in order to expose the posterior aspect of the brain.

He then plunges the head thus prepared in a vessel containing the following solution: Distilled water, 100 ; osmic acid, 0.02 ; acetic acid, 0.50. At the end of a few minutes the brain is of a consistence sufticient to allow the dissection to be fiuished without fear of 
changing its shape. He then allows the reagent to act upon the brain, carefully isolated, until it assumes a deep gray tint. It is then soaked several hours in distilled water, but may be fixed by treating it successively with alcobol diluted one third, alcohol at $70^{\circ}$, and alcohol at $90^{\circ}$. Picces were thus obtained rery evenly impregnated throughout their entire mass with osmium.

In most cases he colored the nuclei by placing the piece some hours in carmine and alum decidedly acidulated with acetic acid.

On being taken ont of this stain and washed, the brain is dehydrited, embedded in parattine, and cut into sections $\frac{1}{200} \mathrm{~nm}$. in thickness, and momnted serially. Besides fromtal, lateral, and sagittal, oblique sections were made.

Signor G. Cuccato, in preparing the brain of Orthoptera, snips off the head of the insect with a pair of scissors, and pins it on cork. Thus fixed, the head is immersed in 0.75 per cent $\mathrm{NaCl}$ solution. Then, with the aid of scissors and forceps, the chitinous sheath and the eyes are removed from the supra-nesophageal ganglion, and the specimen remored to a watch-glass full of salt solntion, wherein the tracher and muscles are remosed. After a short time the object is placed for forty-eight hours in Flemming's mixture, and then, having been well washed, the rest of the muscles and the fat are remored from the ganglion. It is next put in 36 per cent spirit, and gradually hardened. After delydration it is embedded in paraftine. The sections were fixed down by Mayer's method, and stained with a saturated watery solution of acid fuchsin. The fixative used was Rabl's solution (chromo-formic acid and platinum chloride). (Journ. Roy. Micr. Soc, Dec. 185i, p. 1045.)

Preparing the Sympathetic Nervous System of the Cockroach.-Dr. M. Köstler pursued the following mode in examining that of Periplaneta orientalis:-The fresh parts of the insect to be examined were held over osmic acid for two or three minutes, washed, and transferred to weak alcoho:. They were then stained with picro-carmine for twenty-four hours beneath the bell-jar of an air-pump, and were found to be perfectly hardened. When all traces of alcohol had been remored by washing they were placed in filtered white of egg. At the end of about two hours the albumen was coagulated, first by weak and then by absolute alcohol, warmed to $40^{\circ} \mathrm{C}$., so as to bring about as even a coagulation as possible. The object can then be treated in the usual way with oil of cloves, embedded in paraftine, and cut with a microtome. (Zeits. für Wissen. Zoologie, xxxix. 1883, 572; also Journ. Roy. Micr. Soc., 1885, 538.)

Making Sections through and Bleaching the Eyes of Insects.-Dr. S. J. Hickson's method is as follows: "For making sections through the eye of Musca vomitoria I have found it best to dissect away the 
posterior wall of the craninm of the fresh insect and then to expose it to the fumes of 1 per cent osmic acid solution for forty minutes, then to wash in 60 per cent spirit for a few minutes, and finally to harden in absolute alcohol. Crania thus prepared may be eut into fine sections by the automatic microtome, and stained in hæmatoxylin or borax-carmine. With most insects, however, I have found it impossible to use this microtome, owing to the hardness of the chitin of the cranium and of the mouth-appendages. In such eases I have used a Jung's microtome, with the razor set so as to give a long sweep at each stroke, aud the seetions earefully removed from the razor, and mounted one by one.

"I have tried various methods for depigmenting the eyes, such as bleaching-powder, nitric acid, chlorine, etc., but the best is that of exposing the sections when cut to the action of uitrons fumes. This is done in the following manner: The sections are fixed in position on the slide by Mlayer's albumin and glycerine solution, and when the paraftine has been removed by turpentine and the turpentine driven off by absolute alcohol, the slide is inverted over a capsule containing 90 per cent spirit, to which a few drops of strong nitric acid have been added.* Copious nitrous fumes are given off and the pigment dissolves. The action can be stopped at any moment by washing with neutral spirit, and when the washing is complete the sections can be stained in hæmatoxylin or any other solution.

"For teasing the best solution is chloral hydrate. I leave the eye or optic tract in 5 per cent solution of chloral hydrate for twentyfour hours, and then tease with needles and mount in glycerine. In some cases I have made very satisfactory preparations by fixing the teased tissues to the slide with albumen and glycerine solution and then washing with spirit and staining in the ordinary way, or staining after depignenting with nitrous fumes.

"I have tried various kinds of hamatoxylin stains, but the solution which gives the best results, and is in every way the most satisfactory, is one which I have made by following Mitehell's instructions, with a few additional precautions. I will describe here the mode in which I now make hæmatoxylin stain: Take 56 grams of the logwood extract and thoroughly pound it in a mortar. Then place it on a filter, and pour about a litre and a half of ordinary tapwater through it. 'The filtrate may be thrown away and the residue

* Prof. Grenacher, according to Carrière, besides one with nitric acid, employed the following mixture: Glycerine, 1 part; alcohol (80 per cent), 2 parts; and liydrochlorie acid, $2-3$ per cent. The preparation remains in this mixture until the pigment changes color and becomes diffuse. (Amer. Naturalist, 1886, 89.) 
allowed to dry. In the mean time prepare a solution of alum as follows: Take 25 grams of alum, and after it has been thoroughly pounded in a mortar pour it into $250 \mathrm{cc}$. of distilled water. To this solution add strong potash until a precipitate is formed, which will not dissolve upou stirring and standing.

"Pour the alum solution thus made on to the hæmatoxylin residue, and allow it to macerate for three or four days in a warm room. Then filter the hrematoxylin solution into a bottle provided with a closely-fitting stopper, and add to it $10 \mathrm{ce}$. of pure glycerine and $100 \mathrm{cc}$. of 90 per ceut spirit. (The residue need not be thrown away, for it can be macerated again with alum solution for a week or more, and a good strong stain obtained as before.) When the solution is thus made it should be well shaken and allowed to stand for some weeks before being used. This solution of hæmatoxylin improves considerably with age. The oldest I have was made about twelve months ago, and is by far the best.

"The hæmatoxylin stain produced by this recipe possesses several advantages over others. In most cases it differentiates the tissues admirably; nuclei stain deeply, cell protoplasm faintly; it seems to last a long time without showing sigus of farling, and, as it penetrates well, it is very useful for staining in bulk."

Dr. J. S. Kingsley's * method of preparing and cutting the eggs and embryo eyes of the shrimp, which will also apply to the embryonic eyes of insects, is as follows:

The eyes were hardened by means of Perenyi's fluid, followed by alcohol of inereasing strength, a process which works well with almost all Arthropod tissues. In most instances, they were stained entire with Grenacher's alum-carmine, though in some instances Kleinenberg's hæmatoxylin or Grenacher's borax-carmine were employed In the later stages, where the deposition of pigment in the eye interfered with a clear vision of all the structures concerned, the following course was adopted: The eyes were sectioned as usual, the sections being fastened to the slide with Mayer's albumen fixative. After wetting the parafline and allowing the sections to drop into the adhesive mixture, the embedding material was dissolved in turpentine, and this in turu was washed away with alcohol (95 per cent). The sections were then covered with a mixture of equal parts of nitric acid and 95 per cent alcohol, which was allowed to remain until the pigment was removed, - a process requiring from ten to fifteen minutes. The slide was next washed with strong alcohol, and the sections stained deeply with Kleinenberg's hæmatoxylin, and

* Journal of Mlorphology, Boston, 1887, 49. 
the excess then removed with acid alcohol in the usual manner. The sections were then mounted in balsaur.

In order to demonstrate the presence of the corneal hypodermis in the facetted Arthropod eye, and the connection of the socalled "rhabdom" witl the crystalline cone-cells, Mr. Patten says it is necessary to resort to maceration. In most cases it is harlly possible to determine the important points by means of sections alone.

The ommateum of fresh eyes, treated for twenty-four bours or more with weak sulphuric or chromic acid, or in Müller's fluid, may be easily removerl, leaving the corneal facets with the underlying bypodermis uninjured. Surface views of the cornea prepared in this way show the number aud arraugement of the corneal cells on each facet. In macerating the cells of the ommateum it is not possible to give any definite dircetions, for the results vary greatly with different eyes, and $i_{i}$ is also necessary to modify the treatment according to the special point to be determined. It is as essential to isolate the individual cells ats it is to study cross and longitudinal sections of the pigmented eyes. In determining the number and arrangement of the cells and the distribution of the pigment, the latter method is indispensable; it should not be replaced by the study of depigmented sections, which should be resorted to in special cases only.

In fixing the tissues of the eye, it is not sufficient to place the detached head in the hardening fluid; antennæ and mouth-parts sbould be cut off as close to the eye as possible, in order to allow free and immediate access of the fluids to the eye. When it is possible to do so with safety, the head should be cut open, and all unnecessary tissue and hard parts removed. With abunrlant material, one often finds individuals in which it is possible to separate, uninjured, the hardened tissues of the eye from the cuticula. This is, of course, a great advantage in cutting sections. The presence of a hard cuticula is often a serions difficulty in sectioning the eyes of Arthropols. This difficulty can be diminished somewhat by the use of the lardest paraffine, and by placing the broad surface of the cuticula at right angles to the edge of the knife when sectioning. Ribbon-sections cannot be made with very hard paraffine, but it is often necessary to sacrifice this advantage in order to obtain very good sections. (Roy. Mic. Journ., Aug. 1887.)

Expanding and Mounting the Tongue of the House- and Blow-fly.C. M. Vorce remarks that if the head of a living fly be cut off, the tongue will usuaily retract; pressure on the head will expand the tongue, but unless it be secured by some meaus before the pressure on the head is released, it is apt to wholly or partly retract again. "If ouly the tip is wanted, it is easily secured by placing the severed head on a clean slip and pressing with a needle till the tongue is fully 
expanded, when a drop of turpentine is applied, a cover laid on the tongue, and a clip applied before the pressurc is removed from the tongue. To secure the whole tongue, split one end of a small stick for an inch or so, and holding the split open by a knife-blade, place the severed head in the cleft with the top downward, and, withdrawing the knife-blade, allow the stick to close upon the head, when it will fully distend the tongue. Now dip the heal and tongue in turpentine, and leave it immersed for a few days, when it will be found well cleancd, still perfectly distended, and can he released from the stick or cut from thic head without danger of its collapsing. Mounted in a cell in balsam, il is a truly beautiful object." (Amer. Month. Micr. Journ., 1884, 12.)

A. L. Woodward immerses the living fly in alcohol, "and with perfectly satisfactory results. At the moment of death the tongue is forcibly protruded to its entire length. Even the short proboseis of the bouse-fly is satisfactorily displayed." (Amer. Month. Micr. Journ., 1883, 239.)

Mr. H. Sharp mounts the lobes of the proboscis of the blow-fly, without pressure, in a solution of biniodide of mercury in one of iodide of potassium (both saturated solutions), which brings out the details of the structure of the pseudotrachee. "I have several probosces of blow-flies mounted in balsam, with and without pressure, but there is nothing to be seen of the membrane in any of them; I can just see it in a glycerine mount, now that I know what to look for; but the glycerine does not make it visible like the mercury solution." (Journ. Roy. Micr. Journ., 1884, 1003; 1885, 733.)

Microscopic Sections of the Proboscis of Flies, Bugs, and Bees.-The excellent work done by Dimmock on the mouth-parts of the mosquito and other flies, by Kraepelin on those of the fly, flea, and Hemiptera, was chiefly by means of microscopic sections. In order to ascertain whether the pseudotrachex of the fly's labella are hollow or not, Dimmock fed the fly with a mixture of sugar and gum arabic, colored with carmine, then plunging it suddenly into strong alcohol to fix the colored solution in its mouth-parts. Mrr. Cheshire, before cutting sections of the bees and other honey-feeding insects, recommends that the insect to be operated upon should be kept fasting for some time, and then fed on honey mixed with gelatine impregnated with some highly colored dye; the insect should be immediately decapitated, and the head rapidly cooled and theu embedded in gelatine, and the section cut by means of the microtome. The mouth-passage is then easily seen from the presence of the dye.

Sections of the Ovipositor or Sting.-Accorling to Mr. J. W. Hyatt, the insect or organ is placed in alcohot until it is thoroughly permeated, and then removed to a clear alcoholic solution of shellac, in 
which it may remain for a day or two. Fit a cylinder of soft wood into the well of the section-cutter; split this cylinder through the middle, and cut a groove in one or both of the half-cylinders sutticiently large to admit the object without pressure; put the two pieces together with plenty of thick shellac, and tie them with a thread. When the shellac is quite hard, which will be the case in a day or two, place the cylinder in the section-cutter, and, after soaking the wood with warm water, sections the $\frac{1}{500}$ of an inch in thickness, or less, may readily be made.

Should the shellac prove so opaque as to interfere with a proper examination, a drop of borax solution will immediately remove this difficulty. (Amer. Month. Micr. Journ., i. (1880) p. 8.)

Mounting Gizzards of Insects.-Dr. T. J. Sturt kills the specimen with a drop of benzine, cuts off the extreme end of the hind body, removes the head, cuts off the whole intestine, and puts it in a $1.0 z$. vial with five or ten drops of liquid potash. After it has stood about half an hour, partly fill with water and shake it well to detach the muscular coat and trachex; then slit it up, wash, and adjust on a slide. Drain away any moisture, apply a drop of carbolic acid, and put on the thin glass. After a few minutes this will absorb all moisture and render it quite transparent. If it does not, put a drop of acid at the edge and tilt the slide to drive off the first acid; then put a little balsam on the elge, tilt the slide, warming it to render the balsam more limpid, and it will gradually take the place of the acid, the lines of demarcation between the two being distinctly visible. (English Mechanic, 1882, 282.)

Preparation of the Intestine of Insects.-According to Dr. J. Frenzel, chromic acid is not suitable for the examination of the intestine of Arthropoda. A mixture of nitric acid and an alcobolic sublimate solution gave satisfactory results. The strength of the alcohol and the amount of sublimate in solution do not appear to matter. The author used 80 per cent. alcohol with sublimate half saturated. No particular caution is necessary as to the amount of acid; a drop too much or too little doing no damage. To the above solution a drop of concentrated sulphuric acid is added to every onc or two cubic centimetres. The presence of this acid induces a quicker penetration of the preservative fluid into the tissues, and hinders the formation of insoluble mercurial compounds. The more acid the solution and the smaller the piece of tissue the shorter the time it is left in the fluid. For pieces about the size of a pea, five to ten minutes are quite sufficient. After bardening in sublimate, alcohol is advantageous. The tissue is washed and left in 90 per cent alcohol. (Archiv für Micr. Anat., 1885, 229.) 
Preparation of Insect Spiracles.*-Mr. F. Dienelt remarks that in most beetles the spiracles are found on the upper part of the abdomen. The insect should be turned on its back and cut across the thorax close to the abdomen; then turn again, and insert a sharp knife into the opening made, and cut round the whole abdomen. As soon as there is room, insert a small stick of soft wood sharpened to a flat point, by means of which the ohjeet ean be held securely while cutting. All the eutting should be done on the lower side, so that a margin is left on the upper part, which can be trimmed easily after the object has become softened in liquor potassæ. Steeping the insect in this fluid for a couple of hours will destroy all the viscera. Now hold the part down with a softened stick, which for this purpose is far superior to mounting needles, and with a camel-hair pencil remove the viscera and transfer the object to rain-water, removing this two or three times to insure cleansing and to remove the last trace of potash. Keep on brushing until it is certain that the object is elean, and then trim the edges to suit before a final washing. If it be desired to mount the trachex in situ, greater care is necessary in treating, but they show very well through the skin. Or, after most of the viseera have been removed, the tracheæ ean be torn by a sawing motion with the back of the knife from the spiracles and mounted separate. In mounting larvæ entire, they should be left in liquor potassa for a longer time--even a whole day-without injury. In cleaning it is necessary to keep them in the position in which they are to be mounted. Larva of the Lepidoptera show best wheu mounted on the side. In preparing these, hold the larva under water with the pointed stick, and elear out the viscera with a brush through the anal opening by a rolling motion. After a start has been made the process takes but a short time. Larvæ will stand considerable pressure in cleaning, but gentle manipulation of course answers best, especially in those covered with hair. It is best to commence with the largest beetles or larvæ one can find. Larvæ too large to be mounted entire ought to be opened along the back to give the liquor free access.

Twenty-seven grains of potassa fusa to one ounce of water acts but slowl on the chitinous parts of insects, but very promptly on the viscera. It is best kept in a paper-covered bottle, to exclude the light. (Journ. Roy. Mic. Soc., August, 1887.)

Mounting of Tracheæ.-Mr. F. T. Hazlewood dissects out the soft parts and sprearls them on a glass slide, letting them dry perfectly. He then with a pencil-brush gives them a good coating of collodion, after which he melts a little hard pure balsam in a test-tube and puts it on the object with a cover-glass applied at once. The intestines, 
ganglia, and the brain are in this way finely shown, the brain revealing the very abundant ramifications of the tracheæ, especially the immense parallel branches situated between the rods of the eyes. (Psyche, iv. 253.)

Mounting Legs, etc., of Insects.-Mr. R. A. R. Bennett, in regard to this topic, which will also apply to large antennæ, palpi, ete., remarks: The chief difficulty is the appearance of air-bubbles in the object after it has been mounted. To avoid this, there is a little dolge not mentioned in most books. When the leg is taken out of the turpentine, instead of placing it at once on the slide, boil it for a few moments in some balsam, kept for the purpose in another tube. While it is being boiled the air will escape, and the balsam will take its place. There will therefore be not nearly so much ehance of airbubbles arising when the object is mounted. Of course this would be rather rough treatment for some objects; but with the legs of inseets (especially such as Dytiscus marginulis) it generally answers admirably, and saves a vast deal of trouble. (English Mechanic, 1883, 253.)

Mounting the Skin of Caterpillars.-E. E. Jackson soaks the specimen in acetic acid for ten days, then opeus the body carefully with scissors from anus to mouth, and washes it in water. He then soaks it in weak, afterwards in strong, alcohol, following with oil of cloves, turpentine, and balsam. (The Microscope, 1884, 133.)

Dissection and Preparation of the Spermatic Filaments.-F. R. Cheshire proeceds in the following manner: "Secure a drone (not newly latehed) as he is perambulating the combs, open the body, remove the vesicula, hreak one end, and, with the forceps, apply for a moment the ruptured part to the surface of some glass covers upon which a small quantity of water has been placed (one vesieula will give a supply for a dozen slides); leave to dry, keeping from dust; warm in the flame of a spirit-lamp to set the albumen, pour on each three or four drops of watery solution of Spiller's purple, and after five minutes wash, dry, and mount in Canada balsam. For critical examination with high powers, spermatozoa should be mounted in glycorine. If staining be desired, a minnte quantity of the purple added to the glycerine will accomplish it, as in a few weeks the sper. matozoa will have absorbed every trace of the dye. ("Bees ard Bee keeping," 201.)

Prof. v. la Valette St. George recommends, for the examination of the spematic elements of the small cockroach (Blatta germanica, or Croton iagr) a fluid which unites the properties of not being harmful to cells and that of staining certain eell-parts deeply. This is iodized serum, rubhed in with dahlia and fillered. The amniotie fluid can thus be replaced by another indifierent fluid. Dilution of pure nuclear-staining media with iodized serum did not give favorable 
results. For fixing the tissues the author used the mixtures recommended by Gilson and Carnoy, and with the same result, and also Flenming's fluid. (Arehiv für Mikr. Anat., 1886, 1; also Journ. Roy. Mier. Soc., 1886, 590, 1073.)

Making Sections of Eggs. - The eggs should, according to Bobretsky's metbod, be placed, when alive, for a short time in nearly hoiling water, and then bardened in bichromate of potash. They may be stained in picrocarmine or in hematoxylin, and embedrled for cutting in paraftine or coagulated albumen. Patten placed the eggs of Trichoptera in cold water, raising the temperature very gradually to about $80^{\circ} \mathrm{C}$., or when they beeame hard and white; then removed to 20 per cent alcohol, which was increased by 10 per cent once or twice a day until reaching full strength (96 per cent). They were stained with Kleinenberg's hematoxylin and a 70 per cent solution of cochineal, and embedded in paraffine after being claritied in benzole for thirty minutes.

Witlaczil examined the embryos of the viviparous Aphides in a weak salt solution ( $1 \frac{1}{2}$ per cent), in which they live for abont an hour. The early stages in the development of the eggs may be best seen after treatment with hydrochloric acid ( 3 per eent), or acetic acid, as these reagents partially dissolve the yolk elcments, rendering the preparation more transparent; but the litter stages are renilered more opaque by this treatment.

Eggs gradually bardened in alcohol and then ent and stained on the slide with picrocarmine or bematoxylin of fen give good sections. Kowalevsky's sections, made before the days of microtomes, were cut by hand, the eggs having been, after being bardened, cmbedded in paraffine and cut with a razor.

Dr. F. Stuhlman * in the examination of the eggs of insects, spiders, Myriopods, and Peripatus, examined fresh objects in 0.75 per cent salt solution, to which is sometimes added weak acetic and methyl-green acetic acid. The foregoing was only suitable for young eggs, as older ones are too opaque. As a fixative, a cold concentrated sublimate solution proved the best. Water, 33 per cent alcohol, and hot sublimate solution were not so useful. The cold sublimate fixed in 5 to 10 minutes. The preparations were then thoroughly washed; a few drops of tincture of iodine hastened the process. Then 60 per cent spirit, and finally absolute alcohol. The chorion is perforated with a fine needle, but the upper pole is to be avoided. Ovaries are placed for several hours in chloroform, then from one to three lays (according to size) in paraftine at about

* Ber. Naturf. Gesell. Freiburg, i. B. I. (1886); Journ. Roy. Micr. Soc., April, $188 \%$. 
$55^{\circ} \mathrm{C}$. The embedding mass is rapidly cooled. The sections are stuck on with a thin layer of Mayer's fluid. The author states that fresh albumen mass stains less easily than the older. The stains used were Grenacher's borax-carmine, Weigert and Ranvier's picrocarmine, and Flemming's hæmatoxylin. The author recommeuds double staining with picrocarmine and hæmatoxylin ; weak stainingr first with picrocarmine and afterwards with the logwood. The dye is then extracted with acidulated alcohol until a red hue appears; the sections are then transferred to ammoniacal alcohol until the blue color reappears. In order to obtain various shades of color the author advises to stain about $\frac{3}{4}$ of the sections $(s i c)$ with picrocarmine, and then to draw out the slides from the fluid so that the upper part is more deeply stained than the lower. The slide is then turned round and the process reversed with hrematoxylin. Afterwards absolute alcohol, bergamot oil, xylol balsam, Flemming's chromosmium-acetic acid, and safranin staining give good results. Fixation with 3 per cent nitric acid produced vacuoles in the yolk, and was, therefore, of but little use.

Dr. H. Henking, * in his investigations into the development of the Phalangida, adopted various methods of preparing the ova; the animals were sometimes killed with boiling water, and left in it for some time for the albumen to coagulate; they were then hardened in successive strengths of alcohol up to 80 per cent. The ova were never placed direct in alcohol, in consequence of the shrinking caused by such a process. Other specimens were killed with ether, the back laid open, and the animals placed in Flemming's chromosmic-acetic acid or in Kleinenberg's picrosulphuric acid for some hours before removal to alcohol. Eggs that had been deposited were treated with hot water, and with Flemming's fluid, as well as with hot and cold chromic acid, picrosulpburic acid, etc. The best staining reagents were found to be Grenacher's borax-carmine, Hamann's neutral acetic acid carmine, and eosin-hæmatoxylin. Before embedding, the eggs on being taken from absolute alcohol were placed in a mixture of bergamot oil and absolute alcohol, then in pure bergamot oil, and then in a warmed solution of paraftine in bergamot oil, and finally in quite pure paraftinc. By the aid of Speugel's microtome sections from $\frac{1}{80}$ to $\frac{1}{150} \mathrm{~mm}$. thick were prepared.

Dr. F. Blochmann fixes the ovaries of ants and wasps with picric acid or sublimate, staining them on the slide with picrocarmine or borax-carmine. For examining the elements of the yolk, double-

* Zeitschrift für. wiss. Zool., xlv. (1887) pp. 88-90; Journ. Roy. Micr. Soc., August, 1887. 
staining with borax- or picro-carmine and bleu de Lyon are advised. (Zeits. f. wiss. Zool., xliii., 1886, 537; Journ. Roy. Micr. Soc., Oct. 1887,841 .)

Herr J. Nusbaum thinks that one method of preservation can never afford satisfactory material for study, as each method gives different results. He treated fresh eggs with K'leinenberg's or Perenyi's fluid, or treated them a few seconds with hot water and then with bichrornate of potash. The eggs in either case were hardened in 70 per cent and then absolute alcohol; then colored in toto by hæmatoxylin, borax-carmine, or red magdala ; the latter gave a perfect staining reagent, coloring the eggs and embryos in a few hours, and very intensely, though sometimes very uniformly. ${ }^{*}$

Preparing Embryos of Insects. - In a paper on the embryonic development of the Bombycidæ, Dr. S. Selvatico describes the methods he has made use of both for the preparation of entire embryos and for sections. The species employed were Bombyx mori, Attacus mylitta, and Saturnia pyri.

The eggs are first coagulated by plunging them in water at $75^{\circ} \mathrm{C}$. With a pair of fine-pointed forceps a small piece is removed from the shell, in the case of Bombyx, without disturbing the underlying parts. With a little care this is easily done, because on the eggs becoming cold, their contents are somewhat contracted and do not touch the shell. In the case of Attacus and Saturnia the eggs have a harder shell but are larger, and a razor was employed by the author.

They are then hardened by leaving them for twelve hours in a .002 per cent solution of chromic acid, and for twelve hours more in a .005 solution. Then with a little care the shell can be easily removed by employing the forceps or cutting it round with a razor.

The entire contents having been removed, the egg is freed from chromic acid by leaving it in 30 per cent alcohol for a day, the alcohol being renewed until it is no longer colored yellow.

For staining, the egg is placed in picrocarmine for twenty-four hours and washed in 30 per cent alcohol to remove the picric acid. When it has been well washed it may be kept in 30 per cent alcohol until sections are required.

Previous to cutting sections the egg should be placed in absolute alcohol for half an hour, and then for a few moments in essence of bergamot. Dry and embed in a mixture of 4 parts of spermaceti and 1 of cacao butter, to which is added, according to the temperature, some drops of castor-oil. The knife should be moistened with

* Arch. Zool. Expér., 1887, 124; Journ. Roy. Micr. Soc., 1887, 
olive-oil, and each section washed with a mixture of 4 parts of oil of turpentine and 1 of ereosote to dissolve the embedding sulsstance surrounding the section. Mount in Canada balsam.

To preserve the embryo entire, the shell is to be removed as above described, after coagulation. The egg is then placed in a drop of water on the stage, and with a low power the embryo is extracted from the vitellus. It is cleaned as much as possible, so that no portion of the vitellus adheres to it, and mounted in glycerinated gelatine, previously colored with methyl-green. By this method the embryo takes from the gelatine an excess of color, and is thus stained after the preparation is made. If it is colored first and then placed in colorless gelatine it will always lose color (sometimes completely) if the gelatine is only a little greater in volume than the embryo. (Journ. de Microgr., vi. (1882) pp. 220-1.)

Surface Study of Eggs, and Hardening for Cutting, etc.-Mr. W. A. Locy* adopts, for studying the eggs of spiders while alive, the long-used method of immersion in oil, which should be perfectly clear and odorless. The external features can be studied to better advantage by mounting the eggs in alcohol after they have been freed from the chorion and stained. Another valuable method for surface study consists in clearing the already stained egg in cloveoil. The thickness of the blastoderm is most easily determined in this way.

The best method of hardening preparatory to sectioning is that of beating the water to about $80^{\circ} \mathrm{C}$, , and then, after cooling slowly, treating with the usual grades of alcohol. Good results are obtained with Perenyi's fluid, which renders the yolk less brittle. Osmic acid does not penetrate the chorion, and chromic acid or acid alcohol are not easily soaked out on account of the thickness of the chorion.

Borax-carmine is, on the whole, the best staining fluid. It is difficult to make the dye penetrate the chorion, and, after hatching, the cuticula forms a similar obstacle. This difficulty may be overcome by prolonged immersion in the staining fluid. In some cuses seventy-two hours were required to obtain a sufticient depth of color. In order to avoid maceration, which would result from so long-continued immersion in a weak alcoholic dye, the staining process may be interrupted at the end of every twenty-four hours by transferring to 70 per cent alcohol for an hour or more.

After most methods of hardening the yolk becomes very brittle, and the sections crumble. This difticulty may be overeome by collodionizing the cut surface before making each section, in the manner described by Dr. Mark. $†$

* Amer. Natural., xix. (1885), pp. 102-2\%.

† Ibid., p. 628. 
Mounting Dry the Eggs of Insects.-Aceording to Dimmock, eggs and other objects may be mounted in sueh a way as to be easily examined with the microscope. The eggs are mounted in rings of cork between two thin cover-glasses such as are used for mieroseopeslides. Thus mounted, and sealed with black lac or other means, the specinens can be pinued in the collection witl safety and neatness. Specimens can be momnted in Canada balsam in these cork rings in the way described by Cameron, ${ }^{*}$ who, however, used paper in place of cork; the latter, however, is lighter than paper, is more convenient for pinning, and can be easily cut into rings of different sizes with a cork-borer such as is used in chemical laboratories. If eireular cover-glasses are used, the cells ean be neatly sealed on a turn-table for preparing microscope-slides. (Psyche, iv. 133.)

Preparing Fire-flies, etc.-To iuvestigate the seat of oxidation which produces the light in Luciola itulica, Dr. C. Emery killed the living animal in a solution of osmie acid, which stains the luminous plates of the still living and light-developing animals brown. The parts which are to be further examined are macerated for a long time in water, the development of fungi in which is prevented by the addition of crystals of thymol. The osmic acid is especially reduced at the bifurcations of the blind-ending tracheal eapillaries within the luminous plates, and in the tracheal branches before the bifureation. Another method of preservation consists in injecting corrosive sublimate solution into the animal, and subsequent treatment with alcohol. (Zeits. für wissen. Zoologie, xl. (1884) 338; abstract in Journ. Roy. Mier. Soc., 1885, 733.)

Mounting the Appendages of Insects for Pinning in the Cabinet.A writer in the Bulletin of the Brooklyn Entomological Society (vi. 24) says: "The habit of many has been after examining the parts of an inseet and making dissections to throw away the insect after making notes. Others mount them in balsam on glass slides: this latter had been my practice, but slides aceumulate and are inconvenient to keep. A substitute a knowledge of which I owe to Dr. Horn answers admirably for all purposes and is perfeetly simple. A hole, round or square, is punched or cut out of a piece of Bristol board of any desired size; a cover-glass (I use the square) is fastened on one side over the aperture by a thin circle of shellac: this forms a shallow cell in which the part to be examined is placed; a drop of Canada balsam $t$ is put on it, and the whole is covered by another cover-

* Proc. Nat. Hist. Soe. Glasgow, 1881-82, v. 4-7.

t The balsam will be clonded by the moisture contained in the appendages mnless it has been macerated in alcohol and oil of turpentine, or has undergone a long maceration in oil of turpentine. 
glass. Your preparation is thus effectually preserved, and you can put a pin through the end of the card and put it in your cabinet next the insect the object is intended to illustrate. You can put half a dozen cards on a single pin, and the space thus occupied is very small, while the preparation is as convenient for examination as though mounted on a glass slide."

Mounting the "Saw" of the Tenthredinidæ.-Mr. P. Cameron describes his method of mounting and preserving the "saw" of the Tenthredinida for microscopical examination, a method which can be applied to mieroseopical mountung generally.

With fresh speeimens the saws can be extracted by pressing the abdomen, when they will be protruded and readily extracted. With old specimens it can be done equally well by placing the insect in a relaxing-dish, or, more promptly, by steeping it in water for a day, when it can be taken out in the same way as with fresh insects, the ouly aifficulty being experienced with insects full of eggs. For their better examination the four pieces composing the ovipositor proper should be separated; after which they must be steeped in turpentine for a day or two so as to get rid of air. This is best done by enclosing them in a small folded piece of paper; and, if they be properly labelled, many different preparations can be placed in the turpentine-bottle together. Next take a sheet of fine Bristol board, and cut it up into pieces, say 12 lines by 9 lines, and punch at one end a round or square hole, four or five lines across. On the lower side of this fasten, by means of Canada balsam dissolved in benzine, a cover-glass. When this has dried fill up half the cell thus formed with the same composition, spreading it as evenly as possible, and in it arrange your preparation. Put it aside for some hours in a place where no dust will fall on it, then fill the cell with enough balsam to run over the edge of the cell, place a cover-glass over it, and press it down. All that now requires to be done is to allow the preparation to dry, taking special care to keep it flat, to label it, and stick a pin through the card, by means of which it is fixed in the cabinet alongside the insect from which the part was taken. To examine it under the microscope, all that is necessary to do is to place an ordinary glass slide across the stage, and put the card on it, in doing which it is not necessary to take the pin out of it if a short pin be used.

The great advantage of this plan for entomological purposes is that it does not necessitate the formation of two distinct collections, which must be the case if dissections are mounted on glass slides, which cannot of course be placed alongside the insect. Besides that, it is cheaper, more expeditious, and safer; for the eards are so light that no injury comes to them from falling, or getting loose in the box. If desired, 
a colored ring can be put round the top object-glass by the turn-table in the ordinary wiy, but, except for ormament, is not necessary. The author usually prepares twa or three dozen of the cards with one cover-glass on at a time, so as to have them rearly for use. The objeet of letting the dissections harden in the cell, half filled with balsam, is that turee or four separate parts may be arranged in the most snitable way in the same cell withont fear of their being disarranged or injured when the top cover-glass is put on, while both might happen if the whole operation was performed at once.

For the examination of the saws, a quarter-inch objective is the best; the teeth, in some cases, are so fine that they are apt to be overlooked if lower powers are used. (Trans. Entomol. Soc. Lond., 1881, pp. 576-7.) 


\section{THE ENTOMOLOGIST'S LIBRARY.}

WHEN we reflect that perhaps upwards of 175,000 to 200,000 species of insects have been described, and the habits and histories of some of them noted in articles and memoirs scattered through numerous journals, proceedings, and transactions of learned societies, we can get some idea of the vast extent of entomological literature. We can only draw attention to the most indispensable articles, memoirs, and complete works, without which no one can do good general work in entomology. Those who desire to confine their attention to special orders should look to the lists of publications already given under such groups. The titles of works indispensable to the student are printed in heavy-faced type.

\section{BibLIOGRAPHICAL WORKS ON ENTOMOLOGY.}

Agassiz, L. Bibliographia Zoölogiæe et Geologiæ. Edited by H. E. Strickland. i.-iv. Ray Society, London, 1848-54.

- Nomenclator Zoölogicus. Soloduri. 1842-47.

Index Universalis. Soloduri. $4^{\circ}, 1846 ; 8^{\circ}, 1848$.

Carus, J. V., and W. Engelmann. Bibliotheca historico-naturalis. 1846-60. i., ii. Leipzig, 1861.

Carus, J. V., and P. Mayer. Zoölogischer Jahresbericht für 18791888.

Dimmock, G. The entomological writings of Samuel Hubbard Seudder. Cambridge, 1879 .

Engelman, W. Bibliotheca historico-naturalis. 1760-1846. i. Leipzig, 1846.

Hagen, H. A. Bibliotheca entomologica. [Up to 1862.] i., ii. Leipzig, $1862-63$.

Henshaw, S.* The entomological writings of Alpheus Spring Packard. U. S. Department of Ag. Div. Ent. Bull. 16, 1887.

Marschall, A. D. Nomenclator Zoölogicus. Wien, 1873. (A continuation of Agassiz' Nomenclator.)

Packard, A. S. Record of American Entomology for 1868-73. Salem, Mass.

* For Bibliographies of Drs. LeConte and Ilorn see under Coleoptera. 
Scudder, S. H. Nomenclatór Zoölogicus. Part I. Supplemental List (to Agassiz); Part II. Universal Inclex. Washington, 1882.

- Catalogue of scientific serials of all countries. 1633-18\%6. Cambridge, 1879.

Taschenberg, 0. Bibliotheca Zoölogica, 1861-80. Leipzig, 1886-89. i. $-x i i$.

Archiv für Naturgeschichte. Contains annual reports on the progress of Entoruology from 1836 to 1888 .

Royal Society, London. Catalogue of Scientific Papers. 8 vols. $4^{\circ}$. London, 1868-88.

Zoological Record for 1864-88. London, 1865-88.

\section{Entomological Periodicals.}

American Entomologist. i., 1868; ii., 1870; iii., 1880. St. Lonis and New York.

American Naturalist. Salem, Boston, and Philadelphia, 1867-88.

Annals of the Lyceum of Natural History of New York. 1824-76. Since 1876 continued as Annals of the New York Academy of Sciences.

Annales de la Société entomologique Belge. Brussels, 1857-88.

Annales do la Société entomologique da France. Paris, 1832-88.

Berliner Entomolog. Zeitschrift. 1857-88. Berlin.

Deutsche Entomolog. Zeitschrift. 1881-88.

Zeitschrift für wissenschaftliche Zoologie. Leipzig. 1848-88.

Bulletin of the Brooklyn Entomological Society. i.-vi. 1878-84.

Bulletino della Società entomologica Italiana. i.-xx. 1869-88.

Florence.

Canadian Entomologist. i.-xx. 1868-88. London, Canada.

Entomologica Americana. i.-iii. 1885-88. Brooklyn, N. Y.

Entomologische Nachrichten. i.-xiv. 1875-88. Berlin.

The Entomologist. i.-xxii. 1840-80. London.

Entomologist's Monthly Magazine. i.-xxiv. 1864-88. London.

Journal of the Academy of Natural Sciences. Philadelphia. $1817-88$.

Proceedings of the Acadenty of Natural Sciences. Philadelphia $1841-88$.

Journal of the Boston Society of Natural History. i.-vii. 1834-63

Memoirs of the Boston Society of Natural History. i.-iv. 1866-88

Linnæa entomologica. Entomologische Verein. Berlin, 1846-88.

Proceedings of the Boston Society of Natural History. 1834-88.

Proceedings of the Entomological Society of Philadelphia. i.-vi $1861-6 \%$.

Transactions of the American Entomological Society. Philadelphia i. $-x i v .1867-88$.

Psyche. i. - v. 18\%4-88. Cambridge, Mass.

Transactions of the American Philosophical Society. New Series 1818-88. Also Proceedings. i.-xxiv. 1840-88.

Transactions of the Entomological Society of London. 1834-88.

Wiener Entomologische Monatsschrift. i.-viii. 1857-64.

Zeitschrift d. Entomologische Verein. Ber' ${ }^{\prime}$, 1857-88.

Zeitung d. Entomologische V rein. Stettin, 1840-88. 


\section{General Entomology.}

The works of Herbst, Lieuwonhoek, Malphighi, Meckel, Merian, Ramdohr, Swammerdam, Serres, and Suckow.

Buffon. Suites à Buffou et Nouvelles suites à Buffou. Formant avec les Envres de cet anteur un Cours complèt d'Histoire Naturelle. Paris, Dufart, 1798-1807. Paris, Roret, 1834-1864. 8vo. (Insectes, Crustacés, Arachnides, etc., par Amyot, Audinet-Serville, Boisduval, Gervais, Guénée, Lacordaire, Latreille, Lepeletier de St. Fargeau, Macquart, Milne-Edwards, Rambur, et Walkenaer.)

Burmeister, H. Manual of Entomology. Translated by W. E. Shuckard. London, 8vo. 1836.

Burmeister, Hermann. Zoologischer Hand Atlas. Berlin, 1836-43. Fol., 41 plates.

Claus, C. Elementary Text-book of Zoology. Translated and edited by Sedgwick and Heathcote. Vol. i. London, 1884.

Cuvier, G. Le Règne animal distribué d'après son Organisation. Nouvelle édition, accompagnée de planches gravées, représentant les types de tous les Genres, etc., publiée par un réunion de Disciples de G. Cuvier. Paris, 1849. 8vo. (Insectes, Arachnides, Crustacés par Audouin, Blanchard, Doyère, Milne.Edwards et Dugés.) 4 vols. texte et 4 vols. atlas.

Drury, Drew. Illustrations of Natural History, etc. London, 177082. 4to, 3 vols. (ed. Westwood, 1837.)

Fabricius, Joh. Christ. Systema Entomologiæ. 1775.

— Genera Iusectorum. 1777.

— Species Insectorum. i.-ii. 1781.

- Mantissa Insectormn. i.-ii. 1787.

— Entomologia Systematica. i.-iv. 1792-94.

Geer, Carl de. Mémoires pour servir à l'Histoire des Insectes. 1752-78. i.-vii. 4to.

Gerstaecker, A. Arthropoden, in Peters and Carus' Handbuch der Zoologie. Leipzig, 1863.

Godman, F. Ducane, and Salvin, 0. Biologia Centrali-Americana. London, 1877-88.

Graber, v. Die Insekten. Parts I., II. Munich, 1877.

Griffith, E. The Animal Kingdom, described and arranged in conformity with its organization. London, 1824-33. 8vo. Class Insecta. 2 vols. 1832 .

Guérin-Ménerille, F. E. Iconographie du Règne Animal de G. Cuvier, ou représentation d'après nature de l'une des espèces les plus remarquable et souvent non encore figurées de chaque genre d'animaux. Vols. 6 et 7: Annélides, Crustacés, Arachnides, et Insectes. Paris, 1829-44.

Kirby, W., and W. Spence. An Introduction to Entomology; or, Elements of the Natural IHistory of Insects. 4 vols. 8vo. 1828. Seventh edition (comprising vols. 3 and 4 of the early editions). London, 1856. Post 8vo.

Kirby, W. Fauna boreali-Americana, etc. Norwich, 1837. 4to.

Latreille, Pierre André. Précis des caractères générique des Insectes. 1796. 8vo.

- Genera Crustaceorum et Insectorum. 4 vols. 8vo. 1806-09. 
Latreille, Pierre André. Considération générales sur l'Ordre naturel des Auimaux composant les Classes des Crustacés, des Arachnides et des Insectes.

- Insects in Cuvier's Règue animal. 8vo. 1810.

- Familles naturelles du Règne animal. 8vo. 1825.

- Cours d'Entomole gie. 8vo. 1831.

Linnæus, Carolus. Systema Nature. 1735. 12th edition. 1766-68. MacLeay, W. S. Hor:e Entomologice. i., ii. London, 1819.

Miall, L. C., and A. Denny. The Structure and Life-history of the Cockroach. London, 1886.

Newport, G. Article Insecta. (Cyclopædia of Auatomy and Physiology. London, 1839.)

Packard, A. S. Guide to Study of Insects. 9th edition. New York, 1888.

Palisot de Beauvais, A. J. Insectes recueillis en Afrique et en Amérique, dans les royaumes d'Oware et de Benin, à Saint-Dominique et dans les Etats-Unis, pendant les années 1786-97. Fol., with 90 plates. Paris, 1805-21.

Réaumur, Réné Ant. de. Mémoires pour servir à l'Histoire des Insectes. Paris, 1734-42. i.-vii. 4to.

Roesel, Aug. Joh. Der monatlich heransgegeben Insekten-Belustigung. Nïrnberg, 1746-61. i.-iv. 4to. Illustrated.

Savigny, G. C. de. Description de l'Egypte, Histoire naturelle. Crustacés, Arachnides, Myriapodes et Insectes. $53 \mathrm{pl}$. in gr. fol. Paris, 1809-38. Explication sommaire des planches, par J. V. Audouin. Paris, 1826. Fol.

Saussure, H. de. Spicilegia Entomologica Genavensia. I. Genre Hemimerus. Genève, 1879.

Say, T. Amerizan Entomology. i.-iii. Philadelphia, 1824-25-28.

Complete Writings on the Entomology of North America, edited by J. L. LeConte, M.D. 2 vols. 8 vo. Colored plates. New York, 1859.

Westwood, J. 0. An Introduction to the Modern Classification of Insects. 2 vols. 8vo. London, 1839-40.

\section{External Anatomy and Morphology.}

Audouin, J. V. Recherches anatomiques sur le Thorax des Animaux articulés et celui des Insectes hexapodes en particulier. (Auuales d. Sc. Nat. i., 1824 , p. 97 and 416 .)

Huxley, T. H. The anatomy of the invertebrated animals. 1877.

Leuckart, $\mathbf{R}$. Ueber die Morphologie und die Verwaudtschaftsverhältnisse der wirbellosen Thiere. Braunschweig, 1848. 8vo.

Savigny, J. C. Mémoires sur les Animaux sans Vertèbres. I. Partie. Description et Classification des Animaux invertébrés et articulés. 1. Fascicule. Théorie des Organes de la Bouche des Crustacés et des Insectes. Paris, 1816.

\section{Internal Anatomy and Histology.}

Dufour, L. Recherches anatomiques et physiologiques sur les Hemip tères (1833); les Orthoptères, les Hymenoptères, et les Neuroptères (1841); et les Diptères (1851). (Mém. de l'Institut, iv. vii. xi. Also numerous memoirs in Ann. des Sci. Nat.) 
Leydig, F. Traité d'Histologie. Paris, 1866.

Lyonet, $P$. Traité anatomique de la Chenille, etc. La Haye, 1762.

- Anatomie de differentes espèces d'insectes. (Mém. du Museum, xviii.-xx. Paris, 18:9-32.)

Minot, C. S. Histology of the locust. Second Rep. U. S. Ent. Commission. 1880.

Siebold, C. Th. von. Anatomy of the Invertebrata. Boston, 1854.

Strauss Durckheim, H. Considérations générales sur l'Anatomie comparée des Animaux articulés, auxquelles on a joint l'Anatomie descriptive du Melolontha vulgaris. Paris, 1828. 4to, $10 \mathrm{pl}$.

Viallanes, M. H. Recherches sur l'histologie des insectes. Paris, 1882.

\section{a. The Nervous System.}

Blanchard, E. Recherches anatomiques et zoölogiques sur le Système nerveux des Animaux sans vertèbres. Du système nerveux des Insectes. (Annal. d. scienc. natur., 3. sér. v., 1846, p. 273-379.)

- - Du Système nervenx chez les Iuvertébrés dans ses rapports avec la Classification de ces Animaux. Paris, 1849. 8vo.

Flogel, J. H. L. Bau des Gehirns der verschiedenen Insektenordnungen. (Zeits. f. Wissen. Zool., xxx. Supp. 18i8.)

Leydig, F. Vom Bau des thierischen Körpers. 1864.

_- Tafeln zur vergl. Anatomie. 1864.

- Untersuchungen zur Anat. und Histologie der Thiere. 1883. Also numerous works and articles in Miüller's Arehiv., Zeits. für wissen. Zoologie, Nova Atta, etc.

Liénard, V. Recherches sur le Système Nerveux des Arthropodes. Bruxelles, 1880.

Michels, H. Nervensystem von Oryctes nasicornis im Larven-, Puppenund Käferzustande. (Zeits. f, Wissen. Zool., xxxiv,, 1881.)

Newport, G. On the nervons system of the Sphinx ligustri Linn., and on the changes which it undergoes during a part of the metamorphoses of the insect. (Philosoph. Transact., 1832, p. 383-398, and $1834, \mathrm{p} 389-423$.)

- On the structure, relations, and development of the nervous and circulatory systems, and on the existence of a complete circulation of the blood in vessels, in Myriapoda and Macrourous Arachnida. (Philosoph. Transact., 1843, p. 243-302.)

Newton, E. T. On the brain of the cockroach. (Quart. Journ. Micr. Sci., 1879.)

Viallanes, H. Le cerveau de la guêpe. (Vespa. Ann. Sc. Nat. Zool., 1887.)

Le cerveau du criquet. (CEdipoda and Calopteuus. Ann. Sc. Nat. Zool., 1887.)

\section{b. Organs of Special Sense and their Physiology.}

Carrière, J. Die Sehorgan der Thiere. München u. Leipzig, 1885. Exner, S. Ueber das Seheu von Bewegungen und die Theorie des zusammengesetzten Auges. Wien, 1875.

- Die Frage von der Functionsweise des Facettenanges. (Biol. Ceutralb., i., 1881-2.) 
Graber, V. Die tympanalen Sinnesapparate der Orthopteren. Denks. Akad. Wien, xxxio., 1875.

Grenacher, H. Untersuchungen ueber das Sehorgan der Arthropoden. Göttingen, 1879.

Hause, G. Physiologische und histiologische Untersuchungen ueber das Geruchsorgan der Insekten. (Zeits. f. wissen. Zoologie, xxiv., 361, 1880. Alstract in Amer. Nat., xxi., 279, 1887.)

Kraepelin, K. Ueber die Geruchsorgane der Gliederthiere. Hambulg, 1883. (Abstract in Amer. Nat, xx., 889, 973, 1886; xxi., 182, 188\%.)

Krancher, 0. Der Bau der Stigmen bei den Insekten. (Zeits. f. wissen. Zoologie, xxxv., 505, 1881.)

Landois, H. Die Ton- und Stimmapparate der Insecten. Leipzig, $186 \%$.

Leydig, F. Ueber Geruchs- und Gehörorgane der Krebse und Insecten. (Reichert u. du Bois-Reymoud's Arch., 1860.)

Patten, W. Eyes of Molluses and Arthropods. Naples. (Abstract in Journ. Morph. p. 6\%, vol. i., No. 1.) Boston, $188 \%$.

Plateau, F. Recherches expérimentales sur la vision chez les Insectes. (Bull. de l'Acad. Roy. Se. de Belgique, 1885.)

Will, F. Das Geschmacksorgan der Insekten. (Zeits. f. Wissen. Zoologie, 1885.)

Also the writings of Bonsdorf, Burmeister, Erichson, Forel, Gazagnaire, Graber, Hicks, Huber, Künckel, Lehrman, Leydig, Lubbock, Newport, Perris, Pierret, Plateau, Siebold, Voges, and Wolff.

\section{c. Organs of Circulation and Respiration.}

Chun, c. Rectal Drusen bei den Insekten. (Abh. d. Senkenberg. Naturf. Ges., x., 18;6.)

Graber, V. Ueber den propulsatorischen Apparat der Insekten. (Arch. f. Mikr. Anat., ix., 1872. Heart and Pericardium.)

Langendorff. Studien neber die Innervation der A thembewegungen. -Das Athmungscentrum der Insekten. (Arch. f. Anat. u. Phys., 1883.)

Lubbock, J. Distribution of trachese in insects. (Trans. Linn. Soc, xxiii., 1860.)

MacLeod, J. La structure des trachées, et la circulation peritrachéenne. Bruxelles, 1880.

Packard, A S. On the nature and crigin of the so-called "spiral thread" of trachea. (Amer. Nat., xx., 438, 1886.)

Palmén, J. A. Zur Morphologie des Tracheensystem. Leipzig, 1877.

Plateau, F. Recherches experimentales sur les mouvements respiratoires des Insectes. (Mém. de l'Acad. Roy. de Belgịule, xlv., 1884.)

Rathke, M. H. Untersuchungen über den Athmungsprozess der Insekten. (Schrift. d. Phys. Oek. Ges. Königsberg, i., 1861.)

Verloren, M. C. Mémoire sur la circulation dans les insectes. (Acad. Roy. de Belgique, xix., 1847.)

\section{d. Organs of Digestion.}

De Bellesme, Jousset. Recherches experimentales sur la Digestion des Insectes. Paris, 1875. 
Plateau, F. Recherches sur les phénomènes de la digestion chez les incectes. Bruxelles, 1874.

\section{$e$. Organs of Locomotion and their Physiology.}

Carlet, G. Sur la locomotion des insectes et des Arachnides. Compt. Rendus., lxxxix., 1879.

Dahl, F. Beitrïge zur Kenntniss des Baues und der Funktionen der Insektenbeine. Berlin, 1884.

Dewitz, H. Ueber die Fortbewegung der Thiere an senkrechten glatten Flächen vermittels eines Secretes. (Zool. Anzeiger, 1884, $400 ; 1885,15 \%$.)

Lendenfeld, R. von. Der Flıg der Libellen. (Akad. d. Wissensch., lxxxiii., 1881.)

Marey, E. J. Animal Mechanism. New York, 1879. (Flight of Inseets.)

Plateau, F. Articles on the relative and absolute muscular force, in Bull. Acad. Roy. de Belgique, 1865-84.

\section{f. Organs of Reproduction, Ovipositor, etc.}

Brandt, A. Ueber das Ei u. seine Bildungsstätte. Leipzig, 1878.

Lewitz, H. Baı u. Entwicklıng d. Stachels, etc. (Zeit. f. Wissen. Zool, xxv., 1875; xxviii., 187\%.)

Kraepelin, K. Untersuchungen ueber d. Bau, Mechanismus u. d. Entwicklung des Stachels d. bienartigen Thiere. Zeits. f. Wissen. Zool., xxiii., 1873.)

Lacaze-Duthiers, H. Recherches sur l'armure génitale femelle des Insectes. Plates. 8vo. Paris, 1853.

Packard, A. S. On the strueture of the ovipositor and homologous parts in the male insect. (Proc. Boston Soc. Nat. Hist, xi., 1868.)

Palmén, J. A Ueber paarige Ausführungsgänge der Geschlechtsorgane bei Insekten. Helsingfors, 1884.

\section{Embryology of Insects.}

Ayers, H. On the development of Ecanthus niveus and its parasite Teleas. (Mem. Bost. Soc. Nat. Hist., 1884.)

Balfour, F. M. A treatise on comparative embryology. i., ii. London, $1880-81$.

Brandt, A. Beiträge zur Entwickelungsgeschichte der Libelluliden und Hemipteren, etc. St. Petersburg, 1868.

Hatschek, B. Beiträge zur Entwickelungsgeschichte der Lepidopteren. Jena, $18 \% 7$.

Kowalevsky, A. Embryologische Studien an Würmen und Arthropoden. St. Petersburg, 1871.

Patten, W. The development of Phryganids. (Quart. Journ. Micr. Sci., xxiv., 1884.)

Weismann, A. Ueber die Entstehung des volleudeten Insekts in Larve und Puppe. Ein Beitrag zur Metamorphose der Insekten. Frankfurt a. Main, 1863. 4to. 
Weismann, A. Die Entwickelung der Dipteren im Ei, nach Beobachtungen an Chironomus, Musca romitoria und Pulex canis. (Zeitschrift für wissens. Zoologie, xiii., p. 107-204.)

- Die nachembryonale Entwickelung der IIusciden nach Beobachtungen an Musca vonitoria und Sarcophaga carnaria. (The same, xiv., p. $18 \%-336$.

Zaddach, G. Untersuchung inber die Entwickelung und den Bau der Gliederthiere. Heft 1. Die Entwickelung des Phryganiden-Eies. Berlin, 1854.

Also memoirs by Bobretzky, Brandt, Bruce, Butschli, Claus, Dewitz, Ganin, Grimm, Hertwig, Korotneff, Leuckart, Ludwig, Metschnikoff, Melnikow, Nusbaum, Packard. Patten, Tichomiroff, Wagner, Zacharias, Graber, Heider, Van Rees, Wheeler, Witlaczil, Viallanes, Voeltzkow.

\section{Phylogeny or Origin of Insects.}

Brauer, F. Betrachtungen ueber die Verwandlung der Inseckten im Sinne der Descendenz-theorie. (Verh. Zool. bot. Ges. Wien., 1869.)

Lubbock, J. On the origin and metamorphoses of Insects. London, 1874. (Also Journ. Linn. Soe. London, xi., 422, 1873.)

Mayer, P. Ueber Ontogenie und Phylogenie der Insekten. (Jena. Zeits. f. Nat., x., 1876.)

Packard, A. S. Hints on the ancestry of insects. (Chapter xiii. of "Our Common Insects.") Boston, 1873.

- Review of Mayer's article. (Amer. Nat., x., 688, 1876.) Genealogy of the Hexapoda. (3d Rep. U. S. Entomological Commission, 295-304, 1883.)

\section{Insects and the Fertilization of Plants.}

Darwin, c. On the various eontrivances by which British and foreign Orchids are fertilized by Insects. 1862 .

- Animals and plants under domestication. i., ii. 1868. Different forms of Howers. 1880.

Lubbock, J. British wild flowers in relation to insects. London, 1875 .

Müller, H. Alpenblumen, ihre Befruchtung durch Insekten und ihre Ampassungen an dieselben. Leipzig, 1881.

_- Fertilization of Flowers. English Translation. London.

\section{Geographical Distribution.}

LeConte, J. L. The Coleoptera of Kansas and eastern New Mexico. (With colored map in illustration of the entomological provinces of North America. Smithsonian Contributions, 1859.)

Packard, A. S. On the Geographical Distribution of the Moths of Colorado. (Rt. U. S. Geological Survey for 1873.) 1874.

The geographical distribution of the Phalænidæ of the U.S. (pp. 567-594 of Monogr. of Geometrid Moths, 1876.)

- Some characteristies of the eentral zoö-geographical province of the U. S. (Amer. Nat., 1878.) Also see zoö-geographical map of N. A. in $3 d$ Rep. U. S. Entomological Commission, 1883. 
Scudder, S. H. Distribution of insects in New Hampshire. 1874. (Also see Buttertlies of New England. 1888.)

Speyer, Ad. and Aug. Die geographische Verbreitung der Schmetterlinge Deutschlands 11ud der Schweiz. Leipzig, $18 \overline{5} 8$.

Wallace, A. R. The Geographical Distribution of Animals. i., ii. London, 1876.

— Island Life. London, 1880.

\section{Fossil Insects.}

Brauer, F. Ansichten neber die palæozoischen Insekten und deren Deutung. Vienna, 1886.

Brongniart, c. Les Insectes fossiles des Terrains primaires. Rouen, 1885. 5 plates.

- The fossil insects of the primary group of rocks. Translated by M. Stirrup. Salford, 1885 . (No plates.)

Dohrn, A. Eugereon. Mayer's Palæontograph. xiii., 1866; xvi., 1869.

Scudder, S. H. Systematische Uebersicht der fossilen Myriopoden, Arachnoiden und Insekten. (Zittel's Handbuch der Palreontologie.) Mr̈̈uchen u. Leipzig, 1885.

_ Systematic Review of our Present Knowledge of Fossil Insects, etc. Washington, 1886.

Also papers by Scudder in Bull. Hayden's U. S. Geol. Survey, 1868-82, Mem. Bost. Soc. Nat. Hist. 1866-85; A. Dohrn, Germar: Hagen, Heer, von Heyden, Oustalet, etc.

\section{Economic Entomology.}

Boisduval, J. A. Essai sur l'Entomologie horticole. Paris, 1867.

Comstock, J. H. Report of the Entomologist, U. S. Dept. Ag., for 1879 and 1880 . Washington.

- Report upon Cotton Insects. Washington, 1879.

Curtis, John. Farm Insects; being the Natural History and Economy of the Insects injurious to the Field Crops of Great Britain and Ireland. 1860.

Glover, T. Report of the U. S. Entomologist, 1863-7\%. Washington. — Manuscript notes from my journal. Diptera. 1874.

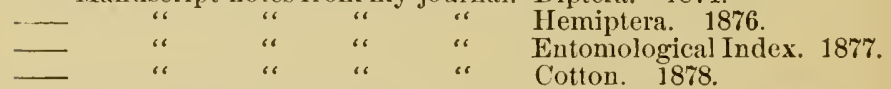

Fitch, A. Reports 1-14 on the noxious, beneficial, and other insects of New York. 1856-70.

Forbes, S. A. Reports and bulletins as Director of Illinois Lab. Nat. Hist., and afterwards as State Entomologist of Illinois. 1876-88.

Harris, T. W. Treatise on the insects of Massachusetts injurious to Vegetation. Boston, 1882.

Hubbard, H. G. Insects affecting the Orange. U. S. Dept. Ag. 1885. Judeich u. Nitzsche. Lehrbuch der mitteleuropïischen Forstinsektenkunde. Wien, 1885.

Le Baron, W. Reports 1-4 on the noxious insects of Illinois. 1871-4. 
Lintner, J. A. First annual report on the injurious and other insects of New York, 188\%; seeond report, 1885. Also numerous other pamphlets, bulletins, and newspaper articles.

Packard, A. S. Reports 1-3 as entomologist to Board of Ag., Mass. 1871-3.

Report on the Rocky Mountain locust, etc. (9th ann. rep. U. S. Geol. Survey for 1875.) 1877.

- Reports 1-3 U. S. Ent. Commission. Joint author. 1877-83. insects) of U. S. Ent. Conm. 1880-81.

- Report ( 5 of U. S. Ent. Comm.) on forest- and shade-tree insects. Washington, 1888.

Ratzeburg, J. S. C. Die Forstinsekten. i.-iii. Berlin, 1837-45.

- Die Waldverderber und ihre Feinde, 1841. 6th edit., 1869. Berlin. $8^{\circ}$.

- Die Waldverderbniss oder dauernder Schade, welcher durch Insektenfrass, etc., an lebenden WäIdbaumen entsteht. i.-ii. 1866-68. Berlin. IIany colored plates. $4^{\circ}$.

Riley, C. v. Reports 1-9 on the noxious, beneficial, and other insects of Missouri. 1869-7\%.

— Reports 1-3 U. S. Ent. Commission. Joint anthor. 187\%-83.

Fourth Report of U. S. Ent. Commission on the Cotton-worm. 1884.

Report of the U.S. Entomologist for 1879-88. Also numerous other works and articles.

Saunders, W. Insects injurious to Fruits. Philadelphia, 1883.

Thomas, C. Reports 1-3 U. S. Ent. Comm. Joint author. 187i-83. - Bulletin 5 U. S. Ent. Commission on the Chinch-bug. 1879.

- Reports 1-5 on the noxious and beneficial insects of Illinois. $1877-81$.

With works or papers by Ashmead, Barnard, Bethune, Cook, Fletcher, Forbes, French, Garman, Hagen, Harrington, Hind, Howard, Kellicott, Osborn, Peck, Rathvon, Reed, Saunders, Treat, Trimble, Walsh, Weed, and others. 



\section{GLOSSARY.}

Ab-Do' MEN (Lat. abdo, to hide, to conceal). The third or hindermost division of the body; the hind body.

AB-ER'RANT. Departing from the regular or normal type.

A-Bort'ED. Obsolete or atrophied.

AC-A-LYP'TRA-TA. Those flies (Muscidæ) in which the tegulæ are absent or rudimentary.

A-CU'Mi-Nate. Ending in a prolonged point.

A riA-MO-GEN'E-SIS (Gr. $a$, without; game, marriage; genesis, birth). Reproduction without fertilization by the male.

AL'U-LA. The membranous flap on the base of the wing itself of flies.

AMI-E.TAB'o-LIC (Gr. $a$, without; metabole, change). Referring to insects and other animals which do not undergo a metamorphosis.

ANAL ANGLE. The hinder and inner corner of a wing.

A-NAL'O-GY (Gr. analogia, proportion). The relation between orgaus which differ in structure, but have a similar function; as the wings of iusects and birds.
A-NAS-To-Mo'sing. Inosculating or lunuing into each other like veins.

An-Dro-Co'NI-A (Gr. aner, gen. andros, man; lonis, dust). Small seales of various shapes peculiar to many male butterflics.

An'NU-LATE. When a leg or antenua is surrounded by narrow rings of a different color.

AN-TE-CU'BI-TAL. Pertaining to the space between the base of the wing and the nodus, in dragon-flies.

AN-TE-hu'ne-RaL. Relating to the space immediately before the origin of the wings.

AN-TIG'E-NY. Opposition or antagonism of the sexes, embrating all forms of secondary sexual diversity.

Ap'i CAL, Relating to the apex or top; in an insect's wing, relatiug to the point farthest from the insertion.

APICA 4 sector. One of the longitudinal veins of the apex of the wings, in dragon-tlies.

Ap'o-Dene. An in wa l d ly directed process to which a muscle is attached.

AP'O-Dous. Footless. 
A P-PEN-Dic'U-LATE. Where the joints of the antennæ have articulated appendages.

AP'TE-Rous (Gr. $a$, without; pteron, wing). Destitute of wings.

A-RACH'Ni-DA (Gr. arachne, a spider). The class of Arthropods, embracing the spiders, scorpions, and mites.

A-RE'O-LA or A-RE'O-LET. One of the little spaces into which the wing is divided by the veins or venules.

A-RE' O-LATE. Furnished with small areas; like a network.

A-RIs'TA. In Diptera a slender bristle situated upon the upper border of the third joint, microscopically jointed near its base. (Williston.)

A-Ris'tate. Furnished with a hair, or arista.

A-Ro'LI-A. A plantula or climbing cushion; one of the lobes of the pulvillus.

AR'ThRo-MERE. (Gr. arthron, a joint; meros, a part or segment). A segment or ring of the body of an Arthropod; somite.

Ar-Throp'o-DA (Gr. arthron, joint; pous, podos, foot). That branch or sub-kingdom cmbracing the Crustacea, Podostomata(Merostomata and Trilobita), Arachnida, Myriopoda, and Insecta.

A-sEx'U-AI. Applied to animals, especially insects, in which the ovaries or reproductive organs are imperfectly developed; and which produce eggs or young by budding.
At'ro-Phied. Wasted away, wanting, obsolete, aborted.

AU-RE'LI-A. Old term for the pupa of an insect.

BE-NOP'O-DA. The thoracic legs of insects.

BA'No-some. The thorax of insects.

BI'FID. Divided into two parts; forked.

BLAs'TO-DERM (blastos, a bud or sprout; derma, skin). The outer layer of the germ-cells of the embryo.

BRA-CHYC'E-IRA (Gr. brachus, short; keras, horn). Applicable to those Diptera orthorhapher, llaving short, 3-jointed antennæ.

BRAN'CH1-A. A gill or respiratory organ of aquatic animals. Brax'ChI-AL. Relating to the gills or branchiæ.

Buc'Cal. Relating to the mouthcavity; or rarely to the cheeks.

Bul'Late. Blistered.

Bur'sa. A wing-pouch in the hind wings of males of certain caddis-tiles, and in connec. tion with a stalked pencil of hairs.

CAL'CA-RA-TED. Armed with spurs.

Cal-Los'r.TY. A thickened spot; a small knob.

C'A-LYP'TRA-TA (Gr. kaluptra, a covering). Those flies (Muscidæ) which have tegulæ or membranous scales above the halteres.

CaN-A-Lic'U-LATE. Clannelled; excavated longitudinally. 
Can'Cel-LAte. Crossed by lines going at right angles to each other; latticed.

Can'tuUs. The chitinous projection dividing the double eyes of certain beetles (Ateuchus, Geotrupes, Gyrinus).

CaP'I-TATE. Ending in a knob. Ca-ptTu-Luxt. The knob of club-shaped antennæ.

CAR'Do (Lat. cardo, a hinge). The basal joint of the maxilla, supporting the stipes.

CA-RI'NA. An elevated keellike sharp ridge.

CAR'Pus. The pterostigma of dragon-flies.

CAR'UN-CLE (Lat. caruncula, din. of caro, tlesh). A naked, soft, fleshy excrescence or protuberance.

CAL-CA'RI-UM (Lat. calcar, a spur). One of the spines on an insect's foot.

Cell'ule. A little area on the wing surrounded by veins.

Ce-Phal'ic. Relating to the cephalum or head.

Ce-Phal'o-Mere. A cephalic segment of an Arthropod.

CE-PHAL'O-sone. The head of insects, A rachnida and $\mathrm{II}$ yriopoda.

Cer-Cop'o-DA (Gr. cercos, tail; pous, podos, foot). The last pair of jointed abdominal appendages of insects; the "cerci."

Chenk. The space, in Diptera, between the lower border of the eye and the oral margin, merging into the face in front, and limited by the occipital margin behind. (Williston.)
CHE'LA. The terminal portion of a limb with a movable lateral part, like the claw of a crab; as in the chelate maxilla of the scorpion.

Chi'tix (Gr. cliton, a tunic). The substance which forms less than one half by weight of the integument of insects, and differing from horn in being insoluble in boiling liquor potassæ.

Chit'i-nous. Composed of chitin; chitinous color is amberyellow.

CHo'ri-on. The shell of the egg. Cirrs'a-Lis. 'The pupa of Lepidoptera.

Chxt.e (Gr. chulos, juice). The milky fluid resulting from the action of the digestive fluids on the food or chyme.

Cirme(Gr. cliumos, juice). The acid, partly fluid or partly digested food, produced by the action of the gastric juice on the food.

Cil'i-Ate. Fringed.

Cil'I-UM (pl. cilia). Microscopic filaments attached to cells, usually within the body, and moving usually rhythmically.

CI-NE'IE-OUS. Ash color; color of wood-ashes.

Cing'U-LA. A colored band.

Cla'vate. Club-shaped.

Clav'o-la. The terminal division of the antenna; the same as flagellum.

Co-Arc'tate. . Contracted; applicable to the pupa-case or puparium of Diptera. 
CE'CaL. Ending blindly or in a cui-ule-sac.

CoE'com. A blind sac; usually applied to one or more appendages of the digestive canal.

Col'Lo-PHoRE. The sucker-like organ extended from the under side of the abdomen of Podurans.

Con-yIs'sure. The nerves connecting two ganglia.

CoM-PREss'Ed. Flattened laterally.

CoN-COL'O-Rous. Of the same color as another part.

Con'Dyte. In inseets, a process at the base of the mandible, by which the latter is articulated to the lower end of the epicranium.

CON'FLU-ENT. Flowing or grow. ing together.

CoN-NATE'. United; not separated by an articulated suture; also applies to the uniou of the elytra where the hind wings are absent.

Cor'bel. A more or less oval space at the distal end of the tibia in beetles, and surrounded by a fringe of short minute bristles.

Cor-bic'U-LA. The pollen-basket; formed by the hollow outer surface of the hind tibia of bees, with hairs on the side and some bent over to keep the load of pollen iu place.

Cor'date. Heart-shaped.

CO-RI-A'CE-ous. Leathery. CoR'NE-ous. Horuy, chitinous.
Con'NI-CLE. The pair of tuhes on $1 \mathrm{~s}$ end of the abdomen of Aphides. (Siphunculus.)

COR'TI-CAL. Relating to the cortéx or inver skin; external, as opposed to medullary.

Cos'tal (Lat. costa, a rib). Relating to the ribs.

Cre-mas'ter. The stont spine at the end of the pupre of Lepidoptera.

Cre'nate. Scalloped, with rounded teeth.

Crib'RI-Form (Lat. cribrum, a sieve; forma, form). With perforations like those of a sieve.

Crop. A partial dilatation of the gullet or œsophagus, the ingluvies; in many insects the fore stomach or proventiculus.

Crura (Lat. crus, a leg). A prop.

CTE-N1D'I-UM (Gr. ktenion, a comb). Comb-like structures situated on various parts of insects, especially fleas, Nycteribia, etc.

Cu'BI-TUs. The vein just behind the radius, or median, in dragon-flies, etc.

CUl-TEL'LuS. One of the bladelike mandibles of flies.

Cur'tri-form. Shaped like a pruning kuife.

CU-NE'I-Form. Wedge-shaped.

Cu'PRE-ous. Coppery in color.

CU-PU'LI-Form. Like a cupule ; Lat. cupula, a little tub.

Cu'Ti-CLE. The outermost layer of the integument. 
De-CID'U-ous. Relating to parts which fall off or are shed during life, as the gills of the frog, etc.

Den'tate. Furnishedwith teeth.

DeN'Ti-CLE. A small tooth.

DE-PRESSED. Inclined downward, or flattened from above downward.

DER-MA-TOF'TE-RA (Gr. derma, skin; pteron, wing). The earwigs.

Ded-Tом'A-LA. The third pair of head appendages of Myriopoda.

DI-CHop'tic. Separation of the eyes by the front in all females and some males of certain Diptera (Helophilus, etc.).

Dif-Fer-En-TI-A'Tion. The specialization or setting apart of special organs for special work, as the specialization of the hand of man as compared with the fore foot of other mammals; also applied to the special development during embryonic life of parts adapted for peculiar or special functions.

Dig'it. A finger or toe.

DI-Go'NEU-TISM. The power of producing two broods in a season.

Di-LAT'ED. Widened, expanded. DI-MID'I-ATE. Half round.

DI-cE'cious. (Gr. dis, two; oikos, house). With distinct sexes.

DIP'TE-RA (Gr. dis, two; pteron, wing). Two-winged flies; an order of insects.
Dis-cor'dal. Relating to the disk or middle; discal.

Dis'Tal. Applied to the farther end of a joint.

DI-VAR'I-CAT-ED. Spreading apart.

Dl-VER-TIC'U-LUM, An offshoot from a vessel or from the alimentary canal.

Do-LAB'RI-Form. Hatchet-shaped.

Dor'sum. In Diptern, the whole upper surface of tile thorax, limited laterally by the dorsopleuralsutures, posteriorly by the scutellnm, and anteriorly by he neck.

Duct. A tube ol passage usually 'eading from glands.

LC-DY'sIs (Gr. ekdusis, casting off). The process of casting the skin; moulting.

E-DENT'U-Lous. Destituteof teeth. EGG'-BURst ER. A projecting ridge or point on the head or other parts of certain embryos used in breaking open the eggshell, in hatching.

E-LA'TER. The spring or forked "tail " of Podurans.

EL'Y-TRA (Gr. elutron, a sheath). The fore-wings of beetles, serving to cover or sheathe the hind wings.

E-MAR'GI-NATE. With an obtuse incision.

EM-Bo'LI-UM. The lobes on each side of the prothorax in $\mathrm{He}$ miptera (Fieber).

Ex'bry-o. The germ or young animal before leaving the egg or body of the parent. 
Exr ro'Di-tu. The spurious claw (pseudonychia) situated between the two normal claws; e.g., Lucanus.

EN'TE-RoN (Gr.enteron). A general term applied to the digestive canal as a whole.

EN-TIRE'. With a simple, not in. dented, edge.

E''I-Lobe. In Carabidæ, a lateral appendage of the lobes of the mentum.

EPI-PHAR'YNX. The soft fold or projection within the mouth situated under the labrum.

E-PIPH'Y-sis. In Lepidoptera, a stout spur on the fore tibia. Any projecting process.

E-PI-PLEU'RA. The portion of the elytron of a beetle bordering the inner edge of the inflexed portion of the elytron. (Le Conte.)

E-pis'to-ma. That part of the face of flies situated between the front and the labrum; the clypeus.

E-RU'CA. Caterpillar.

Ex-CIs'ED. Cut off.

EX-CURv'ED. Curved outwards.

Ex'PlA-NATE. Spread or flattened out.

Ex-sert'Ed, Protruded, thrust out; opposed to enclosed.

Ex-U'vI-UM. The cast skin of insects; exuviate, to cast the skin; to moult.

FA'cies. The face, in Diptera. FaL'Cate. Sickle-shaped.

FAR't-nose. Mealy.

FAs'cta. A stripe broader than a line.
Fau'na. An assemblage of animals peopling any given region or country.

FA-rose'. Pitted, scrobiculate. Fe-Nes'trat-ED. Marked with transparent spots surrounded by a darker color, like windowpanes.

FER-RU'GI-Nots. Rust-colored. Fil-I-form. 'Thread-like.

Fimibri-ate. Fringed.

Fis-siP' A-Rous (Lat. fissus, cleft; pario, to bring forth). Applied to a form of asexual generation where the parent splits into two parts, each part becoming a new individual.

Fla-gel'́lux. The terminal division of the antenua, in wasps, bees, etc.

Fla-ves'cent. Somewhat yellow.

Flex'd-ous. Almost zigzag.

Fo-LI-A'CeOUs, Leaf-like.

Fo-RA'MEN. An opening; a perforation.

FOR'CI-PAT-ED. Forceps-like.

For'Ni-Cate. Concave within and convex without.

Fo've-A. A rounded cavity.

Fo-vE'O-LATE. Covered superficially with cavities like a honeycomb.

Free. Unrestrained in articulated movement; not soldered at the points of contact.

Fren'U-LUM. Diminutive of frenum, a bridle, or band. The sameas frenum; or, in Cicadæ, the triangular lateral piece on the mesonotum which connects with the trochlea. 
Fre'num. A lunate or triangular portion at the inner and hinder base of the wing, in Trichoptera and Odonata.

Front. The fore face bounded by the vertex, eyes, and often beneith by the epistoma or clypeus.

Fur'crum. The chitinized walls of the pharynx.

FU-IIG'I-Nous, Of the color of dark smoke.

FUL-vo-E'Ne-ous. Brazen, with a tinge of brownish-yellow.

Fur'vous. Tawny, color of the common deer.

Fu'NI-CLE. A small cord; a slender stalk. That part of certain antennæ between the scape and club. FUR'CAT-ED. Forked.

Fus'co-Tes-ta'ceous. ' Dull reddish brown.

Fus'cous, Dark brown, approaching black.

Fu'sI-Form. Shaped like a spindle; e.g., the antenuæ of the sphinges.

GA'LE-A. The middle division of the maxilla, situated between the lacinia and palpiger.

GANG'LI-ON (Gr. gagglion, a swelling or lump). A centre of the nervous system, consisting of nerve-cells and fibres.

Gem'I-Nate. Arranged in pairs; twin.

GeM-MrP'A-RoUs (Gr.gemma, bud; pario, to bring forth). Applied to a form of asexual generation where new individuals arise as buds from the body of the parent
GE'sa. Cheek.

GE-NIC'U-LATE (Lat. geniculatus). Bent abruptly like a knee or elbow; elbowed.

Gis'sous. Inflated, swollen. GLA'Brous. Smooth; opposerl to hairy; downy, villous.

Gland. A cellular sac which secretes, i.e. separates, certain constituents of the blood. The liver is a gland secreting bile; the kidneys excrete urine.

GLA d'cous. Bluish green or gray. GLo-Bose'. Globular, spherical. Gnatifite. A jaw or jaw-like appendage. The gnathites aro the mouth-parts.

Gon-A-Porh' r-sis. (Gr.gone, female; apophysis, process). Two pairs of elongated processes in the cockroach, arising from the 8th and 9 th abdominal rings. (Huxley.) They appear to be the equivalents of the rhabdites composing the ovipositor of other insects.

Go-Nop'O-DA (Gr. gone, generation; pous, podos, foot). The modified first pair of abdominal appendages of the male lobster, shrimps, and crabs.

HAB'I-TAT. The place or region an insect inhabits.

HaL'TER-Es (Gr. halteres, poisers). Balancers: the rudimentary hind wings of Diptera.

Ha'mate. Furnished with hooks. Han'Ule. A little hook.

Has'r'ate. Halberd-shaped.

HaUs'TEL-Late. Furnished with a proboseis so as to take food by suction. 
Hem-el'y-tra. Applied to the partly thickened fore wings of Hemiptera.

HE-MIP'TE-RA (Gr. hemi, half; pteron, wing). Au order of insects with the fore wings partly opaque, which are called hemelytra.

Her-ma ph' ro-dite (Gr. Hermes, Mercury; Aphrodite, Venus). Any animal having the organs of both sexes, usually the ovary and testes, combined in the same individual.

HeT-E-Ro'CE-RA (Gr. heteros, different; leras, horn). The moths, in which the antennæ are of different shapes, as distinguished from those of buttertlies.

Het-e-rog'A-MY. Partlienogenesis; applied to those cases in which two sexual generations or a sexual and parthenogenetic generation alternate.

HET-E-ROG'I-NA. (Gr. heteros, different; gune, woman). The ants; referring to the different kinds of individnals of ants, i.e., the females and workers, as distinguished from the males.

HeX-AP'o Dods. Provided with six feet.

HI-BER-NAC'U-LUM. A tent made out of a leaf in which the larva hides or hibernates.

HIR-8UTE', Clothed with stiff hairs.

Hol-or'ric. Contiguity of the eyes in the male tly, between the vertex and the antennæe (Williston.)

Ho-MOL'O-GY (Gr. homologia, agreement). Implies identity in structure betweeu organs which may have different uses; as the fin of a whale, and the foot of a dog, or a bird's wing. Homology implies blood-relatiouship, i.e., a community of origin between parts which may have distinct uses.

Hu'Me-RAL. Relating to the humerus.

HU'ME-RUS. The anterior superior angle of the thorax in Diptera.

HY'A-LINE. Transparent.

HY'DA-TID. The bladder-worm, or the cystic stage of a tapeworm.

HY-MEN-OP'TE-RA (Gr. humen, hymeu, or membrane; pteron, wing). An order of insects with two pairs of membranous wings.

Hyp'o-DERM. The cellular layer which secretes the chitinous cuticula.

Hy-PO-GLOT'TIS. A piece situated between the mentum and labium in Clavicom and Serricoru beetles.

HY-POM'E-RA (Gr. hupo, under; meron, part). 'The inflexed sides of the elytra of beetles. (Casey.)

HY-PO-PHAR'YNX. The lingua; Huxley restricts it to the base of the lingua.

Hy-Po-Py G'I-UM. The male sexual organs and terminal seg. 
ments of the abdomen in Diptera.

Hy-Pos'to-ma. The clypeus in Diptera.

I-MA'Go. The final, or fourth, winged and adult state of insects.

In-ci'sures. The sutures scparating the segments.

IN-CRASS'AT-ED. Rounded and somewhat swollen.

IN'FU-MAT-ED. Clouded.

IN-FUs'CAT-ED. Darkened, with a blackish tinge.

IN-GLU'VI-ES. The crop.

In-sti'tia. A stria of equal breadth throughout.

IN-TER-RUPT'ED. Sudd en ly stopped.

IN'vo-LUT-ED. Rolled inwards spirally.

IR'Ro-RAT-ED. Freckled; sprinkled with atoms.

LA-CIN'I-A (Lat. lacinia, a lappet). The first or innermost division of the maxilla.

LA-CIN'I-ATE. Cut into sharp lobes; jagged; toothed, as on the inner edge of the lacinia.

LA-MEL'LI-FoRM. Leaf-like.

LAM'I-NA. A plat or sheet-like piece.

LAR'va (Lat. larva, a mask). The second stage of the insect; a caterpillar, grub, or maggot.

LAR'VI-FORM. Larva-shaped.

LAT-E-RI'TI-oUs. Brick color, inclining towards yellow.

LEG, False. One of the abdominal legs of a caterpillar.

LEV'I.GATE. With a smooth, somewhat shining surface.
LIG-NIV'o-RoUs. Eating wood.

LIG'U-LATE. Strap-shaped.

LIM'BATE. When a disk is sur rounded by a margin of a different color.

Lin'E-AR. Like a line, or threadlike.

LiN'E-AT-ED. Provided with line-like marks.

Lo'RA. The submentum; small corneous cords upon which the base of the proboscis is seated. (Say.)

Lu'MEN. The cavity of an organ.

LU'NULE. A crescent-shaped figure or spot.

MAC-RO-CHE'TE. Bristles, or large stiff setæ, on the thorax and legs, never on the head, of certain Diptera (Volucella, etc.). (Williston.)

MA-LIP E-DES. The fourth and fiftl pairs of head-appendages of chilopod Myriopods.

MAL-LoPH'A GA (Gr.mallos, wool; phagein, to eat). The bird-lice, a sub-order of Platyptera.

MAN'DI-BLE (Lat. mando, to chew). The first pair of mouthappendages.

Man-Dir'U-Late. Provided with mandibles.

MIAR'GIN-AT-ED. Surrounded by an elevated or attenuated margin.

MAX-IL'LA (Lat. maxilla, a jaw, the dimin. of mala). The sec. ond and third pairs of mouthappendages; the second pair being united and usually called the labium.

Me-CaP'TE-RA (Gr. mecas, long; 
pteron, wing). The order of insects represented by Panorpa.

Mez'An-Ism (Gr. melas, black). Where an iusect is abnormally or unusually dark.

MEM-BRA-NA'CEOUS. Thin; skinny; semi-transparent like parchment.

MEN'ruM (Lat., the chin). The basal piece or sclerite of the labium or second maxillæ of insects. Submentum is the posterior division of the mentum.

MEs-En'TE-RoN. The mid-gut or stomach.

Met'a-meie. The same as somites or arthromeres.

Mo-NIL'I-ForM. Like a string of beads.

Mo-Ne'clous (Gr. monos, single; oikos, louse). With both kinds of sexual glands, etc., existing in the same individual.

I[U'Cro-NATE. Ending suddenly in a sharp point.

MU'TIC. Unarmed.

II YR-I-OP'O-DA (Gr. murios, thousand; pous, podos, foot). The class of Tracheates comprising the Millipedes and Centipedes.

Mrs'tax. In certain Diptera, a patch of bristles or hairs, immediately above the mouth, on the lower part of the hypostoma, below the vibrisse. (Say.)

NE-PHRID'I-A (Gr. nephros, kidney). The segmental organs of worms, etc.
NEU-RA'tion. Sometimes used for the venation or system of veins of the wing.

NEU-ROP'TE-RA (Gr. neuron, nerve; pteron, wing). The order of net-veined insects with a complete metamorphosis.

NiD-A-MEN'TAL. Referring to a nest, or egg-sac.

None. A knot; a knob; nodiform, node-shaped.

No'Dus. A stout, oblique, short vein in the Odonata, at the place where the anterior margin of the wings is somewhat drawn in.

Nrmpir. Usually used as an equivalent of pupa; but in insects with an incomplete metamorphosis applied to the whole period from hatching to the complete winged stage; as in may-flies, Orthoptera, etc.

OB-CORD'ATE. Inversely heartshaped.

OB-o'vate. Inversely ovate; the sualler end turned towards the base.

OB'so-LETE. Indistinct; almost lost to view; disused; rudimentary.

OB-TECT'ED. Covered ; concealed.

O'chre-ous. Of a more or less deep ochre color.

O Do'Na. Applied to the peculiar mouth-parts of Odonata (dragon-flies) by Fabricius, on account of the long teeth on the labium, etc.

O-DO-NA'TA (Gr. odous, odontos, 
teeth). (Derivation obscure.) The dragon-flies.

(E-sopH'A-GUs (Gr. oisos, a reed; phagein, to eat). The gullet.

OL-I-VA'CEOUS. Olive-colored; rich dark green.

ON-ToG'E-NY (Gr. on, ontos, being; gene, birth). The development of the individual, as distinguished from that of the species.

O-мтсн'I-A (Gr. on ux, nail, claw). A small, more or less retractile bristle in the feet of beetles; the empodium of flies; pseudonychium.

O-PER'CU-LUM. In flies (Musca) equivalent to the labrumepipharynx, the latter being composed of the labrum above and epipharynx below. (Dimmock.)

O'RAL. Related to the mouth.

OR'BIT. The ring surrounding the eye.

OR-ThOP'TE-RA. (Gr. orthos, straight; pteron, wing). The order of insects with straight narrow fore wings, as the grasshoppers.

Os-MA-TE'RI-A (Gr. osmetos, that can be smelt). The V-shaped retractile scent-organs of the larval Papilio.

Os'TI-A. The slit-like openings of the heart.

O-VA'RI-OLE. An ovarian tube. (Huxley.)

O-vip'A-Rous (Lat. ovum, an egg; pario, I bring forth). Applied to animals bringing forth eggs instead of living, active young.
O-VI-PO-si'TION. The act of egglaying.

O-vI-Pos'I-ToR (Lat. ovum, an egg; pono, I place). An organ in insects homologous with the sting, by which eggs are deposited in solid substances.

O'vi-sac. A sac or bag-like mem. brane attached to the parent, and containing eggs.

O-vo-vi-VIP'A-Rous (Lat. ovum, an egg; vivus, alive; pario, I bring forth). Applied to such animals as retain their eggs in the body until they are hatched.

PA-Do-Gen'E-SIs. Parthenogenous development in larval in. sects.

PAL-PA'RI-UM. In Carabidæ, etc., the palpal support; the membrane to which the labial palpi are attached, and which admits of an amount of extension of these organs not permissible when they are fixed. (Horn.)

PA-PIL'LA. A minute soft projection.

Par-a-gloss'a. Appendages on each side of the ligula.

Par-a-pleu'ra. The sterual side pieces in beetles.

Pa-1RaP'si-Des (Gr. para, near ; pteron, wing). Lateral pieces of the meso- and metathorax on each side of the scutellum.

Par-O-NrCiI'I-A (Gr. para, near; onux, claw, nail). One or more bristle-like appendages of the onychium or pseudonychium.

PAR-TIIE-NO-GEN'E-SIS (Gr. par 
thenos, virgin; genesis, generation). Reproduction by direct growth of germs from the egg, without fertilization by male germs or spermatozoa, as in the aphis, gall-insects, fluke-worm, etc.

PA-TA'GI-UM (Gr. patageion, a stripe or border to a dress). The shouldertippets; loose pieces of the mesothorax, on each side of the mesoscutum.

Pe-dun'cu-Late. Situated on a peduncle, or stalk.

Pel'Li-cle. A thin skin, i.e., the subimaginal skin shed by the May-fly.

Per-is-to'mi-um. The border of the mouth, or oral margin, in Diptera.

Per'i-treme. The piece enclosing the spiracle.

Per-I-vis'ce-ral. (Gr. peri, around; Lat. viscera, the internal organs, especially of the abdominal cavity). The bodycavity, containing the alimentary canal with its outgrowths.

Pet'I-O-LAT-Ed. Stalked.

PE'T'I-OLE. A stalk.

PiIA-RYn'Ge-AL. Relating to the pharynx.

Pilariynx (Gr. pharugx). The back part of the mouth and upper part of the throat.

PiIY-Log'E-NY (Gr. phulon, stem; gene, birth). The development by evolution of the members of a genus, family, order, class, or the animal kingdom as a whole.

PIIY-SAP'O-DA (Gr. phusa, bel- lows; pous, foot). A synonym of the Thysanoptera.

Piry-Torir A-Gous. Eating plants. PIC'E-ous, Pitchy; the color of pitch; shiniug reddish black.

PiLe. Hair; of ten hair arranged somewhat in rows.

Pi-LIF'E-rous. Pilose, or bear ing hairs.

Pr-LosE'. Clothed with pile, or dense short down.

Plan'ta. Strictly the sole or under side of the foot; according to Cheshire, the first tarsal joint of bees.

Plan'tu.la. One of the soles or climbing-cushions of the foot; also one lobe of the divided pulvillus.

PlA-TYP'TE-RA (Gr. platus, flat; pteron, wine). The order of insects represented by the birdlice, white ants, Psocidæ and Perlidx.

Plev'rum. The side of the thorax; pleurites, the pieces into which the pleurum is divided.

Plex'Us (Lat. a knot). Applied to a kuot-like mass of nerves or blood-vessels.

Pon'i-cal Plates. The two pieces on each side of the vent; thought by Huxley to be rudi. ments of an eleventh abdominal ring; united they form the tergite of a rudimentary eleventh abdominal ring:

Pol'LI-Nose. Dusted over with a fine powder.

PoL-Y-AN'DRY. Where a female insect mates with more than one male. 
Po-LYG'A-MY. Where a male insect mates with more than one female.

Pol-Y-Go-Ned'TISM. The power of producing several broods a season.

Pre-o'ral. In front of the mouth.

Prína-RIEs. The fore wings of Lepidoptera.

Pro-bos'cis. The mouth-parts adapted for sucking.

Proc'ess. A projection; used chiefly in osteology.

Proc-TO-DA'UM. The primitive hind gut, or rectum.

Pro-du'Ced, Drawn out; prolonged.

Prólleg, or Prop'-leg. One of the abdominal legs of a caterpillar.

Pro-PY-GID'I-UM. The dorsal segment or tergite in front of the pygidium, sometimes leftexposed by the elytra, in beetles.

Pro'te-AN-Dry. The appearance of males earlier in the season than females.

Pro-Ton'A-LA. 'The second pair of mouth-appendages of Myriopoda; the so-called mandibles.

Pro'to-Plasm (Gr. protos, first; plasma, from plasso, I mould). The albuminous, elementary matter forming cells and the body-substance of Protozor.

Prox'i-mal (Lat. proximus, next). The fixed end of a $\operatorname{limb}$, bone, or appendage; that nearest the body; opposed to distal, the farther end.

Pru'i-nose. Hoary; frosted.
Pseu-do-nyciti-a. The spurious or third claw; empodium.

Pseu-do-tra'cilechea-like, chitinous, cylindrical channels in the labella of eertain flies, the ends of which project beyond the edge of the fleshy flaps (labella) and seem to file away the substances on which the fly feeds. (Dimmock.)

Pter-o-Gos'tic. Referring to the wings.

Pu-Bes'cent. Coated with very fine hairs.

Pul-Ver'u-lent, Dusty.

Pul-vil'́lus (Lat, a little eushion). The pad between the two claws of the feet. When divided into two or three lobes, each lobe is sometimes erroneously called a pulvillus.

Punc'tur-ed. Marked with numerous small impressed dots; punctate.

Pu'Pa (Lat. a doll). The third or usually quiescent, chrysalis stage of insects.

Pu'Pate. To become a pupa.

PU-PA'tion. The act of becoming a pupa.

PY-GID'I-UMr. The rudimentary terminal abdominal segment of insects; in beetles the last dorsal segment left exposed by the elytra; more properly applicable to the last abdominal segment of trilobites.

RA-DJC'U-LA. Radiele; the basal joint of the antenna, attached to the head.

RA'DI-US. The vein just behind 
the subcostal vein, the median vein of Lepidoptera.

RAP-To'ri-AL. Adapted for seizing prey.

RE-CLI'vate. Curved in a convex, then in a concave, line.

RE-CURVEd'. Curved backwards. REN'I-FORM. Kidney-shaped.

RE-PAND'. Wavy; with alteruate segments of circles and intervening angles.

RE-TIC'U-LAT-ED. Marked like network.

Re-TronsE'. (Siunate) pointing backwards; (serrate) inversely serrated.

Re-Tuse'. Ending in an obtuse sinus or broad, shallow notch. REV-OLUTE. Rolled backwards. Rhab'DI-TES. The blade-like elements of the sting and ovipositor of insects.

RHOP-A-LOC'E RA (Gr. rhopalon, a club; keras, horn). Those Lepidoptera with club-shapel antennæ, i.e., the butterflies.

RI-Mose'. Full of cracks.

Rin'Gent. Gaping.

Ros'trus. A beak.

RU.FEs'CENT. Somewhat reddish.

RU'Fous. Reddish.

RU-Gose'. Wrinkled.

Run'Cl-Nate. Notched; cut into several transverse, acute segments which point backwards. (Say.)

Sac'Cate. Gibbous, or inflated towards one end.

Sag'it-Tal. Equivalent to longitudinal.

SAN-guin'E-ous. Blood red.
ScA'Brous. Rough like a file, with small raised dots.

SCAL'LOP-ED. Edge marked by rounded hollows without intervening angles.

SCAL-PEL'LUS. One of the lancetlike maxillæ of flies.

Scape. The basal joint of certaiu antenuæ (LeConte); usually applied to the three basal joints, as in Hymenoptera, etc.; by some authors the second antenual joint.

SCAP'U-LA. The shoulder-tippets, patagia, or tegulæ, in Lepidoptera.

SCLE'RITE. A single portion of an insect's skin or integument, separated by suture from the adjoining parts; the scutum, scutellum, or sternum is a sclerite.

Sco'PA. The stout bristles on the hind tibia of bees, aiding in forming the corbicula.

ScoP'U-LA. The bristles covering the inside of the plantæ, especially of the hind feet; scopa of Schrank. (Say.)

Scro-BIC'U-LATE. Pitted; having the surface covered with hollows; favose.

Scure. Applied to the dorsal pieces in Myriopods.

SE-BIF'IC. Oily; sebaceous.

SEc'OND-A-RIES. The hind wings of Lepidoptera.

SEc'Tors. Longitudinal veins in Odonata which strike the principal veins at an angle, and usually reach the apex or hind margin of the wing. 
SE-CU'RI-Formr. Hatchet-shaped; dolabriform.

SEP'TUY. A partitiou.

SE-RIC'E-ous. Having the surface with a silk-like gloss, usually from the presence of $\mathrm{mi}$ nute, dense hairs.

SER'RAT-ED. Like the teeth of a saw.

Ses'sile. Having no stalk.

SE-TA'Ce-ous (Lat. seta, a bristle). Bristle-like.

SE-Tose'. Bristly; setous.

SIN'U-AT-ED. Sinuous, winding; with the edge scooped out.

So-matic. Relating to the body.

So'mrte. A segment of a segmented animal, such as is worm.

Spat'd-Late. Battle-door, or spoon-shaped.

SPER-MA-THE'CA. The sac or reservoir in the female containing the spermatic particles.

Spi'Nose. Full of spines; spinous.

SPIR'A-CLE (Lat. spiro, I breathe). The breathing-hole, or lateral opening into the trachea.

Spu'ri-ous. Applied sometimes to the clawless, rudimentary feet of the Nymphalid butterflies.

SQUA'ma. The small scale above the halteres of Muscids; tegula.

Squar'U-LA. A rery small, corneous, concavo-convex scale, covering the base of the fore wings in some insects. (Say.) SQUAR'Rose. Scurfy; consisting of rough scales spreading every way. (Say.)
Ste-tinimi-um. A n tiquated name for thorax.

Stig'MA. A spiracle, or breath. ing-hole; stigmatal, relating to the stigma.

STIG'MA-TA (Gr. stigma, a mark). A synonym of spiracles.

STI'PES. The second division of the maxilla, articulated to the cardo, and bearing the two lobes and palpi.

Stip'i-Tate. Supported on a pedicle.

STOM-O-Da'ur. The primitive mouth and resophagus of the embryo of worms and Arthropoda.

STLeP-sIe'TE-RA (Gr. strephis, a twist; pteron, wing). A group of beetles whose minute front wings appear as if twisted.

STríate. With more or less parallel furrows, grooves, or depressed lines; channelled.

Stri'gA. A small, short, linear, transverse line.

Stri'gate. With strigge.

Sub. Somewhat; approximate to; prefixed to many terms in descriptive entomology.

Sub-AD-Un'CATE. Som e w h a t hooked or curved.

Sub-E-Rod'ED. Somewhat indented, but irregularly so.

Sub-IM-A'Go. In May-flies, the penultimate stage in those which moult once after acquiring their wings. Proimago (Lubbock).

Sub-stig'ma-tal. Applied to a line in caterpillars situated just 
under the row of stigmata or spiracles.

Su'BU-Late. Awl-shaped.

SUc-CıNC'TI (Lat. succinctus, bound round). Those chrysalids of butterflies which are held in place by a silken cord passing around the body.

Suc-To'RI-AL. Adapted for sucking.

Sul'cate. With groove-like excavations.

SUs-PEN'si (Lat. suspensus, suspended). Those buttertlies whose chrysalids are suspended by the tail, i.e., cremaster, head downward.

Su'TURE. A seam or impressed line between the bones of the skull, or parts of the crust of an Arthropod.

SU-TU'RI Form. Suture-sliaped; a suturiform articulation is where a slight suture is visible, as sometimes two abdominal segments in Ichneumons are soldered together without a trace of a suture between them.

TAC'Tile. Relating to the seuse of touch.

TE-NID'I-UM. The band or chitinous fibre forming a part of the so-called "spiral thread" of the trachere of insects.

TAw'NY. Fulvous; a pale, dirty yellow.

Tequen (Lat. tego, to cover). Formerly applied to the fore wings of Orthoptera, Cieada, etc.; a wing-cover.

'TEG'U-LA. The broad covering scale under the base of the wing in Diptera; some authors call it squama; in Lepidoptera, the shoulder-tippets, or pa. tagium.

TEL'sun (Gr. telson, from telos, end). The rudimentary terminal segment of the abdomen of Arthropods, especially Crustacea.

Ten'e-RaL (Lat. tener, tender). A state of the May-fly after exclusion from the pupa, in which it has not fully completed its coloring, clothing, etc.; the subimago.

Ten-Tac'U-Lum (Lat. tento, I touch). A feeler or tentacle.

Ten-To'rı um. A chitinous framework within the head, upon which the brain rests, the cesophagus passing upwards between its anterior crura or props.

'Te-Rete'. Nearly cylindrical.

Ter'gum (Lat. back). The dorsal region of Arthropods.

Tes'sel-late. Spotted like a checker-board.

TES-TA'CEOUS. Dull red; brick color.

Tho'RAX (Gr. thorax, a breast. plate). The middle region of the body in insects and some crustacer.

Thrs-A-NU'RA. (Gr. thusanoi, fringes; oura, tail). The lowest order of insects.

To-MEN-Tose'. Covered with fine matted hairs.

To-Rose'. Protuberant; swelling into knobs or suljerozities 
Tra'che-A (Gr. tracheia, the rough windpipe). The respiratory tube in vertebrates; the air-tube of tracheate insects.

Tri-chot'o-mous. Dividing by threes.

TrI-cus'PI-Date. Ending in three points.

Tri-Dac'TY-LUs. Having three toes or claws.

TRIG'O-Nate. Three-cornered.

Trig-o-NeU'tisu. Where three broods occur in a season.

'Tri-que'tral. Having three more or less long augles; threecornered; triquetrous.

Tro-Chan'ter (Gr. trochanter, the ball on the femur). In insects, the small, short joint between the coxa and femur.

Tro-chan'tin. A piece often present on the outer side of, and sometimes movable on, the coxa.

Troch'LE-A. The thickened base of the hind wings, in Cicada and Trichoptera.

Tro'pHI. Old term for the mouth-parts taken collectively.

TRUn'CAT-ED. Cut squarely off; docked.

TU-BER'CU-LOSE. Covered with tubercles.

Un'CI-NATE. Hooked at the end. UN-GUIC'U-LUS (Lat. a little claw). A claw at the end of a foot.

U-RO-MERE' (Gr. ouros, tail ; meros, a part). Any of the abdominal segments of an Arthropod.

U-RoP'O-DA (Gr. ouros, tail; pous, pods foot). Any of the abdow " feet of Arthropoda.

U'Ro-some (Gr. ouros, tail; meros, a part). The abdomen of Arthropods.

U-RO-STERN'ITE. The sterual or under piece of the uromeres or abdominal segments of insects.

VaL'vule. A swall valve-like process.

Vein. Applied to the ribs or "nervures" of the wings of insects; the branches of the veius are called venules.

Ve'cum. A broad process at the inner eud of the fore tibia of bees.

VE-NA'TION. The system of veins of the wings.

VEN'TER. The whole under surface of the abdomen.

Ven'tral. Applied to the uuder side of the abdomen, or of the body of invertebrates.

VER'MII-FORM. Worm-shaped.

VER-RIC'U-LATE. With thick-set tufts of parallel hairs.

VER'RU-Cose. Covered with wart-like prominences.

Ver'tex. Crown of the head.

Ver-Ti-CIL'Late. Placed in whirls.

Ves'I-CLE (Lat. vesica, a bladder). A little sac, bladder, or cyst.

VI-BRIs'sA. A whisker; curved bristles or hairs situated in certain Diptera between the mystax and the antennæ.

VIL'LOSE. Clothed with soft, rather long hairs.

Vis'ce-RA (Lat. viscus). The interual organs of the body. 
VIt'тATE (Lat. vitta, a stripe). plied to animals which bring Striped. forth their young alive.

VI-VIP'A-Rous (Lat. vivus, alive; XY-LoPH'A-Gous. Eating wood. and pario, I bring forth). Ap- 


\section{N D E X.}

Acanthomera bellardii, 134

Achatodes zeæ, 200

Achorutes nivicola, 57

Acridiidæ, 63

Acrocera bimaculata, 133

Aculeata, 165

Adelops hirtus, 112

Adephaga, 113

Agialites debilis, 103

Aschua heros, 71

Agaristidæ, 157

Ageronia feronia, 161

Agromyza coronata, 126

Agrotis suffusa, 198

Air-sacs, 20

Aletia argillacea, 154, 200

Aleyrodes corni, 80

Alypia 8-maculata, 157

American silk-worm, 155

Amphizoa insolens, 114

Ampulex sibirica, 173

Anasa tristis, 84, 208

Andrena, 186

vicina, 176

Angoumois moth, 151

Anisopteryx vernata, 154

Anisota senatoria, 155

Antherophagus ochraceus, 111

Anthicider, 103

Anthomyia radicum, 206 zeæ, 199

Anthomyidæ, 130

Anthophila, 176
Anthrenus scrophulariæ, 111

Anthribus cornutus, 99

Ants, 170, 183

Apatela, 155

Aphaniptera, 115

Aphides, live, examining, 281

dissecting, 292

preservation of, 303

Aphidius, 169

Aphis, 80

avenæ, 196
grain, 196
hop, 208

Aphœbantus mus, 133

Apidæ, 176

Apis mellifica, 176

Apple-tree borer, 211

Aradus crenatus, 83

Arctia, 156

Argynnis aphrodite, 161,188

Army-worm, 154

(Sciara), 136 northern, 196

wheat-head, 197

Arthromacra ænea, 103

Arthropteridæe, 84

Asilidæe, 134

Asilus novi-scotix, 134

Asopia farinalis, 152

Assembling of moths, 148

Asteia tenuis, 126

Atta, 171

Attacus, 155 
Attelabus rhois, 101, 180

Balaninus nasicus, 100

Baridius trinotatus, 205

Bark-borer, 99

Basket-worm, 156

Bean weevil, 206, 207

Bee, carpenter, 185

leaf-cutter, 186

honey, 162, 176 embryo of, 37

louse, 124

moth, 152

Beetle, 91; carpet, 111

blistering, 203

flea, 204

belmet, 204

snapping, 109

Beetles, collecting, 271

rearing, 276

Belostoma grisea, 83

Bembex fasciata, 174

Bibio albipennis, 135

Bird-lice, 66

Bittacus, 89

Blaps, 103

Blatta orientalis, 62

Blepharocera fasciata, 135

Blissus leucopterus, 84, 195

Blister-beetle, 102

Bombus, 176

Bombycidæ, 155

Bombylius, 133

Bomby x mori, 42, 43, 155

Borers, 105

Boreus, 89

Bots, remedies against, 223

Botys, 152

Brachycera, 133

Bracon, 169

Braconidæ, 169

Brain, 13, 310
Braula cœeca, 124

Braulina, 124

Breathe, how insects, 19,20

Brenthidæ, 100

B-istle-tails, 56

Broods, several, 42

Bruchidæ, 103

Bruchus fabæ, 207

obsoletus, 104

pisi, 104, 206

Bug, 74

chinch, 77

garden, 204

mealy, 79

squash, 74-76

Buprestidæ, 109

Butterflies, 158 metamorphosis of, 145 , 148

scales of, 142,143

Butterfly, 137

Byrrhus americanus, 110

Byrsopidæ, 101

Cabbage bug, 206

Plusia, 205

Cabbage, insects injurious to, 205

Cacœecia rosaceana, 152

Caddis-fly, 90, 108

Cæcilius, 67

Calandra granarius, 100 oryzæ, 100

Calliphora erythrocephala, 130

Callosamia promethea, 155

Calobata antennipennis, 129

Caloptenus femur-rubrum, 2, 63 spretus, 2,63

Calopteryx apicalis, 71

Calosoma calidum, 114

Campodea staphylinus, 58

Caniponotus, 171

Canker-worm, 153 
Cantharis vesicatoria, 102

Capsidæ, 84

Carabidx, 114

Carabus serratus, 114

Carpocapsa pomonella, 213

Case-worm, 91, 183

Castnia licus, 157

('astniadae, $15 \%$

Cataclysta, 152

Caterpillar, 143

Caterpillars, blowing, 267

preserving small, in alcohol, 266

rearing, 247

Catocala, 154

Cecidomyia destructor, 192

grossularixe, 137

Cemonus inornatus, 175

('ephaloon lepturides, 103

C'ephus, 166

Cerambycidæ, 105

Ceratopogon, 135

Cerceris deserta, 174

Cercopidæ, 82

Cercyonis alope, 161

Cliærocampa, 158

Chafer, rose, 107

Chalcidide, 169

Chalcis, 169

Clalcophora virginiensis, 109

Chalcosoma atlas, 96

Chauliodes pectinicornis, 87

Chiasognathus grantii, 97

Chigœ, 116

Chinch bug, 195

Chique, 116

Chironomus, 42 uivoriundus, 135

Chlamys plicata, 183

Chlorops, 126

Chrysalis, 38, 145

Chrysididæ, 170
Chrysis, 170

Chrysobothris femorata, 109

Chrysomelidæ, 104

Chrysopa, 87

Chrysophanus thoe, 160, 223

Chrysops niger, 134

Cicada, septendecim, 82

Cicindela hirticollis, 115 vulgaris, 115

Cicindelide, 114

Cimbex americana, 166

Cimex lectularius, 84

Cinura, 58

Cis fuscipes, 108

Cistela sericea, 10s

Citheronia regalis, 155

Clavicornia, 110

Cleptes, 170

Cleridæe, 108

Clisiocampa americana, 155

Clothes moth, 151

Clypeus, 6

Coccinella novem-notata, 112

Coccus, 79

Cochineal, 79

Cockroach, 62, 311 organs of smell in, 27

Coddling moth, 213

Colopa frigida, 128

Conomyia pallida, 134

Coleoptera, 91. 55

Collecting, 271

Coleothrips trifasciata, 197

Colias philodice, 160

Collembola, 57

Colorado potato-beetle, 202

Colydium lineola, 111

Conopidæ, 131

Conops tibialis, 132

Conorhinus sanguisugus, 83

Conotrachelus nenuphar, 100, 214

Coptosoma globus, 84 
Cordyluridæ, 129

Coreidi, 84

C'orimelæna atra, 84

Corisa interrupta, 83

Corisidae, 83

Coru maggot, 199

weevil, 200

Corrodentia, 66

Corydalis cornutus, 87

Corylophus truncatus, 112

Cosside, 157

Costa, 19

Cotalpa lanigera, 107

Cotton army-worm, 200

Coxa, 6

Crabro sex-maculatus, 175

singularis, 175

Crambus vulgivagellus, 152,153

Cranberry worm, 152

Cricket, musical organ of, 30

Crop, 9

Cryptophagidæ, 111

Cryptus, 168

Ctenucha virginica, 157

Cucujidæ, 111

Culex ciliatus, 135

Cupes capitata, 108

Curculionida, 100

Currant-worm, 217

Cut-worm, 198

Cyclorhapha, 125

Cynipidæ, 166

Cynips quercus aciculata, 166 spougifica, 166

Cyrtidæ, 133

Dactylopius adonidum, 79

Dacne 4-maculata, 112

Dakruma convolutella, 152

Dascyllidæ, 110

Death tick, 67 watch, 67
Delphax arvensis, 82

Deltoids, 154

Dendroctonus terebrans, 99

Dendroides canadensis, 102

Dermaptera, 58, 54

Dermestes lardarius, 111

Dermestidæ, 111

Derodontus maculatus, 110

Dexia analis, 131

Diabrotica vittata, 207

Diapheromera femoratum, 6s

Diastata pulchra, 126

Diedrocephala mollipes, 82

Digestion, 11

Digestive canal, 11

Dione vanillæ, 161

Diopsidæ, 128

Diplax berenice, 68

Diplopteryga, 175

Diplosis tritici. 137,195

Diptera, 55, 117, 285

Diseases of insects, 42

Dixa clavata, 134

Dolichopus cuprinus, 133

Dor bug, 107

Dorylida, 171

Doryphora 10-lineata, 104

Dragon-flies, 68, 282

Drosophila ampelophila, 126

Dryocœtes affaber, 99

Dynastes tityus, 106

Dysdercus suturellus, 84

Dytiscida, 113

Dytiscus fasciventris, 113

Eacles imperialis, 155

Ear, 28

Eciton, 171

Egg, 32, 34, 35

burster, 38

guide, 4, 34

sections of, 319 
Elampus, 170

Elateridæ, 109

Ellema harrisii, 158

Embia savigni, 67

Embryology, 35

Emesa longipes, 83

Empis armipes, 133

Empusa aulicæ, 47 muscæe, 45

Endomychidæ, 112

Endomychus biguttatus, 112

Entimus imperialis, 101

Entomology, economic, 189

Eutomophthora radicans, 47

Ephemera, 71

Ephydra californica, 127 gracilis, 128

halophila, 127

Epicanta cinerea, 102, 203 pensylvanica, 203 vittata, 103, 203

Epicranium, 6

Epilachna borealis, 208

Epimerum, 4

Episternum, 4

Erax bastardii, 134

Erebus odora, 154

Erotylidæ, 112

Erycina, 160

Erythroneura vitis, 82

Eudalimia subsignaria, 154

Eudamus bathyllus, 160

Eudryas grata, 157

unio, 157

Eumenes fraterna, 175, 185

Eumenidæ, 175

Eupsalis minuta, 100

Eurytoma hordei, 169

Evania lævigata, 168

Evaniidæ, 168

Everyx myron, 211, 212

Eyes, 24, 311
Femur, 6

Fertilization of tlowers by in. sects, 217

Figitiuæ, 167

Fire-tly, 110

Flacherie, 43

Flea, 115

beetle, 104

suow, 57

Fly, dragon, 68

house, 118, 314

May, 71

saw, 166

Fœnus jaculator, 168

Footprints of insects, 17

Forceps, insect, 227

Forficula, 58

Formica, 171

Formicidæe, 170

Fonl brood, 44

Frog's spittle, 82

Fruit, insects beneficial to, 217

Fulgora candelaria, 82

Fungi, insect, 42

Galeruca xanthomelæna, 104

Galgulus oculatus, 83

Galleria melonella, 152

Gall-fly, 42, 166

Ganglia, 13

Gastropacha, 155

Gastrophilus equi, 131

Geometridæ, 153

Geomyzidæ, 126

Generations of insects, 42

Georyssidæ, 110

Georyssus pusillus, 110

Gerris remigis, 83,

Glands, rectal, 11

salivary, 9

sebific, 33

Goniocotes burnettii, 66 
Gortyna nitela, 200

Gorytes flavicornis, 174

Grape, insects injurious to, 209 phylloxera, 209

Grasshopper, red-legged, 1 Grease, to remove, 270

Grub, white, 198

Gryllidæe, 63

Gryllotalpa borealis, 63

Gyrinus borealis, 113

Gyropus ovalis, 66

porcelli, 66

\section{Hairs, 31}

Haltica cucumeris, 204

Halictus parallelus, 176

Haliplus fasciatus, 114

Halobates wuellerstorfii, 83

Harpalus caliginosus, 93

Hecatesia, 157

Hedychrum, 170

Heliconia, 161

Helicopsyche, 183

Heliothis armigera, 154

Helomyza apicalis, 129

Hemaris thysbe, 158

Hemerobidæ, 87

Hemileuca maia, 155

Hemiptera, 55, 74

$$
\text { collecting, } 280
$$

Hepialidæ, 157

Hepialus mustelinus, $\mathbf{1 5 7}$

Hesperia tessellata, $\mathbf{1 6 0}$

Hesperidæe, 160

Hessian fly, 192

Heteroceridæ, 110

Heterocerus pallidus, 110

Heterogyna, 170

Heteromera, 101

Heteroneura albimana, 128

Ifeteroptera, 82

IIippobosca equina, 125
Hirmoneura obscura, 133

Hister interruptus, 110

Homalomyia cunicularis, 130

scalaris, 130

Homoptera, 59

Honey bee, 176, 291

Hop aphis, 208

worm, 209

Horu-tails, 166

Humble-bee, 176

Hydrobatidæ, 83

Hydrocampa, 152

Hydrometra lineata, 83

Hydrophilus, embryo of, 36

Hydrophilus triangularis, 113

Hydroscapha natans, 112

Hymenoptera, 55, 161, 288

Hypena humuli, 154, 209

Hyperchiria io, 155

Hyphantria cunea, 157

Hypoderma bovis, 131

Hypodermis, 40

Hyporhagus opaculus, 103

Ibalia, 167

Ichneumon, 168, 218

Ichneumonidæ, 168

Imago, 41

Ingluvies, 9

Inquilines, 167

Insects, auatomy of, external, 1, 8 internal, 7

as architects, 178

beneficial, 217

cabinet for, 238

collecting, 224

dissection of, 289

how they breathe, 19

fly, 19,21

hear, 28

see, 24

smell, 26 
Insects, how they taste, 27

touch, 31 walk, 17

increase in numbers of, 48

insectivorous, 220

metamorphosis of, 32

mounting, 294

naturalized, 189

number of species of, 52

orders of, 54

parasitic, 218

periodicity in appearance of, 52

pinning, 230

senses of, 21

sections of, 296

Insecticides, 222

Intestine, 11

Ips fasciatus, 110

Isomera, 103

Isosoma hordei, 19

vitis, 211

Japyx subterraneus, 58

Jassidæ, 82

Jigger, 116

Joint-worm, 191

Labia, 58

Labidus, 171

Labium, 7

Labrum, 6

Lachneides, 155

Lachnosterna fusca, 94

Lac insect, 79

Lagriidæ, 103

Lamellicornia, 106

Lampyris, 109

Lampyridæ, 109

Laphria, 134

Larch saw-Hy, 166
Larrada semirufa, 174

Larva, 38

Lasia klettii, 133

Lasiocampinæ, 155

Laternaria phosphorea, 82

Leaf-cutter bee, 186

Leaf miners, 151

rollers, 179

Lecanium hesperidum, 79

Legs, 17

Lepidoptera, 55, 137

mounting, 269

rearing, 247

wings of, bleaching, 268

Lepisma domestica, 58

4-seriata, 58 saccharina, 58

Leptinillus validus, 112

Leptinotarsa 10-lineata, 202

Leptinus testaceus, 112

Leptis albicornis, 134

Leucania unipuncta, 154, 196

Libellula trimaculata, 71

Libythæa, 160

Limacodes, 156

Limothrips cerealium, 73

Lingua, 7

Lithosia bicolor, 157

Lobesia botrana, 211

Locust, ears of, 28 red-legged, $1,59,63$

Rocky Mountain, 61, 63

Locustidæ, 63

Lonchæa polita, 128

Lonchoptera riparia, 133

Longicorn beetles, 105

Lophyrus, 166

Louse, 78

bark, 79

bee, 124

bird, 66 
Louse, book, 67 plant, 80

Lucanidæ, 107

Lucanus dama, 107

Lucilia cæesar, 130 macellaria, 130

Lycænidæ, 160

Lycomorpha pholus, 157

Lygæidxe, 84,

Lygrus fasciatus, 84.

Lygus lineolaris, 204

Lymexylon sericeum, 108

Machilis variabilis, 58

Macrobasis, 102

cinerea, 203

Macrodactylus subspinosus, 107

Macrolepidoptera, $\mathbf{1 5 0}$

Malachius æneus, 108

Mallodon melanopus, 106

Mallophaga, 65, 66

Mandible, 7

Manna insect, 79

Mantis carolina, 62

Mantispa interrupta, 87

Masaridæ, 175

Maxilla, 7

May beetle, 94, 107

May-fly, 71, 283

Meal worm, 103

Mecopteri, 55, 88

Megathymus yuccæ, 160

Megistorhynchus longirostris, 133

Melandrya striata, 103

Melanophila drummondi, 109

Melipona, 176, 188

Melitxa phaěton, 161

Melittia ceto, 158

cucurbitæ, 207

Mellinus bimaculatus, 175

Meloè angusticollis, 102
Meloidx, 102

Melophagus ovinus, 125

Membracis foliata, 82

Menopon pallidum, 66

Meromyza americana, 126

Merope tuber, 89

Metabola, 55

Metamorphosis, 38

Metœcus paradoxus, 102

Miastor, 42

Micrococcus bombycis, 43

Microgaster, 169, 219, 220

Microlepidoptera, 150

Micropezidæ, 129

packing, 262

rearing, 254

Micropyle, 34

Microsporidium bombycis, 43

Midas clavatus, 134

Midge, 135

Milyas cinctus, 83

Mimesa cressonii, 175

Monohammus confusor, 106

Monommidæ, 103

Mordella 8-punctata, 103

Mosquito, 135

Moth, bee, 152

Moths, small, packing, 262 wings of, bleaching, 268

Moulting, 39

Moults, number of, in caterpil. lars, 39

Murgantia histrionica, 206

Musca domestica, 130

Muscardine, 44

Muscidæ, 130

Mutilla ferrugata, 172

Mycetobia sordida, 137

Mycetophagus punctatus, 111

Mycetophilide, 136

Mymar, 169

Myodites, 102 
Myrmecocystus, 171

Myrmica molesta, 171

Myrmosa unicolor, 172

Mytilaspis citricola, 79

gloverii, 79

pomorum, 79

Nabis ferus, 83

Nacerdes melanura, 103

Naucoridæ, 83

Necrophorus Americanus, 112

Neides spinosus, 84

Nematocera, 134

Nematus erichsonii, 166 ventricosus, 166,217

Nemestrinidæ, 133

Nepidæ, 83

Nepticula, 151

Nervous system, 13

Net, insect, 226

Neuroptera, 55, 84

Neuroterus lenticularis, 167

Nisoniades brizo, 160

Nit, 78

Nitidula bipustulata, 110

Noctuidæ, 154

Notodontians, 155

Notonecta undulata, 83

Notoxus anchora, 103

Nycteribia westwoodi, 124

Nymph, $\% 2$

Nymphalides, 160

Nysson lateraiis, 174

Odonata, 55, 68

Odontomachidæ, 171

Odontomachus, 171

Odors of insects, 149

Odynerus albophaleratus, 175

Ecanthus niveus, 63

Ecophylla smaragdina, 183

(Edemeridæ, 103
Edipoda caroliua, 63

Eneis semidea, 161

Esophagus, 7

(Estridie, 131

Estropsidæ, 90

Olfactory organs, 26

Oncideres cingulatus, 105

Onthophagus rangifer, 96

Ophion, 168

Opomyza siguicosta, 128

Orgyia, 156

Orphnephila testacea, 135

Orthoptera, 55, 59, 282

Ortalidæ, 129

Orthorhapha, 132

Oscinida, 126

Osmia simillima, 186

Othnius umbrosus, 103

Otiorhynchus sulcatus, 101

Ovaries, 32

Oviduct, 33

Ovipositor, 4, 34

Pachycoris torridus, 84

Palingenia bilineata, 72

Paltostoma torrentium, 135

Pangæus bilineatus, 84

Panorpa, 89

Panorpidxe, 89

Papilionidæ, 160

Papilio ajax, 42

turnus, $139,140,160$

Parandra brumnea, 106

Paraponyx, 152

Paris green, 222

Parnassius, 160

Parnidæ, 110

Parnopes, 170

Parthenogenesis, 41

Passalæcus mandibularis, 175

Passalus cornutus, 107

Peach-tree borer, 215 
Pear slug-worm, 166

Pebrine, 43

Pediculina, 78

Pediculus capitis, 78 pubis, 78

vestimenti, 78

Pelecinidæe, 169

Pelecinus polycerator, 169

Pelidnota punctata, $10 r$

Pelocoris femorata, 83

Pelopæus flavipes, 173, 185

Pemphredonidæ, 175

Pentatomidæ, 84

Periodicity in insect-life, 52

Perla abnormis, 67

Pests, insect, destruction of by fungi, 45

of museums, 237

Petroleum emulsions, 222

Phacellura nitidalis, 208

Phæneus caruifex, 107

Phalacrus ovalis, 112

Phalænidæ, 153

Phaneroptera curvicauda, 63

Phasmidæ, 63

Pheidole, 171

Phengodes, 109

Philanthus vertilabris, 174

Phora incrassata, 12f

Phorbia ceparum, 1su

Phoridx, 126

Plioturis pyralis, 109

Phoxopteris fragariæ, 152

Phryganea, 183

Phryganidæ, 91

Phycinæ, 152

Phycis rubrifasciella, 182

Phycodromidx, 128

Phyllium siccifolium, 63

Phylloxera quercus, 80

vastat rix, 209

Phymata erosa, 83
Phytomyza clematidis, 126

Phytophaga, 103

Pickle-worm, 208

Picris oleracea, 160 rapæ, 160,205

Pimpla, 168

Piophila casei, 128

Pipunculus cingulatus, 131

Pique, 116

Pissodes strobi, 100

Plagionotus speciosus, 106

Platygaster, 169

herrickii, 193

Platymodes pensylvanica, 62

Platynus cupripenne, 114, 115

Platypeza anthrax, 131

Platypsylla castoris, 113

Platyptera, 63, 55

Platypteryx arcuata, 155

Platysamia cecropia, 155

Plectoptera, 71, 55

Plectrotarsus, 90

Pleurite, 2

Plum weevil, 214

Plusia brassicæ, 205

Pocilacapsus lineatus, 84

Poduridx, 57

Pogonomyrmex, 171

Polistes, 185

Polyergus, 171

Polygonia progne, 161

Pompilus formosus, 173

Ponera, 171

Potamanthus marginatus, 72

Potato beetle, 104

insects injurious to, $20 \%$

Prionocyphon discoideus, 110

Prionoxystus robiniæ, 158

Proctotrupidæ, 169

Promachus fitchii, 134

Proventriculus, 9

Pselaphidx, 112 
Pselaphus erichsonii, 112

Psenides, 167

Psen leucopus, 175

Psephenus lecontei, 110

Psila bicolor, 129

Psocus novæ-scotiæ, 67

Psyche helix, 183

Psychodes alternata, 134

Psylla pyri, 82 tripunctata, 81 .

Psyllobora 20-maculata, 112

Pteratomus putnami, 169

Pteromalus puparum, 169, 205, 219

Pteronarcys regalis, 67

Pterophoridæ, 150

Pterophorus periscelidactylus, 150

Ptinus fur, 108

Ptyelus lineatus, 82

Pulex canis, 116 irritans, 116

Pulvinaria innumerabilis, 79

Pupa, 40

Pupx, management of, 252

Puparium, 123

Pupipara, 124

Pyralidx, 152

Pyralina, 152

Pyrgota undata, 129

Pyrochroa flabellata, 102

Pyrochroidæe, 102

Pyrophorus noctilucus, 110

Pyrrhocoridæ, 84

Pytho niger, 103

Radish fly, 206

Rearing beetles, 276

$$
\text { insects, } 243
$$

Reduviidæ, 83

Remedies against insects, 221

Rhagovelia obesa, 83

Rhinopsis canaliculata, 1.73
Rhipiceridæ, 110

Rhipidius pectinicornis, 102

Rispiphoridæ, 102

Rhinomacer elongatus, 101

Rhopalocera, 158

Rhopalum pedicellatum, 175

Rhopobota vacciniana, 152

Rhynchites bicolor, 101

Rhyncophora, 99

Rhyncophorus palmarum, 100

Rhyphus alternatus, 134

Rhyssa, 168

Rhyssodes exaratus, 111

Rurales, 160

Sack-bearer, 183

Salda signoretii, 83

Sandalus petrophya, 110

Sannina exitiosa, 215

Saperda candida, 105, 211

Sapromyza vulgaris, 128

Sapyga martinii, 173

Sarcophaga carnaria, 131 sarracenia, 131

Sarcopsylla penetrans, 116

Sargus decorus, 134

Saw-fly, 166, 324

Scales, 31

Scaphidium quadriguttatum, 112

Scarabæidæ, 106

Scatophaga stercoraria, 130

Scenopinidæ, 133

Scent-scales, 149

Schizura unicornis, 155

Sciara mali, 136

Sciomyza albocostata, 129

Scolia, 172

Scolopendrella immaculata, 5 :

Scolytidæ, 99

Scutelleridæ, 84

Scutellunı, 4

Scutum, 4 
Scydmænus mariæ, 1j\%

Semiotella destructor, 169, 193

Sepsis similis, 128

Serricornia, 108

Sesia pyri, 158

Sesiidæ, 158

Sexual differences in insects, 32

Sialidæ, 87

Silk, 144

Silk-worm, 42

\section{American, 155}

Chinese, 155

Silpha lapponica, 112

Silphidæ, 112

Simulidæe, 135

Simulium meridionale, 135

molestum, 135

pecuarum, 136

Siphonaptera, 55, 115

Sitodrepa panicea, 108

Slug-worm, 166

Smell, organs and sense of, 26

Smerinthus excæcatus, 158

Smynthurus elegans, 57

Snapping beetles, 109

Sounds made by insects, 30

Spanish fly, ${ }^{102}$

Spathegaster baccarum, 167

Sphærius politus, 112

Sphenophorus zeæ, 200

Sphex ichneumonea, 173, 184

Sphindus americanus, 108

Sphinx carolina, 158

$$
\begin{aligned}
& \text { celeus, } 158 \\
& \text { embryology of, } 36
\end{aligned}
$$

Sphyracephala brevicornis, 128

Spilosoma virginica, 156

Spindle-worm, 200

Spiracle, 19, 316

Spraying machines, 222

Spring-tails, 56

Squash beetle, 207
Squash borer, 207

bug, 208

lady-bird, 208

pickle-worm, 208

Stalachtis, 160

Stalk-borer, 200, 205

Staphylinidæ, 112

Staphylinus vulpinus, 112

Stephanidæ, 168

Stephanus cinctipes, 168

Sternite, 2

Stigmata, 19

Stigmus fraternus, 175

Sting, bee's, 164, 315

Stizus speciosus, 174

Stomach, 9

Stomoxys calcitrans, 130

Stratomyia picipes, 134

Strepsiptera, 101

Stylops childreni, 101

Subimago, 72

Sugaring, 246

Sylvanus surinamensis, 111

Symphyla, 57

Synemon sophia, 157

Syrphidæ, 132

Syrphus politus, 132

Systœchus oreas, 133

Tabanus lineola, 134

Tachina, 131, 218, 220

Tachinidæ, 131

Tactile sense, 31

Tanypus annulatus, 135

Tapiuoma, 171

Taste, orgaus aud sense of, 27

Telea polyphemus, 155

Teleas, 169

Temperature, influence of char.

ges of, on insects, 49

Tenebrio molitor, 103

Tencbrionidæ, 103 
Teuthredinidæe, 165

Terebrantia, 165

Tergite, 2

Termes flavipes, 65, 68

T'estes, 34

Thecesternus humeralis, 101

Thereva albiceps, 133

Thrips striatus, 73,197

Throscus constrictor, 109

Thymele proteus, 160

Thysania agrippina, 154

Thyreopus, 175

Thyreus abbotii, 158

Thyrididee, 158

Thyris lugubris, 158

maculata, 158

Thysanoptera, 55, 73

Thysanura, 54, 56

Tibia, 6

Timber-beetle, 99

Tinea biselliella, 151 granella, 151 pelliolella, 151 tapetzella, 151

Tineidæe, 150

Tingis clavata, 84

Tiphia inornata, 172

Tipula trivittata, 134

Tipulidæ, 134

Tomicus pini, 99

Tomicus typographus, 48

Tomocerus plumbeus, 57

Tortricidæ, 151 collecting, 262 rearing, 262

Tortrix fumiferana, 152

Touch, sense of, 31

Trachea, 19, 20, 317

Traps for beetles, 272

moths, 246

Tremex columba, 166

Trichocera regelationis, 134
Trichodectes canis, 66

Trichodes nuttallii, 108

Trichoptera, 55, 90

Trichopteryx aspera, 112

Trigona, 188

Trigonalidie, 168

Trigonalys, 168

Tritoxa flexa, 129

Trochantine, 6

Trogosita virescens, 110

Trypeta florescentiæ, 129

U1inary tubes, 11,13

Uroceridæ, 166

Utetheisa bella, 157

Vanessa antiopa, 161

Veins of the wings, 19

Veliidæ, 83

Ventriculus, 9

Venule, 19

Vespa arenaria, 175 maculata, 175

Vespidæe, 175

Vine-dresser, 211, 212

Wasps, paper, 175, 177, 184

$$
\text { wood, } 174
$$

Weather, influence of changes

of, on insects, 49

Weevil, 99

Wheat, insects injurious to, 191 midge, 195 thrips, 197

Wire-worm, 199

Workers, 32

Xenos peckii, 102

Xyleborus, 99

Xylophagus rufipes, 134

Xyloterus, 99

Zarhipis, 109

Zygæua, 157

Zygrenidac, 157 





PROPERTY OF

Z. P. METCALF 
